\title{
INDENIZAÇÃO PUNITIVA
}

Dissertação de Mestrado Apresentada ao DePartamento de Direito Civil Orientadores: Prof. Titular Antonio Junqueira de Azevedo Prof. Doutor Alcides Tomasetti JR.

FACULDADE DE DIREITO DO LARGO DE SÃO FRANCISCO UNIVERSIDADE DE SÃO PAULO

\author{
SÃO PAULO
}


PEDRO RICARDO E SERPA [USP 3507397]

\section{INDENIZAÇÃO PUNITIVA}

Dissertação de Mestrado apresentada ao Departamento de Direito Civil da Faculdade de Direito da Universidade de São Paulo, como exigência parcial para a obtenção do título de Mestre, sob a orientação do Prof. Titular Antonio Junqueira de Azevedo e do Prof. Doutor Alcides Tomasetti Jr.

FACULDADE DE DIREITO DA USP

SÃO PAULO, 2011 


\section{NOTA INTRODUTÓRIA}

A formatação desta dissertação atendeu às exigências prescritas pela Resolução FD/PÓS n. ${ }^{\circ}$ 1/2002.

Com o intuito de facilitar a identificação, pela banca examinadora, das obras doutrinárias citadas no texto, as notas de rodapé foram elaboradas de modo a conter todos os elementos necessários para a individualização das obras citadas, não se valendo de referência resumida (op. cit.); exceto nos casos em que mais de um trecho de dada obra é referido na mesma nota de rodapé.

Pelas mesmas razões, as obras jurídicas brasileiras foram citadas com referência completa aos nomes de seus respectivos autores, com a indicação de todos os prenomes (em letras minúsculas) e sobrenomes (com o último deles, ou aqueles pelos quais o referido autor é mais conhecido, em caixa alta).

Por fim, com a intenção de tornar a leitura mais fluida, as transcrições de trechos em língua estrangeira, quando feitas no corpo do texto, foram apresentadas em tradução livre, remetendo-se o leitor ao texto original dos trechos citados, sempre reproduzidos em notas de rodapé. 


\section{ÍNDICE}

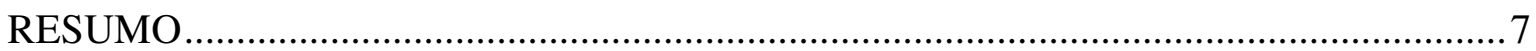

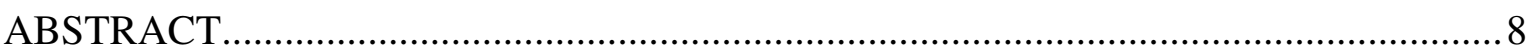

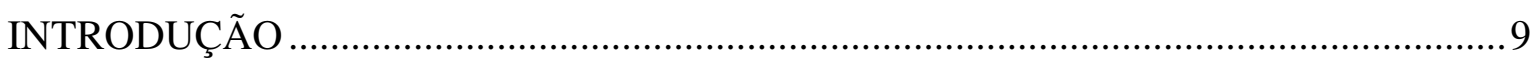

I. Tema a ser desenvolvido: limitações e justificativa.................................................. 9

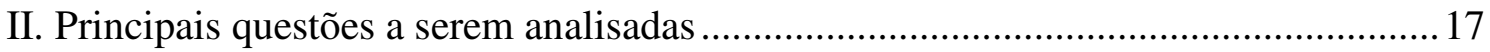

III. A opção pela expressão indenização punitiva ........................................................20

CAPÍTULO I - PUNITIVE DAMAGES NO SISTEMA DA COMMON LAW...................23

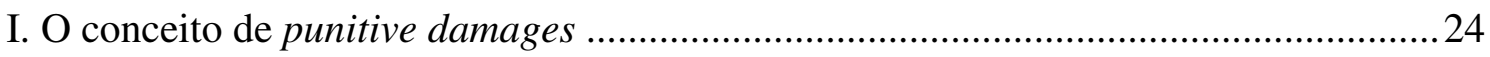

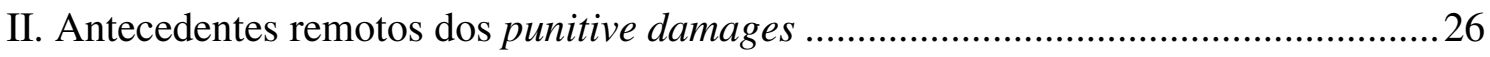

III. Surgimento dos punitive damages na common law: os primeiros precedentes......... 31

IV. Razões para o surgimento dos punitive damages .......................................................35

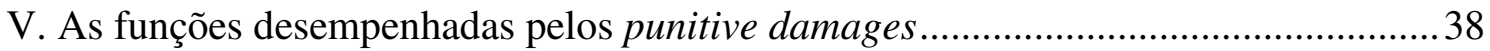

V.I. A função de "justiça pública" ("public justice"): o papel do chamado "private

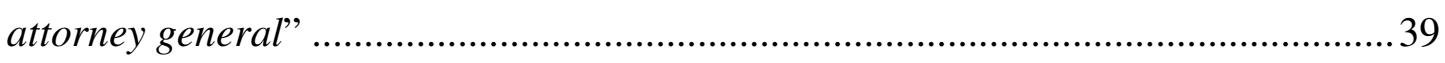

V.II. A função preventiva (deterrence) ................................................................... 42

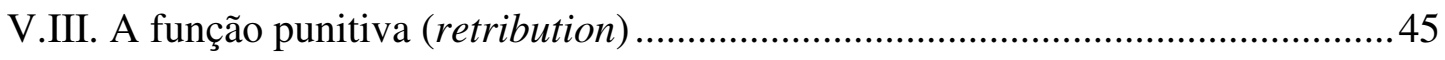

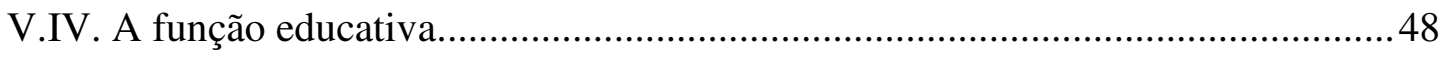

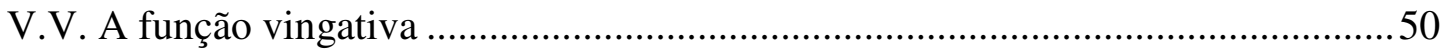

V.VI. Uma (apenas aparente) incongruência: a função compensatória ......................52

VI. Pressupostos objetivos para a incidência dos punitive damages ................................55

VI.I. Ilícito extracontratual (tort) ou inadimplemento contratual (breach of contract)?

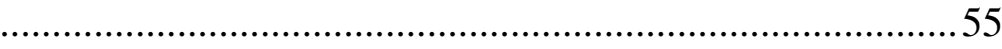

VI.II. Ocorrência de prejuízo ............................................................................5

VII. Pressupostos subjetivos para a incidência dos punitive damages ............................62

VIII. Critérios para quantificação dos punitive damages ................................................65

IX. Questões polêmicas acerca dos punitive damages ..................................................69

IX.I. Responsabilidade do empregador pelo pagamento de punitive damages ("vicarious liability")

IX.II. Punitive damages e responsabilidade pelo fato do produto ("products liability")

IX.III. Contratação de seguro para os punitive damages .............................................79

$\mathrm{X}$. Restrições aos punitive damages no direito inglês .................................................... 82 
XI. Restrições aos punitive damages no direito norte-americano

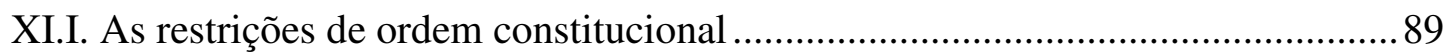

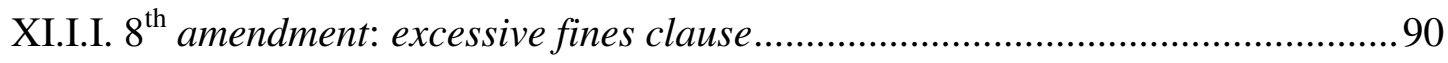

XI.I.II. $14^{\text {th }}$ amendment: due process clause ............................................................. 93

XI.I.III. Uma ponderação sobre a $5^{\text {th }}$ amendment: double jeopardy clause ............... 112

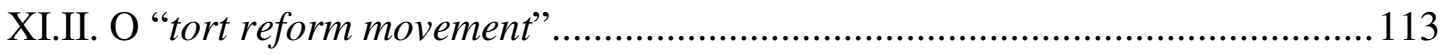

XI.II.I. A abolição total dos punitive damages ...................................................... 115

XI.II.II. Limitação do quantum dos punitive damages: imposição de limites máximos (caps) ou correlação entre compensatory e punitive damages.

XI.II.III. Destinação dos punitive damages: entrega total ou parcial ("split recovery") da condenação a um fundo público

XI.II.IV. Repartição do procedimento ("bifurcation of trial”) e eliminação da prova da riqueza do demandado.

XI.II.V. Elevação do burden of proof: equiparação aos critérios adotados pelo processo penal ("proof beyond reasonable doubt")

XI.II.VI. Eliminação da imprecisão dos pressupostos de incidência dos punitive damages.

XI.II.VII. Exclusão da competência dos jurados para a quantificação dos punitive damages.

CAPÍTULO II - A NECESSIDADE DE ADOÇÃO DA INDENIZAÇÃO PUNITIVA . 135

I. Responsabilidade civil: paradigmas tradicionais e desenvolvimentos contemporâneos 136

II. Insuficiências do paradigma reparatório e a adoção da indenização punitiva 153

II.I. Responsabilidade civil: objetivação, coletivização e a queda da prevenção ..... 153

II.II. A tutela da dignidade da pessoa humana e dos interesses metaindividuais...... 157 II.III. Inadequeção da tutela proporcionada pelo Direito Penal e pelo Direito Administrativo Sancionador. 161

II.IV. A responsabilidade civil como meio adequado para a tutela de direitos e a prevenção de danos 166

III. As novas funções a serem exercidas pela responsabilidade civil .......................... 175

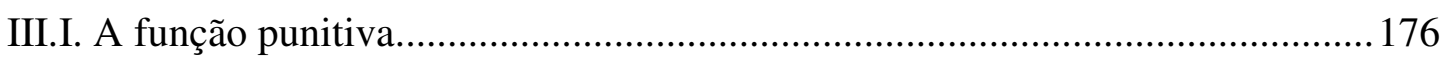

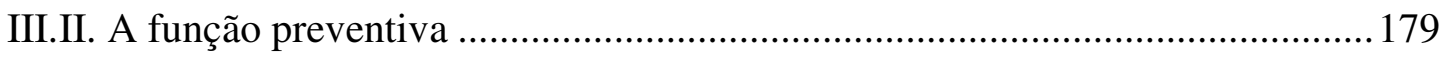

CAPÍTULO III - A VIABILIDADE DA ADOÇÃO DA INDENIZAÇÃO PUNITIVA. 185

I. Críticas doutrinárias à adoção da indenização punitiva ............................................ 186 
I.I. Uma suposta incompatibilidade: punição e direito civil 186

I.I.I. Sanção jurídica e sanção punitiva

I.I.II. As sanções punitivas no código civil de 2002

I.II. Incentivo à litigância frívola ou à dita "indústria do dano moral"

I.III. Incompatibilidade com a responsabilidade objetiva .....................................203

I.IV. Vedação à dupla condenação ("ne bis in idem”) ..............................................209

II. Uma crítica pertinente: a ausência de disposição legal autorizativa.........................214

II.I. O princípio da legalidade das penas ("nulla poena sine lege”) .........................2217

II.II. O princípio da reparação integral ("restitutio in integrum") .............................226

II.III. Vedação ao enriquecimento sem causa .........................................................2 230

CAPÍTULO IV - INTRODUÇÃO DA INDENIZAÇÃO PUNITIVA NO

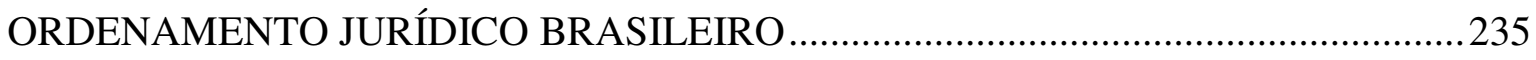

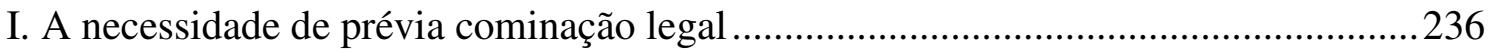

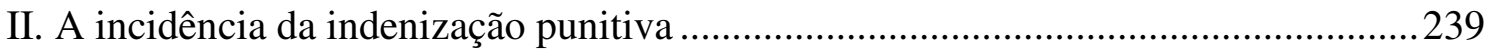

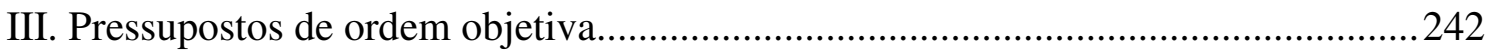

III.I. Ilícito extracontratual ou inadimplemento contratual ....................................243

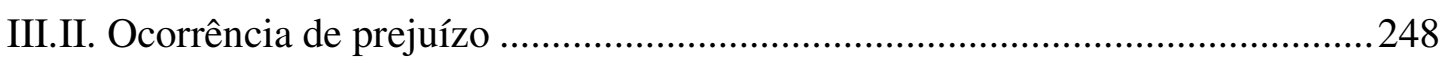

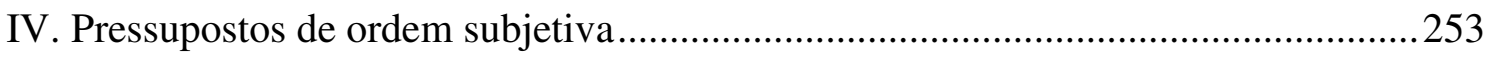

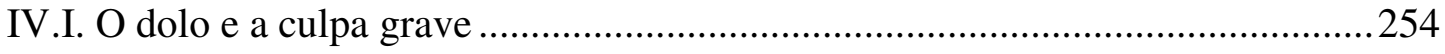

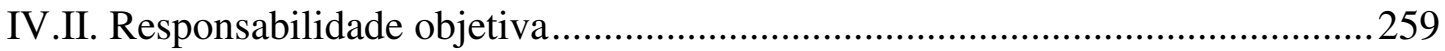

V. Questões materiais correlatas à introdução da indenização punitiva .......................261

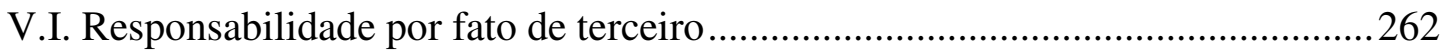

V.II. Contratação de seguro para a indenização punitiva..........................................2265

V.III. A transmissibilidade causa mortis dos direitos e obrigações relacionados à

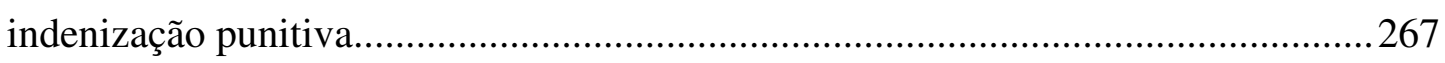

VI. Aspectos processuais relevantes da indenização punitiva....................................221

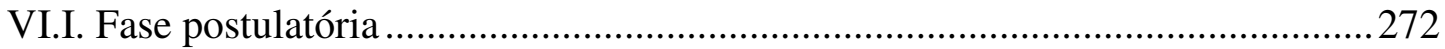

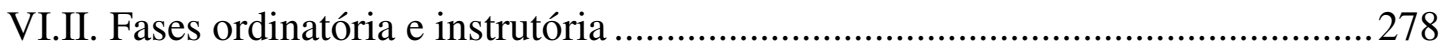

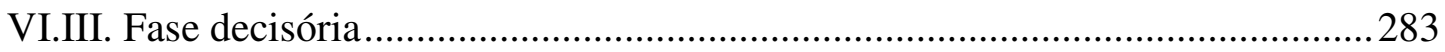

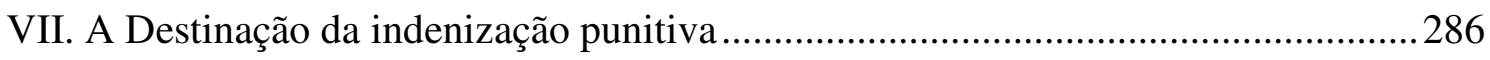

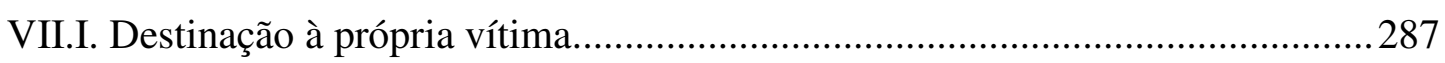

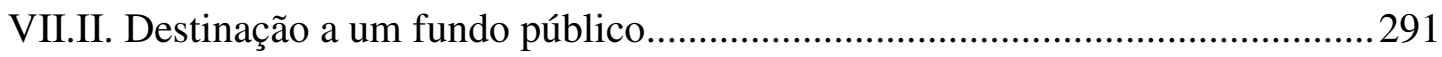

VII.III. Distribuição da indenização punitiva entre a vítima e um fundo público ....298

VIII. O reconhecimento de sentenças estrangeiras no Brasil ........................................300 
I. Critérios para a quantificação da indenização punitiva............................................... 317

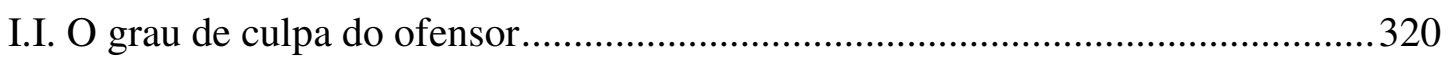

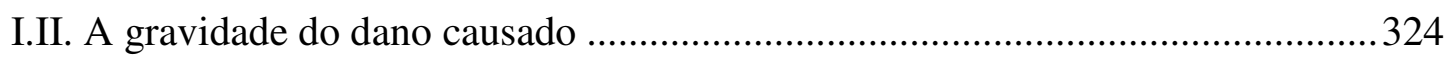

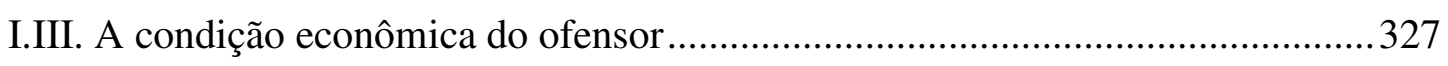

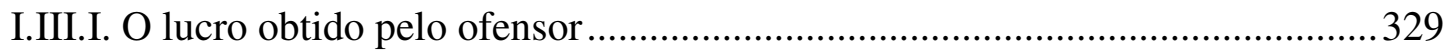

I.IV. Um critério inaplicável: a condição econômica do ofendido ...........................332

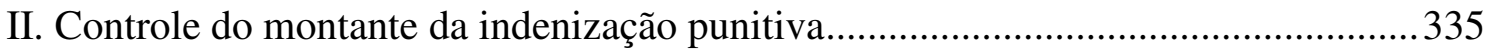

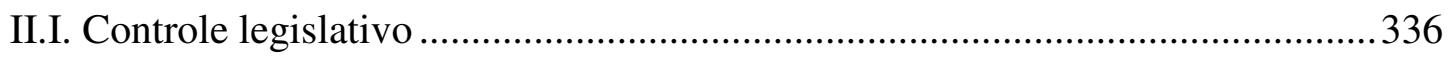

II.II. Controle judicial: proporcionalidade e razoabilidade ..................................... 339

CAPÍTULO VI - A INTRODUÇÃO LEGISLATIVA DA INDENIZAÇÃO PUNITIVA

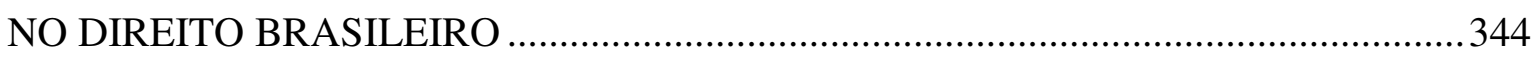

I. As diversas iniciativas legislativas: análise, insuficiências e deficiências ...................344

II. Proposta para a introdução legislativa da indenização punitiva ...............................356

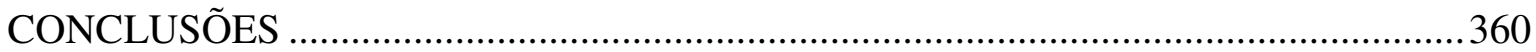

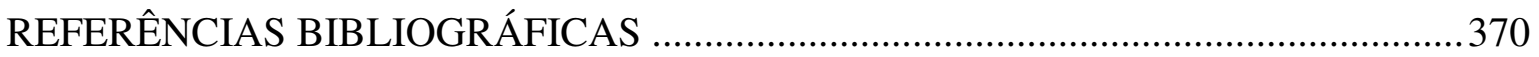




\section{RESUMO}

A presente dissertação parte da premissa de que o ordenamento jurídico brasileiro deve dispor de institutos jurídicos aptos a tutelar, de maneira eficiente, os bens e interesses da maior relevância, bem como a assegurar a manutenção do equilíbrio social. Trata-se da única maneira de garantir, em níveis adequados, a "segurança social" (art. $5^{\circ}$, caput, da $\mathrm{CF} / 88$ ), bem como de perseguir aquele que é tido como um dos objetivos fundamentais da República Federativa do Brasil, o de "construir uma sociedade livre, justa e solidária" (art. $3^{\mathrm{o}}$, I, da CF/88). Deve-se, portanto, impedir o cometimento de atos anti-sociais, direcionados, de maneira intencional ou extremamente negligente, à lesão dos supra referidos interesses, atos estes tão reprováveis que seus efeitos extrapolam o âmbito individual (= da vítima diretamente atingida), causando impactos negativos também no âmbito coletivo (= um rebaixamento do nível social). Acredita-se que, para atingir tais fins, deve-se utilizar um remédio jurídico que seja, ao mesmo tempo, suficientemente flexível (para que possa sancionar todas as condutas potencialmente lesivas) e adequadamente severo (para que possa punir o ofensor e prevenir o cometimento de semelhantes atos no futuro). Nesse sentido, os conhecidos instrumentos do Direito Penal e do Direito Administrativo se mostram insuficientes. Para tanto, deve-se recorrer ao Direito Civil e, mais especificamente, à responsabilidade civil, agregando-se-lhe o mecanismo necessário para que possa desempenhar eficientemente as funções de prevenção e punição, o qual denominamos de indenização punitiva. Trata-se de instituto estrutural e funcionalmente assemelhado aos punitive damages, típicos dos países da common law e que nos servirão de modelo para a indenização punitiva, mas cuja aplicação, dadas as peculiaridades de nosso ordenamento constitucional, demanda prévia cominação legal. Tal regramento deverá estipular não apenas os pressupostos objetivos e subjetivos para a incidência da indenização punitiva (que só deve ocorrer nos casos da mais alta reprovabilidade, quando o ofensor houver se conduzido com dolo ou culpa grave, causando prejuízos a interesses existenciais ou metaindividuais, ou ainda extraindo benefícios econômicos do ilícito perpetrado), mas, também, os critérios a serem utilizados para a quantificação da sanção (os quais não se relacionam com, nem tampouco se limitam à, extensão dos prejuízos sofridos). 


\begin{abstract}
The current paper starts from the premise that the brazilian Law ought to make use of legal institutes that are able to protect, efficiently, the goods and interests of utmost relevance, as well as to assure the maintenance of the social balance. It is the only way to warrant, in adequate levels, the "social security" (art. $5^{\text {th }}$, caput, of FC/88), as well as to pursue that which is held as one of the fundamental objectives of the Federal Republic of Brazil, to "build a free, just and sympathetic society" (art. $3^{\text {rd }}$, I, of FC/88). It is needed, therefore, to preclude the commission of anti-social acts, aimed, in intentional or extremely negligent way, to the injury of the above mentioned interests, acts that are so reprehensible that its effects surpasses the individual context (= of the victim who is directly injured), causing negative impacts also to the social context (= a depreciation of the social level). It is believed that, to achieve these goals, one must use a judicial sanction that is, at the same time, sufficiently flexible (to be able to sanction all of the potentially detrimental conducts) and adequately severe (to be able to punish the offender and prevent the commitment of similar acts in the future). In that sense, the known instruments of Criminal Law and Administrative Law seem insufficient. For that purpose, one must resort to the Civil Law and, most specifically, to the tort law, adding to it the mecanism it needs to fulfill efficiently the functions of deterrence and punishment, which we call indenização punitiva. It is an institute structural and functionally similar to the punitive damages, typical of the countries of common law and which will serve as a model to the indenização punitiva, but whose enforcement demands previous legal provision. That provision must stipulate not only the objective and subjective requirements to the imposition of the indenização punitiva (which will only occur in the cases of utmost reprehensibility, when the offender acts with intent or gross negligence, injuring existential or "metaindividual" interests, or yet deriving economic benefits from the tort perpetrated), but also, the criteria to be used to quantify the sanction (which do not relate, neither limit, to the extension of the harm suffered).
\end{abstract}




\section{INTRODUÇ̃̃o}

\section{TEMA A SER DESENVOLVIDO: LIMITAÇÕES E JUSTIFICATIVA}

Entre institutos jurídicos típicos do Direito Civil, certamente se pode destacar a responsabilidade civil como um dos mais mutáveis e maleáveis, propenso que é a evoluir, a se submeter a modificações estruturais e funcionais, tudo para atender às novas e sempre volúveis necessidades advindas do sistema social ${ }^{1}$.

Do desenvolvimento, assim dito "espetacular", por que passou tal instituto nos dois últimos séculos, resultou a construção de um sistema de responsabilidade civil que se lança quase que cegamente ao objetivo de reparar pronta e integralmente todos os prejuízos suportados pelas vítimas lesadas. Se, de um lado, facilitou-se enormemente a dedução de pretensões reparatórias (o que se fez, por ex., por meio da denominada "objetivação da responsabilidade") e a satisfação do "crédito de indenização", (o que se fez por meio das assim chamadas "coletivização da responsabilidade" ou "socialização dos riscos"), de outro, abriram-se as portas da reparação civil a uma vasta gama de lesões que anteriormente eram tidas como irreparáveis (em fenômeno que se denominou de "expansão dos danos suscetíveis de reparação"), tais como as lesões a interesses existenciais (impassíveis de monetização) e metaindividuais (cuja titularidade não poderia ser atribuída a uma única pessoa ou grupo de pessoas, mas, sim, ao conjunto social) ${ }^{3}$.

A despeito de todos os inegáveis benefícios trazidos pelos desenvolvimentos contemporâneos da responsabilidade civil, a conjugação de tais modificações com a manutenção do paradigma ressarcitório (pelo qual a indenização se limita tão-somente à recomposição do patrimônio lesado) trouxe conseqüências negativas no que toca à prevenção de novos prejuízos e à moralização de condutas ilícitas.

\footnotetext{
${ }^{1}$ Fernando Noronha, Direito das Obrigações, vol. I, $2^{\text {a }}$ ed., São Paulo, Saraiva, 2007, pág. 536.

2 A expressão, no sentido empregado no texto, em contraposição à "dívida de responsabilidade" (que focaliza o responsável pelo prejuízo, em vez da vítima, beneficiária do crédito), foi cunhada por Maria Alice Costa HofmeIster, O Dano Pessoal na Sociedade de Risco, Rio de Janeiro, Renovar, 2002, págs. 100/101.

${ }^{3}$ Sobre o tema, cfr. Fernando Noronha, Direito das Obrigações, vol. I, $2^{\text {a }}$ ed., São Paulo, Saraiva, 2007, págs. 535/548 e Anderson SCHREIBER, Novos Paradigmas da Responsabilidade Civil: Da Erosão dos Filtros da Reparação à Diluição dos Danos, São Paulo, Atlas, 2009, passim.
} 
A uma, em razão da objetivação da responsabilidade [com a desconsideração da culpa quer para a definição das regras de imputação, quer, ainda, para a quantificação da indenização (exceto nas hipóteses em que a excessiva desproporção entre a culpa e o dano justificar a redução eqüitativa do quantum indenizatório, ex vi do art. 944, par. ún., do CC/2002)], nivelam-se "por baixo todos os casos de responsabilidade civil", tornando-se "quase que irrelevante se o causador do dano agiu com dolo, culpa grave, ou culpa leve".

A duas, a manutenção do paradigma ressarcitório possibilita que em determinadas hipóteses um agente possa se valer sua posição de "hipersuficiência" para, de antemão, elaborar cálculos destinados à quantificação do montante dos prejuízos a serem impostos a terceiros em razão da consecução de uma atividade de risco ou da realização de um ato ilícito. Tal possibilidade permite que se calcule ex ante o valor das indenizações a serem suportadas, permitindo ao potencial ofensor sopesar o quantum indenizatório a ser eventualmente pago com os benefícios econômicos a serem extraídos do ilícito. Desse sopesamento, pode-se concluir conscientemente ser mais vantajoso (do ponto de vista econômico) cometer o ato ilícito e efetuar o pagamento das indenizações correspondentes do que respeitar a Lei e evitar os prejuízos ${ }^{5}$.

Desta feita, vê-se que, ao menos no que concerne à persecução dos fins de prevenção de danos e moralização de condutas ilícitas, a evolução da responsabilidade civil encontrou um obstáculo no paradigma ressarcitório.

\footnotetext{
${ }^{4}$ Vitor Fernandes GonÇAlves, A Punição na Responsabilidade Civil: A indenização do dano moral e da lesão a interesses difusos, Brasília, Brasília Jurídica, 2005, pág. 18.

${ }^{5}$ Vitor Fernandes GonÇALVES, A Punição na Responsabilidade Civil, Brasília, Brasília Jurídica, 2005, pág. 18. Nesse contexto, e por tratar de situação em tudo análoga à acima versada, interessa citar a alegoria cunhada pela jurista portuguesa P. C. M. GUIMARÃES, que sustenta que, num ordenamento em que se cogite da aplicação da responsabilidade civil com fins exclusivamente compensatórios, um homem que, porventura, deseje consumir as maçãs plantadas pelo vizinho tem, em vistas ao Direito, duas opções de iguais conseqüências: (i) ou ele opta por respeitar o direito de propriedade de seu vizinho e, com sua permissão, adquire a tão desejada maçã, pagando por ela seu valor de mercado; ou (ii), em desrespeito aos mesmos direitos de propriedade, subtrai a maçã, e, uma vez consumado o ilícito, indeniza o vizinho pelo prejuízo que lhe impôs, pagando-lhe nada mais que o valor de mercado do bem furtado (Os Danos Punitivos e a Função Punitiva da Responsabilidade Civil, in Revista de Direito e Justiça, vol. XV, t. 1, 2001, pág. 178). Com fundamento nessa alegoria, e partindo da premissa de que, tal como o ordenamento jurídico pátrio, também o ordenamento português é caracterizado pela função compensatória da responsabilidade civil (o já referido paradigma ressarcitório), a citada autora conclui que "é então esta a mensagem que a ordem jurídica, como está, transmite: de que é indiferente, e até conveniente muitas vezes, a violação de direitos alheios, porque se poupam os custos de transação e não se dá à outra parte a possibilidade de exigir um preço superior ao de mercado. Um sistema que tenda neste sentido ensina o desrespeito pelos direitos alheios. A conseqüência é a
} 
Por conta desse paradigma, os supra referidos fins passaram a ser exercidos quase que com exclusividade pelo Direito Penal e pelo Direito Administrativo Sancionador ${ }^{6}$, ramos estes que, como bem anotam Eduardo UILAN e S. CARVAL, possuem deficiências para desempenhar adequadamente as funções de prevenção de danos e punição de condutas especialmente reprováveis ${ }^{7}$.

Cria-se, assim, uma espécie de "campo vazio", no qual o ordenamento jurídico não logra êxito em exercer a tutela mais eficiente possível dos bens e interesses cuja reparabilidade havia sido recém reconhecida (a saber: os existenciais e os metaindividuais, os quais, uma vez lesados, dificilmente comportarão a restituição ao status quo anterior à lesão): nem a responsabilidade civil atua eficazmente no sentido de prevenir danos e punir os ofensores que se tenham conduzido de maneira particularmente reprovável, nem, tampouco, assim o fazem o Direito Penal ou o Direito Administrativo.

Acredita-se que a existência desse chamado "campo vazio" abre espaço para o cometimento de atos ilícitos extremamente gravosos (caracterizados pela intencionalidade ou pela flagrante e irresponsável desconsideração em relação aos direitos alheios ou, ainda, motivados pela torpe e ilícita persecução de benefícios econômicos), aptos a causar danos que, pela sua relevância, extrapolam o âmbito individual (= da vítima diretamente atingida pelo ilícito) para afetar, de maneira depreciativa, todo o conjunto social (= acarretando um "rebaixamento imediato do nível de vida da população"). Tratase de atos que acarretam o fenômeno nomeado por Antonio JUNQUEIRA DE AZEVEDo de "dano social"8. Por sua particular relevância e gravidade, torna-se de rigor o desenvolvimento de meios jurídicos adequados tanto para a eficiente prevenção de danos decorrentes desse tipo de conduta (em atuação pro futuro), quanto, nos casos em que a prevenção não logra o esperado sucesso, para a punição daqueles malfeitores que tenhamse conduzido de maneira particularmente reprovável.

de que as pessoas se sentirão menos incentivadas nos seus próprios bens, o que acaba por se traduzir num prejuízo para toda a sociedade" (op. cit., pág. 178).

${ }^{6}$ Eduardo UILAN, Responsabilidade Civil Punitiva, Tese (Doutorado) - Faculdade de Direito da USP, São Paulo, 2003, pág. 47.

${ }^{7}$ Responsabilidade Civil Punitiva, Tese (Doutorado) - Faculdade de Direito da USP, São Paulo, 2003, pág. 2 e La Responsabilitè Civile Dans Sa Fonction de Peine Privée, Paris, L.G.D.J., 1995, págs. 234 e ss.

${ }^{8}$ Por Uma Nova Categoria de Dano na Responsabilidade Civil: O Dano Social, in Novos Estudos e Pareceres de Direito Privado, São Paulo, Saraiva, 2009, págs. 375/384. 
Nesse contexto, e diante das deficiências dos demais ramos do Direito Sancionador, iniciou-se, em doutrina e em jurisprudência, uma verdadeira defesa da utilização da responsabilidade civil (em atuação conjugada com o Direito Penal e o Direito Administrativo) como meio de promoção de outras finalidades que não apenas a de reparar os prejuízos já causados em decorrência dos atos ilícitos perpetrados. Principalmente nas hipóteses em que se está diante da ocorrência de prejuízos impassíveis de recomposição ao status quo anterior à lesão, passou-se a sustentar que a responsabilidade civil, por meio da indenização, deveria exercer, ao lado de sua tradicional função compensatória, outras funções de igual relevância para a consecução de seus escopos, quais sejam, as funções punitiva e preventiva ${ }^{9}$.

Para tanto, faz-se necessário abandonar (ainda que parcialmente) o paradigma ressarcitório, consubstanciado na concepção de que "o que se deve ter em vista [para a quantificação da indenização] é a vítima, assegurando-lhe a reparação do dano $e$ não a idéia de infligir uma pena ao autor do prejuízo causado" ${ }^{10}$ para se abraçar a idéia, já antecipada por R. DEMOGUE no início do século XX, de que “a teoria da indenização compensatória é suficientemente forte para sobreviver, mas fraca demais para vigorar sozinha" ${ }^{11}$. Deve-se admitir que, para atingir aos fins de prevenção e punição (quando assim se fizer necessário), a indenização deverá extrapolar os estritos limites do prejuízo (para além das bordas do art. 944, caput, do CC/2002).

\footnotetext{
${ }^{9}$ Nesse sentido já teve a oportunidade de se manifestar a Corte Constitucional Italiana, afirmando-se, em decisão proferida no ano de 1986, que “"è impossibile negare o ritenere irrazionale che la responsabilità civile da atto illecito sia in grado di provvedere non soltanto alla reintegrazione del patrimonio del danneggiato ma fra l'altro, a volte, anche ed almeno in parte, ad ulteriormente prevenire e sanzionare l'illecito, come avviene appunto per la riparazione dei danni non patrimoniale da reato. Accanto alla responsabilità penale (anzi, forse meglio, insieme ed ulteriormente alla pena pubblica) la responsabilità civile ben può assumere compiti preventivi e sanzionatori." (A. S. GAUDENZI, La Tutela del Contraente Debole e del Lavoratore (L'Applicazione dei Punitive Damages nel Mondo Anglosassone e nell'Europa Continentale), in Lavoro e Previdenza Oggi, anno XXX, n. 3, 2004, pág. 412)

${ }^{10}$ Alvino LiMA, Culpa e Risco, $2^{\mathrm{a}}$ ed. revista e atualizada por Ovídio Rocha Barros Sandoval, São Paulo, RT, 1998, pág. 113.

${ }^{11}$ R. DeMOGUe, Validity of the Theory of Compensatory Damage, in Yale Law Jornal, vol. XXVII, n. 5, mar/1918, pág. 597: "The theory of compensatory indemnity is sufficiently strong to survive, but too weak to rule alone." Também nesse sentido, e tratando especificamente da situação antes analisada, referente aos casos em que é possível balancear, de um lado, os custos de se observar o principio do neminen laedere e, de outro, as despesas que se terão de assumir apenas para se ressarcir prejuízos decorrentes da não utilização de medidas que impeçam a ocorrência destes prejuízos, R. D. PIZARRO, Daño Moral - Prevención. Reparación. Punición, Buenos Aires, Hamurabi, 2000, pág. 383, salienta que "las vias resarcitorias no siempre son adequadas para tal fin, principalmente en aquellos supuestos en los cuales el dañador obtiene un beneficio buscado a través de la comisión del ilícito, aun después de pagar las indemnizaciones pertinentes."
} 
Em nosso país, praticamente toda a discussão a respeito das aludidas funções de punição e prevenção se insere no contexto da condenação ao pagamento de indenização por danos morais ${ }^{12}$. É nesse contexto que, inspirada pela necessidade de ampla proteção à dignidade da pessoa humana [erigida a um dos fundamentos da República Federativa do Brasil (art. $1^{\circ}$, III, da $\mathrm{CF} / 88$ )], nossa doutrina pátria procura atribuir à indenização dos detrimentos não patrimoniais mais do que um fator meramente compensatório.

Assim é que, ao tratar do tema, Sérgio CAVALIERI FILHo sustenta que "não se pode ignorar a necessidade de se impor uma pena ao causador do dano moral, para não passar impune a infração e, assim, estimular novas agressões. A indenização [dos detrimentos morais] funcionará também como uma espécie de pena privada em benefício da vítima" ${ }^{\prime 3}$. Este e tantos outros doutrinadores adotam, para tanto, os fundamentos expostos por Caio Mário da Silva PEREIRA no sentido de que "o que há de preponderar [para a quantificação da indenização por danos morais] é um jogo duplo de noções: a) de um lado, a idéia de punição ao infrator, que não pode ofender em vão a esfera jurídica alheia; não se trata de imiscuir na reparação uma expressão meramente simbólica e, por esta razão, a sua condenação não pode deixar de considerar as condições econômicas e sociais dele, bem como a gravidade da falta cometida, segundo um critério de aferição subjetivo [...] b) de outro lado, proporcionar à vítima uma compensação pelo dano suportado, pondo-lhe o ofensor nas mãos uma soma que não é o pretium doloris, porém uma ensancha de reparação da afronta" ${ }^{\prime 14}$.

\footnotetext{
12 Judith Martins-Costa - Mariana Souza PArgendler, Usos e Abusos da Função Punitiva ('Punitive Damages' e o Direito Brasileiro), in Revista da Ajuris, ano XXXII, n. ${ }^{\circ} 100$, dez/2005, pág. 253.

${ }^{13}$ S. CAVAlieri Filho, Programa de Responsabilidade Civil, 6a ed., São Paulo, Malheiros, 2005, pág. 103

${ }^{14}$ Instituições de Direito Civil, vol. II, $5^{\text {a }}$ ed., Rio de Janeiro, Forense, 1978, pág. 297. Outros ordenamentos de raiz romano-germânica também admitem a dupla função da indenização dos detrimentos morais. Analisando a prescrição do art. 847 do BGB - que versa sobre a compensação de determinados prejuízos extrapatrimoniais, B. R. KERN, A Função de Satisfação na Indenização do Dano Pessoal, in Revista de Direito do Consumidor, n. ${ }^{\circ} 33$, janeiro/março 2000, pág. 10) sustenta que a indenização lá prevista possui duas finalidades, a de compensar os prejuízos suportados e a de representar uma satisfação ao lesado. Tratando expressamente da satisfação acima aludida, sustenta o autor que: "A questão de saber qual a finalidade que a função de satisfação tem de cumprir, o que ela significa, é discutível. Mencionam-se no máximo três finalidades: de trazer ao lesado um sentimento de satisfação, apaziguar seu senso de justiça ferido; de outro, deve impor ao ofensor um sensível sacrifício patrimonial; e, por último, com isto deve atuar preventivamente no futuro." Atribui-se, assim, à indenização de prejuízos morais, também na Alemanha, a dupla função de compensar e punir/desestimular.
} 
Tal concepção (de que a indenização dos detrimentos morais exerce essa múltipla função, atuando, ao mesmo tempo, de modo a reparar ou compensar os prejuízos suportados e a punir o ofensor e desestimulá-lo da prática de atos ilícitos) encontra, ainda, larga acolhida em nossos Tribunais ${ }^{15}$, admitindo-se como critérios para a quantificação da indenização elementos que, para além de nada ter a ver com a recomposição do patrimônio do lesado, relacionam-se ao desempenho das funções de punição e prevenção, tais como a "situação econômica das partes" e o grau de "culpa do ofensor"16.

A teoria da dupla função da indenização por danos morais já é tão disseminada em nosso país ${ }^{17}$ que se chega a cogitar, até mesmo, da superação do obstáculo legislativo presente no art. 944, caput, do CC/2002, o qual, ao traduzir em palavras o princípio da reparação integral, prescreve que " $a$ indenização mede-se pela extensão do prejuízo". Imbuído desse espírito "transgressor", segue o enunciado de n. ${ }^{\circ}$ 379, estabelecido na IV Jornada de Direito Civil, que, em relação ao indigitado dispositivo legal, prescreve: “o art. 944, caput, do Código Civil não afasta a possibilidade de se reconhecer a função punitiva ou pedagógica da responsabilidade civil",18.

\footnotetext{
${ }^{15}$ No STJ, apenas à guisa de exemplo, observe-se: "O valor do dano moral tem o escopo de atender a sua dupla função: reparar o dano e punir o ofensor para que não volte a reincidir (elemento pedagógico punitivo)." (STJ; $3^{\mathrm{a}}$ T.; RESP n. ${ }^{\text {o }}$ 1014624/RJ; Relator: Min. Vasco Della Giustina; J. 10.03.2009). No mesmo sentido: (STJ; $2^{\mathrm{a}}$ T.; RESP n. ${ }^{\circ}$ 715320/SC; Relatora: Min. Eliana Calmon; J. 11.09.2007). (STJ; $2^{\mathrm{a}}$ Turma; RESP n. ${ }^{\circ}$ 792416/SP; Relatora: Min. Eliana Calmon; J. 07.08.2007). (STJ; 2a Turma; RESP n. ${ }^{\circ}$ 860705/DF; Relatora: Min. Eliana Calmon; J. 24.10.2006); (STJ; 2a T.; RESP n. ${ }^{\mathrm{a}} 474786 / \mathrm{RS}$; Relatora: Eliana Calmon; J. 01.04.2004). (STJ; 2 ${ }^{\mathrm{a}}$ T.; RESP n. ${ }^{\circ}$ 487749/RS; Relatora: Eliana Calmon; J. 03.04.2003); (STJ; RESP n. ${ }^{\circ}$ 337739/SP; Relator: Min. Antônio de Pádua Ribeiro; J. 05.02.2002). (STJ; RESP n. ${ }^{\circ}$ 332589/MS; Relator: Min. Antônio de Pádua Ribeiro; J. 08.10.2001); (STJ; RESP n. ${ }^{\circ}$ 389879/MG; Relator: Min. Sálvio de Figueiredo Teixeira; J. 16.04.2002) e (STJ; RESP n. ${ }^{\circ}$ 173366/SP; Relator: Min. Sálvio de Figueiredo Teixeira; J. 03.12.1998).

16 "A indenização do dano moral tem o caráter não só de compensar a dor, mas também de punição e de prevenção da reincidência. Tal indenização deve ser fixada levando em conta a situação econômica das partes e a culpa do ofensor.” (TJDF; Apelação n. 2006.08.1.002333-2; Relator: Des. Cruz Macedo; J. 27.06.2007). Ainda: (STJ; RESP n. ${ }^{\circ}$ 173366/SP; Relator: Min. Sálvio de Figueiredo Teixeira; J. 03.12.1998); (TAMG; 6 ${ }^{\text {a }}$ Câm.; Apelação no 2.0000.00.357429-4/000; Relatora: Juíza Valdete Leite Machado; J. 18.04.2002) e (TJDF; Apelação n. ${ }^{\circ}$ 2003.01.1.116051-8; Relator: Des. José de Aquino Perpétuo; J. 26.09.2007). Há que se lembrar que tais critérios já encontraram previsão na Lei 5.250/1967 (Lei de Imprensa), a qual estipulava que, para o arbitramento da indenização por danos morais, o juiz da causa deveria ter em conta elementos como "a posição social e política do ofendido" (art. 53, I), "a intensidade do dolo ou o grau de culpa do responsável", bem como "sua situação econômica” (art. 53, I).

17 Nesse sentido, Regina Beatriz Tavares da SILVA aponta que "[a] teoria do desestímulo não só se desenvolveu, bem como se pacificou em nossos Tribunais [...] como meio inibitório de novas ofensas, de novas agressões a direitos da personalidade, que via de regra são os direitos atingidos pelas agressões que acarretam danos morais". (Critérios de Fixação da Indenização do Dano Moral, in Mario Luiz DELGADO Jones Figueirêdo Alves (coords.), Questões Controvertidas no Novo Código Civil, São Paulo, Método, 2003, pág. 262).

${ }^{18}$ Por todas as razões que iremos explorar ao longo da presente dissertação, ousamos discordar do texto do aludido enunciado, advogando pela inafastabilidade do princípio da reparação integral, a não ser no caso da (muito desejada) prévia cominação legislativa a respeito da indenização punitiva.
} 
Assim é que, com o objetivo de encontrar subsídios filosóficos e jurídicos para a implantação e desenvolvimento da teoria da dupla função da indenização por danos morais, doutrina e jurisprudência pátrias passaram a procurar modelos semelhantes no âmbito do Direito Comparado, lançando suas atenções com especial fervor sobre um determinado instituto jurídico, característico dos países da common law, denominado de punitive damages.

Segundo noticiam Judith Martins-Costa e Mariana Souza PARgEndLer, a atração exercida por tal instituto está justamente em sua capacidade de ultrapassar a (supostamente intransponível) cisão entre Direito Público e Direito Privado (especificamente no que tange à contraposição entre Direito Penal e Direito Civil), “introduzindo na responsabilidade civil (e, portanto, em matéria sujeita ao juízo cível) a idéia de "pena privada""19.

Diante do encanto exercido por tal instituto, passou-se a advogar, quer em sede doutrinária ${ }^{20}$, quer em sede jurisprudencial ${ }^{21}$, pela inserção dos punitive damages em nosso Ordenamento Jurídico; isso quando não se procurou, mesmo sem que houvesse prévia e expressa adoção de norma legal nesse sentido, a comparar a estrutura e função de tal instituto com a indenização por danos morais ${ }^{22}$.

${ }^{19}$ Usos e Abusos da Função Punitiva ('Punitive Damages' e o Direito Brasileiro), in Revista da Ajuris, ano XXXII, n. ${ }^{\circ} 100$, dez/2005, pág. 231.

${ }^{20}$ Tratando especificamente sobre a responsabilidade civil do empregador por atos ilícitos perpetrados contra o empregado, mas em lição que nos é de interesse, Enoque Ribeiro dos SANTOS recomenda "fortemente a aplicação dos princípios do exemplary and punitive damages, que se amolda à teoria sancionatória, nos casos concretos que tramitam em grande quantidade em nossos Pretórios, de forma a aumentar o sentimento de prevenção e de maior cuidado quando se trata de manejo de direitos extrapatrimoniais". (Contribuições à Fixação da Indenização do Dano Moral Trabalhista - A tese da aplicação dos exemplary ou punitive damages, in Suplemento Trabalhista, ano 40, vol. 90, São Paulo, LTr, 2004, pág. 400).

${ }^{21}$ Seguem nesse sentido as palavras do Des. Amorim Cantuária, como se observa de excertos de alguns dos julgados de sua relatoria: "lastimável que no nosso direito não exista a figura do punitive damage, tão importante no direito anglo-saxão, como mecanismo de tutela à boa-fé e à lealdade, que devem reger as relações sociais, e, em especial o cumprimento das obrigações derivadas de contratos." (TJSP; Apelação n. ${ }^{\circ}$ 974.204-00/6; Relator: Des. Amorim Cantuária; J. 03.03.2009). Ainda, da lavra do mesmo relator, interessa o seguinte trecho: "Já é hora de admitirmos a sanção civil como fórmula para punir empresas irresponsáveis" (TJSP; Apelação n. ${ }^{\circ}$ 939442-0/0; Relator: Des. Amorim Cantuária; J. 04.11.2008).

22 "Os danos morais se revestem de caráter indenizatório, visando reparar o prejuízo psíquico experimentado e de caráter punitivo, representando uma censura ao comportamento da parte ofensora. A doutrina norte-americana bem salienta esse caráter ao discorrer sobre os 'punitive damages'." (TJSP; Apelação n. ${ }^{\circ}$ 504.287-4/8-00; Relator: Des. Maurício Simões de Almeida Botelho Silva; J. 29.10.2008). No mesmo sentido: (TJSP; Apelação n. ${ }^{\circ}$ 7140024-1; Relator: Des. Maurício Simões de Almeida Botelho Silva; J. 20.06.2008); (TJSP; Apelação n. ${ }^{\circ}$ 619.421-5/8-00; Relator: Des. Almeida Sampaio; J. 27.08.2009) e (TJSP; Apelação n. ${ }^{\circ}$ 1248314-8; Relator p/acórdão: Des. Soares Levada; J. 16.08.2007). 
A constância com que se alude a este tema em nossos Tribunais, bem como a atualidade e relevância da questão atinente à indenização por danos morais e proteção da dignidade da pessoa humana deram ensejo à produção intelectual em nosso país destinada a estudar, especificamente, as funções punitiva e dissuasória da responsabilidade civil, e a traçar termos comparativos com o instituto dos punitive damages ${ }^{23}$, mesmo caminho seguido, também, por parte da doutrina de países da Europa Continental ${ }^{24}$.

Mais do que a produção monográfica a respeito do tema, seguindo uma linha previamente iniciada por uma vasta gama de leis europeias (tal como se verificou, por ex., na Grécia ${ }^{25}$, Itália ${ }^{26}$ e na Espanha ${ }^{27}$ ), também em nosso país procurou-se introduzir, por meio de iniciativas legislativas, de uma maneira ou de outra, uma função punitiva para a responsabilidade civil.

\footnotetext{
${ }^{23}$ Veja-se, especificamente sobre o tema, em ordem cronológica de publicação e/ou apresentação, Eduardo UILAN, Responsabilidade Civil Punitiva, Tese (Doutorado) - Faculdade de Direito da USP, São Paulo, 2003; Vitor Fernandes GonçALVES, A Punição na Responsabilidade Civil: A indenização do dano moral e da lesão a interesses difusos, Brasília, Brasília Jurídica, 2005; André Gustavo Corrêa de ANDRADE, Dano Moral e Indenização Punitiva: Os punitive damages na experiência do common law e na perspectiva do Direito brasileiro, Rio de Janeiro, Forense, 2006; Caroline VAZ, Funções da Responsabilidade Civil - Da Reparação à Punição e Dissuasão - Os punitive damages no Direito Comparado e Brasileiro, Porto Alegre, Livraria do Advogado, 2009 e Marcela Alcazas BASSAN, As Funções da Indenização por Danos Morais e a Prevenção de Danos Futuros, Dissertação (Mestrado) - Faculdade de Direito da USP, São Paulo, 2009.

${ }^{24}$ Especificamente sobre o tema, novamente em ordem cronológica de publicação, P. GALlo, Pene Private e Responsabilità Civile, Milano, Giuffrè, 1996, P. M. LourençO, A Função Punitiva da Responsabilidade Civil, Coimbra, Coimbra, 2006 e M. G. Baratella Le Pene Private, Milano, Giuffrè, 2006.

${ }^{25}$ A respeito do ordenamento grego, G. GEORGIADES noticia que a Section 10 (9) (b) do Greek Consumer Protection Act prevê a possibilidade de que se condene determinada empresa ao pagamento de determinada quantia, a título de "satisfação", caso ela seja acionada em demanda promovida por associação de consumidores que pretenda ver-se ressarcida por práticas tais como "use of unfair terms in contract", "selling of defective services or products" ou "engagement in misleading advertising or deceptive selling practices." Para aferir o quantum indenizatório, "the court shall take into consideration the intensity of the insult of the law and order that the illegal conduct has caused, the size of the defendant's enterprise and especially its annual turnover, as well as the needs for general and specific prevention". (Punitive Damages in Europe and the USA: Doctrinal Differences and Practical Convergence, in Revue Hellénique de Droit International, ano 58, Éditions Ant. N. Sakkoulas, 2005, pág. 156/158).

${ }^{26}$ A Lei italiana de 8 de julho de 1986, de Proteção do Ambiente, impõe ao lesante a obrigação de pagar " $a$ título de indemnización un importe superior al daño realmente sufrido por la víctima, hasta representar el monto del beneficio económico alcanzado por el responsable como consecuencia del ilícito." A respeito de tal disposição legal, R. D. PIZARro sustenta que tal plus indenizatório tem "función netamente punitiva" (Daño Moral - Prevención, Reparación, Punición: El Daño Moral em las Diversas Ramas del Derecho, Buenos Aires, Hammurabi, 1996, pág. 376).

${ }^{27}$ A Lei n. ${ }^{\circ}$ 1, de 5 de maio de 1982, denominada "Protección civil del derecho al honor, a la intimidad personal y familiar y a la propia imagen" prevê, em seu art. $9^{\circ}$, que a indenização deve também levar em conta "el beneficio obtenido por el causante de la lesióncomo consecuencia de la misma"; ainda que a utilização deste critério faça com que o valor da indenização supere o montante dos prejuízos efetivamente suportados. Sobre o tema, cfr. R. D. PiZArro, Daño Moral - Prevención, Reparación, Punición: El Daño Moral em las Diversas Ramas del Derecho, Buenos Aires, Hammurabi, 1996, pág. 376 e P. M. LOURENÇO, A Função Punitiva da Responsabilidade Civil, Coimbra, Coimbra, 2006, pág. 402.
} 
Assim o foi com a redação original (objeto de veto presidencial) dos artigos 16 e 45 do Projeto de Código de Defesa do Consumidor, que, para além da indenização decorrente de fato do produto ou do serviço, previam a incidência da figura da multa civil, em valor equivalente a até "um milhão de Bônus do Tesouro Nacional”, incidente quando estivéssemos diante de alta periculosidade do produto ou serviço que provocou o dano, ou grave imprudência, negligência ou imperícia do fornecedor.

Também foi o caso do Projeto de Lei de n. ${ }^{\circ}$ 6960/2002, de autoria do então deputado federal Ricardo Fiúza, que previa justamente a inclusão de um parágrafo segundo ao artigo 944 do Código Civil, incluindo a menção de que "a reparação do dano moral deve constituir-se em compensação ao lesado e adequado desestímulo ao lesante"; mesma redação planejada por seu substitutivo, o Projeto de Lei n. ${ }^{\circ}$ 276/2007.

É, ademais, o caso do ainda pendente Projeto de Lei do Senado n. ${ }^{\circ}$ 413/07, de relatoria do senador Renato Casagrande, que, sob o pretexto de dar fundamento legal ao já constante entendimento jurisprudencial, e a menções doutrinárias acerca da dupla finalidade da indenização por danos morais, também propõe seja acrescido um parágrafo segundo ao artigo 944, CC para que se passe a admitir expressamente as funções compensatória, preventiva e punitiva da indenização.

Vê-se, que as prévias tentativas de introdução legislativa do instituto da indenização punitiva, as contendas doutrinárias, a aplicação praticamente pacífica que se faz em nossos Tribunais e, principalmente, a atual discussão acerca do tema, demonstram claramente a relevância das questões a serem analisadas na presente dissertação, o que nos motiva a lançar com maior profundidade os olhos sobre a questão.

\section{Principais QUeStões A SEREM ANALISADAS}

$\mathrm{Na}$ presente dissertação, tem-se por escopo o estudo do instituto da responsabilidade civil, com a finalidade de delinear as funções a serem por ela exercidas para que se possa assegurar a existência e manutenção de uma sociedade solidária e segura, pautada pelos princípios e valores consagrados pela Constituição da República. 
Nesse contexto, procuraremos desenvolver o raciocínio dogmáticocientífico que culminará com as conclusões principais de que: (i) o ordenamento jurídico deve dispor de instrumentos adequados para tutelar eficazmente os bens e interesses de maior relevância social, bem como para manter o equilíbrio social, o que se fará por meio da criação e manutenção de uma sociedade livre, justa, solidária e segura (valores estes insculpidos nos arts. $3^{\circ}$, I, e $5^{\circ}$, caput, da CF/88); (ii) os instrumentos de que se dispõe no momento (especificamente o Direito Penal e o Direito Administrativo Sancionador) não se mostram adequados para a persecução desses objetivos, devendo dar lugar a um instrumento que seja, ao mesmo tempo, suficientemente flexível e adequadamente severo; (iii) nesse contexto, é interessante que o instituto da responsabilidade civil, caracterizado pela flexibilidade de atuação e pela ampla possibilidade de sancionar condutas ilícitas, seja aparelhado com um mecanismo adequado para o eficiente desempenho de tais funções, de prevenção e punição; (iv) o supra referido mecanismo é justamente o que se passará a denominar de indenização punitiva, sanção a ser aplicada por meio dos pressupostos, regras e princípios da responsabilidade civil, mas que não exercerá função compensatória, destinando-se justamente à punição do ofensor e à prevenção de novos atos ilícitos; e, por fim, (v) a conclusão de que é plenamente admissível que o instituto da responsabilidade civil passe a ser utilizado para a persecução de tais finalidades, contanto que haja a prévia cominação legal que prescreva não apenas os pressupostos (objetivos e subjetivos) para a incidência da indenização punitiva, mas, também, os critérios a serem seguidos pelo julgador quando da dosimetria da pena (os quais não se confundirão com, e não se limitarão à, extensão do dano).

Para atingirmos tais conclusões, dividiremos a presente dissertação em seis capítulos.

No primeiro capítulo ("punitive damages no sistema da common law"), analisaremos detidamente os assim chamados punitive damages, instituto típico dos países da common law que tem o condão de unificar a flexibilidade do Direito Civil e as funções ordinariamente exercidas pelo Direito Penal (de punição do ofensor e prevenção de ilícitos). A apreciação de suas origens, suas funções, suas estremas e as polêmicas em que atualmente se insere serão de grande valia para as ponderações que, na seqüencia, procuraremos fazer a respeito da indenização punitiva. 
No segundo capítulo ("necessidade de adoção da indenização punitiva"), analisaremos os desenvolvimentos contemporâneos pelos quais passou o instituto da responsabilidade civil nos países da civil law, para, à luz de tais considerações, respondermos à questão de se, nesse contexto, é ou não necessária a adoção de um mecanismo como a indenização punitiva para assegurar a eficiente tutela dos bens e interesses de maior relevância social.

No terceiro capítulo (“a viabilidade da adoção da indenização punitiva”), procuraremos enfrentar (e, quando assim o entendermos possível, rejeitar) as críticas mais costumeiramente erguidas contra a indenização punitiva, utilizando-nos de tal análise para concluir que, dadas as características de nossa ordenação constitucional, a adoção da indenização punitiva demanda a prévia cominação legal, tanto para delinear seus pressupostos de incidência, quanto para fixar os critérios para a sua quantificação.

Vencidas as críticas, no quarto capítulo ("introdução da indenização punitiva no ordenamento jurídico brasileiro") procuraremos tratar de todas as questões relevantes a respeito do regramento legislativo que se deve emprestar à indenização punitiva, desde seus pressupostos (objetivos e subjetivos) de incidência, até questões correlatas, pertinentes ao direito material e ao direito processual.

No quinto capítulo (“a quantificação da indenização punitiva”), trataremos sobre o mister judicial de arbitramento da indenização punitiva, oportunidade na qual versaremos sobre os critérios considerados aptos para tanto, bem como sobre os métodos para o controle (judicial ou legislativo) do quantum indenizatório.

Ao final, utilizaremos o sexto capítulo ("a introdução legislativa da indenização punitiva") para, em primeiro lugar, passar em revista aquelas que consideramos as mais notórias e relevantes tentativas de se introduzir tal instituto jurídico em nosso país, ponderando suas qualidades e deficiências, para, na seqüência, apresentarmos nossas modestas sugestões de lege ferenda para o tema. 


\section{A OPÇÃO PELA EXPRESSÃO INDENIZAÇÃo PUNITIVA}

Cumpre-nos, ainda em sede preliminar, tecer alguns comentários acerca da expressão que dá nome ao presente estudo e que passará a ser utilizada para designar a utilização do instituto da responsabilidade civil em sua função de punição, qual seja, indenização punitiva. Trata-se, a nosso ver, daquela que, de um lado, melhor traduz a expressão inglesa punitive damages e que, de outro, melhor representa os fins a que se pretende chegar com o presente estudo.

Por certo, a expressão indenização punitiva não é isenta de críticas, das quais a que nos parece mais incisiva é justamente aquela que, partindo do conteúdo usualmente atribuído ao vocábulo indenização, afirma que a expressão "indenização punitiva" representaria verdadeira "contradição em termos".

Com efeito, partindo-se da premissa de que a responsabilidade civil assume função primordialmente compensatória, a expressão indenizar significa "apagar o dano, o que só se consegue através da reposição do patrimônio na situação em que se encontrava antes $^{, 28}$. Neste sentido, indenização é, propriamente, a eliminação do prejuízo imposto e, por ser um instrumento de persecução da função compensatória da responsabilidade civil, a mesma expressão (indenização) não poderia ser indistintamente utilizada para também designar a persecução de eventuais fins punitivos ${ }^{29}$. Por tais razões, Eduardo Ribeiro de OLIVEIRA sustenta não se tratar de expressão das mais adequadas ${ }^{30}$.

Ainda que pese a autoridade da crítica, após lançarmos os olhos sobre as demais expressões às quais aludem doutrina e jurisprudência para designar o mesmo instituto (a sanção pecuniária, decorrente de um processo civil, imposto sobre o causador do ilícito com as finalidades de puni-lo pelo mal causado e dissuadi-lo e à sociedade quanto ao cometimento de novos ilícitos), não nos afigura adequada a opção por outra.

\footnotetext{
${ }^{28}$ Fernando Noronha, Direito das Obrigações, vol. I, $2^{\text {a }}$ ed., São Paulo, Saraiva, 2007, pág. 437.

${ }^{29}$ P. M. Lourenço, A Função Punitiva da Responsabilidade Civil, Coimbra, Coimbra, 2006, pág. 377

${ }^{30}$ Prefácio, in Vitor Fernandes GonçALVES, A Punição na Responsabilidade Civil: A indenização do dano moral e da lesão a interesses difusos, Brasília, Brasília Jurídica, 2005, pág. 12.
} 
Por um lado, a expressão "danos punitivos", comumente utilizada como tradução para punitive damages, parece-se-nos nada mais que um falso cognato ${ }^{31}$, saltando aos olhos sua inadmissibilidade por, ao menos, dois motivos.

A uma, como se verificará com maior profundidade adiante, a expressão damages, em inglês, é representativa não apenas dos danos suportados pelo ofendido, mas, também, da quantia em dinheiro, devida pelo ofensor ao ofendido, como compensação pelo ilícito perpetrado ${ }^{32}$, quantia esta à qual chamamos de indenização.

A duas, e o que se mostra ainda mais grave, é certo que o que se procura punir é o cometimento de atos ilícitos altamente reprováveis, qualificados pelo dolo ou culpa grave do ofensor, e não os danos decorrentes desse ilícito. Nesse sentido, os danos jamais poderiam ser tidos como punitivos ${ }^{33}$.

Por outro lado, mostram-se igualmente inaplicáveis as expressões empregadas por Caroline $\mathrm{VAZ}^{34}$, tais como "sanção pecuniária" ou "prestações punitivas/dissuasórias".

Em primeiro lugar, a expressão "sanção pecuniária" é muitíssimo ampla, a qual abrange não apenas o que aqui designamos de indenização punitiva, mas, também, todas as sanções que possuem, como estrutura, a imposição de obrigação ao pagamento de determinada quantia em pecúnia, entre as quais se encontram, e.g., a indenização compensatória, as multas criminais e administrativas e as astreintes, sanções estas que exercem funções nitidamente distintas entre si.

31 Também nesse sentido, Maria Celina Bodin de MoRAes, Punitive Damages em Sistemas Civilistas: Problemas e Perspectivas, in RTDC, vol. 18, abr./jun. 2004, págs. 47/48. Veja-se, ainda quanto a este ponto, o recente julgado proferido pelo Tribunal de Justiça de São Paulo: “[c]ompreender-se-á a expressão alienígena 'punitive damages' como a indenização fixada como o intuito de punir o agente da conduta causadora do dano cujo ressarcimento é autorizado pela Lei em favor da vítima. Em tradução livre a expressão significaria 'danos punitivos', sendo perceptível uma falha semântica eis que na verdade não se trata de 'danos' mas sim de uma indenização com o propósito de sancionar o infrator." (TJSP; Apelação n. ${ }^{\circ}$ 7.133.727-6; Relatora: Des. Maria Goretti Farias; J. 14.12.2007).

32 B. A. GARNER, Black's Law Dictionary, $7^{\text {th }}$ ed., St. Paul, West Group, 1999, pág. 393: “[d]amages are sum of money which a person wronged is entitled to receive from the wrongdoer as compensation for the wrong."

${ }^{33}$ R. D. Pizarro, Daño Moral - Prevención, Reparación, Punición: El Daño Moral em las Diversas Ramas del Derecho, Buenos Aires, Hammurabi, 1996, pág. 374 e P.M. LouRENÇO, A Função Punitiva da Responsabilidade Civil, Coimbra, Coimbra, 2006, pág. 378.

${ }^{34}$ Funções da Responsabilidade Civil - Da Reparação à Punição e Dissuasão - Os punitive damages no Direito Comparado e Brasileiro, Porto Alegre, Livraria do Advogado, 2009. 
Em segundo lugar, também nos parece inadequadamente ampla a expressão "prestações punitivas/dissuasórias", que, a nosso ver, serve para designar todas e quaisquer prestações aptas a exercer uma função punitiva ou dissuasória, prestações estas que não necessariamente incluem o pagamento de quantia em pecúnia.

Desta feita, mostra-se muito mais adequada, para a consecução dos fins aqui pretendidos, a utilização da expressão indenização punitiva. Ela designa de maneira clara: (i) seu caráter de sanção; (ii) o fato de ser imposta em processo realizado sob a égide do Juízo Cível; (iii) sua estrutura de obrigação ao pagamento de quantia em pecúnia; e (iv) sua função punitiva. Trata-se, enfim, da "mais perfeita tradução para o português da expressão inglesa punitive damages" ${ }^{35}$, instituto sobre o qual lançaremos, em primeiro lugar, nossos olhos para, dessa análise, procurarmos extrair as conclusões a que se pretendeu atingir com o presente estudo.

\footnotetext{
${ }^{35}$ Vitor Fernandes GonÇALVES, A Punição na Responsabilidade Civil: A indenização do dano moral e da lesão a interesses difusos, Brasília, Brasília Jurídica, 2005, pág. 25; Anderson SCHREIBER, Novos Paradigmas da Responsabilidade Civil: Da Erosão dos Filtros da Reparação à Diluição dos Danos, São Paulo, Atlas, 2009, pág. 203 e Paulo de Tarso Vieira SAnseverino, Princípio da Reparação Integral (Indenização no Código Civil), São Paulo, Saraiva, 2010, pág. 68.
} 


\section{CAPÍTULO I - PUNITIVE DAMAGES NO SISTEMA DA COMMON} LAW

Partindo das constatações de que, há algumas décadas, a indenização punitiva passou a se tornar um tema de grande relevância no Brasil e nos demais países de raiz romano-germânica, e de que, para buscar maiores subsídios filosóficos e jurídicos para a adoção desse sanção, os juristas desses países lançam os olhos avidamente sobre o instituto dos punitive damages, característico dos países da common law, procuraremos, no presente capítulo, analisar as características essenciais de tal instituto.

Para atingirmos tal objetivo, procuraremos traçar um perfil geral dos punitive damages, tratando, de maneira aprofundada, de aspectos que nos pareceram relevantes para a correta compreensão do instituto, desde sua conceituação, passando pela análise de seus antecedentes históricos, das razões comumente aventadas para justificar o seu surgimento e das atuais controvérsias e polêmicas acerca de sua incidência e quantificação. No desempenho dessa tarefa, focalizaremos nossa atenção no tratamento empregado a tal instituto na Inglaterra e, principalmente, nos Estados Unidos da América, país no qual os punitive damages se desenvolveram de modo a representar uma marcante faceta da responsabilidade civil daquele país ${ }^{36}$.

Da análise realizada neste capítulo, procuraremos extrair pontos de convergência para a exposição comparativa que será realizada na segunda parte desta dissertação, na qual, à luz do quanto expusermos sobre os punitive damages, iremos nos debruçar sobre o interesse/necessidade e a viabilidade da introdução, em países de raiz jurídica romano-germânica (e em nosso país, em particular), da indenização punitiva.

\footnotetext{
${ }^{36}$ Em razão das características específicas do regime federalista adotado pelos Estados Unidos da América, procurar-se-á, na presente dissertação, evitar a utilização de expressões como “o direito norte-americano", "o ordenamento dos Estados Unidos" ou congêneres. Ademais, pelas mesmas razões, quando se tratar do regime jurídico dos puntive damages em especial, bem como de quaisquer outros institutos jurídicos típicos daquele país, procurar-se-á apresentar, sempre que possível, as eventuais peculiaridades de tratamento adotado em diversos Estados Membros, ou mesmo no âmbito federal. Sobre as peculiaridades do regime federalista norte-americano, e sobre suas complicações para o estudioso do Direito, cfr. Guido Fernando Silva SoARES, Common Law: Introdução ao Direito dos EUA, $2^{\text {a }}$ ed., São Paulo, Saraiva, 2000, esp. págs. 58 e ss.
} 


\section{O CONCEITO DE PUNITIVE DAMAGES}

De saída, e para que os estudos que se seguem possam ser mais proveitosos, cumpre-nos analisar o que se quer, propriamente, dizer com a expressão punitive, exemplary ou aggravated damages ${ }^{37}$.

Para tanto, há de se frisar que, nos países da common law, a expressão damages serve para designar as conseqüências pecuniárias decorrentes do cometimento de um ato ilícito ("tort") ${ }^{38}$, expressão esta que poderíamos traduzir, com as ressalvas já expostas, para a nossa "indenização". Demais disso, e novamente em atenção às peculiaridades do sistema de responsabilidade civil dos países da common law, os damages podem assumir diversas feições e funções ${ }^{39}$. Destas diversas espécies, interessam-nos, no momento, para fins comparativos, os assim chamados compensatory e os punitive damages.

Os primeiros são aqueles "concedidos para reparar um prejuízo real, colocando o autor [da demanda], tanto quanto o dinheiro permita, na posição em que estaria se o ilícito não tivesse ocorrido" ${ }^{40}$; ou, nas palavras de B. A. GARNER, uma "quantia em montante suficiente para indenizar a pessoa prejudicada pelo dano suportado"41. Os compensatory damages, como se depreende de sua própria nomenclatura, destinam-se a compensar o ofendido pelos prejuízos suportados, devendo-se consubstanciar numa quantia em pecúnia suficiente para restitui-lo ao status quo ante. Trata-se, portanto, de conceito muito próximo ao que temos de indenização compensatória, nos moldes em que prevista no art. 944, CC/2002.

\footnotetext{
${ }^{37}$ Há que se frisar, desde já, que a expressão aggravated damages designa institutos jurídicos diferentes na Inglaterra e nos Estados Unidos da América. Apenas nestes é que a expressão é sinônimo de punitive damages. Sobre o tema, A. J. SeboK - V. WilcoX, Aggravated Damages, in H. KoziOL - V. WILcoX, Punitive Damages: Common Law and Civil Law Perspectives, Wien, Springer, 2009, págs. 257/274.

38 "[D]amages are sum of money which a person wronged is entitled to receive from the wrongdoer as compensation for the wrong." (B. A. GARNER, Black's Law Dictionary, 7ª ed., St. Paul, West Group, 1999, pág. 393). Ainda sobre o conceito de damages, cfr. S. DEAKIN - A. JOHNSTON - B. MARKESINIS, Markesinis and Deakin's Tort Law, $6^{\text {th }}$ ed., New York, Oxford, 2008, págs. 939 e ss.

${ }^{39}$ Sobre as diversas espécies de damages, cfr. Eduardo Uilan, Responsabilidade Civil Punitiva, Tese (Doutorado) - Faculdade de Direito da USP, São Paulo, 2003, pág. 28.

${ }^{40}$ Eduardo UILAN, Responsabilidade Civil Punitiva, Tese (Doutorado) - Faculdade de Direito da USP, São Paulo, 2003, pág. 28.

${ }^{41}$ No original: "[d]amages sufficient in ammount to indemnify the injured person for the loss suffered" (Black's Law Dictionary, $7^{\text {th }}$ ed., St. Paul, West Group, 1999, pág. 394).
} 
Já os últimos, a despeito de se aproximarem dos primeiros por, assim como eles, representarem uma sanção pecuniária decorrente do cometimento de um ato ilícito, imposta sobre o ofensor no curso de um processo civil, deles se distinguem nitidamente por não exercerem (ao menos não de maneira principal) uma função compensatória. Eles são, nas palavras de E. URSO, "uma condenação pecuniária que pode ser imposta ao lesante se seu comportamento for considerado particularmente reprovável", quantia esta que "se soma à condenação imposta a título compensatório (compensatory damages)"42. Ou, como afirma D. G. OwEN, “[p]unitive ou exemplary damages são impostos em adição aos compensatory damages para punir o demandado pelo cometimento de um ato grave ou abusivo, bem como para prevenir que o demandado e outros venham a cometer condutas semelhantes no futuro" ${ }^{, 43}$.

Como se disse, ao contrário dos compensatory damages, que se destinam a compensar a vítima pelo prejuízo suportado, os punitive damages visam a, primordialmente, punir o ofensor pelo ilícito cometido e desestimular o ofensor em especial, e a Sociedade em geral, do cometimento de semelhantes ilícitos no futuro ${ }^{44}$. Justamente por servirem de instrumento de punição e desestímulo, os punitive damages miram apenas os ilícitos civis mais reprováveis, incidindo adequadamente apenas quando o ofensor se conduz de maneira intencional, maliciosa, ou com grave negligência e indiferença em relação aos direitos e interesses do ofendido ${ }^{45}$.

\footnotetext{
${ }^{42}$ No original: "uma condanna pecuniaria que può esse inflitta al danneggiante ove il suo comportamento sia stato particularmente riprovevole, e che si aggiunge alla condanna avente finalità risarcitorie (compensatory damages)". (Recenti Sviluppi nella Giurisprudenza Statunidense e Inglese in Materia di Punitive Damages: $i$ Casi TXO Production Corporation v. Alliances Resources Corporation e AB v. South West Water Services Ltd., in Rivista di Diritto Civile, vol. 41, n. 1, genn.-febr./1995, pág. 81).

${ }^{43}$ No original: "[p] unitive damages are assessed in addition to compensatory damages to punish the defendant for the commission of an aggravated or outrageous act of misconduct and to deter him and others from such conduct in the future." (Punitive Damages in Products Liability, in Michigan Law Review, vol. 74, 1976, pág. 1265).

${ }^{44}$ Nesse sentido, a Supreme Court norte-americana afirmou, em Gertz v. Robert Welch Inc. que os punitive damages não representam “compensação pelo prejuízo, mas multas privadas impostas por um júri civil para punir condutas reprováveis e prevenir seu cometimento futuro". No original: "[punitive damages are] not compensation for injury, but private fines levied by civil juries to punish reprehensible conduct and to deter its future occurence" (418 U.S. 323 1974, pág. 350).

45 D. G. Owen, Punitive Damages in Products Liability, in Michigan Law Review, vol. 74, 1976, págs. 1265/1266 e Eduardo UILAn, Responsabilidade Civil Punitiva, Tese (Doutorado) - Faculdade de Direito da USP, São Paulo, 2003, pág. 28.
} 
Ademais, tanto na Inglaterra quanto nos Estados Unidos da América, os punitive damages são usualmente (salvo expressas exceções legislativas, características de determinados Estados norte-americanos) impostos e quantificados por meio de um corpo de jurados, e não pelo juiz togado ${ }^{46}$.

É, enfim, nesse sentido que se passará a utilizar a expressão punitive damages: de quantia pecuniária, geralmente imposta por um corpo de jurados, como forma de sanção a um ato ilícito altamente reprovável, cuja função é a de punir o ofensor e de prevenir o cometimento de novos ilícitos futuros, e que, por fim, deve ser imposta ao ofensor em adendo e independentemente de eventual indenização compensatória a que possa fazer jus o ofendido.

\section{ANTECEDENTES REMOTOS DOS PUNITIVE DAMAGES}

De um modo geral, a doutrina aponta que os punitive damages, nos moldes em que os conhecemos atualmente, ter-se-iam originado de previsões normativas que impunham ao ofensor, como resposta ao cometimento de atos ilícitos danosos, o pagamento de quantia que correspondesse a um múltiplo do valor dos prejuízos

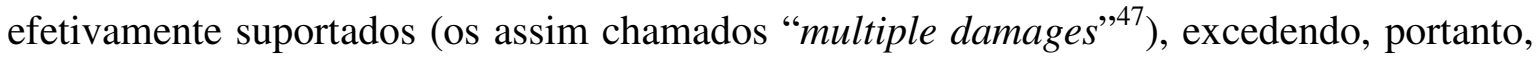
seus limites e extrapolando a mera compensação.

Ao procurar buscar as origens de tais previsões normativas, verifica-se que os punitive damages lançam raízes, ao mesmo tempo, em dispositivos legais do Direito Antigo [tais como o Código de Hamurabi (2000 AC) e o Código de Manu (200 AC)], no Direito Romano (e isto desde a Lei das XII Tábuas) ${ }^{48}$, bem como no direito inglês medieval ${ }^{49}$.

\footnotetext{
${ }^{46}$ Vitor Fernandes GonÇALVES, A Punição na Responsabilidade Civil: A indenização do dano moral e da lesão a interesses difusos, Brasília, Brasília Jurídica, 2005, págs. 75/78.

${ }^{47}$ G. B. BELL - P. E. PEARCE, Punitive Damages and the Tort System, in University of Richmond Law Review, vol. 22, 1987, pág. 3: "Punitive damages evolved from the statutory remedy of awarding multiple damages." No mesmo sentido, Marcela Alcazas BASSAn, As Funções da Indenização por Danos Morais e a Prevenção de Danos Futuros, Dissertação (Mestrado) - Faculdade de Direito da USP, São Paulo, 2009, pág. 56.

${ }^{48}$ M. M. Belli SR., Punitive Damages: Their History, Their Use and Their Worth in Present-Day Society, in UMKC Law Review, vol. 49, n. 1, 1980, págs. 2/3 e G. B. BELL - P. E. PEARCE, Punitive Damages and the Tort System, in University of Richmond Law Review, vol. 22, 1987, pág. 3. K. M. ZITZER relembra que até mesmo no Velho Testamento se previa a incidência de uma espécie de multiple damages, ao se prescrever (cfr. Exodus
} 
Aos que sustentam a existência de inspiração romana no instituto dos punitive damages, estes teriam decorrido da previsão, constante tanto na Lei das XII Tábuas quanto em dispositivos subseqüentes, no sentido de apenar determinadas condutas por meio do pagamento de um múltiplo do dano efetivamente sofrido pela vítima ${ }^{50}$.

Nesse sentido, a doutrina noticia que os delitos privados ("delicta privata", "delictum" ou "maleficium"), os quais, em oposição aos delitos públicos ("crimen"), consubstanciavam-se em ofensas à pessoa ou ao patrimônio de um indivíduo, eram sancionados por meio da imposição de uma pena ("poena privata"), verdadeira sanção punitiva, a qual consistia, geralmente, na imposição de uma sanção pecuniária de valor equivalente a um múltiplo do prejuízo suportado (o dobro, o triplo ou o quádruplo) $)^{51}$.

Não tendo o Direito Romano previsto uma regra geral no que toca aos ilícitos civis, esses eram tidos como hipóteses típicas, as quais se resumiam, essencialmente, em quatro figuras: (i) o furtum ("o apoderamento fraudulento, com vista à obtenção dum lucro, ou duma coisa ou do seu uso ou da sua posse") $)^{52}$, o qual, como decorrência de uma ação penal, poderia dar ensejo à condenação do ofensor ao pagamento do dobro ou do triplo do valor da coisa furtada, se o ofensor não fosse pego em flagrante ${ }^{53}$; (ii) a rapina (a "subtração violenta de uma res alheia") ${ }^{54}$, a qual, em razão da violência que lhe era característica, era sancionada por meio do pagamento de valor mais elevado do que o exigido em caso de furtum, equivalente ao quádruplo do prejuízo causado ${ }^{55}$; (iii) a iniuria (a "ofensa à

22:1) que "[s]e um homem furtar um touro, ou uma ovelha, e matá-lo, ou vendê-lo, ele deverá devolver cinco touros por um touro, e quatro ovelhas por uma ovelha". No original: "If a man shall steal an ox, or a sheep, and kill it, or sell it, he shall restore five oxen for an ox, and four sheep for a sheep." (Punitive Damages: A Cat's Clavicle in Modern Civil Law, in The John Marshall Law Review, vol. 22, 1988, pág. 660).

${ }^{49}$ K. M. ZITZER, Punitive Damages: A Cat's Clavicle in Modern Civil Law, in The John Marshall Law Review, vol. 22, 1988, págs. 559/662 e Eduardo UILAN, Responsabilidade Civil Punitiva, Tese (Doutorado) Faculdade de Direito da USP, São Paulo, 2003, pág. 30.

${ }^{50}$ Eduardo UILAN, Responsabilidade Civil Punitiva, Tese (Doutorado) - Faculdade de Direito da USP, São Paulo, 2003, pág. 28.

${ }^{51}$ P. M. LouREnÇO, A Função Punitiva da Responsabilidade Civil, Coimbra, Coimbra, 2006, págs. 35/37, José Carlos MoreIRA Alves, Direito Romano, vol. II, 6 a ed. Rio de Janeiro, Forense, 2000, págs. 223/224 e A. S. JuSTO, Direito Privado Romano, vol. II, $3^{\mathrm{a}}$ ed., Coimbra, Coimbra, 2008, págs. 119/123.

${ }_{52}$ A. S. Justo, Direito Privado Romano, vol. II, $3^{\mathrm{a}}$ ed., Coimbra, Coimbra, 2008, pág. 123.

${ }^{53}$ P. M. Lourenço, A Função Punitiva da Responsabilidade Civil, Coimbra, Coimbra, 2006, págs. 39/40. Afirma a autora que, se o ofensor fosse pego em flagrante delito ("furtum manifestum"), a sanção poderia, inclusive, ser a de pena de morte.

${ }^{54}$ A. S. Justo, Direito Privado Romano, vol. II, $3^{\text {a }}$ ed., Coimbra, Coimbra, 2008, pág. 128.

${ }^{55}$ P. M. Lourenço, A Função Punitiva da Responsabilidade Civil, Coimbra, Coimbra, 2006, pág. 38. 
integridade física ou moral de uma pessoa") ${ }^{56}$, cuja sanção, no período clássico, passou a ser livremente imposta pelo pretor, de acordo com a maior ou menor gravidade do ilícito perpetrado ${ }^{57}$; e (iv) o damnum iniuria datum (a "produção culposa de um dano em res alheia" ${ }^{58}$, o qual, no específico caso da destituição de tutor que houvesse se conduzido com dolo, causando prejuízo ao tutelado, poderia dar ensejo à condenação do ofensor ao pagamento do dobro do prejuízo imposto ${ }^{59}$.

Sustenta-se que o regramento dos delitos privados, especialmente as sanções previstas pelos romanos quanto ao pagamento de múltiplos do valor do prejuízo sofrido, teria servido "de modelo aos legisladores da época de Eduardo I [rei da Inglaterra] para atribuir, à parte prejudicada por ato de terceiro, o dobro ou o triplo dos danos por ela sofridos" ${ }^{\prime 60}$; previsões legais estas que, como se verá abaixo, teriam influenciado os modernos punitive damages.

Já no que toca ao direito medieval inglês, diz-se que a teoria dos punitive damages finca suas origens no período anglo-saxônico, anterior à invasão normanda ${ }^{61}$. Com efeito, o sistema saxão não distinguia ilícitos de natureza civil (os quais, posteriormente, dariam origem aos "torts") e os ilícitos de origem criminal (os quais, no futuro, constituiriam "crimes"), prevendo, sempre, o pagamento de uma quantia em pecúnia como resposta a uma "má conduta" ("wrongdoing") ${ }^{62}$. Justamente em razão da

${ }_{57}^{56}$ A. S. Justo, Direito Privado Romano, vol. II, 3 a ed., Coimbra, Coimbra, 2008, pág. 129.

${ }^{57}$ José Carlos MoreIRA Alves, Direito Romano, vol. II, 6 ${ }^{\mathrm{a}}$ ed. Rio de Janeiro, Forense, 2000, pág. 233. P. M. LOURENÇO afirma que a dificuldade de quantificação da sanção decorrente da iniuria levou à comparação deste delito com os punitive damages típicos dos países da common law (A Função Punitiva da Responsabilidade Civil, Coimbra, Coimbra, 2006, pág. 47).

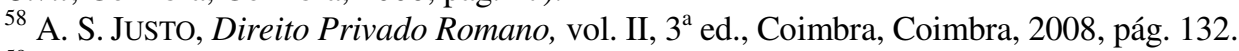

${ }^{59}$ P. M. LourenÇO, A Função Punitiva da Responsabilidade Civil, Coimbra, Coimbra, 2006, pág. 42.

${ }^{60}$ Eduardo Uilan, Responsabilidade Civil Punitiva, Tese (Doutorado) - Faculdade de Direito da USP, São Paulo, 2003, pág. 30. Com efeito, C. R. MASSEY informa que, à época do rei Eduardo I, os legisladores ingleses passaram a experiementar a introdução da função punitiva na responsabilidade civil, editando uma série de normas que continham previsões de pagamento de valores superiores ao prejuízo efetivamente sofrido, geralmente um múltiplo de dobro, triplo ou quádruplo (The Excessive Fines Clause and Punitive Damages: Some Lessons From History, in Vanderbilt Law Review, vol. 40, n. 6, nov.-1987, pág. 1265).

${ }^{61}$ K. M. ZITZER, Punitive Damages: A Cat's Clavicle in Modern Civil Law, in The John Marshall Law Review, vol. 22, 1988, pág. 660. Sobre os diversos períodos de desenvolvimento do Direito Inglês, cfr. R. DAvid, Os Grandes Sistemas do Direito Contemporâneo, trad. Hermínio A. Carvalho, $4^{\text {a }}$ ed., São Paulo, Martins Fontes, 2002, págs. 355 e ss.

${ }^{62}$ C. R. MASSEY, The Excessive Fines Clause and Punitive Damages: Some Lessons From History, in Vanderbilt Law Review, vol. 40, n. 6, nov.-1987, págs. 1257/1258. O autor menciona que sanções pecuniárias, originalmente, assumiam três distintas espécies, o wer (quantia monetária que correspondia ao valor que o Direito Saxônico atribuía a uma vida humana, cujo montante variava de acordo com o status do falecido), o wite (referente aos pagamentos feitos diretamente ao rei ou a outras autoridades públicas) e o bote (expressão genérica que envolvia compensação de um modo geral). Posteriormente, as espécies de sanções pecuniárias 
confusão entre direito civil e direito penal, tais sanções pecuniárias exerciam, ao mesmo tempo, funções compensatória (de reposição do patrimônio lesado) e punitiva (como resposta ao sério ilícito cometido pelo ofensor) ${ }^{63}$.

Após a invasão normanda, o sistema de pagamento de sanções pecuniárias (as quais se tornaram cada vez mais complexas e específicas em seu conteúdo, e cada vez mais expressivas em sua quantificação) foi rapidamente substituído pela imposição de sanções denominadas amercements ${ }^{64}$. As amercements, assim como os institutos que veio a substituir, eram uma sanção pecuniária destinada a repreender tanto os ilícitos civis quanto criminais, ramos estes que permaneceram, àquela época, interligados. Ao contrário das sanções pecuniárias do direito anglo-saxão, contudo, as amercements eram devidas exclusivamente ao rei ou aos seus representantes. Aquele que cometesse uma má conduta deveria se submeter aos desígnios da corte, a qual, em resposta ao ilícito perpetrado, impunha-lhe a sanção pecuniária que julgasse adequada e proporcional à gravidade da conduta cometida ${ }^{65}$.

Em tese, as amercements substituíram as sanções pecuniárias do Direito anglo-saxão com vantagem para o ofensor, uma vez que, para a sua quantificação, dever-seia obedecer a um critério de proporcionalidade ${ }^{66}$. Os abusos cometidos pelo rei e seus representantes na imposição de tais sanções, contudo, teriam levado tal instituto ao declínio, vindo a suportar restrições após a edição da Magna Carta, no ano de $1215^{67}$.

foram se tornando cada vez mais complexas, criando-se outras sub-espécies tais como a manbote (compensação paga em razão do cometimento de um homicídio) e blodwite (quantia destinada a compensar o ofendido em razão do derramamento de sangue).

${ }^{63}$ K. M. ZITZER, Punitive Damages: A Cat's Clavicle in Modern Civil Law, in The John Marshall Law Review, vol. 22, 1988, pág. 660.

${ }^{64}$ C. R. MASSEY afirma ser controvertida a a origem do instituto das amercements, divergindo a doutrina entre a concepção de que se tratava de um instituto novo, trazido pelo povo normando, ou se tal instituto teria sido inspirado justamente nas sanções pecuniárias do direito anglo-saxão (The Excessive Fines Clause and Punitive Damages: Some Lessons From History, in Vanderbilt Law Review, vol. 40, n. 6, nov.-1987, pág. 1258).

${ }^{65}$ C. R. MASSEY, The Excessive Fines Clause and Punitive Damages: Some Lessons From History, in Vanderbilt Law Review, vol. 40, n. 6, nov.-1987, págs. 1259/1261.

${ }^{66}$ C. R. MASSEY noticia a existência, à época, de um writ denominado moderata misericordia, ao qual o ofendido poderia recorrer se julgasse que a amercement a ele imposta havia sido quantificada de maneira excessiva, o que poderia ocorrer, e.g., se a sanção imposta fosse desproporcional em relação à gravidade da ofensa (The Excessive Fines Clause and Punitive Damages: Some Lessons From History, in Vanderbilt Law Review, vol. 40, n. 6, nov.-1987, págs. 1260/1261).

${ }^{67}$ J. T. SIMPSONS JR., Discovery of Net Worth in Bifurcated Punitive Damages Cases: A Suggested Approach After Transportation Insurance Co. v. Moriel, in South Texas Law Review, vol. 37, 1996, pág. 199 e K. M. 
Ao largo da utilização das amercements (que se constituíam de sanções judicialmente impostas), a doutrina noticia que a existência de sanções pecuniárias que exerciam, ao mesmo tempo, funções punitiva e compensatória foi insculpida em normas escritas ainda em meados do Século XIII, período do rei Eduardo I, sendo que a primeira delas teria sido o primeiro Statute of Westminster, de 1275, que prescrevia que "aquele que causar prejuízos a uma pessoa religiosa deve arcar com o dobro do prejuízo causado" "68. Incluindo este primeiro estatuto, o Parlamento Inglês teria editado, nos quinhentos anos que se seguiram, um total de sessenta e cinco normas que previam a indenização do ofendido por meio do pagamento de sanções pecuniárias equivalentes a um múltiplo (dobro, triplo ou quádruplo) do dano sofrido ${ }^{69}$.

Com a posterior distinção entre o Direito Penal e o Direito Civil, a utilização do instituto das amercements (ainda um híbrido que detinha características dos dois ramos do Direito) foi-se tornando cada vez mais rara. Assim foi que, entre os séculos XVII e XVIII, o uso de amercements no âmbito criminal foi substituído pela imposição de "multas" ("fines", sanções pecuniárias de função punitiva), e, no âmbito civil, pela imposição de indenização compensatória (“compensatory damages", os quais substituíram o viés compensatório das amercements, mas não seu aspecto punitivo) ${ }^{70}$.

Sustenta a doutrina, então, que com o declínio das amercements, os punitive damages teriam surgido justamente para re-introduzir, na responsabilidade civil, a função punitiva originalmente exercida pelas sanções pecuniárias do direito saxônico e pelas amercements, função esta posteriormente relegada a segundo plano após o desenvolvimento dos compensatory damages ${ }^{71}$.

ZITZER, Punitive Damages: A Cat's Clavicle in Modern Civil Law, in The John Marshall Law Review, vol. 22, 1988, pág. 662.

${ }^{68}$ No original "[t]respassers against religious persons shall yield double damages." (D. G. OWEN, A Punitive Damages Overview: Functions, Problems and Reform, in Villanova Law Review, vol. 39, 1994, pág. 368). No mesmo sentido, P. Gallo, Pene Private e Responsabilità Civile, Milano, Giuffrè, 1996, pág. 47, Judith Martins-Costa - Mariana Souza PARgendler, Usos e Abusos da Função Punitiva ('Punitive Damages' $e$ o Direito Brasileiro), in Revista da Ajuris, ano XXXII, n. ${ }^{\circ} 100$, dez/2005, pág. 239 e Maria Celina Bodin de MoraEs, Punitive Damages em Sistemas Civilistas: Problemas e Perspectivas, in RTDC, vol. 18, abr./jun. 2004 , pág. 56.

${ }^{69}$ D. G. OwEn, Punitive Damages in Products Liability, in Michigan Law Review, vol. 74, 1976, pág. 1263.

${ }^{70}$ K. M. ZITZER, Punitive Damages: A Cat's Clavicle in Modern Civil Law, in The John Marshall Law Review, vol. 22, 1988, pág. 662.

${ }^{71}$ C. R. MASSEY, The Excessive Fines Clause and Punitive Damages: Some Lessons From History, in Vanderbilt Law Review, vol. 40, n. 6, nov.-1987, págs. 1264 e ss. e K. M. ZITZER, Punitive Damages: A Cat's Clavicle in Modern Civil Law, in The John Marshall Law Review, vol. 22, 1988, pág. 662. 


\section{SURgImento dOS PUNITIVE DAMAGES NA COMMON LAW: OS PRIMEIROS PRECEDENTES}

A doutrina noticia que, à luz do escorço histórico acima delineado, foi apenas ao final do Século XVIII que teriam surgido os primeiros precedentes judiciais (em um primeiro momento na Inglaterra e, depois, por influência destes, nos Estados Unidos da América) a prever, expressamente, a utilização da responsabilidade civil na forma de uma sanção punitiva, destinada não apenas à compensação dos prejuízos do ofendido, mas, também e principalmente, à punição do ofensor em razão da flagrante gravidade da conduta por ele perpetrada ${ }^{72}$.

$\mathrm{Na}$ Inglaterra, a doutrina aponta como pioneiros os julgamentos de Huckle vs. Money (95 Eng. Rep. 768) e Wilkes vs. Wood (98 Eng. Rep. 489), ambos julgados pela House of Lords no ano de $1763^{73}$.

Tratou-se, no primeiro caso, de demanda indenizatória ajuizada por um tipógrafo viajante em face de um mensageiro do Rei, o qual teria, sem base legal alguma, invadido sua residência e lhe mantido encarcerado durante seis horas, sob suspeita de responsabilidade pela impressão do periódico denominado "North Briton, $n .^{\circ} 45^{\prime}$, artigos de cunho subversivo. Nas instâncias ordinárias, o corpo de jurados reconheceu a responsabilidade do demandado pelo cometimento dos torts de trespass, assault e false imprisonment $^{74}$, condenando-o ao pagamento de quantia correspondente a 300 libras, valor este tido como muito excedente àquele necessário para compensar os prejuízos do

\footnotetext{
${ }^{72}$ M. R. IsIDRO, Punitive Damages y su Notificación en el Contexto del Convenio de la Haya de 15 de Octubre de 1965, in Revista Española de Derecho Internacional, vol. XLVIII, n. 2, jul./dic. 1996, pág. 74.

${ }^{73}$ Vitor Fernandes GonÇALVES, A Punição na Responsabilidade Civil: A indenização do dano moral e da lesão a interesses difusos, Brasília, Brasília Jurídica, 2005, pág. 33. No mesmo sentido, P. Gallo, Pene Private e Responsabilità Civile, Milano, Giuffrè, 1996, pág. 47 e Caroline VAZ, Funções da Responsabilidade Civil - Da Reparação à Punição e Dissuasão - Os punitive damages no Direito Comparado e Brasileiro, Porto Alegre, Livraria do Advogado, 2009, págs. 43/44.

${ }^{74}$ K. M. ZITZER, Punitive Damages: A Cat's Clavicle in Modern Civil Law, in The John Marshall Law Review, vol. 22, 1988, pág. 663.
} 
demandante que, segundo assentado, teria sido tratado, no curto período em que permaneceu sob custódia, de maneira absolutamente civilizada ${ }^{75}$.

Irresignado com a expressiva condenação, o demandado recorreu à House of Lords para pleitear um "novo julgamento" ("new trial"), sob o fundamento de que, em precedentes anteriores (entre os quais destacava-se Chambers v. Robinson), a Corte havia dado provimento a recursos nos quais se havia alegado a excessividade das indenizações impostas nas instâncias inferiores.

Ao apreciar o caso, e mesmo diante do fato de que os prejuízos efetivamente suportados pela vítima montavam em importe muito inferior do que a indenização concedida pelas instâncias ordinárias, a House of Lords houve por bem manter a condenação ao pagamento do que denominou "exemplary damages". Após tecer severos comentários sobre a gravidade das condutas perpetradas, o Lord Chief Justice afirmou, na oportunidade, que "invadir uma residência com fulcro em um mandado inválido, com o objetivo de buscar provas, é pior do que a Inquisição Espanhola; Direito sob o qual nenhum homem inglês gostaria de viver nem mesmo por uma hora; representou uma absurda violação às liberdades do cidadão,76.

Já no segundo caso, a residência do Sr. John Wilkes, um conhecido editor de jornais, foi injustamente invadida por um Secretário de Estado que, acompanhado de outros funcionários públicos, arrombou-lhe a porta e confiscou, sem um mandado judicial apropriado ("search warrant"), uma série de papéis que se encontravam no local. Em razão do cometimento do tort de trespass, o Sr. Wilkes propôs demanda indenizatória na qual pleiteou o recebimento de indenização equivalente a 5000 libras $^{77}$.

\footnotetext{
75 P. Gallo, Pene Private e Responsabilità Civile, Milano, Giuffrè, 1996, pág. 47: "Nel caso di specie [Huckle vs. Money] un tipografo era stato arrestato senza motivo e trattenuto in carcere per circa sei ore; $i$ giudici ritennero opportuno concedere una somma di 300 L di gran lunga eccedente rispetto al danno effetivamente subito." Ao comentar o caso, V. WILCOX afirma que a condenação ao pagamento de 300 libras foi mantida a despeito de se ter consignado que o demandante havia sido bem tratado, tendo-se-lhe oferecido, inclusive, bifes e cerveja ("beefstakes and beer") durante o período em que ficou sob a guarda dos agentes públicos (Punitive Damages in England, in H. KozIOL - V. WilcoX (eds.), Punitive Damages: Common Law and Civil Law Perspectives, Wien, Springer, 2009, pág. 31).

${ }^{76}$ No original, "[t]o enter a man's house by virtue of a nameless warrant, in order to procure evidence, is worse than the Spanish Inquisition; a law under which no Englishman would wish to live an hour; it was a most daring public attack made upon the liberty of the subject." (95 Eng. Rep. 769).

${ }^{77}$ P. Gallo, Pene Private e Responsabilità Civile, Milano, Giuffrè, 1996, pág. 47: "Il caso successivo é Wilkes vs. Wood. La casa dell'edittore di un giornale era stata perquisita ingiustamente; si agì in trespass ed anche in quest'occasione i giudici concessero i danni esemplari."
} 
Diante dos fatos concernentes ao caso, a House of Lords referendou a condenação ao pagamento de indenização no importe de expressivas 1000 libras. Entendeu-se que, em razão da gravidade das condutas levadas a efeito, a indenização (denominada, então, de "aggravated damages") poderia exceder os limites impostos pelo prejuízo efetivamente suportado. Na oportunidade, o Lord Chief Justice afirmou que " $o$ júri tem o poder de impor indenizações que excedam o prejuízo suportado. A indenização se destina não apenas a compensar o lesado, mas também a punir o culpado, a desestimular condutas semelhantes no futuro, e a demonstrar a desaprovação do júri quanto ao ilícito cometido"

Vê-se, enfim, que em ambos os casos, "os punitive damages surgiram em virtude dos graves abusos de autoridade por parte de funcionários públicos" ${ }^{\text {,79 }}$, tendo sido concedidos não apenas para compensar o ofendido pelos prejuízos efetivamente suportados (os quais, ao menos em Huckle v. Money, foram de pequena monta), mas, também e principalmente, para punir o ofensor pelo ilícito cometido e prevenir o cometimento de ilícitos semelhantes no futuro.

Não tardou para que o instituto recém desenvolvido dos punitive damages ultrapassasse o atlântico e chegasse aos Estados Unidos da América, onde, poucos anos depois dos precedentes fixados pela House of Lords, foram julgados os casos Genay v. Norris (1 S.C.L. 6 1784) ${ }^{80}$ e Coryell v. Colbaugh (1 N.J.L. 77 1791) ${ }^{81}$.

No primeiro caso, a Supreme Court do Estado de South Carolina concedeu uma quantia de grandes proporções, à qual denominou de "indenização vingativa" ("vindictive damages"), à vítima de um médico que, intencionalmente, a havia

\footnotetext{
${ }^{78}$ No original: "a jury have it in their power to give damages for more than the injury received. Damages are designed not only as satisfaction to the injured person, but likewise as a punishment to the guilty, to deter from any such proceedings for the future, and as proof of the detestation of the jury to the action itself' (98 Eng. Rep. 499).

${ }^{79}$ P. M. LourençO, A Função Punitiva da Responsabilidade Civil, Coimbra, Coimbra Editora, 2006, pág. 165.

${ }^{80}$ Caroline VAZ, Funções da Responsabilidade Civil - Da Reparação à Punição e Dissuasão - Os punitive damages no Direito Comparado e Brasileiro, Porto Alegre, Livraria do Advogado, 2009, pág. 50. Ainda, M. G. BAratella, Le Pene Private, Milano, Giuffrè, 2006, pág. 203 e Anderson SchreIBER, Novos Paradigmas da Responsabilidade Civil: Da Erosão dos Filtros da Reparação à Diluição dos Danos, São Paulo, Atlas, 2009, pág. 203.

${ }^{81}$ A. S. GAUDENZI, La Tutela del Contraente Debole e del Lavoratore (L'Applicazione dei Punitive Damages nel Mondo Anglosassone e nell'Europa Continentale), in Lavoro e Previdenza Oggi, anno XXX, n. 3, 2004, pág. 402.
} 
envenenado $^{82}$. No caso, em razão de um desentendimento anterior, demandante e demandado se preparavam para resolver suas disputas por meio de um duelo de pistolas quando o médico propôs um brinde reconciliatório. Imbuído de má-fé, o médico introduziu veneno na bebida de seu oponente, causando-lhe dores excruciantes ${ }^{83}$.

Em razão da gravidade das condutas levadas a efeito pelo demandado (o qual se conduziu de maneira intencional, com o único propósito de ver sua vítima sofrer), a Corte instruiu os jurados de que "os seríssimos prejuízos suportados pelo demandante [...] lhe autorizavam a receber uma indenização muito exemplar ("very exemplary damages"), especialmente de um médico profissional, que não poderia alegar desconhecimento do funcionamento e dos potentes efeitos do veneno" utilizado ${ }^{84}$.

Já no segundo caso, a Corte de Apelação do Estado de New Jersey julgou uma ação indenizatória ajuizada em face de determinado cavalheiro que rompeu a promessa de casamento ofertada a dama da sociedade norte-americana após tê-la previamente engravidado ${ }^{85}$.

Nesse caso, "a corte instruiu o júri de que eles não deveriam quantificar a indenização com o fim de compensar um prejuízo efetivamente suportado, mas, sim, quantificar uma indenização 'que servisse de exemplo'. O propósito dos punitive damages neste caso foi o de punir o ofensor e prevenir que condutas similares fossem cometidas no futuro" $"$.

${ }^{82}$ D. G. Owen, A Punitive Damages Overview: Functions, Problems and Reform, in Villanova Law Review, vol. 39, 1994, pág. 369.

${ }^{83}$ P. M. LouREnçO, A Função Punitiva da Responsabilidade Civil, Coimbra, Coimbra, 2006, pág. 169.

${ }^{84}$ No original: "a very serious injury to the plaintiff [...] entitled him to very exemplary damages, especially from a professional character, who could not plead ignorance of the operation and powerful effects of this medicine" (M. RUSTAD - T. KOENIG, The Historical Continuity of Punitive Damages Awards: Reforming the Tort Reformers, in The American University Law Review, vol. 42, 1992, pág. 1291)

${ }^{85}$ P. M. Lourenço, A Função Punitiva da Responsabilidade Civil, Coimbra, Coimbra, 2006, págs. 169/170 e M. Rustad - T. KoEnig, The Historical Continuity of Punitive Damages Awards: Reforming the Tort Reformers, in The American University Law Review, vol. 42, 1992, pág. 1291.

${ }^{86}$ No original: "[ $\left.\mathrm{t}\right]$ he Coryell court instructed the jury that they should not estimate damages to compensate an actual injury, but rather should award 'damages for example's sake'. The purpose of the punitive damages in this case was to punish the wrongdoer and to deter others from similar conduct in the future." (K. M. ZITZER, Punitive Damages: A Cat's Clavicle in Modern Civil Law, in The John Marshall Law Review, vol. 22, 1988, pág. 663). 
Vê-se que, diferentemente dos primeiros casos ingleses, relacionados à proteção das liberdades civis dos cidadãos contra atos arbitrários cometidos por autoridades estatais, nos primeiros casos norte-americanos os punitive damages atuaram como punição a condutas "propositais" ("willful”) ou "injustificadas" ("wanton") que causaram prejuízos que extrapolavam o âmbito material ${ }^{87}$.

Com o passar dos anos, o instituto se desenvolveu de maneira verdadeiramente avassaladora (especialmente nos Estados Unidos da América), passando a incidir em uma série de hipóteses distintas ${ }^{88}$, de tal modo que, nas palavras de D. G. OwEN, "em meados do século XIX, os punitive damages já se haviam transformado em uma constante no Direito Norte-Americano" ${ }^{\text {" }}$.

Tanto foi assim que, já no início do século passado, à exceção de cinco estados norte americanos (nomeadamente, Massachusetts, Nebraska, Washington, New Hampshire e a Louisiana), todos os demais admitiam, de maneira geral, a condenação de demandados ao pagamento de indenização punitiva caso devidamente comprovados os requisitos necessários; e, mesmo nesses cinco estados ditos "renegados", admitia-se a incidência dos punitive damages em determinadas e específicas hipóteses ${ }^{90}$.

\section{RAZÕES PARA O SURGIMENTO DOS PUNITIVE DAMAGES}

Ao procurar extrair, dos primeiros casos em que se passou a admitir a condenação do demandado que havia se portado de maneira particularmente reprovável em valor que excedia os limites da mera compensação, as razões históricas para o surgimento do instituto dos punitive damages (além, como acima exposto, de ser instituto que deita

\footnotetext{
${ }^{87}$ M. Rustad - T. Koenig, The Historical Continuity of Punitive Damages Awards: Reforming the Tort Reformers, in The American University Law Review, vol. 42, 1992, pág. 1291.

88 Sobre o desenvolvimento dos punitive damages nos Estados Unidos da América após os primeiros precedentes judiciais, cfr. M. RUSTAD - T. KoENIG, The Historical Continuity of Punitive Damages Awards: Reforming the Tort Reformers, in The American University Law Review, vol. 42, 1992, págs. 1292/1296.

89 No original, "By the mid-nineteenth century, punitive damages had become an established fixture in American Law." (A Punitive Damages Overview: Functions, Problems and Reform, in Villanova Law Review, vol. 39, 1994, pág. 369)

${ }^{90}$ D. G. Owen, A Punitive Damages Overview: Functions, Problems and Reform, in Villanova Law Review, vol. 39, 1994, págs. 369/370.
} 
raízes no Direito Antigo e no Direito Romano), a doutrina enumera, basicamente, duas teorias $^{91}$ : (i) o fato de, nos países da common law, mesmo os processos de índole civil serem julgados por um corpo de jurados (direito este que é, inclusive, expressamente previsto na $7^{\text {a }}$ Emenda à Constituição Americana); e (ii) a original impossibilidade de compensação de prejuízos que extrapolavam o âmbito patrimonial.

Quanto à primeira das razões acima aventadas, J. D. GHIARDI sustenta que os punitive damages podem ter-se originado do fato de que, originalmente, os Tribunais Ingleses possuíam restrições para acolher requerimentos de limitação das condenações impostas pelos primeiros júris, ainda que tais condenações excedessem flagrantemente o montante suficiente para compensar todos os prejuízos materiais suportados pela vítima.

Ainda segundo o citado autor, entendiam os Tribunais Ingleses que, como os primeiros júris eram formados por cidadãos locais (componentes de grupos comunitários de proporções muitíssimo mais modestas do que as atuais), intimamente familiarizados com a disputa sub judice, a manutenção da condenação imposta pelo corpo de jurados era a melhor maneira de defender sua expertise como conhecedores dos fatos.

Os punitive damages, como instituto individualizado, teriam surgido, portanto, da necessidade de que os Tribunais justificassem a disparidade entre a condenação pecuniária (em valor elevado) e os prejuízos efetivamente suportados pela vítima (os compensatory damages) ${ }^{92}$.

Caso se restringissem apenas a este aspecto, as razões para o surgimento dos punitive damages teriam deixado de existir com o desenvolvimento posterior dos remédios processuais que passaram a permitir ao juiz da causa que revisasse as condenações impostas pelo corpo de jurados ${ }^{93}$.

${ }^{91}$ Eduardo UILAN, Responsabilidade Civil Punitiva, Tese (Doutorado) - Faculdade de Direito da USP, São Paulo, 2003, pág. 31. Ainda: J. D. GHIARd, The Case Against Punitive Damages, in The Forum, vol. 8, 1972, págs. 411/412 e K. M. ZITZER, Punitive Damages: A Cat's Clavicle in Modern Civil Law, in The John Marshall Law Review, vol. 22, 1988, pág. 662.

92 The Case Against Punitive Damages, in The Forum, vol. 8, 1972, pág. 411. No mesmo sentido, K. M. ZITZER, Punitive Damages: A Cat's Clavicle in Modern Civil Law, in The John Marshall Law Review, vol. 22, 1988, pág. 662.

93 J. D. GHIARDI, The Case Against Punitive Damages, in The Forum, vol. 8, 1972, pág. 411. 
É da segunda teoria acima aventada, contudo, que se podem extrair considerações mais interessantes acerca do tema, especialmente por servir de ponto de partida para que se possa traçar um paralelo entre o surgimento e desenvolvimento dos punitive damages, nos países da common law, e o desenvolvimento da teoria acerca da ressarcibilidade dos danos morais, nos países de raiz romano-gerâmica.

Ao tratar do tema, anota a doutrina que, durante o desenvolvimento da law of torts nos países da common law, não se admitia a indenização de prejuízos não materiais (as assim chamadas "non pecuniary losses"), sob o argumento, citado por J. O'CONNEL e K. CARPENTER de que "tais prejuízos faziam parte das desventuras da vida, das quais todo homem deveria suportar sua quota"94. O conceito de compensatory damages, portanto, era originalmente mais restritivo, limitando-se apenas à reparação dos prejuízos que poderiam ser imediatamente exprimidos em pecúnia.

Em razão dessa inicial impossibilidade de ressarcimento pelos prejuízos não materiais (vez que estes não eram abarcados pelos compensatory damages), ter-se-ia utilizado os recém desenvolvidos punitive damages como forma de impedir que os detrimentos suportados pelo demandado não restassem sem tutela ${ }^{95}$. É nesse sentido que se afirma que, na origem, os punitive damages também exerciam função compensatória: atribuía-se ao instituto, também, a finalidade de compensar o lesado por prejuízos que, de ordinário, jamais seriam recompostos apenas pela aplicação dos compensatory damages.

Apenas em idos do século XIX a jurisprudência inglesa e norte-americana passou a consolidar o entendimento de que também os prejuízos ditos imateriais (e.g., "pain and suffering" e "emotional distress") compunham os prejuízos passíveis de indenização compensatória (“compensatory damages”) e, sob esta rubrica, o demandado deveria ser condenado, mesmo em casos nos quais não estavam presentes os requisitos para a condenação ao pagamento de punitive damages ${ }^{96}$.

\footnotetext{
${ }^{94}$ A citação é atribuída ao Chief Justice Baron Pollock, proferida no julgamento do caso Theobald v. Railway Passengers' Assur. Co., 26 Eng. L. and Eq. R. 4381854 (Payment for Pain and Suffering Through History, in Insurance Counsel Journal, vol. 50, 1983, pág. 412).

95 Judith Martins-Costa - Mariana Souza PARgEndler, Usos e Abusos da Função Punitiva ('Punitive Damages' e o Direito Brasileiro), in Revista da Ajuris, ano XXXII, n. ${ }^{\circ}$ 100, dez/2005, pág. 239.

96 J. O'CONNEL - K. CARPENTER, Payment for Pain and Suffering Through History, in Insurance Counsel Journal, vol. 50, 1983, págs. 412/413. Ainda: Judith MARTINS-COSTA - Mariana Souza PARGENDLER, Usos e Abusos da Função Punitiva ('Punitive Damages' e o Direito Brasileiro), in Revista da Ajuris, ano XXXII, n. ${ }^{\circ}$
} 
Vê-se, desta feita, que, ao menos na origem, os punitive damages exerciam uma função mista: puniam o ofensor pela conduta altamente reprovável por ele perpetrada, mas, ao mesmo tempo, compensavam o ofendido pelos prejuízos não materiais que este houvesse suportado em razão da ofensa ${ }^{97}$. Tal função mista não se distancia muito daquela que, até hoje, os Tribunais nacionais atribuem à indenização por danos morais, e que nos serve, em alto grau, de incentivo para o aprofundamento do presente estudo ${ }^{98}$.

Importa de ver, enfim, que, ante à evolução do conceito de compensatory damages, nenhuma das duas razões concebidas pela doutrina como fundamento para o surgimento dos punitive damages persiste atualmente, de modo que é outra a ordem de fatores que ainda sustenta a manutenção de tal instituto nos países da common law.

\section{AS FUNÇÕES DESEMPENHADAS PELOS PUNITIVE DAMAGES}

Sustenta-se, então, que a justificativa para a permanência dos punitive damages mesmo após séculos de desenvolvimento da tort law e, principalmente, após terem sido eliminadas as razões que são usualmente aventadas para justificar o surgimento do aludido instituto, é o fato de, mesmo atualmente, tal sanção ainda conseguiria atingir, de maneira adequada, todas as funções para as quais foi originalmente cunhada.

100, dez/2005, pág. 240 e G. B. BELL - P. E. PEARCE, Punitive Damages and the Tort System, in University of Richmond Law Review, vol. 22, 1987, pág. 4.

97 G. V. Robredo, Daños Punitivos en el Proceso Civil Norteamericano, in Revista de la Universidad de Deusto, vol. 57, fasc. 97, jul-dic./ 1996, pág. 182.

98 Marcela Alcazas BASSAN, As Funções da Indenização por Danos Morais e a Prevenção de Danos Futuros, Dissertação (Mestrado) - Faculdade de Direito da USP, São Paulo, 2009, pág. 57. Ainda: Judith Martins-Costa - Mariana Souza Pargendler, Usos e Abusos da Função Punitiva ('Punitive Damages' $e$ o Direito Brasileiro), in Revista da Ajuris, ano XXXII, n. ${ }^{\circ} 100$, dez/2005, págs. 239/240. Para um exemplo da orientação jurisprudencial quanto à dupla (ou tripla, quando às funções compensatória e punitiva se acresce, também, a função preventiva) função da indenização dos danos morais, veja-se: “Cabe ao Superior Tribunal de Justiça o controle do valor fixado a título de indenização por dano moral, que não pode ser ínfimo ou abusivo, diante das peculiaridades de cada caso, mas sim proporcional à dúplice função deste instituto: reparação do dano, buscando minimizar a dor da vítima, e punição do ofensor, para que não volte a reincidir." (STJ; $2^{\mathrm{a}}$ T.; RESP n. ${ }^{\circ}$ 575023/RS; Relatora: Min. Eliana Calmon; J. 27.04.2004). Ainda: (STJ; $2^{\text {a }}$ T.; RESP n. ${ }^{\circ}$ 474786/RS; Relatora: Eliana Calmon; J. 01.04.2004) e (STJ; $2^{\text {a }}$ T.; RESP n. ${ }^{\circ}$ 487749/RS; Relatora: Eliana Calmon; J. 03.04.2003). 
Segundo pontua a doutrina, os punitive damages ainda seriam aptos a desempenhar as funções: (i) de "justiça pública" ("public justice"), o que fariam ao incentivar os cidadãos a perseguir o escorreito cumprimento da Lei, exercendo verdadeiro munus público (denominado pela doutrina de "private attorney general"); (ii) preventiva, de desestímulo (“deterrence”) ao comentimento de novos ilícitos, o qual se direciona tanto à própria pessoa do ofensor (specific deterrence) quanto à sociedade em geral, para que nela não surjam novos ofensores em potencial (general deterrence); e, ainda, (iii) a função punitiva, relacionada com a natureza quase criminal dos punitive damages.

Intimamente ligadas às principais funções exercidas pelos punitive damages (preventiva e punitiva), estão (iv) a assim chamada "função educativa" (relacionada ao ofensor, tanto o efetivo causador do prejuízo, diretamente apenado, quanto o potencial, o qual se pretende ver desestimulado de cometer ilícitos); e, ainda, (v) a "função vingativa", que atua de modo a prevenir que o ofendido venha a desrespeitar a Lei, respondendo ao ilícito contra ele cometido por meio do exercício arbitrário (e, conseqüentemente, ilícito) de suas razões.

Aventa-se, por fim, e o que sobressai como uma apenas aparente incongruência, que os punitive damages também exercem uma (vi) função compensatória, referente aos prejuízos usualmente não indenizáveis em razão do ilícito perpetrado.

\section{V.I. A função de "justiça pública" ("public justice"): o papel do chamado "private attorney general"}

A primeira das funções cuja persecussão é atribuída aos punitive damages é a assim chamada "justiça pública". Quer-se dizer, com tais palavras, que, a despeito de serem um instituto jurídico inserido no âmbito do Direito Privado, os punitive damages atuam adequadamente de modo a assegurar, com sua incidência, o escorreito respeito à Lei e aos direitos subjetivos dos cidadãos, especialmente em hipóteses nas quais o Direito Penal (ou outros ramos sancionadores do Direito, e.g., o Direito Administrativo Sancionador), não incide ${ }^{99}$. 
Com efeito, em atenção ao princípio da intervenção mínima do Direito Penal (ou da ultima ratio), sua incidência somente se justifica se outras sanções jurídicas (civis ou administrativas) não forem suficientes para o restabelecimento da ordem jurídica violada ${ }^{100}$. Por tal motivo, a lesão a determinados bens jurídicos, a despeito de seu alto grau de reprovabilidade, pode constituir apenas um ilícito civil, mas não, propriamente, um ilícito penal (a conduta ilícita será, portanto, um tort, mas não, necessariamente, também um crime).

Nessas hipóteses, em que se está diante de um ilícito civil (tort), o sancionamento à conduta lesiva não ocorre por iniciativa do Estado (em contraste, por exemplo, com o que ocorre nos âmbitos do Direito Penal e do Direito Administrativo Sancionador), dependendo, portanto, da atuação dos particulares que, lesados em seu patrimônio, deverão buscar, junto ao Poder Judiciário, a compensação pelos prejuízos sofridos, bem como, conseqüentemente, o restabelecimento da ordem jurídica violada pelo ilícito ${ }^{101}$.

Ocorre que, em determinadas circunstâncias, apesar de o ato ilícito cometido ser especialmente reprovável, os prejuízos dela decorrentes ao lesado são de pequenas proporções, o que pode fazer com que o ofendido se sinta desestimulado a perseguir seus direitos perante o Poder Judiciário. Vale dizer: os custos do ajuizamento da demanda (que envolvem não apenas as custas e despesas processuais, mas, também, os honorários advocatícios, os quais, especialmente nos Estados Unidos da América, não são reembolsados pela parte sucumbente) podem igualar ou superar o montante indenizatório a ser eventualmente atribuído ao ofendido, caso este se sagrasse vencedor da demanda judicial, o que lhe serve, portanto, de desestímulo a buscar o Poder Judiciário ${ }^{102}$.

\footnotetext{
99 D. G. Owen, A Punitive Damages Overview: Functions, Problems and Reform, in Villanova Law Review, vol. 39, 1994, pág. 381.

${ }^{100}$ Eduardo UILAN, Responsabilidade Civil Punitiva, Tese (Doutorado) - Faculdade de Direito da USP, São Paulo, 2003, pág. 48. Nesse sentido seguem as palavras de D. G. OWEN, em defesa da aplicação dos punitive damages nas hipóteses em que não se justificaria a incidência de sanções de natureza criminal (em especial a pena restritiva de liberdade). Sustenta o autor que "[w]here the private law can as cheaply and successfully accomplish the same objectives, and where public condemnation in the extreme by a criminal conviction (and possibly imprisonment) is not required, the civil law should be allowed to perform its office. Not only is the punitive damages doctrine apt to perform the law-enforcement function more cheaply than the criminal law, because of its partial funding by the wrongdoer, but it also is apt to perform it better because of the personal, monetary incentives that punitive damages provide to victim-enforcers and their lawyers." (A Punitive Damages Overview: Functions, Problems and Reform, in Villanova Law Review, vol. 39, 1994, pág. 384).

${ }^{101}$ Eduardo UILAN, Responsabilidade Civil Punitiva, Tese (Doutorado) - Faculdade de Direito da USP, São Paulo, 2003, pág. 53.
} 
Diz-se, então, que os punitive damages atuam de modo a eliminar ou, ao menos, mitigar esse desestímulo à propositura de demandas judiciais. À medida em que os punitive damages, de maneira geral, acarretam o recebimento de quantia expressiva pelo ofendido, a qual supera os limites estritos do prejuízo por ele suportado ${ }^{103}$, eles atuam de modo a incentivá-lo a buscar o Poder Judiciário ${ }^{104}$, ajuizando demanda que buscará não apenas a satisfação de seus interesses particulares (por meio da recomposição de seu patrimônio), mas, também e principalmente, a reestruturação da ordem jurídica violada pelo ilícito (especialmente nos casos em que, de uma mesma conduta ilícita ou atividade danosa, decorrem prejuízos para diversas pessoas).

É nesse sentido que A. SARAVALlE afirma que "[a] perspectiva de obter uma condenação ao pagamento de punitive damages em montante expressivo constitui, portanto, um importante incentivo para que a parte lesada proponha uma demanda judicial", concluindo que, ao assim fazer, o particular age como um substituto ao Ministério Público, exercendo um munus de verdadeiro "procurador público-privado" (o assim chamado "private attorney general") ao perseguir não apenas seus interesses particulares, mas, também, aqueles de toda a sociedade ${ }^{105}$.

O incentivo para que o particular acione o Poder Judiciário é, nas palavras de Eduardo UILAN, especialmente importante (e necessário) nas hipóteses em que uma mesma atividade causa prejuízos a diversas pessoas (tais como, e.g., no desenvolvimento e comercialização de um produto perigoso) e nas quais tais prejuízos não são de expressiva monta. Se não houvesse o incentivo à demanda, representado pelos punitive damages, o

\footnotetext{
${ }^{102}$ M. M. Belli Sr., Punitive Damages: Their History, Their Use and Their Worth in Present-Day Society, in UMKC Law Review, vol. 49, n. 1, 1980, págs. 5/6.

${ }^{103}$ Quanto a este ponto, contudo, há que se frisar que a destinação da condenação ao pagamento de punitive damages ao demandante é medida hoje nada menos do que muito controvertida nos Estados Unidos da América. Mais do que isso, uma das medidas de maior adesão no âmbito do assim chamado tort reform movement (do qual abaixo se tratará pormenorizadamente) é justamente aquela que objetiva a remessa total ou parcial da condenação ao pagamento de punitive damages a um fundo público (medida esta denominada de "split recovery").

${ }^{104}$ Nas palavras de D. G. OWEN, "it is the very existence of a prospective windfall that helps to motivate reluctant victims to press their claims and enforce the rules of law." (A Punitive Damages Overview: Functions, Problems and Reform, in Villanova Law Review, vol. 39, 1994, pág. 380).

105 No original: "La prospettiva di ottenere una condanna al pagamento di danni punitivi per importo rilevanti costituisce pertanto un importante incentivo per la parte lesa a proporre l'azione civile. Si parla in questi casi dell'attore come di un sostituto del Pubblico Ministero (Private Attorney General) in quanto, ancorchè esso agisca nel proprio interesse economico, persegue fini di interesse generale." (I Punitive Damages nelle Sentenze delle Corti Europee e dei Tribunali Arbitrali, in Rivista di Diritto Internazionale Privato e Processuale, anno XXIX, n. 4, ott.-dic./1993, pág. 871).
} 
ofensor persistiria com sua atividade danosa, até porque, em muitos dos casos, tal atividade lhe é bastante lucrativa ${ }^{106}$.

\section{V.II. A função preventiva (deterrence)}

Para além da supra citada função de "justiça pública", a doutrina e os Tribunais ${ }^{107}$ indicam que uma das principais funções desempenhadas é a de, atuando $e x$ ante (ou pro futuro), desestimular (“deter") o cometimento de novos ilícitos. Segundo E. D'AlESSANDRO, “os punitive damages exercem também uma função preventiva pro futuro, na medida em que, por meio de sua imposição, busca-se evitar que no futuro sejam repetidos comportamentos danosos semelhantes ao cometido, quer por parte do sancionado (a assim chamada função preventiva especial), quer por parte da sociedade em geral (a assim chamada função preventiva geral)"108.

A idéia principal por traz de tal função é a de que, ao desestimular o cometimento de novos ilícitos (e, em especial, de ilícitos particularmente reprováveis, caracterizados por condutas intencionais ou grosseiramente negligentes), os punitive damages agem de modo a estimular o respeito à Lei e a promover o bem estar social ${ }^{109}$.

A doutrina especializada faz, contudo, uma importante ressalva quanto ao adequado desempenho da função preventiva. Afirma-se que a condenação ao pagamento

\footnotetext{
${ }^{106}$ Responsabilidade Civil Punitiva, Tese (Doutorado) - Faculdade de Direito da USP, São Paulo, 2003, pág. 54.

${ }^{107}$ Uma afirmação muitas vezes referida para justificar a incidência dos punitive damages é aquela que se extrai do famoso julgamento BMW of North America v. Gore, proferido pela Supreme Court dos Estados Unidos da América (ao qual retornaremos em diversos pontos deste capítulo), no sentido de que "Punitive damages may properly be imposed to further a State's legitimate interest in punishing unlawful conduct and deterring its repetition." (517 U.S. 559 1995, pág. 568). Dessa afirmação, pode-se extrair a importância da função preventiva, posta lado a lado com a função punitiva (a qual se verifica na expressão "punishing unlawful conduct").

${ }^{108}$ No original: "I danni punitivi hanno dunque una funzione espiatoria e deterrente pro futuro, in quanto attraverso la loro irrogazione si vuole evitare che in futuro si ripetano comportamenti dannosi simili a quella commesso, sia da parte del sanzionato (c.d. funzione specialpreventiva), sia da parte della generalità dei consociati (c.d. funzione generalpreventiva), il cui comportamento dovrebbe essere indirizzato dalla esemplarità della sanzione." (Pronunce Americane di Condanna al Pagamento di Punitive Damages e Problemi di Riconoscimento in Italia, in Rivista di Diritto Civile, anno LIII, n. 3, mag.-giug./2007, pág. 385). No mesmo sentido, A. J. SEBoK, Punitive Damages in The United States, in H. KOZIOL - V. WILCOX (eds.), Punitive Damages: Common Law and Civil Law Perspectives, Wien, Springer, 2009, pág. 178.

${ }^{109}$ D. G. Owen, A Punitive Damages Overview: Functions, Problems and Reform, in Villanova Law Review, vol. 39, 1994, pág. 380 e D. D. Ellis JR., Fairness and Efficiency in the Law of Punitive Damages, in Southern California Law Review, vol. 56, 1982, pág. 8.
} 
de indenização (mesmo aquela que exerce função exclusivamente compensatória, característica dos compensatory damages), na medida em que representa a imposição de uma sanção (conseqüência negativa decorrente do descumprimento de uma norma) que atinge negativamente o patrimônio do ofensor, reduzindo-o, também exerce, ainda que de maneira indireta, uma função preventiva, atuando de modo a desestimular o cometimento de novos ilícitos semelhantes (o ofensor, que suporta as consequiências negativas da sanção, deseja não mais suportar tais efeitos negativos e, por isso, condiciona-se a não mais agir de modo a dar ensejo à aplicação da sanção). Em razão de a indenização compensatória também exercer essa função preventiva (ainda que de maneira indireta), afirma-se que a defesa dos punitive damages como meio apto a prevenir o cometimento de novos ilícitos deve partir da resposta adequada à seguinte pergunta: por que (e em quais casos) a prevenção exercida pela condenação ao pagamento de indenização compensatória é insuficiente para atingir às exigências sociais quanto à prevenção ${ }^{110}$ ?

A resposta a tal questionamento não pode ser apresentada sem que se atente para as condutas que se pretende sancionar por meio da aplicação dos punitive damages. Como tal instituto visa sancionar condutas "propositais" ("willful"), "injustificadas" ("wanton") ou grosseiramente negligentes ("reckless"), todas elas marcadas pela intencionalidade ou, no mínimo, consciência dos prejuízos que dela resultarão (não são, diga-se, acidentes), a utilização dos punitive damages como meio de prevenção será sempre adequada quando a responsabilização do lesante ao pagamento de indenização compensatória ("compensatory damages") for insuficiente para inibi-lo (bem como a outros potenciais ofensores) de cometer o ilícito. Isso ocorrerá sempre que os custos para evitar o prejuízo sejam maiores do que aqueles necessários para recompor o patrimônio do ofendido. Os punitive damages adequadamente desestimulam ilícitos futuros quando é necessária a utilização de uma ferramenta jurídica que aumente os custos de uma determinada atividade, tornando-a economicamente desvantajosa (com a incidência de tal sanção, acrescida aos compensatory damages que ordinariamente recairiam sobre o ofensor, os custos decorrentes do cometimento do ilícito passam a ser maiores do que os custos para evitar o prejuízo). É nesse sentido que G. T. SCHWARTZ afirma que "[s]e os

${ }^{110}$ G. T. Schwartz, Deterrence and Punishment in the Common Law of Punitive Damages: A Comment, in Southern California Law Review, vol.56, 1982, págs. 137/138. Mostrando preocupação semelhante, D. D. ELLIS JR., Fairness and Efficiency in the Law of Punitive Damages, in Southern California Law Review, vol. 56, 1982, pág. 9. 
punitive damages efetivamente desestimulam [o cometimento de novos ilícitos], isso se deve ao princípio econômico de que aumentar o custo de uma atividade necessariamente reduz sua freqüência" ${ }^{, 11}$.

Ao apreciar tal questão, D. D. ElLIS JR. anuncia que três são as hipóteses nas quais os punitive damages atuam de maneira eficiente e necessária, em conjunto com os compensatory damages para prevenir o cometimento de novos ilícitos: (i) casos nos quais a probabilidade de o ofensor vir a ser responsabilizado pelos prejuízos sofridos é menor do que a de causar tais prejuízos (e, ao se reduzir a probabilidade de condenação ao pagamento de indenização, torna-se interessante a assunção deste risco, principalmente diante dos custos para evitar o prejuízo, que permanecem iguais); (ii) casos nos quais a indenização compensatória (compensatory damages) a ser paga pelo ofensor é inferior aos prejuízos efetivamente suportados pelo ofendido (o que também torna vantajosa a assunção do risco de cometer o ilícito e, conseqüentemente, de causar o prejuízo) e, por fim, (iii) casos nos quais o ofensor extrai lucro do cometimento do ato ilícito ${ }^{112}$.

Nesses casos, em que se deve utilizar uma sanção jurídica mais severa para desestimular o cometimento de graves atos ilícitos, diz-se que a função preventiva é adequadamente exercida porque informa o lesante e a outros potenciais ofensores que: (i) "certos tipos de condutas violadoras dos interesses alheios são impróprias e sujeitas a sanções legais"; (ii) "ilícitos graves ou intencionais serão submetidos a punição em montantes que excedam o valor do prejuizo suportado" pelo lesado; e, ainda, que, (iii) “ainda que não se tenha certeza da punição, ela é suficientemente provável (em razão do incentivo monetário atribuído às vítimas para demandarem em face dos ofensores), e seu montante pode ser grande o suficiente para eliminar a aparente rentabilidade do ilícito. Em suma, a mensagem que se passa aos potenciais ofensores é a de que o preço de ser responsabilizado excede o lucro passível de ser obtido pelo cometimento do ilícito" ${ }^{113}$.

\footnotetext{
${ }^{111}$ No original: "If punitive damages do indeed deter, it is due to the economic principle that adding to the cost of an activity necessarily decreases its frequency" (Deterrence and Punishment in the Common Law of Punitive Damages: A Comment, in Southern California Law Review, vol.56, 1982, pág. 135).

112 Fairness and Efficiency in the Law of Punitive Damages, in Southern California Law Review, vol. 56, 1982, pág. 25.

${ }^{113}$ No original: A função preventiva dos punitive damages atua na medida em que a sua incidência informa aos potenciais ofensores que: (i) "certain types of conduct violating the interests of other persons are improper and subject to legal remedy [...]"; (ii) "intentional and other flagrant violations of the law are further subject to punishment in amounts exceeding the return of the stolen goods" e, ainda, que, (iii) "although punishment may be uncertain, it is likely enough (because of the monetary incentive given victims
} 
Diz-se, então, que, para exercerem adequadamente sua função preventiva, os punitive damages devem incidir nas hipóteses em que, ao menos aparentemente, os custos para evitar o prejuízo seriam superiores àqueles necessários para recompor o patrimônio do lesado e, em especial, naquelas hipóteses em que, do cometimento do ilícito (e da imposição do prejuízo) o ofensor poderia vir a extrair lucro, valor este que o estimularia a agir em desconformidade com a Lei ${ }^{114}$.

\section{V.III. A função punitiva (retribution)}

A despeito da indiscutível importância da função preventiva, cuja análise foi acima exposta, parte da doutrina sustenta que a mais importante função exercida pelos punitive damages é justamente aquela que se extrai diretamente da denominação do instituto, qual seja, a de punir o ofensor pelas graves condutas cometidas ${ }^{115}$.

Diz-se, nesse sentido, que, como os punitive damages se destinam, exclusivamente, a sancionar os ilícitos civis mais reprováveis, marcados que são pela intencionalidade ou pelo flagrante desrespeito para com os direitos alheios [condutas estas

to prosecute such offenders) and may be large enough to take the apparent profitability out of contemplated thefts. In sum, the deterrence message directed at would-be thieves is that the price of getting caught, discounted by the risk thereof, exceeds the value of the booty." (D. G. OWEN, A Punitive Damages Overview: Functions, Problems and Reform, in Villanova Law Review, vol. 39, 1994, págs. 377/378).

${ }^{114}$ Nesse sentido, D. G. OWEN afirma que "[t]hus, punitive damage awards provide a signal that the law will not tolerate the degeneration of illicit profits through exploitation of the vagueness in the liability rules and the resulting under-enforcement of responsibility for compensatory damages. Instead, punitive assessments put manufacturers and other actors on notice that the law will force them to disgorge all such ill-gotten gains, and possibly much more." (A Punitive Damages Overview: Functions, Problems and Reform, in Villanova Law Review, vol. 39, 1994, pág. 378).

${ }^{115}$ Nesse sentido, A. SARAvalle, I Punitive Damages nelle Sentenze delle Corti Europee e dei Tribunali Arbitrali, in Rivista di Diritto Internazionale Privato e Processuale, anno XXIX, n. 4, ott.-dic./1993, pág. 870 e I. Englard, The Philosophy of Tort Law, Aldershot, Dartmouth, 1993, pág. 145. Nas palavras de G. T. SCHWARTZ, reconhecer-se a função punitiva como a função primordialmente exercida pelos punitive damages não só tem o valor de dar à linguagem o valor devido, mas, também, explica de maneira mais adequada uma série de fatores ligados a tal instituto jurídico, tais como, e.g., a incidência apenas em casos nos quais as condutas perpetradas pelo ofensor sejam intencionais (caracterizadas, por exemplo, por "malice") ou gravemente culposas, e a utilização de critérios como o "grau de reprovabilidade" ("degree of reprehensibility") dessas condutas para a quantificação da indenização. (Deterrence and Punishment in the Common Law of Punitive Damages: A Comment, in Southern California Law Review, vol.56, 1982, págs. 143/144). De nossa parte, queremos crer que, em que pese tal posicionamento, a indenização punitiva exerce como função primordial a proteção de interesses e direitos especialmente tutelados, o que faz essencialmente por meio do adequado desempenho de sua função preventiva. A função punitiva, à evidência, exerce 
que, por sua especial gravidade, são taxadas pela doutrina de quase criminais ("quasicriminal")], eles "permitem ao júri externar a desaprovação social quanto às graves condutas realizadas por meio da imposição da punição que o ofensor merece"116.

Os punitive damages atuam, portanto, como verdadeiras "multas civis" ("civil fines") ${ }^{117}$, direcionadas a impor ao ofensor uma punição pela gravidade do ilícito cometido, relegando aos compensatory damages a função de recompor o patrimônio do ofendido. Nesse sentido, essencialmente punitivo, é que A. H. SCHEINER afirma que os punitive damages são "a marreta da Justiça Civil"118, utilizados que são como instrumento de força, próximo às sanções do Direito Penal.

Ao tratar do tema, D. G. OWEN propõe a utilização do que denomina "metáfora do ladrão" ("a metaphor based on theft") para, de maneira didática, abordar os aspectos da função punitiva dos punitive damages.

Nas palavras do citado autor, quando o ofensor (o "ladrão") comete um ilícito altamente reprovável (passível, portanto, de sancionamento por meio da incidência dos punitive damages), ele fere não apenas o ofendido (por se apropriar ilicitamente de determinados bens ou valores aos quais não faz jus, bem como por ferir a "autonomia" do ofendido, enviando-lhe a mensagem velada de que seus bens e interesses têm menos valor do que aqueles do ofensor, e que, portanto, o ofendido deve-se submeter às vontades do ofensor. A atuação do ofensor, portanto, extrai bens e valores do ofendido, que se empobrece na exata medida em que o ofensor se enriquece); mas, também, a própria sociedade (uma vez que, ao invadir intencionalmente a órbita jurídica de outra pessoa, extrapolando os limites impostos pelo ordenamento, o ofensor também viola, indiretamente, os direitos e interesses de todos os demais membros da sociedade que respeitam tais limites. Em comparação com o ofensor, os membros da sociedade que

relevante papel moralizador das condutas, mas, a nosso ver, coloca-se um degrau de importância abaixo da função preventiva.

${ }^{116}$ No original: "Punitive damages allow the jury to express the comunity's outrage at egregious wrongful conduct by imposing punishment that the wrongdoer deserves." (C. CALLEROS, Punitive Damages, Liquidated Damages and Clauses Pènales in Contract Actions: A Comparative Analysis of the American Common Law and the French Civil Code, in Brooklyn Journal of International Law, vol. 32, 2006, pág. 78).

117 A. J. SeboK, Punitive Damages in The United States, in H. KozIOL - V. WILCoX (eds.), Punitive Damages: Common Law and Civil Law Perspectives, Wien, Springer, 2009, pág. 175. 
respeitam os limites impostos pelo contrato social são igualmente empobrecidos, na exata medida em que o ofensor se enriquece por meio da apropriação indevida dos bens do ofendido, e do desrespeito às normas de comportamento social).

Como a conduta perpetrada pelo ofensor, marcada por um alto grau de reprovabilidade, atinge não apenas o ofendido (por reduzir seu patrimônio), mas, também e principalmente, a própria sociedade (por desmerecer os cidadãos que respeitam os limites impostos pelo contrato social e, com isso, impactar de maneira negativa a qualidade de vida em sociedade), ela precisa ser sancionada de maneira exemplar. Não basta que se retire do ofensor os bens materiais por ele indevidamente apropriados (o que se faria por meio da incidência dos compensatory damages). Deve-se assegurar, enfim, que a sanção irá extrapolar os limites do prejuízo suportado pelo ofendido, permitindo-a abarcar também os prejuízos que tal conduta impôs à própria sociedade ${ }^{119}$.

Em razão de todo o quanto acima exposto, o adequado desempenho da função punitiva dos punitive damages demanda a escorreita obediência ao que D. D. ELLIS JR. denomina de princípio do "justo merecimento", o qual exige, para a imposição de punição: (i) que o ofensor tenha prévio conhecimento de que o ato por ele cometido é tido pelo ordenamento como particularmente indesejado e, portanto, passível de sancionamento adequado a seu grau de reprovação social; e (ii) que a punição seja adequada, em um sentido absoluto, ao ato cometido. Vale dizer: "a punição deve-se adequar ao crime" cometido $^{120}$ (deve guardar, portanto, relação de proporção com a gravidade da conduta).

Quanto ao primeiro aspecto acima enumerado, pede-se licença para remeter o leitor à análise da "função educativa" dos punitive damages, oportunidade na qual são tecidas considerações acerca do prévio conhecimento que se deve dar acerca dos standards exigidos pelo ordenamento e das sanções jurídicas decorrentes do desrespeito a tais standards para a adequada persecução das funções preventiva e punitiva da indenização.

\footnotetext{
${ }^{118}$ No original: "[p]unitive damages are the hammer of civil justice" (Judicial Assessment of Punitive Damages, The Seventh Amendment and The Politics of Jury Power, in Columbia Law Review, vol. 91, 1991, pág. 142).

${ }_{119}$ A Punitive Damages Overview: Functions, Problems and Reform, in Villanova Law Review, vol. 39, 1994, pág. 375/377.
} 
Já quanto ao segundo aspecto, a idéia expressa pela função punitiva dos punitive damages, muito assemelhada àquela atribuída ao Direito Penal, é justamente a de que quanto mais reprovável for o ato cometido pelo lesante, maior será a sensação de prejuízo suportada pelo lesado e, conseqüentemente, mais grave deverá ser a resposta da sociedade contra o mal-feitor. A previsão de uma sanção mais severa, proporcional à maior gravidade da conduta perpetrada pelo lesante e à depreciação dos valores sociais que tal conduta acarretou, é importante justamente para que se possa ter certeza de que a vítima (individualmente) e a sociedade (coletivamente) são dignos de proteção ${ }^{121}$. O ordenamento não poderia tratar duas condutas de gravidades diferentes (e.g., uma decorrente de um acidente, outra intencionalmente dirigida a causar o prejuízo) da mesma maneira (sancionando-as exatamente com a mesma intensidade), sob pena de, por um lado, atribuir a dois bens jurídicos de valores distintos o mesmo remédio (o que representaria tratamento desigual e injusto ao lesado e à sociedade), e, por outro, responder de maneira idêntica a condutas de diversas gravidades (o que representaria tratamento desigual e injusto ao ofensor que houvesse cometido o ilícito de menor gravidade).

\section{V.IV. A função educativa}

Intimamente ligada ao desempenho das funções punitiva e preventiva dos punitive damages está aquela que a doutrina passou a denominar de função educativa. $\mathrm{Na}$ linha do quanto acima exposto, por incidirem de maneira autônoma e em adição aos compensatory damages (sanção esta que, ao contrário dos punitive damages, exerce função essencialmente compensatória) e, especialmente, por incidirem apenas em resposta àquelas condutas que, para além de ilícitas, são reputadas pelo ordenamento jurídico como de alto grau de reprovabilidade (decorrente da imprescindível presença de dolo ou culpa grave), os punitive damages exercem importantíssima função educativa, quer em relação ao ofensor, quer, ainda, em relação à sociedade em geral.

\footnotetext{
${ }^{120}$ Fairness and Efficiency in the Law of Punitive Damages, in Southern California Law Review, vol. 56, 1982, págs. $5 / 8$.

${ }^{121}$ D. LuBAN, A Flawed Case Against Punitive Damages, in The Georgetown Law Journal, vol. 87, 1998, págs. 378/379.
} 
Nas elucidativas palavras de D. G. OWEN, tal função educativa se mostra presente em dois distintos aspectos: em primeiro lugar, a incidência dos "punitive damages certifica, de um lado, a existência de um determinado direito ou interesse legalmente protegido do demandado, bem como, de outro, o correlativo dever legal, por parte do demandado, de respeitar tal interesse"; e, em segundo lugar, "os punitive damages proclamam a importância que o Direito atribui àquele interesse violado, bem como a correspondente condenação da Sociedade à flagrante violação do direito decorrente do tipo de conduta levada a cabo pelo demandado" ${ }^{\text {122 }}$.

Certo é que a prescrição de uma sanção reforça a imperatividade da norma jurídica à qual ela se liga ${ }^{123} \mathrm{e}$, conseqüentemente, intensifica a proteção aos interesses tutelados pela aludida norma. Nesse sentido, ao prever a incidência de uma sanção mais gravosa, que atua de maneira autônoma e em adição àquela meramente compensatória, o Direito evidencia não só a importância do interesse tutelado por aquela norma de conduta, mas, também, o alto grau de reprovabilidade das condutas específicas atingidas por tal sanção (condutas estas, como se viu, caracterizadas por dolo ou culpa grave).

Ao assim estipular, o sistema jurídico, refletindo o sistema social ${ }^{124}$, sinaliza claramente quais os stantards a serem seguidos pelos homens (educando-os, nesse processo, para que, futuramente, procurem se conduzir de maneira a respeitar tais standards). Evidencia-se, dessa forma, que determinados interesses e direitos são especialmente importantes (e, por isso, tutelados de maneira mais intensa) e, igualmente, que determinadas condutas, marcadas pelo alto grau de desconsideração de tais interesses e direitos, são especialmente gravosas (e, por isso, sancionadas de maneira mais rígida).

\footnotetext{
${ }^{122}$ No original, "[p] unitive damages serve a strong educative function for both the individual offender and society in general, in two significant respects. First, punitive damages certify the existence of a particular legally protected right or interest belonging to the plaintiff, on the one hand, and a correlative legal duty on the part of the defendant to respect that interest, on the other. Second, punitive damages proclaim the importance that the law attaches to the plaintiff's particular invaded right, and the corresponding condemnation that society attaches to its flagrant invasion by the kind of conduct engaged in by the defendat."(A Punitive Damages Overview: Functions, Problems and Reform, in Villanova Law Review, vol. 39, 1994, pág. 374).

${ }^{123}$ J. O. AsCEnsÃo, Introdução à Ciência do Direito, $3^{\mathrm{a}}$ ed., Rio de Janeiro, Renovar, 2005, págs. 55 e ss.

124 É nesse sentido que Antonio JUNQUEIRA DE AZEVEDO afirma que o sistema jurídico é um sistema de segunda ordem, cuja existência está em função de um sistema maior, o sistema social (O Direito como Sistema Complexo e de $2^{a}$ Ordem; sua Autonomia. Ato Nulo e Ato Ilícito. Diferença de Espírito entre Responsabilidade Civil e Penal. Necessidade de Prejuízo para Haver Direito de Indenização na Responsabilidade Civil, in Estudos e Pareceres de Direito Privado, São Paulo, Saraiva, 2004, pág. 27).
} 
Nas palavras do já citado D. G. Owen, "essa forma de punição judicial expressa a desaprovação social de determinados condutas seriamente reprováveis, tais como o flagrante descumprimento das regras que determinam de que maneiras as pessoas devem tratar umas às outras. Demais disso, ela reafirma publicamente o comprometimento da Sociedade para a manutenção de seus padrões legais e morais" ${ }^{\prime 25}$.

Vê-se, enfim, que a função educativa, da maneira como acima exposta, é essencial para que os punitive damages possam desempenhar adequadamente suas funções preventiva e punitiva.

No que toca à função preventiva (especialmente em seu aspecto de prevenção geral), é indispensável que todos os potenciais ofensores tenham pleno conhecimento de quais os standards de comportamento que a Sociedade reputa indesejáveis, justamente para que possam ser desestimulados de cometê-los em razão da imposição de sanções particularmente gravosas (as quais também devem ser adequada e previamente conhecidas).

Já no que concerne à função punitiva, o prévio conhecimento do grau de reprovabilidade das condutas cometidas é essencial para que o ofensor possa ser punido em razão de seu cometimento. Suas condutas são reputadas particularmente indesejadas por serem intencionalmente destinadas a desrespeitar as normas jurídicas e a violar direitos subjetivos. Se o ofensor desconhecesse as normas de conduta que deveria respeitar, ou a existência dos direitos subjetivos que não deveria lesar, não se poderia reputá-lo como mal-feitor.

\section{V.V. A função vingativa}

Um aspecto que nos parece especialmente ligado à função punitiva, acima analisada, é aquele denominado de função vingativa dos punitive damages (os quais,

125 No original: "[t]his form of judicial punishment expresses the community's disapproval of serious misconduct such as flagrant breaches of rules governing how people are to treat one another. Furthermore, it publicly reaffirms society's commitment to mainteining its moral and legal standards." (A Punitive Damages Overview: Functions, Problems and Reform, in Villanova Law Review, vol. 39, 1994, pág. 375) 
historicamente, também foram denominados de vindictive damages $\left.{ }^{126}\right)$. Sustenta parte da doutrina que, por servirem como meio de punição ao ofensor, que é atingido por uma sanção cuja intensidade varia de acordo com o grau de reprovação da conduta por ele levada a cabo, os punitive damages atuam de modo a apaziguar um natural (e em tudo indesejável) sentimento de vingança por parte do ofendido; promovendo, nesse sentido, a busca pelo Poder Judiciário, que servirá como órgão para a heterocomposição dos conflitos, em detrimento do exercício arbitrário das próprias razões ${ }^{127}$.

Nas palavras de A. J. SEBOK, "os punitive damages, quando utilizados para 'vingar' o demandante, permitem-no atingir diretamente o demandado e, em assim o fazendo, recompor ou 'resgatar' sua honra”, lesada pelo ilícito cometido. Neste sentido, o numerário recebido a título de punitive damages "não compensa um prejuízo, servindo de meio para que a honra lesada do demandante seja recomposta"128. Tal raciocínio é concluído por C. CALlEROS, ao afirmar que a "punição do mal-feitor atribui à vítima do ilícito um sentimento de satisfação, de que a Justiça foi feita, ou outro sentimento de satisfação, decorrente da vingança imposta ao ofensor ${ }^{, 129}$.

Sob esta ótica, mais do que efetivamente compensar a vítima pelos prejuízos suportados, os punitive damages servem como meio de ver "vingados" ("vindicated") seus direitos e interesses, representando a imposição de sanção severa ao ofensor. Deste modo, ao ofendido mais importaria a condenação imposta ao demandado do que, propriamente, o numerário que lhe fosse transferido como resultado da condenação ${ }^{130}$.

126 A. J. SEBOK, Punitive Damages in The United States, in H. KOZIOL - V. WILCOX (eds.), Punitive Damages: Common Law and Civil Law Perspectives, Wien, Springer, 2009, pág. 172.

${ }^{127}$ Tal posicionamento é citado, entre outros, por M. M. BELli SR., Punitive Damages: Their History, Their Use and Their Worth in Present-Day Society, in UMKC Law Review, vol. 49, n. 1, 1980, pág. 5.Em sentido semelhante, C. CAlleros, Punitive Damages, Liquidated Damages and Clauses Pènales in Contract Actions: A Comparative Analysis of the American Common Law and the French Civil Code, in Brooklyn Journal of International Law, vol. 32, 2006, pág. 79.

${ }^{128}$ No original: "punitive damages, when used to 'vindicate' the plaintiff, allowed the plaintiff to actively addres the defendant, and in doing so, recover or 'rescue' his or her honour. [...] the money received does not replace a loss, but is a menos by which the plaintiff's lost honour ir returned." (Punitive Damages in The United States, in H. KozIOL - V. Wilcox (eds.), Punitive Damages: Common Law and Civil Law Perspectives, Wien, Springer, 2009, pág. 174).

129 No original: "punishment of the wrongdoer provides the victim of the wrongdoing with sense of satisfaction that justice has been done, or a sense of satisfaction that may come with exacting revenge on the wrongdoer" (Punitive Damages, Liquidated Damages and Clauses Pènales in Contract Actions: A Comparative Analysis of the American Common Law and the French Civil Code, in Brooklyn Journal of International Law, vol. 32, 2006, págs. 78/79).

${ }^{130}$ É nesse sentido que A. J. SEBOK afirma que, sob a ótica da "função vingativa", "the payment of the money to the plaintiff is less importante than the imposition of the monetary penalty on the defendant" (Punitive 
Assim, por permitirem que o ofendido possa satisfazer seus sentimentos de vingança por meio de um procedimento judicial legítimo, realizado sob o crivo do Poder Judiciário e em atenção a todos os princípios e garantias constitucionais, os punitive damages exercem uma importante e socializadora função, limitadores que são do exercício da auto-tutela ${ }^{131}$.

\section{V.VI. Uma (apenas aparente) incongruência: a função compensatória}

Cogita-se, ademais, que, ao longo de sua história (e até mesmo nos dias atuais), os punitive damages exerceram, para além das funções acima consignadas, uma verdadeira função compensatória. Diz-se, assim, que tal sorte de condenação já se destinou (e, em certa medida, ainda se destina) à recomposição do patrimônio (material ou imaterial) do lesado, e não só à punição do lesante pela ofensa causada ou à prevenção de novos ilícitos.

Como já se teve a oportunidade de frisar acima, em um primeiro momento os países da common law não admitiam a compensação dos prejuízos não materiais (o conceito de compensatory damages não abrangia aquele das assim chamadas "non pecuniary losses", ou seja, só se compensavam prejuízos que podiam ser imediatamente exprimidos em pecúnia). A despeito da impossibilidade de reparação integral do patrimônio do ofendido por meio da utilização dos compensatory damages, nos casos em que o ofendido houvesse suportado detrimentos não materiais em razão de condutas intencionais ou grosseiramente negligentes, os júris passaram a admitir a condenação do ofensor ao pagamento de uma soma denominada de punitive ou exemplary damages, uma quantia que, propositadamente, era calculada em valor que excedia os limites estritos do prejuízo material suportado.

Damages in The United States, in H. KOZIOL - V. WILCOX (eds.), Punitive Damages: Common Law and Civil Law Perspectives, Wien, Springer, 2009, pág. 174)

131 J. T. SImPSOnS JR., Discovery of Net Worth in Bifurcated Punitive Damages Cases: A Suggested Approach After Transportation Insurance Co. v. Moriel, in South Texas Law Review, vol. 37, 1996, pág. 202:

"Today, victims tend to refrain from violent vengeance, knowing they can take someone to court and receive 
Ao serem utilizados em casos nos quais o ofendido houvesse suportado detrimentos não materiais, os punitive damages, ao menos na origem, exerciam uma função mista: se, de um lado, serviam como punição do ofensor em razão da gravidade das condutas por ele perpetradas, de outro, também atribuíam ao ofendido uma quantia em pecúnia como resposta à lesão a direitos que, de ordinário, não seriam reparados. Os punitive damages serviam, portanto, à punição assim como serviam à compensação, exercendo também verdadeira função compensatória.

Ocorre que, a despeito de hoje as "non pecuniary losses" serem integralmente abrangidas pelo conceito de compensatory damages, tendo-se extraído dos punitive damages a finalidade de servir de remédio para a compensação desta sorte de prejuízos, não é isenta de reparos a afirmação de que tal evolução eclipsou "toda a [sua] finalidade compensatória" ${ }^{\prime 132}$.

Nessa linha, D. G. Owen afirma que, ao menos nos Estados Unidos da América, mesmo hoje os punitive damages ainda exercem marcada função compensatória, uma vez que, além de exercer suas finalidades de punição e prevenção, tal condenação “também serve para reembolsar o demandante pelas perdas que, de ordinário, não são compensadas por meio dos compensatory damages, tais como perdas que o demandante não é capaz de provar ou para as quais a responsabilidade civil não proporciona remédio, incluindo e o que é mais importante, as despesas decorrentes da litigância"133. Entre tais despesas, sobressaem em importância os honorários de advogado.

more through punitive damages than through violent confrontation. Victims realize that taking money from a wrongdoer's pocketbook injures the wrongdoer more than resorting to physical violence."

${ }^{132}$ E. URSO. Recenti Sviluppi nella Giurisprudenza Statunidense e Inglese in Materia di Punitive Damages: $i$ Casi TXO Production Corporation v. Alliances Resources Corporation e AB v. South West Water Services Ltd., in Rivista di Diritto Civile, vol. 41, n. 1, genn.-febr./1995, págs. 84/85.

${ }^{133}$ No original: "[the punitive damages] also serve to reimburse the plaintiff for losses not ordinarily recoverable as compensatory damages, such as actual losses the plaintiff is unable to prove or for which the rules of damages do not provide relief, including and most importantly, the expenses of bringing suit." (A Punitive Damages Overview: Functions, Problems and Reform, in Villanova Law Review, vol. 39, 1994, págs. 378/379). Ainda, G. V. Robredo, Costes Legales y Honorarios de Abogados em el Proceso Civil (Observaciones sobre la Situación em los Estados Unidos y em Europa), in Revista de la Universidad de Deusto, vol. 45, fasc. 98, ene-jun./1997, pág. 153. O fundamento por traz da função compensatória dos punitive damages, especialmente no que toca à reposição dos custos da litigância, é a de que "a person with a legitimate cause of action should not be discouraged from seeking relief because of the prohibitive expenses of litigation, especially if the wrongdoer acted upon an improper motive". (M. L. MINER, Expanding Availability of Punitive Damages in Contract Actions, in Indiana Law Review, vol. 8, 1975, pág. 671). 
Isso se dá porque, ao contrário do que ocorre nos países de tradição processualística romano-germânica, nos Estados Unidos da América não vige o princípio processual da causalidade ${ }^{134}$, que prescreve que aquele que "deu causa" ao processo (seja deduzindo pretensão inadmissível contra aquela que tinha razão, seja, de outro lado, opondo resistência injustificada à satisfação do direito alheio, tornando necessária a demanda) deve responder pelos custos despendidos durante a tramitação processual, os quais abarcarão, necessariamente, as custas e despesas processuais, além dos honorários advocatícios devidos ao patrono da parte vencedora. Desse princípio, consubstanciado no art. 20 de nosso Código de Processo Civil, extrai-se a conclusão apresentada por Cândido Rangel DinAMARCo de que “[o] processo deve propiciar a quem tem razão a mesma situação econômica que ele obteria se as obrigações alheias houvessem sido cumpridas voluntariamente ou se seus direitos

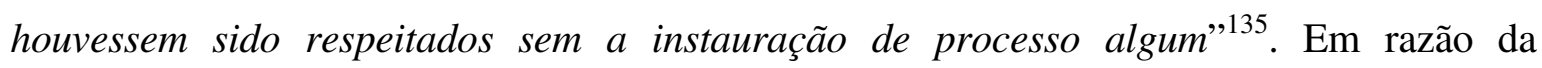
inobservância (ou, melhor dizendo, da inexistência) do princípio processual da sucumbência, nos Estados Unidos da América cada uma das partes litigantes arca com as custas e despesas processuais por ela incorridas, bem como com os honorários de seus patronos, seja qual for o resultado final da demanda ${ }^{136}$.

Assim é que, mesmo atualmente, os punitive damages também exercem, ainda que em menor grau, uma função dita compensatória, atuando como verdadeiro sucedâneo do princípio da causalidade ${ }^{137}$ ao reembolsar o demandante das despesas que

\footnotetext{
134 A. SARavalle, I Punitive Damages nelle Sentenze delle Corti Europee e dei Tribunali Arbitrali, in Rivista di Diritto Internazionale Privato e Processuale, anno XXIX, n. 4, ott.-dic./1993, pág. 871. Importa ressaltar, quanto a este ponto, que até mesmo a Inglaterra prevê, em seu sistema processual, a incidência do princípio da causalidade, determinando que o sucumbente arque com as despesas processuais e honorários advocatícios da parte vencedora. Comparando as chamadas "regra americana" (= inexistência do princípio da causalidade) com a "regra inglesa" (= existência do princípio da causalidade), cfr. M. C. T. PATRÍ́cIO, Análise Económica da Litigância, Coimbra, Almedina, 2005, págs. 85/93.

${ }^{135}$ Instituições de Direito Processual Civil, vol. II, 2 a ed., São Paulo, Malheiros, 2002, pág. 648.

${ }^{136}$ G. V. Robredo, Daños Punitivos en el Proceso Civil Norteamericano, in Revista de la Universidad de Deusto, vol. 57, fasc. 97, jul-dic./1996, págs. 182/183 e E. D’ALESSANDRO, Pronunce Americane di Condanna al Pagamento di Punitive Damages e Problemi di Riconoscimento in Italia, in Rivista di Diritto Civile, anno LIII, n. 3, mag.-giug./2007, pág. 385. Ainda sobre a assim chamada "regra americana" (= inexistência do princípio da causalidade), G. V. RoBREDO, Costes Legales y Honorarios de Abogados em el Proceso Civil (Observaciones sobre la Situación em los Estados Unidos y em Europa), in Revista de la Universidad de Deusto, vol. 45, fasc. 98, ene-jun./1997, págs. 141/172.

${ }^{137}$ E. D'Alessandro, Pronunce Americane di Condanna al Pagamento di Punitive Damages e Problemi di Riconoscimento in Italia, in Rivista di Diritto Civile, anno LIII, n. 3, mag.-giug./2007, págs. 385/386 e G. V. Robredo, Daños Punitivos en el Proceso Civil Norteamericano, in Revista de la Universidad de Deusto, vol. 57, fasc. 97, jul-dic./1996, págs. 182/183.
} 
vier a dispender durante o curso do processo, bem como dos honorários do profissional contratado por ele para representá-lo em juízo ${ }^{138}$.

\section{PRESSUPOSTOS OBJETIVOS PARA A INCIDÊNCIA dOS PUNITIVE DAMAGES}

Já tendo ultrapassado a análise acerca do conceito dos punitive damages, bem como das funções a eles atribuídas pela doutrina, cumpre-nos, deste ponto em diante, lançar os olhos sobre os prerequisitos usualmente exigidos para a sua incidência. Procuraremos iniciar nossa análise pela verificação dos prerequisitos ditos “objetivos", para cuja aferição é dispensável perquirir sobre as intenções do ofensor, quais sejam: (i) a ocorrência de um ato ilícito (oportunidade na qual investigaremos se os punitive damages podem ser extraídos apenas em caso de ocorrência de ilícitos extracontratuais, os assim chamados "torts", ou se, do contrário, é admissível sua imposição mesmo em casos nos quais há apenas ilícitos contratuais, as assim chamadas "breaches of contract"); e (ii) a ocorrência de prejuízo (oportunidade na qual verificaremos se os punitive damages devem ser impostos apenas quanto, do ilícito cometido, decorrem efetivos prejuízos, denominados de "compensatory damages", ou se, de outro lado, admite-se sua incidência mesmo na hipótese de, do ilícito, resultarem apenas os "prejuízos simbólicos", denominados de "nominal damages").

\section{VI.I. Ilícito extracontratual (tort) ou inadimplemento contratual (breach of contract)?}

Pode-se dizer que o primeiro e mais relevante pressuposto para aferir-se o cabimento da condenação ao pagamento de punitive damages é a ocorrência de um ato ilícito (um "civil wrong", a violação a um "dever legal" ou a um "interesse juridicamente tutelado"). Neste ponto, procuraremos investigar se, aos olhos da doutrina e da jurisprudência, a sanção punitiva deve incidir apenas nos casos em que estamos diante do cometimento de um ilícito extracontratual ("tort") ou se, de outro lado, também se admite

\footnotetext{
${ }^{138}$ E. D’Alessandro, Pronunce Americane di Condanna al Pagamento di Punitive Damages e Problemi di Riconoscimento in Italia, in Rivista di Diritto Civile, anno LIII, n. 3, mag.-giug./2007, pág. 385: "[I]nfatti, $i$ punitive damages servono sempre anche a rifondere $i$ costi processuali al vincitore della causa, posto che nel loro ammontare è inclusa sia la somma dovuta a titolo di onorario al legale della parte vittoriosa, sia la somma necessaria alla rifusione dele spese vive patite da quest'ultima."
} 
sua incidência no âmbito contratual, em razão do inadimplemento total ou parcial (as assim chamadas "breaches of contract").

Antes de proceder a tal análise, importa ressaltar que, como anuncia Eduardo UILAN, nos "sistemas de Common Law, o tort é o ilícito civil por excelência, ainda que seja difícil achar-lhe uma tradução sob medida nas categorias jurídicas utilizadas pelos sistemas de raiz romano-germânica"139.

Prosseguem S. DeAKIn, A. Johnston e B. MARKESINIS ao anunciar que, de uma maneira geral, todo o tort envolve o descumprimento de um "dever legal" ("legal duty"), tendo-se este como a proibição, legalmente imposta, de que o particular realize determinado comportamento em uma certa circunstância. Mas não é só: a despeito de não se poder traçar uma regra geral que abranja os elementos de existência comuns a todas as espécies de torts, não é errado dizer que a maioria delas somente é considerada completa se presentes ao menos quatro elementos: (i) a conduta ("conduct"), (ii) a culpa ("fault" ou "blameworthiness"), (iii) o dano ("damage") e, por fim, (iv) o nexo de causalidade (“causation") entre a conduta e o dano dela decorrente ${ }^{140}$.

Vê-se, em adendo à idéia inicialmente apresentada, que o conceito de tort se assemelha, por vezes, ao nosso conceito de regra de imputação, abrangendo não apenas o conceito de ato ilícito, mas, também os conceitos de culpa, dano e nexo de causalidade. Importa destacar, ademais, que, por se envolver a violação a um "dever legal", cuja existência e conteúdo não são, em regra, definidos pelas partes, que não possuem relação jurídica anterior, o tort não se confunde com o mero inadimplemento contratual ("breach of contract") ${ }^{141}$. É apenas nesse sentido (o de oposição entre tort e breach of contract) que traduzimos a expressão tort para "ilícito extracontratual" ou "aquiliano".

Feita tal ressalva, responde-se ao objeto da presente investigação com a afirmação de L. P. SIMPSON, no sentido de que "[a] regra da common law, seguida na grande maioria dos Estados [norte-americanos], é a de que punitive damages não podem

\footnotetext{
${ }^{139}$ Responsabilidade Civil Punitiva, Tese (Doutorado) - Faculdade de Direito da USP, São Paulo, 2003, pág. 26.

${ }^{140}$ Markesinis and Deakin's Tort Law, $6^{\text {th }}$ ed., New York, Oxford, 2008, pág. 30.

${ }^{141}$ Sobre a distinção entre contracts e torts, cfr. S. DEAKIN - A. JOHNSTON - B. MARKESINIS, Markesinis and Deakin's Tort Law, $6^{\text {th }}$ ed., New York, Oxford, 2008, págs. 17/29.
} 
ser impostos em ações que versem sobre inadimplemento contratual, não importando as circunstâncias de malícia, abuso, injustiça ou opressão em que se deu o inadimplemento" ${ }^{142}$.

A despeito de tal regra geral, após o julgamento do caso Welborn v. Dixon (70 S.C. 10849 S.E. 232 1904) pela Corte de Apelação do Estado de South Carolina, a jurisprudência norte-americana passou a admitir a imposição de punitive damages em casos relacionados ao inadimplemento contratual, contanto que o inadimplemento fosse acompanhado de uma conduta fraudulenta ou de algum outro ato intencional, abusivo, ou grosseiramente negligente que se caracterize, por si só, como tort ${ }^{143}$.

Para a imposição de punitive damages, não é necessário que o ato fraudulento seja realizado em direta conexão ou no mesmo momento que o inadimplemento contratual. Com efeito, a fraude pode ocorrer: (i) antes mesmo da formação do contrato (quando, e.g., uma das partes contratantes faz uso de mentiras deliberadas com o fim de fazer com que a outra celebre contrato que, de ordinário, não celebraria); (ii) durante a execução do contrato, mas antes do inadimplemento propriamente dito (L. P. SIMPSON cita como exemplo caso no qual, celebrado contrato de venda e compra de grãos pelo meio do qual o comprador havia se obrigado a colher e pesar os grãos, pagando por eles o preço correspondente ao peso aferido, o comprador foi condenado ao pagamento de compensatory e punitive damages por ter não apenas descumprido o contrato, mas, também, fraudulentamente alterado os dados da pesagem dos grãos); ou, ainda, (iii) em conjunto e em direta associação com o inadimplemento contratual (tais como, e.g., a dispensa ilegal de empregado ou o despejo ilegal de locatário) ${ }^{144}$.

\footnotetext{
${ }^{142}$ No original: " $[\mathrm{t}]$ he common law rule, adhered to in the great majority of states, is that punitive damages may not be assessed in an action for breach of contract, no matter what the circumstances of malice, abuse, wantonness or appression that attend the breach". (Punitive Damages for Breach of Contract, in Ohio State Law Journal, vol. 20, 1959, pág. 284). C. CALLEROS identifica, na antiga vedação à execução específica (enforcement) das assim chamadas "conditional bonds" (instrumento jurídico surgido no ordenamento inglês em meados do Século XIV com a finalidade de impor uma penalidade ao devedor que descumprisse uma obrigação contratual), quando estas possuíam flagrante caráter punitivo, fixadas, portanto, em valor que extrapolasse os limites do prejuízo passível de ser suportado pelo credor em razão do inadimplemento, uma razão histórica para a inadmissão dos punitive damages por descumprimento contratual, ainda que doloso (Punitive Damages, Liquidated Damages and Clauses Pènales in Contract Actions: A Comparative Analysis of the American Common Law and the French Civil Code, in Brooklyn Journal of International Law, vol. 32, 2006, págs. 75/76).

${ }^{143}$ L. P. SimPSON, Punitive Damages for Breach of Contract, in Ohio State Law Journal, vol. 20, 1959, pág. 284.

${ }^{144}$ L. P. Simpson, Punitive Damages for Breach of Contract, in Ohio State Law Journal, vol. 20, 1959, págs. $285 / 286$.
} 
Em atenção a tais premissas, a doutrina noticia que as exceções mais comumente observadas à regra que veda a incidência de punitive damages por inadimplemento contratual são ${ }^{145}$ : (i) o rompimento de noivado ("breach of promise to marry"), quando o que ocorre, em verdade, é a sedução da dama por meio de uma promessa de casamento fraudulenta ${ }^{146}$; (ii) a cessação injustificada, por uma empresa concessionária, da prestação de determinado serviço público que, além de obrigação contratual constitui-se como "dever legal" ("legal duty"); e, por fim, (iii) o inadimplemento que, além de representar descumprimento de obrigação contratual, implica a infração a um "dever fiduciário" (“fiduciary duty”), tal como, e.g., a negativa, de má-fé, de pagamento da indenização devida ao segurado (“bad faith denial” em contratos de seguro).

Ao analisar tais hipóteses, D. G. OwEN conclui que "cada exceção apresentada, contudo, confirma a regra que veda a condenação ao pagamento de punitive damages apenas por conta do inadimplemento, uma vez que envolve condutas que extrapolam os limites do inadimplemento e que podem se configurar com um tort independente, para o qual a condenação ao pagamento de punitive damages seria concedida de qualquer maneira" ${ }^{\text {147 }}$.

\section{VI.II. Ocorrência de prejuízo}

Uma vez demonstrado que os punitive damages somente devem incidir em resposta ao cometimento de um ato ilícito (i.e., em atenção ao cometimento de um ato que desrespeite uma previsão normativa), cumpre-nos investigar se, para a incidência de tal sanção (cujas funções primordiais não se confundem com a recomposição do patrimônio

\footnotetext{
${ }^{145}$ M. M. Belli SR., Punitive Damages: Their History, Their Use and Their Worth in Present-Day Society, in UMKC Law Review, vol. 49, n. 1, 1980, págs. 16/17. Tais exemplos são também referidos por C. CALLEROS, Punitive Damages, Liquidated Damages and Clauses Pènales in Contract Actions: A Comparative Analysis of the American Common Law and the French Civil Code, in Brooklyn Journal of International Law, vol. 32, 2006, págs. 71/73 e por D. G. OwEN, Punitive Damages in Products Liability, in Michigan Law Review, vol. 74, 1976, págs. 1271/1972.

${ }^{146}$ M. L. MINER, Expanding Availability of Punitive Damages in Contract Actions, in Indiana Law Review, vol. 8, 1975, págs. 677/678.

${ }^{147}$ No original: "[e]ach purported exception, however, is ultimately reconcilable with the underlying rule that precludes the recovery of punitive damages for breach of contract, since each involves conduct apart from the breach itself that may amount to an independent tort for which puntive damages could be awarded anyway". (Punitive Damages in Products Liability, in Michigan Law Review, vol. 74, 1976, pág. 1972).
} 
da vítima), é indispensável que, do ilícito cometido, decorram prejuízos. Para o adequado desempenho desta tarefa, é imprescindível que nos debrucemos rapidamente sobre as características específicas do sistema jurídico da common law, em particular sobre as regras de responsabilidade civil, uma vez que das marcadas diferenças em relação ao sistema dos países de raiz romano-germânica, poderiam resultar confusões quanto às conclusões que se seguem.

Em apertada síntese, o sistema de responsabilidade civil dos países da common law é denominado de "sistema pluralista", ou seja, aquele no qual a responsabilidade se funda na previsão de inúmeros remédios jurídicos distintos, cada um deles aplicável à lesão de um interesse juridicamente tutelado. A esse "sistema pluralista", contrapõe-se o "sistema monista", o qual, em vez de se fundar em diversos remédios jurídicos distintos, prevê uma regra geral de responsabilidade civil (como, e.g., aquela inserida nos artigos 188 e 927 de nosso Código Civil) ${ }^{148}$.

Segundo afirma Eduardo UILAN, uma conseqüência dessa "fragmentação" da responsabilidade civil no "sistema pluralista" é a de que "a noção unitária de dano a que estamos habituados a usar não encontra equivalentes na experiência da common law”. Conclui o citado autor que, “[u]ma vez que não há cláusula geral de responsabilidade, faz-se necessário especificar a natureza do dano, buscando sua conexão com o interesse lesado. $O$ dano só é ressarcido se resultar da lesão a um interesse típico protegido" 149 .

Ainda em atenção às peculiaridades do sistema jurídico dos países da common law, nota-se, como acima exposto, que a responsabilidade civil exerce não apenas uma função compensatória, mas, também, e de maneira ostensiva, funções punitiva e preventiva. Nestes casos, as atenções deixam de se voltar para a vítima para retornar ao ofensor, àquele que infringe as normas jurídicas e desrespeita um "interesse típico protegido". Assim é que S. DeAKIn, A. Johnston e B. Markesinis sustentam que "[e]m algumas hipóteses [a responsabilidade civil] é usada para vingar a lesão a direitos subjetivos e, nelas, a condenação ao pagamento de indenização não está relacionada com

\footnotetext{
${ }^{148}$ Eduardo UILAN, Responsabilidade Civil Punitiva, Tese (Doutorado) - Faculdade de Direito da USP, São Paulo, 2003, pág. 26.

${ }^{149}$ Responsabilidade Civil Punitiva, Tese (Doutorado) - Faculdade de Direito da USP, São Paulo, 2003, pág. 27.
} 
os prejuízos do demandante (até porque tais prejuízos podem comumente não ocorrer), mas apenas para afirmar os direitos" lesados ${ }^{150}$.

Em atenção a estas específicas funções da responsabilidade civil, o ordenamento prevê que a proteção a determinados interesses se dê de maneira ainda mais intensa, mesmo que da lesão a tais interesses não resulte prejuízo efetivamente quantificável. Prevê-se, para a proteção desses interesses, os torts "dedutíveis per se" ("actionable per se"), tais como o "trespass to land", "assault", "false imprisonment" e "libel", os quais podem fundamentar uma demanda indenizatória ainda que o demandante não alegue ou demonstre ter suportado efetivos prejuízos. "O fato de não se ter sofrido prejuízo não afetará a responsabilidade, apesar de poder afetar a quantificação da indenização" ${ }^{, 151}$.

Nestes casos, o "prejuízo" ("damage") é justamente a lesão a um "interesse juridicamente tutelado", enquanto que a indenização (“damages") representará a quantia a ser concedida em razão da violação ao citado interesse ${ }^{152}$. Tal quantia, na hipótese em que o tort é "dedutível per se", será meramente "nominal" ("nominal damages") 153 , a não ser que o demandante consiga demonstrar ter efetivamente suportado prejuízos, hipótese na qual fará jus ao recebimento de indenização compensatória (“compensatory damages”) ${ }^{154}$.

\footnotetext{
${ }^{150}$ No original: "[i]n some instances it [a responsabilidade civil] is used to vindicate private rights and here the award of damages is not related to the claimant's loss (since often there may be none), but merely asserts his rights". (Markesinis and Deakin's Tort Law, $6^{\text {th }}$ ed., New York, Oxford, 2008, pág. 940).

${ }^{151}$ No original: "The fact that no harm was suffered will not affect liability, though it may affect the quantum of damages". (S. DEAKIN - A. JOHNSTON - B. MARKESINIS, Markesinis and Deakin's Tort Law, $6^{\text {th }}$ ed., New York, Oxford, 2008, pág. 940).

${ }^{152}$ S. DEAKIN - A. JOHNSTON - B. MARKeSINIS, Markesinis and Deakin's Tort Law, $6^{\text {th }}$ ed., New York, Oxford, 2008, pág. 940. A utilização da expressão prejuízo entre aspas, como tradução da palavra "damage", foi proposital. No contexto em que inserida, a expressão "prejuizo" designa algo muito mais próximo do que Antonio JUNQUEIRA DE AZEVEDO denomina de dano-evento do que, propriamente, aquilo que usualmente nos referimos como prejuízo. Trata-se da lesão a um bem ou interesse juridicamente tutelado (dano-evento, portanto), e não, propriamente, das consequiências prejudiciais decorrentes de tal lesão (este, sim, danoprejuízo). Sobre a distinção entre as duas categorias, cfr. Antonio JUNQUEIRA DE AZEVEDO, Cadastros de Restrição ao Crédito. Conceito de Dano Moral, in Estudos e Pareceres de Direito Privado, São Paulo, Saraiva, 2004, págs. 291 e ss.

${ }^{153}$ B. A. GARNER, Black's Law Dictionary, 7ª ed., St. Paul, West Group, 1999, pág. 396: "[N]ominal damages are damages awarded for the infraction of a legal right, where the extent of the loss is not dependent upon loss or damage, as in the case of rights of bodily immunity or right to have one's material property undisturbed by direct invasion. The award of nominal damages is made as a judicial declaration that the plaintiff's right has been violated."

${ }^{154}$ S. DEAKIN - A. JOHNSTON - B. MARKESINIS, Markesinis and Deakin's Tort Law, $6^{\text {th }}$ ed., New York, Oxford, 2008, pág. 940.
} 
Vê-se, desta feita, que ao contrário do que ocorre nos países de raiz romanogermânica, em que o dano é considerado como elemento inafastável para a responsabilidade civil, nos países da common law admite-se (nos casos em que o tort é "dedutivel per se") a responsabilização do ofensor mesmo na completa ausência de efetivo prejuízo para o ofendido (compensatory damages).

Feita tal digressão, pode-se transcrever a afirmação de G. B. BELL e P. E. PEARCE no sentido de que "a maioria dos Estados que permitem a incidência de punitive damages exige também a condenação ao pagamento de actual ou compensatory damages como pré-requisito para a imposição de punitive damages. Contudo, a quantia de actual ou compensatory damages exigida não é especificamente definida, e, desta forma, a imposição de nominal damages é geralmente suficiente" para fundamentar uma condenação ao pagamento de punitive damages ${ }^{155}$.

Desta feita, pode-se dizer que que a pretensão à condenação ao pagamento de punitive damages não depende da ocorrência, alegação ou comprovação de efetivo prejuízo. Depende, contudo e no mínimo, da ocorrência de um tort que dê ensejo, independentemente da ocorrência do prejuízo, a uma pretensão condenatória bem sucedida. Nas palavras de M. M. BELLI SR., "como os punitive damages são incidentais a uma cause of action, eles jamais podem, sozinhos, constituir a causa de pedir de uma demanda. Assim, [para a procedência de uma demanda que vise à condenação do demandado ao pagamento de punitive damages], o demandante tem de demonstrar que ele sofreu efetivo prejuízo ou que seus direitos foram lesados" $" 156$.

\footnotetext{
${ }^{155}$ No original: "[t]he majority of jurisdictions allowing punitive damages require actual or compensatory damages as a prerequisite to an award of punitive damages. However, the amount of actual or compensatory damages required is not specifically defined, and nominal actual damages will often suffice." (Punitive Damages and the Tort System, in University of Richmond Law Review, vol. 22, 1987, pág. 6). No mesmo sentido: A. J. SeboK, Punitive Damages in The United States, in H. KozIOL - V. WILCOX (eds.), Punitive Damages: Common Law and Civil Law Perspectives, Wien, Springer, 2009, pág. 171 e B. MCALLISTER, Punitive Damages - Judgement Granting Equitable Relief Cannot Support Award of Punitive Damages Where Actual Damages Are Not Also Recovered, in St. Mary's Law Journal, vol. 17, 1986, pág. 536.

${ }^{156}$ No original: "Since punitive damages are merely incidental to a cause of action, they alone never may constitute the basis of the action. Thus, the plaintiff must show that he has been injured or that his rights have been infringed." (Punitive Damages: Their History, Their Use and Their Worth in Present-Day Society, in UMKC Law Review, vol. 49, n. 1, 1980, pág. 9). Em razão da subsidiariedade da pretensão ao recebimento de punitive damages (sempre incidental à cause of action necessária para o ajuizamento da ação), deve-se ler cum granum salis a afirmação de Vitor Fernandes GONÇALVES de que a indenização punitiva é autônoma em relação ao pedido indenizatório, e que "o indeferimento da indenização compensatória não implica na [sic] prejudicialidade da indenização punitiva, nem vice versa". (A Punição na Responsabilidade Civil: A indenização do dano moral e da lesão a interesses difusos, Brasília, Brasília Jurídica, 2005, págs. 81/82). A
} 


\section{Pressupostos SUbJetivos Para A INCIDÊNCIA dOS PUNITIVE DAMAGES}

Pudemos observar, acima, que os punitive damages são utilizados como sanção punitiva contra o cometimento de atos ilícitos ("torts"). Mais do que isso, afirmouse em mais de uma oportunidade que os punitive damages se destinam a sancionar os atos ilícitos de maior grau de reprovabilidade, efetivamente punindo o ofensor pela grave conduta por ele perpetrada e desestimulando o ofensor e a sociedade em geral quanto ao cometimento de atos ilícitos de gravidade semelhante. O que se busca, portanto, não é apenas e tão-somente dar resposta a atos ilícitos danosos (para tanto, basta a incidência da indenização compensatória, adequada a recompor o patrimônio lesado), mas, sim, dar resposta exemplar a atos ilícitos específicos, permeados por um elemento subjetivo tal que os torna mais gravosos do que os demais, quer pela intencionalidade da conduta do ofensor (direcionada propositadamente ao cometimento do ilícito), quer, ainda, por sua flagrante e grosseira desconsideração para com os direitos alheios.

A despeito de o regramento atinente aos punitive damages variar sensivelmente em cada Estado norte-americano, pode-se dizer que somente se admite sua incidência se, ao cometer o ato ilícito, o ofensor estiver imbuído do adequado "estado de espírito" ("state of mind") ${ }^{157}$. Este "estado de espírito", característico da "culpa" ("fault"), elemento indissociável da grande maioria dos "atos ilícitos" ("torts"), pode variar em três diferentes graus, os quais, do mais reprovável ao mais brando, são: (i) a "malícia" (“malice"); (ii) a "intenção" ("intent"), à qual se equipara a "temeridade" ("recklesness"); e, por fim, a mera "negligência" ("negligence") ${ }^{158}$.

condenação ao pagamento de punitive damages é, realmente, dissociada de qualquer pedido de pagamento de compensatory damages, mas não é correto dizer que a improcedência do pedido principal (de responsabilização do ofensor, ainda que, deste pedido, resultem apenas nominal damages) não é prejudicial à apreciação do pedido acessório, de pagamento de punitive damages. Se o ofensor não for considerado responsável pelo tort, o pedido de indenização punitiva será necessariamente julgado improcedente. Além disso, não se pode deduzir, de maneira autônoma, o pedido de condenação ao pagamento de punitive damages, o qual, como se disse, é incidental à causa principal.

${ }^{157}$ M. M. Belli Sr., Punitive Damages: Their History, Their Use and Their Worth in Present-Day Society, in UMKC Law Review, vol. 49, n. 1, 1980, pág. 8.

158 S. DEAKIN - A. JohnSTON - B. MARKeSInIS, Markesinis and Deakin's Tort Law, $6^{\text {th }}$ ed., New York, Oxford, 2008, págs. 30/32. 
A "malícia" ("malice"), como se disse, é o mais reprovável de todos os "estados de espírito" (“state of mind"), e envolve não apenas o cometimento intencional de um ato ilícito (i.e., a consciência de que o ato é vedado pelo ordenamento, e de que suas eventuais conseqüências prejudiciais terão de ser sancionadas), mas, também, a presença de um dolo específico. Vale dizer, "o agente tem de [...] dirigir o seu querer a um resultado especialmente reprovável, ligado à causação de prejuízo, moral ou patrimonial, a outrem"159.

A "intenção" ("intent") é, como se depreende de sua própria nomenclatura, o cometimento intencional do ato ilícito, ou seja, "o estado de espírito da pessoa que prevê e deseja um resultado particular [ilícito e possivelmente danoso] (ou é considerada como tendo previsto e desejado um resultado inevitável [novamente, ilícito e possivelmente doloso]"160 ${ }^{\text {. Trata-se, assim, de elemento que se assemelha ao nosso dolo direto }}{ }^{161}$.

Já a "temeridade" ("recklessness") se assemelha ao que denominamos de culpa consciente ou, até mesmo, quando mais gravoso, do que chamamos de dolo eventual $^{162}$, uma vez que representa a circunstância em que "o autor [do dano] prevê, mas não deseja, o resultado causado, que não é por ele considerado como inevitável" 163.

Por fim, a "negligência" ("negligence") é elemento que se assemelha à nossa culpa, caracterizado que é por um comportamento descuidado, a falha em se

\footnotetext{
${ }^{159}$ Vitor Fernandes GonÇALVes, A Punição na Responsabilidade Civil: A indenização do dano moral e da lesão a interesses difusos, Brasília, Brasília Jurídica, 2005, pág. 67. S. DEAKIN, A. Johnston e B. MARKESINIS afirmam que apenas alguns torts específicos exigem a presença de malice como elemento de seu suporte fático (tais como, e.g., a malicious prosecution e a malicious falsehood), mas, mesmo em relação aos torts que não a exigem para a sua configuração, a presença de malice pode trazer conseqüências jurídicas, tais como eliminar possíveis defesas do demandado (como ocorre no tort de defamation) ou agravar a indenização a ser concedida para a vítima (Markesinis and Deakin's Tort Law, $6^{\text {th }}$ ed., New York, Oxford, 2008, pág. 31).

${ }^{160}$ No original: "the state of mind of a person who foresees and desires a particular result (or is deemed to have foreseen and desired an inevitable result)." (S. DEAKIN - A. JOHNSTON - B. MARKESINIS, Markesinis and Deakin's Tort Law, $6^{\text {th }}$ ed., New York, Oxford, 2008, pág. 31).

${ }^{161}$ Sobre a caracterização do dolo, cfr. Marcelo Junqueira CALIXTO, A Culpa na Responsabilidade Civil (Estrutura e Função), Rio de Janeiro, Renovar, 2008, pág. 110 e J. M. ANTUNES VARELA, Das Obrigações em Geral, vol. I, 10 a ed., Coimbra, Almedina, 2000, págs. 569/572.

${ }^{162}$ Sobre a comparação entre os dois institutos no direito brasileiro, cfr. Paulo José da Costa, Direito Penal (Curso Completo), $8^{\mathrm{a}}$ ed., São Paulo, Saraiva, 2000, págs. 83/84.

163 No original: "the actor foresees, but does not desire, a particular result that is not regarded as inevitable”. (S. DEAKIN - A. JOHNSTON - B. MARKESINIS, Markesinis and Deakin's Tort Law, $6^{\text {th }}$ ed., New York, Oxford, 2008, pág. 31).
} 
comportar como um homem prudente se comportaria. Vale dizer: a falha não intencional em prever as consequiências potencialmente ilícitas e danosas da conduta cometida ${ }^{164}$.

Renovada a ressalva acima exposta quanto à possível diferença de regramento dos punitive damages nos diversos Estados norte-americanos, pode-se dizer que, no geral, eles se destinam a sancionar atos ilícitos cometidos de maneira "maliciosa" ("malicious"), "intencional" ("intentional", "willful" ou "wanton") ou, ainda, com "imprudente desconsideração dos direitos alheios", o que caracteriza conduta "temerária" ("reckless") 165. Inadmite-se, portanto, a condenação ao pagamento de punitive damages em situações nas quais a conduta do ofensor haja sido meramente "negligente" ("negligent") ${ }^{166}$.

Com efeito, e como abaixo se verá ao se tratar especificamente de tais questões, mesmo quando se permite a incidência de punitive damages em casos nos quais as regras de imputação não dependem da alegação e comprovação de culpa por parte do ofensor (como se dá, por exemplo, nos casos de responsabilidade pelo fato do produto), exige-se a identificação de "um comportamento qualificado por parte do produtor, a saber, a flagrante indiferença pelos mais altos valores defendidos pelo Direito, como a vida e a integridade física da pessoa humana" ${ }^{167}$.

Mesmo nos casos em que a responsabilização pelo pagamento de punitive damages recai sobre pessoa diversa daquela que cometeu o ilícito tido por altamente reprovável (caso, por exemplo, da responsabilidade do empregador por atos de seus empregados, assunto ao qual retornaremos abaixo), diversos Estados exigem que o

\footnotetext{
${ }^{164}$ S. DEAKIN - A. JohnSTON - B. MARKESINIS, Markesinis and Deakin's Tort Law, $6^{\text {th }}$ ed., New York, Oxford, 2008, pág. 31.

${ }^{165}$ E. D’ Aless Andro, Pronunce Americane di Condanna al Pagamento di Punitive Damages e Problemi di Riconoscimento in Italia, in Rivista di Diritto Civile, anno LIII, n. 3, mag.-giug./2007, pág. 386.

${ }^{166}$ E. URSO. Recenti Sviluppi nella Giurisprudenza Statunidense e Inglese in Materia di Punitive Damages: $i$ Casi TXO Production Corporation v. Alliances Resources Corporation e AB v. South West Water Services Ltd., in Rivista di Diritto Civile, vol. 41, n. 1, genn.-febr./1995, pág. 83. Ainda, Marcela Alcazas BASSAN, As Funções da Indenização por Danos Morais e a Prevenção de Danos Futuros, Dissertação (Mestrado) Faculdade de Direito da USP, São Paulo, 2009, pág. 58. P. M. LOURENÇO informa que apenas no final do Século XIX a jurisprudência norte-americana passou a admitir a incidência dos punitive damages também para casos de temeridade ou "negligência grosseira" ("reckless"), quando antes admitia sua incidência apenas em resposta aois atos ilícitos dolosamente cometidos (A Função Punitiva da Responsabilidade Civil, Coimbra, Coimbra, 2006, pág. 170). Ainda sobre o tema, Vitor Fernandes GonçALVES, A Punição na Responsabilidade Civil: A indenização do dano moral e da lesão a interesses difusos, Brasília, Brasília Jurídica, 2005, pág. 66/68.

167 Marcela Alcazas BASSAN, As Funções da Indenização por Danos Morais e a Prevenção de Danos Futuros, Dissertação (Mestrado) - Faculdade de Direito da USP, São Paulo, 2009, pág. 59.
} 
responsável indireto tenha, ele próprio e em algum grau, participado do cometimento do ilícito, quer autorizando-o expressamente (antes de seu cometimento), ratificando-o (após seu cometimento) ou conscientemente contratando pessoa inadequada para o desempenho de tais funções.

\section{CRITÉRIOS PARA QUANTIFICAÇÃO DOS PUNITIVE DAMAGES}

Uma crítica posta pela doutrina quanto à aplicação do instituto dos punitive damages é a de que, após ter-se decidido pela imposição de tal sanção, os critérios usualmente aventados para sua quantificação são "exessivamente vagos", 168 , atribuindo ao júri um perigoso grau de discricionariedade.

A referida "vagueza", contudo, é defendida por outra parcela da doutrina, que sustenta que "a indeterminação prévia do montante da indenização punitiva emprestalhe uma maior eficácia, nomeadamente tendo em vista sua finalidade preventiva, na medida em que a imposição de tal verba apresenta-se como um evento de conseqüências incertas para um potencial ofensor que, por não saber o quanto terá de pagar em caso de agir ilicitamente, resta impedido de fazer prevalecer um raciocínio puramente econômico, em prejuízo do cumprimento da lei, terminando por evitar, ainda que a contragosto, qualquer comportamento passível de punição"169.

A despeito da polêmica acima apresentada, e ainda que pese o argumento exposto pela crítica, o fato é que existem, sim, critérios usualmente referidos pela doutrina e já consolidados na jurisprudência para a quantificação dos punitive damages. Apesar de, a bem da verdade, não se tratar de critérios rígidos, aptos a possibilitar uma quantificação milimetricamente precisa, não se pode olvidar a sua pertinência para a mensuração de uma

168 Os argumentos usualmente expostos pela crítica à incidência dos punitive damages são apresentados por D. G. Owen, Punitive Damages in Products Liability, in Michigan Law Review, vol. 74, 1976, págs. 1314/1315. No mesmo sentido, G. L. PRIEST afirma que "the instructions presented to juries for the determination of the appropriate punitive damages verdict are extremely vague and employ terms that are largely undefined" (Introduction: The Problem and Efforts to Understand It, in C. S. SUNSTEIN et al., Punitive Damages: How Juries Decide, Chicago, University of Chicago Press, 2002, pág. 3)

${ }^{169}$ Vitor Fernandes GonçALVES, A Punição na Responsabilidade Civil: A indenização do dano moral e da lesão a interesses difusos, Brasília, Brasília Jurídica, 2005, pág. 99. 
sanção que exerce, ao mesmo tempo, viés punitivo, preventivo e, mesmo em menor grau, compensatório.

Nesse sentido é que, após conceituar os punitive damages, o $§ 908$ do Restatement (Second) of Torts ${ }^{170}$ prescreve que, na quantificação de tal sorte de condenação, "o julgador poderá levar em consideração as características das condutas do demandado, a natureza e extensão dos prejuízos causados ao demandante que os demandados causaram ou tencionaram causar, bem como a capacidade econômica do demandado" ${ }^{, 171}$.

Por primeiro, até mesmo pela ordem como expostos pelo Restatement of Torts, pode-se verificar que o principal critério para a quantificação dos punitive damage é justamente a gravidade ou o "grau de reprovabilidade" ("degree of reprehensibility") dos atos ilícitos cometidos pelo ofensor ${ }^{172}$. Com efeito, em especial atenção à sua função punitiva, os punitive damages não apenas incidem, mas são, também, quantificados em montante mais elevado quando se destinam a apenar condutas perpetradas com o mais alto "grau de reprovabilidade", aquelas condutas repudiadas severamente pela Sociedade, quais sejam: condutas intencionalmente direcionadas ao cometimento do prejuízo (assim chamadas de "willful” ou "wanton conducts"), ou, ainda, condutas imbuídas de flagrante, grosseira e consciente desconsideração pelos direitos alheios (as assim chamadas "reckless conducts"). A lógica aqui obedecida é a de que a sanção deve ser tão severa quanto a ofensa perpetrada, de modo que, quanto mais grave for a ofensa (= quanto mais reprovável for o ato ilícito), maior será a condenação ao pagamento de punitive damages.

\footnotetext{
${ }^{170}$ Eugênio FACCHINI NETO, ao tratar do tema, comenta que os Restatements são uma peculiaridade do direito norte-americano. Trata-se de compilações elaboradas pela American Law Institute (uma organização privada formada por juristas), que reúnem o "atual estado da arte" de diversos institutos jurídicos (como, e.g., os contracts e os torts), por meio da análise da jurisprudência federal e estadual. Os Restatements são, portanto, obras doutrinárias atentamente voltadas à aplicação prática dos diversos institutos jurídicos, e que, por sua abrangência e completude, são muito referidas quer em doutrina, quer, ainda, em jurisprudência. (Prefácio, in Caroline Vaz, Funções da Responsabilidade Civil - Da Reparação à Punição e Dissuasão - Os punitive damages no Direito Comparado e Brasileiro, Porto Alegre, Livraria do Advogado, 2009, pág. 14).

${ }^{171}$ No original: "[i]n assessing such [punitive] damages, the trier of fact can properly consider the character of defendant's acts, the nature and extent of harm to the plaintiff which defendants caused or intended to cause, and the wealth of the defendant." (Restatement of Torts $\S 908)$.

${ }^{172}$ D. G. Owen, A Punitive Damages Overview: Functions, Problems and Reform, in Villanova Law Review, vol. 39, 1994, pág. 387: "The flagrancy of the misconduct is thought to be the primary consideration in determining the amount of punitive damages [...]." Sobre os critérios para verificar o "grau de reprovabilidade" das condutas do demandado, cfr. BMW of North America v. Gore (517 U.S. 559 1995), abaixo referido.
} 
Por segundo, apesar de a expressão "natureza e extensão dos prejuízos causados" nos remeter diretamente à idéia de compensação dos prejuízos e não, propriamente, à de punição do ofensor ou prevenção de novas condutas ilícitas, importa ressaltar que a extensão dos prejuízos suportados pela vítima é, sim, um fator relevante para a aferição dos punitive damages. Isso se dá porque, em especial nos Estados Unidos da América, é possível que o demandante não venha a ser integralmente compensado mesmo após o recebimento de indenização compensatória.

Isso se dá porque, na linha do quanto já exposto, em razão da assim chamada "regra americana", os custos da litigância não são reembolsados pela parte sucumbente, de modo que a vítima que se viu forçada a demandar para fazer jus aos seus direitos pode não vir a ser integralmente indenizada pelos prejuízos causados pelo ofensor. $\mathrm{Na}$ melhor das hipóteses, ainda que seu patrimônio tenha sido restabelecido no que toca às conseqüências imediatas do ilícito cometido, os custos da litigância terão sido perdidos.

Nesse sentido, em se tratando de condutas altamente reprováveis e indesejadas, os ilícitos passíveis de condenação ao pagamento de punitive damages deveriam, no mínimo, comportar uma condenação que recompensasse plenamente a vítima pelos prejuízos suportados, aí incluídos os custos de litigância, os quais, nas palavras de D. G. OwEN, deveriam representar a quantia mínima a ser atribuída a título de punitive damages ${ }^{173}$.

A "natureza e extensão dos prejuizos" causados em decorrência do ato ilícito são, portanto, importante elemento para a quantificação dos punitive damages, especialmente quanto tais prejuízos não são ordinariamente reembolsados pela aplicação isolada dos compensatory damages.

Por terceiro, de curial relevância para a quantificação dos punitive damages, especialmente para que se possa adequadamente atingir suas funções preventiva (em seu aspecto de prevenção especial) e punitiva, é a consideração acerca da capacidade econômica do ofensor ${ }^{174}$.Como acertadamente pontuado por Lord Devlin ao julgar Rookes 173 Punitive Damages in Products Liability, in Michigan Law Review, vol. 74, 1976, págs. 1315/1316.
174 J. T. SIMPSONS JR., Discovery of Net Worth in Bifurcated Punitive Damages Cases: A Suggested
Approach After Transportation Insurance Co. v. Moriel, in South Texas Law Review, vol. 37, 1996, pág. 201.
R. D. CoOTER, contudo, questiona a conclusão de que a riqueza do demandado é um critério apto a auxiliar
no desempenho da função preventiva dos punitive damages (em particularmente em seu aspecto de 
v. Barnard, a consideração acerca da riqueza do demandado, a despeito de irrelevante para a fixação dos compensatory damages, é importante para a quantificação dos punitive damages, uma vez que a quantia suficiente para apenar sensivelmente um homem comum pode ser indiferente para uma grande corporação ${ }^{175}$.

A uma, para fins de prevenção especial, a aferição da riqueza do demandado (e, principalmente, das repercussões econômico-financeiras do cometimento do ato ilícito para a sua riqueza) será sempre relevante quando ele vier a extrair lucro por meio do cometimento do ato ilícito. A imposição de punitive damages, para adequadamente desestimular o ofensor, deve impedir que ele venha a lucrar às custas da vítima, devendose perquirir, portanto, sobre sua riqueza para que se possa extrair de seu patrimônio todos os benefícios econômicos obtidos em razão das condutas ilícitas punidas.

A duas, a riqueza do demandado será sempre um critério a ser considerado para a quantificação dos punitive damages quando o que se busca é o adequado desempenho da função punitiva. Com efeito, justamente em atenção à capacidade econômica do demandado, a quantia suficiente para levar à bancarrota uma pequena empresa, punindo-a em demasia pelos ilícitos perpetrados, pode-se mostrar indiferente para uma imensa corporação, a qual não será adequadamente punida pelas atividades perigosas por ela levadas a efeito.

Por outro lado, a capacidade econômica da vítima apenas excepcionalmente deverá ser levada em consideração para a quantificação dos punitive damages. Vale dizer: apenas quando servir para aferir o "grau de reprovabilidade" das condutas do ("degree of reprehensibility") do demandado ${ }^{176}$, como, por ex., poder-se-ia verificar em casos de ilícitos perpetrados contra pessoas que, em razão de sua baixa renda, pudessem ser tidas como mais frágeis e propícias a serem prejudicadas em decorrência de determinado ilícito.

prevenção especial). Sustenta o autor que o desestímulo para o cometimento de ilícitos futuros será atingido se os custos de obediência à Lei, para evitar o prejuízo ("costs of compliance"), forem superiores aos custos para reparar o prejuízo ("costs of liability"). As considerações acerca da riqueza do demandado, portanto, seriam irrelevantes para a atingir-se a adequada prevenção, porque o fato de ele ter um maior ou menor potencial econômico em nada afetaria os custos de obediência à Lei. (Punitive Damages for Deterrence: When and How Much, in Alabama Law Review, vol. 40, 1989, pág. 1177).

${ }^{175}$ V. WILCOX, Punitive Damages in England, in H. KOZIOL - V. WILCOX (eds.), Punitive Damages: Common Law and Civil Law Perspectives, Wien, Springer, 2009, pág. 25.

${ }^{176}$ V. WILCOX, Punitive Damages in England, in H. KOZIOL - V. WILCOX (eds.), Punitive Damages: Common Law and Civil Law Perspectives, Wien, Springer, 2009, pág. 25. 
Por fim, e ao largo dos critérios enumerados no Restatement of Torts, entende-se, ainda, que a própria conduta do demandante, lesado pelo ilícito perpetrado pelo demandado, deve ser levada em consideração quando da imposição e quantificação dos punitive damages. Nesse sentido, ao julgar o caso Thompson v. Commissioner of Police of the Metropolis (1998 QB 498), Lord Woolf frisou que, mesmo se o demandante demonstrar com sucesso a responsabilidade do demandado pelos prejuízos por ele suportados, toda e qualquer conduta ilícita perpetrada pelo próprio demandante pode e deve ser levada em consideração para reduzir ou, até mesmo, eliminar a condenação ao pagamento de punitive damages se a ilicitude de sua conduta causou, ou contribuiu para, o cometimento do ilícito do demandado ${ }^{177}$.

\section{QUESTÕES POLÊMICAS ACERCA DOS PUNITIVE DAMAGES}

Neste ponto, passaremos a tratar de três questões intimamente relacionadas com o adequado desempenho das funções preventiva e punitiva dos punitive damages $\mathrm{e}$ que, a despeito do desenvolvimento do debate doutrinário e jurisprudencial, continuam especialmente polêmicas: (i) a imposição de indenização punitiva por ato de terceiro (com atenção particular à responsabilidade civil do empregador por atos de seus empregados); (ii) a condenação ao pagamento de punitive damages em casos de responsabilidade pelo fato do produto ("products liability"); e, por fim, (iii) a contratação de seguro de responsabilidade civil que tenha por objeto a transferência do risco de o segurado vir a ser condenado ao pagamento de punitive damages.

\section{IX.I. Responsabilidade do empregador pelo pagamento de punitive damages ("vicarious liability")}

Assim como ocorre nos países de raiz romano-germânica, os países da common law também admitem, por uma série de razões, que a responsabilidade pelos 
prejuízos causados por atos ilícitos venha a recair sobre pessoa diversa daquela que efetivamente se conduziu de tal maneira e, conseqüentemente, causou os prejuízos. Deste gênero (o qual denominamos de responsabilidade por ato de terceiro) extraem-se diversas espécies, entre as quais aquela que nos apresenta particular interesse, a responsabilidade do empregador por atos de seu empregado (a qual é denominada, nos países da common law, de "vicarious liability").

Entende-se, de maneira geral, que o empregador pode vir a ser responsabilizado a indenizar os prejuízos que seus empregados venham a, ilicitamente, causar a terceiros durante o exercício das atividades designadas por seu empregador, ainda que o empregador, ele próprio, não se tenha conduzido de maneira ilícita ${ }^{178}$. Em linhas gerais, para que a responsabilidade seja imposta ao empregador, basta que reste demonstrado que: (i) o ofensor é seu empregado; (ii) que o ofensor cometeu um ato ilícito ("tort"); e (iii) que tal ilícito foi cometido durante o exercício das atividades do empregado $^{179}$.

Quando se insere, neste ponto, a possibilidade de condenação ao pagamento de punitive damages, a questão passa a se tornar polêmica na medida em que se deixa de versar apenas e tão-somente sobre a responsabilidade do empregador pela recomposição do patrimônio lesado (o que será feito por meio do pagamento de indenização compensatória), para discutir a possibilidade de punir o empregador (o que será feito por meio do pagamento de indenização punitiva) por um ato que, a despeito de altamente reprovável, foi cometido por seu empregado, e não por ele.

Nesse sentido, parte da doutrina se opõe veementemente à possibilidade de imposição de punitive damages ao empregador em razão de condutas realizadas por seus empregados. Afirma-se, em resumo, que "a atribuição de danos punitivos a pessoas

\footnotetext{
177 V. WILcox, Punitive Damages in England, in H. KOZIOL - V. WILCOX (eds.), Punitive Damages: Common Law and Civil Law Perspectives, Wien, Springer, 2009, págs. 31.

${ }^{178}$ As razões aventadas pela doutrina dos países da common law para a responsabilização do empregador são muito semelhantes àquelas aventadas em países de raiz romano-germânica. Em linhas gerais, sustenta-se que a responsabilidade "vicariante" se justifica quer porque o empregador (i) possui maiores e melhores condições para recompor o patrimônio do lesado; quer porque (ii) possui, em maior ou menor grau, "poder de controle" sobre seus empregados; quer, ainda, porque (iii) extrai lucros das atividades por eles realizadas. Nesse sentido, cfr. S. DEAKIN - A. JOHNSTON - B. MARKESINIS, Markesinis and Deakin's Tort Law, $6^{\text {th }}$ ed., New York, Oxford, 2008, pág. 665.
} 
coletivas é ineficaz, na medida em que não pune os responsáveis nem previne a adopção de semelhantes condutas no futuro por parte desse agente, mas ao invés, pune os accionistas das sociedades comerciais e os consumidores" ${ }^{\prime 180}$.

A despeito da intensidade da crítica, o fato é que "a maioria das Cortes [Estaduais] norte-americanas, sem embargo, estendem a responsabilidade punitiva ao empregador, especialmente quando este é uma grande corporação, mesmo na ausência de expressa autorização ou ratificação" das condutas dos empregados ${ }^{181}$. É certo, ademais, que até mesmo a Supreme Court norte-americana considera constitucional a imposição de punitive damages ao empregador por atos ilícitos perpetrados por seus empregados ${ }^{182}$.

De um lado, sustenta-se que a função preventiva dos punitive damages é desempenhada adequadamente mesmo quando tal sanção punitiva é imposta ao empregador (pessoa diversa daquela que efetivamente cometeu o ilícito altamente reprovável), uma vez que é justamente o empregador aquele que se encontra em melhores condições para adotar as medidas de prevenção necessárias a fim de que não se repitam as condutas danosas perpetradas por seus empregados ${ }^{183}$.

Como o empregado se encontra em situação de subordinação em relação ao empregador, submetendo-se a sua ingerência e às suas determinações, o empregador pode (rectius: deve), no exercício de suas prerrogativas, sancionar o empregado que se conduz de maneira negligente ou indiferente em relação aos direitos alheio, quer por meio de advertências, quer, ainda, pela dispensa.

\footnotetext{
${ }^{179}$ S. DEAKIN - A. JOHNSTON - B. MARKESINIS, Markesinis and Deakin's Tort Law, $6^{\text {th }}$ ed., New York, Oxford, 2008, pág. 666.

${ }^{180}$ P. M. LourenÇO, A Função Punitiva da Responsabilidade Civil, Coimbra, Coimbra, 2006, pág. 189. Em sentido semelhante, J. D. GHIARDI, The Case Against Punitive Damages, in The Forum, vol. 8, 1972, pág. 419.

${ }^{181}$ R. D. PiZARro, Daño Moral - Prevención, Reparación, Punición: El Daño Moral em las Diversas Ramas del Derecho, Buenos Aires, Hammurabi, 1996, pág. 392.

${ }^{182}$ No caso Pacif Mutual Life Insurance Co. v. Haslip (1991), a Supreme Court entendeu constitucional (sob a ótica da due process clause) a condenação de determinada empresa ao pagamento de indenização punitiva por ato de seu empregado, afirmando que "a imposição de punitive damages em casos de responsabilidade por fato de terceiro não é fundamentalmente injusta." No original, "the imposition of punitive damages on a vicarious liability basis is not fundamentally unfair." (D. G. OWEN, A Punitive Damages Overview: Functions, Problems and Reform, in Villanova Law Review, vol. 39, 1994, págs. 401/402).

${ }^{183}$ R. D. Pizarro, Daño Moral - Prevención, Reparación, Punición: El Daño Moral em las Diversas Ramas del Derecho, Buenos Aires, Hammurabi, 1996, pág. 392.
} 
De outro lado, sustenta-se ser admissível a imposição de punitive damages ao empregador, "especialmente se a conduta ilícita [levada a efeito pelos empregados] é aprovada pela empresa, mesmo de maneira tácita"184. Isso porque, seria inadmissível permitir que o empregador extraísse lucros dos ilícitos realizados por seus empregados justamente com o intuito de beneficiar o empregador. Na medida em que o lucro auferido por determinada pessoa jurídica resulta de uma conduta praticada por um de seus empregados que flagrantemente viola direitos alheios (fazendo, portanto, jus à condenação ao pagamento de indenização punitiva), os aludidos lucros poderiam ser tidos por maculados. Nesse sentido, os acionistas, que em última análise viriam a se beneficiar da conduta altamente reprovável de um dos empregados de sua empresa, não fariam jus ao recebimento de tal "lucro ilícito", resultado benéfico que poderia ser vedado até mesmo pelo instituto do enriquecimento sem causa ${ }^{185}$.

Nessa linha de raciocínio, a Corte de Apelação do Estado do Maine teve a oportunidade de assentar, em Goddard v. The Grand Trunk Railway of Canada (57 Maine Reports Me. 202 1869), que apenas "quando for devidamente compreendido que não é rentável contratar empregados descuidados e indiferentes, ou funcionários desidiosos e insolentes, é que melhores homens ficarão com seus postos de trabalho, e não antes"186.

Em meio a este embate de idéias, os Estados norte-americanos tendem a adotar uma de três possíveis posições quanto ao tema: (i) em caráter absolutamente minoritário, impedir a incidência de punitive damages, o que, conseqüentemente, elimina a questão quanto à sua imposição por ato de terceiro ${ }^{187}$; e $\underline{(i i)}$ em caráter majoritário, a admissão dos punitive damages, bem como de sua imposição ao empregador, o que pode se dar de maneira mais branda, (1ii.i) na qual os "punitive damages podem ser impostos com fundamento no princípio do respondeat superior. Isso significa que um empregador é

\footnotetext{
${ }^{184}$ No original: "especially if the misconduct is approved by the enterprise, even if only tacitly." (D. G. Owen, A Punitive Damages Overview: Functions, Problems and Reform, in Villanova Law Review, vol. 39, 1994, pág. 391).

${ }^{185}$ D. G. Owen, A Punitive Damages Overview: Functions, Problems and Reform, in Villanova Law Review, vol. 39, 1994, pág. 392.

${ }^{186} \mathrm{O}$ caso é citado por A. J. SEBOK e, no original, lê-se: “[w]hen it is thoroughly understood that it is not profitable to employ careless and indifferent agents, or reckless and insolent servants, better men will take their places, and not before" (Punitive Damages in The United States, in H. KOZIOL - V. WILCOX (eds.), Punitive Damages: Common Law and Civil Law Perspectives, Wien, Springer, 2009, pág. 178).

${ }^{187}$ M. F. STURLEY, Vicarious Liability for Punitive Damages, in Lousiana Law Review, vol. 70, 2010, pág. 513. Abaixo, quando tratarmos do tort reform movement, analisaremos os argumentos trazidos pelos doutrinadores que pleiteiam a abolição completa dos punitive damages.
} 
responsável por punitive damages impostos em razão de condutas de seus empregados realizadas durante o curso e dentro do escopo de seu emprego - contanto que a conduta justifique a imposição de punitive damages" ${ }^{\text {"188; }}$; ou, ainda, pode se dar de maneira mais restritiva, (ii.ii) estabelecendo-se que “um empregador não é responsável pelo pagamento de punitive damages a não ser que ele se tenha tornado responsável por implicar a si mesmo, agindo de maneira intencional"; o que pode ser feito pelo empregador ao "autorizar o ato [altamente reprovável cometido por seu empregado] antes de seu cometimento, ratificar o ato após o seu cometimento ou por negligentemente contratar uma pessoa inadequada para exercer determinada função" ${ }^{\text {"189. }}$.

\section{IX.II. Punitive damages e responsabilidade pelo fato do produto ("products liability")}

Outra questão de grande polêmica é aquela que ronda a possibilidade de incidência de punitive damages em razão de prejuízos causados pelo "fato do produto", ou seja, pelo desenvolvimento, fabricação, distribuição, montagem ou venda de produtos defeituosos que, em razão de seu defeito, venham a causar danos aos consumidores diretos ou a terceiras pessoas que venham a manusear tais produtos (os assim chamados "bystanders"). Assim como ocorre em nosso país (especialmente após a promulgação da Lei 8.078/1990, denominada de Código de Defesa do Consumidor) a responsabilidade pelo "fato do produto" nos Estados Unidos da América e na Inglaterra (nesta, por influência do direito norte-americano e das diretivas da União Europeia, e especialmente após a internalização da Diretiva 85/374/EEC e da promulgação do Consumer Protection Act 1987) é tida por "objetiva" ("strict liability"). Vale dizer, para a procedência da demanda indenizatória, não é necessário que o demandante alegue ou demonstra a ocorrência de “culpa" ("fault"), i.e., o elemento subjetivo da conduta do demandado (a qual pode assumir

\footnotetext{
${ }^{188}$ No original: "punitive damages may be recovered on a respondeat superior basis. This means that an employer is liable for punitive damages based on conduct of its employees that occurs during the course and scope of the employee's job - assuming that the conduct will justify punitive damages." (M. M. BELLI SR., Punitive Damages: Their History, Their Use and Their Worth in Present-Day Society, in UMKC Law Review, vol. 49, n. 1, 1980, pág. 20). Segundo nos informa M. F. STURLEY, este é o caso do Estado de Oklahoma (Vicarious Liability for Punitive Damages, in Lousiana Law Review, vol. 70, 2010, pág. 513).

${ }^{189}$ No original: "an employer is not liable for punitive damages unless he has created liability by implicating himself through an intentional act. This may be accomplished by authorizing the act before its performance, by ratifying the act after its performance or by negligently hiring an unfit person for the act" (M. M. BELLI SR., Punitive Damages: Their History, Their Use and Their Worth in Present-Day Society, in UMKC Law Review, vol. 49, n. 1, 1980, pág. 20).
} 
três diferentes graus, que variam, do mais severo para o mais brando, de "malice" a “negligence", passando, em grau intermediário, por "intentional" ou "reckless") ${ }^{190}$.

Justamente porque se trata de uma espécie de "strict liability", a qual não depende de aferição do elemento "culpa" para a imputação de responsabilidade ao ofensor, parte da doutrina inadmite a aplicação dos punitive damages em casos de products liability. Sustenta-se, em argumento citado por D. G. OWEN (um expresso defensor da incidência dos punitive damages, inclusive em casos de responsabilidade objetiva), que "a pretensão ao recebimento de punitive damages, baseada que é na alegação de culpa grave, é logicamente incompatível com uma demanda que verse sobre responsabilidade pelo fato do produto, na qual a diligência do produtor, ou a sua negligência, é irrelevante para a determinação da responsabilidade para o pagamento de compensatory damages" ${ }^{\prime 191}$.

O mesmo D. G. OwEN responde a tal crítica ao afirmar que a alegada incompatibilidade entre os punitive damages e a responsabilidade independentemente de culpa ("strict liability") é nada mais do que falaciosa, quer porque: (i) a teoria da responsabilidade objetiva surgiu com a exclusiva finalidade de compensar (i.e., de exercer função unicamente compensatória) os ofendidos em casos nos quais a prova do elemento subjetivo da conduta seria de difícil produção, jamais se estipulando limitação dos remédios passíveis de aplicação contra a conduta realizada; quer, ainda, porque (ii) os fatos necessários para a procedência da pretensão compensatória não se confundem, necessariamente, com aqueles necessários para a imposição dos punitive damages, de modo que, mesmo em uma demanda que verse sobre responsabilidade objetiva, pode-se alegar e provar a existência de culpa do ofensor sem que isso prejudique a procedência do pedido compensatório ${ }^{192}$.

\footnotetext{
${ }^{190}$ Sobre o desenvolvimento da teoria sobre a responsabilidade objetiva pelo fato do produto nos Estados Unidos e na Inglaterra, cfr. S. DEAKIN - A. JOHNSTON - B. MARKESINIS, Markesinis and Deakin's Tort Law, $6^{\text {th }}$ ed., New York, Oxford, 2008, págs. 703/719. Também tratando da responsabilidade pelo fato do produto, F. L. TOZER afirma que, para a aferição da responsabilidade pelo pagamento de indenização compensatória, "in a products case, negligence of the manufacturer need not be proved. All the manufacturer had to do was sell it; not even extreme care for the welfare of the consumer would protect the manufacturer if the product proved defective. His tests, his inspections, his attention to detail would protect him no longer." (Punitive Damages and Products Liability, in Insurance Counsel Journal, vol. 39, jul.-1972, pág. 301).

191 No original: "a punitive damages claim based upon allegations of aggravated fault is logically incompatible with a strict products liability action in which the manufacturer's care, or absence thereof, is not relevant to the determination of liability for compensatory damages." (Punitive Damages in Products Liability, in Michigan Law Review, vol. 74, 1976, págs. 1268/1269).

${ }^{192}$ Punitive Damages in Products Liability, in Michigan Law Review, vol. 74, 1976, págs. 1269/1970.
} 
Alinhada com os fundamentos acima apontados, a jurisprudência norteamericana passou a admitir, a partir da década de 1960, que demandas indenizatórias fundadas em responsabilidade por fato do produto dessem ensejo, além da indenização compensatória, à condenação ao pagamento de punitive damages, especialmente se fosse possível aferir, da atividade levada a cabo pelo produtor, condutas individualizadas direcionadas intencionalmente ao cometimento do prejuízo, ou realizadas em flagrante e consciente desconsideração para com os direitos dos consumidores.

Assim foi que, no ano de 1967, foram julgados dois casos nos Estados Unidos da América, posteriormente elevados a leading cases, nos quais houve a imposição de punitive damages em decorrência da produção de um medicamento defeituoso, denominado 'MER29'. Tratou-se de Roginsky v. Richardson-Merrel Inc. (378 F. 2d. 832 2d Cir. 1967) e Toole v. Richardson-Merrel Inc. (251 Cal. App. 2d 68960 Cal. Rptr. 398 1967) ${ }^{193}$.

Em ambos os casos, deduziu-se demandas indenizatórias em face da empresa Richardson-Merrel Inc., responsável pela fabricação de medicamento destinado a combater o colesterol que possuía, como efeito colateral, alta probabilidade de causar cataratas em seus consumidores. Para além dos prejuízos compensatórios decorrentes das lesões à integridade física suportadas pelos usuários do medicamento, pleiteou-se a condenação da empresa ao pagamento de punitive damages sob o argumento de que ela tinha prévio conhecimento dos graves efeitos colaterais decorrentes da utilização do medicamente, mas omitiu-se de informálos ao público e às agências reguladoras competentes (nomeadamente, a FDA norteamericana), lançando o produto no mercado a despeito disso.

No primeiro caso (Roginsky), a fabricante do medicamento foi condenada, em primeira instância, ao pagamento de USD 17.500,00 a título de compensatory damages, além de USD 100.000,00 a título de punitive damages, condenação esta, contudo, posteriormente cassada pela Corte de Apelação ${ }^{194}$.

\footnotetext{
193 André Gustavo Corrêa de ANDRADE, Dano Moral e Indenização Punitiva: Os punitive damages na experiência do common law e na perspectiva do Direito brasileiro, Rio de Janeiro, Forense, 2006, pág. 199. 194 André Gustavo Corrêa de ANDrAde, Dano Moral e Indenização Punitiva: Os punitive damages na experiência do common law e na perspectiva do Direito brasileiro, Rio de Janeiro, Forense, 2006, pág. 199 e G. V. Robredo, Daños Punitivos en el Proceso Civil Norteamericano, in Revista de la Universidad de Deusto, vol. 57, fasc. 97, jul-dic./ 1996, págs. 190/192.
} 
Já no segundo caso (Toole), além das quantias referentes à indenização compensatória, o demandante logrou êxito em obter a condenação da fabricante do medicamento ao pagamento de USD 250.000,00 a título de punitive damages, mesmo após o crivo da Supreme Court do Estado da Califórnia. Segundo noticia G. V. RoBredo, a pena teria sido mantida por restarem comprovados os seguintes fatos: (i) a demandada teria tido prévio conhecimento do defeito do medicamento por força dos testes em animais, num dos quais 20 das 24 cobaias teriam sido cegadas como efeito colateral do medicamento; (ii) importantes razões econômicas fizeram com que demandada optasse por manter o medicamento em mercado pelo maior período de tempo possível; (iii) a demandada nada fez para consertar o defeito do medicamento; (iv) Richardson-Merrel tentou ocultar a existência do defeito do órgão estatal de controle de drogas (FDA); e, ainda, (v) não restou claro se a droga efetivamente atingia o fim a que se destinava (não se chegou a concluir que o medicamento era inefetivo, mas o fato de que os benefícios prometidos não eram tão evidentes pesou negativamente no entendimento dos julgadores) ${ }^{195}$.

Outro exemplo emblemático de imposição de punitive damages em decorrência de responsabilidade pelo fato do produto se deu quando do julgamento de Grimshaw v. Ford Motor Co. (119 Cal. App. 3d. 757174 Cal. Rptr. 348 1981) ${ }^{196}$.

Em razão de um defeito de concepção do automóvel Ford Pinto, impactos que atingissem a traseira do veículo (absolutamente comuns em acidentes automobilísticos) causavam, com frequiência anormalmente alta, o rompimento do tanque de combustível, acarretando o incêndio do veículo e, muitas das vezes, ferimentos seríssimos a seus ocupantes. Acidente semelhante vitimou o rapaz Richard Grimshaw, que, após a colisão do veículo em que se encontrava, veio a suportar queimaduras intensas causadas pelo vazamento e posterior explosão do tanque de combustível, o que o levou a demandar em face da Ford Motors Co. para pretender a condenação da fabricante ao pagamento de compensatory e punitive damages.

\footnotetext{
195 Daños Punitivos en el Proceso Civil Norteamericano, in Revista de la Universidad de Deusto, vol. 57, fasc. 97, jul-dic./ 1996, pág. 192.

${ }^{196}$ Eduardo UILAN, Responsabilidade Civil Punitiva, Tese (Doutorado) - Faculdade de Direito da USP, São Paulo, pág. 79 e André Gustavo Corrêa de ANDRADE, Dano Moral e Indenização Punitiva: Os punitive damages na experiência do common law e na perspectiva do Direito brasileiro, Rio de Janeiro, Forense, 2006, págs. 200/202.
} 
Durante o curso do processo, constatou-se que o aludido defeito de concepção, não obstante tenha sido verificado por engenheiros da fabricante do veículo ainda antes de sua introdução no mercado, deixou intencionalmente de ser corrigido por se aferir que as despesas necessárias para a correção das imperfeições (custos para evitar o prejuízo) superariam aquelas bastantes para custear as eventuais condenações decorrentes de ações indenizatórias de consumidores lesados (custos para indenização) ${ }^{197}$.

Em razão da gravidade das condutas realizadas pela Ford Motors Co., justificou-se, além da imposição de indenização compensatória, a condenação ao pagamento de punitive damages que, em primeira instância, atingiram o montante de USD 125 milhões, posteriormente reduzidos para USD 3 milhões ${ }^{198}$.

Neste caso em específico, a flagrante "ineficácia da função reparatória da responsabilidade civil impôs o recurso aos punitive damages, de forma a assegurar que os comportamentos dos agentes económicos não comprometam o direito à vida e à integridade física da pessoa humana, mas antes pautam-se pelo respeito por tais direitos, elevando-se assim o nível de segurança dos produtos"199.

Após analisar extensamente estes e outros casos típicos da jurisprudência norte-americana a respeito do tema, G. V. ROBREDO procurou delimitar os critérios usualmente aventados para a imposição de punitive damages em casos de responsabilidade pelo fato do produto. Chegou o autor à conclusão de que a penalização das atividades produtoras se justificaria em cinco hipóteses: (i) quando o demandado conhecia a

\footnotetext{
${ }^{197}$ André Gustavo Corrêa de ANDRADE, ao estudar o referido caso, noticia que uma "[m]atéria jornalística publicada pouco depois do julgamento expôs que, em uma estimativa conservadora, o Ford Pinto, em razão do defeito na concepção de seu projeto, teria provocado a morte de cerca de 500 pessoas, talvez 900 . Nessa matéria foi revelado que um memorando interno da Ford continha estudo que calculava, de um lado, o custo estimado das indenizações com acidentes envolvendo o Ford Pinto (U\$ 200.000,00, por vida perdida, multiplicados por prováveis 180 mortes por ano, além de U\$67.000,00 por estimadas 180 lesões não fatais, mais os danos com os veículos) e, de outro, o valor que teria de ser gasto para corrigir o problema do veículo (cerca de U\$ 11,00 por unidade, multiplicados por 12.5000.000 de unidades). A conclusão do estudo foi de que, do ponto de vista estatístico o pagamento das indenizações, ao custo total estimado de U\$ 49,5 milhões, seria economicamente mais vantajoso do que o aperfeiçoamento necessário em todos os veículos, ao custo total de U\$137,5 milhões, para prevenir cerca de 180 mortes por ano e um número equivalente de ferido". (Dano Moral e Indenização Punitiva: Os punitive damages na experiência do common law e na perspectiva do Direito brasileiro, Rio de Janeiro, Forense, 2006, pág. 202)

${ }^{198}$ Vitor Fernandes GonÇALVES, A Punição na Responsabilidade Civil: A indenização do dano moral e da lesão a interesses difusos, Brasília, Brasília Jurídica, 2005, pág. 45.
} 
existência do defeito de que padecia seu produto e, mesmo assim, assumiu o risco de desenvolvê-lo e comercializá-lo ${ }^{200}$; (ii) quando o demandado auferiu importantes benefícios econômicos pela fabricação e comercialização do produto defeituoso ${ }^{201}$; (iii) quanto o demandado não realizou investigações suficientes sobre os riscos potenciais do produto, ou, após aperceber-se destes riscos, não realizou esforço algum para evitar o prejuízo $^{202}$; (iv) quando o comportamento do demandado não se adequou aos standards de conduta exigidos pelo mercado, quer no que toca à realização de testes e investigações preliminares à introdução do produto no mercado, quer, ainda, no que toca às providências posteriores à introdução de tal produto (tais como, e.g., o recall) ${ }^{203}$; ou, ainda, (v) quando o produto defeituoso e potencialmente perigoso não oferecia benefícios substanciais a ponto de compensar o risco, assumido pelo fabricante, de introduzi-lo no mercado ${ }^{204}$.

\footnotetext{
${ }^{199}$ P. M. LOURENÇO, A Função Punitiva da Responsabilidade Civil, Coimbra, Coimbra, 2006, pág. 178.

${ }^{200}$ Segundo o autor, "[e]ste conocimiento se alcanza com las pruebas que el fabricante o distribuidir realizó antes de poner el producto en el mercado o por medio de informes de accidentes sufridos por los consumidores posteriores a la venda del producto." (Daños Punitivos en el Proceso Civil Norteamericano, in Revista de la Universidad de Deusto, vol. 57, fasc. 97, jul-dic./ 1996, pág. 195).

201 Nestes casos específicos, em que o demandado obtém lucros por meio do desenvolvimento de uma atividade perigosa, e a despeito das lesões causadas à propriedade e às pessoas, a prova da capacidade econômica do ofensor ou dos benefícios econômicos por ele obtidos em razão da fabricação e posterior comercialização do produto defeituoso se mostra especialmente importante quer (i) para provar a indiferença do fornecedor em relação ao consumidor, cuja conduta teria sido direcionada à obtenção de benefícios econômicos em detrimento da saúde e bem estar do consumidor potencialmente lesado pela inserção do produto defeituoso no mercado; quer, ainda, (1i) para o cálculo do quantum dos punitive damages, com particular atenção à sua função preventiva. (Daños Punitivos en el Proceso Civil Norteamericano, in Revista de la Universidad de Deusto, vol. 57, fasc. 97, jul-dic./ 1996, pág. 196).

${ }^{202}$ Como afirma o citado autor, a inserção e manutenção de um produto defeituoso (e potencialmente perigoso) no mercado decorre, geralmente, de duas razões possíveis: ou (i) não se detectou a existência do defeito antes de inserir o produto no mercado; ou, ainda que se tenha detectado a existência do defeito, (ii) nada se fez para corrigi-lo ou retirar o produto de circulação uma vez posto à venda (por meio de recall, por ex.). Nestes casos, "[u]na condena de daños punitivos puede deberse a que el demandado no há cumplido con el estándar de cuidado aplicable a las pruebas anteriores o posteriores a la venta del producto para remediar los posibles defectos." (Daños Punitivos en el Proceso Civil Norteamericano, in Revista de la Universidad de Deusto, vol. 57, fasc. 97, jul-dic./ 1996, pág. 196).

${ }^{203}$ Daños Punitivos en el Proceso Civil Norteamericano, in Revista de la Universidad de Deusto, vol. 57, fasc. 97, jul-dic./ 1996, págs. 197/198.

${ }^{204}$ Nas palavras do autor, tal critério se refere aos casos em que o produto defeituoso e pontencialmente perigoso é uma droga fabricada pela indústria farmacêutica. São casos em que as drogas produzidas podem acarretar um efeito colateral ("side effect") conhecido e perigoso, mas de rara ocorrência. Dado o benefício produzido pelo remédio, o potencial risco é mitigado e os eventuas prejuízos resultantes deste efeito colateral são desconsiderados para fins de imputação de punitive damages se o fabricante houver informado devidamente seus consumidores quanto ao risco assumido. "Si el demandado puede demonstrar que cuidadosamente valoró el daño frente al beneficio para la sociedad, que advirtió a los consumidores del peligro potencial, y que además fue incapaz de remediar dicho defecto en el producto, entonces no será declarado responsable." (Daños Punitivos en el Proceso Civil Norteamericano, in Revista de la Universidad de Deusto, vol. 57, fasc. 97, jul-dic./ 1996, pág. 198).
} 


\section{IX.III. Contratação de seguro para os punitive damages}

Tratemos, enfim, de questão que se mostra especialmente tormentosa e polêmica $^{205}$ : a de se é, ou não, legalmente admissível que se celebre contrato de seguro de responsabilidade civil que tenha por objeto transferir à empresa seguradora o risco de que o segurado venha a ser condenado ao pagamento de punitive damages.

Ao analisar a questão, I. EBERT aponta ao menos três argumentos usualmente aventados para permitir a celebração de contratos de seguro que versem sobre punitive damages $^{206}$.

A uma, diz-se que o segurado (que acredita ter transferido integralmente os riscos de sua atividade à seguradora) deve ser protegido pelo contrato de seguro, ainda que, em demanda indenizatória ajuizada contra ele, venha-se a considerar que as condutas por ele cometidas ultrapassaram o limite da "mera negligência" ("mere negligence") para atingir o campo da "negligência grosseira" ("gross negligence"), tornando-se aptas a permitir a incidência de punitive damages. Tal argumento, sustenta o citado autor, mostrase especialmente válido para o campo da responsabilidade civil objetiva [caso, e.g., da responsabilidade pelo fato do produto ("products liability")], uma vez que a linha que separa a conduta que é passível de condenação por meio de punitive damages daquela que não o é pode ser tênue, e o valor da condenação pode exceder, em muito, aquele ordinariamente necessário para compensar o ofendido, surpreendendo o segurado.

A duas, sustenta-se que, mesmo diante de uma questão dita de ordem pública, o princípio da liberdade contratual não deveria ser restringido. Dever-se-ia permitir, portanto, que as empresas seguradoras oferecessem serviços que abarcassem a cobertura de indenizações punitivas se o ordenamento expressamente admite tal sorte de condenação (se há o risco, deveria ser admitida a celebração de contrato de seguro para transmiti-lo à empresa seguradora).

\footnotetext{
${ }^{205}$ G. L. PRIEST, Insurability and Punitive Damages, in Alabama Law Review, vol. 40, 1989, pág. 1009.

206 Punitive Damages and Liability Insurance, in H. KOZIOL - V. WILCOX (eds.), Punitive Damages: Common Law and Civil Law Perspectives, Wien, Springer, 2009, pág. 214.
} 
Por fim, alega-se que, de um lado, o contrato de seguro de punitive damages ajuda a evitar (ou, ao menos, prevenir) a falência do segurado, possivelmente sujeito à condenações em montante expressivo, e, de outro, a garantir que os ofendidos efetivamente receberão o montante ao qual fazem jus, antes de que o patrimônio do ofendido seja irremediavelmente atingido.

Contra tais argumentos, sustenta parte da doutrina que admitir a celebração de contratos de seguro que tenham por objeto a assunção do risco de uma condenação ao pagamento de punitive damages "além de prejudicar as funções sancionatória e dissuasória da condenação, põe-se em contraste com a ordem pública, ou seja, com um princípio fundamental admitido tanto pela common law quanto pela legislação atinente à matéria, que proíbe a celebração de contratos de seguro que tenham por objeto garantir o risco dos prejuízos provenientes de atos ilícitos dolosos"207.

No mesmo sentido, alega-se que "o impacto punitivo dos punitive damages seria certamente diminuído, ou a menos desviado, caso se permitisse por lei a celebração de seguro de dano nesse sentido" ${ }^{208}$. Sustenta-se, assim, que a transmissibilidade do risco de condenação a uma pena (sanção com função punitiva) deve, certamente, ser repudiada pelo Direito, ainda que se trate de sanção civil de natureza pecuniária. Traçando uma parábola, D. G. OwEN sustenta que "o direito certamente não toleraria ou admitiria como exeqüíveis contratos de seguro contra o risco de uma sentença de reclusão ou de imposição de multas criminais" ${ }^{209}$.

Permitir a transmissão desse risco à empresa seguradora é, portanto, flagrantemente prejudicial, uma vez que poderia incentivar a ocorrência do fenômeno

\footnotetext{
${ }^{207}$ No original, "oltre a vanificare la funzione sanzionatoria e deterrente della condanna, si porrebbe in contrasto con la public policy, ossia con un fundamentale principio accolto dalla common law e della legislazione in materia, che impone il divieto dell'assicurazione sulla responsabilità civile per gli illeciti dolosi." (E. URSO, Recenti Sviluppi nella Giurisprudenza Statunidense e Inglese in Materia di Punitive Damages: i Casi TXO Production Corporation v. Alliances Resources Corporation e AB v. South West Water Services Ltd., in Rivista di Diritto Civile, vol. 41, n. 1, genn.-febr./1995, pág. 138).

${ }^{208}$ No original, "The punitive impact of punitive damages assessments surely is diminished, or at least diverted, if liability insurance is permitted by the law and if offered by insurers to cover such awards." (D. G. OWEN, A Punitive Damages Overview: Functions, Problems and Reform, in Villanova Law Review, vol. 39, 1994, pág. 389). Na mesma linha, Marcela Alcazas BASSAN, As Funções da Indenização por Danos Morais e a Prevenção de Danos Futuros, Dissertação (Mestrado) - Faculdade de Direito da USP, São Paulo, 2009, pág. 62.

${ }^{209}$ No original, "The law certainly would not tolerate or enforce insurance policies against the risk of a jail sentence or of a criminal fine [...]."'(A Punitive Damages Overview: Functions, Problems and Reform, in Villanova Law Review, vol. 39, 1994, pág. 389)
} 
denominado pelos economistas de "moral hazard"210. Como anota I. EBERT, nesta hipótese, "o segurado pode até mesmo se sentir encorajado a embarcar em comportamentos arriscados, sentindo-se à salvo por saber que todas as possíveis conseqüências de suas condutas, incluindo a obrigação de pagar punitive damages, serão suportadas por outra pessoa"211.

Aventa-se, ainda, uma segunda ordem de argumentos contra a contratação de seguro de punitive damages, desta feita relacionada à quantificação de eventual condenação. Diz-se que, ao saber que o risco de o demandado vir a ser condenado é protegido por um contrato de seguro, os jurados tenderiam a elevar a quantia que, de ordinário, seria suficiente para, adequadamente, servir de punição para o mal cometido e desestimular o cometimento de novos ilícitos; especialmente porque, na hipótese de contratação de seguro, não existiria o risco de retirar o demandado do mercado por meio da imposição de uma condenação exagerada ("overdeterrence") ${ }^{212}$.

Em razão da controvérsia acima exposta, I. EBERT noticia que, atualmente, praticamente metade dos Estados norte-americanos proíbe a celebração de contratos que tenham por objeto a transferência, à empresa seguradora, do risco de o segurado vir a ser condenado ao pagamento de punitive damages ${ }^{213}$.

Em alguns Estados, contudo, admite-se que os contratos de seguro prevejam uma distinção entre a cobertura de prejuízos decorrentes de condutas diretamente cometidas pelo segurado e a cobertura de prejuízos decorrentes de condutas realizadas por terceiras

\footnotetext{
${ }^{210}$ Segundo E. D. BEAL, a expressão "moral hazard" passou a ser utilizada para designar as indesejáveis características comportamentais de um segurado que implicam o aumento da probabilidade de ocorrência do sinistro. Tais características indesejáveis não se restringem a uma pré-disposição de caráter, sendo certo que mesmo pessoas que, ordinariamente, não possuiriam tais características, podem passar a agir de maneira negligente ou irresponsável diante da certeza de que não suportarão as consequiências negativas de suas condutas. As condutas que compõem o assim chamado "moral hazard" podem, nesse sentido, adotar quatro vertentes possíveis: (i) o segurado pode intencionalmente causar o sinistro; (ii) o segurado pode passar a tomar menos cuidado do que ordinariamente tomaria para evitar o sinistro; (iii) o segurado pode intencionalmente aumentar os prejuízos decorrentes do sinistro; ou, ainda, (iv) o segurado pode deixar de tomar precauções que, de ordinário, tomaria para mitigar os prejuízos decorrentes do sinistro (Posner and Moral Hazard, in Connecticut Insurance Law Journal, vol. 7, 2000, págs. 84/85).

211 Punitive Damages and Liability Insurance, in H. KOZIOL - V. WILCOX (eds.), Punitive Damages: Common Law and Civil Law Perspectives, Wien, Springer, 2009, pág. 213.

212 I. EBERT, Punitive Damages and Liability Insurance, in H. KOZIOL - V. WILCOX (eds.), Punitive Damages: Common Law and Civil Law Perspectives, Wien, Springer, 2009, pág. 215.

213 Punitive Damages and Liability Insurance, in H. KOZIOL - V. WILCOX (eds.), Punitive Damages: Common Law and Civil Law Perspectives, Wien, Springer, 2009, pág. 213.
} 
pessoas, mas pelos quais o segurado poderia vir a ser responsabilizado [em razão da possível responsabilidade por fato de terceiro ("vicarious liability")]. Nesses Estados, admite-se a contratação de seguro de responsabilidade civil que cubra a imposição de punitive damages ao segurado, se tal condenação decorreu, por exemplo, de fato [ainda que "proposital" (“willful”) ou "injustificado" (“wanton")] cometido por um de seus empregados ${ }^{214}$.

Há, por fim, Estados como o Texas que rejeitam a possibilidade de celebração de contratos de seguro que cubram o risco de cometimento de ilícitos intencionais (e, conseqüentemente, arquem com a condenação ao pagamento de punitive damages decorrentes de tais condutas), mas que permitem que a empresa seguradora venha a suportar condenações decorrentes de condutas "grosseiramente negligentes" ("grossly negligent") ${ }^{215}$.

\section{RESTRIÇÕES AOS PUNITIVE DAMAGES NO DIREITO INGLÊS}

Após se ter desenhado, nos tópicos acima apresentados, os contornos gerais dos punitive damages (tendo-se descrito as razões de seu surgimento, as hipóteses gerais de incidência e os critérios para a sua quantificação), cumpre-nos tecer algumas considerações quanto aos aspectos mais atuais do aludido instituto, quer na Inglaterra, seu país de origem, quer, ainda, nos Estados Unidos da América, país no qual os punitive damages encontraram campo fértil para crescimento e desenvolvimento. Tanto numa quanto noutra sede, os punitive damages vêm sendo alvo de intenso e caloroso debate, tendo-se advogado por sua restrição ou, até mesmo, por sua absoluta abolição.

Tomemos a oportunidade, então, para lançar os olhos inicialmente sobre a atual conjuntura dos punitive damages no Direito Inglês, ordenamento no qual, como se verá, os punitive damages encontram aplicação muito restrita, bem ao contrário do que se constata nos Estados Unidos da América.

${ }^{214}$ I. EBERT noticia que este é o caso, e.g., dos Estados da California, Florida, Illinois, Indiana, Kansas, Maine, New Jersey, Oklahoma e Pennsylvania (Punitive Damages and Liability Insurance, in H. KOZIOL V. Wilcox (eds.), Punitive Damages: Common Law and Civil Law Perspectives, Wien, Springer, 2009, págs. 215/216). 
Com efeito, especialmente a partir da segunda metade do século $\mathrm{XX}$, os Tribunais britânicos passaram a se orientar no sentido de restringir o âmbito de incidência dos punitive damages, quiçá com a finalidade de, dessa maneira, impedir o desenvolvimento descontrolado do instituto, bem como as conseqüências prejudiciais que, porventura, acompanhariam tal fenômeno.

$\mathrm{O}$ primeiro e mais relevante dos casos nos quais se buscou restringir a incidência dos punitive damages se deu em 1964, ano no qual a House of Lords inglesa julgou Rookes v. Barnard (1964 A.C. 1129). Tratou-se, na hipótese, de ação indenizatória ajuizada pelo Sr. Rookes, um projetista de aviões empregado pela British Overseas Aircraft Company (B.O.A.C.), em face de determinados membros do sindicato ao qual o Sr. Rookes era afiliado (denominado Association of Engineering and Shipbuilding Draughtsmen, ou A.E.S.D.), sob o fundamento de que tais membros teriam agido ilicitamente ao induzir a empresa B.O.A.C. a dispensar o Sr. Rookes, pelo simples fato de ele ter-se desvinculado do sindicato. Diante dos fatos barrados, o júri condenou Barnard ao pagamento de indenização correspondente a $£ 7.500,00$, tanto a título de compensatory quanto de punitive damages. Irresignado, Barnard recorreu à Court of Appeal para buscar a reforma integral da decisão proferida em primeira instância, especialmente para rejeitar a caracterização dos atos perpetrados como ilícitos (torts). A Court of Appeal acolheu a pretensão recursal de Barnard, dando ensejo, portanto, à interposição de novo recurso, desta vez por parte do Sr. Rookes, endereçado à House of Lords.

No aludido julgamento, a despeito de se ter dado provimento ao recurso interposto para restabelecer a condenação imposta (an debeatur), a House of Lords, especialmente em razão do teor do voto proferido por Lord Devlin, aproveitou a oportunidade para determinar a realização de novo julgamento para a quantificação da indenização (quantum debeatur), sob o argumento de que, no caso em comento, não se justificaria a imposição de condenação ao pagamento de punitive damages.

Ao esmiuçar o caso, a House of Lords fixou balizas (as assim chamadas “categories test”) para a futura condenação ao pagamento de punitive damages, passando a admitir a incidência de tal instituto apenas nas hipóteses em que: (i) "atos opressivos, 
arbitrários ou inconstitucionais [tenham sido] cometidos por funcionários do governo",216; (ii) " a conduta do demandado tenha sido 'calculada' com a finalidade de produzir para si um lucro que exceda a indenização compensatória a ser paga ao demandante" ${ }^{217}$; e, ainda, (iii) nos "casos em que a imposição de exemplary damages está expressamente autorizada por Lei" ${ }^{218}$, como, e.g., na Section 97.2, do Copyright, Designs and Patent Act, de $1988^{219}$.

Após fixar as três balizas (“categories test”) para a imposição de punitive damages, a House of Lords, por meio do voto de Lord Devlin, ditou ainda mais uma restrição à sua incidência: frisou-se que, antes de emitir seu veredicto em um caso no qual a condenação ao pagamento de punitive damages seria, em tese, apropriada, o corpo de jurados deveria ser sempre orientado no sentido de que tal condenação mereceria aplicação "se, e somente se" " iff, but only if') a quantia a ser aplicada para compensar o demandante (formada pelos compensatory damages e já acrescida de eventuais aggravated damages, incidentes caso as

Damages: Common Law and Civil Law Perspectives, Wien, Springer, 2009, pág. 216.

216 No original, "oppressive, arbitrary or unconstitutional action by the servants of the government" (S. DEAKIN - A. JOHNSTON - B. MARKESINIS, Markesinis and Deakin's Tort Law, $6^{\text {th }}$ ed., New York, Oxford, 2008, pág. 945). Após o julgamento de Holden v. Chief Constable of Lancashire [1986 QB 380] pela Court of Appeal Inglesa, fixou-se o entendimento de que a preposição "or" ("ou”), que liga as expressões "oppressive", "arbitrary" e "unconstitutional" atribui a elas alternatividade, de modo que os punitive damages serão devidos ainda que a conduta não acumule duas ou mais dessas características. Basta, e.g., que a prisão tenha se dado de maneira inconstitucional (como ocorre nos casos de wrongful arrest) para que a condenação ao pagamento de punitive damages seja devida, ainda que o aprisionado não tenha sido tratado de modo opressivo. (V. WILCOX, Punitive Damages in England, in H. KOZIOL - V. WILCOX (eds.), Punitive Damages: Common Law and Civil Law Perspectives, Wien, Springer, 2009, págs. 9/10).

${ }^{217}$ No original, "the defendant's conduct was 'calculated' to make a profit for himself wich could exceed the compensation payable to the claimant." (S. DEAKIN - A. JOHNSTON - B. MARKESINIS, Markesinis and Deakin's Tort Law, $6^{\text {th }}$ ed., New York, Oxford, 2008, pág. 947). Segundo anota V. WILCOX, os casos mais comuns de incidência de punitive damages sob a rubrica desta segunda categoria são os de difamação ("defamation cases") levados a efeito por meio da publicação de jornais, revistas ou livros - casos nos quais os editores procuram obter lucro fácil por meio da publicação de fatos escandalosos (não necessariamente verdadeiros) sobre celebridades - e os de despejo ilegal ("wrongful eviction") - casos nos quais os locadores/proprietários lançam mão de artifícios ilícitos para obter a desocupação de seus imóveis com vistas à obtenção de aluguéis mais vultosos do que aqueles pagos pelo atual locatário. Interessante notar, quanto ao último exemplo, que o despejo ilegal ("wrongful eviction") é considerado um tort, e não mero descumprimento contratual ("breach of contract"), motivo pelo qual não se questiona a incidência de punitive damages nessa hipótese. (Punitive Damages in England, in H. KOZIOL - V. WILCOX (eds.), Punitive Damages: Common Law and Civil Law Perspectives, Wien, Springer, 2009, págs. 12/21)

${ }^{218}$ No original, "cases where exemplary damages are expressly authorized by statute." (S. DEAKIN - A. JOHNSTON - B. MARKESINIS, Markesinis and Deakin's Tort Law, $6^{\text {th }}$ ed., New York, Oxford, 2008, pág. 948) 219 A qual prevê expressamente a condenação ao pagamento de indenização adicional ("additional damages") caso a gravidade da conduta do lesante, ou a obtenção de lucro em razão da infração assim o justifiquem; prescrevendo, in verbis: "Provisions as to damages in infringement action. [...] (2) The court may in an action for infringement of copyright having regard to all the circumstances, and in particular to (a)the flagrancy of the infringement, and (b) any benefit accruing to the defendant by reason of the infringement, - award such additional damages as the justice of the case may require." 
características da conduta do demandado assim o autorizem ${ }^{220}$ ) não se mostrar suficiente para, ainda que indiretamente, punir o ofensor em razão da gravidade de sua conduta, evidenciar o desaprovação da sociedade (representada pelo corpo de jurados) quanto à conduta realizada e, ainda, prevenir o cometimento de novos e semelhantes ilícitos ${ }^{221}$.

Ao julgar Rookes v. Barnard, a House of Lords adotou, inegavelmente, "uma posição muito restritiva" em relação aos punitive damages, "limitando substancialmente seu âmbito de incidência"222. Nesse sentido, não são exageradas as palavras de M. M. BELli SR., para quem o referido precedente praticamente aboliu os punitive damages do Direito britânico ${ }^{223}$, tendo-se considerado, como aponta Maria Celina Bodin de MORAES, que estes "seriam incompatíveis com a natureza estritamente compensatória da reparação de danos",224.

\footnotetext{
${ }^{220}$ Neste ponto, é importante frisar que o conceito de aggravated damages, conforme adotado na Inglaterra, especialmente após Rookes v. Barnard, é muito distante daquele (hoje raramente) referido nos Estados Unidos da América. Na Inglaterra, o conceito de aggravated damages passou a designar uma quantia de índole compensatória, a ser concedida ao demandante, em adição a quaisquer compensatory damages aos quais ele faça jus (e independentemente da imposição de eventuais punitive damages), caso estejam presentes os seguintes requisitos: (i) a conduta do ofensor deve ter sido direcionada intencionalmente para o comentimento do ilícito, ou, após o seu cometimento, sua conduta deve ter, de maneira intencional, atuado de modo a agravar o prejuízo; e, em razão das condutas perpetradas, (ii) o ofendido deve ter suportado prejuízos não materiais ("mental distress"). Assim como os punitive damages, os aggravated damages exigem requerimento expresso do demandante, mas, ao contrário dos primeiros, os aggravated damages não se sujeitam aos critérios fixados em Rookes v. Barnard nem, tampouco, servem para, ostensivamente, punir o ofensor e prevenir o cometimento de novos ilícitos. A finalidade ostensiva dos aggravated damages é a de compensar o ofendido pelos prejuízos imateriais por ele suportados, mas, para a imposição e quantificação da condenação, admite-se a observação de características da conduta do ofensor. Os aggravated damages são, usualmente, concedidos em razão do cometimento de alguns torts específicos (tais como, e.g., "assault and battery", "deceit", "intimidation", "false imprisonment", "malicious prosecution" e "defamation"), mas nunca nos casos de "mera negligência" ("negligence") ou inadimplemento contratual ("breach of contract"); e, como já se afirmou, sua concessão sempre exige que, dos ilícitos perpetrados, decorram prejuízos não materiais. Já nos Estados Unidos da América, o desenvolvimento do instituto dos punitive damages fez desaparecer toda e qualquer distinção entre estes e os aggravated damages, de modo que, atualmente, as expressões punitive, aggravated ou exemplary damages são utilizadas como sinônimos. Por isso, a afirmação de que uma condenação ao pagamento de punitive damages se deu em adição a uma outra, desta vez referente ao pagamento de aggravated damages, só faz sentido se estivermos diante de um Tribunal inglês. Sobre o tema, A. J. SEBoK - V. Wilcox, Aggravated Damages, in H. KozIOL - V. Wilcox, Punitive Damages: Common Law and Civil Law Perspectives, Wien, Springer, 2009, págs. 257/274.

${ }^{221}$ V. WILCOX, Punitive Damages in England, in H. KOZIOL - V. WILCOX (eds.), Punitive Damages: Common Law and Civil Law Perspectives, Wien, Springer, 2009, pág. 26.

${ }^{222}$ A. Saravalle, I Punitive Damages nelle Sentenze delle Corti Europee e dei Tribunali Arbitrali, in Rivista di Diritto Internazionale Privato e Processuale, anno XXIX, n. 4, ott.-dic./1993, pág. 873. No mesmo sentido, M. G. BARATElla, Le Pene Private, Milano, Giuffrè, 2006, pág. 202.

${ }^{223}$ Punitive Damages: Their History, Their Use and Their Worth in Present-Day Society, in UMKC Law Review, vol. 49, n. 1, 1980, pág. 4.

${ }^{224}$ Punitive Damages em Sistemas Civilistas: Problemas e Perspectivas, in Revista Trimestral de Direito Civil, vol. 18, abr./jun. 2004, pág. 56.
} 
O entendimento então firmado pela House of Lords tornou-se ainda mais restritivo quando, anos mais tarde, a Court of $\mathrm{Appeal}^{225}$ teve a oportunidade de julgar o caso AB v. South West Water Services Ltd. (QB 507 1993), momento no qual tal corte, pela primeira vez após a fixação das “categories test" em Rookes, veio a analisar diretamente a questão jurídica acerca do âmbito de aplicabilidade dos exemplary damages ${ }^{226}$.

No caso em tela, discutiu-se a responsabilidade de South West Water, uma empresa responsável pela distribuição de água na região de Camelford, pelos danos causados a diversos habitantes da região que utilizavam seus serviços. Como se verificou ao longo do julgamento, por acidente, empregados de South West Water haviam introduzido, na tubulação hídrica que levava água potável aos habitantes de Camelford, cerca de vinte toneladas de sulfato de alumínio, substancia altamente poluente e apta a causar diversas sortes de danos à saúde. Em razão do consumo da água contaminada, nada menos do que cento e oitenta e dois habitantes de Camelford vieram a suportar prejuízos à sua saúde, contraindo males de diversos graus de intensidade. Em razão dos prejuízos suportados, os demandantes pretenderam a condenação de South West Water ao pagamento de compensatory damages e, em razão da reprovabilidade das condutas da demandada, sua condenação também ao pagamento de exemplary damages. Tal pretensão se fundou nos fatos (comprovados ao longo da instrução processual) de que, a despeito de já sabedora do acidente causado por seus empregados, e ciente dos primeiros prejuízos à saúde suportados pelos habitantes de Camelford, South West Water emitiu nota por escrito assegurando-os da potabilidade da água; conduta esta que, certamente, agravou em intensidade e em duração os prejuízos suportados pelos demandantes ${ }^{227}$.

\footnotetext{
${ }^{225}$ Assim como a House of Lords, a Court of Appeal também é considerada uma "corte de apelação", i.e., um órgão jurisdicional competente para o julgamento de recursos interpostos contra decisões de órgãos inferiores (no caso da Court of Appeal, contra decisões proferidas nas High Courts). Trata-se, contudo, de Tribunal hierarquicamente inferior à House of Lords. Sobre a organização judiciária na Inglaterra, ver Ricardo de Carvalho APRigliano, O Princípio do Duplo Grau de Jurisdição nos Sistemas da Common Law e Civil Law: Uma Breve Comparação, in Milton Paulo de CARVALHo (coord.), Direito Processual Civil, São Paulo, Quartier Latin, 2007, págs. 334/336. Ainda, N. ANDrews, O Moderno Processo Civil, trad. Teresa Arruda Alvim Wambier, São Paulo, RT, 2009, págs. 35 e ss.

${ }^{226}$ E. URSO, Recenti Sviluppi nella Giurisprudenza Statunidense e Inglese in Materia di Punitive Damages: $i$ Casi TXO Production Corporation v. Alliances Resources Corporation e AB v. South West Water Services Ltd., in Rivista di Diritto Civile, vol. 41, n. 1, genn.-febr./1995, pág. 144.

${ }^{227}$ E. Urso, Recenti Sviluppi nella Giurisprudenza Statunidense e Inglese in Materia di Punitive Damages: $i$ Casi TXO Production Corporation v. Alliances Resources Corporation e AB v. South West Water Services Ltd., in Rivista di Diritto Civile, vol. 41, n. 1, genn.-febr./1995, págs. 145/146.
} 
Após instruir o feito, o juiz de primeira instância, julgou procedentes ambos os pedidos deduzidos pelos demandantes (para que o demandado fosse condenado ao pagamento de compensatory e punitive damages), acolhendo-os sob o fundamento de que South West Water havia cometido o tort de public nuisance ${ }^{228}$.

Em suas razões recursais, South West Water, a despeito de não pugnar pela reforma da decisão no que tocava à sua responsabilização ao pagamento de compensatory damages, insurgiu-se diretamente contra sua condenação ao pagamento de exemplary damages. Para tanto, a então recorrente se utilizou de uma interpretação restritiva do precedente Rookes v. Barnard (1964). Sustentou-se, na oportunidade, que, ao fixar o category test que exigia que toda imposição de punitive damages decorresse de conduta sancionada expressamente pela lei, a House of Lords, em verdade, somente teria admitido que condenações dessa natureza atingissem condutas ilícitas que, até o momento da fixação daquele precedente (i.e., em 1964), já haviam sido previamente sancionadas daquela maneira. Nessa toada, South West Water pretendeu a reforma do capítulo da decisão que a havia condenado ao pagamento de exemplary damages sob o fundamento de que o tort de public nuisance jamais havia servido de base para a imposição de uma condenação dessa natureza antes de 1964.

A tese recursal foi integralmente acolhida pela Corte de Apelação, que opinou pela reforma da decisão condenatória proferida em primeira instância ${ }^{229}$. A partir de então, os Tribunais ingleses passaram a exigir, para além dos três categories test fixados em Rookes v. Barnard, aquilo que se passou a chamar de cause of action test ${ }^{230}$. Decidiu-

\footnotetext{
${ }^{228}$ E. URSO, Recenti Sviluppi nella Giurisprudenza Statunidense e Inglese in Materia di Punitive Damages: $i$ Casi TXO Production Corporation v. Alliances Resources Corporation e AB v. South West Water Services Ltd., in Rivista di Diritto Civile, vol. 41, n. 1, genn.-febr./1995, pág. 146. Como afirmam S. DEAKIN, A. JOHNSTON e B. MARKESINIS o conceito de public nuisance é muitíssimo vago, abarcando uma série de ilícitos que, de maneira não muito clara, podem ser reunidos em dois grandes grupos: (i) atos não admitidos por lei ("not warranted by law") e (ii) descumprimento de dever legal ("legal duty"), sempre se tendo como efeito destes atos a periclitação da vida, da saúde, de propriedade, dos costumes ou do conforto do público (Markesinis and Deakin's Tort Law, $6^{\text {th }}$ ed., New York, Oxford, 2008, pág. 550).

${ }^{229}$ E. URSO, Recenti Sviluppi nella Giurisprudenza Statunidense e Inglese in Materia di Punitive Damages: $i$ Casi TXO Production Corporation v. Alliances Resources Corporation e AB v. South West Water Services Ltd., in Rivista di Diritto Civile, vol. 41, n. 1, genn.-febr./1995, pág. 149.

${ }^{230}$ Pode-se dizer que, a grosso modo, cause of action é um conjunto de fatos que, devidamente ordenados, dão ensejo ao surgimento de uma relação de direito e dever ("right and duty") da qual se pode extrair a pretensão ao recebimento de determinada prestação jurisdicional (“relief”). Nesse sentido, S. A. HARRIS, What is a Cause of Action?, in California Law Review, vol. XVI, n. 6, 1928, págs. 459/477. O conceito de cause of action, contudo, não encontra fácil tradução para nosso ordenamento e não pode ser identificado com a nossa causa petendi (E. URSO, Recenti Sviluppi nella Giurisprudenza Statunidense e Inglese in
} 
se, no aludido julgamento, que a condenação ao pagamento de punitive damages não poderia ser imposta para sancionar condutas ilícitas (torts) que não haviam sido sancionadas dessa maneira antes de Rookes v. Barnard ou que, antes do citado precedente, não eram tidas como torts (tais como, e.g., são os torts de negligence, public nuisance, deceit, sex ou race discrimination, patent infringements, etc., todos eles erigidos à categoria de tort após o precedente fixado em Rookes v. Barnard ${ }^{231}$.

A adoção do cause of action test pela Corte de Apelação, orientação esta de caráter extremamente restritivo, não passou isenta de críticas pela comunidade jurídica britânica. Com efeito, a maior parte dos juristas ingleses passou a considerar injustificado, sob o ponto de vista lógico, o critério fixado pela jurisprudência em $A B$ v. South West Water Services Ltd. (1993), sobretudo porque ele prescreve a necessária contraposição entre os diversos tipos de ato ilícito, para que se verifique se determinada conduta poderia ser reputada, antes de 1964, como apta a suportar a condenação ao pagamento de exemplary damages ${ }^{232}$.

Assim foi que, anos mais tarde, a própria House of Lords, ao julgar o caso Kuddus v. Chief Constable of Leicestershire (2002), derrubou a cause of action test fixada anteriormente em $A B$; tendo admitido, no caso, a condenação ao pagamento de punitive damages em razão do tort de misfeasance in public office ${ }^{233}$, ilícito para o qual não se havia admitido, antes de Rookes v. Barnard, a imposição de punitive damages. A partir de tal decisão, proferida pelo mais alto órgão judiciário britânico, retornou-se ao uso dos três categories test fixados pelo Lord Devlin em Rookes v. Barnard ${ }^{234}$.

Materia di Punitive Damages: $i$ Casi TXO Production Corporation v. Alliances Resources Corporation e AB v. South West Water Services Ltd., in Rivista di Diritto Civile, vol. 41, n. 1, genn.-febr./1995, pág. 145); a qual, nos termos preconizados no art. 282, III, CPC, abarca tanto (i) os fatos dos quais decorreriam o direito à obtenção do bem da vida pretendido quanto (ii) o preceito legal pelo qual os fatos narrados gerariam o alegado direito (Cândido Rangel Dinamarco, Instituições de Direito Processual Civil, vol. II, $2^{\mathrm{a}}$ ed., São Paulo, Malheiros, 2002, pág. 126).

${ }^{231}$ Os exemplos citados são todos mencionados por S. DEAKIN - A. JOHNSTON - B. MARKESINIS, Markesinis and Deakin's Tort Law, $6^{\text {th }}$ ed., New York, Oxford, 2008, págs. 945/946.

${ }^{232}$ E. URSO, Recenti Sviluppi nella Giurisprudenza Statunidense e Inglese in Materia di Punitive Damages: $i$ Casi TXO Production Corporation v. Alliances Resources Corporation e AB v. South West Water Services Ltd., in Rivista di Diritto Civile, vol. 41, n. 1, genn.-febr./1995, pág. 151.

${ }^{233}$ Trata-se de ato de abuso de poder, intencional ou maliciosamente levado a efeito por agente público ("abuse of public office"), do qual decorrem prejuízos a determinada pessoa (S. DEAKIN - A. JOHNSTON - B. MARKESINIS, Markesinis and Deakin's Tort Law, $6^{\text {th }}$ ed., New York, Oxford, 2008, págs. 427/428). 


\section{RESTRIÇÕES AOS PUNITIVE DAMAGES NO DIREITO NORTE-AMERICANO}

Já ultrapassada a análise da atual situação dos punitive damages no Direito Inglês (âmbito no qual, principalmente após o julgamento de Rookes v. Barnard, tal instituto tem suas hipóteses de incidência fortemente limitadas), passaremos a tratar das discussões travadas nos Estados Unidos da América, tanto em âmbito doutrinário e legislativo quanto em sede judicial, para restringir o desenvolvimento dos punitive damages. Há que se ressaltar, contudo, que o cenário de supressão das hipóteses de condenação ao pagamento de indenização punitiva, nos moldes acima indicados, é um fenômeno tipicamente inglês, não tendo atingido com a mesma intensidade os Estados Unidos da América, país no qual, nas palavras de P. GALlo, e a despeito das discussões a seguir expostas, verifica-se "um notabilíssimo florescimento e expansão" dos punitive damages ${ }^{235}$.

Feita tal ressalva, passaremos a tratar daquelas que são vistas pela doutrina como as duas ordens de fatores que, atualmente, influenciam o regime jurídico geral dos punitive damages: (i) "os limites constitucionais", impostos pela Constituição dos Estados Unidos da América à incidência e, principalmente, quantificação dos punitive damages; e (ii) as propostas de alteração legislativa apresentadas pelo que se passou a denominar de tort reform movement, todas elas tendentes a restringir, em maior ou menor grau, o desenvolvimento do instituto em comento ${ }^{236}$.

\section{XI.I. As restrições de ordem constitucional}

De saída, partiremos da análise das discussões de ordem constitucional feitas pelos doutrinadores e Tribunais norte-americanos quanto à imposição e quantificação dos punitive damages.

${ }^{234}$ S. DEAKIN - A. JOHNSTON - B. MARKESINIS, Markesinis and Deakin's Tort Law, $6^{\text {th }}$ ed., New York, Oxford, 2008, pág. 946.

${ }^{235}$ No original: "una notevolissima fioritura ed espansione" dos punitive damages (Pene Private $e$ Responsabilità Civile, Milano, Giuffrè, 1996, pág. 49). 
A investigação acerca da constitucionalidade do instituto será travada pelo estudo daqueles que são referidos pela doutrina especializada como os casos mais emblemáticos acerca do tema, todos eles julgados pela Supreme Court norte-americana (Tribunal que possui competência recursal para apreciar, em última instância, os recursos advindos dos Tribunais Estaduais e dos Tribunais Federais ${ }^{237}$.

Para uma melhor compreensão da evolução da jurisprudência constitucional acerca do tema, os julgados serão expostos em sua ordem cronológica, apresentando-se, em primeiro lugar, aquele no qual se discutiu a constitucionalidade dos punitive damages em face da vedação às "multas excessivas" ("excessive fines clause", inserida na $8^{\mathrm{a}}$ Emenda à Constituição norte-americana) para, depois, analisarmos os diversos julgados em que se questionou a adequada quantificação dos punitive damages em face da necessidade de observância do "devido processo legal" ("due process clause", inserido na $14^{\mathrm{a}}$ Emenda).

Ao final, e a despeito de ainda não se ter notícia de que tal questionamento tenha sido apreciado pela Supreme Court, trataremos da questão atinente à constitucionalidade dos punitive damages em face da "proibição à dupla condenação", insculpida na $5^{\text {a }}$ Emenda.

\section{XI.I.I. $8^{\text {th }}$ amendment: excessive fines clause}

Aponta a doutrina que a primeira oportunidade em que a Supreme Court norte-americana analisou seriamente a constitucionalidade do instituto dos punitive damages ocorreu no ano de 1988, durante o julgamento do caso Browning-Ferris Industries of Vermont v. Kelco (492 U.S. 257 1988) ${ }^{238}$.

\footnotetext{
${ }^{236}$ Eduardo UILAN, Responsabilidade Civil Punitiva, Tese (Doutorado) - Faculdade de Direito da USP, São Paulo, págs. 32/33.

${ }^{237}$ Sobre a competência recursal da Supreme Court, cfr. Guido Fernando Silva SoARES, Common Law: Introdução ao Direito dos EUA, $2^{\mathrm{a}}$ ed., São Paulo, RT, 2000, págs. 91/92 e J. E. NowAK - R. D. RotUNDA, Principles of Constitutional Law, $3^{\text {rd }}$ ed., St. Paul, Thomson West, 2007, págs. 15/17.

${ }^{238}$ A. S. GAudenzI, La Tutela del Contraente Debole e del Lavoratore (L'Applicazione dei Punitive Damages nel Mondo Anglosassone e nell'Europa Continentale), in Lavoro e Previdenza Oggi, anno XXX, n. 3, 2004, pág. 403. Também, E. URSO, Recenti Sviluppi nella Giurisprudenza Statunidense e Inglese in Materia di Punitive Damages: i Casi TXO Production Corporation v. Alliances Resources Corporation e AB v. South West Water Services Ltd., in Rivista di Diritto Civile, vol. 41, n. 1, genn.-febr./1995, págs. 94.
} 
Versou-se, no caso, sobre ilícita captação de clientela, hipótese na qual a empresa Browning-Ferris Industries of Vermont, atuante no ramo de coleta e tratamento de lixo, por temer as conseqüências negativas decorrentes da concorrência iniciada pela empresa Kelco, passou a agir de todos os modos para excluir esta última do mercado. As condutas de Browning-Ferris, deliberadamente direcionadas a prejudicar a atuação comercial de Kelco, foram tidas por ilícitas tanto pelos julgadores em primeira instância (da U. S. District Court for the District of Vermont, uma vara no âmbito federal) quanto pelo Tribunal de Apelação ${ }^{239}$ (a U. S. Court of Appeals for the Second Circuit) ${ }^{240}$, consubstanciando-se o tort de interference with contractual relations ${ }^{241}$. Em resposta a tais condutas, impôs-se à demandada Browning-Ferris uma condenação ao pagamento de punitive damages no importe de USD 6 milhões ${ }^{242}$.

Irresignada com a condenação, Browning-Ferris recorreu à Supreme Court Americana sob o argumento de que tal condenação ao pagamento de punitive damages era desproporcional e, nesse sentido, violava a norma insculpida na $8^{\mathrm{a}}$ Emenda à Constituição, a assim chamada excessive fines clause ${ }^{243}$; a qual, introduzida no corpo da Constituição norteamericana no ano de 1791, prevê expressamente que "fianças excessivas não serão exigidas, nem multas excessivas impostas, nem punições cruéis ou não usuais serão infligidas" ${ }^{244}$.

\footnotetext{
${ }^{239}$ E. URSO, Recenti Sviluppi nella Giurisprudenza Statunidense e Inglese in Materia di Punitive Damages: $i$ Casi TXO Production Corporation v. Alliances Resources Corporation e AB v. South West Water Services Ltd., in Rivista di Diritto Civile, vol. 41, n. 1, genn.-febr./1995, págs. 94.

${ }^{240}$ Sobre a organização judiciária norte-americana, especialmente no que toca à organização da justiça federal (responsável pelo julgamento, nas instâncias ordinárias, de Browning-Ferries), ver Ricardo de Carvalho APRigliano, O Princípio do Duplo Grau de Jurisdição nos Sistemas da Common Law e Civil Law: Uma Breve Comparação, in Milton Paulo de CARvalho (coord.), Direito Processual Civil, São Paulo, Quartier Latin, 2007, págs. 331/332.

${ }^{241}$ Trata-se da "atuação intencional de um terceiro para que uma parte contratante deixe de cumprir com o contratado, causando prejuizo para a relação entabulada entre as partes contratantes". No original: "A third party's intentional inducement of a contracting party to break a contract, causing damage to the relationship between the contracting parties." (B. A. GARnER, Black's Law Dictionary, $8^{\mathrm{a}}$ ed., St. Paul, West Group, 2004, pág. 1527).

${ }^{242}$ D. G. Owen, A Punitive Damages Overview: Functions, Problems and Reform, in Villanova Law Review, vol. 39, 1994, pág. 401.

${ }^{243}$ M. R. ISIDRO, Punitive Damages y su Notificación en el Contexto del Convenio de la Haya de 15 de Octubre de 1965, in Revista Española de Derecho Internacional, vol. XLVIII, n. 2, jul./dic. 1996, pág. 75. Ainda, T. C. Galligan JR., U.S. Supreme Court Tort Reform: Limiting State Power to Articulate and Develop Tort Law - Defamation, Preemption and Punitive Damages, in University of Cincinnati Law Review, vol. 74, 2006, pág. 1244.

${ }^{244}$ No original, "excessive bail shall not be required, nor excessive fines imposed, nor cruel and unusual punishments inflicted."
} 
Nessa oportunidade, a Supreme Court, partindo da premissa de que os institutos previstos na $8^{\mathrm{a}}$ Emenda (bail e fines, ou, respectivamente, em tradução livre, fiança e multas) dizem respeito ao Direito Penal, ou, quando muito, referem-se a condenações devidas ao Estado ${ }^{245}$, concluiu que a restrição constitucional prevista na excessive fines clause não se presta a restringir a condenação imposta a título de punitive damages em um processo civil iniciado entre dois particulares ${ }^{246}$. Sustentou o Tribunal que a limitação contida na $8^{\mathrm{a}}$ Emenda "não restringe a condenação ao pagamento de indenização em dinheiro em um processo civil quando o Estado não ajuizou a demanda nem tampouco tem direito de receber uma parcela da indenização concedida."247

A despeito de, ao julgar Browning-Ferris, a Supreme Court ter rechaçado o argumento de inconstitucionalidade dos punitive damages à luz da $8^{\mathrm{a}}$ Emenda, parte da doutrina norte-americana sustenta que o fundamento utilizado pela Corte ainda mantém viva tal discussão. Advoga-se que, com o advento do assim chamado tort reform movement, que prevê, como uma das medidas possíveis para o controle da imposição e quantificação dos punitive damages a destinação de toda ou parte da condenação a um fundo público, o Estado passaria a "receber uma parcela da indenização concedida"; fator

\footnotetext{
${ }^{245}$ Com efeito, o instituto jurídico da bail, assemelhado àquele da fiança prevista nos artigos 321 e ss., de nosso Código de Processo Penal, é descrito como sendo "uma garantia, tal como dinheiro ou gravame; esp. garantia exigida por um Tribunal para a soltura de um prisioneiro que precisa se apresentar novamente ao Tribunal em momento futuro < a fiança é fixada em USD 500>." No original, "[a] security such as cash or a bond; esp. security required by a court for the release of a prisoner who must appear at a future time $<$ bail

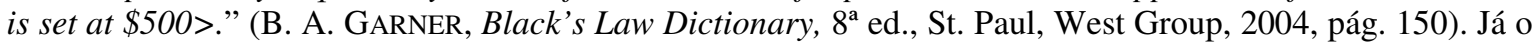
instituto das fines, assemelhado, por sua vez, à pena de multa prevista nos artigos 49 e ss., do nosso Código de Processo Penal, é descrito como sendo "uma punição criminal ou penalidade civil de natureza pecuniária a ser paga à Fazenda Pública." No original, "[a] pecuniary criminal punishment or civil penalty payable to the public treasury." (B. A. GARnER, Black's Law Dictionary, $8^{a}$ ed., St. Paul, West Group, 2004, pág. 664).

246 J. R. MCKnown, Punitive Damages: State Trends and Developments, in The Review of Litigation, vol. 14, 1994/1995, pág. 427. Ainda, T. C. Galligan JR., U.S. Supreme Court Tort Reform: Limiting State Power to Articulate and Develop Tort Law - Defamation, Preemption and Punitive Damages, in University of Cincinnati Law Review, vol. 74, 2006, pág. 1244.

${ }^{247}$ No original, "'does not constrain an award of money damages in a civil suit when the government neither has prosecuted the action nor has any right to receive a share of the damages awarded." (J. R. MCKNOWN, Punitive Damages: State Trends and Developments, in The Review of Litigation, vol. 14, 1994/1995, pág. 428). No mesmo sentido, T. H. DuPreE JR., Punitive Damages and the Constitution, in Louisiana Law Review, vol. 70, 2010, pág. 423; A. S. GAUDENZI, La Tutela del Contraente Debole e del Lavoratore (L'Applicazione dei Punitive Damages nel Mondo Anglosassone e nell'Europa Continentale), in Lavoro e Previdenza Oggi, anno XXX, n. 3, 2004, pág. 404 e E. URSO, Recenti Sviluppi nella Giurisprudenza Statunidense e Inglese in Materia di Punitive Damages: $i$ Casi TXO Production Corporation v. Alliances Resources Corporation e AB v. South West Water Services Ltd., in Rivista di Diritto Civile, vol. 41, n. 1, genn.-febr./1995, págs. 94.
} 
este que poderia trazer à tona novamente a discussão acerca da pertinência da excessive fines clause como fator limitador dos punitive damages ${ }^{248}$.

A despeito da atualidade e pertinência dessa discussão, especialmente após o advento do tort reform movement, o questionamento levado à Supreme Court norteamericana seguiu outro caminho que não o da suposta infringência à excessive fines clause; não tendo o aludido órgão jurisdicional, pelo que se tem notícia, chegado a reapreciar a questão em demandas nas quais toda, ou parte, da condenação ao pagamento de punitive damages foi destinada a um fundo público.

\section{XI.I.II. $14^{\text {th }}$ amendment: due process clause}

Após o julgamento de Browning-Ferris, empresas ou particulares condenados ao pagamento de quantias exorbitantes a título de punitive damages passaram a questionar a constitucionalidade dessa sanção punitiva não mais sob a ótica da excessive fines clause ( $8^{\mathrm{a}}$ Emenda à Constituição Americana), mas, sim, sob o crivo da due process clause $^{249}$. Tal princípio, insculpido na Seção 1 da $14^{\mathrm{a}}$ Emenda à Constituição Americana, impede que qualquer pessoa seja privada de sua vida, de sua liberdade ou de seu patrimônio sem o respeito ao devido processo legal (due process) ${ }^{250}$.

A primeira ocasião em que a Supreme Court, após o julgamento de Browning-Ferris, apreciou a constitucionalidade dos punitive damages sob a ótica da due process clause se deu quando do julgamento de Pacific Mutual Life Insurance Co. v. Haslip (499 U.S. 1 1990).

\footnotetext{
248 Nesse sentido, D. G. OWEn, A Punitive Damages Overview: Functions, Problems and Reform, in Villanova Law Review, vol. 39, 1994, pág. 401.

249 T. C. Galligan JR., U.S. Supreme Court Tort Reform: Limiting State Power to Articulate and Develop Tort Law - Defamation, Preemption and Punitive Damages, in University of Cincinnati Law Review, vol. 74, 2006, pág. 1245.

${ }^{250}$ A aludida Section 1 da $14^{\text {th }}$ Amendment, inserida no corpo da Constituição Americana no ano de 1868 , assim dispõe: "No State shall make or enforce any law which shall abridge the privileges or immunities of citizens of the United States; nor shall any State deprive any person of life, liberty, or property, without due process of law; nor deny to any person within its jurisdiction the equal protection of the law."
} 
Tratou-se, no caso, de demanda fundada no tort de rraud $^{251}$, ajuizada pela Sra. Cleopatra Haslip em face da empresa responsável pela gestão de seu contrato de seguro saúde (Pacific Mutual), bem como de seu corretor de seguros (profissional vinculado à empresa Pacific Mutual), sob o fundamento de que ambos os demandados continuaram a lhe exigir o pagamento de diversas parcelas correspondentes ao prêmio, mesmo após a apólice de seguros de que se beneficiada a demandante ter sido cancelada sem prévia notificação à segurada ${ }^{252}$. Pelo que consta do julgado, a Sra. Haslip somente veio a tomar ciência do cancelamento de sua apólice quando necessitou de uma internação hospitalar, vindo a suportar vultosas despesas médicas que, de ordinário, seriam custeadas por Pacific Mutual ${ }^{253}$.

Após terem sido instruídos, pelo juízo de primeira instância, de que caso fosse verificada a ocorrência de fraud, seria admissível a imposição de uma condenação a título de punitive damages, em adição a quaisquer prejuízos efetivamente sofridos pela demandante, os jurados condenaram os demandados ao pagamento de quantia próxima de USD 1 milhão, a qual englobava tanto compensatory quanto punitive damages.

Irresignada, Pacific Mutual se insurgiu contra o veredicto por meio de recurso rejeitado por maioria de votos pela Supreme Court do Estado do Alabama. A despeito de se ter mantido o conteúdo da decisão proferida em primeira instância, dois dos juízes da corte externaram, na fundamentação de seus votos divergentes, que a condenação ao pagamento de punitive damages, no caso em questão, havia violado a due process clause em seus dois aspectos (substantive e procedural) ${ }^{254}$.

Amparada desses novos subsídios, Pacific Mutual recorreu novamente, desta vez à Supreme Court Americana, para pleitear a reforma da sentença proferida em primeiro grau sob o fundamento de que o jurí do Estado do Alabama dispunha de excessiva discricionariedade para o exercício da tarefa de aplicar e quantificar punitive

\footnotetext{
${ }^{251}$ Trata-se de ilícito consistente na "alteração intencional da verdade ou omissão intencional de um fato com a intenção de induzir terceiro a agir em seu próprio detrimento." No original: "A knowing misrepresentation of the truth or concealment of a material fact to induce another to act in his or her detriment". (B. A. GARNER, Black's Law Dictionary, 8 a ed., St. Paul, West Group, 2004, pág. 685).

${ }^{252}$ T. C. Galligan JR., U.S. Supreme Court Tort Reform: Limiting State Power to Articulate and Develop Tort Law - Defamation, Preemption and Punitive Damages, in University of Cincinnati Law Review, vol. 74, 2006, pág. 1245.

253499 U.S. 1 1990, págs. 2/6.
} 
damages; discricionariedade esta que feriria as garantias processuais consubstanciadas na due process clause $e^{255}$.

Ao apreciar a pretensão recursal deduzida por Pacific Mutual, a Supreme Court, por maioria de votos e a despeito das opiniões divergentes, reconheceu que, ao menos em tese, a $14^{\mathrm{a}}$ Emenda efetivamente impõe restrições à aplicação dos punitive damages, tanto de ordem substancial (que exige o respeito à razoabilidade e à proporcionalidade da condenação) quanto de ordem procedimental (que exige uma correta instrução do júri para que este possa exercer adequadamente seu mister decisório) ${ }^{256}$.

Diante das circunstâncias que cercavam o caso em questão, contudo, a Supreme Court julgou que a condenação aplicada à Pacific Mutual "não havia cruzado a linha para a inconstitucionalidade ${ }^{, 257}$, respeitando-se os limites impostos pela due process clause.

No que toca à due process clause em seu aspecto substancial, a Supreme Court concluiu que a questão atinente à razoabilidade da sanção imposta certamente deveria ser levada em consideração no chamado "cálculo constitucional” da condenação ${ }^{258}$. Afirmou-se, contudo, não ser possível traçar uma clara linha divisória que indicasse com precisão quando determinada condenação ao pagamento de punitive damages, em razão de alegada ausência de proporcionalidade ou razoabilidade, deixaria de

\footnotetext{
254499 U.S. 1 1990, pág. 7.

${ }^{255}$ E. URSO, Recenti Sviluppi nella Giurisprudenza Statunidense e Inglese in Materia di Punitive Damages: $i$ Casi TXO Production Corporation v. Alliances Resources Corporation e AB v. South West Water Services Ltd., in Rivista di Diritto Civile, vol. 41, n. 1, genn.-febr./1995, págs. 97.

256 P. S. KARLAN, 'Pricking the Lines': The Due Process Clause, Punitive Damages and Criminal Punishment, in Minnessota Law Review, vol. LXXXVIII, 2003/2004, pág. 904: "[T]he Court finally held, in Pacific Mutual Life Insurance Co. v. Haslip, that the Due Process Clause imposes both a procedural and a substantive limit on the size of punitive damages awards. The procedural component requires that juries be properly instructed on the purposes of punitive damages and the factors to be taken into account in deciding whether to award punitive damages and if so, what amount. It also requires appellate review of jury awards to ensure reasonableness. The substantive component requires that the award in fact be reasonable, rather than 'grossly excessive' or disproportionate." No mesmo sentido segue M. A. GEISTFELD, o qual, ao analisar a distinção entre os dois aspectos da due process clause, sustenta que "the procedural problem [da due process clause] has nothing to do with the size of the damages award. Procedural due process may simply require minimal amount of process, a requirement that can be violated by overly vague jury instructions concerning the appropriate modulus for determining the punitive award. [...] Procedural due process requires courts to give jurors sufficient guidance of how to compute punitive damages." (Punitive Damages, Retribution, and Due Process, in South California Law Review, vol. 81, 2007/2008, pág. 304).

${ }^{257}$ No original, "[w]e conclude, after careful consideration, that in this case it [a condenação ao pagamento de punitive damages] does not cross the line into the area of constitutional impropriety." (499 U.S. 1 1990, págs. 23/24).

${ }_{258}$ "We can say, however, that general concerns of reasonableness and adequate guidance from the court when the case is tried to a jury properly enter into the constitutional calculus." (499 U.S. 1 1990, pág. 18).
} 
ser constitucional para se tornar inconstitucional ${ }^{259}$. Vale dizer: "uma linha matematicamente clara entre a constitucionalidade $e$ a inconstitucionalidade [da condenação ao pagamento de punitive damages] não poderia ser desenhada" ${ }^{260}$.

Já no que toca à due process clause em seu aspecto processual, a opinião majoritária da Supreme Court seguiu no sentido de que, por hipótese, o descumprimento de determinadas garantias procedimentais, tais como a discricionariedade ilimitada dos jurados para a imposição de punitive damages (i.e., sem as adequadas instruções quanto aos seus pressupostos objetivos e subjetivos de incidência, bem como às funções a serem perseguidas com tal condenação e os critérios a serem utilizados para a sua quantificação), poderia dar ensejo à imposição desanções desproporcionais que atentassem à garantia constitucional da due process clause ${ }^{261}$. Ao apreciar as circunstâncias do caso em questão, contudo, a Supreme Court entendeu que "as instruções aos jurados, os procedimentos pós julgamento e a revisão do julgado pelos Tribunais eram suficientes"262 para atender às exigências da due process clause, não havendo que se cogitar, portanto, de inconstitucionalidade da condenação.

Apenas dois anos mais tarde, em idos de 1993, a Supreme Court americana voltou a analisar a questão acerca da constitucionalidade dos punitive damages, novamente sob a ótica da due process clause, durante o julgamento do caso TXO Production Corp. $v$. Alliance Resources Corp (509 U.S. 443 1992).

No caso em questão, TXO, uma renomada e portentosa empresa do ramo petrolífero, havia entabulado relação jurídica contratual com Alliance Resources (especificamente um leasehold interest) pela qual passaria a exercer, com exclusividade, os

\footnotetext{
${ }^{259}$ T. H. DUPREE JR., Punitive Damages and the Constitution, in Louisiana Law Review, vol. 70, 2010, pág. 423.

${ }^{260}$ No original, "a mathematical bright line between the constitutional and unconstitutional could not be drawn." (T. C. Galligan JR., U.S. Supreme Court Tort Reform: Limiting State Power to Articulate and Develop Tort Law - Defamation, Preemption and Punitive Damages, in University of Cincinnati Law Review, vol. 74, 2006, pág. 1245).

${ }^{261}$ Nesse sentido, J. R. MCKnown, Punitive Damages: State Trends and Developments, in The Review of Litigation, vol. 14, 1994/1995, pág. 430: Sustentou-se no caso Pacific Mutual Life Insurance Co. v. Haslip (1991) que "'[o]ne must concede that unlimited jury discretion - or unlimited judicial discretion for that matter - in the fixing of punitive damages may invite extreme results that jar one's constitutional sensibilities." Tecendo considerações semelhantes, T. H. DUPREE JR., Punitive Damages and the Constitution, in Louisiana Law Review, vol. 70, 2010, pág. 423.

${ }^{262}$ No original, "[t]he jury instructions, post-trial procedures, and appellate review were sufficient." (T. C. Galligan JR., U.S. Supreme Court Tort Reform: Limiting State Power to Articulate and Develop Tort Law Defamation, Preemption and Punitive Damages, in University of Cincinnati Law Review, vol. 74, 2006, pág. 1245)
} 
direitos de exploração de petróleo e gás em imóvel de propriedade desta última (grande porção de terras denominada "Blevins Tract"), pagando-lhe, em troca, quantias tão expressivas que faziam o contrato muito vantajoso à empresa Alliance Resources. Tencionando descumprir a avença e fazer-se valer, indevidamente, de cláusula resolutiva expressa prevista no aludido contrato (a qual estabelecia que a relação jurídica em questão seria resolvida se TXO viesse a descobrir que o imóvel arrendado possuía gravame que o impedisse de ser por ela explorado ou que Alliance Resources, por alguma razão, não era a única titular dos direitos cedidos), TXO passou a se conduzir deliberadamente de modo fraudulento, procurando de todas as formas, e sem amparo legal, contestar a higidez do título de propriedade ostentado por Alliance Resources; tudo para que TXO pudesse exercer livremente os direitos exploratórios sobre o imóvel sem ter de remunerar Alliance Resources, conforme contratualmente previsto. Tais investidas levaram TXO (depois de ter distratado o contrato com Alliance Resources e de, sem conhecimento desta, ter procurado celebrar negócios jurídicos com terceiros que supostamente lhe autorizariam a, por outra via, exercer os mesmos direitos exploratórios sobre o imóvel em questão) a ajuizar demanda declaratória em face de Alliance Resources (um declaratory judgment to a quiet title) com o fim de ver reconhecido seu próprio direito de explorar o imóvel, sem a necessidade de cumprir a avença anteriormente entabulada. Inconformada com o ocorrido, Alliance Resources não só respondeu à demanda ajuizada por TXO como ajuizou, ela própria, uma demanda reconvencional (counter claim) na qual pretendeu a condenação de TXO ao pagamento de indenização por ter perpetrado o tort de slander of title ${ }^{263}$.

Em razão do prejuízo causado, a empresa $T X O$ foi condenada, nas instâncias ordinárias, ao pagamento de indenização por danos materiais (compensatory damages) no importe de USD 19 mil (valor referente às despesas suportadas por Alliance Resources na defesa de seus interesses durante o curso do declaratory judgement) e, em razão do alto grau de reprovabilidade de suas condutas, ao pagamento de punitive damages no vultoso importe de USD 10 milhões, quantia esta 526 vezes superior àquela atinente aos compensatory damages ${ }^{264}$.

\footnotetext{
263 "Uma falsa declaração, feita oralmente ou por escrito, que põe em dúvida os direitos de propriedade de outra pessoa". No original, "[a] false statement, made orally or in writing, that casts doubt on another person's ownership of property". (B. A. GARNER, Black's Law Dictionary, $8^{\text {a }}$ ed., St. Paul, West Group, 2004, pág. 1422).

${ }^{264}$ J. R. MCKNown, Punitive Damages: State Trends and Developments, in The Review of Litigation, vol. 14, 1994/1995, pág. 433.
} 
Procurando a reforma da decisão então referendada pelos Tribunais inferiores, TXO recorreu à Supreme Court sob o fundamento de que a significativa quantia a ela imposta a título de punitive damages deveria ser reputada inconstitucional frente à due process clause, quer porque: (i) a adequada imposição de tal sorte de condenação exigia que o juiz de primeiro grau houvesse instruído corretamente o júri quanto a todos os elementos a serem considerados para tanto (tais como o prejuízo efetivamente causado e aquele que, em razão da conduta lesiva, poderia ter surgido; o grau de reprovabilidade, a duração e a freqüência com que, porventura, repetiu-se a conduta lesiva; bem como o comportamento do lesante após o cometimento do ilícito e causação do prejuízo), tendo-se violado, no caso, a due process clause em seu aspecto processual (procedural due process); quer, ainda, porque (ii) a excessividade da quantia imposta a título de punitive damages, por supostamente não ostentar uma "relação razoável" com os compensatory damages, teria significado uma verdadeira privação de propriedade sem respeito à due process clause em seu aspecto substantivo (substantive due process) ${ }^{265}$.

No que toca ao aspecto processual da due process clause, a Supreme Court entendeu que, ao ordenar o processo, o juiz de primeira instância havia instruído corretamente os jurados, que levaram em consideração todos os elementos adequados para a imposição da condenação ao pagamento dos punitive damages, vindo a proferir, ao final, uma decisão corretamente fundamentada. Decidiu-se que, no caso em comento, não se poderia considerar que a condenação, a despeito de ter resultado verdadeiramente expressiva, decorreu de um julgamento "injusto, arbitrário ou irracional" ("unfair, arbitrary or irrational"). Concluiu-se, assim, que a due process clause, em seu aspecto processual, havia sido devidamente respeitada pelas instâncias ordinárias ${ }^{266}$.

Já quanto ao aspecto substancial da due process clause, e levando em consideração as circunstâncias específicas do caso concreto, entendeu a Supreme Court que não era possível afirmar categoricamente que a condenação ao pagamento de punitive

\footnotetext{
${ }^{265}$ E. URSO, Recenti Sviluppi nella Giurisprudenza Statunidense e Inglese in Materia di Punitive Damages: $i$ Casi TXO Production Corporation v. Alliances Resources Corporation e AB v. South West Water Services Ltd., in Rivista di Diritto Civile, vol. 41, n. 1, genn.-febr./1995, págs. 110/111.

${ }^{266}$ E. URSO, Recenti Sviluppi nella Giurisprudenza Statunidense e Inglese in Materia di Punitive Damages: $i$ Casi TXO Production Corporation v. Alliances Resources Corporation e AB v. South West Water Services Ltd., in Rivista di Diritto Civile, vol. 41, n. 1, genn.-febr./1995, pág. 116.
} 
damages, ainda que em flagrante descompasso com a condenação necessária para compensar os prejuízos efetivamente suportados pela vítima (expressa pelos compensatory damages), poderia ser considerada grosseiramente excessiva (apta, portanto, a merecer revisão ante ao princípio insculpido na due process clause $)^{267}$. Para a opinião majoritária, a condenação imposta à $T X O$ se mostrava razoável (a ponto não importar em desrespeito à due process clause), porque, no caso em tela, era absolutamente lícito ao juiz (e ao júri) levar em consideração, para a quantificação da sanção punitiva, não apenas os prejuízos efetivamente impostos à vítima direta do ilícito, mas, também, aqueles prejuízos que esta vítima (e eventuais terceiros) poderia vir a suportar, bem como a má-fé da empresa lesante (TXO), o fato de que suas condutas faziam parte de um plano fraudulento maior, direcionado à obtenção de lucro às expensas da lesada (Alliance Resources) e, ainda, as condições econômicas da lesante ${ }^{268}$. Entendeu-se, enfim, que, para que os punitive damages pudessem atuar de maneira adequada, em persecução à sua função dissuasória (deterrence), sua quantificação não poderia se dar apenas em atenção a um critério de ordem puramente objetiva (i.e., apenas e tão-somente em atenção aos compensatory damages), mas, também, em atenção aos critérios de ordem subjetiva anteriormente enumerados.

Até então, a Supreme Court havia analisado, nas duas oportunidades acima narradas, a constitucionalidade de condenações ao pagamento de punitive damages, chegando a apontar algumas vagas diretrizes a serem seguidas pelos Tribunais inferiores, sem, contudo, efetivamente reformar ou cassar as decisões recorridas. Tal cenário mudaria apenas menos de um ano mais tarde, quando do julgamento do caso Honda Motor Co. v. Oberg (512 U.S. 415 1993).

Tratou-se, no caso, de ação indenizatória ajuizada pelo Sr. Oberg em face de Honda Motor Co. em razão de um acidente de veículo (um triciclo "all-terrain" fabricado pela demandada) causado por uma falha no projeto do aludido veículo, do qual Honda tinha ou devia ter conhecimento. Em atenção aos danos suportados pelo demandante, o

\footnotetext{
${ }^{267}$ E. URSO, Recenti Sviluppi nella Giurisprudenza Statunidense e Inglese in Materia di Punitive Damages: $i$ Casi TXO Production Corporation v. Alliances Resources Corporation e AB v. South West Water Services Ltd., in Rivista di Diritto Civile, vol. 41, n. 1, genn.-febr./1995, págs. 98.

${ }^{268}$ T. C. Galligan JR., U.S. Supreme Court Tort Reform: Limiting State Power to Articulate and Develop Tort Law - Defamation, Preemption and Punitive Damages, in University of Cincinnati Law Review, vol. 74, 2006, pág. 1246. Ainda, E. URSO, Recenti Sviluppi nella Giurisprudenza Statunidense e Inglese in Materia di Punitive Damages: i Casi TXO Production Corporation v. Alliances Resources Corporation e AB v. South West Water Services Ltd., in Rivista di Diritto Civile, vol. 41, n. 1, genn.-febr./1995, pág. 116.
} 
Juízo de primeira instância (um corpo de jurados do Estado do Oregon) condenou Honda ao pagamento de uma quantia de aproximadamente USD 900 mil a título de compensatory damages (quantia esta reduzida em 20\%, para um importe de aproximadamente USD 735 mil, em razão da culpa concorrente da vítima na causação do acidente) e de USD 5 milhões a título de punitive damages ${ }^{269}$.

Irresignada, Honda se insurgiu contra tal decisão interpondo recursos tanto à Court of Appeals quanto à Supreme Court do Estado do Oregon, aduzindo, em síntese e com amparo no recente precedente fixado em Pacific Mutual v. Haslip, que a condenação ao pagamento de punitive damages não poderia persistir, pois: (i) tal quantia havia sido fixada em montante excessivo e não razoável, ferindo a due process clause em seu aspecto substancial; e, ainda, porque (ii) em razão de uma previsão específica da constituição do Estado do Oregon, a revisão judicial da condenação encontrava grande limitação, o que feriria a due process clause em seu aspecto processual ${ }^{270}$.

Após ver rejeitadas sua pretensão recursal endereçada aos Tribunais inferiores, justamente com fundamento na vedação constitucional à revisão judicial dos punitive damages $^{271}$, Honda recorreu à Supreme Court para pretender a cassação de tais decisões, sob o (então repisado) argumento de que a condenação a ela imposta pelos jurados do Estado do Oregon, posteriormente referendada pelas Cortes Estaduais, havia violado a due process clause.

Ao apreciar o caso, a Supreme Court focou suas atenções na alegada violação ao aspecto processual da due process clause, justamente resultante da extremada limitação imposta pelo ordenamento constitucional do Estado do Oregon à revisão judicial da condenação. Após repassar a jurisprudência consolidada desde o século XVIII, quando dos primeiros casos nos quais houve imposição ao pagamento de punitive damages, a Supreme Court anotou que nas Cortes Federais, e em todos os Estados - exceto no Oregon

\footnotetext{
${ }^{269}$ D. G. Owen, A Punitive Damages Overview: Functions, Problems and Reform, in Villanova Law Review, vol. 39, 1994, pág. 404.

${ }^{270}$ Com efeito, uma emenda à constituição do Estado do Oregon proíbe a revisão judicial do quantum indenizatório pago a título de punitive damages, "a não ser que a corte possa afirmar categoricamente que não existiram provas suficientes para embasar o veredicto" concedido. No original: "[a]n amendment to the Oregon Constitution prohibits judicial review of the amount of punitive damages awarded by a jury 'unless the court can affirmatively say there is no evidence to support the verdict'”. (512 U.S. 415 1993, pág. 418)
} 
-, “a revisão judicial do valor da condenação ao pagamento de punitive damages tem sido uma garantia contra veredictos excessivos" ${ }^{, 72}$.

Enfatizou-se, ao julgar o caso em questão, que, quantificados como foram na hipótese, e sem que fosse permitida uma nova apreciação da condenação por um Tribunal, os punitive damages "representavam um grave risco de privação arbitrária da propriedade", anotando-se, ainda que "o surgimento de grandes corporações, em nível interestadual ou multinacional, tem agravado o problema de imposição de condenações arbitrárias e de potencial parcialidade dos jurados" 273 . Tudo para que se pudesse concluir que o escorreito atendimento à due process clause, em seu aspecto prossual, exige a ampla possibilidade de revisão judicial, não só da condenação ao pagamento de punitive damages (i.e., da fixação do an debeatur), mas, também, do montante da indenização (i.e., do quantum debeatur $)^{274}$.

Forte nesses fundamentos, a Supreme Court deu provimento ao recurso para cassar ("reverse") a decisão proferida pelo Tribunal do Estado do Oregon, determinando sua remessa ao Tribunal a quo para a prolação de novo julgamento ("remand") que atentasse aos ditames prescritos pela Supreme Court quanto à possibilidade de reexame da condenação $^{275}$.

Oberg assumiu, desta feita, enorme relevância na jurisprudência constitucional norte-americana, a uma por ter se tratado do primeiro caso no qual houve

${ }^{271}$ D. G. Owen, A Punitive Damages Overview: Functions, Problems and Reform, in Villanova Law Review, vol. 39, 1994, págs. 404/405.

${ }^{272}$ No original, "[j] udicial review of the size of punitive damages awards has been a safeguard against excessive verdicts for as long as punitive damages have been awarded." (512 U.S. 415 1993, pág. 421).

${ }^{273}$ No original, "In that case, the Court emphasized that punitive damages 'pose an acute danger of arbitrary deprivation of property' and noted that 'the rise of large, interstate and multinational corporations has agravated the problem of arbitrary awards and potentially biased juries." (T. H. DUPREE JR., Punitive Damages and the Constitution, in Louisiana Law Review, vol. 70, 2010, pág. 423).

${ }^{274}$ A Supreme Court externou todas as suas preocupações ao fundamentar a inadequação dos procedimentos esposados pela ordem constitucional do Estado do Oregon ao sustentar que "[p]unitive damages pose an acute danger of arbitrary deprivation of property. Jury instructions tipically leave the jury with wide discretion in choosing amounts, and the presentation of evidence of a defendant's net worth creates the potential that juries will use their verdicts to express biases against big business, particularly those without strong local presences. Judicial review of the amount awarded was one of the few procedural safeguards wich the common law provided against that danger. Oregon has removed that safeguard without providing any substitute procedure and without any indication that the danger of arbitrary awards has in any way subsided over time. For these reasons, we hold that Oregon's denial of judicial review of the size of punitive damages awards violates the Due Process Clause of the Forteenth Amendment." (512 U.S. 415 1993, pág. 432). 
efetiva cassação de uma imposição ao pagamento de punitive damages por razões de ordem constitucional e, a duas, por ter trazido considerações que impactavam o próprio princípio federalista; vale dizer: a decisão proferida "necessariamente limitou a competência estadual para criar e aplicar suas próprias leis no que concerne aos punitive damages" ${ }^{276}$.

Poucos anos mais tarde, ao julgar BMW of North America vs. Gore (517 U.S. 559 1995), a Supreme Court voltou a analisar a questão acerca da constitucionalidade dos punitive damages. Nessa oportunidade, a Supreme Court pôde aprofundar as considerações fixadas nos casos anteriormente julgados para, efetivamente, passar a indicar três critérios ("guideposts") que deveriam ser seguidos pelos Tribunais Estaduais ao imporem ou reformarem uma condenação ao pagamento de punitive damages.

No caso em questão, um médico do Estado do Alabama de nome Gore havia recém adquirido um automóvel $B M W$ novo, pagando por ele seu preço de mercado. Após constatar o que acreditava serem pequenas imperfeições no acabamento externo do veículo, Gore o encaminhou a um pintor de sua confiança que constatou que, antes de lhe ser vendido como novo e sem que nenhuma dessas informações lhe houvessem sido prestadas, o automóvel havia sofrido danos decorrentes de chuva ácida e certamente recebido uma repintura pelo fabricante. Após conduzir investigações particulares, Gore veio a descobrir que a $B M W$ possuía uma orientação empresarial, aplicável em âmbito nacional, no sentido de que, se determinado automóvel houvesse suportado prejuízos na fase pré-venda em montante inferior a $3 \%$ de seu valor de mercado, ele seria reparado e vendido como novo, sem que tal fato fosse informado às concessionárias de veículos ou ao consumidor final $^{277}$. Sob a alegação de que a conduta perpetrada por $B M W$ se amoldava ao tort de fraud, conforme previsto no ordenamento do Estado do Alabama ${ }^{278}$, Gore

\footnotetext{
${ }^{275} \mathrm{O}$ dispositivo do acórdão prescreveu que "[t]he judgement is reversed, and the case is remanded to the Oregon Supreme Court for further proceedings not inconsistent with this opinion." (512 U.S. 415 1993, pág. 435).

${ }^{276}$ No original, "The decision necessarily limited the state's ability to articulate and apply its own law of punitive damages." (T. C. GALligAN JR., U.S. Supreme Court Tort Reform: Limiting State Power to Articulate and Develop Tort Law - Defamation, Preemption and Punitive Damages, in University of Cincinnati Law Review, vol. 74, 2006, pág. 1247).

${ }^{277}$ T. C. Galligan JR., U.S. Supreme Court Tort Reform: Limiting State Power to Articulate and Develop Tort Law - Defamation, Preemption and Punitive Damages, in University of Cincinnati Law Review, vol. 74, 2006, pág. 1247.

${ }^{278}$ Ao relatar o caso, a Supreme Court anotou que, em 1907, o Estado do Alabama codificou as causas de pedir (causes of action) do tort de fraud, considerando, para o que toca ao caso em questão, que a omissão de um fato (suppression of a material fact) poderia ser considerada fraud. No original "[t]he statute provides: Suppression of a material fact wich the party is under an obligation to communicate constitutes fraud. The obligation to
} 
demandou a construtora de automóveis para lhe exigir o pagamento de indenização. Ao julgar o caso, o júri condenou $B M W$ ao pagamento de USD 4 mil a título de compensatory damages e, ainda, de USD 4 milhões a título de punitive damages (quantia esta mil vezes superior à dos compensatory damages).

Irresignada com a condenação, a qual julgou "grosseiramente excessiva" ("grossly excessive"), BMW recorreu para vê-la reduzida, obtendo, em um primeiro momento, julgamento parcialmente favorável da Supreme Court do Estado do Alabama, que limitou a condenação ao pagamento de punitive damages ao valor de USD 2 milhões; sob o argumento de que, para atingir os USD 4 milhões originais, o júri havia levado em consideração o número de vendas em situação similar (aquelas nos quais não teria ocorrido a revelação, ao consumidor final, acerca da existência de defeito no produto) em âmbito nacional, e não apenas no Estado do Alabama ${ }^{279}$.

Ainda insatisfeita com a desproporcionalidade da condenação, $B M W$ recorreu à Supreme Court sob o argumento de que os punitive damages a ela impostos, mesmo após a redução para o patamar de USD 2 milhões, eram grosseiramente excessivos e, por isso, violavam a due process clause prevista na $14^{\mathrm{a}}$ Emenda.

Ao julgar o caso, a Supreme Court partiu, principalmente, da análise da função educativa dos punitive damages para concluir que a condenação imposta a $B M W$ era grosseiramente excessiva e, portanto, afrontava a due process clause. Sustentou a Supreme Court que, para a correta imposição e quantificação dos punitive damages, é indispensável aferir se o demandado tinha efetivo conhecimento prévio de que a conduta por ele perpetrada é passível de punição e, com exatidão, do grau de punição a ele aplicável em caso de cometimento do ilícito. Nesse sentido, afirmou a Supreme Court que "noções elementares de justiça inseridas em nossa jurisprudência constitucional ditam que

communicate may arise from the confidential relations of the parties or from the particular circumstances of the cause’ Ala. Code §6-5-102 (1993); see Ala. Code § 4299 (1907).” (517 U.S. 559 1995, pág. 563).

${ }^{279}$ Ao expor suas razões ao júri, Gore demonstrou que, desde 1983, quando foi desenvolvida uma política empresarial, aplicável em todo o território dos EUA, de reparar pequenos defeitos em automóveis e vendê-los como se novos fossem, sem informar as concessionárias e consumidores finais, BMW teria lesado 983 clientes nos EUA, sendo 14 deles apenas no Estado do Alabama. Levando-se em consideração uma alegada depreciação de $10 \%$ no valor de cada automóvel repintado, um preço final de venda estimado em USD 40 mil por veículo, e um número absoluto de aproximadamente 1000 veículos vendidos sob tais condições, defendeu Gore que a condenação ao pagamento de USD 4 milhões a título de punitive damages era perfeitamente razoável (517 U.S. 559 1995, pág. 564). 
a pessoa deve receber previamente informação adequada não apenas acerca da conduta que, caso perseguida, lhe submeterá à punição, mas, também, da severidade da sanção que o Estado poderá impor em razão dessa conduta" ${ }^{280}$; para concluir que, no caso concreto, a condenação deveria ter obedecido a três critérios (guideposts) que, por não terem sido observados, tornaram a condenação inconstitucional. Eram $\operatorname{eles}^{281}$ : (i) a gravidade da conduta perpetrada pelo demandado ("the degree of reprehensibility of the defendant's conduct") ${ }^{282}$; (ii) a proporção ("ratio") entre os compensatory damages e os punitive damages resultantes da mesma conduta ilícita, em razão do princípio de que a condenação justa e adequada exige uma relação razoável ("reasonable relationship") entre eles ${ }^{283}$; e, por fim, (iii) a comparação entre a condenação ao pagamento de punitive damages e as demais sanções civis e criminais que às quais o demandado poderia se submeter pelo cometimento do mesmo ilícito ("comparing the punitive damages award to the civil or criminal penalties a defendant would have faced for the same conduct") $)^{284}$.

\footnotetext{
${ }^{280}$ No original, "[e]lementary notions of fairness enshrined in our constitutional jurisprudence dictate that a person receive fair notice not only of the conduct that will subject him to punishment but also of the severity of the penalty that a state may impose." (T. H. DUPREE JR., Punitive Damages and the Constitution, in Louisiana Law Review, vol. 70, 2010, pág. 424)

${ }^{281}$ Sobre os três guideposts fixados em BMW of North America v. Gore, ver P. S. KARLAN, 'Pricking the Lines': The Due Process Clause, Punitive Damages and Criminal Punishment, in Minnessota Law Review, vol. LXXXVIII, 2003/2004, págs. 906/909. Ainda: E. D’ALESSANDRO, Pronunce Americane di Condanna al Pagamento di Punitive Damages e Problemi di Riconoscimento in Italia, in Rivista di Diritto Civile, anno LIII, n. 3, mag.-giug./2007, pág. 404 e Maria Celina Bodin de MoRAES, Punitive Damages em Sistemas Civilistas: Problemas e Perspectivas, in Revista Trimestral de Direito Civil, vol. 18, abr./jun. 2004, pág. 62.

${ }^{282}$ Entendeu-se, no caso, que nenhum dos fatores que poderiam elevar a gravidade da conduta perpetrada por $B M W$ estavam presentes. Pelo contrário: (i) os prejuízos efetivamente impostos a Gore foram apenas de ordem material; (ii) os consertos levados a efeito antes da venda do automóvel (atinentes à repintura de parte da lataria que havia sido afetada pela chuva ácida) não prejudicaram o desempenho do veículo ou, até mesmo, sua aparência, ao menos nos primeiros nove meses após a venda; e (iii) as condutas de $B M W$ não externaram indiferença ou falta de consideração pela saúde e bem estar de terceiros. (517 U.S. 559 1995, pág. 576).

${ }^{283}$ A despeito de se reiterar a afirmação anteriormente expressa em Haslip (quanto à impossibilidade de se fixar uma "linha matemática" que, aplicável à generalidade dos casos, fosse apta a indicar com precisão quando uma condenação ao pagamento de punitive damages deixava de ser constitucional para se tornar inconstitucional), entendeu-se que, no caso, a razão de 500 para 1 entre os punitive e os compensatory damages era inaceitável e dela se podia extrair a conclusão de que a condenação era grosseiramente excessiva (517 U.S. 559 1995, págs. 580/583).

${ }^{284}$ Ao se comparar a condenação ao pagamento de punitive damages com demais sanções civis previstas nas legislações estaduais (o Deceptive Trade Practices Act do Estado do Alabama, e.g., previa sanção máxima de USD 2 mil pelo cometimento de conduta semelhante: omitir informações relevantes do consumidor final, levando-o a adquirir determinado produto. Em outros Estados, a condenação máxima para o cometimento de ilícitos semelhantes variava entre USD 5 mil e USD 10 mil), a Supreme Court entendeu que o valor de USD 2 milhões era "grosseiramente excessivo" (517 U.S. 559 1995, págs. 583/585).
} 
Com forte amparo nos três critérios então fixados, a Supreme Court cassou a decisão proferida pela Supreme Court do Estado do Alabama ("reverse") e determinou que os autos retornassem ao Tribunal inferior para prolação de nova decisão ("remand") ${ }^{285}$.

Sobressai, portanto, a relevância do julgamento vez que, em Gore, a Supreme Court, pela primeira vez em sua história, reverteu uma condenação ao pagamento de punitive damages sob o fundamento de que a pena imposta violava a due process clause em seu aspecto substancial ${ }^{286}$.

Após a virada do século, a Supreme Court veio a apreciar novamente os critérios (guideposts) fixados em Gore, o que ocorreu pela primeira vez quando do julgamento de State Farm Mutual Automobile Insurance Co. v. Campbell (538 U.S. 408 2003).

Tratou-se de demanda ajuizada pelos Srs. Curtis e Inez Campbell em face de State Farm Mutual, empresa responsável pela gestão do seguro de danos de seu automóvel, sob a alegação de que esta última, teria deliberadamente descumprido o contrato de seguro, deixando de indenizar terceiros lesados em acidente de trânsito provocado pelos Campbells. Tal conduta (que caracterizava os torts de bad faith denial e fraud) teria levado os Campbells a suportar, como réus, uma extenuante demanda judicial que, ao final, condenou-os a pagar quantia que superava em muito aquela prevista como limite na apólice de seguro; causandolhes prejuízos de ordem material e moral.

Por terem logrado êxito em demonstrar que a negativa de State Farm Mutual em dar cumprimento ao contrato de seguro decorreu efetivamente de uma política empresarial (denominada, internamente, de "Performance, Planning and Review" ou apenas $P P \& R$ ) levada a efeito em escala nacional, com o fim declarado de cortar despesas e reduzir recolhimentos fiscais, os Campbells sagraram-se vitoriosos em primeira instância.

\footnotetext{
285 Assim prescreveu o dispositivo do acórdão: “[a]s in Haslip, we are not prepared to draw a bright line markingthe limits of a constitutionally acceptable punitive damages award. Unlike that case, however, we are fully convinced that the grossly excessive award imposed in this case transcends the constitutional limit. Wheter the apropriate remedy requires a new trial or merely an independent determination by the Alabama Supreme Court of the award necessary to vindicate the economic interests of Alabama consumers is a mather that should be addressed by the state court in the first instance. The judgement is reversed, and the case is remanded for further proceedings not inconsistent with this opinion". (517 U.S. 559 1995, págs. 585/586).

286 T. C. GALligan JR., U.S. Supreme Court Tort Reform: Limiting State Power to Articulate and Develop Tort Law - Defamation, Preemption and Punitive Damages, in University of Cincinnati Law Review, vol. 74, 2006, pág. 1248.
} 
Os jurados, diante dos fatos narrados, impuseram à State Farm Mutual a condenação ao pagamento de compensatory damages no importe de USD 2,6 milhões e de punitive damages no montante de USD 145 milhões; quantias estas que foram reduzidas pelo juiz para, respectivamente, USD 1 milhão e USD 25 milhões $^{287}$.

Irresignadas, ambas as partes recorreram à Supreme Court do Estado de Utah (Corte Estadual), a qual, partindo dos critérios (guideposts) fixados pela Supreme Court norte-americana em Gore (1996), concluiu que a conduta perpetrada por State Farm Mutual era suficientemente repreensível para dar ensejo à condenação ao pagamento de punitive damages e restabeleceu o montante apontado pelo júri, no importe de USD 145 milhões $^{288}$.

Diante do restabelecimento da condenação originalmente imposta pelos jurados, State Farm Mutual interpôs recurso endereçado à Supreme Court para pleitear a cassação ou a reforma da decisão recorrida sob o fundamento de que o quantum indenizatório extrapolava os limites constitucionalmente impostos pela due process clause.

Ao apreciar o mérito recursal, e em oposição ao entendimento anteriormente firmado pela Corte Estadual, a Supreme Court se valeu justamente dos critérios (guideposts) anteriormente fixados em Gore (1996) para reputar a condenação excessiva, afirmando, de saída, ter constituído verdadeiro erro o restabelecimento do montante apontado pelos jurados ${ }^{289}$.

No que tocava ao primeiro critério, o "grau de reprovabilidade da conduta do demandado" ("degree of reprehensibility of the defendant's conduct”), a despeito de se ter reconhecido a inafastabilidade da imposição de punitive damages no caso (i.e., reconheceu-se a adequação do an debeatur), a Supreme Court entendeu inadmissíveis os critérios utilizados pela Corte Estadual para a quantificação da condenação (i.e., reconheceu-se a inadequação do quantum debeatur); especialmente porque para se atingir o vultoso montante apontado originalmente pelos jurados, levou-se em consideração não só

\footnotetext{
${ }^{287}$ Os fatos do caso encontram-se narrados em M. A. FRANKLIN - R. L. RABIN - M. D. GREEN, Tort Law and Alternatives (Cases and Materials), $8^{\text {th }}$ ed., New York, Foundation Press, 2006, págs. 749/751.

${ }^{288}$ M. A. FRANKLIN - R. L. RABIN - M. D. GREEN, Tort Law and Alternatives (Cases and Materials), $8^{\text {th }}$ ed., New York, Foundation Press, 2006, pág. 751.

${ }^{289}$ M. A. FRANKLIN - R. L. RABIN - M. D. GREEN, Tort Law and Alternatives (Cases and Materials), $8^{\text {th }}$ ed., New York, Foundation Press, 2006, pág. 752.
} 
a conduta de State Farm Mutual em face dos Campbells, mas, também e principalmente, os eventuais impactos a nível nacional que a política de $P P \& R$ da demandada poderia causar. Houvesse a Corte Estadual considerado apenas a esfera jurídica dos Campbells e as condutas perpetradas contra eles, uma punição muito mais modesta teria sido suficiente ${ }^{290}$.

No que se referia ao terceiro critério, a "disparidade entre a condenação ao pagamento de punitive damages e as sanções pecuniárias autorizadas ou impostas em casos análogos" ("disparity between the punitive damages award and the civil penalties authorized or imposed in comparable cases"), a Supreme Court, em mais uma oportunidade, entendeu inadequadas as considerações feitas pela Corte Estadual; especialmente porque a quantia referendada havia sido obtida após a consideração de sanções penais que somente seriam aplicáveis à State Farm Mutual se impostas em atenção às condutas por ela perpetradas em nível nacional, e não apenas à conduta levada a efeito em face dos Campbells ${ }^{291}$.

Independentemente das considerações anteriormente tecidas, a interessante novidade trazida por State Farm Mutual diz respeito à aplicação do segundo critério fixado em Gore, a "razão entre o prejuízo potencial ou efetivamente suportado pelo demandante e a condenação ao pagamento de punitive damages" ("ratio between harm, or potential harm, to the plaintiff and the punitive damages award"). Levando em consideração que, no caso em comento, havia imensa disparidade entre as condenações ao pagamento de compensatory damages (no valor de já expressivos USD 1 milhão) e punitive damages (no vultoso montante de USD 145 milhões, exatamente 145 vezes os prejuízos efetivamente suportados pelos lesados), a Supreme Court fixou, em State Farm Mutual, um "limite maleável" ("plastic limit") ${ }^{292}$ para a razão que, em casos futuros, dever-se-ia procurar impor entre as duas sortes de condenação. A despeito de se ressalvar a possibilidade de que

\footnotetext{
${ }^{290}$ M. A. FRANKLIN - R. L. RABIN - M. D. GREEN, Tort Law and Alternatives (Cases and Materials), $8^{\text {th }}$ ed., New York, Foundation Press, 2006, págs. 752/754. Tal questionamento se liga intimamente ao regime federalista norte-americano, tendo-se fixado, em State Farm Mutual, que órgãos do Poder Judiciário de determinado Estado não seriam legitimados para punir condutas perpetradas fora de seus limites territoriais e que, nos Estados em que foram cometidas, poderiam ser consideradas lícitas. Nesse sentido, T. C. GALLIGAN JR., U.S. Supreme Court Tort Reform: Limiting State Power to Articulate and Develop Tort Law Defamation, Preemption and Punitive Damages, in University of Cincinnati Law Review, vol. 74, 2006, págs. $1252 / 1253$

${ }^{291}$ M. A. FRANKLIN - R. L. RABIN - M. D. GREEN, Tort Law and Alternatives (Cases and Materials), $8^{\text {th }}$ ed., New York, Foundation Press, 2006, págs. 755/756.

292 P. S. KARLAN, 'Pricking the Lines': The Due Process Clause, Punitive Damages and Criminal Punishment, in Minnessota Law Review, vol. LXXXVIII, 2003/2004, pág. 909.
} 
uma diferente conclusão decorresse das especificidades do caso concreto (daí a maleabilidade do limite imposto $)^{293}$, sustentou-se que, “na prática, poucas condenações que excedam a razão de um dígito [= de 1 a 9 vezes] entre os punitive e compensatory damages irão satisfazer, de maneira significativa, a due process clause"294.

Desta feita, trabalhando os conceitos já anteriormente fixados em Gore, e mesmo sem criar novos critérios para o controle da constitucionalidade da condenação ao pagamento de punitive damages à luz da due process clause ${ }^{295}$, a Supreme Court cassou a decisão proferida pela Corte Estadual e determinou a remessa dos autos às instâncias ordinárias para a prolação de nova decisão (reverse and remand).

Anos mais tarde, a Supreme Court voltaria a analisar, ainda uma vez mais, a questão acerca da constitucionalidade dos punitive damages em face da due process clause quando do julgamento de Phillip Morris USA v. Williams (05-1256 U.S. 1 2006).

Tratou-se, no caso, de ação indenizatória ajuizada pelo espólio do Sr. Williams, um fumante inveterado, ajuizada em face da empresa de tabaco Phillip Morris

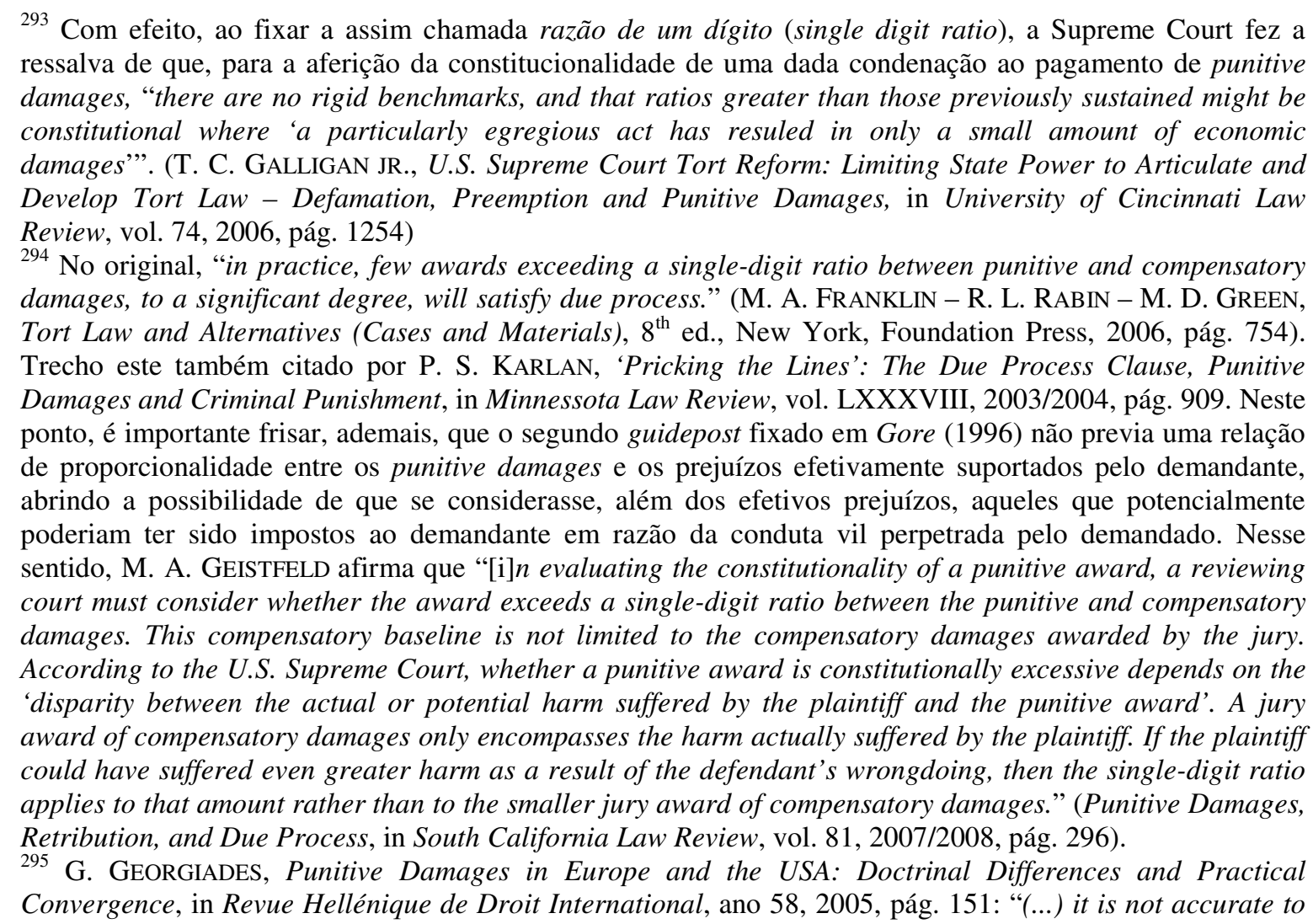


USA, fabricante dos cigarros favoritos de Williams, sob o argumento de que, durante todo o período em que Williams fez uso dos cigarros, Phillip Morris intencionalmente falseou informações para fazê-lo (e a tantos outros) acreditar que se tratava de um hábito de consumo seguro para a saúde (e, ao assim proceder, Phillip Morris cometeu o tort de deceit $^{296}$ ). Ao analisar o caso, o júri do Estado do Oregon condenou a demandada ao pagamento de USD 821.485,00 a título de compensatory damages, bem como de USD 79,5 milhões a título de punitive damages, em razão da maneira fraudulenta com a qual Phillip Morris teria induzido o Sr. Williams a fumar. Para atingir tal exorbitante quantia, pesou para o júri o fato de que a demandada se engajara em um esquema duradouro e fraudulento destinado a convencer o público em geral a fumar cigarros ${ }^{297}$.

A quantia de USD 79,5 milhões foi originalmente reduzida a menos da metade (para USD 32 milhões) pelo próprio juiz da causa, que a havia reputado grosseiramente excessiva, mas, posteriormente, foi restabelecida pela Court of Appeals e pela Supreme Court do Estado do Oregon, que acolheram os recursos interpostos por Williams e rejeitaram aqueles apresentados por Phillip Morris.

Irresignada, Phillip Morris recorreu à Supreme Court sob o argumento de que a exorbitante condenação ao pagamento de punitive damages havia violado a due process clause, uma vez que, em seu aspecto processual, o ditado insculpido na $14^{\mathrm{a}}$ Emenda: (i) exige a adoção de standards adequados para a correta instrução do júri, evitando-se, dessa maneira, que ele atue de maneira discricionária; (ii) impede a adoção de instruções ao corpo de jurados que os levem a considerar, diretamente, o prejuízo causado a terceiros alheios à demanda para a quantificação dos punitive damages, punindo, assim, $\mathrm{o}$ demandado por danos que não causou ao demandante; e (iii) impede que os Tribunais

say that Campbell has enunciated new rules or guideposts regarding punitive damages. It has only applied the existing jurisprudence (esp. BMW)."

${ }^{296}$ Trata-se de uma falta declaração destinada a fazer com que o receptor da declaração aja de determinada maneira, e em seu próprio detrimento. "Os requisitos para a responsabilidade são os seguintes: o demandado deve fazer (1) uma falsa declaração (2) de um fato real (3) com o conhecimento da falsidade e com a intenção de que o demandante aja de acordo com a declaração falsa, com o resultado (4) de que o demandante aja em seu próprio detrimento." No original: "[t]he requirements of liability are as follows: the defendant must make (1) a false statement (2) of existing fact (3) with knowledge of its falsity and with the intention that the claimant should act on it, with the result (4) that the claimant acts on it to his detriment." (S. DEAKIN - A. JOHNSTON - B. MARKESINIS, Markesinis and Deakin's Tort Law, $6^{\text {th }}$ ed., New York, Oxford, 2008, pág. 565)

${ }^{297}$ M. A. GeISTFELD, Punitive Damages, Retribution, and Due Process, in South California Law Review, vol. 81, 2007/2008, págs. 265/266. 
Estaduais referendem procedimentos de primeira instância que permitam uma atuação vaga e arbitrária do corpo de jurados ${ }^{298}$.

Ao apreciar o caso, a Supreme Court, por maioria de votos, deixou de enfrentar a questão acerca da potencial excessividade da condenação (o que a levaria a apreciar eventual violação da due process clause sob seu aspecto substancial), limitando-se a esmiuçar os procedimentos adotados pelas instâncias inferiores ao fixar e referendar a condenação ao pagamento de punitive damages (restringindo sua análise, portanto, à alegada violação da due process clause em seu aspecto processual).

Ao assim proceder, a Supreme Court concluiu pela inconstitucionalidade da condenação, sob o argumento de que "a garantia constitucional ao due process proíbe que determinado Estado faça uso de punitive damages para punir um demandado por prejuízos que ele tenha infligido a terceiros ou àqueles diretamente representados por tais terceiros, i.e., prejuízos causados àqueles que são, essencialmente, estranhos ao litígio" ${ }^{299}$. A garantia constitucional a um processo justo impediria a utilização de tais critérios para a quantificação dos punitive damages, especialmente, por duas ordens de fatores:

A uma, porque a due process clause impede que um demandado seja apenado sem que, contra a acusação que lhe é lançada, seja-lhe proporcionada "uma

\footnotetext{
298 Neste ponto, a pretensão recursal deduzida por Phillip Morris se funda no fato de que, durante o julgamento em primeira instância, os patronos do demandante haviam insistido intensamente nos prejuízos que o hábito de fumar teria causado, nos últimos quarenta anos, aos habitantes do Estado do Oregon, prejuízos estes que, à evidência, nada diziam respeito àqueles efetivamente suportados pelo Sr. Williams. Diante do impacto de tais afirmações, os patronos da demandada pugnaram pela adoção de uma instrução ao júri no sentido de que, para a quantificação de eventual condenação ao pagamento de punitive damages, os prejuízos potencialmente causados a terceiros poderiam ser levados em consideração, mas apenas para a aferição da "relação razoável" (reasonable relationship) entre os punitive damages a serem calculados e os compensatory damages efetivamente suportados pelo Sr. Williams. Não se poderia, contudo, utilizar tal elemento como base de cálculo direta para a quantificação dos punitive damages destinados ao Sr. Williams. Em vez de adotar tal orientação, o juiz da causa apresentou aos jurados instrução muito mais vaga, no sentido de que "os punitive damages são concedidos contra um demandado para punir ilícitos e impedir o cometimento de novos ilícitos" e que tais punitive damages "não objetivam compensar o demandante ou qualquer outra pessoa por danos causados pela conduta do demandado." A irresignação de Phillip Morris decorreu da crença de que esta instrução vaga levou o júri do Estado do Oregon a quantificar os punitive damages de maneira arbitrária. (05-1256 U.S. 1 2006, págs. 2/3).

${ }^{299}$ No original: "In reviewing the award, the US Supreme Court held that 'the Constitution's Due Process Clause forbids a State to use a punitive damages award to punish a defendant for injury that it inflicts on nonparties or those whom they directly represent, i.e., injury that it inflicts on those who are, essentially, strangers to the litigation." (M. A. GEISTFELD, Punitive Damages, Retribution, and Due Process, in South California Law Review, vol. 81, 2007/2008, pág. 266).
} 
oportunidade de apresentar toda e qualquer defesa possível"300. À evidência, um demandado apenado por danos supostamente causados a terceiros é impedido de, no curso de um processo judicial do qual tais terceiros não fizeram parte, alegar e provar, e. g., que tais terceiros não fariam jus ao recebimento de indenização, ou que a indenização a eles devida deveria ser reduzida ante à ocorrência de algum elemento mitigador.

A duas, porque a due process clause também veda a utilização de critérios de julgamento e instruções ao corpo de jurados que o levem a atuar de maneira meramente especulativa ou arbitraria, tal como ocorreria caso se admitisse a consideração direta dos prejuízos supostamente causados a terceiros. Nesse sentido, "permitir punição por prejuízos causados a terceiros poderia atribuir uma dimensão quase ilimitada à quantificação dos punitive damages. Quantas outras vítimas teria havido? Quão seriamente elas teriam sido prejudicadas? Em quais circunstâncias o prejuízo teria ocorrido? O julgamento provavelmente não responderá tais questões para os terceiros que não participaram do processo. O júri será deixado à mera especulação"301.

Amparada nesses fundamentos, a Supreme Court anotou ser "particularmente importante que os Estados proíbam procedimentos que, de maneira desnecessária, retirem do júri a adequada orientação"302 para a quantificação de uma condenação ao pagamento de punitive damages, motivo pelo qual cassou a decisão proferida pela Supreme Court do Estado do Oregon e determinou a remessa dos autos à instância inferior para prolação de nova decisão ${ }^{303}$.

\footnotetext{
${ }^{300}$ No original, "the due process clause prohibits a State from punishing an individual without first providing that individual with 'an opportunity to present eveery available defense'. Lindsey v. Normet, 405 U.S. 56, 66 (1972).” (05-1256 U.S. 1 2006, pág. 5).

301 No original, "to permit punishment for injuring a nonparty victim would add a near standardless dimension to the punitive damages equation. How many such victims are there? How seriously were they injured? Under what circumstances did injury occur? The trial will not likely answer such questions as to nonparty victims. The jury will be left to speculate." (05-1256 U.S. 1 2006, pág. 6).

${ }^{302}$ No original, "it is particularly important that States avoid procedure that unnecessarily deprives juries of proper legal guidance." (05-1256 U.S. 1 2006, pág. 7).

${ }^{303}$ Assim prescreveu o dispositivo de tal decisão: "[a]s the preceding discussion makes clear, we believe that the Oregon Supreme Court applied the wrong constitutional standard when considering Phillip Morris appeal. We remand this case so that the Oregon Supreme Court can apply the standard we have set forth." (05-1256 U.S. 1 2006, pág. 10).
} 


\section{XI.I.III. Uma ponderação sobre a $5^{\text {th }}$ amendment: double jeopardy clause}

Em arremate, cumpre-nos tecer algumas considerações acerca da constitucionalidade da imposição e quantificação da condenação ao pagamento de punitive

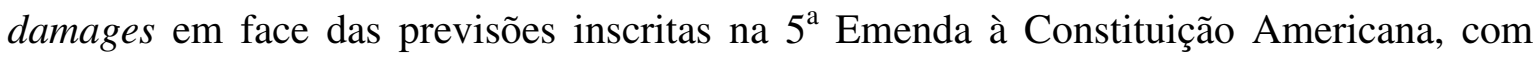
enfoque especial na "proibição à dupla condenação" ("double jeopardy clause") 304.

A despeito de não se ter notícia de que tal questão tenha sido decidida pela Supreme Court Americana, isto não impediu os doutrinadores e os tribunais estaduais de apreciá-la, sustentando-se que a restrição prevista na "double jeopardy clause" se destinaria a evitar duas ordens de problemas: (i) a condenação do mesmo ofensor a suportar duas sanções punitivas de ordens distintas (tais como uma sanção de natureza criminal e outra de natureza civil, mais especificamente os punitive damages) em decorrência de uma mesma conduta ilícita (a qual poderia ser tida, ao mesmo tempo, como um ilícito civil e criminal); e (ii) a condenação do mesmo ofensor ao pagamento de múltiplas indenizações punitivas, devidas a inúmeros ofendidos como decorrência de uma únida conduta ou atividade (como se verifica, e.g., nos casos em que um produto ou serviço perigosos acabam por atingir uma série de consumidores, causando-lhes prejuízos - os assim chamados casos de "mass tort litigation") 305.

Quanto ao primeiro aspecto, G. B. BELL e P. E. PEARCE afirmam que, nos casos em que um mesmo demandado pode vir a ser condenado ao pagamento de diversas sanções punitivas distintas, ainda que oriundas de ramos diferentes do Direito, as funções punitiva e preventiva inerentes às sanções impostas podem ser desvirtuadas, punindo o ofensor além dos limites da proporcionalidade e da razoabilidade, bem como atingindo fatores indesejáveis de prevenção (o que, na pior das hipóteses, poderia significar a

\footnotetext{
${ }^{304}$ A $5^{\mathrm{a}}$ Emenda à Constituição Americana, inserida em seu corpo no ano de 1791, estabelece uma série de garantias procedimentais a serem seguidas no processo penal, tais como a necessidade de observância do devido processo legal ("due process"), a vedação à auto-incriminação e a "proibição à dupla condenação" (“double jeopardy"), prescrevendo, in verbis, que: "[n]o person shall be held to answer for a capital or otherwise infamous crime, unless on a presentment or indictment of a Grand Jury, except in cases arising in the land or naval forces, or in the Militia, when in actual service in time of War or public danger; nor shall any person be subject for the same offense to be twice put in jeopardy of life or limb; nor shall be compelled in any criminal case to witness against himself, nor shall be deprived of life, liberty or property, without due process of law; nor shall private property be taken by public use, without just compensation."

${ }^{305}$ Nesse sentido, E. URSO, Recenti Sviluppi nella Giurisprudenza Statunidense e Inglese in Materia di Punitive Damages: $i$ Casi TXO Production Corporation v. Alliances Resources Corporation e AB v. South West Water Services Ltd., in Rivista di Diritto Civile, vol. 41, n. 1, genn.-febr./1995, págs. 102.
} 
eliminação do mercado de um agente empresarial, ou a restrição indesejada a um serviço ou produto) $)^{306}$.

Já quanto ao segundo aspecto, J. R. MCKNOWN apresenta ainda outras preocupações. Como se está diante de duas ou mais sanções punitivas que envolvem o pagamento de quantia em dinheiro, a "dupla condenação" pode acarretar não apenas o excesso de punição e prevenção ("over punishment" e "over compensation"), com desvirtuamento das funções inerentes a tais sanções punitivas, mas, também, pode culminar na depauperação precoce do patrimônio do ofensor, levando-o à falência antes que ele possa efetivamente compensar a todos os eventuais prejudicados ${ }^{307}$.

Apesar da controvérsia doutrinária quanto às restrições impostas pela "proibição à dupla condenação", a notícia que se tem é a de que "a maioria dos estados norte-americanos admite a condenação ao pagamento de punitive damages mesmo que o ofensor seja também réu em processo criminal pelo cometimento da mesma conduta"308. Aduz-se, como o fez a Supreme Court do Estado do Maine ao julgar Tuttle v. Raymond (1985), que, "no sentido constitucional, a proibição à dupla condenação é uma expressão técnica que abrange apenas o risco inerente a procedimentos essencialmente criminais", não impedindo que uma mesma conduta possa ser sancionada, também, por meio de punitive damages ${ }^{309}$.

\section{XI.II. O "tort reform movement"}

Provavelmente em resposta ao desenfreado desenvolvimento do instituto dos puntive damages durante as décadas de 1970 e 1980, com aumento significativo não só do valor das condenações impostas a este título, mas, também e principalmente, das hipóteses de incidência desta sorte de condenação (admitindo-se, como se viu, hipóteses de strict liability, casos nos quais não se cogitava, originalmente, acerca da gravidade da culpa

\footnotetext{
${ }^{306}$ Punitive Damages and the Tort System, in University of Richmond Law Review, vol. 22, 1987, pág. 5.

${ }^{307}$ Punitive Damages: State Trends and Developments, in The Review of Litigation, vol. 14, 1994/1995, pág. 461.

${ }^{308}$ K. M. ZITZER, Punitive Damages: A Cat's Clavicle in Modern Civil Law, in The John Marshall Law Review, vol. 22, 1988, pág. 668.
} 
do demandado ${ }^{310}$ ), tal instituto passou a ser alvo de intensos debates e árduas críticas do que se passou a chamar de tort reform movement; expressão utilizada para descrever um movimento, levado a cabo pelo lobby realizado especialmente por empresas dos ramos financeiro e securitário, para a criação de óbices jurisprudenciais e legislativas à incidência e quantificação dos punitive damages ${ }^{311}$.

Em razão da atuação incisiva deste "movimento reformista", determinados Tribunais Estaduais, bem como um grande número dos Estados norte-americanos, passaram a desenvolver barreiras judiciais e legislativas com o intuito de limitar a proliferação supostamente "desenfreada" dos punitive damages ${ }^{312}$. Passaremos a tratar, deste ponto em diante, daquelas que são tidas pela doutrina norte-americana como as principais vertentes em que se desenvolveu o assim chamado tort reform movement, observando com maior atenção as propostas de reforma que envolvem: (i) a abolição total dos punitive damages; (ii) a limitação do quantum dos punitive damages por meio da imposição de limites máximos (caps) ou de uma necessária correlação entre os compensatory e punitive damages; (iii) destinação total ou parcial da condenação ao pagamento de punitive damages a um fundo público, em detrimento do autor da demanda; (iv) a repartição do procedimento (“bifurcation of trial”) para que, conseqüentemente, seja eliminada a possibilidade de que se produza prova sobre a riqueza do demandado antes da fixação do an debeatur (i.e., antes da condenação ao pagamento de punitive damages); (v) a elevação do ônus da prova (“burden of proof”), para que se equipare aos critérios adotados no processo penal ("proof beyond reasonable doubt"); (vi) a eliminação da imprecisão (ou vagueza) dos pressupostos (objetivos e subjetivos) para a incidência dos punitive damages; e, por fim, (vii) a exclusão da competência dos jurados para a quantificação dos punitive damages.

\footnotetext{
${ }^{309}$ No original, "[i]n the constitutional sense, jeopardy is a technical term that encompasses only the risk inherent in proceedings that are essentially criminal" (J. R. MCKNOWN, Punitive Damages: State Trends and Developments, in The Review of Litigation, vol. 14, 1994/1995, pág. 459).

310 Para uma análise pormenorizada sobre diversos fatores considerados como significativos para o desenvolvimento, por assim dizer, desenfreado dos punitive damages, bem como para a majoração das condenações a este título, conferir págs. W. A. LovetT, Exxon Valdez, Punitive Damages and Tort Reform, in Tort Trial \& Insurance Practice Law Journal, vol. 38, 2002, págs. 1095/1102.

${ }^{311}$ D. G. OwEn, A Punitive Damages Overview: Functions, Problems and Reform, in Villanova Law Review, vol. 39, 1994, pág. 371.

${ }^{312}$ D. G. OwEN, A Punitive Damages Overview: Functions, Problems and Reform, in Villanova Law Review, vol. 39, 1994, pág. 371. A notoriedade da questão fez dela, inclusive, objeto de recente obra de ficção (J. GRISHAM, The Appeal, trad. Michele Gerhardt MacCulloch, Rio de Janeiro, Rocco, 2008).
} 


\section{XI.II.I. A abolição total dos punitive damages}

Entre todas as medidas aventadas por doutrinadores, certamente a "mais radical" é aquela que não visa, propriamente, a refrear o desenvolvimento e expansão dos punitive damages, mas, sim, sua completa abolição ${ }^{313}$; extirpando-se em absoluto tal sorte de sanção punitiva ou restringindo-a a tal ponto que sua incidência seja limitada a pouquíssimos casos, todos eles expressamente previstos em lei (“statutes").

Os defensores dessa rígida posição, com os quais faz coro G. V. RoBREDO, sustentam, em síntese, que: (i) "os punitive damages são inadmissíveis em um direito civil moderno" e "que pertencem ao passado", (ii) "que não cumprem nenhuma das funções a eles atribuídas" e, ainda, (1iii) "que estão levando a economia norte-americana à ruína"314.

Quanto ao primeiro aspecto, sustentam os doutrinadores que, de um lado, o direito civil moderno deve procurar extrair da responsabilidade civil (no caso dos países da common law, da "law of torts") uma função exclusivamente compensatória: a indenização deve buscar recompor o patrimônio atingido pelo ilícito, recolocando o lesado no estado em que se encontrava antes da lesão e, para tanto, o quantum indenizatório deve se restringir apenas e tão somente aos estritos limites do prejuízo sofrido. Nada mais, nada menos.

De outro lado, sustenta-se que toda e qualquer finalidade compensatória que os punitive damages poderiam ter exercido no passado (e que poderia ainda, por hipótese, justificar sua incidência), foi extirpada a partir do momento em que o conceito de compensatory damages passou a abranger também os prejuízos não pecuniários ("non pecuniary losses", tais como "mental and physical pain and suffering").

Desta feita, os punitive damages teriam perdido sua única justificável razão de ser, que seria a de assegurar a compensação do lesado por conta de prejuízos que, de

\footnotetext{
${ }^{313}$ E. URSO, Recenti Sviluppi nella Giurisprudenza Statunidense e Inglese in Materia di Punitive Damages: $i$ Casi TXO Production Corporation v. Alliances Resources Corporation e AB v. South West Water Services Ltd., in Rivista di Diritto Civile, vol. 41, n. 1, genn.-febr./1995, pág. 142.

${ }^{314}$ No original, "los daños punitivos no tienen cabida en un Derecho civil moderno, que pertencen al pasado, que no cumplen ninguna de las funciones que tiene encomendadas, y que están llevando a la ruina a la
} 
ordinário, não poderiam ser reparados por meio da condenação do lesante ao pagamento de compensatory damages $^{315}$.

No que toca ao segundo aspecto, parte da doutrina afirma que os punitive damages não seriam aptos a exercer, de maneira adequada, nem a função preventiva nem, tampouco, a função punitiva, tanto alardeadas pelos defensores do instituto.

A uma, a função preventiva não seria atingida com eficiência pela simples adição, à condenação, de uma quantia que extrapolasse os limites do prejuízo efetivamente suportado pela vítima (os punitive damages), uma vez que, em razão das incertezas quanto aos critérios de incidência e quantificação dos punitive damages, o lesante dificilmente disporia de "informação adequada" ("fair notice") acerca de como se conduzir diante do cometimento de determinado ilícito, bem como de quais seriam, exatamente, as sanções decorrentes do eventual cometimento deste ilícito. Nesse sentido, sustenta J. D. GHIARDI que a função preventiva seria mais adequadamente atingida apenas diante da certeza da condenação do lesante ao pagamento de compensatory damages, os quais, por si sós, já teriam o condão de atuar como desestimulante para o lesante e a sociedade em geral ${ }^{316}$.

A duas, nem mesmo a função punitiva seria adequadamente atingida por meio da incidência dos punitive damages, uma vez que tal instituto, por fugir ao âmbito de incidência do Direito Penal, deixa, conseqüentemente, de suportar as limitações inerentes a este ramo do Direito [tais como o mais elevado ônus probatório ("beyond any reasonable doubt", em detrimento da mais facilmente atingida "preponderance of evidence"), a impossibilidade de auto-incriminação e, ainda, a vedação à dupla condenação pelo cometimento do mesmo ilícito (ambas garantias inseridas na $5^{\mathrm{a}}$ Emenda à Constituição Americana)] o que permitiria a atuação discricionária dos jurados, com prejuízo à adequada punição ${ }^{317}$.

economía norteamericana." (Daños Punitivos en el Proceso Civil Norteamericano, in Revista de la Universidad de Deusto, vol. 57, fasc. 97, jul-dic./1996, pág. 200)

315 J. D. GHIARDI, The Case Against Punitive Damages, in The Forum, vol. 8, 1972, págs. 412/413.

${ }^{316}$ J. D. GHIARDI, The Case Against Punitive Damages, in The Forum, vol. 8, 1972, pág. 418.

317 J. D. GHIARDI, The Case Against Punitive Damages, in The Forum, vol. 8, 1972, págs. 418/419 e K. M. ZITZER, Punitive Damages: A Cat's Clavicle in Modern Civil Law, in The John Marshall Law Review, vol. 22, 1988, pág. 667. 
Por fim, quanto ao terceiro aspecto, G. L. PRIEST sustenta que a reiterada condenação de sociedade empresárias ao pagamento de punitive damages (essencialmente em casos nos quais há responsabilidade objetiva, tais como a responsabilidade por fato do produto, denominada de "products liability") causa severos e negativos impactos na economia norte-americana: o valor de tais condenações, suportado pelas sociedades empresarias, seria repassado por elas aos preços de seus produtos e serviços, encarecendoos de modo a prejudicar os consumidores internos (cujo custo de vida será elevado), bem como a competitividade norte-americana no mercado internacional ${ }^{318}$.

Parte significativa da doutrina norte-americana, contudo, insurge-se veementemente contra os ataques dos reformistas. Para além dos argumentos já expostos a favor da adoção e manutenção dos punitive damages, sustentam tais doutrinadores que, diante dos dados empiricamente constatados, não se poderia afirmar que os punitive damages estariam "fora de controle", ou que suas condenações usualmente atingiriam patamares excessivamente elevados ${ }^{319}$.

Nessa toada, e amparado em estudos levados a efeito por institutos ligados ao Poder Judiciário Americano durante a década de 1990, D. LUBAN afirma que os punitive damages são concedidos em não mais do que $4 \%$ das demandas que versam sobre responsabilidade civil, nas quais o demandante tenha-se sagrado vitorioso e que, em média, as condenações ao pagamento de punitive damages tendem a ser de pequenas proporções, não excedendo a quantia de USD $50 \mathrm{mil}^{320}$.

Seguem, nesse sentido, as palavras de P. S. KARLAN, para quem "[r]ecentes estudos empíricos sugerem que, se existe um problema [acerca da imposição e quantificação dos punitive damages], ele consiste essencialmente de um pequeno número

\footnotetext{
${ }^{318}$ Punitive Damages Reform: The Case of Alabama, in Louisiana Law Review, vol. 56, 1995, págs. 882/883.

${ }^{319}$ É nesse sentido que J. K. RoBBENNOLT frisa "ser claro que, para dizer o mínimo, a realidade dos punitive damages não condiz com a retórica reformista - as condenações são muito mais restritas do que comumente se pensa. Porém, é a percepção de que existe um problema, mais do que dados empiricamente comprovados, que tende a motivar a atuação legislativa reformista." No original: "[i]t is clear that, at the very least, the reality of punitive damages does not live up to the reform rhetoric-awards are much more restrained that is commonly thought. However, it is the perception that there is a problem rather than empirical findings that tends to drive legislative action." (Determining Punitive Damages: Empirical Insights and Implications for Reform, in Buffalo Law Review, vol. 50, 2002, pág. 167).

${ }^{320}$ A Flawed Case Against Punitive Damages, in The Georgetown Law Journal, vol. 87, 1998, págs. 360/362.
} 
de casos com condenações exorbitantes, e não de um aumento generalizado na incidência e montante das condenações ao pagamento de punitive damages"321.

Por outro lado, J. K. RobBEnNOLT, também advogando contra a abolição dos punitive damages, dá-nos notícia de análises de campo concluíram que os jurados, ao se verem diante de uma conduta danosa especialmente reprovável, ordinariamente passível de ser sancionada por meio de punitive damages, mas na impossibilidade (constitucional, legislativa ou judicial) de fazê-lo, tendem a lançar mão dos instrumentos jurídicos de que dispõem para assegurar que o demandado será adequadamente punido pela grave conduta por ele perpetrada. Assim é que, sustenta a autora, em Estados nos quais os punitive damages não são admissíveis, a condenação ao pagamento de compensatory damages por prejuízos não materiais (como, por exemplo, aqueles decorrentes de "pain and suffering") é costumeiramente mais elevada ${ }^{322}$.

Constata-se, enfim, que, se existem, de um lado, inúmeras vozes doutrinárias que advogam pela extinção dos punitive damages, há, de outro, tantas (ou mais) outras que, fundadas em estudos empíricos, concluem no sentido de que as premissas de que partem os reformistas são equivocadas, não se podendo afirmar que os punitive damages seriam um instituto jurídico "fora de controle".

Postos em meio ao acirrado debate acima exposto, atualmente apenas cinco estados norte-americanos (nomeadamente: Louisiana, Massachussets, Nebraska, New Hampshire e Washington) proíbem, em maior ou menor grau, a ampla incidência dos punitive damages, autorizando sua aplicação apenas em expressas e rígidas hipóteses legalmente $\operatorname{previstas}^{323}$. O Estado de Michigan, apesar de não proibir expressamente a incidência dos punitive damages, atribui a eles fim unicamente compensatório, admitindoos em hipóteses bastante restritas ${ }^{324}$.

\footnotetext{
${ }^{321}$ No original: "[r]ecent empirical studies suggested that, if there is a problem, it lies primarily in a small number of cases with staggering awards, rather than in a general increase in either the incidence or size of punitive damages awards [...]"('Pricking the Lines': The Due Process Clause, Punitive Damages and Criminal Punishment, in Minnesota Law Review, vol. LXXXVIII, 2003/2004, pág. 912).

${ }_{322}$ Determining Punitive Damages: Empirical Insights and Implications for Reform, in Buffalo Law Review, vol. 50, 2002, págs. 168/169.

${ }^{323}$ W. A. LovetT, Exxon Valdez, Punitive Damages and Tort Reform, in Tort Trial \& Insurance Practice Law Journal, vol. 38, 2002, pág. 1106.

${ }^{324}$ H. KozIol - V. WilcoX (eds.), Punitive Damages: Common Law and Civil Law Perspectives, Wien, Springer, 2009, pág. 316.
} 
XI.II.II. Limitação do quantum dos punitive damages: imposição de limites máximos (caps) ou correlação entre compensatory e punitive damages

Como alternativa à abolição total dos punitive damages, aventa-se, quer em âmbito estritamente jurisprudencial, quer, ainda, no âmbito legislativo, uma série de medidas que têm por finalidade eliminar ou, ao menos, mitigar aqueles que são considerados como os maiores inconvenientes da aplicação dos punitive damages. Entre esses ditos inconvenientes, destaca-se a quantificação da condenação ao pagamento de punitive damages, usualmente tida pelos detratores do instituto como imprecisa, anticientífica e, por vezes, desproporcional e exagerada.

Tencionando combater justamente a suposta imprecisão de que padeceria a quantificação da condenação ao pagamento de punitive damages, aqueles que advogam pela reforma sugerem duas possíveis soluções: (1) a imposição de uma limitação da condenação por meio da criação de uma necessária correlação entre os compensatory damages e os punitive damages (por meio da qual a quantificação destes últimos passaria a ser um múltiplo da quantificação dos primeiros, e.g., o dobro ou o triplo); ou (ii) a criação de limites objetivos, quer mínimos ("floors"), quer máximos (“caps") para a quantificação da condenação ${ }^{325}$.

Como se teve a oportunidade de expor, no julgamento de BMW of North America v. Gore, a Supreme Court americana consignou que a relação razoável ("reasonable relationship") entre a indenização compensatória ("compensatory damages") e a indenização punitiva ("punitive damages") é um dos três critérios ("guideposts") a serem considerados para que se possa afirmar se a quantificação dos punitive damages se deu de maneira constitucional ou se, por se extrapolar os limites da razoabilidade, tornouse grosseiramente excessiva ("grossly excessive") e, portanto, violadora da due process clause em sua vertente substancial.

\footnotetext{
${ }^{325}$ D. G. Owen, A Punitive Damages Overview: Functions, Problems and Reform, in Villanova Law Review, vol. 39, 1994, págs. 387/388 e W. A. LovetT, Exxon Valdez, Punitive Damages and Tort Reform, in Tort Trial \& Insurance Practice Law Journal, vol. 38, 2002, pág. 1107.
} 
Posteriormente, em State Farm Mutual v. Haslip, a mesma Supreme Court, ao trabalhar os conceitos já fixados em Gore, afirmou que poucas condenações que excedessem a razão de um dígito entre compensatory e punitive damages satisfariam a due process clause, novamente analisada sob seu aspecto substancial.

Pode-se dizer, portanto, que a questão acerca da limitação da condenação ao pagamento de punitive damages não é nova nem tampouco tão controvertida quanto a abolição do instituto. Pelo contrário, a adoção de medidas nesse sentido foi, inclusive, vista pela mais alta corte americana como necessária para assegurar a razoabilidade e constitucionalidade das condenações.

A despeito de menos severa do que a sugestão de sua abolição, a adoção de limites objetivos à quantificação dos punitive damages não passou isenta de críticas por parte da doutrina. Assim é que, avesso a restrições desse jaez, D. G. OwEn sustenta que "tais medidas restritivas, por sua própria natureza, restringem a flexibilidade de que dispõe o julgador para atingir o grau ótimo de Justiça, dimensionando a punição para se adequar ao ilícito e ao lesante no caso concreto" ${ }^{, 326}$.

Independentemente de tais críticas, a presente medida, por ser muitíssimo menos drástica do que a abolição completa do instituto, foi bem aceita pelos Poderes Legislativos Estaduais, que acabaram por abraçá-la de maneira mais ou menos uniforme. Nesse sentido segue a notícia trazida por W. A. LOVETT, que afirma que os ordenamentos de ao menos 21 dos Estados norte-americanos (entre os quais, e.g., estão Alabama, Alaska, Arizona, Colorado e Florida) prevêem alguma forma de limitação da quantificação dos punitive damages, quer para todos os casos em que tal condenação seria admissível, quer, apenas para determinados casos específicos (como, e.g., o de erro médico, denominado "medical malpractice") $)^{327}$.

\footnotetext{
${ }^{326}$ No original: "[S]uch approaches by their very nature simultaneously deprive the decision-maker of the flexibility of achieving optimal justice in particular cases by tailoring the punishment to fit the particular wrongdoer and the particular crime." (A Punitive Damages Overview: Functions, Problems and Reform, in Villanova Law Review, vol. 39, 1994, pág. 409).

${ }^{327}$ Exxon Valdez, Punitive Damages and Tort Reform, in Tort Trial \& Insurance Practice Law Journal, vol. 38, 2002, pág. 1107.
} 


\section{XI.II.III. Destinação dos punitive damages: entrega total ou parcial ("split recovery") da condenação a um fundo público}

Outra medida considerada com bons olhos por parte da doutrina norteamericana é aquela que não busca, propriamente, impor restrições ou limites ao quantum indenizatório, mas, sim, atribuir outra destinação à totalidade ou a parte da condenação ao pagamento de punitive damages que não a própria vítima, evitando-se, dessa maneira, que esta última venha a ser excessivamente beneficiada em decorrência do ilícito pelo que se passou a chamar, pejorativamente, de "windfall payments" ${ }^{328}$. A presente proposta reformista visa, justamente, retirar da vítima a quantia que, de ordinário, receberia a título de punitive damages para repassá-la, no todo ou em parte, a um fundo público (ou ao próprio erário), controlado por entes estatais, para que se pudesse, com maior eficiência, vincular tais quantias às finalidades para as quais foram cogitadas: compensar integralmente as vítimas de ilícitos e evitar que novos ilícitos sejam perpetrados.

Segundo seus defensores, a adoção desta proposta, por retirar, de um lado, a possibilidade de obtenção de lucro por parte do demandante e de seu advogado (por meio da condenação do demandado ao pagamento de quantia que superasse àquela necessária para compensar o prejuízo efetivamente sofrido), mas manter, de outro, todas as demais características intrínsecas aos punitive damages, serve para "provar a sinceridade" dos defensores dos punitive damages como instituto apto a exercer, adequadamente, as funções preventiva e punitiva da responsabilidade $\operatorname{civil}^{329}$. Afinal de contas, afirma-se, as funções atribuídas aos punitive damages são atingidas por força da condenação imposta ao demandado, e não de sua entrega ao demandante. Para este, basta que seja integralmente compensado pelo prejuízo suportado, função esta adequadamente exercida pelos compensatory damages.

Em contraposição, aqueles que enaltecem a figura do demandante como "private attorney general" (o cidadão comum que, ao litigar contra um notório mal-

\footnotetext{
${ }^{328}$ W. A. LovetT, Exxon Valdez, Punitive Damages and Tort Reform, in Tort Trial \& Insurance Practice Law Journal, vol. 38, 2002, págs. 1110/1111. A expressão, de cunho depreciativo, procura designar uma elevada quantia de dinheiro recepcionada pelo lesado sem que ele, efetivamente, fizesse jus ao seu recebimento.
} 
feitor, atua não só em seu próprio interesse, mas também naquele de toda a Sociedade) sustentam que a adoção de uma tal medida poderia, de alguma maneira, "reduzir o incentivo" para demandar ${ }^{330}$.

Com efeito, em razão da assim chamada "regra americana" (que impõe a cada parte litigante a obrigação de suportar todos os custos do processo, aí incluídas as custas e despesas processuais e, principalmente, os honorários advocatícios de seu patrono, independentemente do resultado da demanda), faz-se uso, em alto grau, dos acordos de quota litis ou "contingent fees" (acordos pelos quais a remuneração do patrono será composta de um percentual do benefício econômico a ser obtido com a demanda, o que, nos casos que versem sobre responsabilidade civil, significa um percentual da indenização a ser concedida ao demandante) $)^{331}$.

Desta feita, caso se adotasse tal sugestão reformista, com a destinação de parte ou toda a condenação a título de punitive damages a um fundo público (e não à vítima), os acordos para pagamento de honorários advocatícios ficariam impactados, reduzindo não só o interesse do próprio lesado em litigar (vez que lhe retira a perspectiva de, ao final, vir a obter uma condenação vultosa), mas, também, de seu patrono (vez que tem a perspectiva de drástica redução de seus honorários advocatícios).

A doutrina aventa, ainda, um outro complicador especialmente decorrente da adoção desta medida reformista: a possível discrepância de tratamento entre os casos em que se chega a um acordo extra (e muitas vezes pré) judicial e aqueles nos quais a indenização punitiva é imposta por decisão judicial. Sustenta G. V. RoBREDO que, por se tratar de restrição legislativa que incide sobre condenações judicialmente impostas (ou seja, após a prolação de decisão final ao menos em primeira instância), tal proposta reformista permite que, nos casos em que a demanda é extinta antes da prolação de sentença de mérito de procedência (ou seja, antes de que haja, propriamente, condenação

${ }^{329}$ G. V. Robredo, Daños Punitivos en el Proceso Civil Norteamericano, in Revista de la Universidad de Deusto, vol. 57, fasc. 97, jul-dic./1996, pág. 203. No mesmo sentido: J. R. MCKnown, Punitive Damages: State Trends and Developments, in The Review of Litigation, vol. 14, 1994/1995, pág. 437.

${ }^{330}$ D. G. Owen, A Punitive Damages Overview: Functions, Problems and Reform, in Villanova Law Review, vol. 39, 1994, pág. 410 e J. K. RobBennolt, Determining Punitive Damages: Empirical Insights and Implications for Reform, in Buffalo Law Review, vol. 50, 2002, pág. 181. 
do demandado), as partes cheguem a um acordo que inclua a previsão ao pagamento de indenização que exceda os limites do prejuízo efetivamente suportado pela vítima (computando-se, portanto, os punitive damages), sem que tal valor excedente viesse a ser remetido a um fundo público. A proposta reformista seria, portanto, incompleta, ao permitir que nem todas as quantias calculadas com base na possível (ou certa) incidência dos punitive damages viessem a ser entregues a um outro destinatário que não a própria vítima da ofensa ${ }^{332}$.

Por fim, mas ainda quanto ao tema, sustenta-se que a adoção desta proposta poderia trazer, inclusive, reflexos de ordem constitucional para a quantificação da condenação ao pagamento de punitive damages. Isso porque, conforme fixado pela Supreme Court em Browning-Ferris Industries of Vermont v. Kelco (492 U.S. 257 1988), a excessive fines clause, inserida na $8^{\mathrm{a}}$ Emenda à Constituição Americana, somente não imporia restrições à quantificação de indenização concedida em um processo civil se o Estado não houvesse ajuizado a demanda indenizatória nem fosse beneficiário do todo ou parte desta condenação. Diante de tal previsão, sustenta D. G. OWEN que, à medida que o Estado (quer o próprio erário, quer, ainda, um fundo gerido por entes da administração pública) passasse a ser destinatário ao menos de parte da indenização a ser paga a título de punitive damages, poder-se-ia cogitar da incidência da excessive fines clause como novo fundamento para a limitação do quantum indenizatório ${ }^{333}$.

Como já se teve a oportunidade de frisar, contudo, mesmo após o advento do tort reform movement, e da adoção desta proposta reformista, não há notícias de que alguma condenação ao pagamento de punitive damages teria sido reduzida com fundamento na $8^{\mathrm{a}}$ Emenda à Constituição Americana. Como já se expôs, ao menos no âmbito da Supreme Court, a questão atinente aos limites constitucionais da condenação ao pagamento de punitive damages passou a se restringir à observância da due process clause, não mais se perquirindo sobre eventual desrespeito à excessive fines clause.

\footnotetext{
${ }^{331}$ G. V. RoBRedo, Costes Legales y Honorarios de Abogados em el Proceso Civil (Observaciones sobre la Situación em los Estados Unidos y em Europa), in Revista de la Universidad de Deusto, vol. 45, fasc. 98, ene-jun./1997, págs. 151/153.

332 Daños Punitivos en el Proceso Civil Norteamericano, in Revista de la Universidad de Deusto, vol. 57, fasc. 97, jul-dic./1996, pág. 204.
} 
Noticia-se que, ao largo das discussões aqui relatadas acerca da adequação desta sugestão reformista, sete Estados norte-americanos prevêem, de alguma maneira, a remessa de parte ou toda a condenação ao pagamento de punitive damages a um fundo público (nomeadamente: Colorado, Georgia, Indiana, Iowa, New York, Oregon e Utah) ${ }^{334}$.

\section{XI.II.IV. Repartição do procedimento (“bifurcation of trial”) e eliminação da prova da riqueza do demandado}

Como já asseverado, entende-se, de uma maneira geral, que um dos elementos para que os punitive damages sejam quantificados de modo a atingir, adequadamente, suas funções de punição e prevenção é a riqueza do demandado. Entendese que, para efetivamente desestimular o ofensor e lhe servir de punição, a condenação deve ser quantificada não apenas de acordo com a gravidade da conduta por ele perpetrada, mas, também, de acordo com suas características pessoais, entre as quais sobressai sua capacidade financeira. Por se tratar de elemento indispensável para a quantificação da indenização punitiva, a questão acerca da riqueza do ofensor é usualmente introduzida no processo pelo ofendido, passando a integrar o objeto da prova ${ }^{335}$.

Parte da doutrina, contudo, considera excessivamente prejudicial a possibilidade de que provas sobre a riqueza do demandado sejam produzidas durante o curso do processo, antes mesmo de que se tenha chegado a uma conclusão quanto à sua responsabilidade ("liability”) pelos prejuízos supostamente suportados pelo demandante. Afirma-se que, diante de provas nesse sentido (as quais, há que se frisar, são irrelevantes para a aferição das regras de imputação, que definirão a responsabilidade pelos prejuízos suportados pelo demandante), "o jurado prejulgará o ofensor e emitirá seu veredicto, principalmente, com base em sua riqueza e não em seu comportamento" ${ }^{336}$, ferindo os

\footnotetext{
333 A Punitive Damages Overview: Functions, Problems and Reform, in Villanova Law Review, vol. 39, 1994, pág. 410.

${ }^{334}$ W. A. LovetT, Exxon Valdez, Punitive Damages and Tort Reform, in Tort Trial \& Insurance Practice Law Journal, vol. 38, 2002, pág. 1111.

335 J. T. Simpsons JR., Discovery of Net Worth in Bifurcated Punitive Damages Cases: A Suggested Approach After Transportation Insurance Co. v. Moriel, in South Texas Law Review, vol. 37, 1996, pág. 194.

${ }^{336}$ No original: "el jurado prejuzgara al agente y emitiera su veredicto, principalmente, em base a su riqueza y no a su comportamiento." (G. V. Robredo, Daños Punitivos en el Proceso Civil Norteamericano, in Revista de la Universidad de Deusto, vol. 57, fasc. 97, jul-dic./1996, pág. 206)
} 
direitos constitucionalmente assegurados quanto a um processo justo ${ }^{337}$. Como pontuou a Supreme Court no julgamento de Oberg v. Honda Motors Co. (512 U.S. 415 1993), “ $a$ produção de provas acerca da riqueza do demandado possibilita que os jurados usem o seu veredicto para expressar eventuais preconceitos contra grandes corporações"338.

Para precatar o risco de que eventuais preconceitos sejam utilizados para embasar uma condenação ao pagamento de punitive damages, parte da doutrina vê como uma das mais promissoras e populares propostas reformistas aquela que objetiva a repartição do procedimento ("bifurcation of trial”) para a ação indenizatória em duas fases distintas, ambas julgadas pelo mesmo corpo de jurados: (i) uma na qual serão produzidas as provas para a aferição das regras de imputação, culminando com uma sentença que definirá a responsabilidade do ofensor ("liability”) para o pagamento de compensatory e punitive damages; e (ii) outra, subseqüente, na qual serão produzidas apenas as provas para a quantificação dos punitive damages, se tal condenação houver sido imposta pelos jurados ao término da primeira fase ${ }^{339}$.

Vê-se, assim, que a sub-divisão do procedimento, com fases instrutórias distintas, permite que não se faça uso de provas quanto à capacidade econômica do ofensor em momento procedimental no qual se está ainda a definir sua responsabilidade quanto ao pagamento de compensatory damages. Diz-se que, além de irrelevante para a definição da relação de imputação, a prova de capacidade econômica do potencial ofensor é prejudicial ao julgamento, vez que atua de maneira negativa no julgamento realizado pelos jurados. Estes, influenciados pela eventual discrepância econômica entre ofensor e ofendido, tenderiam a desconsiderar as demais evidências para impor a condenação a um demandado que, não necessariamente, é responsável pelo dano causado, julgando-o pelo que ele é, em detrimento ao que ele, comprovadamente, causou ou deixou de causar. A admissão da prova da

337 J. R. MCKnown, Punitive Damages: State Trends and Developments, in The Review of Litigation, vol. 14, 1994/1995, pág. 448: “A party's right to a fair trial may be infringed by the admission of evidence that is irrelevant to and unduly prejudicial to the calculation of compensatory damages, but is proper for computing a punitive damage award."

${ }^{338}$ No original: "[j] ury instructions typically leave the jury with wide discretion in choosing amounts, and the presentation of evidence of a defendant's net worth creates the potential that juries will use their verdicts to express biases against big business, particularly those without strong local presences." (512 U.S. 415 1993, pág. 432)

339 J. R. MCKnown, Punitive Damages: State Trends and Developments, in The Review of Litigation, vol. 14, 1994/1995, pág. 446 e J. T. SIMPSONS JR., Discovery of Net Worth in Bifurcated Punitive Damages Cases: A Suggested Approach After Transportation Insurance Co. v. Moriel, in South Texas Law Review, vol. 37, 1996, págs. 195/196. 
capacidade econômica do ofensor é indispensável para a quantificação da indenização punitiva, mas irrelevante e, até mesmo, prejudicial para o restante do julgamento ${ }^{340}$.

A despeito de adequadamente evitar que o juízo quanto à responsabilidade do demandado seja afetado por dados acerca de sua riqueza (o que serve de grande incentivo para a adoção de tal proposta reformista), D. G. OWEN anota que a repartição do procedimento pode trazer um sério inconveniente: por dividir em dois um procedimento originalmente uno, tornando necessária a realização de duas fases instrutórias, o "bifurcated trial" pode elevar sensivelmente os custos de litigância, custos estes que, em razão da "regra americana", são suportados pelo autor da demanda, mesmo que, ao final, sagre-se vitorioso ${ }^{341}$.

Ao largo das ponderações acima expostas, J. K. RoBBENNOLT noticia que ao menos 17 Estados norte-americanos (entre os quais se encontram, apenas à guisa de exemplo, Alaska, California, Georgia, Kansas, Minnesota, New Jersey e o Texas) admitem, de maneira obrigatória ou facultativa (a requerimento de uma das partes) a bifurcação do procedimento de ações indenizatórias que podem culminar em condenação ao pagamento de punitive damages ${ }^{342}$.

\section{XI.II.V. Elevação do burden of proof: equiparação aos critérios adotados pelo processo penal ("proof beyond reasonable doubt")}

Ainda uma outra medida destinada a impedir a incidência desenfreada dos punitive damages (e esta, defendida pela doutrina, é amplamente acolhida pelo Poder

\footnotetext{
340 J. T. Simpsons JR., Discovery of Net Worth in Bifurcated Punitive Damages Cases: A Suggested Approach After Transportation Insurance Co. v. Moriel, in South Texas Law Review, vol. 37, 1996, pág. 196 e D. G. Owen, A Punitive Damages Overview: Functions, Problems and Reform, in Villanova Law Review, vol. 39, 1994, pág. 386.

${ }^{341}$ A Punitive Damages Overview: Functions, Problems and Reform, in Villanova Law Review, vol. 39, 1994, pág. 409. Esta é, também, a crítica feita por J. T. SIMPSONS JR. ao sistema de repartição procedimental levado a efeito no Estado de New York, que somente admite que a produção de provas quanto à riqueza do demandado seja iniciada após a prolação de sentença quanto à sua responsabilidade, o que alonga, por deveras, o procedimento, tornando-o sensivelmente mais custoso (Discovery of Net Worth in Bifurcated Punitive Damages Cases: A Suggested Approach After Transportation Insurance Co. v. Moriel, in South Texas Law Review, vol. 37, 1996, pág. 212/215).

${ }^{342}$ Determining Punitive Damages: Empirical Insights and Implications for Reform, in Buffalo Law Review, vol. 50, 2002, pág. 178.
} 
Legislativo dos Estados norte-americanos) é aquela que propugna a elevação do ônus da prova ("burden of proof") 343 para a procedência da demanda indenizatória.

Em defesa desta sugestão, pontua a doutrina que "os punitive damages são atribuídos em demandas de natureza civil e, portanto, as diversas proteções de ordem constitucional ou legislativa disponíveis aos réus em ações penais geralmente não são disponíveis em demandas que versem sobre punitive damages" ${ }^{344}$. Por considerarem que o menor número de garantias processuais incidentes nas demandas cíveis (mesmo naquelas das quais possa resultar a imposição de uma sanção punitiva, de que os punitive damages são uma espécie) atenta contra o princípio constitucional do devido processo legal (“due process"), tais doutrinadores advogam pela ampliação de tais garantias, o que passa, necessariamente pela elevação do ônus da prova para que atinja o mesmo "grau de persuasão" exigido em processos criminais ${ }^{345}$, ou, ao menos, um "grau de persuasão"

\footnotetext{
${ }^{343}$ Importa de ver, para a adequada compreensão desta sugestão reformista, que, nos países da common law, a expressão "burden of proof' (a qual traduzimos livremente para "ônus da prova") é ambígua, utilziada que é para designar, essencialmente, dois fenômenos distintos: (i) o encargo (ou, tecnicamente, ônus) de uma das partes do processo de produzir provas de determinados fatos, sob pena de ver suas pretensões serem rechaçadas pelo Juízo (o termo "ônus da prova", contido no art. 333, CPC, expressa exatamente este significado); e (ii) a quantidade e qualidade das provas que uma das partes do processo precisa produzir para obter o convencimento do julgador (fenômeno também denominado de "risco de não persuação", ou, no original, "risk of nonpersuasion"). Sobre o tema, cfr. M. C. DOESBURG, Jury Instructions - Burden of Proof - Cases Requiring Proof by Clear, Cogent, and Convincing Evidence, in Missouri Law Review, vol. 42, 1977, págs. 662/663. Ao tratar deste segundo fenômeno atinente ao "burden of proof", J. P. MCBAINE sustenta que, na grande maioria das jurisdições norte-americanas, exige-se, para o convencimento do juiz, um de três possíveis "graus de persuação" ("degrees of persuasion"), cuja aplicação depende, em regra, do tipo de litígio (civil ou criminal) ou, ainda, das características dos fatos que se pretendem ver comprovados. Do mais singelo ao mais robusto, os "graus de persuasão", segundo o citado autor, são os de: (i) "preponderância de provas" ("preponderance of evidence"), utilizado na maioria das demandas de natureza civil; (ii) "provas claras e convincentes" ("clear and convincing evidence"), utilizado em determinadas pretensões e demandas, ainda de natureza civil; e, por fim, aquele que exige, para a procedência das pretensões deduzidas pela parte, que os fatos por ela alegados restem demonstrados (iii) "além de qualquer dúvida razoável" ("beyond any reasonable doubt"), critério este incidente nas demandas de natureza criminal e em determinadas demandas de natureza civil, tais como, e.g., as atinentes à presunção de paternidade de filhos nascidos na constância do casamento (Burden of Proof: Degrees of Belief, in California Law Review, vol. 32, 1944, pág. 245/246).

${ }^{344}$ No original, "punitive damages are awarded in civil cases and, thus, the various constitutional and statutory protections available to criminal defendants are generally not available in punitive damages cases." (T. C. Galligan JR., U.S. Supreme Court Tort Reform: Limiting State Power to Articulate and Develop Tort Law - Defamation, Preemption and Punitive Damages, in University of Cincinnati Law Review, vol. 74, 2006, pág. 1244).

${ }^{345}$ G. V. Robredo, Daños Punitivos en el Proceso Civil Norteamericano, in Revista de la Universidad de Deusto, vol. 57, fasc. 97, jul-dic./1996, pág. 205. Importa de ver, contudo, que a despeito dos argumentos trazidos por parte da doutrina, a Supreme Court, em Pacific Mutual v. Haslip afirmou não serem inconstitucionais, em face da due process clause (em nenhum de seus aspectos), as condenações ao pagamento de punitive damages em processos regidos pelo "grau de persuasão" denominado "preponderância de provas" (499 U.S. 23 1990, pág. 23).
} 
mais rígido do que aquele normalmente exigido em processos civis que não envolvem a imposição de sanções punitivas.

Sobre o tema, G. V. RoBREDO afirma que a sugestão reformista para que, para a imposição de punitive damages, seja abandonado o "grau de persuasão" ordinariamente exigido em demandas civis, denominado de "preponderância de provas" ("preponderance of evidence"), para que se passe a adotar um critério mais rígido, quer aquele que demanda "provas claras e convincentes" ("clear and convincing evidence"), quer, ainda, aquele que exige a demonstração dos fatos "além de qualquer dúvida razoável" ("beyond any reasonable doubt"), acarretaria, mais do que "uma mera diferença terminológica", uma verdadeira "redução do número de condenações ao pagamento de punitive damages por falta de provas" $" 346$.

Partindo das premissas acima enumeradas, D. G. OwEN sustenta que a adoção de um "grau de persuasão" intermediário, como é o de "provas claras $e$ convincentes", é, para a imposição de punitive damages, "não apenas apropriado, mas verdadeiramente necessário para assegurar a justiça para com o demandado"347.

\footnotetext{
346 "La importancia de esta desigual apreciación em la prueba va más allá de la mera diferencia terminológica, ya que si aplicamos el criterio más restrictivo de prueba ('under no reasonable doubt') veríamos reducido el numero de las condenas de daños punitivos como consecuencia de falta de prueba." (Daños Punitivos en el Proceso Civil Norteamericano, in Revista de la Universidad de Deusto, vol. 57, fasc. 97, jul-dic./1996, pág. 205). Ao tratar sobre as diferenças entre os três "graus de persuasão", J. P. MCBAINE, após pontuar que no campo da instrução processual não é possível aferir a certeza absoluta da ocorrência dos fatos alegados pelas partes, sustenta que: (i) para a aferição da "preponderância de provas", basta que o julgador, após analisar as provas produzidas durante o processo, entenda ser provavelmente verdadeiros os fatos alegados por uma das partes (sua ocorrência é mais provável do que a ocorrência dos fatos alegados pela parte contrária); (ii) já para a aferição das "provas claras e convincentes", critério mais rígido do que o anterior, exige-se que o julgador, após a análise do conjunto probatório, entenda ser altamente provável a ocorrência dos fatos alegados por uma das partes; por fim, para a aferição dos fatos (iii) "além de qualquer dúvida razoável", exige-se que o julgador entenda haver quase certeza da existência dos fatos alegados pela parte, cuja tese deve estar imune a qualquer "dúvida séria e bem fundada", ou a "dúvidas que pudessem fazer um homem prudente exitar ante à tomada de decisões importantes" (Burden of Proof: Degrees of Belief, in California Law Review, vol. 32, 1944, pág. 247/257). Pode-se procurar traçar um paralelo entre este último "grau de persuasão" e o nosso princípio da presunção de inocência, consubstanciado no art. 5', LVII, $\mathrm{CF} / 88$, que protege o acusado em processos criminais. Acerca dos reflexos deste princípio quanto ao ônus da prova no curso do processo criminal, Guilherme de Souza NuCCI afirma que "[é] fundamental considerar que a culpa, no cenário criminal, deriva da prova inconteste da prática de uma infração penal", para concluir que "gerada a dúvida razoável no espírito do julgador, ingressa o princípio da prevalência do interesse do réu, devendo haver a absolvição." (Princípios Constitucionais Penais e Processuais Penais, São Paulo, RT, 2010, págs. 240 e 242)

${ }^{347}$ No original: "[A] 'mid-level' burden of proof, such as by 'clear and convincing evidence', is not only appropriate, but plainly necessary in the interest of fairness to the 'accused'." (A Punitive Damages Overview: Functions, Problems and Reform, in Villanova Law Review, vol. 39, 1994, pág. 383).
} 
Em razão dos argumentos aqui aventados, W. A. LovetT noticia que, atualmente a maioria dos Estados norte-americanos (tais como, apenas a título exemplificativo, Hawaii, New Jersey, Florida, Alabama, Alaska, Arizona e California) adota, para a prolação de decisões que envolvam a condenação ao pagamento de punitive damages, o standard intermediário de "clear and convincing evidence"348. Apenas no Estado do Colorado se exige o standard do "beyond reasonable doubt" para a incidência dos punitive damages ${ }^{349}$.

\section{XI.II.VI. Eliminação da imprecisão dos pressupostos de incidência dos punitive damages}

Segundo os detratores da indenização punitiva (entre os quais se inserem, de maneira geral, os doutrinadores cujas idéias servem de fundamento para o tort reform movement), uma das dificuldades mais sérias no que concerne aos punitive damages é justamente a imprecisão terminológica das normas que regulamentam a imposição e quantificação de tal condenação (sejam tais normas estatutárias ou jurisprudenciais). Sustenta-se que a vagueza de tais normas atribui ao julgador (seja ele um juiz togado ou um corpo de jurados) uma exageradamente ampla discricionariedade sobre quais condutas deveriam ser apenadas dessa maneira, ou sobre qual deveria ser o patamar de uma condenação dessa natureza ${ }^{350}$.

Nesse sentido seguem as palavras de D. G. OwEN, o qual, a despeito de figurar entre os defensores do instituto dos punitive damages, reconhece que, "na maioria das jurisdições, os standards que definem quando os punitive damages são apropriados

\footnotetext{
348 J. K. RoBBENNOLT anota, contudo, que, mesmo nesses Estados o "grau de persuasão" para a condenação ao pagamento de compensatory damages permanece o de "preponderância de provas". Uma vez comprovada a ocorrência dos fatos que dão ensejo à responsabilidade civil (liability) por meio da "preponderância de provas", o demandante somente fará jus ao recebimento de uma quantia a título de punitive damages se demonstrar a ocorrência dos fatos constitutivos de seu direito por meio de "provas claras e convincentes" (Determining Punitive Damages: Empirical Insights and Implications for Reform, in Buffalo Law Review, vol. 50, 2002, pág. 176).

${ }^{349}$ Exxon Valdez, Punitive Damages and Tort Reform, in Tort Trial \& Insurance Practice Law Journal, vol. 38, 2002, pág. 1109.

${ }^{350}$ G. V. Robredo, Daños Punitivos en el Proceso Civil Norteamericano, in Revista de la Universidad de Deusto, vol. 57, fasc. 97, jul-dic./1996, pág. 206
} 
são realmente vagos, e, em geral, nem jurados nem juízes possuem critérios adequados para para definir quando os punitive damages devem incidir ${ }^{\prime 351}$.

Diante de tal premissa, G. V. RoBREDo sustenta que "[e]sta falta evidente de uma definição precisa e uniforme afeta de forma especial a descrição da conduta do agente necessária para dar lugar à responsabilidade punitiva. Uma descrição exata da conduta necessária para a condenação ao pagamento de punitive damages melhoraria o ambiente que rodeia toda a teoria. O julgador teria uma melhor compreensão acerca da conduta que deve julgar. Uma definição mais concreta limitaria o âmbito de investigação do julgador. Ademais, [uma definição mais concreta de suas hipóteses de incidência] poderia garantir que os punitive damages fossem impostos de maneira mais adequada e em conformidade com seus propósitos" ${ }^{\natural 52}$.

Ao procurar solucionar tais problemas, causados pela imprecisão terminológica, os reformistas propõem a adoção de duas possíveis medidas: (i) promover alterações legislativas com o fim de reduzir a imprecisão dos pressupostos para incidência dos punitive damages, em busca de expressões mais claras e precisaspara tanto; ou (ii) criar mecanismos procedimentais que permitam (ii.i) a adequada instrução do júri quanto à

\footnotetext{
${ }^{351}$ No original, "The standards in most jurisdictions defining when punitive damages art appropriate are vague indeed, and neither juries nor judges are generally provided with meaningful 'tests' of when punitive damages are proper." (A Punitive Damages Overview: Functions, Problems and Reform, in Villanova Law Review, vol. 39, 1994, pág. 384). Pela notícia que traz a doutrina norte-americana, a imprecisão das normas concernentes à imposição e quantificação dos punitive damages parece ser uma constatação geral. E tal imprecisão não é típica apenas das normas legais ("statutory provisions"), mas, também, das instruções dadas aos jurados antes de prolatarem seu veredicto ("jury instructions"). A título exemplificativo, J. K. ROBBENNOLT aponta que uma das instruções comuns para a imposição de punitive damages é a seguinte: "[i]f you find that the defendant's conduct was willful and wanton and proximately caused injury to the plaintiff and if you believe that justice and the public good require it, you may, in addition to any other damages to which you find the plaintiff entitled, award an amount which will serve to punish the defendant and to deter the defendant and others from similar conduct." (Determining Punitive Damages: Empirical Insights and Implications for Reform, in Buffalo Law Review, vol. 50, 2002, pág. 185). Tais instruções não só pecam pela vagueza das expressões utilizadas para definir a conduta apta a ser sancionada pela aplicação dos punitive damages [limitando-se a taxá-la de "proposital" ("willful") ou "injustificada" ("wanton")], mas, também e principalmente, por não trazerem critérios para a quantificação da condenação (diz-se, de maneira excessivamente genérica, que os punitive damages devem servir para punir o ofensor e desestimulá-lo da prática de outros ilícitos, mas não se diz em que medida a condenação deve ser mensurada para atingir a tais propósitos).

${ }^{352}$ No original: "[e]sta falta evidente de una definición precisa y uniforme afecta de forma especial a la descripción de la conducta del agente necesaria para dar lugar a la responsabilidad punitiva. Una descripción exacta de la conducta necesaria para la condena de daños punitivos mejoraría al ambiente que rodea a toda la teoría. El juzgador tendría un mejor entendimiento de la conducta que debe juzgar. Una definición más concreta limitaría el ámbito de investigación del juzgador. Además, podría garantizar que los daños punitivos fuesen más equitativos y em conformidad con sus propósitos." (Daños Punitivos en el Proceso Civil Norteamericano, in Revista de la Universidad de Deusto, vol. 57, fasc. 97, jul-dic./1996, pág. 207).
} 
natureza e às funções dos punitive damages, bem como quanto às suas hipóteses de incidência e critérios para a sua quantificação; (ii.ii) a minuciosa aferição, pelo juiz da causa e a posteriori, de que o veredicto ditado pelos jurados realmente atentou às instruções acima mencionadas, bem como ao conjunto probatório produzido no curso do processo; e, por fim, (iii.iii) a escorreita e precisa fundamentação da decisão judicial, para que sejam expressas as razões que levaram, ou não, à imposição dos punitive damages ${ }^{353}$.

Ao tratar do tema, J. K. RoBBENOLT noticia que, em razão das preocupações acima expressas, alguns Estados norte-americanos têm procurado desenvolver critérios legais ("statutory standards") que indiquem, com maior grau de precisão, em quais casos é adequada a condenação ao pagamento de punitive damages e, em havendo condenação, qual o patamar adequado para que tal condenação atinja, de maneira proporcional e razoável, suas funções punitiva e preventiva. Tal é, por exemplo, o caso do Estado da California, que passou a adotar instruções aos jurados (“jury instructions”) mais minuciosas não só quanto às hipóteses de cabimento dos punitive damages (descrevendo as características de que se deve revestir a conduta ilícita para ser sancionada por meio de punitive damages), mas, também, quanto aos elementos que devem ser levados em conta para a quantificação da condenação (indicando, expressamente, que a condenação deve ser quantificada de acordo com a gravidade da conduta perpetrada, a riqueza do demandado e, sempre, de maneira proporcional com os compensatory damages; anotando-se, ademais, que a condenação ao pagamento de punitive damages deve ser calculada e imposta em separado, independentemente de qualquer condenação ao pagamento de compensatory damages) ${ }^{354}$.

\section{XI.II.VII. Exclusão da competência dos jurados para a quantificação dos punitive damages}

Ao final, há que se lembrar ainda uma última medida aventada pela doutrina para o controle das condenações ao pagamento de punitive damages: a de que se retire dos jurados a competência para a análise desta sorte de condenação. Tal medida, de acordo com

\footnotetext{
353 A Punitive Damages Overview: Functions, Problems and Reform, in Villanova Law Review, vol. 39, 1994, págs. 384/385.

${ }^{354}$ Determining Punitive Damages: Empirical Insights and Implications for Reform, in Buffalo Law Review, vol. 50, 2002, págs. 188/189.
} 
critérios de política legislativa, poderia assumir um caráter mais ou menos restritivo: (i) caso se advogasse por retirar dos jurados tanto a competência para a imposição da condenação (an debeatur) quanto para sua quantificação (quantum debeatur); ou, ainda, (ii) caso se defendesse que a imposição da condenação deveria ser mantida sob o crivo dos jurados, enquanto que ao juiz togado restaria apenas a competência para sua quantificação ${ }^{355}$.

Segundo seus defensores, a adoção de tal reforma visa a evitar ou, ao menos, mitigar inconvenientes resultantes da atuação supostamente errática dos jurados, tidos como inaptos para exercer a importantíssima atribuição que lhes é incumbida de impor e quantificar os punitive damages ante à possibilidade de que seu julgamento venha a ser motivado por paixões ou outros fatores de ordem exclusivamente subjetiva e pessoal. Os juízes togados, por outro lado, por serem técnicos aplicadores do Direito, não tenderiam a sucumbir a tais motivações subjetivas com freqüência, assegurando-se, dessa maneira, uma aplicação mais adequada da sanção ${ }^{356}$. Nas palavras de G. V. RoBREDO, que bem resumem tal linha argumentativa, "os juízes são aqueles que têm experiência $e$ familiaridade com os conceitos legais, pelo que são melhor capacitados que os jurados para distinguir aqueles comportamentos que merecem castigo daqueles que não"357.

A proposta ora aventada, contudo, não passa isenta de críticas pela doutrina especializada, que contra ela se insurge tanto porque ela padece de um (ao menos aparente) preconceito quanto à atuação dos jurados, quanto porque ela toca numa delicada questão de

\footnotetext{
${ }^{355}$ E. URSO, Recenti Sviluppi nella Giurisprudenza Statunidense e Inglese in Materia di Punitive Damages: $i$ Casi TXO Production Corporation v. Alliances Resources Corporation e AB v. South West Water Services Ltd., in Rivista di Diritto Civile, vol. 41, n. 1, genn.-febr./1995, pág. 143.

${ }^{356}$ G. T. SCHWARTZ anuncia que os juízes norte-americanos também compartilham desta preocupação, narrada pela doutrina, quanto à atuação discricionária do corpo de jurados para a imposição e quantificação dos punitive damages. O autor cita um estudo do qual participou, realizado ao final da década de 1970, no qual os juízes da Supreme Court do Estado da California foram instigados a responder um questionário sobre suas considerações acerca do trabalho do corpo de jurados. Seis em cada dez juízes entrevistados consideravam que os veredictos emitidos por jurados, no que concerne à imposição e quantificação de punitive damages, nem sempre eram sensatos. Ainda, $56 \%$ dos juízes entrevistados disseram-se favoráveis à adoção de medidas legislativas que imputassem ao juiz ou ao Tribunal a competência para impor e quantificar os punitive damages, retirando-se tal competência do corpo de jurados (Deterrence and Punishment in the Common Law of Punitive Damages: A Comment, in Southern California Law Review, vol.56, 1982, págs. 146/147).

${ }^{357}$ No original: "Los jueces son quienes tienen experiencia y familiaridad con los conceptos legales, por lo que están mejor capacitados que los jurados para distinguir aquellos comportamientos que merecen um castigo de los que no." (Daños Punitivos en el Proceso Civil Norteamericano, in Revista de la Universidad de Deusto, vol. 57, fasc. 97, jul-dic./1996, pág. 204). Em sentido semelhante, mas menos incisivo, D. G. Owen, A Punitive Damages Overview: Functions, Problems and Reform, in Villanova Law Review, vol. 39, 1994, págs. 412: "Judges are generally more qualified than jurors - in training, temperament and experience - to fix the amounts of such sanctions."
} 
ordem constitucional (a competência dos jurados para o julgamento de seus pares, inclusive para matérias de âmbito civil).

A uma, diz-se que aqueles que advogam a exclusão da competência dos jurados no que tange à quantificação dos punitive damages partem de uma premissa correta (a de que faltaria aos jurados o treinamento e a experiência técnico-jurídicos possuídos pelos juízes) para, dela, extraírem uma conclusão que não parece adequada (a de que, em razão das circunstâncias acima narradas, os jurados tendem a ser parciais no que toca à quantificação dos punitive damages e, portanto, menos capacitados do que os juízes para o exercício desta tarefa específica). Com efeito, partindo de estudos empíricos sobre o tema, J.K. RoBBENNOLT afirma não ser verídica a alegação de que juízes tendem a discordar dos veredictos impostos por jurados no que toca à condenação ou quantificação dos punitive damages. Pelo contrário, dos dados coletados extrai-se justamente a conclusão contrária: demandantes que pretendem obter punitive damages geralmente têm mais sucesso diante de um juiz do que de um corpo de jurados ${ }^{358}$.

A duas, continuam os defensores da competência do corpo de jurados, já existem meios efetivos para combater a eventual (e, frise-se, patológica) parcialidade dos jurados na imposição ou quantificação de punitive damages. Assim é que, ao analisar as restrições aos punitive damages que resultam da due process clause, a Supreme Court norte-americana já teve a oportunidade de pontuar que "quando uma condenação ao pagamento de punitive damages reflete parcialidade, paixão ou preconceito por parte do júri, ao invés de preocupações racionais com prevenção e punição, a constituição é violada, independentemente do montante absoluto ou relativo da condenação" ${ }^{359}$. Diante da verificação de que a condenação decorre de julgamento parcial, é dever do julgador em

\footnotetext{
${ }^{358}$ Determining Punitive Damages: Empirical Insights and Implications for Reform, in Buffalo Law Review, vol. 50, 2002, págs. 184/185. A. H. SCHEINER, contudo, discorda parcialmente de tais conclusões, afirmando, também com fundamento em estudos empíricos, que, a despeito de não se constatar sensíveis divergências entre juízes e jurados no que toca às regras de imputação de responsabilidade (“liability”), verifica-se grande divergência no que toca à quantificação dos punitive damages. Sustenta o citado autor que, por inexistirem critérios legais rígidos a serem seguidos para a quantificação dos punitive damages, é difícil extrair, da análise dos casos, as reais razões para as divergências de entendimento entre juízes e jurados. Por tal motivo, o autor credita tais disparidades a eventuais desentendimentos quanto aos montantes necessários para a indenização possa cumprir, adequadamente, suas funções punitiva e preventiva (Judicial Assessment of Punitive Damages, The Seventh Amendment and The Politics of Jury Power, in Columbia Law Review, vol. 91, 1991, págs. 166/168.

${ }^{359}$ No original: "[w]hen a punitive damages award reflects bias, passion, or prejudice by the jury, rather than a rational concern for deterrence and retribution, the Constitution has been violated, no matter what the absolute or relative size of the award." (509 U.S. 443 1992, pág. 444)
} 
primeira instância, bem como dos Tribunais, decotar ou eliminar tal condenação, eivada que estará de nulidade.

A três, e assim o aponta D. G. OwEN, é igualmente certo que, muito embora também se trate de situação patológica, até mesmo o juíz pode vir a ser parcial; o que poderia fazer com que ele viesse a emitir seu julgamento mais em razão de pré-conceitos que pudesse ter (quer em relação à parte, à atividade por ela exercida, à ofensa praticada, quer, ainda, em relação às características pessoais da vítima) do que, propriamente, em razão das regras de imputação de responsabilidade ou às hipóteses de incidência dos punitive damages. Ainda que a sugestão reformista fosse acolhida, portanto, não se eliminaria por completo a possibilidade de que a condenação ao pagamento de punitive damages viesse a ser quantificada por um julgador parcial (não mais o grupo formado pelos jurados, mas, desta feita, o juiz togado), motivado por convicções próprias e não pelos ditames legais ${ }^{360}$.

Por fim, uma parcela da doutrina aponta para as possíveis repercussões constitucionais das iniciativas legislativas que buscam retirar do corpo de jurados a competência para a imposição e quantificação dos punitive damages ${ }^{361}$. Sustenta-se que, em atenção às razões pelas quais o direito de julgamento por um conjunto de seus pares (formado pelo corpo de jurados) surgiu, não se poderia excluir, por iniciativa legislativa, a competência do júri para a aferição dos punitive damages, sob pena de, assim o fazendo, subverter-se a garantia insculpida na $7^{\text {a }}$ Emenda à Constituição Americana ${ }^{362}$.

Em meio à grande controvérsia acima exposta, J. K. ROBBENOLT noticia que ao menos dois Estados norte-americanos (nomeadamente, Connecticut e Kansas) adotaram, na década de 1990, iniciativas legislativas para excluir do corpo de jurados a competência para quantificar a condenação ao pagamento de punitive damages ${ }^{363}$.

\footnotetext{
360 A Punitive Damages Overview: Functions, Problems and Reform, in Villanova Law Review, vol. 39, 1994, págs. 412.

${ }^{361}$ A. H. SCHEINER, Judicial Assessment of Punitive Damages, The Seventh Amendment and The Politics of Jury Power, in Columbia Law Review, vol. 91, 1991, págs. 223/226.

${ }^{362}$ A $7^{\text {th }}$ Amendment à Constituição Americana, inserida em seu corpo no ano de 1791, assim dispõe: "In suits at common law where the value in controversy shall exceed twenty dollars, the right of trial by jury shall be preserved, and no fact tried by a jury shall be otherwise reexamined in any Court of the United States, than according to the rules of common law".

${ }^{363}$ Determining Punitive Damages: Empirical Insights and Implications for Reform, in Buffalo Law Review, vol. 50, 2002, pág. 184.
} 


\section{CAPÍTULO II - A NECESSIDADE DE ADOÇÃO DA INDENIZAÇÃO PUNITIVA}

Após passarmos em revista as principais características do instituto jurídico, típico dos países da common law, denominado de punitive damages, e verificarmos de que maneira, naqueles países, tal instituto é utilizado para punir condutas altamente reprováveis e desestimular potenciais ofensores quanto ao cometimento de novos atos ilícitos, parece certamente tentador, seguindo a linha adotada por inúmeros doutrinadores e Tribunais pátrios, procurar meios de transpor imediatamente aquele modelo jurídico alienígena para a realidade nacional, buscando, dessa maneira, atingir os mesmos fins alcançados pelo instituto em seus países de origem. Tal procedimento, contudo, deve-se operar com a mais extrema cautela ${ }^{364}$ : antes mesmo de se verificar a eventual compatibilidade entre tal instituto jurídico e os contornos constitucionais e legais do ordenamento brasileiro, é imprescindível constatar a "real necessidade desta importação, ou seja, deve-se antes, explorar as potencialidades preventivas postas pelo sistema jurídico nacional" 365 .

Imbuídos de tal propósito, procuraremos traçar, no presente capítulo, um panorama geral de como se fixaram e desenvolveram as características tradicionais da responsabilidade civil. Dessa análise, procuraremos extrair uma conclusão precisa acerca das reais possibilidades de esse instituto, no atual estágio de desenvolvimento em que se encontra, vir a desempenhar adequadamente as funções de punição do ofensor (pelos atos gravemente reprováveis por ele perpetrados) e prevenção do próprio ofensor e da sociedade como um todo.

\footnotetext{
364 Judith Martins-Costa - Mariana Souza PARgendler, Usos e Abusos da Função Punitiva ('Punitive Damages' e o Direito Brasileiro), in Revista da Ajuris, ano XXXII, n. ${ }^{\circ}$ 100, dez/2005, págs. 229/230.

365 Marcela Alcazas BASSAN, As Funções da Indenização por Danos Morais e a Prevenção de Danos Futuros, Dissertação (Mestrado) - Faculdade de Direito da USP, São Paulo, 2009, pág. 2.
} 
Na seqüência, passaremos a analisar de que maneira os demais ramos do Direito Sancionador (a saber, o Direito Penal e o Direito Administrativo Sancionador) são aptos a, isoladamente, exercer as funções acima enumeradas quando a responsabilidade civil é incapaz de fazê-lo.

Por fim, diante das conclusões preliminares atingidas em cada uma dessas etapas, procuraremos concluir no sentido de que, para que seja possível tutelar eficazmente os bens e interesses de maior relevância jurídica (a saber, os direitos decorrentes da dignidade da pessoa humana e os direitos e interesses metaindividuais), de cuja violação decorrem graves conseqüências para o bem estar social (causando o que, nas palavras de Antonio JUNQUEIRA DE AZEVEDO, veio a se denominar de "dano social"366), é imprescindível que seja mitigado um dos paradigmas tradicionais da responsabilidade civil (o assim chamado paradigma ressarcitório), passando-se a admitir que, em se verificando a ocorrência de determinados pressupostos subjetivos e objetivos, a indenização seja majorada para que a própria responsabilidade civil exerça adequadamente as funções de punição do ofensor e prevenção (geral e especial).

\section{RESPONSABILIDADE CIVIL: PARAdigmas TRADICIONAIS E DESENVOLVIMENTOS CONTEMPORÂNEOS}

Segundo o conceberam os juristas da Modernidade (em especial os franceses, cujo ideário iluminou o desenvolvimento do Código Civil de Napoleão, corpo legislativo que consolidou os ideais modernos quanto ao direito privado e que serviu de inspiração para a edição dos códigos que o seguiram, inclusive, e especialmente no que concerne à responsabilidade civil, do Código Civil Brasileiro de $1916^{367}$ ), o instituto da

\footnotetext{
366 Por Uma Nova Categoria de Dano na Responsabilidade Civil: O Dano Social, in Novos Estudos e Pareceres de Direito Privado, São Paulo, Saraiva, 2009, págs. 377/384.

${ }^{367}$ Cláudio Luiz Bueno de GodoY, Responsabilidade Civil pelo Risco da Atividade, São Paulo, Saraiva, 2009, pág. 32. Ao tratar da influência do Direito Francês sobre outros ordenamentos, Antonio JUNQUEIRA DE AZEVEDO afirma que, "[a] partir de 1804 [ano da promulgação do Code], [...] é quase universal a influência do Código Civil Francês" (Influência do Direito Francês sobre o Direito Brasileiro, in Novos Estudos e Pareceres de Direito Privado, São Paulo, Saraiva, 2009, pág. 590). Mais à frente, ao analisar o regramento previsto no Código Civil Brasileiro de 1916, o mesmo autor sustenta que "[a] teoria da responsabilidade civil no Código Civil brasileiro é totalmente derivada do Código de Napoleão" (Antonio JUNQUEIRA DE AZEVEDO, op. cit., pág. 594).
} 
responsabilidade civil representa um sistema de regras de imputação fundado no mau uso da liberdade individual (intimamente inspirado, portanto, na ideologia liberal e individualista dos fins do século XVIII e início do século XIX), impondo-se ao indivíduo a obrigação legal de indenizar os prejuízos por ele causados a terceiros em decorrência do cometimento de condutas que extrapolassem um determinado (e amplo) limite lícito de atuação autorizado por Lei. Compreendia-se, assim, que os conceitos de responsabilidade (conjunto das diversas regras de imputação) e liberdade (entendida esta essencialmente como "liberdade individual", i.e., espaço no qual se permitia a atuação lícita do particular) eram intimamente relacionados, um servindo de fundamento ao outro ${ }^{368}$.

Para o controle do exercício adequado dessa liberdade individual (e, conseqüentemente, para a fixação das regras de imputação que dariam ensejo à incidência da responsabilidade civil em caso de abuso dessa liberdade), mostravam-se igualmente inadequados os sistemas de responsabilização então em vigor na Europa Continental. Tanto aquele que propugnava a responsabilidade coletiva e a vingança familiar, típico do direito germânico (o qual representava a verdadeira antítese do conceito de liberdade individual $^{369}$, quanto aquele que previa a responsabilidade delitual, excessivamente rígido (fundado que era na delimitação típica dos delitos e das penas), eram tidos como impróprios para o regramento que se pretendia dar ao instituto ${ }^{370}$.

Decorre, enfim, da incapacidade dos sistemas então vigentes para dar resposta aos anseios ideológicos da sociedade francesa, a necessidade de que se desenvolvesse um novo sistema que, de maneira mais maleável (dotado, portanto, de mecanismos menos "engessados" do que a tipificação delitual), estipulasse regras de

\footnotetext{
368 Anderson SchreIBer, Novos Paradigmas da Responsabilidade Civil: Da Erosão dos Filtros da Reparação à Diluição dos Danos, São Paulo, Atlas, 2009, pág. 12.

${ }^{369}$ Com efeito, ao tratar do tema, J. GILISSEN afirma que "[o]s direitos germânicos, como a maior parte dos direitos arcaicos, mal conheciam a responsabilidade individual; qualquer acto humano compromete todo o grupo (família, clã, etc.) ao qual ele pertence; se alguém causou uma injustiça ou um dano a um homem de um outro grupo, é todo o grupo lesado que se vingará em relação a qualquer membro do grupo do autor do acto incriminado. Este sistema de vingança privada (faida germânica, vendetta, etc.) supõe a solidariedade activa e passiva do grupo familiar." (Introdução Histórica ao Direito, trad. A. M. Hespanha e L. M. Macaísta Malheiros, $5^{\text {a }}$ ed., Lisboa, Fundação Calouste Gulbenkian, 2008, pág. 751).

370 Anderson SchreIBER, Novos Paradigmas da Responsabilidade Civil: Da Erosão dos Filtros da Reparação à Diluição dos Danos, São Paulo, Atlas, 2009, págs. 12/13.
} 
imputação de responsabilidade individual, fundadas no exercício abusivo das supra referidas liberdades ${ }^{371}$.

Justamente em razão desses anseios ideológicos, procurou-se disciplinar o instituto da responsabilidade civil com fundamento em três princípios basilares ${ }^{372}$, a saber: (i) o universalismo, do qual derivava a tentativa de construção de um "princípio de alcance geral" (ou de uma "cláusula geral") para a imposição da obrigação de indenizar; (ii) o individualismo, do qual se podia extrair a concepção de que a obrigação de indenizar deveria recair, com exclusividade, sobre um indivíduo especificamente considerado, responsável direto pela causação do prejuízo; e, por fim, (iii) o moralismo, do qual se extraía a idéia de abuso das liberdades individuais, impondo-se a obrigação de indenizar apenas e tão-somente àqueles indivíduos que houvessem apresentado um desvio de conduta, desvio este caracterizado pela noção de culpa.

Foi à luz desses três princípios inspiradores que se cunhou a redação dos artigos 1.382 e 1.383, do Código Civil Francês, da qual se pode extrair os três paradigmas tradicionais da responsabilidade civil $^{373}$, quais sejam: (i) a responsabilidade individual (não mais "coletivizada", repartida entre o indivíduo causador do dano e o grupo social no qual se inseria) $)^{374}$; (ii) a responsabilidade fundada na culpa $^{375}$; e, por fim, (iii) o paradigma reparatório/ressarcitório ${ }^{376}$.

371 Anderson SchreIBER, Novos Paradigmas da Responsabilidade Civil: Da Erosão dos Filtros da Reparação à Diluição dos Danos, São Paulo, Atlas, 2009, pág. 13.

${ }^{372}$ Sobre o tema, cfr. Cláudio Luiz Bueno de GoDOY, Responsabilidade Civil pelo Risco da Atividade, São Paulo, Saraiva, 2009, pág. 10.

${ }^{373}$ Sobre os paradigmas tradicionais da responsabilidade civil, cfr. Maria Alice Costa HoFMEISTER, O Dano Pessoal na Sociedade de Risco, Rio de Janeiro, Renovar, 2002, págs. 93/95 e Cláudio Luiz Bueno de Godoy, Responsabilidade Civil pelo Risco da Atividade, São Paulo, Saraiva, 2009, pág. 10.

${ }^{374}$ Paradigma este que decorre tanto da redação do art. 1.382 (o qual prescreve que "tout fait quelconque de l'homme, qui causa à autrui un dommage, oblige celui par la faute duquel est arrivé, à le réparer") quanto daquela atribuída ao art. 1.383 (no qual se lê “chacun est responsable du dommage qu'il a causé non seulement par son fait, mais encore par as négligence ou par son imprudence"), da qual se consegue facilmente extrair a idéia de imputação individuada da responsabilidade apenas àquela que diretamente causou o prejuízo.

${ }^{375}$ Igualmente aferível tanto da redação do art. 1.382 (no qual se pode verificar a alusão à expressão faute) quanto daquela atribuída ao art. 1.383 (do qual se extraem as noções de fait, négligence e imprudence).

${ }^{376} \mathrm{O}$ qual se extrai, especificamente, da parte final do art. 1.382, que prevê apenas a obrigação do ofensor de reparar o dano injustamente causado (e nada mais). Eduardo UILAN aponta, ainda, que o paradigma reparatório teria origem no Code des Délits et des Peines (3 brumaire, an 4), que teria previsto a separação entre responsabilidade criminal, a ser exercida por meio da uma "ação pública" destinada a punir o ofensor (o citado Código prescrevia, em seu art. $5^{\circ}$, a existência da "action publique a pour objet de punir les atteintes portées à l'ordre social", a qual "appartient essentiellement au peuple"), e a responsabilidade civil, a ser exercida por uma "ação civil" cuja finalidade precípua era não mais punir o ofensor, mas, sim, ressarcir os prejuízos suportados pelo ofendido (o art. $6^{\circ}$ do citado Código previa a existência de uma "action civile a 
Quanto ao primeiro paradigma (o da responsabilidade individual), diz-se que decorreu do fato de o Code ter surgido em um contexto sócio-econômico no qual as atividades mercantes apresentavam-se, principalmente, de maneira artesanal, cuidando de relações exclusivamente entre indivíduos. As tragédias, quando ocorriam, eram tragédias individuais, e podia-se, com maior facilidade, apontar um único responsável pela causação dos prejuízos, os quais, de ordinário, atingiam uma única vítima ${ }^{377}$.

Já quanto ao segundo paradigma (o da responsabilidade fundada na culpa), afirma-se ter suas origens no fato de se ter cunhado as regras de responsabilidade civil com a finalidade de "moralizar as condutas individuais" que se mostravam socialmente indesejadas. Quando tais condutas se desviavam do standard legislativamente previsto, i.e., quando o indivíduo extrapolava os limites do exercício razoável de sua liberdade einvadia a órbita jurídico de outrem, causando-lhe prejuízos como resultado de uma conduta negligente ou intencional, este indivíduo deveria ser sancionado, obrigando-se-lhe a reparar todos os prejuízos causados por sua conduta injusta, indesejável e, a partir de então, também reputada de ilícita ${ }^{378}$.

Por fim, quanto ao terceiro e último paradigma tradicional (o assim chamado paradigma reparatório ou ressarcitório), diz-se que, em razão da repartição entre as responsabilidades criminal e civil, conduziu-se o instituto da responsabilidade civil a definir regras que restringissem o sancionamento do ofensor tão-somente aos estritos limites do prejuízo suportado pelo ofendido. Para o que toca à dosimetria da sanção, unificou-se o conceito de culpa (que antes se tripartia em culpa grave, culpa leve e culpa levíssima), impondo-se ao ofensor apenas a obrigação de ressarcir os prejuízos (os quais teriam a mesma monta, independentemente do grau de culpa com que houvesse obrado o ofensor $)^{379}$. Tal obrigação, ainda, surgiria apenas após o cometimento do ilícito e após a ocorrência do dano, em uma atuação ex post da responsabilidade civil que servir para

pour objet la réparation du dommage que le délit a causé", a qual "appartient à ceux qui ont souffert ce dommage"). (Responsabilidade Civil Punitiva, Tese (Doutorado) - Faculdade de Direito da USP, São Paulo, 2003, pág. 46).

${ }^{377}$ Maria Alice Costa Hofmeister, O Dano Pessoal na Sociedade de Risco, Rio de Janeiro, Renovar, 2002, págs. 93/94.

${ }^{378}$ Maria Alice Costa Hofmeister, O Dano Pessoal na Sociedade de Risco, Rio de Janeiro, Renovar, 2002, pág. 95. 
tutelar "um interesse do credor que se pode chamar de expectativa na preservação da situação atual (ou de manutenção do status quo)",380.

Tratando-se, contudo, de um sistema de segunda ordem, cuja existência se dá em função do sistema maior, o sistema social ${ }^{381}$, o Direito comporta modificações evolutivas, decorrentes justamente da necessidade de que suas normas e princípios se adaptem "aos novos modelos sociais e às novas necessidades impostas pela cambiante realidade cultural ${ }^{382}$. Especificamente no que toca à responsabilidade civil, nota-se que as insuficiências verificadas em seus paradigmas tradicionais, não mais capazes de dar respostas eficientes às novas espécies de conflitos surgidos em uma sociedade que evolui e se modifica a passos largos, fizeram da responsabilidade civil um instituto jurídico mutável, maleável, apto a evoluir e a moldar tais paradigmas ao longo dos anos com a finalidade de atender a essas novas necessidades sociais ${ }^{383}$.

Conforme narrado por Fernando NORONHA, em razão das extremas modificações que se abateram sobre o seio social mundial, em especial nos séculos XIX e $\mathrm{XX}$ (entre os quais se insere com muito destaque a revolução industrial), a responsabilidade civil foi acometida por um "triplo fenômeno" de desenvolvimento, o qual abarcou, ao mesmo tempo: (i) "a objetivação da responsabilidade" (em rompimento, ainda que parcial, do paradigma da responsabilidade fundada na culpa); (ii) a "coletivização da responsabilidade" (em ruptura, ao menos parcial, do paradigma da responsabilidade individual); e, ainda, (iii) "a expansão dos danos suscetíveis de reparação"384.

Em atenção ao primeiro dos fenômenos acima apontados (a objetivação da responsabilidade civil), vale lembrar que, desde meados do século XIX, a humanidade vem experimentando um sensível e intenso desenvolvimento tecnológico, com o passar das três

\footnotetext{
${ }^{379}$ Maria Alice Costa Hofmeister, O Dano Pessoal na Sociedade de Risco, Rio de Janeiro, Renovar, 2002, pág. 95.

${ }^{380}$ Fernando Noronha, Direito das Obrigações, vol. I, $2^{\text {a }}$ ed., São Paulo, Saraiva, 2007, pág. 435.

${ }^{381}$ Antonio JunqueIRA DE AZEVEdo, O Direito como Sistema Complexo e de $2^{a}$ Ordem; sua Autonomia. Ato Nulo e Ato Ilícito. Diferença de Espírito entre Responsabilidade Civil e Penal. Necessidade de Prejuízo para Haver Direito de Indenização na Responsabilidade Civil, in Estudos e Pareceres de Direito Privado, São Paulo, Saraiva, 2004, pág. 27.

${ }^{382}$ Diogo Leonardo Machado de Melo, Ainda sobre a Função Punitiva da Reparação dos Danos Morais (e a Destinação de Parte da Indenização para Entidades de Fins Sociais - Artigo 883, Parágrafo Único, do Código Civil de 2002), in Revista de Direito Privado, vol. 26, jun.-2006, págs. 105 e ss.

${ }^{383}$ Fernando NoronHA, Direito das Obrigações, vol. I, 2 $2^{\mathrm{a}}$ ed., São Paulo, Saraiva, 2007, pág. 536.

${ }^{384}$ Direito das Obrigações, vol. I, $2^{\text {a }}$ ed., São Paulo, Saraiva, 2007, págs. 540/541.
} 
fases da assim chamada Revolução Industrial. As modificações socioeconômicas decorrentes da Revolução, especialmente em seus primeiros momentos, permitiram a transformação de sociedades basicamente agrícolas e comerciais em sociedades mecanizadas, nas quais a produção industrial passasse a ser o "carro chefe" 385 .

Nessas sociedades industriais, mecanizadas, criaram-se novos meios de transporte, terrestre e aéreo, muitas vezes permitindo o transporte massificado, e, ainda, desenvolveram-se os meios de produção, substituindo-se homens por máquinas e ampliando-se em escala geométrica a velocidade de produção. Fez-se, dessa maneira, surgir toda uma vasta gama de novas “invenções criadoras de perigo" "386, cada uma delas apta expor o homem a riscos nunca antes imaginados.

Para além disso, decorreram da industrialização fenômenos sociais como a intensa urbanização (com o conseqüente adensamento das metrópoles e aumento das possíveis relações entre os homens) e a modificação das relações trabalhistas (com o desequilíbrio, na sociedade capitalista, da relação entre capital e trabalho, impondo-se à classe trabalhadora uma série de circunstâncias insalubres, tais como jornadas de trabalho excessivamente longas, submissão a condições arriscadas, etc.) ${ }^{387}$.

Todas estas modificações atingiram e intensificaram de forma mais que sensível os relacionamentos humanos, acarretando um "aumento vertiginoso, crescente $e$ invencível, de momentos e de motivos para colisões de direitos" 388 e tornando mais que necessária a existência de um instituto jurídico que adequadamente desse resposta à ilicitude, que compensasse prejuízos. Por esse motivo, já se afirmava que o instituto da responsabilidade civil era o tópico de maior interesse social em todo o âmbito jurídico ${ }^{389}$.

Nesse contexto, problema de primeira importância passou a ser a justa solução dos inúmeros conflitos então surgidos, observando-se que tantas inovações -

\footnotetext{
${ }^{385}$ Marco Fábio Morsello, Responsabilidade Civil no Transporte Aéreo, São Paulo, Atlas, 2007, pág. 3.

386 Alvino LIMA, Culpa e Risco, $2^{\mathrm{a}}$ ed. revista e atualizada por Ovídio Rocha Barros Sandoval, São Paulo, RT, 1998, pág. 113.

${ }^{387}$ Marco Fábio MoRsello, Responsabilidade Civil no Transporte Aéreo, São Paulo, Atlas, 2007, págs. 3/4.

388 Alvino LiMA, Culpa e Risco, $2^{\mathrm{a}}$ ed. revista e atualizada por Ovídio Rocha Barros Sandoval, São Paulo, RT, 1998, pág. 16. Ainda nesse sentido, cfr. Maria Alice Costa HofMEISTER, O Dano Pessoal na Sociedade de Risco, Rio de Janeiro, Renovar, 2002, pág. 96.
} 
tecnológicas, sociais e econômicas -, para além de aumentarem as possibilidades nas quais as pessoas poderiam vir a suportar prejuízos, passaram a impor aos prejudicados dificuldades ainda mais severas em obter a condenação do agente causador dos danos. Isso porque, uma vez fundada na culpa como único critério de imputação de responsabilidade, o instituto da responsabilidade civil exigia do lesado, para a procedência de seu pleito, a cabal comprovação desse elemento subjetivo - a culpa -; prova esta que se mostrava, muitas das vezes, verdadeiramente diabólica ${ }^{390}$.

Em face de situações verdadeiramente iníquas, em que se proporcionava nada mais do que a impunidade do lesante (ante à dificuldade - quando não verdadeira impossibilidade - de o lesado demonstrar a ocorrência de todos os elementos èépoca exigidos para a imputação da responsabilidade), passou-se a tornar evidente a insuficiência da teoria clássica da culpa para dar respostas adequadas aos inúmeros conflitos que passaram a surgir.

Partindo-se das premissas de que as exigências então prescritas para a imputação da responsabilidade eram de difícil verificação em um grande número de casos, e de que "certas atividades do homem criam um risco especial para outros homens" (em especial no contexto da Revolução Industrial, em que os riscos não apenas eram criados, mas eram novos, inusitados, surgindo onde antes sequer deles se cogitava), passou-se a cogitar que o exercício de determinados direitos ou a realização de determinadas atividades deveria, por si só, "implicar ressarcimento dos danos causados" ${ }^{391}$. Passou-se a clamar por mecanismos normativos mais aptos a assegurar o ressarcimento de danos, principalmente nas hipóteses em que não se podia mais cogitar, propriamente, de uma conduta claramente individualizada e imputável a um único responsável, que houvesse obrado com dolo ou negligência, e da qual houvesse resultado prejuízos.

A tentativa de superar as iniqüidades decorrentes da necessidade de alegar e provar a existência de culpa deu ensejo à adoção, inicialmente em sede doutrinária e

\footnotetext{
389 Alvino LiMA, Culpa e Risco, $2^{\text {a }}$ ed. revista e atualizada por Ovídio Rocha Barros Sandoval, São Paulo, RT, 1998, pág. 15.

390 Anderson SCHREIBER, Novos Paradigmas da Responsabilidade Civil: Da Erosão dos Filtros da Reparação à Diluição dos Danos, São Paulo, Atlas, 2009, págs. 17/19.

${ }^{391}$ Zelmo DenARI, Código Brasileiro de Defesa do Consumidor Comentado pelos Autores do Anteprojeto, $9^{\mathrm{a}}$ ed., Rio de Janeiro, Forense Universitária, 2007, pág. 187.
} 
jurisprudencial, de uma série de medidas destinadas a facilitar o acesso do lesado ao pronto e justo ressarcimento ${ }^{392}$. Entre tais medidas, surgiu com grande destaque, pela eficiência em dar resposta aos clamores acima analisados, a concepção de responsabilização pelo risco (a assim chamada responsabilidade objetiva), e não mais pela culpa, o que permitira verdadeiramente dar ensejo ao ressarcimento de eventuais prejuízos resultantes da realização de determinados atos, ou de determinadas atividades (os quais expunham os seres humanos a riscos), independentemente da alegação e comprovação de culpa ${ }^{393}$.

Surgia a teoria do "risco proveito" (a qual, resumida no brocardo "ubi emolumentum, ibi onus”, imputa a responsabilidade àquele que extrai proveitos econômicos da atividade de risco por ele levada a efeito, hipótese característica da atividade industrial: lucrativa, mas arriscada), posteriormente substituída pela teoria do "risco criado", mais ampla que a anterior, capaz que é de abarcar todas as atividades de risco, ainda que delas não se extraia proveitos econômicos ${ }^{394}$.

Assim é que, como anota Anderson SCHREIBER, "a responsabilidade objetiva veio a ser adotada em quase todos os ordenamentos jurídicos, por meio de leis especiais, aplicáveis a setores específicos, relacionados aos anseios sociais mais graves no campo da responsabilidade civil" 395.

Nesse contexto, teve no Brasil papel de grande relevância o Decreto 2.681/1912 (o qual regulava a responsabilidade civil das estradas de ferro). A despeito de se prever textualmente, em seus arts. $1^{\circ}$ e 17 , que a responsabilização das estradas de ferro ocorreria presumindo-se sua culpa, fato é que, pelas excludentes de responsabilidade previstas nos mesmos artigos [relacionadas apenas à relação de causalidade entre a atividade e o dano, notadamente o caso fortuito ou força maior e a culpa (rectius: fato) da vítima],

\footnotetext{
392 Anderson SchreIBER, Novos Paradigmas da Responsabilidade Civil: Da Erosão dos Filtros da Reparação à Diluição dos Danos, São Paulo, Atlas, 2009, pág. 18.

${ }^{393}$ Cláudio Luiz Bueno de GodoY, Responsabilidade Civil pelo Risco da Atividade, São Paulo, Saraiva, 2009 , pág. 14.

394 Teresa Ancona LoPEZ, Princípio da Precaução e Evolução da Responsabilidade Civil, São Paulo, Quartier Latin, 2010, págs. 44/45. Sobre as duas teorias, cfr. B. STARCK, Essai d'une Théorie Générale de la Responsabilité Civile Considèrèe em as Double Fonction de Garantie et de Peine Privèe, Paris, L. Rodstein, 1947, págs. 18/21.

395 Novos Paradigmas da Responsabilidade Civil: Da Erosão dos Filtros da Reparação à Diluição dos Danos, São Paulo, Atlas, 2009, pág. 19.
} 
podia-se falar em verdadeira responsabilidade objetiva, e não apenas em presunção de culpa $^{396}$.

Após a promulgação do aludido decreto em nosso país, nota-se uma verdadeira expansão das hipóteses em que se admitia a objetivação da responsabilidade, instituto que encontrou guarida no art. 1.529 do $\mathrm{CC} / 1916^{397}$ e que acabou pontuando uma série de leis esparsas, tais como a legislação sobre acidentes de trabalho (constituída pelo Decreto 3.724/1919, pelo Decreto 24.637/1934, pelo Decreto 7.036/1944, pela Lei 5.316/1967 e, finalmente, pela Lei 6.367/197), sobre responsabilidade civil por danos nucleares (Lei 6.453/1977) e sobre responsabilidade civil das agências de empregados (Lei 7.195/1984), etc. ${ }^{398}$. Tal evolução veio a culminar na adoção, pelo Código de Defesa do Consumidor, de um sistema de responsabilização objetiva do fornecedor de produtos ou serviços (previsto nos arts. 12 e 18, do CDC) e, finalmente, na previsão de uma cláusula geral de responsabilidade objetiva pelo risco da atividade (no art. 927, do CC/2002).

Do breve excurso acima apresentado, verifica-se a evolução pela qual passou o primeiro dos paradigmas tradicionais da responsabilidade civil: na mudança do século XIX para o século XX, substituem-se, como "pivôs da responsabilidade civil", as figuras do sujeito, causador do dano, e, principalmente, da conduta por ele perpetrada ${ }^{399}$, pelas figuras da vítima e do prejuízo por ela suportado. Substitui-se a idéia da indenização como sanção voltada a remediar uma conduta ilícita e culposa (aí imbuídos todos os aspectos morais que levavam à reprovação da culpa) pela de "reparação do dano injusto"

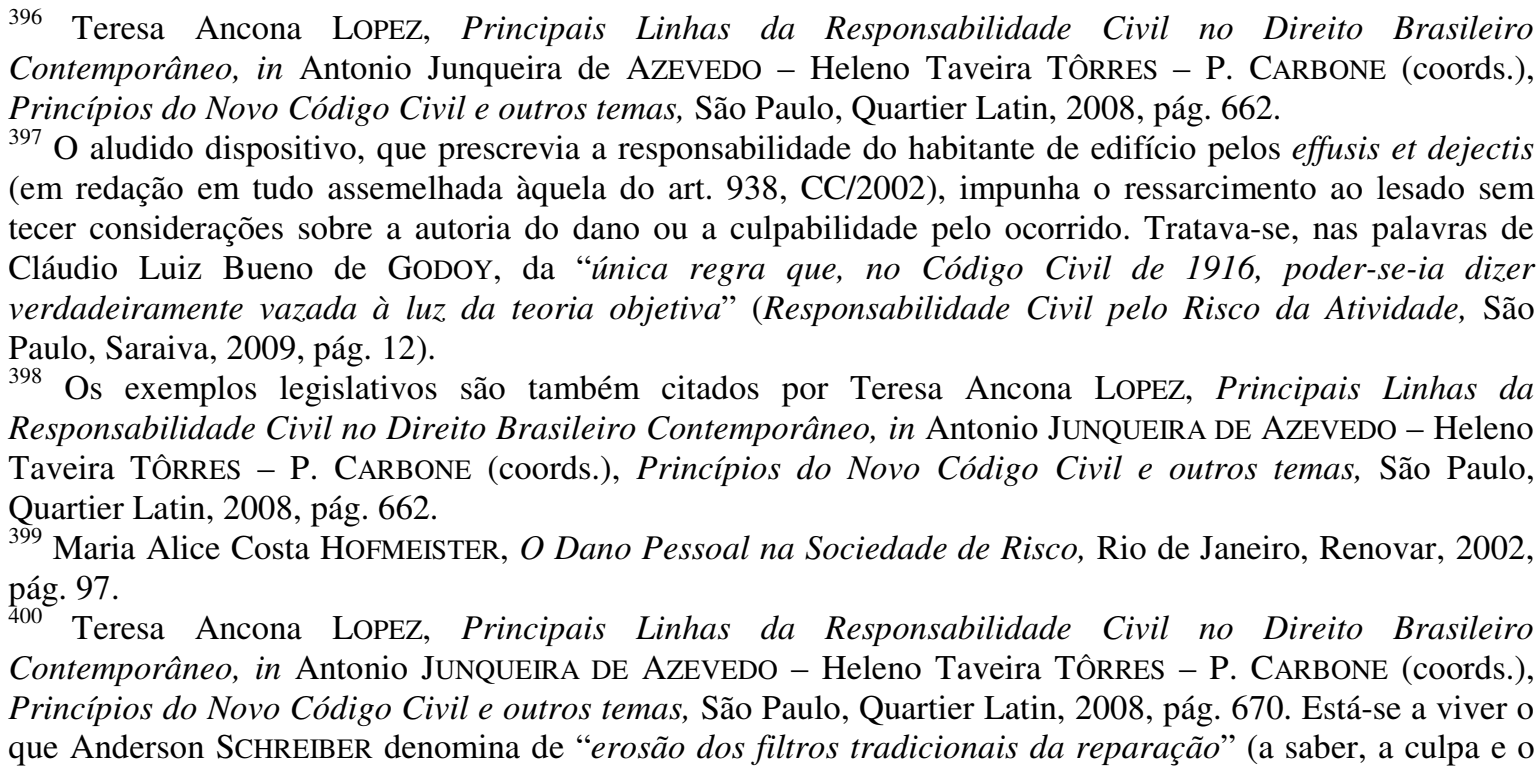


Na mesma medida em que as evoluções socioeconômicas acima narradas ensejaram, por seu impacto no sistema jurídico, uma sensível ruptura no paradigma tradicional da responsabilidade fundada na culpa (acarretando o surgimento das teorias que fundamentaram a responsabilidade objetiva), elas também promoveram, pelas mesmas razões, uma alteração no paradigma da responsabilidade individual (acarretando o surgimento do segundo fenômeno acima apontado, que se passou a denominar de coletivização da responsabilidade ou socialização dos riscos).

Com o advento da Revolução Industrial e de todos os reflexos sociais que se lhe seguiram (em especial a urbanização, a massificação da produção e as transformações que se sucederam no âmbito das relações de trabalho), “[à]s tragédias individuais”, típicas da economia mercantilista que vigorava até então, "somaram-se as tragédias coletivas", características de uma sociedade de massa, em que se multiplicam as circunstâncias nas quais os direitos conflitam e, conseqüentemente, nas quais os prejuízos afloram ${ }^{401}$. Ao passo que as atividades (industrializadas, mecanizadas e massificadas) passam a impactar um maior número de pessoas (consumidores de serviços e produtos, trabalhadores, etc.), elas também expõem esse mesmo número de pessoas aos riscos delas decorrentes, acarretando, dessa maneira, uma multiplicação dos danos e, conseqüentemente, uma multiplicação das indenizações. Tal fenômeno se torna ainda mais sensível quando se observa, ao lado do crescimento do número de pessoas prejudicadas pelas atividades empresariais (de risco), o desenvolvimento e alastramento da responsabilidade objetiva, do qual resulta um crescimento exponencial do número de indenizações concedidas (a denominada "erosão dos filtros de reparação" é causa da facilitação no acolhimento das demandas indenizatórias e, como consequiência, do maior número de condenações).

Atingido pelos fenômenos acima narrados, e com forte fundamento ético no princípio da solidariedade social, o instituto da responsabilidade civil passou a sofrer, como já se expôs, com uma transferência de foco: mais do que sancionar o ofensor pela

nexo de causalidade), dada a menor importância que tais elementos (e, para o que se expõe no momento, toma-se com especial atenção o elemento culpa) vêm encontrando para a fixação das regras de imputação ou para a efetiva e pronta reparação dos prejuízos (Novos Paradigmas da Responsabilidade Civil: Da Erosão dos Filtros da Reparação à Diluição dos Danos, São Paulo, Atlas, 2009, págs. 11/12). 
conduta reprovável por ele perpetrada e pelos prejuízos por ele impostos à vítima, passa-se a cogitar da necessidade de reparar pronta e adequadamente os prejuízos suportados por esta mesma vítima ${ }^{402}$. Tal transferência de foco (do causador do dano, para a vítima dos prejuízos), acarretou uma modificação no sistema, o qual passou a deixar de lado, em determinados casos, as regras de imputação da responsabilidade para, mais do que pensar em uma "dívida de responsabilidade" (a ser paga pelo ofensor, após sua identificação e a aferição da existência de todos os pressupostos para a sua responsabilização), passar-se a perseguir um "crédito de indenização" (a ser recebido pela vítima) ${ }^{403}$.

Para assegurar que tal "crédito de indenização" fosse recebido em todas as inúmeras hipóteses em que surgissem prejuízos (mesmo naquelas em que houvesse grande dificuldade - ou, até mesmo, impossibilidade - de se aferir a existência de todos os elementos necessários para a responsabilização de alguém), desenvolveu-se o que se passou a denominar de coletivização da responsabilidade, ou "socialização dos riscos", fenômeno este que, nas palavras de Fernando NorONHA, impõe o "declínio da responsabilidade individual, perante o desenvolvimento de processos comunitários para a reparação de diversos danos, especialmente os que atingem a integridade física ou psíquica das pessoas" ${ }^{404}$.

Tais danos, continua o citado autor, "são postos a cargo de todo um grupo social, ou mesmo de toda a sociedade", essencialmente por meio de duas circunstâncias: (i) o desenvolvimento do contrato de seguro de responsabilidade civil, o qual "passa a garantir melhor a reparação do dano sofrido pelo lesado, ao mesmo tempo que alivia o ônus incidente sobre o responsável: este fica transferido para a coletividade das pessoas que exercem uma mesma atividade, geradora do mesmo risco, e que são quem paga os prêmios relativos ao seguro respectivo"; e (ii) o "desenvolvimento da seguridade social", a

\footnotetext{
${ }^{401}$ Maria Alice Costa Hofmeister, O Dano Pessoal na Sociedade de Risco, Rio de Janeiro, Renovar, 2002, pág. 95. Em sentido semelhante, Cláudio Luiz Bueno de Godoy, Responsabilidade Civil pelo Risco da Atividade, São Paulo, Saraiva, 2009, pág. 13.

${ }_{402}$ Teresa Ancona LOPEZ, Princípio da Precaução e Evolução da Responsabilidade Civil, São Paulo, Quartier Latin, 2010, pág. 51 e Anderson SCHREIBER, Novos Paradigmas da Responsabilidade Civil: Da Erosão dos Filtros da Reparação à Diluição dos Danos, São Paulo, Atlas, 2009, págs. 216/217. Sobre o princípio da solidariedade e seus reflexos nos diversos âmbitos do Direito Privado, cfr. Rosa Maria de Andrade Nery, Introdução ao Pensamento Jurídico e à Teoria Geral do Direito Privado, São Paulo, RT, 2008, págs.239/247.

${ }^{403}$ Maria Alice Costa Hofmeister, O Dano Pessoal na Sociedade de Risco, Rio de Janeiro, Renovar, 2002, págs. 100/101.

${ }^{404}$ Direito das Obrigações, vol. I, $2^{\text {a }}$ ed., São Paulo, Saraiva, 2007, pág. 540.
} 
qual "tem um objetivo que vai além do da previdência social: visa garantir a reparação, a cargo da própria sociedade, dos principais danos corpóreos que as pessoas podem sofrer, como a morte e a incapacidade para o trabalho" ${ }^{405}$.

A despeito de o desenvolvimento da contratação de seguros privados se dar em direção à coletivização da responsabilidade, bem aponta Teresa Ancona LoPEZ que " $a$ verdadeira 'socialização dos riscos' é aquela na qual há a difusão do seguro obrigatório e a criação dos Fundos estatais ou também de fundos que, além das reservas provindas do Poder Público, se mantém com a contribuição financeira das empresas que mais expõem a riscos a sociedade ${ }^{\text {406 }}$. Nesse contexto, em que se passa a prestar muito mais atenção aos prejuízos sofridos pela vítima e à necessidade de pronta reparação, independentemente das causas, "perde importância a fundamentação da responsabilidade na teoria da culpa ou do risco "407. Deixa-se, então, de perquirir sobre as regras de imputação, de procurar pelo responsável pelo dano causado, para passar a analisar tão-somente quem é a vítima e quanto ela perdeu. Retiram-se, por completo, os holofotes do ofensor e da conduta por ele perpetrada para focalizar apenas o prejuízo e o prejudicado, buscando-se, dessa sorte, o ressarcimento integral do prejuízo, e a eliminação de todos os prejuízos suportados.

Em atenção a essas circunstâncias, talvez o exemplo mais completo, inovador e criativo no que toca à socialização dos riscos seja aquele adotado pelo ordenamento jurídico da Nova Zelândia ${ }^{408}$. Após a edição do Accident Compensation Act 1972, que entrou em vigor em $1^{\circ}$ de abril de 1974, passou-se a lançar mão de um sistema complexo que busca a mais ampla e irrestrita compensação de todos os danos pessoais suportados por pessoas residentes, domiciliadas, ou em trânsito pela Nova Zelândia, sem a necessidade de perquirir sobre as causas do acidente, sobre regras de imputação ou sobre as características subjetivas das condutas levadas a cabo pelo causador de danos. Foca-se, com especial atenção, a vítima e o prejuízo por ela suportados, buscando-se nada mais do que sua pronta reparação.

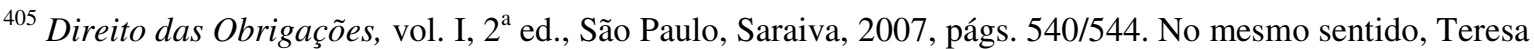
Ancona LOPEZ, Princípio da Precaução e Evolução da Responsabilidade Civil, São Paulo, Quartier Latin, 2010, pág. 51.

${ }^{406}$ Princípio da Precaução e Evolução da Responsabilidade Civil, São Paulo, Quartier Latin, 2010, pág. 51.

407 Teresa Ancona LoPEZ, Princípio da Precaução e Evolução da Responsabilidade Civil, São Paulo, Quartier Latin, 2010, pág. 53.

${ }^{408}$ Maria Alice Costa HOFMEISTER, O Dano Pessoal na Sociedade de Risco, Rio de Janeiro, Renovar, 2002, págs. 110/111.
} 
Ao tratar do tema, Teresa Ancona LOPEZ procura resumi-lo em suas cinco principais características $^{409}$, a saber: (1) a indenização das vítimas é custeada pelo Estado neozelandês (o que se faz por meio da criação de diversos fundos públicos, geridos por um órgão controlador denominado de Accident Compensation Corporation, cada qual destinado à compensação de uma sorte específica de prejuízos ${ }^{410}$ ); (ii) as características subjetivas da conduta do ofensor (i.e., se ele se conduziu com culpa ou dolo) não importam para a atribuição ou quantificação da reparação dos danos ${ }^{411}$; (iii) a indenização resultante do Accident Compensation Act alcança todas as pessoas que estiverem em trânsito no território neozelandês, ainda que nele não residam ou sejam nele domiciliados ${ }^{412}$; (iv) não há a necessidade de ajuizamento de demandas judiciais para obter a reparação; e, em razão da introdução desse sistema de socialização dos $\operatorname{riscos}^{413}$, (v) suprime-se o direito de ajuizar demandas indenizatórias em face dos causadores de dano ${ }^{414}$.

O sistema neozelandês, o qual ainda permanece em vigor em moldes muito semelhantes àqueles de sua inovadora origem (apesar de ter sofrido com uma série de

${ }^{409}$ Princípio da Precaução e Evolução da Responsabilidade Civil, São Paulo, Quartier Latin, 2010, pág. 53.

410 Sobre o tema, cfr. Maria Alice Costa HofMEISTER, O Dano Pessoal na Sociedade de Risco, Rio de Janeiro, Renovar, 2002, págs. 110/112. As atribuições da Accident Compensation Corporation se encontram previstas nas Sections 6 a 42 do Accident Compensation Act 1972, enquanto que os diversos fundos públicos a custear o reembolso dos prejuízos decorrentes de acidentes pessoais estão previstos na Section 31 e nas Sections 54 e ss., do mesmo Act.

${ }^{411}$ Com efeito, os dispositivos que versam especificamente sobre a indenização referem-se exclusivamente à vítima e aos prejuízos por ela suportados, tornando irrelevantes as considerações a respeito do ofensor (ou das características subjetivas de sua conduta). Veja-se, por exemplo, a Section 55(1), que, ao versar sobre a indenização de prejuízos suportados por trabalhadores, prescreve que: "[s]ubject to the provisions of this Act, all persons who suffer personal injury by accident in New Zeland and are earners at the time of the accident shall have cover in respect of the injury under the earners' scheme." Disposições semelhantes se encontram na Section 92, que versa sobre a compensação de prejuízos suportados em razão de acidentes automobilísticos e, ainda, da Section 102B, que versa sobre a indenização de prejuízos resultantes de acidentes não cobertos pelas duas seções previamente analisadas.

${ }_{412}$ É justamente o que se extrai da leitura das Sections 55(1), 92 e 102B, acima referidas.

${ }^{413}$ As solicitações para o recebimento de indenização em decorrência de acidentes previstos pelo Accident Compensation Act devem ser feitas diretamente a agentes com poder delegado pela comissão gestora dos fundos estatais, sem a necessidade de ajuizamento de demandas cíveis em face do causador do dano. Os procedimentos para tanto são previstos nas Sections 139 a 169, do Accident Compensation Act 1972.

${ }^{414}$ Assim prescrevia a Section 5(1) do Accident Compensation Act 1972: "[s]ubject to the provisions of this section, where any person suffers personal injury by accident in New Zeland or dies as a result of personal injury so suffered, or where any person suffers outside New Zeland personal injury by accident in respect of which he has cover under this Act or dies as a result of personal injury so suffered, no proceedings for damages arising directly or indirectly out of the injury or death shall be brought in any Court in New Zeland independently of this Act, whether by that person or any other person, and whether under any rule of law or any enactment". Também sobre o tema, cfr. Maria Alice Costa HofMEIsTER, O Dano Pessoal na Sociedade de Risco, Rio de Janeiro, Renovar, 2002, pág. 112. 
avanços e retrocessos durante seus quase quarenta anos de história ${ }^{415}$ ), não deixou de suportar uma série de severas críticas, quer por trazer impactos negativos no orçamento governamental, quer, ainda e principalmente, por representar um sensível enfraquecimento da função preventiva no que toca às atividades de risco ${ }^{416}$.

No Brasil, certamente tiveram papel de grande relevância no contexto da socialização dos riscos o desenvolvimento da legislação sobre os seguros obrigatórios (Decreto 61.867/1967, que estipulou a contratação de seguros de responsabilidade civil por proprietários de veículos automotores, pelos construtores de imóveis em zonas urbanas, pelos transportadores aéreos, etc.) e sobre a indenização dos acidentes de trabalho. Em ambos os casos, está-se diante da criação de seguros obrigatórios ou fundos públicos destinados ao custeio das indenizações devidas em razão da ocorrência de acidentes.

Em paralelo a todo este movimento em prol da facilitação da reparação dos prejuízos suportados em decorrência das inúmeras inovações socioeconômicas pelas quais passou a humanidade nos últimos séculos (levada a efeito pela objetivação da responsabilidade e pela socialização dos riscos), a "necessidade sentida pela sociedade de não deixar dano nenhum sem reparação" deu ensejo a um último fenômeno: a expansão dos danos suscetíveis de reparação ${ }^{417}$. Tal fenômeno, nas palavras de Anderson SCHREIBER, desenvolveu-se essencialmente em duas vertentes: (i) por meio do reconhecimento da necessidade de tutela dos interesses existenciais, do que resulta a admissão da indenização por danos morais; e (1i) o reconhecimento dos interesses metaindividuais ou transindividuais como dignos de proteção e, conseqüentemente, de ressarcimento em caso de violação ${ }^{418}$.

\footnotetext{
415 Sobre as posteriores alterações legislativas do Accident Compensation Act 1972, cfr. Anderson SCHREIBER, Novos Paradigmas da Responsabilidade Civil: Da Erosão dos Filtros da Reparação à Diluição dos Danos, São Paulo, Atlas, 2009, págs. 230/231.

${ }^{416}$ Sobre as críticas ao sistema neozelandês, cfr. Teresa Ancona LOPEZ, Princípio da Precaução e Evolução da Responsabilidade Civil, São Paulo, Quartier Latin, 2010, pág. 55. Retomaremos, abaixo, as consequiências negativas decorrentes do sistema de socialização dos riscos para o adequado desempenho da função preventiva da responsabilidade civil.

${ }^{417}$ Fernando NORONHA, Direito das Obrigações, vol. I, $2^{\text {a }}$ ed., São Paulo, Saraiva, 2007, pág. 541.

${ }^{418}$ Novos Paradigmas da Responsabilidade Civil: Da Erosão dos Filtros da Reparação à Diluição dos Danos, São Paulo, Atlas, 2009, pág. 83. A essas duas vertentes, Fernando NORONHA ainda adiciona uma terceira, a qual denomina de "diminuição das exigências para o reconhecimento de certos danos" (Direito das Obrigações, vol. I, $2^{\mathrm{a}}$ ed., São Paulo, Saraiva, 2007, pág. 542). Tal situação nos parece assemelhada à que Anderson SCHREIBER demomina de "erosão dos filtros da reparação" e que, portanto, compreendemos ser melhor tratada quando dissertamos sobre a objetivação da responsabilidade.
} 
Quanto à primeira das duas vertentes acima enumeradas, vale ressaltar que a valorização dos interesses existenciais deu-se recentemente, "fruto de elaborações doutrinárias germânica e francesa da segunda metade do século XIX" "419. A partir de tais desenvolvimentos doutrinários, o lançar de olhos para o "interior" do indivíduo fez com que se passasse a considerar a ocorrência de uma nova sorte de prejuízos. Não mais aqueles concretamente aferíveis, refletidos apenas em uma redução patrimonial sensível, mas, sim, verificáveis no âmago do ser humano.

Surgiu, nesse contexto, a categoria dos prejuízos (ou detrimentos) ditos morais, ou extrapatrimoniais, prejuízos estes cuja indenização, em um primeiro momento, ainda sob a vigência do Código Civil de 1916, era reputada como inadmissível. Fundamentava-se a oposição doutrinária e jurisprudencial, entre outros argumentos igualmente rechaçáveis, na inexistência de previsão expressa para a reparação dos prejuízos morais no $\mathrm{CC} / 1916^{420}$ e na idéia, então prevalecente, de que não se poderia reparar prejuízos de ordem moral, uma vez que não se poderia atribuir preço à dor ${ }^{421}$.

Tais objeções foram devidamente combatidas pela evolução doutrinária, jurisprudencial e legislativa ${ }^{422}$; que culminou com a elevação da dignidade da pessoa humana a garantia constitucional e fundamento da República Federativa do Brasil (art. $1^{\circ}$,

\footnotetext{
419 Gustavo TePedino, A Tutela da Personalidade no Ordenamento Civil-Constitucional Brasileiro, in Temas de Direito Civil, 4a ed., Rio de Janeiro, Renovar, 2008, pág. 26.

${ }^{420}$ Apesar da opinião de Clóvis BEVILÁQUA, que fundamentava a possibilidade de indenização dos danos morais na previsão contida no art. 76, CC/1916, de que para propor ou contestar uma ação seria necessário legítimo interesse econômico ou moral. Sustentava o autor que "se o interesse moral justifica a ação para defendê-lo ou restaurá-lo, é claro que tal interesse é indemnizavel, ainda que o bem moral se não exprima em dinheiro. É por uma necessidade os nossos meios humanos, sempre insufficientes, e, não raro, grosseiros, que o direito se vê forçado a acceitar que se computem em dinheiro o interesse de affeição e os outros interesses moraes.” (Código Civil dos E. U. B., vol. I, ed. histórica, $7^{\text {a }}$ tiragem, Rio de Janeiro, Estácio de Sá, 1975, pág. 321)

${ }^{421}$ Clayton REIS, Dano Moral, $3^{\text {a }}$ ed., Rio de Janeiro, Forense, 1994, pág. 49.

${ }^{422}$ Exerceram papel de extrema relevância, nesse processo da evolução legislativa brasileira: (i) a Lei 4.117/1962 (Código Brasileiro das Telecomunicações), que previu, em seu art. 81 (em sua redação original, antes de ser revogado pelo DL 236/1967), independentemente da responsabilidade criminal, a indenização por danos morais decorrentes de calúnia, difamação ou injúria cometidas por meio de radiodifusão; (ii) a Lei 4.737/1965 (Código Eleitoral Brasileiro), que previu, em seu art. 247, $\S \S 1^{\circ}$ e $2^{\circ}$ (em redação atribuída pela Lei 4.961/1966), independentemente da responsabilidade criminal, a indenização por danos morais decorrentes de calúnia, difamação ou injúria perpetrados por meio de propaganda eleitoral; (iii) a Lei 5.250/1967 (Lei de Imprensa), que previu, em seus arts. 53, 56 e 57, a indenização por danos morais decorrentes do exercício das atividades regulamentadas naquela lei; e (iv) a Lei 5.988/1973 (Lei de Direitos Autorais), que previu, em seu art. 126 (em sua redação original, antes de ser revogado pela Lei 9.610/1998), a indenização por danos morais do autor que tivesse obra intelectual sua reproduzida sem o devido crédito.
} 
III, $\mathrm{CF} / 88)^{423}$ e a admissão da indenização por danos meramente morais em âmbito constitucional (art. 5 $5^{\circ}, \mathrm{V}$ e X, CF/88) ${ }^{424}$ e infraconstitucional (art. 186, CC/2002, que expressamente prevê a responsabilização daquele que causar dano "ainda que exclusivamente moral"). Tal processo evolutivo concluiu pela substituição da idéia de que toda a indenização exerceria apenas uma função reparatória (recompondo o patrimônio do lesado, por meio da busca, no máximo grau possível, de retorno deste patrimônio ao status quo anterior à prática do ato ilícito e à ocorrência do prejuízo) pela noção de que a indenização dos detrimentos morais admite uma função compensatória.

Diz-se, então, que a pecúnia, na indenização por detrimentos morais, não representa a eliminação do prejuízo e suas conseqüências - fato este que seria, ademais, de todo impossível -, mas, sim, uma compensação para a vítima ${ }^{425}$, um alento que os bens e vantagens que se podem adquirir por meio da pecúnia têm o condão de trazer. Por meio dessa compensação, procura-se atenuar, ainda que de maneira indireta, as consequiências do sofrimento suportado pelo lesado ${ }^{426}$.

Verificou-se, assim, "uma construção metódica e progressiva dos elementos fornecidos pela doutrina e jurisprudência" ${ }^{427}$ para a tutela e devida compensação dos detrimentos morais, proporcionando, dessa maneira, uma ampla indenização dos prejuízos suportados em decorrência de atividades de risco.

Por fim, quanto à segunda das duas vertentes acima apontadas, viu-se que os desenvolvimentos pelos quais passou a sociedade nos últimos séculos, principalmente no

\footnotetext{
${ }^{423}$ No dizer de Sérgio CAVALIERI FILHO, “a atual Carta, na trilha das demais Constituições elaboradas após a eclosão da chamada questão social, colocou o Homem no vértice do ordenamento jurídico da Nação, fez. dele a primeira e decisiva realidade, transformando os seus direitos no fio condutor de todos os ramos jurídicos.” (Programa de Responsabilidade Civil, 6ª ed., São Paulo, Malheiros, 2005, pág. 100).

${ }_{424}$ Nesse sentido, Clóvis Veríssimo do Couto e SILVA afirma que, após o advento da Constituição da República de 1988, com a introdução expressa dos dispositivos insculpidos no art. $5^{\circ}, \mathrm{V}$ e X, passou-se a poder "afirmar a existência do princípio da reparação de um dano moral com generalidade, fora das regras do Código Civil Brasileiro." (O Conceito de Dano no Direito Brasileiro e Comparado, in Revista dos Tribunais, ano 80, vol. 667, mai/1991, pág. 14).

${ }^{425}$ Yussef Said CAHALI, Dano Moral, $2^{\mathrm{a}}$ ed., São Paulo, RT, 1998, pág. 42.

${ }^{426}$ Sérgio CAVAliERI FILHo, Programa de Responsabilidade Civil, 6 ${ }^{\text {a }}$ ed., São Paulo, Malheiros, 2005, pág. 103. Também nesse sentido, ao versar sobre a finalidade da função compensatória da indenização dos detrimentos morais, B. R. KERN afirma que "[a] função de compensação deve reparar tanto as dores sofridas como a perda da alegria de viver. Ao ofendido têm de ser 'oferecidas vantagens de outra natureza por seu prejuízo imaterial'”. (A Função de Satisfação na Indenização do Dano Pessoal, in Revista de Direito do Consumidor, n. ${ }^{\circ} 33$, janeiro/março 2000, pág. 10).

${ }^{427}$ Clayton REIS, Dano Moral, $3^{\mathrm{a}}$ ed., Rio de Janeiro, Forense, 1994, pág. 74.
} 
que concerne a seus aspectos científicos e industriais, aumentou vertiginosamente a potencialidade lesiva da autonomia privada: a produção em massa (contraposta ao consumo, também massificado), o acesso a meios de transporte coletivos, a utilização de fontes de energia mais produtivas, mas menos seguras, todos esses fenômenos acarretaram um aumento sensível no risco a que se expõe a humanidade. Mais grave do que isso, os riscos decorrentes de tais atividades muitas vezes se concretizam em acidentes de grandes proporções, capazes de lesar não apenas um único indivíduo, mas a todo um grupo social ou, até mesmo, toda a humanidade (basta pensar em acidentes de consumo decorrentes de defeitos de concepção de remédios, aptos a atingirem um grande grupo de consumidores, ou, ainda, em acidentes que causem danos ambientais, tais como os que atingem mananciais, capazes de prejudicar toda uma comunidade $)^{428}$.

Nesse ponto, bem anota Anderson SchreIBER que a dificuldade de se enquadrar a tutela aos prejuízos e interesses coletivos (em sentido lato) em um esquema dogmático todo desenvolvido para a tutela dos interesses individuais foi superada pelo desenvolvimento dos instrumentos processuais, que passaram a admitir as ações coletivas (como a ação popular, prevista na Lei 4.717/1965, e a ação civil pública, prevista na Lei $7.347 / 1985)^{429}$. Tomando-se por base a ação civil pública, que visa a sancionar as condutas ou atividades que tenham atingido interesses metaindividuais e, como consequiência, causado prejuízos capazes de atingir toda uma coletividade (exemplificativamente previstos no art. $1^{\circ}$, da Lei 7.347/1985, tais como os danos causados ao meio ambiente, ao consumidor, ao patrimônio de valor artístico, histórico, turístico ou paisagístico, etc.), vêse que seu desenvolvimento a tornou um instrumento apto a atuar sobre uma cláusula geral de proteção de interesses coletivos (especialmente após ter seu âmbito de atuação ampliado pela edição do Código de Defesa do Consumidor, o qual, em seus arts. 81 e ss., regrou a proteção dos interesses transindividuais relacionados ao consumidor) e a perseguir, como fim último, "o desenvolvimento equilibrado e a ordem social" $"$ "30.

\footnotetext{
428 Anderson SCHREIBER, Novos Paradigmas da Responsabilidade Civil: Da Erosão dos Filtros da Reparação à Diluição dos Danos, São Paulo, Atlas, 2009, pág. 84 e Fernando NoronHA, Direito das Obrigações, vol. I, $2^{a}$ ed., São Paulo, Saraiva, 2007, pág. 542.

429 Anderson SCHREIBER, Novos Paradigmas da Responsabilidade Civil: Da Erosão dos Filtros da Reparação à Diluição dos Danos, São Paulo, Atlas, 2009, págs. 84/85.

${ }^{430}$ Caroline VAZ, Funções da Responsabilidade Civil - Da Reparação à Punição e Dissuasão - Os punitive damages no Direito Comparado e Brasileiro, Porto Alegre, Livraria do Advogado, 2009, pág. 150.
} 
Vê-se, enfim, que ao longo dos últimos séculos a responsabilidade civil passou por uma radical transformação: consolidado na era moderna como um instituto fundado em três paradigmas clássicos (a saber, a responsabilidade individual, a responsabilidade fundada na culpa e o paradigma ressarcitório), dois deles foram mitigados em razão das modificações socioeconômicas pelas quais passou a humanidade desde a Revolução Industrial. Ocorre que, a despeito de o desenvolvimento da responsabilidade civil ter impactado seus dois primeiros paradigmas tradicionais, o mesmo não se pode dizer sobre o paradigma resarcitório, o qual persistiu quase que intocado ${ }^{431}$.

Procurar-se-á, a partir deste ponto, expor as razões pelas quais se entende que os fenômenos sociais, econômicos e jurídicos acima narrados tornaram o paradigma ressarcitório incapaz de sancionar adequadamente todas as condutas ilícitas e atividades de risco aptas a causar prejuízos ao homem e à sociedade em geral. Quer-se acreditar, como abaixo será demonstrado, que a linha evolutiva pela qual passa o instituto da responsabilidade civil ainda não atingiu um estágio definitivo, reservando-se claro espaço para que também seu último paradigma tradicional tenha sua importância diluída, tudo com fins a assegurar uma tutela jurídica adequada do equilíbrio social.

\section{INSUFICIÊNCIAS DO PARAdIGMA REPARATÓRIO E A ADOÇÃo DA INDENIZAÇÃo PUNITIVA}

\section{II.I. Responsabilidade civil: objetivação, coletivização e a queda da prevenção}

Do breve excurso histórico acima exposto, pôde-se verificar que o instituto da responsabilidade civil caminhou para que se desse cada vez menos importância aos aspectos anímicos da conduta perpetrada pelo ofensor, relegando-se a culpa para segundo plano, enquanto se alocava, para assumir papel de primeira importância, a vítima e o prejuízo por ela suportado. Tal fenômeno, inegavelmente, atingiu de maneira negativa as perspectivas de que a responsabilidade civil viesse a atuar adequadamente como um instrumento moralizador de condutas ilícitas.

431 André Gustavo Corrêa de ANDRADE, Dano Moral e Indenização Punitiva: Os punitive damages na 
Por um lado, e como acima já se adiantou, o desenvolvimento da socialização dos riscos, sem que se adotasse um sistema de atuação paralela, que, ao mesmo tempo, permitisse a indenização mais ampla e imediata possível e o adequado sancionamento das condutas ilícitas cometidas, em atenção a seu grau de reprovabilidade, acabou por enfraquecer sensivelmente as possibilidades de a responsabilidade civil ser utilizada como um instituto apto a prevenir condutas ilícitas ou atividades de risco.

Explica-se: com o escopo de assegurar a pronta e integral reparação de todos os prejuízos suportados pelo corpo social, construiu-se um sistema indenizatório marcado pelo afloramento dos contratos de seguro de responsabilidade civil e pelo desenvolvimento da seguridade social, com a instituição de uma série de fundos públicos destinados a custear a reconstrução do patrimônio lesado. Se, de um lado, tal sistema permitiu que as vítimas tivessem fácil (e certo) acesso à reparação (impedindo, inclusive, que as condenações levassem o ofensor à insolvência civil, o que, ainda que em via indireta, poderia impedir ou reduzir a reparação de algumas das vítima lesadas), de outro, possibilitou que os agentes causadores de prejuízos transferissem licitamente os riscos de sua atividade (e, com eles, a obrigação de suportar os custos das condenações resultantes dos prejuízos causados) às empresas seguradores por eles custeadas, ou aos fundos de gestão pública, custeados por toda a sociedade. Chegou-se, inclusive, a construir entendimento doutrinário e jurisprudencial no sentido de admitir que as vítimas demandassem diretamente as empresas seguradoras (responsáveis pela gestão dos contratos de seguro facultativo de responsabilidade civil), facilitando-se ainda mais o acesso das vítimas à indenização (e, de outro lado, dispensando os verdadeiros causadores de prejuízos dos inconvenientes de, ao menos em um primeiro momento, ter de suportar os custos da litigância decorrentes da demanda movida pelas vítimas e de ter de ajuizar a subseqüente e, até então indispensável, demanda regressiva em face da empresa seguradora, exigida pelo art. 70, III, do CPC $)^{432}$.

experiência do common law e na perspectiva do Direito brasileiro, Rio de Janeiro, Forense, 2006, pág. 242. ${ }^{432}$ Em doutrina, cfr. Luciano de Camargo PenTEAdo, Efeitos Contratuais Perante Terceiros, São Paulo, Quartier Latin, 2007, págs. 57/74. Na jurisprudência, a despeito da inexistência de relação jurídica direta entre o terceiro lesado e a empresa seguradora (que mantém contrato de seguro com o autor do prejuízo), nossos Tribunais vem admitindo que o lesado deduza em juízo sua pretensão indenizatória diretamente em face da empresa segurador. Nesse sentido: "Processual civil. Recurso Especial. [...] Acidente de trânsito. Culpa do segurado. Ação indenizatória. Terceiro prejudicado. Seguradora. Legitimidade passiva ad causam. [...]. - A ação indenizatória de danos materiais, advindos do atropelamento e morte causados por segurado, 
Assim, a despeito de possuir conseqüências positivas (no que concerne exclusivamente à indenização pelos prejuízos já causados), a transferência da obrigação de indenizar a pessoas ou empresas que não se confundem com o causador do dano, pode também acarretar conseqüências prejudiciais (especialmente no que se refere ao desestímulo quanto ao cometimento de novos prejuízos). Retoma-se, aqui, tudo o quanto já exposto a respeito das conseqüências negativas da contratação de seguros de responsabilidade civil e do fenômeno denominado pelos economistas de "moral hazard"433: o fato de o causador dos danos transferir a terceiro a obrigação que oridinariamente lhe incumbiria de indenizar a vítima pelos prejuízos a ela impostos pode servir de desestímulo para que ele deixe de, no futuro, cometer novos ilícitos, ou de expor as pessoas a riscos desnecessários. A transferência dessa particular obrigação a um terceiro pode, enfim, servir a um propósito negativo, fazendo com que o potencial ofensor deixe de se sentir estimulado a respeitar a Lei e a prevenir a ocorrência de prejuízos aos interesses alheios. É nesse sentido que se afirma que "a socialização dos riscos não acaba com os riscos, ao contrário, pode tornar os responsáveis por eles menos cuidadosos" ${ }^{\text {434 }}$.

A conclusão a que se chega é a de que, em razão das evoluções pelas quais passou a responsabilidade civil (em especial no que concerne à socialização dos riscos), tal instituto perdeu cada vez mais sua aptidão para atuar de modo a prevenir o cometimento de condutas socialmente indesejáveis (e, conseqüentemente, a ocorrência de prejuízos). Por conta disso, sua função preventiva e dissuasória deixou de ser exercida com eficiência, relegando-se tal tarefa quase que com exclusividade aos demais ramos do Direito Sancionador, tais como o Direito Penal e o Direito Administrativo ${ }^{435}$, ramos estes que, como abaixo se verá, possuem limitações principiológicas que os tornam inaptos a dar respostas adequadas a todas as situações lesivas.

pode ser ajuizada diretamente contra a seguradora, que tem responsabilidade por força da apólice securitária e não por ter agido com culpa no acidente. [...] Recurso provido na parte em que conhecido." (STJ; $3^{\mathrm{a}}$ T.; RESP n. ${ }^{\circ}$ 444.716/BA; Relatora: Min. Nancy Andrighi; J. 11.05.2004). Há que se lembrar que tal discussão se põe apenas nos casos em de seguro facultativo de responsabilidade civil, vez que, nos casos em que o seguro é obrigatório, a demanda direta da vítima em face da empresa seguradora decorre de expressa disposição legal (art. 788, do CC/2002).

${ }^{433}$ Sobre o tema, cfr. E. D. BEAL, Posner and Moral Hazard, in Connecticut Insurance Law Journal, vol. 7 , 2000, págs. 84/85.

${ }^{434}$ Teresa Ancona LoPEZ, Princípio da Precaução e Evolução da Responsabilidade Civil, São Paulo, Quartier Latin, 2010, pág. 55.

${ }^{435}$ Eduardo UILAN, Responsabilidade Civil Punitiva, Tese (Doutorado) - Faculdade de Direito da USP, São Paulo, 2003, pág. 47. 
Por outro lado, é certo que nem mesmo a ampliação das hipóteses em que a responsabilização do causador do dano ocorre sem que seja necessário perquirir sobre a ocorrência de culpa (chegando-se, inclusive, a erigir uma cláusula geral de incidência da responsabilidade objetiva no art. 927, par. ún., do CC/2002) pode assegurar a retomada da eficiência da função preventiva da responsabilidade civil.

Com efeito, o desenvolvimento da sociedade de consumo e da produção em massa permitem ao grande fornecedor internalizar os custos das indenizações por eles devidas em razão dos riscos de sua atividade. Ao analisar tal circunstância, José Reinaldo de Lima LOPES esclarece que, "diante do consumidor, [o grande fornecedor] pode dispor de um recurso a mais: o custo da indenização pode entrar no seu cálculo de custos de produção, sendo posteriormente repassado no custo das mercadorias. Se o custo é tal que pode ser facilmente suportado pelo mercado, a responsabilidade é absorvida como risco da empresa" ${ }^{\text {"36 }}$. Conclui, então, o citado autor que "a responsabilidade civil do fabricante, [mesmo] quando definida em termos de responsabilidade objetiva pode não surtir os efeitos imaginados de desestímulo se funcionar para a empresa calcular seus custos de produção e concluir que mesmo assim vale à pena correr determinados riscos" ${ }^{\text {437. }}$.

$\mathrm{Na}$ mesma linha de raciocínio, M. A. GEISTFELD afirma que "[u]ma regra de responsabilidade objetiva [...] não especifica quão seguramente o agente deve se comportar, e, assim, o agente racionalmente exporá a vítima a uma situação de risco quando isso se mostrar economicamente eficiente"; para concluir que a "[r]esponsabilidade objetiva demonstra que o agente não é necessariamente impedido de expor as vítimas a riscos de em troca estiver disposto a pagar o 'preço' da indenização" 438 .

Pode-se concluir, portanto, que os desenvolvimentos pelos quais passou o instituto da responsabilidade civil (em especial sua coletivização e objetivação, com a

\footnotetext{
${ }^{436}$ Responsabilidade Civil do Fabricante e a Defesa do Consumidor, São Paulo, RT, 1992, pág. 94.

${ }^{437}$ Responsabilidade Civil do Fabricante e a Defesa do Consumidor, São Paulo, RT, 1992, pág. 94.

${ }^{438}$ No original, "[a] rule of strict liability [..] does not specify how safely the duty-holder should behave, and so the duty-holder rationally imposes a risk on the right-holder when it would be cost-effective to do so"; concluindo que "[s]trict liability shows that a duty-holder is not necessarily barred from imposing risks on
} 
conseqüente perda de relevância dos aspectos anímicos da conduta cometida pelo causador do prejuízo), impactaram de maneira negativa as possibilidades de que, por meio de sua incidência, pudesse ser adequadamente assegurada a prevenção de novos danos. Nesse sentido, quer-nos parecer que a solução isolada pela socialização dos riscos e pela objetivação da responsabilidade civil não se mostra a mais eficiente, na medida em que é muito mais desejável prevenir o cometimento de atos ilícitos do que assegurar (ainda que) a mais ampla reparação das vítimas após o seu cometimento. A indenização, mesmo quando se dá de maneira integral, jamais é capaz de "apagar" o dano causado, eliminandoo da história como se jamais houvesse ocorrido. Quando muito, o numerário recebido pela vítima pode ser destinado à recomposição de seu patrimônio, nas hipóteses em que ele pode ser recomposto. No mais das vezes, em especial quando se está diante de bens e interesses particularmente relevantes (como o são os interesses existenciais e os metaindividuais), o prejuízo é eternizado, e a indenização, ainda que a mais ampla possível, nada mais serve do que de mero alento pelos danos suportados pela vítima (ou por toda a sociedade).

\section{II.II. A tutela da dignidade da pessoa humana e dos interesses metaindividuais}

Como já acima anunciado, para além dos fenômenos relacionados à facilitação da reparação de danos (os quais envolvem, em particular, a socialização dos riscos e a objetivação da responsabilidade), os desenvolvimentos contemporâneos pelos quais passou o instituto da responsabilidade civil deram ensejo a ainda um terceiro fenômeno: a expansão dos danos suscetíveis de reparação, que passaram a abranger os danos a interesses existenciais (do que resulta a admissão da indenização por danos morais ou extrapatrimoniais) e os danos a interesses meta ou transindividuais (tais como os difusos, os coletivos e os individuais homogêneos, descritos no art. 81 , do CDC) ${ }^{439}$.

the right-holder in exchange for paying the 'price' of compensatory damages [...]." (Punitive Damages, Retribution, and Due Process, in South California Law Review, vol. 81, 2007/2008, pág. 273).

${ }^{439}$ Sobre o desenvolvimento da tutela dos interesses existenciais, cfr. André Gustavo Corrêa de ANDRADE, Dano Moral e Indenização Punitiva: Os punitive damages na experiência do common law e na perspectiva do Direito brasileiro, Rio de Janeiro, Forense, 2006, págs. 139/174. Sobre a evolução doutrinária no que concerne à tutela dos interesses metaindividuais, cfr. Vitor Fernandes GonçALVES, A Punição na Responsabilidade Civil: A indenização do dano moral e da lesão a interesses difusos, Brasília, Brasília Jurídica, 2005, págs. 209 e ss. 
Um primeiro aspecto (e de particular relevância) no que concerne a esses novos direitos e interesses é o de que, ao contrário do que de ordinário acontece com os prejuízos exclusivamente patrimoniais (e, em especial, com aqueles prejuízos que, além de meramente patrimoniais, são individuais, atingindo apenas uma pessoa ou entidade jurídica em particular), da lesão aos interesses existenciais e metaindividuais geralmente decorrem prejuízos que, uma vez causados, tendem a se eternizar, pois que é difícil (para não dizer impossível) restituir o ente lesado ao status quo anterior ao cometimento do ilícito.

A uma, e no que toca aos prejuízos decorrentes de lesões a interesses existenciais, não é preciso realizar uma digressão muito aprofundada para notar que, diante de situações como a afronta à boa imagem de um indivíduo ou instituição, o falecimento de um ente querido ou, mesmo, a causação de um dano estético, é especialmente difícil devolver a vítima à posição em que se encontrava antes do dano, ainda que, em vez da via indenizatória, procure-se lançar mão de mecanismos alternativos de reparação. Faça-se o que for, dificilmente a honra atingida por uma matéria jornalística pejorativa poderá ser recomposta (ainda que exercido direito de resposta), o ente querido falecido jamais tornará a viver e, ainda, o dano estético, mesmo se adequadamente reparado por cirurgia, não deixará de impor à vítima os efeitos deletérios de ter convivido com a angústia causada ${ }^{440}$.

A duas, o mesmo se pode dizer sobre a lesão a interesses metaindividuais, principalmente no que toca aos interesses difusos em sentido estrito (tais como os decorrentes de lesões ao meio ambiente, aos "bens e direitos de valor artístico, histórico, turístico e paisagístico", à "ordem urbanística" e todos os outros enumerados no art. $1^{\text {o }}$, da Lei $7.347 / 1985)^{441}$. Difícil, senão impossível, é reparar todos os prejuízos casados pelo derramamento de óleo em uma bacia marítima, pela extinção de uma espécie animal, pela

\footnotetext{
${ }^{440}$ Quanto à extrema dificuldade (quando não impossibilidade) de retorno ao status quo ante no que concerne aos danos extrapatrimoniais, cfr. André Gustavo Corrêa de ANDRADE, Dano Moral e Indenização Punitiva: Os punitive damages na experiência do common law e na perspectiva do Direito brasileiro, Rio de Janeiro, Forense, 2006, págs. 148/150.

441 Sobre a distinção técnica entre direitos difusos, coletivos e individuais homogêneos (nomenclatura utilizada pelo art. 81, do CDC), cfr. Kazuo Watanabe, Código Brasileiro de Defesado Consumidor Comentado pelos Autores do Anteprojeto, $9^{\text {a }}$ ed., Rio de Janeiro, Forense Universitária, 2007, págs. 821/832. Tomando-se tal exposição e a apresentada por Vitor Fernandes GoNÇALVES, vemos que os interesses difusos são caracterizados essencialmente (i) pela indeterminação e (ao menos em regra) indeterminabilidade dos sujeitos, os quais são, em regra, ligados uns aos outros por circunstâncias de fato (tais como, e.g., os fatos de residirem em uma mesma região demográfica, de terem sido atingidos por uma mesma propaganda abusiva, etc.) e (ii) pela indivisibilidade de seu objeto (o qual não pode ser partilhado, em parcelas eqüânimes, entre tantos quantos forem seus titulares, até porque é, em regra, impossível individuá-los). (A Punição na Responsabilidade Civil, Brasília, Brasília Jurídica, 2005, págs. 216/225).
} 
destruição de um monumento histórico ou pelo completo desvirtuamento das características urbanísticas de uma determinada zona especialmente protegida ${ }^{442}$.

Um segundo aspecto relacionado aos interesses existenciais e metaindividuais é o de que, para além de todas as vicissitudes atinentes à tendência de perenização dos prejuízos decorrentes de lesões a tais interesses, a utilização da responsabilidade civil como meio de compensação desses prejuízos é dificultada por conta de todos os percalços para a adequada quantificação da indenização. Assim é que, no que toca aos danos extrapatrimoniais, Antonio JUNQUEIRA DE AZEVEDO nos lembra que, apesar "do tempo decorrido, da intensa produção doutrinária e da vasta jurisprudência" produzida a respeito do tema, ainda não se chegou a "a nenhum critério que pudesse pacificar o debate sobre sua quantificação" $"$ " $\mathrm{O}$ mesmo se pode dizer sobre "a apuração dos danos causados a interesses difusos", a qual, nas palavras de Vitor Fernandes GONÇALVES, "é freqüentemente muito difícil, senão mesmo impossível". Em relação ao tema, questiona, com pertinência, o citado autor: "como se pode saber com precisão qual o prejuízo causado com a veiculação de uma publicidade enganosa? Como determinar o prejuízo sofrido em razão de um derramamento de óleo em uma baía, ou em função da destruição de um sítio de valor histórico?"444.

Vê-se, assim, que, se de um lado, o reconhecimento dos prejuízos decorrentes de lesões a interesses existenciais e metaindividuais como passíveis de reparação denota uma importantíssima evolução do Direito Privado e, em especial, da responsabilidade $\operatorname{civil}^{445}$, de outro, as dificuldades atinentes à reparação desses prejuízos demonstram uma certa ineficiência do paradigma ressarcitório da responsabilidade civil tutelar adequadamente estes que são direitos de maior relevância ${ }^{446}$.

\footnotetext{
${ }^{442}$ Sobre a dificuldade de restauração das lesões a interesses difusos, com especial atenção aos danos causados ao meio ambiente, cfr. Caroline VAZ, Funções da Responsabilidade Civil - Da Reparação à Punição e Dissuasão - Os punitive damages no Direito Comparado e Brasileiro, Porto Alegre, Livraria do Advogado, 2009, pág. 158 e, na jurisprudência, STJ; $2^{\mathrm{a}}$ T.; RESP 299.400/RJ; Relatora p/acórdão: Min. Eliana Calmon; J. 01.06 .2006

${ }^{443}$ Por Uma Nova Categoria de Dano na Responsabilidade Civil: O Dano Social, in Novos Estudos e Pareceres de Direito Privado, São Paulo, Saraiva, 2009, pág. 377.

${ }^{444}$ A Punição na Responsabilidade Civil: A indenização do dano moral e da lesão a interesses difusos, Brasília, Brasília Jurídica, 2005, pág. 238.

${ }^{445}$ Maria Alice Costa HofMeISTER, O Dano Pessoal na Sociedade de Risco, Rio de Janeiro, Renovar, 2002, pág. 89 e Gustavo TePedino, O Direito Civil Constitucional e suas Perspectivas Atuais, in Temas de Direito Civil, vol. III, Rio de Janeiro, Renovar, 2009, pág. 40.

446 André Gustavo Corrêa de ANDRADE, Dano Moral e Indenização Punitiva: Os punitive damages na experiência do common law e na perspectiva do Direito brasileiro, Rio de Janeiro, Forense, 2006, pág. 234.
} 
Quer-nos parecer que, em razão das insuficiências apresentadas pelo paradigma ressarcitório para recompor adequadamente os prejuízos causados aos direitos aqui analisados (tidos como de especial relevância), a melhor maneira de tutelá-los é assegurar, no maior grau possível, que tais direitos não venham a ser lesados, prevenindo, assim, a ocorrência dos prejuízos ${ }^{447}$. Assim, "a prevenção das condutas danosas", que é tida por Marcela Alcazas BASSAN como "absolutamente consonante com o princípio da dignidade da pessoa humana, um dos grandes fundamentos da Constituição Federal"448, é também analisada por Luiz Guilherme MARINONI como "a única [medida] capaz de impedir que os direitos não patrimoniais sejam transformados em pecúnia, através de uma inconcebível expropriação de direitos fundamentais para a vida humana"449.

Inegavelmente, é muito mais salutar e eficiente prevenir a ocorrência de danos do que ter de atuar a posteriori, procurando restaurar uma situação lesiva já configurada (ainda mais em hipóteses como as aqui analisadas, nas quais os prejuízos tendem a se eternizar). É, portanto, justamente para o atingimento desse escopo principal (o de prevenir adequadamente o cometimento de condutas danosas aos interesses existenciais e metaindividuais) que se propugna, no presente trabalho, que se admita uma mitigação do paradigma ressarcitório da responsabilidade civil (na mesma medida que os desenvolvimentos contemporâneos do instituto operaram em relação aos demais paradigmas). Quer-se, com isso, que a responsabilidade civil possa exercer com eficiência essa função preventiva, que nos parece primordial para assegurar o equilíbrio social.

\footnotetext{
${ }^{447}$ Vale, neste ponto, repisar a ponderação feita por M. A. GEISTFELD quanto à insuficiência do paradigma exclusivamente ressarcitório para a prevenção de danos. Sustenta o citado autor que "[i]f liability were always limited to compensatory damages, a defendant duty-holder could choose to violate the plaintiff's tort right in exchange for paying the 'price' of compensatory damages." (Punitive Damages, Retribution, and Due Process, in South California Law Review, vol. 81, 2007/2008, pág. 270).

${ }^{448}$ As Funções da Indenização por Danos Morais e a Prevenção de Danos Futuros, Dissertação (Mestrado) Faculdade de Direito da USP, São Paulo, 2009, pág. 91.

${ }^{449}$ Tutela Inibitória (Individual e Coletiva), 4 a ed., São Paulo, RT, 2006, pág. 24. Vale lembrar que o referido autor denomina de "tutela inibitória" a técnica processual que propugna a diluição de importância do procedimento ordinário e da concepção trinária das sentenças de mérito, admitindo meios mais eficientes para prevenir a ocorrência dos prejuízos. No presente estudo, optamos por focar nossos esforços nas possibilidades preventivas da responsabilidade civil, resultando em um remédio que, a despeito de atuar após a ocorrência de um prejuízo em específico, destina-se a punir o ofensor pelo mal já causado e a prevenir o cometimento de novos e semelhantes atos ilícitos.
} 


\section{II.III. Inadequeção da tutela proporcionada pelo Direito Penal e pelo Direito Administrativo Sancionador}

Pelo que acima se expôs, pôde-se concluir, por primeiro, que os fenômenos da socialização dos riscos e da objetivação da responsabilidade trouxeram duas grandes conseqüências para o desempenho do instituto da responsabilidade civil. Se, de um lado, serviram para facilitar o pronto recebimento, pela vítima do ilícito, da indenização mais ampla possível (em atendimento ao paradigma tradicional denominado de ressarcitório), de outro, ao rebaixar a segundo plano os aspectos anímicos das condutas do ofensor para a imputação da responsabilidade de indenizar, tais fenômenos causaram uma diluição das potencialidades preventivas da responsabilidade civil. Como conseqüência, relegou-se a função de prevenir o cometimento de novos ilícitos, quase que com exclusividade, aos demais ramos do direito sancionador, a saber, o Direito Penal e o Direito Administrativo.

Por segundo, viu-se que o fenômeno da expansão dos danos suscetíveis de reparação passou a permitir que se cogitasse da proteção jurídica de bens e interesses antes tidos como impassíveis de tutela. Tais interesses, alçados à mais elevada importância, principalmente após a edição da Carta Constitucional de 1988 [que consagrou a dignidade da pessoa humana como um dos fundamentos da República Federativa do Brasil (art. $1^{\circ}$, III, da CF/88), e a persecução de uma "sociedade livre, justa e solidária" como um de seus objetivos fundamentais (art. $3^{\circ}, \mathrm{I}$, da $\mathrm{CF} / 88$ )], não podem ser adequadamente protegidos apenas pela incidência a posteriori da indenização com fins exclusivamente compensatórios. Por darem ensejo à ocorrência de prejuízos que, em regra, tendem à perenização (por não se lograr êxito, no mais das vezes, na reposição da vítima ao status quo anterior ao cometimento do prejuízo), as lesões a tais interesses devem ser adequadamente prevenidas. Tem-se, portanto, que a tutela adequada e eficiente desses bens e direitos é a preventiva, e não aquela simplesmente ressarcitória.

Se os interesses existenciais e metaindividuais devem ser objeto de tutela preventiva, e se tal tutela não pode ser adequadamente exercida pelo instituto da responsabilidade civil (ao menos nos moldes acima delimitados, em que se mantém intocado seu paradigma ressarcitório), torna-se de crucial relevância analisar se os demais ramos do direito sancionador podem, no lugar da responsabilidade civil, desempenhar tal função com eficiência. 
Ao tratar do tema, S. CARVAL afirma que a eficiência de determinada ação sancionadora depende essencialmente de dois fatores: (1) "a maior ou menor facilidade com a qual se investe a autoridade do poder de sanção"; e (1ii) "a importância dos limites sob os quais é exercido o poder repressivo" ${ }^{450}$. A esses dois aspectos, entende-se por bem acrescentar ainda um terceiro, especificamente relevante para o Direito Penal, que é o de que este ramo em particular somente deve incidir como ultima ratio, ou seja, apenas para sancionar as condutas do mais alto grau de reprovabilidade, que não encontram resposta adequada nas sanções previstas pelos demais ramos do Direito.

Por primeiro, muito ao contrário do que ocorre com a indenização resultante da responsabilidade civil [que é imposta ao responsável como consequiência de uma demanda movida, em regra, pela própria vítima do ato ilícito ou, excepcionalmente, por outro co-legitimado (como, e.g., aqueles previstos no art. $5^{\circ}$, da Lei 7.347/1985, para o ajuizamento de ações civis públicas de cunho ressarcitório)], as sanções previstas pelo Direito Penal e pelo Direito Administrativo Sancionador somente são impostas após se passar pelo imprescindível crivo um órgão especializado [o qual pode ser o parquet, no caso do Direito Penal, ou órgãos técnicos fiscalizatórios, no caso do direito administrativo, tais como, por ex., a Secretaria Municipal do Verde e do Meio Ambiente, para o caso de investigação e persecução de infrações administrativas ambientais (art. $2^{\circ}$, do Decreto Municipal 42.883/2003)], o qual, em maior ou menor grau, deve decidir sobre a conveniência ou não de iniciar um processo repressivo ${ }^{451}$. Existe, portanto, um "filtro" exercido por tais órgãos especializados, o qual impede que a autoridade competente tenha pronto conhecimento da totalidade dos atos ilícitos cometidos, fator este que coloca tais ramos do Direito Sancionador em desvantagem em relação à responsabilidade civil.

Por segundo, a eficiência de um determinado sistema repressivo também depende do grau de severidade dos limites a que tal sistema de submete, o que se pode verificar de duas maneiras: (i) pela possibilidade de sancionar adequadamente qualquer sujeito causador de ilícitos, quer ele seja uma pessoa natural, quer ela seja uma pessoa

\footnotetext{
${ }^{450}$ No original: (i) "la plus ou moins grande facilitè avec laquelle est saisie l'autorité investie du pouvoir de sanction"; e (ii) "l'importance des limites dans lesquelles est enserré son pouvoir répressif”. (La Responsabilitè Civile Dans Sa Fonction de Peine Privée, Paris, L.G.D.J., 1995, pág. 234).

${ }^{451}$ S. Carval, La Responsabilitè Civile Dans Sa Fonction de Peine Privée, Paris, L.G.D.J., 1995, pág. 235.
} 
jurídica (do que se extrai uma limitação subjetiva ao exercício do poder repressivo); e (ii) a exigência de que se obedeça de maneira estrita ao princípio da legalidade das penas, inclusive e principalmente no que concerne à tipificação das condutas ilícitas (do que se extrai uma limitação objetiva ao exercício do poder repressivo) $)^{452}$.

Quanto ao primeiro aspecto, vê-se que, também ao contrário do que ocorre com a responsabilidade civil, o Direito Penal encontra severa restrição quanto aos sujeitos passíveis de sancionamento, uma vez que, em nosso ordenamento, inexiste regra geral que admita a responsabilização penal das pessoas jurídicas. Com efeito, a penalização das condutas e atividades levadas a efeito por pessoas jurídicas é, para nós, uma rara excepcionalidade, prevista até o momento apenas no art. $3^{\circ}$, da Lei 9.605/1998 (Lei de Crimes Ambientais), que prescreve que “[a]s pessoas jurídicas serão responsabilizadas administrativa, civil e penalmente [...], nos casos em que a infração seja cometida por decisão de seu representante legal ou contratual, ou de órgão colegiado, no interesse ou benefício de sua entidade ${ }^{, 453}$.

Importa de ver, contudo, que tal restrição não se verifica da mesma maneira no âmbito do Direito Administrativo Sancionador, que, de maneira mais eficiente do que o Direito Penal, historicamente admite a ampla responsabilização das pessoas jurídicas, inclusive no que concerne à incidência de sanções punitiva ${ }^{454}$.

Já quanto ao segundo aspecto, verifica-se que tanto o Direito Penal quanto o Direito Administrativo Sancionador devem obediência estrita ao princípio da legalidade

\footnotetext{
${ }^{452}$ S. CARVAL, La Responsabilitè Civile Dans Sa Fonction de Peine Privée, Paris, L.G.D.J., 1995, pág. 243.

${ }^{453}$ Carlos Alberto de SALLES nos lembra que tal dispositivo legal veio a concretizar a previsão inserida no art. $225, \S 3^{\circ}$, da $\mathrm{CF} / 88$, que já antecipava a possibilidade de que aqueles que cometessem infrações contra o meio ambiente, fossem eles pessoas físicas ou jurídicas, viriam a ser punidos nos âmbitos do Direito Penal e do Direito Administrativo, independentemente de sua obrigação de reparar o dano causado. (Responsabilidade Penal da Pessoa Jurídica e a Proteção ao Meio Ambiente: Finalidade e Aplicação, in Revista Brasileira de Ciências Criminais, vol. 36, dez.-2001, págs. 51 e ss.). Segundo Eduardo Luiz Santos CABETTE, o atual cenário do ordenamento penal brasileiro tem como origem a individualização da responsabilidade, a qual, além de ter-se tornado um dos paradigmas tradicionais da responsabilidade civil, também teria atingido a responsabilidade penal, eliminando a responsabilidade coletiva típica dos povos germânicos e passando-se, a partir de então, a admitir apenas a responsabilidade individual também no que toca à responsabilização penal. Noticia o citado autor que, quanto ao tema em questão, pode-se dividir os países em dois blocos: um dos quais inadmite a responsabilização penal das pessoais jurídicas, e outro que vem admitindo tal responsabilização, mesmo que em situações excepcionais, verificáveis principalmente nos campos econômico e ambiental. (Responsabilidade Penal da Pessoa Jurídica - Breve Estudo Crítico, in Revista Brasileira de Ciências Criminais, vol. 41, mar./2003, págs. 152 e ss.).
} 
das penas (nulla poena sine lege, insculpido no art. $5^{\circ}$, XXXIX, da $\mathrm{CF} / 88$ ), inclusive no que se refere à tipificação das condutas passíveis de punição. Além disso, no que toca à descrição do tipo legal, tais ramos do Direito admitem apenas de maneira restritiva a utilização de conceitos abertos e normas em branco, exigindo que a conduta passível de sancionamento se encontre estabelecida em Lei da maneira mais adequada possível ${ }^{455}$.

Como abaixo se verá, assim como o Direito Penal, também o Direito Civil se submete ao princípio da legalidade das penas (como assim o fazem todos os ramos do Direito, quer pertencentes ao Direito Público, quer ao Direito Privado). Contudo, de maneira bem mais flexível do que o Direito Penal (ou mesmo do que o Direito Administrativo Sancionador), o Direito Civil é muito mais afeito à utilização de conceito jurídicos indeterminados e de cláusulas gerais, motivo pelo qual se admite grande mitigação de sua submissão à tipificação das condutas lesivas.

Por terceiro, e novamente em aspecto que atinge em particular o Direito Penal, vê-se que tal ramo do Direito deve obediência ao princípio da mínima intervenção, também nominado de princípio da ultima ratio. Em razão de tal princípio, só se admite a penalização das condutas dotadas do mais alto grau de reprovabilidade, incidindo o Direito Penal apenas para o restabelecimento da ordem jurídica que não pode ser feito pela incidência do direito civil e do direito administrativo ${ }^{456}$. Diz-se, em atenção ao que aqui se discute, que, "se outras formas de sanção ou outros meios de controle social revelarem-se suficientes para a tutela desse bem, a sua criminalização é inadequada e não recomendável" 457 ; para concluir que "[o] desrespeito a essas diretrizes dogmáticas [no que toca à incidência excepcional do Direito Penal] dá ensejo a uma inflação legislativa que tem por conseqüência o uso inconstitucional e ineficaz do direito penal como instrumento de controle social" 458 .

\footnotetext{
${ }^{454}$ Sobre o tema, cfr. Fábio Medina OsÓRIO, Direito Administrativo Sancionador, $3^{\mathrm{a}}$ ed., São Paulo, RT, 2010, págs. 374/382.

${ }^{455}$ Para uma análise do tema sob a ótica do Direito Penal, cfr. Princípios Constitucionais Penais e Processuais Penais, São Paulo, RT, 2010, págs. 188/205. Já sob a ótica do Direito Administrativo, cfr. Fábio Medina Osório, Direito Administrativo Sancionador, $3^{\text {a }}$ ed., São Paulo, RT, 2010, págs. 209/263.

${ }^{456}$ Judith Martins-Costa - Mariana Souza PARgendler, Usos e Abusos da Função Punitiva ('Punitive Damages' e o Direito Brasileiro), in Revista da Ajuris, ano XXXII, n. ${ }^{\circ}$ 100, dez/2005, pág. 249.

${ }^{457}$ Eduardo UILAN, Responsabilidade Civil Punitiva, Tese (Doutorado) - Faculdade de Direito da USP, São Paulo, 2003, pág. 48.

${ }^{458}$ Eduardo UILAN, Responsabilidade Civil Punitiva, Tese (Doutorado) - Faculdade de Direito da USP, São Paulo, 2003, pág. 48. Nesse contexto, vale ressaltar as considerações feitas por Vitor Fernandes GONÇALVES ao tratar da Lei 9.605/1998 (Lei dos Crimes Ambientais). Segundo o citado autor, a referida Lei Federal, que
} 
Em arremate, vale ressaltar que a previsão de sanções criminais como resposta mesmo a delitos de menor grau de reprovabilidade enfraquece a força de intimidação do Direito Penal como instituto e, ainda, compromete a mobilização de seus recursos, que deveriam ser direcionados apenas para a persecução dos ilícitos mais graves $^{459}$.

Vê-se, enfim, que o Direito Penal encontra uma série de obstáculos que o impedem de atuar, com a eficiência necessária, como forma de punição e repressão de todas as sortes de atos ilícitos. Pelo contrário, até mesmo em atenção ao princípio da ultima ratio, deve-se restringir a incidência desse ramo do Direito, admitindo-se a penalização apenas das condutas mais reprováveis (o que exclui, de seu âmbito de atuação, a generalidade dos atos ilícitos cometidos no curso das atividades humanas).

Por outro lado, também o Direito Administrativo Sancionador se subjeita a óbices que, mesmo que menos rígidos que aqueles enfrentados pelo Direito Penal, limitam sua aplicação eficiente para a tutela dos interesses e direitos existenciais e metaindividuais (os quais, por sua amplitude, não recebem tutela adequada se os remédios para tanto devem ser taxativamente previstos em Lei).

Identificam-se, neste ponto, dois fenômenos de grande relevância, a saber: (i) os direitos e interesses existenciais e metaindividuais demandam o exercício eficiente de uma tutela preventiva, que impeça, da maneira mais adequada possível, o cometimento de infrações e a ocorrência de prejuízos; (ii) tal tutela preventiva não pode ser eficientemente exercida nem pela responsabilidade civil (ao menos enquanto se mantiver intocado o seu paradigma ressarcitório), nem, tampouco, pelos demais ramos do Direito Sancionador.

\footnotetext{
tipificou um sem número de condutas lesivas ao meio ambiente, que vão desde os mais banais maus-tratos a animais domésticos (art. 32, da Lei 9.605/1998) à gravíssima conduta de provocar incêndio em matas ou florestas nativas (art. 41, da Lei 9.605/1998), "banaliza de tal forma a responsabilidade criminal que praticamente todo e qualquer possível dano ao meio ambiente passa a ser considerado um crime, não tendo andado bem o legislador, nesse particular, uma vez que deveria ter criminalizado tão somente as mais graves infrações ao meio ambiente, assim entendidos aqueles casos causadores de prejuízo considerável, ou que atinjam um grande número de pessoas, adquirindo maior dimensão social'. (A Punição na Responsabilidade Civil: A indenização do dano moral e da lesão a interesses difusos, Brasília, Brasília Jurídica, 2005, págs. 231/232).
} 
Nesse contexto, parece-nos indispensável que o ordenamento jurídico preveja um mecanismo adequado para exercer eficientemente tal tutela preventiva, sob pena de se admitir o cometimento irrefreado de atos ilícitos lesivos aos direitos e interesses reputados como de elevada relevância social.

\section{II.IV. A responsabilidade civil como meio adequado para a tutela de direitos e a prevenção de danos}

Diante da constatação de que os meios sancionadores de que se dispõe são insuficientes para assegurar a eficiente tutela preventiva dos interesses e direitos acima enumerados, acredita-se poder recorrer à responsabilidade civil, que se mostra muito mais flexível do que o Direito Penal ou o Direito Administrativo, como instrumento apto a assegurar não apenas o restabelecimento do equilíbrio individual (desestabilizado pelo cometimento do ilícito e causação do prejuízo; e o que, em regra, pode-se remediar pela aplicação da indenização em sua função compensatória), mas, também, o equilíbrio social $^{460}$ (atingido pelos reflexos socialmente negativos dos ilícitos que, a despeito de altamente reprováveis, não são adequadamente reprimidos pelo Direito Penal; e o que, em regra, somente se pode remediar pela previsão de uma sanção que não apenas compense os prejuízos sofridos pela vítima, mas, também, sirva de punição ao ofensor pelo mal causado e de desestímulo a ele e à sociedade quanto ao cometimento de novos ilícitos) ${ }^{461}$.

\footnotetext{
${ }^{459}$ Eduardo UILAN, Responsabilidade Civil Punitiva, Tese (Doutorado) - Faculdade de Direito da USP, São Paulo, 2003, pág. 49.

${ }^{460}$ No sentido acima exposto, Regina Beatriz Tavares da SILVA relembra que "[a] teoria da responsabilidade civil visa ao restabelecimento da ordem ou equilíbrio pessoal e social, por meio da reparação dos danos morais e materiais oriundos de ação lesiva a interesse alheio, único meio de cumprir-se a própria finalidade do Direito, que é viabilizar a vida em sociedade, dentro do conhecido ditame neminem laedere. [...] A multiplicação dos danos, o que resulta da vida moderna, em que os atritos de interesses são cada vez mais intensos, leva o ser mais egoísta a imaginar que um dia poderá experimentar o mesmo infortúnio, do que surge a reação social contra a ação lesiva, de modo que a responsabilidade civil tornou-se uma concepção social, quando antes tinha caráter individual." (Critérios de Fixação da Indenização do Dano Moral, in Mario Luiz Delgado e Jones Figueirêdo Alves (coords.), Questões Controvertidas no Novo Código Civil, São Paulo, Método, 2003, págs. 260/261).

${ }^{461}$ Em sentido semelhante ao que aqui se propugna, B. STARCK sustenta que,"[e]n présence de cette impuissance du droit pénal d'atteindre toutes les activités nuisibles et coupables, il faut permettre au juge civil de collaborer par ses moyens propres à l'oeuvre générale de prévention." (Essai d'une Théorie Générale de la Responsabilité Civile Considèrèe em as Double Fonction de Garantie et de Peine Privèe, Paris, L. Rodstein, 1947, pág. 382).
} 
Para que a responsabilidade civil possa adequadamente exercer tal escopo, é imprescindível que se reconheça a insuficiência de seu paradigma ressarcitório (o qual lhe limita a desempenhar com eficiência apenas a primeira função acima enumerada, de restabelecimento do equilíbrio individual), permitindo-se que a indenização seja quantificada não apenas em atenção aos estritos limites do prejuízo suportado, mas, também, em atenção a outros critérios (quer particulares do ofensor, quer característicos da conduta por ele perpetrada).

É nesse contexto que Eduardo UILAN vaticina a insuficiência do paradigma ressarcitório da responsabilidade civil para "dar cabo dos problemas contemporâneos que a sociedade coloca nas mãos dos operadores do direito" "462 ; no que é secundado por André Gustavo Corrêa de ANDRADE, para o qual todos os fenômenos acima expostos são "sinais evidentes do que se pode reconhecer como uma verdadeira 'crise' de paradigma, que tende a uma superação do tradicional modelo reparatório”. Tal superação, bem pontua o referido autor, "não se traduz, por óbvio, no abandono da idéia de reparação, mas no redimensionamento da responsabilidade civil, que, para atender aos modernos $e$ complexos conflitos sociais, deve exercer várias funções" ${ }^{\text {463. }}$.

Assim, em atenção às necessidades de tutela preventiva dos bens e interesses acima apontados (os quais não encontram proteção suficiente se tal tutela se restringir ao âmbito do Direito Público ${ }^{464}$ ), sustenta-se que se deve admitir uma interpenetração entre as funções ordinariamente exercidas pelos Direitos Público e Privado, entre os Direitos Penal e Civil, para que se crie "uma nova arquitetura para a responsabilidade civil, que deve ser vista como um conjunto ordenado de princípios e regras voltado para a tutela simultânea do indivíduo e da sociedade ${ }^{\natural 65}$.

\footnotetext{
${ }^{462}$ Responsabilidade Civil Punitiva, Tese (Doutorado) - Faculdade de Direito da USP, São Paulo, 2003, pág. 46.

463 Dano Moral e Indenização Punitiva: Os punitive damages na experiência do common law e na perspectiva do Direito brasileiro, Rio de Janeiro, Forense, 2006, pág. 234.

464 Gustavo TePEDINO, A Incorporação dos Direitos Fundamentais pelo Ordenamento Brasileiro: Sua Eficácia nas Relações Jurídicas Privadas, in Temas de Direito Civil, vol. III, Rio de Janeiro, Renovar, 2009, pág. 62.

465 André Gustavo Corrêa de ANDRAde, Dano Moral e Indenização Punitiva: Os punitive damages na experiência do common law e na perspectiva do Direito brasileiro, Rio de Janeiro, Forense, 2006, pág. 244. No mesmo sentido segue P. M. LOURENÇO, para quem um "reforço da tutela dos valores relativos à pessoa humana [...] pode ser alcançado pela responsabilidade civil, desde que esta assuma sua dupla função punitiva ('retribuindo o mal') e preventiva ('prevenindo ofensas'), a qual assume particular relevância na avaliação dos danos não patrimoniais" (A Função Punitiva da Responsabilidade Civil, Coimbra, Coimbra, 2006, págs. 384/385).
} 
Em reforço ao que aqui se propugna, há que se frisar que, por suas características intrínsecas, a responsabilidade civil é um instituto que, em se admitindo uma mitigação de seu paradigma exclusivamente ressarcitório, pode desempenhar a tutela preventiva dos interesses existenciais e metaindividuais de maneira bem mais eficiente do que o Direito Penal ou mesmo o Direito Administrativo.

Em atenção aos mesmos fatores acima aventados para questionar a eficiência dos demais ramos do Direito Sancionador, vê-se que, por primeiro, a indenização incide sobre o demandado como conseqüência de uma medida judicial aforada pela própria vítima, não se exigindo a prévia análise de tal pretensão por um órgão especializado; fato este que é, nas palavras de S. CARVAL, "o pilar de uma eficaz política repressiva" ${ }^{466}$.

Vê-se que, no que concerne à pena privada a ser exercida por meio da responsabilidade civil (a qual denominamos, no presente trabalho, de indenização punitiva), os particulares atuam como verdadeiros "procuradores público-privados" (nossa tradução para a expressão norte-americana "private attorney general"): na mesma medida em que levam ao conhecimento do Poder Judiciário uma pretensão individual (= de reparação ou compensação por prejuízos suportados em razão de um determinado ato ilícito), também desempenham um munus público, ao deduzir em juízo a pretensão de ver punido um ofensor que, na mesma medida em que lhe causou prejuízos, cometeu um ato que abalou o equilíbrio social, e que merece ser sancionado de maneira proporcional ao seu grau de reprovabilidade. O particular, nesse sentido, avoca para si as atribuições que ordinariamente seriam exercidas por um órgão especializado do próprio Poder Público (quer o parquet, no caso do Direito Penal, quer um ente da Administração Direta ou um órgão de classe, no caso do Direito Administrativo Sancionador), e, em assim o fazendo, atua de maneira eficiente, inclusive economizando recursos desses órgãos especializados, que poderão ser consumidos, por ex., na persecução de ilícitos ainda mais gravosos, e na adequada prevenção de danos à sociedade ${ }^{467}$.

466 La Responsabilitè Civile Dans Sa Fonction de Peine Privée, Paris, L.G.D.J., 1995, pág. 235. Semelhantemente, M. G. BARATElla, Le Pene Private, Milano, Giuffrè, 2006, págs. 216.

${ }^{467}$ Eduardo UILAN, Responsabilidade Civil Punitiva, Tese (Doutorado) - Faculdade de Direito da USP, São Paulo, 2003, pág. 51. 
Por segundo, e como acima já se anunciou, a responsabilidade civil também se submete a restrições muito menos severas do que aquelas impostas aos demais ramos do Direito Sancionador, tanto no que se refere a aspectos subjetivos (admitindo-se a ampla responsabilização de pessoas jurídicas), quanto no que toca a aspectos objetivos (não se submetendo, com tanta rigidez, ao princípio da taxatividade das penas) ${ }^{468}$.

De mais a mais, vale lembrar que a sanção à qual aqui se cogita atribuir uma função punitiva tem como estrutura uma condenação pecuniária, que atua exclusivamente sobre o patrimônio do responsável e, portanto, não exige maiores dificuldades de gestão de sua execução pelo Poder Público (flagrante vantagem se a compararmos com a sanção punitiva de restrição de liberdade, cuja execução demanda a construção de todo um aparato institucional, e o dispêndio de esforços e recursos públicos) ${ }^{469}$.

A conclusão a que se chega, nas corretas palavras de M. G. BARATELLA, é a de que, "especialmente em razão da mescla de tais elementos [a saber: as funções tipicamente exercidas por sanções administrativas ou criminais, de punição e prevenção, às características tipicamente civis, tais como a incidência da sanção por iniciativa da própria vítima e a flexibilidade de sua aplicação] permite às penas privadas superar os limites e as insuficiências dos outros instrumentos de tutela previstos no ordenamento, intervindo de modo a garantir a efetividade do sistema quando estes não operam ou parecem inadequados para os escopos por eles perseguidos [de punição do ofensor e, principalmente, prevenção de prejuízos]”470.

\footnotetext{
468 Antonio JunQueIRA DE AZEvedo, Por Uma Nova Categoria de Dano na Responsabilidade Civil: O Dano Social, in Novos Estudos e Pareceres de Direito Privado, São Paulo, Saraiva, 2009, pág. 379. Além de não se exigir um respeito tão estrito ao princípio da taxatividade, a incidência de sanções punitivas no âmbito do Direito Civil é mais eficiente do que aquela operada no Direito Penal e no Direito Administrativo Sancionador também porque: (i) no âmbito do processo civil, são admitidas flexibilizações ordinariamente inaceitáveis no processo penal, tais como a transação quanto a direitos patrimoniais e a desistência do processo pelo demandante (bem ainda a renúncia ao direito em que se funda a demanda); e, ainda, porque (ii) é desnecessário que se realize um procedimento investigativo preliminar, para a formação de um conjunto probatório que venha a sustentar a demanda, como ocorre na ação penal. Nesse sentido, cfr. Eduardo UILAN, Responsabilidade Civil Punitiva, Tese (Doutorado) - Faculdade de Direito da USP, São Paulo, 2003, pág. 51. ${ }^{469}$ M. G. BARAtella, Le Pene Private, Milano, Giuffrè, 2006, págs. 198.

${ }^{470}$ No original: "[p]recipuamente la commistione degli indicati elementi consente alle pene private di superare $i$ limiti e le insufficienze degli altri instrumenti di tutela previsti dall'ordinamento, intervendo a garantire l'effettività del sistema ove questi non operino o appaiano inadeguati al fine perseguito [...]." (Le Pene Private, Milano, Giuffrè, 2006, págs. 214). Importa de ver, contudo e como abaixo se verá, que nada impede que uma conduta particularmente reprovável seja objeto de sancionamento (mesmo que por mais de uma sanção que exerça função punitiva) por mais de um âmbito do Direito (tal como sói ocorrer com os ilícitos ambientais, punidos que podem ser nos âmbitos criminal, administrativo e civil). O que aqui se defende não é a eliminação do Direito Penal e do Direito Administrativo Sancionador como instrumentos de
} 
É de se pontuar, contudo, que a despeito do que se vem aqui expondo, não são poucas as vozes em doutrina que se opõem às conclusões aqui apresentadas, sustentando que os desenvolvimentos contemporâneos da responsabilidade civil não conduzem a uma renovação das discussões a respeito de suas funções preventiva e punitiva (com o que caminha uma renovação da importância que se deve atribuir às características anímicas das condutas do ofensor, em especial para a quantificação da indenização que exercerá não apenas finalidade compensatória, mas, igualmente, punitiva e preventiva).

Porta voz de tal posicionamento, Anderson SCHREIBER refuta categoricamente a elevação, a primeiro plano, das funções puntiva e preventiva da indenização, sustentando tratar-se de proposta que se coloca "na contramão da evolução mais recente da responsabilidade civil". Nas palavras do citado autor, "o avanço da responsabilidade objetiva e as alterações na própria noção de culpa têm conduzido a responsabilidade civil a uma campo dissociado de preocupações subjetivistas e cada vez menos sensível à idéia de culpabilidade". Nesse contexto, a indenização punitiva representaria "a essência da orientação contrária", por se fundar "inteiramente, no grau de culpabilidade do agente" e fincar raízes "na idéia de reprovação moral e castigo exemplar do ofensor". Tal instituto, em sua opinião, opor-se-ia a "toda a marcha que a responsabilidade civil vem desenvolvendo nos dois últimos séculos" e, por isso mesmo, careceria "de lugar no cenário que se anuncia: o da solidarização da reparação dos danos" ${ }^{, 471}$.

Ousa-se discordar de tal entendimento, rogando-se venia para, ao se apropriar das palavras expostas pelo próprio Anderson SCHREIBER, afirmar que "[s]eria tolice acreditar [...] que a responsabilidade civil caminha segundo uma tendência evolutiva única" ${ }^{, 72}$, a qual desconsideraria os aspectos anímicos da conduta do ofensor tanto para a

punição de condutas indesejáveis. Pelo contrário, propugna-se que a responsabilidade civil seja utilizada em relação de complementariedade com os demais ramos do direito sancionador, como instrumento de punição e prevenção nas hipóteses em que, por suas características intrínsecas, ela pode atuar com vantagens sobre os outros ramos sancionadores do ordenamento jurídico. (Eduardo UILAN, Responsabilidade Civil Punitiva, Tese (Doutorado) - Faculdade de Direito da USP, São Paulo, 2003, pág. 51).

${ }^{471}$ Novos Paradigmas da Responsabilidade Civil: Da Erosão dos Filtros da Reparação à Diluição dos Danos, São Paulo, Atlas, 2009, pág. 209. Com cores mais ou menos fortes, tal também é a opinião esposada por Giovanni Ettore NANNI, Enriquecimento sem Causa, 2a ed., São Paulo, Saraiva, 2010, pág. 355 e Marcela Alcazas BASSAN, As Funções da Indenização por Danos Morais e a Prevenção de Danos Futuros, Dissertação (Mestrado) - Faculdade de Direito da USP, São Paulo, 2009, págs. 62/63.

${ }^{472}$ Novos Paradigmas da Responsabilidade Civil: Da Erosão dos Filtros da Reparação à Diluição dos Danos, São Paulo, Atlas, 2009, pág. 48. 
estipulação das regras de imputação da responsabilidade, quanto para a eventual quantificação da indenização, mesmo em casos de alto grau de reprovabilidade.

Isso porque, o que aqui se defende é que a indenização punitiva, ainda que traga considerações a respeito de aspectos subjetivos da conduta do ofensor, não substitui a indenização compensatória, nem, tampouco, se imiscui nos critérios desenvolvidos ao longo dos séculos para a definição de suas regras de imputação (os quais, em atenção ao mais do que louvável escopo de reparar integralmente todos os prejuízos sofridos pela vítima, abandonaram, em maior ou menor grau, as considerações de ordem subjetiva). Pelo contrário: propugna-se que a indenização punitiva deve ser adiciona à indenização compensatória, incidindo em hipóteses fáticas específicas e apenas para desempenhar adequadamente as funções de punição e prevenção quando isto se fizer necessário (ou seja, quando se estiver diante de lesão a interesses e direitos existenciais ou metaindividuais, ou nas quais os demais ramos do Direito Sancionador não desempenham eficientemente tais funções). Como se desenvolverá pormenorizadamente a seguir, a atuação dos dois institutos deve ser complementar, e não mutuamente excludente, de modo que a evolução da responsabilidade civil no que toca à objetivação da responsabilidade e à socialização dos riscos continua incontestável (repita-se: a adoção da indenização punitiva em nada altera as regras de imputação da responsabilidade com fins compensatórios).

Nesse sentido, Teresa Ancona LOPEZ sustenta que a responsabilidade civil no século XXI poderia ser robustecida caso se admitisse a aplicação, de maneira cumulada, das concepções advindas da socialização dos riscos com os princípios da prevenção (para riscos conhecidos) e da precaução (para os riscos incertos), para os quais se pode atentar às características subjetivas da conduta do ofensor ${ }^{473}$.

Sobre a compatibilidade de tais concepções ("erosão dos filtros" da responsabilidade, para fins de fixação das regras de imputação, e consideração do grau de culpa do ofensor, para fins de quantificação da indenização), é interessante notar que, mesmo na Nova Zelândia, onde vige sistema extremo no que toca à socialização dos riscos, passou-se a admitir o convívio, no mesmo contexto, da pronta compensação dos prejuízos (para o que, ao menos no que toca aos acidentes pessoais, sequer é necessário acionar o

\footnotetext{
${ }^{473}$ Princípio da Precaução e Evolução da Responsabilidade Civil, São Paulo, Quartier Latin, 2010, pág. 55.
} 
Poder Judiciário, quanto mais perquirir sobre culpa ou dolo por parte do ofensor) com a possibilidade de se ajuizar medidas judiciais que busquem não a compensação pelos prejuízos suportados, mas, sim, a punição do ofensor e a prevenção de novos atos ilícitos, por meio da imposição de punitive damages nos casos em que se verifica a ocorrência de atos ilícitos altamente reprováveis.

Com efeito, ao julgar Donselaar v. Donselaar (1 NZLR 97 1982), a Court of Appeal neozelandeza firmou seu entendimento no sentido de que o regramento jurídico da responsabilidade civil deveria se amoldar para bem acomodar as necessidades sociais, o que implica admitir o ajuizamento de demandas que busquem a incidência de sanções que não visem apenas à compensação do lesado (compensação esta que, dentro dos limites nele previstos, estaria abarcada pelo sistema previsto no Accident Compensation Act 1972 e, posteriormente, pelos instrumentos legais que o sucederam), mas, sim, à punição do ofensor ou ao desestímulo do lesante e da sociedade quanto ao cometimento de novos atos ilícitos ${ }^{474}$. Tal entendimento se tornou direito posto quando da edição do Accident Insurance Act 1998, um dos sucessores do Accident Compensation Act 1972, cuja Section 396 previu expressamente a possibilidade de ajuizamento de demandas nas quais se pleiteasse a condenação do ofensor ao pagamento de exemplary damages, ainda que em decorrência de ato ilícito que houvesse causado danos pessoais cuja compensação estaria assegurada pelo referido $A c t^{475}$.

Do exemplo neozelandês, é possível extrair as linhas gerais de um sistema no qual convivem, em razoável harmonia, os dois fenômenos que uma parcela da doutrina nacional acredita serem absolutamente incompatíveis (a saber: a socialização dos riscos e a indenização punitiva). O que aqui se defende, em resposta ao ceticismo apresentado pela doutrina, é que a convivência harmônica desses dois fenômenos é não apenas possível, mas indispensável para assegurar a tutela eficiente dos interesses e direitos de maior relevância jurídica e social.

\footnotetext{
${ }^{474}$ Sobre o tema, cfr. S. TODD, A New Zeland Perspective on Exemplary Damages, in Common Law World Review, vol. 33, 2004, pág. 258 e C. M. RYAN, Civil Punishment of the Uncivil: The Nature and Scope of Exemplary Damages in New Zeland, in Auckland University Law Review, vol. 5, 1984, págs. 65/70.

${ }^{475}$ Assim dispôs o caput da referida Section 396: “[n] othing in this act, and no rule of law, prevents any person from bringing proceedings in any court in New Zealand for exemplary damages for conduct by the defendant that has resulted in (a) personal injury covered by this Act; or (b) personal injury covered by former Acts." Disposição semelhante foi inserida na Section 319 do Injury Prevention, Rehabilitation and Compensation Act 2001, texto legal que substituiu o Accident Insurance Act 1998.
} 
Assim, por meio da adequada utilização da indenização punitiva, procura-se sancionar o ofensor pelo mal cometido e, principalmente, prevenir o cometimento ou a reiteração de atos ilícitos. Por meio da socialização dos riscos, pretende-se assegurar a mais pronta reparação dos danos causados, quando nem mesmo a indenização punitiva houver logrado êxito em preveni-los. A atação dos fenômenos é, repita-se, conjugada, e não excludente: a indenização punitiva visa a punir e prevenir, enquanto que a socialização dos riscos se destina a reparar.

Por fim, uma última questão que nos parece relevante a respeito do tema, e que, mal interpretada, poderia dar ensejo a mais uma crítica à introdução legislativa do instituto da indenização punitiva (das quais trataremos no capítulo subseqüente), é a de se saber por que a responsabilidade civil, que sempre atua a posteriori (após o cometimento do ilícito e a causação do dano), deve ser utilizada como instrumento de prevenção de prejuízos se nosso ordenamento jurídico já prevê, como nos lembra Luiz Guilherme MARINONI, mecanismos para assegurar uma tutela inibitória de tais direitos, a qual pode ser exercida antes mesmo do cometimento do ilícito e, dessa maneira, impedir sua ocorrência, bem como a dos prejuízos que dele decorreriam ${ }^{476}$.

Em resposta a tal questionamento, e evitando incorrer no equívoco (o qual, se cometido, seria de graves proporções) de deixar de enaltecer tais medidas inibitórias, corolários que são de um princípio geral de prevenção, bem como verdadeiramente indispensáveis para o efetivo acesso à Justiça (art. $5^{\circ}, \mathrm{XXXV}$, da CF/88) e a eficiente tutela dos direitos ${ }^{477}$, vale ressaltar que, para o desempenho da tutela jurisdicional inibitória, é indispensável a propositura de uma demanda judicial prévia ${ }^{478}$ (a qual poderá ter como fundamento legal, por ex., o art. 461, do CPC, ou o art. 84, do CDC), a ser movida pela potencial vítima do ato ilícito (ou da atividade de risco) ou por algum dos co-legitimados para tanto (nos casos de tutela inibitória coletiva), ante à potencialidade de ocorrência do ilícito e dos prejuízos que dele poderiam decorrer.

\footnotetext{
${ }^{476}$ Tutela Inibitória (Individual e Coletiva), $4^{\mathrm{a}}$ ed., São Paulo, RT, 2006, passim.

${ }^{477}$ Luiz Guilherme MARINONI, Tutela Inibitória (Individual e Coletiva), $4^{\mathrm{a}}$ ed., São Paulo, RT, 2006, págs. $71 / 82$.

${ }^{478}$ Ao tratar do tema, Luis Guilherme MARINONI afirma que nos casos em que "a função preventiva da norma é alcançada apenas na jurisdição, ou em que a tutela inibitória desejada pelo direito material somente pode ser obtida através da propositura da ação processual, há tutela jurisdicional inibitória". (Tutela Inibitória (Individual e Coletiva), 4 a ed., São Paulo, RT, 2006, pág. 63).
} 
Por conta da imprescindibilidade da propositura de demanda prévia, quer-nos parecer que, ainda que tais mecanismos sejam indispensáveis para a persecução de uma eficaz prevenção de danos, eles não lograriam atingir tal escopo se atuasse isoladamente, sem a participação do instituto da indenização punitiva. Isso porque, ao que nos parece, a tutela jurisdicional inibitória só pode ser adequadamente exercida se a vítima em potencial (ou algum dos co-legitimados para a persecução da tutela coletiva) pode antever o ato danoso e o potencial prejuízo dele decorrente (apenas nesse caso podendo deduzir em juízo sua pretensão inibitória). Nas hipóteses em que não se pode sequer cogitar se e quando o ato ilícito será cometido (ou se uma determinada atividade impõe, ou não, riscos à sociedade), os mecanismos da tutela inibitória não atuam com a mesma eficiência e, mesmo existindo, não logram impedir o cometimento de ilícitos e a ocorrência de prejuízos.

Por outro lado, é importante frisar que mesmo a existência de tais medidas inibitórias não desestimula o potencial ofensor de, nas hipóteses em que puder obter vantagens econômicas, vir a cometer o ato ilícito e a submeter a sociedade a riscos e prejuízos. Diante das vantagens econômicas que lhe podem ser proporcionadas pelo cometimento do ilícito, ele ainda o irá cometer, procurando, apenas, evitar que a vítima anteveja seu planejamento escuso e, dessa forma, possa-se valer de uma medida inibitória para impedir que os lucros sejam auferidos pelo ofensor.

Nesses casos, a indenização punitiva, por representar um acréscimo à condenação compensatória que é, em regra, impassível de quantificação a priori pelo ofensor (e que, portanto, não possibilita a realização de um cálculo matemático para que se possa aferir se o cometimento do ilícito irá compensar), efetivamente atua de modo a desestimulá-o do cometimento de atos ilícitos (ainda mais se lhe for claro que todo o eventual lucro por ele auferido ser-lhe-á retirado se ele vier a ser sancionado).

Desta feita, para que se atinja eficientemente o escopo de prevenir os prejuízos e assegurar o equilíbrio social, acredita-se que o ordenamento jurídico deve ser moldado de maneira a abarcar tantos quantos forem os mecanismos adequados para tanto, os quais, atuando conjuntamente, lograrão êxito na persecução desse escopo. A indenização punitiva pode, portanto, ser utilizada em conjunto com os mecanismos de 
tutela jurisdicional inibitória, especialmente quando estes se mostrarem insuficientes para, atuando isoladamente, atingir suas finalidades preventivas.

À luz do quanto acima exposto, acredita-se ser possível afirmar, como já o havia feito R. DEMOGUE no início do século passado, que "seria [...] equivocado acreditar que a aplicação irrestrita da idéia de indenização compensatória representa um estágio definitivo na evolução do Direito" ${ }^{479}$; para concluir, nas palavras de André Gustavo Corrêa de ANDRADE, que a indenização punitiva "deve, pois, ser vista como legítima resposta jurídica a determinados comportamentos, ofensivos a certa categoria de bens jurídicos, em situações nas quais outras medidas ou formas de sanção se mostram inaptas ou falhas" ${ }^{\circ 80}$.

\section{AS NOVAS FUNÇÕES A SEREM EXERCIDAS PELA RESPONSABILIDADE CIVIL}

Em atenção aos fenômenos acima narrados, vê-se que, para assegurar a tutela mais eficiente possível àqueles interesses considerados como especialmente relevantes, a responsabilidade civil deve se mostrar efetivamente "poli-funcional". Nos casos em que assim se exigir, a responsabilidade civil deverá exercer, ao lado de sua tradicional função reparatória, e com igual relevância, uma função punitiva (também nomeada de sancionatória) e uma função preventiva (também denominada de dissuasória) ${ }^{481}$. Não se está, aqui, a pensar em funções a serem desempenhadas de maneira subordinada àquela ressarcitória ${ }^{482}$, mas, sim, de uma atuação efetivamente parelha, em que as três funções da responsabilidade civil atuem conjuntamente para garantir a mais eficiente dosimetria do quantum indenizatório, em um patamar que sirva para, ao mesmo tempo e de maneira integral, compensar o ofendido pelo prejuízo suportado (em atenção à função ressarcitória), punir o ofensor pela conduta altamente reprovável por ele cometida

\footnotetext{
479 No original: "[i]t would, however, be wrong to believe that the general application of the idea of compensatory indemnity is a definite stage in the evolution of law." (Validity of the Theory of Compensatory Damage, in Yale Law Jornal, vol. XXVII, n. 5, mar/1918, pág. 596).

480 Dano Moral e Indenização Punitiva: Os punitive damages na experiência do common law e na perspectiva do Direito brasileiro, Rio de Janeiro, Forense, 2006, pág. 242.

${ }^{481}$ M. G. BARAtella, Le Pene Private, Milano, Giuffrè, 2006, págs. 197.

${ }^{482}$ Como o sustentam Carlos Roberto Gonçalves, Comentários ao Código Civil, São Paulo, Saraiva, 2003, pág. 359, Marcela Alcazas BASSAN, As Funções da Indenização por Danos Morais e a Prevenção de Danos Futuros, Dissertação (Mestrado) - Faculdade de Direito da USP, São Paulo, 2009, pág. 96 e Wesley de
} 
(por força da função punitiva) e, ainda, desestimular o ofensor e a sociedade em geral de cometer, no futuro, atos semelhantes (o que se faz à luz da função preventiva).

A seguir procuraremos analisar de que modo e em que medida a responsabilidade civil deve exercer adequada e suficientemente suas funções punitiva e preventiva (a qual, por sua vez, desdobra-se em duas "sub-funções", a de prevenção geral, destinada a dissuadir todos os membros do grupo social a não cometerem atos ilícitos semelhantes ao cometido pelo ofensor, e a de prevenção especial, direcionada a desestimular o próprio ofensor quanto ao cometimento de novos ilícitos).

\section{III.I. A função punitiva}

Até mesmo por uma questão de ordem lexical (por ser esta a qualificação que, com a finalidade de distingui-la da "indenização compensatória", empresta-se à locução “indenização punitiva”), tratemos, em primeiro lugar, daquela que se denomina de função punitiva; expressão da qual se procura extrair não apenas as justificativas para a incidência da indenização punitiva, mas, igualmente, ao menos alguns dos critérios utilizados para a quantificação dessa sanção pecuniária, para que ela possa guardar uma relação de justa proporcionalidade com as condutas por ela sancionadas.

Por primeiro, e no que concerne à incidência da indenização punitiva, vale repisar que tal sanção se destina exclusivamente a remediar condutas particularmente reprováveis, caracterizadas pela intencionalidade do ofensor (que pode se restringir apenas à intenção de cometer o ato ilícito, impondo um mal ao ofendido, ou, ainda, vir acompanhada de outras características ainda mais indesejáveis, como, por ex., a intenção de extrair vantagens financeiras do ato ilícito cometido) ou, no mínimo, de uma flagrante e grosseira desconsideração em relação aos direitos alheios (o que, se não é o suficiente para caracterizar o dolo, certamente se configura como culpa grave, muito aproximada daquela primeira concepção) ${ }^{483}$.

Oliveira Louzada Bernardo, Dano Moral: Critérios de Fixação de Valor, Rio de Janeiro, Renovar, 2005, pág. 177.

${ }^{483}$ Daí se verifica que a indenização punitiva jamais será utilizada para sancionar condutas meramente culposas (caracterizadas por mera negligência, leve imprudência ou por imperícia), vez que estas poderão ser, no mais das vezes, adequadamente remediadas pela aplicação isolada da indenização compensatória (medida 
Para além disso, também se verificou que a indenização punitiva é uma sanção que atua exclusivamente para assegurar a efetiva tutela de bens e interesses de especial relevância (em particular aos direitos da personalidade, aos direitos e interesses metaindivudiais e, ainda, o equilíbrio social); não se imiscuindo no âmbito em que a indenização compensatório poderia atuar, ainda que isoladamente, de maneira eficiente.

Diante dessas premissas, pode-se afirmar que, no que toca à sua incidência (e em retomada, ainda que parcial, do quanto se disse acerca do paradigma tradicional da responsabilidade fundada na culpa), a indenização punitiva exerce uma "função moralizadora" (ou, como preferimos denominar, punitiva): voltam-se os olhos ao passado, para sancionar com especial rigor uma determinada conduta que se tenha caracterizado pelo mais alto grau de reprovabilidade, e da qual resultaram lesões a bens e interesses de particular relevância ${ }^{484}$. Pune-se, assim, o ofensor, fazendo-o suportar não apenas uma sanção compensatória, mas, também, uma outra, de índole punitiva, para que ele experimente a reprovação da sociedade quanto ao ilícito por ele perpetrado.

Ainda quanto a este aspecto, mas sob o ponto de vista das vítimas do ato ilícito, dá-se razão às palavras de Fernando NORONHA, para o qual, "quando a conduta da pessoa obrigada à reparação for censurável, também é compreensível que a punição do responsável ainda seja uma forma de satisfação proporcionada aos lesados" ${ }^{485}$. De uma certa maneira, a imposição de uma sanção pecuniária que possua expressamente uma função punitiva atua de modo a acalentar o desejo de vingança do ofendido, o qual se sente ultrajado não apenas por ter suportado o prejuízo, mas, também, pelo fato de tal prejuízo decorrer de uma conduta particularmente reprovável, marcada que é pela intencionalidade ou, ao menos, pela grave desconsideração de seus direitos. Nesse sentido, ao exercer sua função punitiva, a indenização também atua de modo a assegurar "um convívio social pacífico, na medida em que [...] impede a vingança pessoal da vítima"486.

que se destina apenas a reparar os prejuízos suportados pelo ofendido). Nesse sentido, cfr. Vitor Fernandes GonçAlves, A Punição na Responsabilidade Civil: A indenização do dano moral e da lesão a interesses difusos, Brasília, Brasília Jurídica, 2005, pág. 143.

${ }_{484}$ P. Gallo, Pene Private e Responsabilità Civile, Milano, Giuffrè, 1996, pág. 169.

${ }^{485}$ Direito das Obrigações, vol. I, $2^{\text {a }}$ ed., 2007, São Paulo, Saraiva, pág. 438.

${ }^{486}$ Vítor Fernandes GonçAlves, A Punição na Responsabilidade Civil: A indenização do dano moral e da lesão a interesses difusos, Brasília, Brasília Jurídica, 2005, pág. 141. Quanto ao tema ora em comento, remetemos o leitor ao quanto se disse, acima, sobre a "função vingativa" dos punitive damages. 
Por segundo, e no que se refere à quantificação da indenização punitiva, a função punitiva atua de modo a selecionar critérios distintos daquele utilizado para a aferição da indenização compensatória, o que se faz justamente em atenção às diferentes finalidades exercidas pelas duas sanções. Se, no caso da indenização compensatória, o ponto de relevância se encontra na vítima e no prejuízo por ela suportado (limite único, mínimo e máximo da indenização, ex vi do art. 944, caput, do CC/2002), na indenização punitiva tal ponto se encontra no ofensor e na conduta por ele perpetrada, majorando-se a sanção quanto mais reprovável for tal conduta ${ }^{487}$.

Com a utilização da função punitiva, nota-se, portanto, uma nova modificação de foco no que toca à responsabilidade civil: abandona-se, para esta finalidade, a vítima e o dano por ela sofrido, para que se possa lançar os olhos novamente ao ofensor e à conduta por ele perpetrada. Essa mudança de foco permite a realização de um "juízo valorativo diferenciado", possibilitando sancionar de modo mais gravoso o responsável pela conduta mais reprovável ${ }^{488}$.

Tal aspecto atende a uma exigência de proporcionalidade (ou seja, de que a indenização punitiva guarde uma relação de proporção em sentido estrito com a conduta que se destina a sancionar). Como bem anota a doutrina especializada, repugnaria ao senso comum de justiça que duas condutas ilícitas em diversos graus de reprovabilidade fossem sancionadas exatamente da mesma maneira, sem que se lhes emprestasse solução diversa na medida em que se distinguem uma da outra ${ }^{489}$.

\footnotetext{
487 André Gustavo Corrêa de ANDRADE, Dano Moral e Indenização Punitiva: Os punitive damages na experiência do common law e na perspectiva do Direito brasileiro, Rio de Janeiro, Forense, 2006, pág. 253.

${ }^{488}$ André Gustavo Corrêa de ANDRADE, Dano Moral e Indenização Punitiva: Os punitive damages na experiência do common law e na perspectiva do Direito brasileiro, Rio de Janeiro, Forense, 2006, pág. 254.

${ }^{489}$ André Gustavo Corrêa de ANDRADE, Dano Moral e Indenização Punitiva: Os punitive damages na experiência do common law e na perspectiva do Direito brasileiro, Rio de Janeiro, Forense, 2006, pág. 258. Em sentido semelhante, Vitor Fernandes GonÇALVES, A Punição na Responsabilidade Civil: A indenização do dano moral e da lesão a interesses difusos, Brasília, Brasília Jurídica, 2005, pág. 143.
} 


\section{III.II. A função preventiva}

Em que pese toda a relevância que se deve atribuir à supra referida função punitiva (também nominada de moralizadora), a qual não se procura negar ou diminuir, acredita-se que a mais importante função a ser exercida pela indenização punitiva (e aquela que, de maneira mais incisiva e convincente, justifica a adoção de tal instituto pelo ordenamento jurídico nacional) é a assim chamada função preventiva ${ }^{490}$ (também denominada de função de desestímulo $)^{491}$. Tanto é assim que a prevenção é tida como uma das mais relevantes funções a serem exercidas pela responsabilidade civil mesmo por parte da doutrina que não admite que esse e outros escopos do instituto se operem por meio da majoração do quantum indenizatório ${ }^{492}$ (considerado limitado à extensão dos prejuízos suportados pela vítima, em atenção ao princípio da reparação integral).

Trata-se, portanto, de escopo dotado de inegável relevância, ao qual, com atenção ao nosso ordenamento, são atribuídas raízes constitucionais, a serem encontradas

\footnotetext{
490 André Gustavo Corrêa de ANDRADE, Dano Moral e Indenização Punitiva: Os punitive damages na experiência do common law e na perspectiva do Direito brasileiro, Rio de Janeiro, Forense, 2006, pág. 258. Ao tratar do tema, Fernando NoRONHA afirma que a função preventiva é, por vezes, também denominada de "função educativa", a despeito da crítica de parte da doutrina que sustenta que, por meio da incidência da função preventiva, o que se pretende não é, propriamente, ensinar o homem ou os agentes econômicos a se conduzirem de maneira mais adequada, mas, sim, dissuadi-los do cometimento de novas condutas ilícitas. (Direito das Obrigações, vol. I, $2^{\mathrm{a}}$ ed., 2007, São Paulo, Saraiva, pág. 440). Como já se teve a oportunidade de analisar, quando tratamos das funções usualmente exercidas pelos punitive damages, preferimos sustentar que a dita função educativa é uma sub-função, relacionada tanto à função preventiva quanto à função punitiva, e tem por finalidade dar ao ofensor e à sociedade prévio conhecimento sobre quais condutas são vistas como socialmente indesejáveis (e que, portanto, não devem ser cometidas), e qual o grau de intensidade da sanção prevista pelo ordenamento como resposta ao cometimento de tais condutas. Dessa maneira, ao sinalizar que existem direitos e interesses especialmente protegidos, e que as condutas lesivas a tais direitos serão severamente sancionadas, o ordenamento jurídico (por meio da utilização da responsabilidade civil) educa a sociedade sobre quais os padrões de comportamento são tidos por aceitáveis. Nesse sentido é que, acreditamos, pode-se falar em função educativa.

${ }^{491}$ Essa é a expressão invocada por Carlos Alberto BITTAR, quando o autor trata da necessidade de que a indenização por danos morais seja quantificada em atenção a critérios particulares do ofensor (tais como sua capacidade econômica ou os proveitos por ele auferidos em razão do cometimento do ato ilícito), tudo com vistas a dissuadir o ofensor e a sociedade quanto à reiteração de tais atos ilícitos (Reparação Civil por Danos Morais, São Paulo, RT, 1993, págs. 221/226).

${ }^{492}$ Nesse sentido, cfr. Marcela Alcazas BASSAN, As Funções da Indenização por Danos Morais $e$ a Prevenção de Danos Futuros, Dissertação (Mestrado) - Faculdade de Direito da USP, São Paulo, 2009, pág. 27, 98 e 103; e Clóvis Veríssimo do Couto e Silva, O Conceito de Dano no Direito Brasileiro e Comparado, in Revista dos Tribunais, ano 80, vol. 667, mai/1991, pág. 11. Acerca do escopo preventivo da responsabilidade civil, Fernando NORONHA noticia que,"[e]m especial quanto aos danos transindividuais [...], com destaque para os resultantes de infrações ao meio ambiente, tem sido muito enfatizada a necessidade de punições 'exemplares', através da responsabilidade civil, como forma de coagir as pessoas, empresas e outras entidades a adotar todos os cuidados que sejam cogitáveis, para evitar a ocorrência de danos." (Direito das Obrigações, vol. I, $2^{\text {a }}$ ed., 2007, São Paulo, Saraiva, pág. 439).
} 
especialmente nos princípios da segurança (art. $5^{\circ}$, caput, CF/88), da solidariedade social $\left(\text { art. } 3^{\circ}, \mathrm{I}, \mathrm{CF} / 88\right)^{493}$ e, especificamente no que toca aos danos ambientais, no dever de preservação do meio ambiente para as gerações futuras (art. 225, caput, CF/88) ${ }^{494}$.

Ao contrário da função punitiva (que mira sempre um ato passado, especialmente reprovável, contra o qual se acredita dever aplicar uma sanção mais severa do que a mera compensação dos prejuízos, que guarde uma relação de proporcão com o grau de reprovabilidade da conduta perpetrada, para a adequada punição do agente), a função preventiva é exercida com vistas a um comportamento futuro ${ }^{495}$. Explica-se: a despeito de ser desempenhada por meio de um instrumento jurídico (= a indenização) que só incide após a ocorrência de um ato ilícito danoso, a função preventiva visa a desestimular o cometimento de novos atos ilícitos semelhantes àquele que então é sancionado. À luz desse escopo, a responsabilidade civil passa a mirar não tanto o ato ilícito já cometido (e os prejuízos dele resultantes), mas, sim, aqueles atos ilícitos potenciais, que ainda não ocorreram, procurando sinalizar ao ofensor e à sociedade em geral que tais atos são reputados indesejáveis e, conseqüentemente, sancionados com particular gravidade, em atenção às características pessoais do ofensor que o levaram a cometer o ato ilícito (para que a imposição da sanção lhe sirva, em especial, de desestímulo), ou aos proveitos auferidos por meio de seu cometimento (para que a imposição da sanção sinalize à sociedade que o ordenamento jurídico não admite que se retenha os frutos econômicos da atuação ilícita).

Como se vê, procura-se dar à função preventiva a aplicação mais ampla possível. Por meio dela, busca-se “dissuadir a pessoa responsável pelo dano, e a outros, para que não tomem parte em atividades ou comportamentos que lesionem um terceiro. A função dissuasória não vai, unicamente, dirigida ao demandado do caso concreto [em atuação que se chama de "prevenção especial", moldada em atenção às características pessoais do ofensor]. Pelo contrário, ela "pretende ser uma mensagem dirigida à sociedade [em atuação que se chama de "prevenção geral", moldada em atenção a características

\footnotetext{
493 Teresa Ancona LoPEZ, Princípio da Precaução e Evolução da Responsabilidade Civil, São Paulo, Quartier Latin, 2010, págs. 75/76.

${ }^{494}$ Patrícia Faga Iglecias Lemos, Meio Ambiente e Responsabilidade Civil do Proprietário (Análise do Nexo Causal), São Paulo, RT, 2008, pág. 67.

${ }^{495}$ Antonio JunqueIRA DE AZEVEDo, Por Uma Nova Categoria de Dano na Responsabilidade Civil: O Dano Social, in Novos Estudos e Pareceres de Direito Privado, São Paulo, Saraiva, 2009, pág. 380.
} 
específicas do ato cometido e dos resultados dele decorrentes, em especial os proveitos de ordem econômica]"496.

Assim, em atenção à sua função preventiva, a indenização punitiva atua de modo a estimular o respeito à Lei e a promover o bem estar social ${ }^{497}$ : ao se demonstrar, ao causador do ato ilícito e à sociedade em geral, que determinados atos ilícitos (em particular aqueles mais reprováveis, marcados pela intencionalidade ou pela irresponsável desconsideração em relação aos direitos alheios) são severamente sancionados pelo ordenamento, coarcta-se a ocorrência desses mesmos atos ilícitos (o que se faz por meio da ameaçada de sancionamento mais severo, que extrapola os estritos limites do prejuízo suportado pelo ofendido) ${ }^{498}$.

Desta feita, nos moldes do que se expôs acima sobre a função preventiva dos punitive damages (pedindo-se licença para remeter o leitor a este ponto, em especial para que se relembre os argumentos invocados para ultrapassar as ressalvas doutrinárias à sua forma de atuação), acredita-se que o escopo preventivo da indenização punitiva somente será alcançado por meio da utilização de "medidas economicamente mais pesadas [= indenizações mais severas] para que" seja gerada "uma ameaça ou temor efetivos em todos os cidadãos" ${ }^{\prime 99}$, os quais, dessa maneira, sentir-se-ão efetivamente desestimulados da prática de novos atos ilícitos. Procura-se, dessa maneira, elevar o quantum indenizatório para, tornando tal sanção mais severa, reforçar-se a imperatividade da norma de conduta que a subjaz, incentivando o próprio ofensor e a sociedade em geral a passar a respeitar os direitos e interesses alheios ${ }^{500}$.

\footnotetext{
${ }^{496}$ No original: "[s]e busca dissuadir a la persona responsable del daño, y a otros, para que no tome parte en el futuro en actividades o comportamientos que lesionen a um tercero. La función disuasoria no va, únicamente, dirigida al demandado del caso concreto, sino que pretende ser un mesaje dirigido a la sociedad." (G. V. Robredo, Daños Punitivos en el Proceso Civil Norteamericano, in Revista de la Universidad de Deusto, vol. 57, fasc. 97, jul-dic./ 1996, pág. 184). Em sentido semelhante, Fernando Noronha, Direito das Obrigações, vol. I, $2^{a}$ ed., 2007, São Paulo, Saraiva, pág. 439.

${ }^{497}$ D. G. Owen, A Punitive Damages Overview: Functions, Problems and Reform, in Villanova Law Review, vol. 39, 1994, pág. 380 e D. D. Ellis JR., Fairness and Efficiency in the Law of Punitive Damages, in Southern California Law Review, vol. 56, 1982, pág. 8.

${ }^{498}$ Teresa Ancona LOPEZ, Princípio da Precaução e Evolução da Responsabilidade Civil, São Paulo, Quartier Latin, 2010, págs. 79.

${ }^{499}$ Teresa Ancona LOPEZ, Princípio da Precaução e Evolução da Responsabilidade Civil, São Paulo, Quartier Latin, 2010, pág. 80.

${ }^{500}$ Carlos Alberto BITTAR, Reparação Civil por Danos Morais, São Paulo, RT, 1993, pág. 221 e Vitor Fernandes GonçAlves, A Punição na Responsabilidade Civil: A indenização do dano moral e da lesão a interesses difusos, Brasília, Brasília Jurídica, 2005, pág. 147. É também nesse sentido que, ao tratar da proteção ao meio ambiente, Patrícia Faga Iglecias LEMOS anuncia que a responsabilidade civil somente poderá exercer
} 
Ao tratar do tema em comento, André Gustavo Corrêa de ANDRADE nos apresenta interessante alegoria ao afirmar que, nas hipóteses em que a indenização compensatória não consegue, por si só, desestimular o ofensor quanto ao cometimento de novos ilícitos (e serve, dessa maneira, como que de estímulo para o cometimento de tais ilícitos, ao permitir que o ofensor apure, por meros cálculos matemáticos, ser economicamente mais vantajoso arcar com os custos da indenização do que se conduzir de maneira lícita, evitando o prejuízo), ela atua como "medicamente que ataca os sintomas sem combater a própria doença, trazendo uma falsa sensação de cura, pois a doença persiste e volta cada vez mais forte, acabando por se tornar imune ao ataque"501.

Para assegurar a eficiente tutela do equilíbrio social, é imprescindível que a responsabilidade civil atue de modo a impedir que o ofensor possa, de um modo ou de outro, optar conscientemente pelo cometimento do ilícito, desrespeitando, portanto, os direitos e interesses alheios como bem lhe aprouver, apenas porque tal conduta é economicamente mais vantajosa do que aquela legalmente esperada. Para tanto, a sanção punitiva deverá ser quantificada de acordo com critérios pessoais, característicos do ofensor, tais como sua capacidade econômico-financeira (o que se fará em atenção à "prevenção especial", adequando a sanção à pessoa do ofensor) ou, ainda, o montante dos benefícios de ordem econômica que ele, porventura, vier a extrair do ilícito perpetrado (o que se fará em atenção à "prevenção geral", evitando que se possa nutrir qualquer expectativa de lucrar por meio de uma atuação ilícita) ${ }^{502}$.

Nesse sentido, o amoldamento da indenização à pessoa do ofensor (ou aos proveitos que a conduta ilícita lhe proporciona) atua de modo a reforçar a imperatividade da norma jurídica violada, permitindo, dessa maneira, eliminar (ou mitigar) a ocorrência de

\footnotetext{
adequadamente sua função preventiva (à qual atribui papel de grande relevância) se "o sistema de responsabilização for efetivo e exigente"; concluindo que "a responsabilidade civil somente assume seu viés preventivo se o poluidor percebe que é mais barato prevenir do que reparar o dano. Enquanto isso não ocorrer, a opção do poluidor será sempre de causar o dano em vez de preveni-lo." (Meio Ambiente e Responsabilidade Civil do Proprietário (Análise do Nexo Causal), São Paulo, RT, 2008, pág. 68).

501 Dano Moral e Indenização Punitiva: Os punitive damages na experiência do common law e na perspectiva do Direito brasileiro, Rio de Janeiro, Forense, 2006, págs. 258/259.

${ }^{502}$ Em sentido semelhante, cfr. A. P. ScARSo, Punitive Damages in Italy, in H. KozIOL - V. WILCOX (eds.), Punitive Damages: Common Law and Civil Law Perspectives, Wien, Springer, 2009, pág. 103.
} 
comportamentos ilícitos que não seriam atingidos apenas pela indenização compensatória $^{503}$.

Por derradeiro, uma última preocupação levantada pela doutrina a respeito do tema diz respeito aos potenciais impactos que a função preventiva poderia trazer o exercício da livre iniciativa (igualmente erigida a fundamento da República Federativa do Brasil, em relação à qual se reconhece seu "valor social", ex vi do art. $\left.1^{\circ}, \mathrm{IV}, \mathrm{CF} / 88\right)$. Ao tratar do tema, G. V. RoBREDo externa sua preocupação ao afirmar que "[o] que não está claro é se o nível dissuasório que se alcança [por meio da utilização da indenização punitiva] é um nível eficiente ou se, pelo contrário, este tipo de condenação leva a não se tomar parte em atividades que, ainda que contenham um componente de risco, são benéficas para a sociedade" ${ } 504$. Ainda mais soturno se mostra Clóvis Veríssimo do Couto e SILVA, o qual afirma que "se o que se deve pagar a título de indenização superar, em grande medida, o prejuízo sofrido, este fato se constituirá em grave impedimento à livre atividade dos indivíduos em sociedade ${ }^{, 505}$.

Em que pese a autoridade dos expositores, quer-nos parecer que as preocupações acima externadas não concretizam em um sistema em que a indenização punitiva incide de maneira eficiente e adequada. Isso porque a medida correta entre a prevenção eficiente (denominada pela doutrina norte-americanda apenas de "deterrence") e a prevenção excessiva (denominada de "overdeterrence") é questão que se relaciona às hipóteses de incidência e à quantificação da indenização punitiva. A simples existência do instituto não acarreta, de per se, a prevenção excessiva. O que se deve fazer, como se sustenta no presente estudo, é conjugar a indenização punitiva à indenização compensatória apenas e tão-somente nas exatas hipóteses em que tal conjugação se fizer

\footnotetext{
503 André Gustavo Corrêa de ANDRADE, Dano Moral e Indenização Punitiva: Os punitive damages na experiência do common law e na perspectiva do Direito brasileiro, Rio de Janeiro, Forense, 2006, pág. 259.

${ }^{504}$ No original: "Lo que nos está claro es si el nivel disuasorio que se alcanza es un nivel eficiente o si por el contrario este tipo de condenas lleva a no tomar parte en actividades, que aunque contienen un componente de riesgo, son beneficiosas para la sociedad." (Daños Punitivos en el Proceso Civil Norteamericano, in Revista de la Universidad de Deusto, vol. 57, fasc. 97, jul-dic./ 1996, págs. 186). Há, evidentemente, uma série de atividades que, a despeito de comportarem um alto grau de risco, trazem benefícios igualmente elevados à sociedade. Basta tomar como exemplo a indústria farmacêutica. As preocupações do autor espanhol são também referidas por J. R. MCKNOWN, ao sustentar que "[e]xcessive punitive damage awards arguably threaten research and development of new products and may have led to the abandonment of potentially useful products." (Punitive Damages: State Trends and Developments, in The Review of Litigation, vol. 14, 1994, pág. 424).

505 O Conceito de Dano no Direito Brasileiro e Comparado, in Revista dos Tribunais, ano 80, vol. 667, mai/1991, pág. 11.
} 
necessária para atingir de maneira eficiente os fins a que a indenização punitiva se destina. Como abaixo será demonstrado, o simples fato de se exercer uma atividade de risco não impõe ao agente o risco de vir a ser condenado ao pagamento de indenização punitiva. Em qualquer caso, é indispensável a presença do componente subjetivo da conduta ou atividade (dolo ou culpa grave), de modo que, quando incidir, a indenização punitiva não visará ao controle do risco (tal fim já é atingido pela indenização compensatória, em especial após o desenvolvimento da teoria da responsabilidade objetiva). Frise-se: a indenização punitiva somente incidirá em hipóteses nas quais a responsabilização se dá de maneira objetiva se o risco natural da atividade houver sido agravado por uma conduta intencional ou gravemente culposa (a qual, por se tratar de conduta gravemente reprovável, dará ensejo à incidência de um sancionamento mais severo do que a mera recomposição do patrimônio das vítimas).

Acredita-se, portanto, que a utilização eficiente da indenização punitiva não acarretará impactos negativos para o exercício da livre iniciativa, não servindo de desestímulo para o desempenho de atividades naturalmente arriscadas. Incidirá o instituto apenas para sancionar aquelas atividades cujos riscos houverem sido agravados de maneira intencional ou gravemente irresponsável ${ }^{506}$.

\footnotetext{
506 Tome-se, por ex., duas empresas do ramo farmacêutico, ambas produtoras de medicamentos que, inseridos no mercado, podem vir a causar danos aos consumidores em razão de seus efeitos colaterais. No primeiro caso, os efeitos colaterais surgem, atingindo aos consumidores mesmo após cuidadosa análise prévia realizada pela empresa, que levou a cabo todos os testes exigidos pelos órgãos estatais competentes. Imediatamente após o conhecimento desses fatos, a empresa farmacêutica promove as retificações necessárias no medicamento, retirando os produtos potencialmente danosos do mercado e mitigando ao máximo os prejuízos suportados por seus consumidores. Já no segundo caso, a empresa fraudou documentos submetidos à aprovação dos órgãos estatais competentes, com a intenção de obter a rápida aprovação de um medicamento que se sabia, de antemão, ser inadequado para os consumidores. Em ambos os casos, a responsabilização das empresas pelos danos impostos se dá independentemente da alegação ou comprovação de culpa (trata-se, portanto, de responsabilidade objetiva pelo fato do produto), mas se pode perceber que, no segundo caso, existe um elemento cubjetivo que, ainda que não se considere doloso, certamente caracteriza uma conduta extremamente negligente e uma irresponsável desconsideração para com o bem estar dos consumidores (típica da culpa grave). No primeiro caso, não incidirá a indenização punitiva, enquanto que no segundo, sim.
} 


\section{CAPÍTULO III - A VIABILIDADE DA ADOÇÃO DA INDENIZAÇÃO PUNITIVA}

Tendo-se respondido afirmativamente ao questionamento posto no capítulo anterior, quanto à necessidade de adoção de figura análoga aos punitive damages em nosso ordenamento (a qual denominamos de indenização punitiva), para que o instituto da responsabilidade civil possa exercer, adequadamente, suas funções de punição e prevenção, cumpre-nos, no presente capítulo, dar resposta a uma outra questão: do modo como se encontra o ordenamento jurídico brasileiro hoje, é admissível a introdução da figura da indenização punitiva?

Para atingir tal finalidade, procuraremos analisar as críticas levantadas com maior freqüência por juristas de países de tradição jurídica romano-germânica contra a adoção da indenização punitiva, apresentando, ao final, nossas conclusões.

Antecipamos, desde já, nossa posição no sentido de que a admissão da indenização punitiva (sanção jurídica que exerce diretamente uma função punitiva) demanda prévia (e, no momento, inexistente) cominação legal, sob pena de violação do princípio da reserva legal (insculpido no art. $5^{\circ}, \mathrm{XXXIX,} \mathrm{CF/88).}$

Em virtude da adoção de tal posicionamento, procuraremos distribuir os temas a serem abordados no presente capítulo em dois grandes grupos: (i) o primeiro dos quais será destinado a enfrentar (e rebater) as críticas doutrinárias que julgamos inaptas a obstar a introdução da indenização punitiva em nosso ordemanento jurídico; e (ii) o segundo, no qual procuraremos analisar as críticas doutrinárias que, em razão da inexistência de prévia e expressa cominação legal, parecem-nos pertinentes. 


\section{CRÍTICAS DOUTRINÁRIAS À ADOÇÃo DA INDENIZAÇÃo PUNITIVA}

Por primeiro, cumpre-nos passar em revista as críticas doutrinárias que, a despeito de comumente levantadas com o intuito de contra-indicar a admissão da indenização punitiva por nosso ordenamento jurídico, não nos parecem capazes de se sustentar por seus próprios argumentos. Tais críticas, às quais procuraremos rebater abaixo, uma a uma, resumem-se às seguintes afirmações: (i) o Direito Civil é incompatível com a idéia de punição; (ii) a indenização punitiva serve de incentivo à litigância frívola, ou ao que se denomina de "indústria do dano moral"; (iii) a indenização punitiva é incompatível com as hipóteses de responsabilidade objetiva; e, por fim, (iv) a indenização punitiva violaria o princípio segundo o qual não se admite a imposição de duas ou mais penas em razão do mesmo ato ilícito ("ne bis in idem").

\section{I.I. Uma suposta incompatibilidade: punição e direito civil}

A primeira crítica levantada pela doutrina à admissão da indenização punitiva remonta à tradicional dicotomia jurídica entre Direito Público e Direito Privado, mais especificamente àquela atinente à separação entre o Direito Civil e o Direito Penal. Desta dicotomia, procura-se extrair o argumento de que ao Direito Civil compete tão-somente a reparação ou compensação dos prejuízos (por meio da responsabilidade civil), enquanto que ao Direito Penal incumbe, com exclusividade, a a punição do ofensor pelos ilícitos perpetrados, em argumento muito bem sintetizado nas incisivas palavras de Agostinho ALVIM, que afirma categoricamente que "o direito civil não pune" $"$ "

Ainda que, em uma primeira análise, a tese ora apresentada possa parecer sedutora, ela não sobrevive a uma análise mais aprofundada, da qual procuraremos extrair duas conclusões: (i) a de que as sanções jurídicas distinguem-se entre si pelas funções que, em caráter primordial, desempenham, e não por suas estruturas ou pelo ramo do Direito no qual se inserem; e (ii) o Direito Privado e, em especial, o Direito Civil é repleto de sanções que exercem, primordialmente, função punitiva. 


\section{I.I.I. Sanção jurídica e sanção punitiva}

A primeira premissa que pretendemos desconstruir é a de que as penas (expressão que significa sanção de caráter punitivo, que não se prende à recomposição do patrimônio lesado, mas, sim, a retribuir ao ofensor o mal por ele causado, punindo-o) seriam sanções típicas e exclusivas do Direito Criminal; inexistentes, portanto, nos demais ramos do Direito.

Para atingir tal objetivo, partiremos da verificação do conceito de sanção jurídica, e pela análise de suas diversas espécies, que se diferenciam não por sua distinta estrutura, mas, sim, pelas funções que exercem.

Nesse desiderato, vale ressaltar que, em termos amplos, sanção é a consequiência jurídica (rectius: efeito jurídico ${ }^{508}$ ) desfavorável ${ }^{509}$, decorrente do descumprimento de uma norma jurídica, por meio da qual se reforça a imperatividade da norma violada ${ }^{510}$. A sanção jurídica é, portanto, componente indissociável da norma, e que atua de modo a garantir que prescrição normativa seja efetivamente cumprida por seus sujeitos.

É o que nos basta para afirmar que o conceito de sanção jurídica é amplo, abarcando as mais diversas formas de conseqüências jurídicas desfavoráveis, de modo a não se poder confundir os conceitos de sanção jurídica (gênero) e pena (espécie), ainda que ambos tenham, em maior ou menor grau, uma conotação negativa para o sujeito da sanção.

${ }^{507}$ Da Doação, $3^{a}$ ed., São Paulo, Saraiva, 1980, pág. 278. Sobre a alegada incompatibilidade, cfr. Clayton REIS, Os Novos Rumos da Indenização do Dano Moral, Rio de Janeiro, Forense, 2003, págs. 215/223.

${ }^{508}$ J. O. AsCEnsÃo, Introdução à Ciência do Direito, $3^{\mathrm{a}}$ ed., Rio de Janeiro, Renovar, 2005, pág. 57.

509 Tem-se, para o que concerne ao presente estudo, o conceito de sanção apenas e tão-somente como a conseqüência jurídica desfavorável, aflitiva, que decorre do descumprimento de determinado preceito jurídico, conceito este que exclui o da assim chamada sanção premial ou sanção positiva. Não se ignora, nesta sede, a existência de conseqüências jurídicas positivas (e.g. a isenção tributária ou aquisição de determinada posição jurídica de vantagem, a honraria, o prêmio) pela observância a determinado preceito legal, nem sua importância para a persecução das funções a que se destina o Direito (sobre o tema, por todos, N. BobBio, As Sanções Positivas, in Da Estrutura à Função, trad. Daniela Beccaccia Versiani, Barueri, Manole, 2007, págs. 23/32). O que se sustenta, para os fins a que se destina a presente dissertação, é apenas que tal sorte de consequiência jurídica (positiva) não se amolda ao conceito de sanção como meio de reforçar a imperatividade da norma jurídica e, por isso, não será abordado com profundidade. Nesse sentido, cfr. Goffredo Telles JR., Iniciação na Ciência do Direito, São Paulo, Saraiva, 2001, págs. 83/85 e J. O. ASCENSÃo, Introdução à Ciência do Direito, $3^{\text {a }}$ ed., Rio de Janeiro, Renovar, 2005, págs. 58/59. 
Com efeito, após caracterizar a sanção jurídica, dentro do raciocínio que vimos delineando, como "produção compulsória de um mal", H. KELSEN procura subdividir o gênero sanção jurídica em duas espécies, às quais denomina pena (em sentido estrito, conceito no qual se enquadram, e.g., as sanções penais de privação de liberdade ou restrição de direitos) e execução (execução forçada, conceito no qual o autor enquadra, e.g., a sanção indenizatória) ${ }^{511}$.

Vê-se, portanto, que o leque no qual se revelam as sanções jurídicas é amplo, de modo a se poder denominar de sanções jurídicas as diversas conseqüências negativas do descumprimento de preceitos normativos, tais como, por ex., a obrigação de indenizar que decorre do cometimento de um ato ilícito ${ }^{512}$, a nulidade ou anulabilidade dos atos reputados como inválidos ${ }^{513}$ e, até mesmo, a produção de efeitos de determinados negócios jurídicos ${ }^{514}$.

O que importa de ver, para o que ora se pretende expor, é que as diversas maneiras pelas quais a sanção jurídica se revela (as quais se poderia denominar espécies) não se distinguem entre si por força de seu conteúdo (estrutura), mas, sim, pela finalidade específica que desempenham no ordenamento (função).

Assim é que, procurando delinear as distinções entre as duas espécies de sanção jurídica acima referidas por H. KELSEN, F. CARNELUTTI sustenta que, também sobre este tema, a função prevalece sobre a estrutura ${ }^{515}$. De maneira mais elucidativa, J. O. ASCENSÃO afirma que as "várias espécies de sanções não se distinguem entre si por trações estruturais, ou por representarem específicas figuras jurídicas: distinguem-se pela

\footnotetext{
${ }^{510}$ J. O. AsCEnsão, Introdução à Ciência do Direito, $3^{\mathrm{a}}$ ed., Rio de Janeiro, Renovar, 2005, pág. 55.

${ }^{511}$ Teoria Pura do Direito, trad. João Batista Machado, 6 a ed., São Paulo, Martins Fontes, 2000, pág. 122.

${ }^{512}$ Eduardo UILAN, Responsabilidade Civil Punitiva, Tese (Doutorado) - Faculdade de Direito da USP, São Paulo, 2003, pág. 7.

${ }^{513}$ Nesse sentido, Marcos Bernardes de Mello, Teoria do Fato Jurídico (Plano da Validade), $8^{\text {a }}$ ed., São Paulo, Saraiva, 2008, págs. 52/53. Contra, J. O. ASCENSÃO, para quem os "valores negativos do negócio jurídico", entre os quais se enquadra a invalidade, não seria uma sanção (Introdução à Ciência do Direito, $3^{\mathrm{a}}$ ed., Rio de Janeiro, Renovar, 2005, págs. 68/74).

514 Veja-se, nesse sentido, a impossibilidade de alegação da excepctio doli quando ambas as partes contratantes houverem se conduzido de maneira dolosa (art. 150, CC).

515 F. CARnelutTi, Arte del Derecho (Seis Meditaciones sobre el Derecho), Buenos Aires, Ediciones Juridicas Europa America, 1948, pág. 81.
} 
função que desempenham" ${ }^{516}$ no ordenamento. Ao apreciar as diversas funções exercidas pelas sanções jurídicas, o citado autor conclui por subdividi-las em cinco espécies: compulsórias, reconstitutivas, compensatórias, preventivas e punitivas ${ }^{517}$.

Para o presente estudo, interessa-nos especificamente a análise das sanções que exercem função compensatória e punitiva.

A primeira delas tem lugar sempre que, cometido determinado ato ilícito do qual decorre prejuízo, não é possível, por um motivo ou outro, a recomposição do patrimônio lesado por meio da restituição ao status quo ante. Diante de tal impossibilidade, parte-se para o ressarcimento, realizado sempre pela via indenizatória, i.e., por meio da entrega, ao ofendido, de uma quantia em pecúnia que lhe sirva de lenitivo pelos prejuízos suportados, o que pode englobar o valor do bem efetivamente lesado (dano emergente), outros prejuízos de ordem material (lucros cessantes) ou, até mesmo, prejuízos de ordem extrapatrimonial (danos ou detrimentos morais).

Já a segunda delas tem lugar quando "já não interessa reconstituir a situação que existiria se o fato [ilícito] se não tivesse verificado",518, mas, sim, aplicar um mal ao ofensor, um castigo que lhe sirva de sofrimento e reprovação pelo ato extremamente gravoso por ele perpetrado. Em nada se confunde, portanto, com a indenização acima descrita ${ }^{519}$.

\footnotetext{
${ }_{517}^{516}$ J. O. AsCENSÃo, Introdução à Ciência do Direito, $3^{\text {a }}$ ed., Rio de Janeiro, Renovar, 2005, pág. 58.

${ }^{517}$ Por fugirem do escopo do presente trabalho, não trataremos, de maneira pormenorizada, das sanções compulsória e reconstitutiva. Sobre o tema, J. O. AsCENSÃo, Introdução à Ciência do Direito, $3^{\mathrm{a}}$ ed., Rio de Janeiro, Renovar, 2005, págs. 58/68. Como se verá adiante, a indenização punitiva exerce, também, marcada função preventiva, pois que visa a desestimular o cometimento de atos ilícitos altamente reprováveis. Contudo, justamente por se destinar ao desestímulo apenas desses atos ilícitos mais graves (caracterizados que são dolo ou culpa grave de seu agente) e, ao mesmo tempo, a impor uma retribuição ao ofensor pelo mal causado (punindo-o, portanto), procuraremos, no âmbito desta dissertação, tratar da indenização punitiva sob a ótica das sanções punitivas (até porque, para uma parcela da doutrina, são estas - as punitivas, e não as preventivas - as sanções alegadamente inadmissíveis fora do alcance do Direito Penal).

${ }_{518}$ J. O. AsCENSÃo, Introdução à Ciência do Direito, $3^{\mathrm{a}}$ ed., Rio de Janeiro, Renovar, 2005, pág. 66.

${ }^{519}$ Nas palavras de H. A. FISCHER, "[l]a pena se impone para castigar la culpa del delinquente; la indemnización, para reparar el daño del perjudicado. La pena puede existir sin necessidad de que el delito haya producido un daño (tentativa de delito), cosa incompatible con la indemnización; la extensión y alcance de ésta, mídense por la extensión y alcance del daño, y no per el grado de culpabilidad. La finalidad de la indemnización es reparar un mal inferido. La pena se propone castigar un mal causado, infligiendo al causando outro nuevo. La pena es siempre consecuencia de un delito; en el régimen de indemnización, el acto ilícito es una de tantas causas determinantes." (Los Daños Civiles y Su Reparación, trad. W. Roces, Madrid, 1928, pág. 223).
} 
É fato que as ditas sanções punitivas, por corresponderem "às violações mais gravosas da ordem jurídica" ${ }^{\natural 20}$, são mais comumente associadas às penas criminais, mas é um verdadeiro equívoco sustentar que se tratam de sanções exclusivas do Direito Penal. Nesse sentido, ao tratar das sanções jurídicas, H. KELSEN afirma que não apenas as sanções tipicamente características do Direito Penal podem-se qualificar como penas, concluindo que também são tidas como penas "a privação de outros direitos" (que não a liberdade): "tal a demissão [rectius: dispensa] ou a perda dos direitos políticos" 521.

Sob esta ótica, vê-se que as sanções punitivas se encontram presentes nos mais diversos ramos do Direito, sempre que o descumprimento de determinada norma jurídica tem por consequiência a imposição uma sanção cuja função principal é a imposição de um mal ao ofensor, que lhe serve de reprovação pela má conduta cometida (respondese, assim, o mal com o mal).

Veja-se, apenas à guisa de exemplo, que, no âmbito do Direito Processual Civil, são sanções punitivas as inúmeras hipóteses de incidência de multas pelo cometimento de atos atentatórios à dignidade da Justiça ou de litigância de má-fé (arts. 14, par. ún., 18, caput, 475-J, caput, 538, par. ún., 557, § $2^{\circ}$; e 601, todos do $\left.\mathrm{CPC}\right)^{522}$; a restrição à interposição de novos recursos pela parte que houver sido previamente apenada, salvo se recolher o valor da multa previamente imposta (arts. 538, par. un. e 557, § $2^{\circ}$, ambos do CPC) e, até mesmo, a antecipação dos efeitos da tutela na hipótese em que "ficar caracterizado o abuso de direito de defesa ou o manifesto propósito protelatório do réu"

\footnotetext{
${ }^{520}$ J. O. AsCEnSÃo, Introdução à Ciência do Direito, $3^{\text {a }}$ ed., Rio de Janeiro, Renovar, 2005, pág. 66.

${ }^{521}$ H. KelSEN, Teoria Pura do Direito, trad. João Batista Machado, 6 a ed., São Paulo, Martins Fontes, 2000, pág. 122.

${ }_{522}$ Theotonio Negrão, Código de Processo Civil e legislação processual em vigor, 39a ed., São Paulo, Saraiva, 2007, pág. 145: "A multa prevista neste artigo [art. 18, CPC] é uma sanção punitiva. Para que ela possa ser aplicada conjuntamente com outras sanções é necessário que elas exerçam funções distintas ( $p$. ex., coercitiva ou reparatória). Um mesmo comportamento não pode ser sancionado mais de uma vez com a mesma finalidade. São também punitivas as sanções previstas nos arts. $14 \S$ ún., 161, 196, 233, $538 \S$ ún., $557 \S 2^{\circ}$, 601-caput, $740 \S$ ún. e $764 \S 3^{\circ}$; logo, não podem ser impostas cumulativamente. Em cada caso concreto, deve ser aplicada a multa mais específica. Dado o caráter genérico da multa prevista no art. 18, sua efetiva incidência fica prejudicada nas situações em que também exista suporte material para a aplicação de punição prevista nos artigos arrolados anteriormente. Todavia, isso não impede que, conjuntamente com as sanções dos arts. $14 \S$ ún., $538 \S$ ún., 557 § 2o, 601-caput, 740 ún. e $746 \S 3^{\circ}$, seja imposta a condenação a indenizar, a pagar honorários advocatícios e a ressarcir despesas previstas neste art. 18, na medida em que se trata de sanção reparatória, ou seja, distinta da punitiva. Tanto a multa como as demais verbas previstas neste art. 18 são cumuláveis com a multa prevista nos arts. $461 \S 4^{o}$, $621 \S$ ún. $e$ 645-caput, que tem distinta finalidade coercitiva." No mesmo sentido, Eduardo TALAMINI, Tutela Relativa aos Deveres de Fazer e de Não Fazer e sua Extensão aos Deveres de Entrega de Coisa (CPC, arts. 461 e 461-A, CDC, art. 68), 2ª ed., São Paulo, RT, 2003, pág. 180.
} 
(art. 273, II, CPC) $)^{523}$. Não são poucos, ainda, aqueles que vêem nas astreintes (previstas nos arts. $287,461, \S 4^{\circ}$ e 645 , todos do CPC e no art. $84, \S 4^{\circ}$, CDC) o caráter de sanção punitiva $^{524}$, a despeito de não ser este o entendimento prevalecente entre os processualistas $^{525}$.

\section{I.I.II. As sanções punitivas no código civil de 2002}

Feita tal digressão a respeito do conceito de sanção jurídica e estipuladas as bases metodológicas para a distinção das diferentes espécies de sanção em razão das distintas funções por elas exercidas, surge a oportunidade de desconstruir a segunda premissa, qual seja, a de que o Direito Civil não pune.

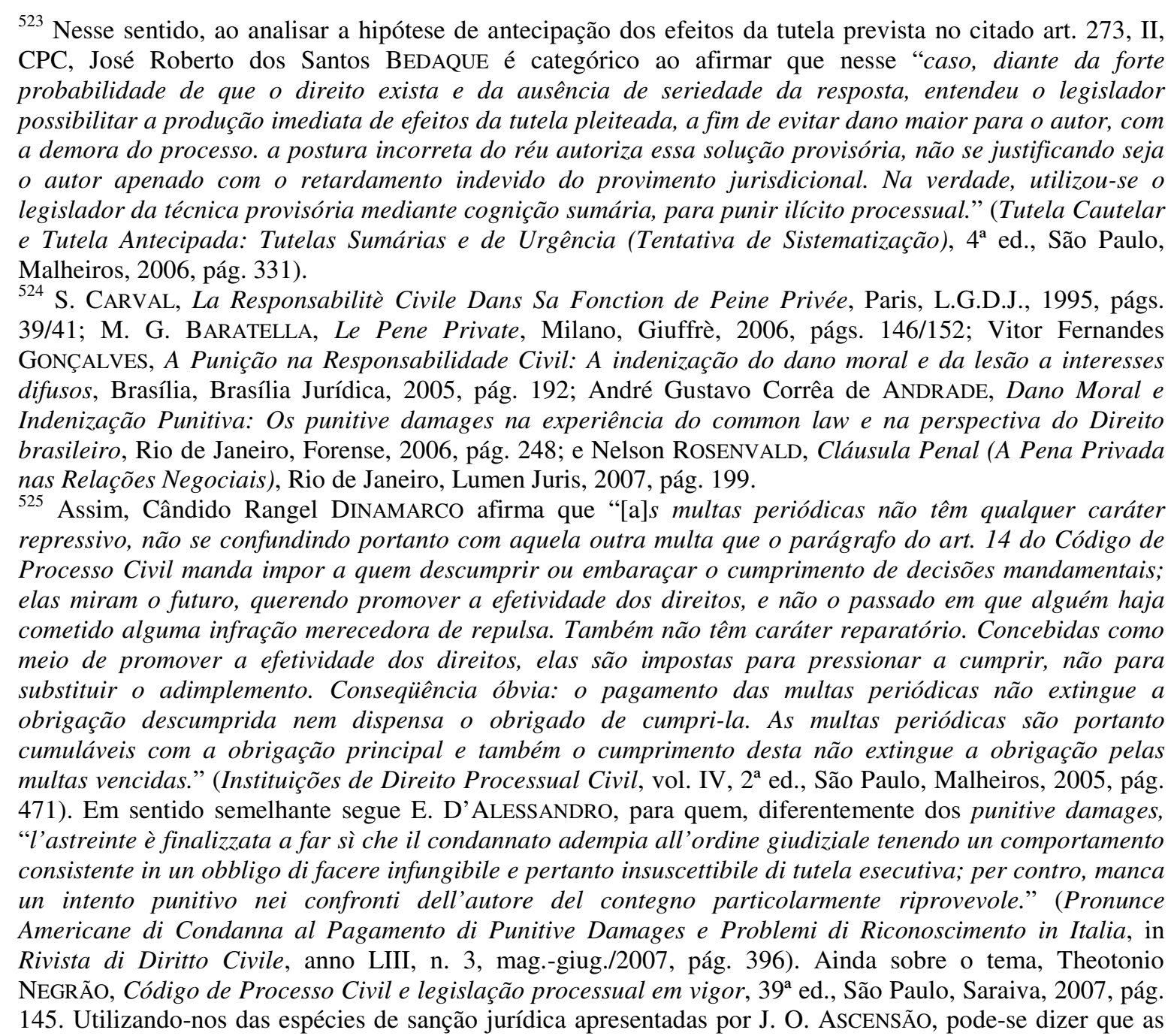


Em oposição ao que sustenta parcela da doutrina, uma análise pormenorizada do texto de nosso Código Civil revela claramente que "não é verdade que o direito civil não puna"526. Pelo contrário, o Código está repleto de exemplos de sanções que exercem função punitiva "as quais", nas palavras de André Gustavo Corrêa de ANDRADE, "podem tomar a forma da exclusão de algum benefício a que teria direito o autor do ato [ilícito] ou consistir na imposição de uma verba sem relação com o prejuízo real ou efetivo do lesado" ${ }^{, 527}$.

Partindo de tais pressupostos, procuraremos, sem a pretensão de esgotar o tema, passar em revista as prescrições normativas contidas em nosso Código Civil que, aos olhos da doutrina, prevêem a incidência de sanções punitivas.

Na Parte Geral, sustenta-se exercerem função punitiva, por ex.: (i) a sanção de perdimento dos frutos dos bens do ausente em favor de seus sucessor, aplicável àquele que houver se ausentado de maneira voluntária e injustificável (art. 33, par. ún., do $\mathrm{CC} / 2002)^{528}$; e (1i) a inadmissibilidade de que se pretenda a anulação de negócio jurídico quando há dolo de ambas as partes (art. 150, do CC/2002) ${ }^{529}$.

Já no que toca à Parte Especial, as sanções às quais se atribui função punitiva passam a ser mais comuns. Em relação ao Direito das Obrigações, afirma-se serem sanções punitivas, por ex.: (i) a inversão do risco de deterioração da coisa na hipótese de perpetuatio obligationes (art. 399, do CC/2002) (530 $^{\text {;ii) }}$ os juros de mora, a cujo

astreintes compõem hipótese de sanção compulsória, e não de sanção punitiva (Introdução à Ciência do Direito, $3^{\text {a }}$ ed., Rio de Janeiro, Renovar, 2005, págs. 59/61).

${ }^{526}$ Antonio JunqueIRA DE AzEvedo, Por Uma Nova Categoria de Dano na Responsabilidade Civil: O Dano Social, in Novos Estudos e Pareceres de Direito Privado, São Paulo, Saraiva, 2009, págs. 378/379.

527 Dano Moral e Indenização Punitiva: Os punitive damages na experiência do common law e na perspectiva do Direito brasileiro, Rio de Janeiro, Forense, 2006, pág. 247.

${ }^{528}$ Gustavo TePEDINO, Heloísa Helena BARBOZA e Maria Celina Bodin de MoRAES afirmam tratar-se de "verdadeira sanção à negligência do ausente, abrindo-se mão de uma excessiva proteção ao seu interesse". (Código Civil Interpretado Conforme a Constituição da República, vol. I, $2^{\mathrm{a}}$ ed., Rio de Janeiro, Renovar, 2007, pág. 95)

${ }^{529}$ Sílvio de Salvo VENOSA afirma que "[s]e ambas as partes procederam com dolo, há empate, igualdade na torpeza. A lei pune a conduta de ambas, não permitindo a anulação do ato. [...]. O que a lei faz é tratar com indiferença ambas as partes que foram maliciosas, punindo-as com a impossibilidade de anular o negócio, pois ambos os participantes agiram de má-fé". (Direito Civil, vol. I, $5^{\text {a }}$ ed., São Paulo, Atlas, 2005, págs. 448/449).

${ }^{530}$ Marcela Alcazas BASSAN, As Funções da Indenização por Danos Morais e a Prevenção de Danos Futuros, Dissertação (Mestrado) - Faculdade de Direito da USP, São Paulo, 2009, pág. 80; Antonio JunqueIRA De AZEvedo, Por Uma Nova Categoria de Dano na Responsabilidade Civil: O Dano Social, in 
pagamento está obrigado o devedor inadimplente, "ainda que não se alegue prejuízo" (art. 407, do CC/2002) $)^{531}$; (iii) a cláusula penal, cujo pagamento pelo devedor inadimplente é igualmente exigível sem que seja necessário que o credor alegue prejuízo (art. 416, do $\mathrm{CC} / 2002)^{532}$; e, ainda, (iv) as arras, confirmatórias (arts. 417 a 419, do CC/2002) ou penitenciais (art. 420, do CC/2002), as quais são exigíveis independentemente da ocorrência de efetivo prejuízo ${ }^{533}$.

Novos Estudos e Pareceres de Direito Privado, São Paulo, Saraiva, 2009, pág. 379 e P. M. LouRENÇo, A Função Punitiva da Responsabilidade Civil, Coimbra, Coimbra, 2006, págs. 303/304.

${ }^{531}$ André Gustavo Corrêa de ANDRADE atribui função punitiva aos juros moratórios sob o argumento de que "[o] que denuncia a natureza penal da figura é a circunstância de ser ela aplicável ainda que o devedor possa comprovar que o credor nenhum dano teve com a mora, o que é incompatível com toda idéia de reparação." (Dano Moral e Indenização Punitiva: Os punitive damages na experiência do common law e na perspectiva do Direito brasileiro, Rio de Janeiro, Forense, 2006, págs. 247/248). Parece-nos, contudo, ser contestável a conclusão de que os juros moratórios exercem função exclusivamente punitiva. Como se depreende do art. 404, caput, do CC/2002, tem-se os juros moratórios como parcela integrante das perdas e danos (o que já se considera suficiente para extrair desse instituto ao menos algum aspecto compensatório). Mais do que isso, o art. 404, par. ún., do CC/2002, também atribui aos juros moratórios caráter compensatório, prescrevendo que "[p]rovado que os juros da mora não cobrem o prejuízo, e não havendo pena convencional, pode o juiz conceder ao credor indenização suplementar." Acredita-se, assim, que os juros moratórios desempenham dupla função, servindo, de um lado, de compensação pelos prejuízos decorrentes do atraso [prejuízos estes que são presumidos, assumindo um mínimo legal (ex vi do art. 406, do CC/2002)] e, de outro, de punição do devedor pelo ilícito perpetrado. É essa, também, a posição adotada por P. M. Lourenço, A Função Punitiva da Responsabilidade Civil, Coimbra, Coimbra, 2006, págs. 302/303.

${ }_{532}$ André Gustavo Corrêa de ANDRADE, Dano Moral e Indenização Punitiva: Os punitive damages na experiência do common law e na perspectiva do Direito brasileiro, Rio de Janeiro, Forense, 2006, pág. 248; Vitor Fernandes GonÇALVES, A Punição na Responsabilidade Civil: A indenização do dano moral e da lesão a interesses difusos, Brasília, Brasília Jurídica, 2005, pág. 190 e Marcela Alcazas BASSAN, As Funções da Indenização por Danos Morais e a Prevenção de Danos Futuros, Dissertação (Mestrado) - Faculdade de Direito da USP, São Paulo, 2009, pág. 79. Não é certo, contudo, que a cláusula penal sempre exercerá funções punitivas. É plenamente admissível que a aludida cláusula seja estipulada pelas partes contratantes apenas com a finalidade de servir de pré-fixação das perdas e danos devidas pelo inadimplemente à parte inocente. Será, assim, um instrumento a facilitar o ressarcimento (de índole compensatória), e não a inibir as partes quanto ao descumprimento (de índole punitiva e preventiva). Como bem anota C. CALLEROS, a cláusula penal será vista como uma pena, imposta com o fim de compelir o cumprimento específico da obrigação contratualmente assumida, apenas quando o valor estipulado na cláusula penal exceder qualquer estimativa razável acerca dos limites da indenização que, sob os standards legais, a parte lesada poderia vir a receber em razão do inadimplemento. (Punitive Damages, Liquidated Damages and Clauses Pènales in Contract Actions: A Comparative Analysis of the American Common Law and the French Civil Code, in Brooklyn Journal of International Law, vol. 32, 2006, pág. 89). No mesmo sentido segue a orientação de Nelson ROSENVAL, para quem as distinções entre a cláusula penal dita stricto sensu (aquela fixada com função punitiva) e a de pré-fixação de indenização deverão ser extraídas por meio da interpretação das disposições contratuais (Cláusula Penal (A Pena Privada nas Relações Negociais), Rio de Janeiro, Lumen Juris, 2007, págs. 105/116).

${ }^{533}$ Essa é a posição admitida por André Gustavo Corrêa de ANDRADE, para quem as arras possuem sempre caráter punitivo, sejam elas confirmatórias ou penitenciais, uma vez que, enqualquer dos casos, "não estão relacionadas com um dano efetivo, o que revela o seu caráter sancionatório, a despeito de o art. 420 do Código Civil indicar que ela exerce função unicamente indenizatória." (Dano Moral e Indenização Punitiva: Os punitive damages na experiência do common law e na perspectiva do Direito brasileiro, Rio de Janeiro, Forense, 2006, pág. 248). Também parece ser esta a posição adotada por Marcela Alcazas BASSAN, As Funções da Indenização por Danos Morais e a Prevenção de Danos Futuros, Dissertação (Mestrado) Faculdade de Direito da USP, São Paulo, 2009, pág. 79. Em sentido parcialmente divergente, Vitor Fernandes GONÇALVES só atribui função punitiva às arras ditas penitenciais, afirmando que "[o] sinal, é verdade, não possui sempre o caráter de punição, isto é, não é de sua natureza ser penitencial. [...] Quando, entretanto, a vontade das partes for expressa e inequívoca no sentido de utilizar o sinal para delimitar a sua 
No campo do Direito dos Contratos, também não são raros os exemplos de sanções às quais se atribui função punitiva, podendo-se aludir, apenas à guisa de exemplo: (i)

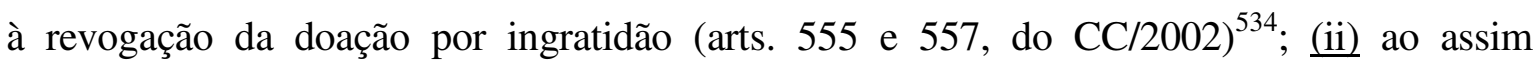
chamado "aluguel pena", devido pelo locatário que deixar de restituir a coisa no termo

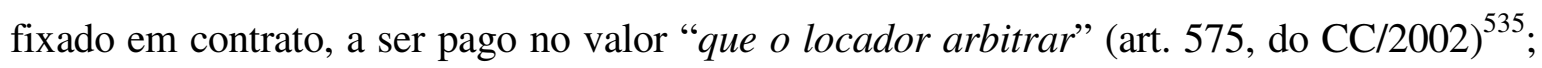
(iii) ao do também denominado "aluguel pena", devido pelo comodatário que incorre em mora (art. 582, in fine, do CC/2002) ${ }^{536}$; (iv) ainda quanto ao contrato de comodato, à inversão do risco de deterioração da coisa emprestada, se o comodatário antepuser a salvação de seus próprios bens, abandonando o do comodante, hipótese na qual responderá também

responsabilidade em caso de arrependimento do contrato, a perda do sinal prestado, ou a sua devolução em dobro, impede o pagamento de qualquer outra indenização suplementar, nesse caso é que a doutrina fala em caráter penitencial, e isto apesar da letra do art. 420 do Código Civil de 2002 afirmar que a hipótese contempla uma função unicamente indenizatória." (A Punição na Responsabilidade Civil: A indenização do dano moral e da lesão a interesses difusos, Brasília, Brasília Jurídica, 2005, pág. 187). Quer-nos parecer, contudo, não ser adequada a conceituação das assim chamadas arras penitenciais como verdadeira sanção punitiva. Nessa hipótese, as partes contratantes estipulam a existência de um verdadeiro direito de arrependimento, de modo que aquele que deixa de cumprir o contrato não está, propriamente, infringindo o contrato, mas, sim, valendo-se de uma permissiva prévia expressamente pactuada. É nesse sentido que. Gustavo TePedino, Heloísa Helena BArboza e Maria Celina Bodin de MoRAES afirmam que, "[h]avendo esta opção [de arrependimento], aquele que desiste de cumprir o contrato não o infringe, mas se utiliza do direito potestativo de arrepender-se, que o próprio instrumento contratual lhe outorgou. Assim, também não são devidas perdas e danos [vez que inexiste ilícito]." (Código Civil Interpretado Conforme a Constituição da República, vol. I, $2^{\mathrm{a}}$ ed., Rio de Janeiro, Renovar, 2007, pág. 772). Aqui não se fala, propriamente, em ilícito contratual, mas, sim, em exercício de direito, contra o quê se deve pagar um "preço", consubstanciado nas arras denominadas penitenciais. Já quanto às arras confirmatórias (essas, sim, remédio destinado a combater o descumprimento do contrato), ainda que sejam exigíveis independentemente de alegação de prejuízo (art. 418, do CC/2002), também é claro seu caráter, ao menos parcialmente, compensatório (ante a previsão do art. 419, do CC/2002, que as define como um "mínimo da indenização"). Quando muito, acreditamos, poder-se-ia advogar pelo duplo caráter das arras confirmatórias, atribuindo-se-lhes funções compensatória e punitiva.

${ }^{534}$ Sustentam Gustavo TePEDINO, Heloísa Helena BARBOZA e Maria Celina Bodin de MorAEs que, "[p]ossui a revogação, neste caso, natureza de penalidade para o donatário que, por realizar alguma das condutas previstas na lei, se mostra desmerecedor do ato de liberalidade realizado pelo doador". (Código Civil Interpretado Conforme a Constituição da República, vol. II, Rio de Janeiro, Renovar, 2006, pág. 239). No mesmo sentido: Caio Mário da Silva PEREIRA, Instituições de Direito Civil, vol. III, $11^{\text {a }}$ edição, Rio de Janeiro, Forense, 2003, pág. 266 e Nelson Rosenvald, Cláusula Penal (A Pena Privada nas Relações Negociais), Rio de Janeiro, Lumen Juris, 2007, pág. 198.

${ }^{535}$ Nesse sentido, Paulo NADER afirma que "o quantum [atribuído ao aluguel pena] deverá corresponder ao valor real da locação, acrescido de parcela razoável a título de penalidade”. (Curso de Direito Civil, vol. 3, $4^{\mathrm{a}}$ ed., Rio de Janeiro, Forense, 2009, pág. 250). Na exata medida em que deixasse de remunerar o locador pela utilização de seu imóvel (extrapolando os limites do "valor real da locação"), o aluguel pena passaria a exercer, justamente, uma função punitiva. Admitindo expressamente o caráter de pena, o art. 1.045, do Código Civil Português estipula que, caso "o locatário se constitua em mora [no que toca à sua obrigação de restituir a coisa locada], a indemnização é elevada ao dobro".

${ }^{536}$ Parece-nos contrária a tal acepção a orientação seguida por Paulo NADER, para quem o aluguel arbitrado pelo comodante "deverá corresponder ao valor da época e do lugar, não se justificando uma cifra elevada". $\mathrm{O}$ aluguel teria, portanto, função compensatória, remunerando adequada e proporcionalmente o comodante pela utilização indevida de seu imóvel. (Curso de Direito Civil, vol. 3, 4ª ed., Rio de Janeiro, Forense, 2009, págs. 274/275). 
por força maior e caso fortuito (art. 583, do CC/2002); (v) à obrigação de que o terceiro que alicia pessoas obrigadas por contrato escrito de prestação de serviços pague, ao contratante dos serviços, "a importância que ao prestador de serviço, pelo ajuste desfeito, houvesse de caber durante 2 (dois) anos" (art. 608, do CC/2002) ${ }^{537}$; (vi) à ampliação da responsabilidade do mandatário que, mesmo diante da proibição do mandante, substabelece os poderes que lhe foram concedidos pelo contrato de mandato (art. 667, $\S 1^{\circ}$, do $\left.\mathrm{CC} / 2002\right)^{538}$; e, por fim, em relação ao contrato de seguro, (vii) à perda do direito à garantia pelo segurado que desatende o princípio da boa-fé objetiva, quer por fazer “declarações inexatas ou omitir circunstâncias que possam influir na aceitação da proposta ou na taxa do prêmio" (art. 766, caput, do $\mathrm{CC} / 2002)^{539}$, quer, ainda, por agravar intencionalmente o risco ao qual está sujeito (art. 768, do CC/2002) e, ainda, a obrigação do segurador de pagar o prêmio estipulado, caso expeça a apólice de seguro mesmo ciente de que, ao tempo do contrato, não mais existia o risco que se pretendia cobrir (art. 773, do CC/2002) $)^{540}$.

No âmbito da Responsabilidade Civil, é também atribuída função punitiva às sanções previstas para o "credor que demandar o devedor antes de vencida a dívida, fora dos casos em que a lei o permita" (art. 939, do CC/2002) e ao credor que "demandar por dívida já

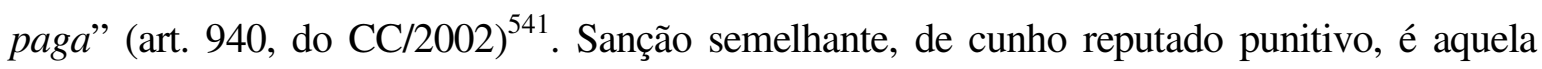
prevista para aquele que cobra de consumidor "quantia indevida" (art. 42, do CDC) ${ }^{542}$.

\footnotetext{
${ }^{537}$ Nelson RosenVALD, afirma cuidar-se de "imposição de pena privada em face do aliciador, ao atrair ou recrutar pessoas já comprometidas contratualmente com outras" (Cláusula Penal (A Pena Privada nas Relações Negociais), Rio de Janeiro, Lumen Juris, 2007, pág. 197); no que é seguido por Vitor Fernandes GonçAlves, A Punição na Responsabilidade Civil: A indenização do dano moral e da lesão a interesses difusos, Brasília, Brasília Jurídica, 2005, pág. 188.

${ }^{538}$ Antonio JunqueIRA DE AZEVEdo, Por Uma Nova Categoria de Dano na Responsabilidade Civil: O Dano Social, in Novos Estudos e Pareceres de Direito Privado, São Paulo, Saraiva, 2009, pág. 379.

539 “[O] art. 766 do Código Civil Brasileiro pune o segurado com a perda do direito à garantia, se não tiver prestado declarações verdadeiras, completas ou se o segurado omitir circunstância que poderia ter influenciado na aceitação ou na fixação do valor do prêmio". (TJRJ; $17^{\mathrm{a}}$ Câm. Cível; Apelação 000809358.2007.8.19.0209; Relator: Des. Edson Vasconcelos; J. 02.12.2010).

${ }^{540}$ Vitor Fernandes GonÇALVES, A Punição na Responsabilidade Civil: A indenização do dano moral e da lesão a interesses difusos, Brasília, Brasília Jurídica, 2005, pág. 185.

${ }^{541}$ Nelson Rosenvald, Cláusula Penal (A Pena Privada nas Relações Negociais), Rio de Janeiro, Lumen Juris, 2007, pág. 197; André Gustavo Corrêa de ANDRADE, Dano Moral e Indenização Punitiva: Os punitive damages na experiência do common law e na perspectiva do Direito brasileiro, Rio de Janeiro, Forense, 2006, pág. 248; Vitor Fernandes GonÇALVES, A Punição na Responsabilidade Civil: A indenização do dano moral e da lesão a interesses difusos, Brasília, Brasília Jurídica, 2005, pág. 185; Carlos Roberto GonÇALVES, Comentários ao Código Civil, vol. 11, São Paulo, Saraiva, 2003, pág. 319; Sérgio SEvero, Os Danos Extrapatrimoniais, São Paulo, Saraiva, 1996, pág. 184 e Antonio JunQUEIRA DE AZEVEdo, Por Uma Nova Categoria de Dano na Responsabilidade Civil: O Dano Social, in Novos Estudos e Pareceres de Direito Privado, São Paulo, Saraiva, 2009, pág. 379.

542 Nelson Rosenvald, Cláusula Penal (A Pena Privada nas Relações Negociais), Rio de Janeiro, Lumen Juris, 2007, pág. 199.
} 
No que concerne ao Direito das Coisas, são também reputadas como sanções com função punitiva: (i) a perda do direito à indenização pelas benfeitorias úteis ou voluptuárias erigidas erigidas pelo possuidor de má-fé em imóvel alheio (art. 1220, do $\mathrm{CC} / 2002)^{543}$; (ii) a indenização devida por aquele que, de má-fé, edifica em área que excede a vigésima parte de terreno alheio, a qual deve ser paga em dobro, além de acompanhada da demolição das construções erigidas (art. 1.259, in fine, do CC/2002); e, no que toca ao condomínio edilício, (iii) a multa moratória, equivalente a $2 \%$ sobre o débito, a ser paga pelo condômino que se encontre inadimplente em relação às cotas condominiais (art. 1.336, $\S 1^{\circ}$, do $\mathrm{CC} / 2002$ ) e a multa pelo descumprimento dos deveres insculpidos no art. 1.336, inc. II a IV, do CC/2002, no importe de até cinco vezes o valor das contribuições condominiais, a qual incide "independentemente das perdas e danos que se apurarem" (arts. 1.336, § $2^{\circ}$ e 1.337 , do CC/2002 $)^{544}$.

Por fim, quanto ao Direito das Sucessões, consideram-se sanções com função punitiva: (i) a exclusão dos herdeiros por indignidade ou deserdação (arts. 1814 e 1961, do CC/2002) ${ }^{545}$; e, ainda, (ii) a perda dos direitos sucessórios do herdeiro que houver dolosamente sonegado bens da herança (art. 1992, CC/2002) $)^{546}$, sanção esta denominada textualmente como pena pelo Código Civil (art. 1993, CC/2002) $)^{547}$.

\footnotetext{
${ }^{543}$ Antonio JunqueIRA DE AZEvedo, Por Uma Nova Categoria de Dano na Responsabilidade Civil: O Dano Social, in Novos Estudos e Pareceres de Direito Privado, São Paulo, Saraiva, 2009, pág. 379.

${ }^{544}$ Antonio JunqueIRa DE AzEVEdo, Por Uma Nova Categoria de Dano na Responsabilidade Civil: O Dano Social, in Novos Estudos e Pareceres de Direito Privado, São Paulo, Saraiva, 2009, pág. 379.

${ }^{545}$ Zeno Veloso, Comentários ao Código Civil, vol. 21, São Paulo, Saraiva, 2003, pág. 311; Caio Mário da Silva PereIRA, Instituições de Direito Civil, vol. VI, 15ª ed., Rio de Janeiro, Forense, 2004, pág. 335; Nelson Rosenvald, Cláusula Penal (A Pena Privada nas Relações Negociais), Rio de Janeiro, Lumen Juris, 2007. pág. 198; Marcela Alcazas BASSAN, As Funções da Indenização por Danos Morais e a Prevenção de Danos Futuros, Dissertação (Mestrado) - Faculdade de Direito da USP, São Paulo, 2009, pág. 80 e Antonio JunqueIRA De AZEvedo, Por Uma Nova Categoria de Dano na Responsabilidade Civil: O Dano Social, in Novos Estudos e Pareceres de Direito Privado, São Paulo, Saraiva, 2009, pág. 379.

546 Zeno Veloso, Comentários ao Código Civil, vol. 21, São Paulo, Saraiva, 2003, pág. 311; Orlando Gomes, Sucessões, 14 ${ }^{\mathrm{a}}$ ed., Rio de Janeiro, Forense, 2008, pág. 304; Sérgio SEVERo, Os Danos Extrapatrimoniais, São Paulo, Saraiva, 1996, pág. 184 e Marcela Alcazas BASSAN, As Funções da Indenização por Danos Morais e a Prevenção de Danos Futuros, Dissertação (Mestrado) - Faculdade de Direito da USP, São Paulo, 2009, pág. 78.

547 Antonio JunqueIRA DE AZEVEDO, Por Uma Nova Categoria de Dano na Responsabilidade Civil: O Dano Social, in Novos Estudos e Pareceres de Direito Privado, São Paulo, Saraiva, 2009, pág. 379.
} 
Pode-se concluir, portanto e com segurança, que as "sanções punitivas são utilizadas em todos os quadrantes do ordenamento jurídico" ${ }^{„ 548}$, e o Direito Civil não é exceção. Pelo contrário, observa-se em todos os meandros do Direito Civil a previsão de sanções jurídicas que exercem função essencialmente punitiva.

\section{I.II. Incentivo à litigância frívola ou à dita "indústria do dano moral"}

Uma segunda crítica levantada pela doutrina que refuta a admissibilidade da indenização punitiva diz respeito aos eventuais impactos sociais que poderiam decorrer da adoção deste instituto jurídico. Sustenta-se, tendo-se em vista, principalmente, os casos relacionados à indenização dos detrimentos morais, que a adoção de instituto assemelhado aos punitive damages norte-americanos tende a incentivar a "litigância frívola" "549, ou o que, em nosso país, passou-se a chamar de "indústria do dano moral"

Com a expressão "litigância frívola", quer-se designar "a litigância com baixa probabilidade de êxito provocada pelo queixoso" ${ }^{551}$. Vale dizer: o ajuizamento de uma demanda "ilegítima", na qual o demandante, sem ser titular do direito material alegado, pretende a obtenção de uma tutela jurisdicional à qual sabe não fazer jus, usualmente com a finalidade de utilizar-se do processo para auferir benefício ilícito (tal como, por ex., por meio do recebimento de quantia indevida, decorrente da celebração de transação judicial com a parte contrária).

Segundo M. C. T. PATRício, o ajuizamento de uma demanda na qual o autor possui baixa probabilidade de êxito é, ao menos à primeira vista, ilógico, justamente porque, em regra, os custos da litigância (despesas necessárias para propor e conduzir a demanda), por si sós, já serviriam de desestímulo suficiente contra a persecução desta

\footnotetext{
548 Nelson Rosenvald, Cláusula Penal (A Pena Privada nas Relações Negociais), Rio de Janeiro, Lumen Juris, 2007, pág. 193.

${ }^{549}$ É nesse sentido que Maria Celina Bodin de MORAES afirma que a adoção da indenização punitiva poderia acarretar um "incentivo à malícia” (Punitive Damages em Sistemas Civilistas: problemas e perspectivas, in Revista Trimestral de Direito Civil, vol. 18, abril/junho 2004, pág. 76).

${ }^{550}$ Ao utilizar o cenário processual dos Estados Unidos da América como parâmetro, Sérgio Luiz JUNKES sustenta que "[o]s punitive damages, tal qual vem ocorrendo nos Estados Unidos, fomentam sobremaneira a indústria do dano moral ao ensejar a fixação de indenizações milionárias e aleatórias." (A Culpa e a Punição Não Podem Servir de Critério Para a Fixação da Indenização por Dano Moral, in Jurisprudência Catarinense, ano XXXI, n. 107, 2005, pág. 229).
} 
verdadeira "aventura jurídica",552. Existem, contudo, uma série de fatores que poderiam incentivar a "litigância frívola", entre os quais o citado autor destaca (i) a possibilidade de ocorrência de erros judiciais na condenação e o fato de, em determinadas hipóteses, (ii) o queixoso poder ajuizar a demanda com um custo inicial baixo, procurando, no curso do processo, a obtenção de um acordo que lhe seja vantajoso ${ }^{553}$.

Tratando-se de uma demanda fundada na responsabilidade civil, cujo pedido é a obtenção de indenização, a ocorrência de um erro judicial em benefício do queixoso pode-se revelar, basicamente, de duas maneiras: (1) a condenação do demandado ao pagamento de indenização inteiramente indevida, em hipótese na qual não se encontram presentes os requisitos para a imputação de responsabilidade; ou (ii) a condenação do demandado ao pagamento de quantia que supera aquela à qual o queixoso faria jus.

A crítica à adoção da indenização punitiva se insere justamente no contexto pertinente à segunda hipótese acima enumerada, em que, em razão de uma determinada demanda, decorre a condenação ao pagamento de uma condenação em valor indevido.

${ }^{551}$ M. C. T. PATRÍCIO, Análise Económica da Litigância, Coimbra, Almedina, 2005, pág. 63.

552 Espera-se que os Tribunais, diante de uma demanda desta natureza, reconheçam seu caráter ilegítimo, julgando improcedentes os pedidos deduzidos sem o amparo legal. Por se tratar de uma demanda de baixa probabilidade de êxito, ao menos em tese, os valores que devem ser despendidos com o ajuizamento da ação (custos de litigância, tais como os honorários advocatícios, taxas e demais custas processuais) superam aqueles que poderiam ser obtidos pelo queixoso, o que, sob a ótica econômica, faz-nos parecer ilógico tal sorte de procedimento. Sobre o tema, M. C. T. PATrício, Análise Económica da Litigância, Coimbra, Almedina, 2005, pág. 63/84. Nesse sentido, considerando justamente o (ao menos em tese) alto grau de probabilidade de uma demanda infundada vir a ser rejeitada pelos Tribunais, sem que o demandante possa vir a se ressarcir das despesas suportadas durante o processo, D. G. OwEN, afirma ser "unlikely that many plaintiffs or their attorneys will risk the cost, time and trouble of investigating a nonmeritous lawsuit simply because they think that for some reason (other than merit) they will win the lawsuit, and will go to win a punitive damages award to boot." (A Punitive Damages Overview: Functions, Problems and Reform, in Villanova Law Review, vol. 39, 1994, pág. 396).

${ }^{553}$ M. C. T. PATRício autor agrupa os demais possíveis fatores em dois grandes blocos: (i) a assimetria de informações; e (ii) as distintas percepções das partes quanto ao resultado do julgamento, o que poderia influenciar o litigante frívolo se, de antemão, tivesse ciência da aversão ao risco do demandado. (Análise Económica da Litigância, Coimbra, Almedina, 2005, pág. 65). Em relação ao tema, vale ressaltar que nosso ordenamento possui algumas previsões normativas que poderiam, ao menos em tese, contribuir para incentivar o ajuizamento de demandas não meritórias por criarem a possibilidade de que sejam deduzidas pretensões em juízo com custo inicial baixo ou inexistente. Como exemplo desses dispositivos, têm-se, no processo civil, os benefícios previstos nos arts. $2^{\circ}$ e $3^{\circ}$ da Lei 1.060/1950 e no art. 54 da Lei dos Juizados Especiais Cíveis e Criminais (Lei 9.099/1995) e, no processo do trabalho, os benefícios previstos nos arts. 14 e ss. da Lei 5.584/1970 (que regulamentam a assistência judiciária gratuita no âmbito do processo do trabalho). Tais mecanismos, criados para assegurar o acesso à Justiça, podem também - e infelizmente prestar-se a fins ilegítimos, servindo de incentivo ao ajuizamento de demandas frívolas ante à certeza (ou maior garantia) de que, ainda que o demandante venha a ser derrotado em Juízo (por meio do reconhecimento da "ilegitimidade" de sua pretensão), não deverá arcar com os custos de litigância (vez que as taxas judiciárias, as despesas processuais e, até mesmo, os honorários advocatícios decorrentes de sua sucumbência não lhe poderão ser carreados). 
Diante da existência de um instituto jurídico que, em tese, admite a imposição de sanção pecuniária em valor que excede aquele referente aos prejuízos efetivamente suportados pelo ofendido, ocorreria a "sobrestimação dos ganhos do queixoso", o que, nas palavras do citado M. C. T. PATRício poderia acarretar um acréscimo no número de processos.

No mesmo sentido seguem aqueles que, voltando os olhos às hipóteses de condenação ao pagamento de indenização por danos morais, fazem alusão à assim chamada "indústria do dano moral" $" 554$. Tal expressão, de cunho nitidamente pejorativo, procura abarcar tanto as situações nas quais se impõe indevidamente ao lesante a obrigação de indenizar (em hipótese na qual não se verificam os requisitos ensejadores da imputação de responsabilidade $)^{555}$; quanto aquelas nas quais o valor da indenização é majorado de forma a exceder os limites dos efetivos prejuízos suportados pelo ofendido ${ }^{556}$.

Diz-se que o amparo judicial de tais situações garante, a curto prazo, o cometimento de verdadeira injustiça, vez que se faz do agente causador do ato ilícito uma nova vítima. A médio e longo prazo, tais situações implicariam verdadeiro "colapso do sistema" ${ }^{557}$, contribuindo "em certa medida para um clima de verdadeira desagregação social e de desconfiança nas próprias instituições" $" 558$.

\footnotetext{
554 Marcela Alcazas BASSAN sustenta que "em função de toda fama de que gozam os punitive damages americanos e a errônea idéia de que são plasmáveis para a realidade nacional, as ações de responsabilidade civil por danos morais são uma crescente e incontrolável realidade nos tribunais nacionais. [...] A doutrina já fala em 'indústria do dano moral' e é bom que se compreenda bem a expressão: a alusão ao termo 'indústria' remete-nos à idéia de mecanização, artificialidade das demandas, na busca descarada pela possibilidade de obtenção de lucro por parte das vítimas." (As Funções da Indenização por Danos Morais e a Prevenção de Danos Futuros, Dissertação (Mestrado) - Faculdade de Direito da USP, São Paulo, 2009, pág. 77). Em sentido semelhante, Anderson SCHREIBER afirma que "[m]ais do que a preocupação com o crescimento exponencial do número de ações de indenização por dano moral, o que o uso do termo indústria anuncia é uma frontal rejeição à produção mecânica, algo artificial, com vistas à obtenção de lucro, em uma espécie de abordagem capitalizada de um instituto ontologicamente existencial." (Novos Paradigmas da Responsabilidade Civil: Da Erosão dos Filtros da Reparação à Diluição dos Danos, São Paulo, Atlas, 2009, pág. 190).

555 "[C]erto é que não se deve deferir a indenização por dano moral por qualquer contrariedade. Caso contrário, além do enriquecimento indevido, estar-se-ia colaborando com a vulgarização do dano moral, especialmente com a chamada 'indústria do dano moral', tão combatida por este Tribunal." (STJ; $4^{\mathrm{a}}$ Turma; RESP n. ${ }^{\circ}$ 504639/PB; Relator: Min. Sálvio de Figueiredo Teixeira; J. 26.06.2003). Ainda: O que se chama de "indústria do dano moral" são "aquelas situações onde pessoas, vítimas de determinadas situações não graves, ingressam com pedidos de indenização, visando, na verdade, obter alguma vantagem do fato ocorrido." (TJSP; Apelação n. ${ }^{\circ}$ 1264981-9; Relator: Des. Paulo Jorge Scartezzini Guimarães; J. 18.09.2009) 556 "[O] Tribunal de Justiça deve evitar a criação de uma 'indústria do dano moral', pela qual aquele exposto à cobrança indevida lucraria com a situação.” (TJSP; Apelação n. ${ }^{\circ}$ 321.076.4/1-00; Relator: Des. neves Amorim; J. 10.11.2009).

${ }^{557}$ Assim seguem as palavras de Gustavo TEPEDINO, para quem "[o] dever de reparar não há de ser admitido sem a presença do dano e do nexo de causalidade entre a atividade e o evento danoso, tendo por escopo o ressarcimento da vítima. [...] Tão grave quanto a ausência de reparação por um dano injusto mostra-se a imputação do dever de reparar sem a configuração de seus elementos essenciais, fazendo-se do agente uma
} 
Em face de tais ponderações, cumpre-nos frisar, desde já, que refutamos, de maneira veemente, toda e qualquer sorte de utilização "ilegítima” do processo, qualquer que seja seu rótulo (indistinto, portanto, chamá-la de "litigância frívola" ou "indústria do dano moral'). Independentemente da forma com que se concretiza, trata-se, inegavelmente, de situação patológica que, muito ao contrário de merecer fomento, deve ser duramente combatida.

Feita ressalva acima, há de se rejeitar, de maneira igualmente veemente, a afirmação de que a indenização punitiva serviria de fomento para a "litigância frívola" ou para a "indústria do dano moral".

Em primeiro lugar, e na esteira do quanto acima exposto, é de se notar que o incentivo à "litigância frívola" não decorre do uso do instituto da indenização punitiva, mas sim de seu abuso, quer aquele buscado pelos supostos ofendidos, que se lançam ao judiciário à busca de bens da vida aos quais não fazem jus, quer, ainda, aquele perpetrado pelos Tribunais, que, ao cometerem erros judiciais, enviam à sociedade mensagem exatamente oposta à que deveriam: a de que, antes de servir de meio de proteção à dignidade da pessoa humana, a indenização punitiva pode servir de meio de locupletamento ilícito.

Quanto a este ponto, faz-se coro com R. D. PIZARro, no sentido de que “os possíveis abusos que a aplicação de uma instituição possam gerar não servem para desqualificá-la por completo" ${ }^{\text {559 }}$. Em vez de se propugnar pela rejeição liminar da

nova vítima. A indenização imposta sem a observância de seus pressupostos representa, a médio prazo, o colapso do sistema, uma violência para a atividade econômica e um estímulo ao locupletamento." (O Futuro da Responsabilidade Civil, in Temas de Direito Civil, vol. III, Rio de Janeiro, Renovar, 2009, pág. 407).

${ }^{558}$ Sérgio Luiz Junkes, A Culpa e a Punição Não Podem Servir de Critério Para a Fixação da Indenização por Dano Moral, in Jurisprudência Catarinense, ano XXXI, n. 107, 2005, pág. 220.

${ }^{559}$ R. D. Pizarro, Daño Moral - Prevención, Reparación, Punición: El Daño Moral en las Diversas Ramas del Derecho, Buenos Aires, Hammurabi, 1996, pág. 389: “Los posibles abusos que la aplicación de una institución pueda generar no alcanzan para descalificarla totalmente." A despeito de se posicionar contrariamente à adoção da indenização punitiva, esta também parece ser a opinião de Anderson SCHREIBER no que toca ao alegado incentivo à litigância frívola, supostamente causado pela expansão das categorias de danos indenizáveis. Nesse sentido, sustenta o autor que "[o] que não parece admissível [...] é que se ataque o objeto pelo uso que se lhe dá. [...] O alvo parece inteiramente equivocado, na medida em que a expansão da ressarcibilidade corresponde a uma legítima ampliação de tutela dos interesses individuais e coletivos, sendo, antes, a sua invocação sem fundamento a causa das angústias que afligem a doutrina e banalizam a 
indenização punitiva, o que se impõe-se é a tomada de medidas preventivas e corretivas, justamente para que se evite o possível abuso de tal instituto.

Nesse sentido, há que se ver que os erros judiciais aos quais se sujeita a condenação ao pagamento de indenização punitiva podem ser evitados pela adequada utilização de duas ordens de medidas, ambas já devidamente previstas e estabelecidas em nosso ordenamento, quais sejam: (i) a possibilidade de revisão do mérito das decisões judiciais; e (ii) a improcedência de demandas efetivamente ilegítimas.

A uma, a possibilidade de sucessivas revisões do mérito do julgado, quer por meio do sistema recursal, quer por meio de ações autônomas de impugnação, "reduz em muito o risco de fixação de indenizações excessivas ou desproporcionais" $" 560$; possibilitando à parte sucumbente, irresignada com o resultado do processo, procurar a reforma do julgado e a conseqüente correção do erro judicial cometido.

A duas, há que se ver que aquele que se lança ao Judiciário de maneira frívola, ilegítima, deturpando as finalidades a que se destina o processo, litiga de má-fé, cometendo verdadeiro abuso ${ }^{561}$ (em conduta que, apenas a título de exemplo, poderia se subsumir às hipóteses legais previstas nos arts. 14, III, e 17, I, CPC), que merece e deve ser coibido por meio da aplicação das sanções cabíveis (na esteira do exemplo acima, nas sanções punitivas previstas no art. 18,CPC). Assim, em adição à reiterada rejeição desta sorte de demandas, a aplicação severa e escorreita das sanções jurídicas previstas para a espécie servirão de remédio suficiente para coibir tais práticas nocivas ${ }^{562}$.

atuação dos tribunais." (Novos Paradigmas da Responsabilidade Civil: Da Erosão dos Filtros da Reparação à Diluição dos Danos, São Paulo, Atlas, 2009, pág. 190).

${ }_{560}$ André Gustavo Corrêa de ANDRADE, Dano Moral e Indenização Punitiva: Os punitive damages na experiência do common law e na perspectiva do Direito brasileiro, Rio de Janeiro, Forense, 2006, págs. 291/292.

${ }^{561}$ Helena Najjar ABDO, O Abuso do Processo, São Paulo, RT, 2007, págs. 87/92.

${ }^{562}$ Assim seguem as palavras de André Gustavo Corrêa de ANDRADE, para quem "[o] remédio contra ações infundadas e abusivas que busquem especular com o instituto do dano moral deve vir, primeiro, da formação de uma jurisprudência firme, que rejeite as pretensões desarrazoadas. O sistemático não-acolhimento de postulações dessa índole desestimularia os aventureiros e acarretaria a paulatina diminuição de tais demandas. Além disso, impõe-se uma aplicação rigorosa das normas que tratam de litigância de má-fé, com a imposição das respectivas sanções até mesmo de ofício, como permite o art. 18 do CPC." (Dano Moral e Indenização Punitiva: Os punitive damages na experiência do common law e na perspectiva do Direito brasileiro, Rio de Janeiro, Forense, 2006, pág. 296). No mesmo sentido, Anderson SCHREIBER, Novos Paradigmas da Responsabilidade Civil: Da Erosão dos Filtros da Reparação à Diluição dos Danos, São Paulo, Atlas, 2009, pág. 201/203. 
Em segundo lugar, também há que se ver que, muito ao contrário da premissa esposada pela crítica ora combatida, a adoção da indenização punitiva não implica, necessariamente, a "sobrestimação de ganhos do queixoso" (fator este que poderia acarretar o ajuizamento em maior número de demandas judiciais ilegítimas).

Com efeito, ao se analisar as propostas apresentadas pelo tort reform movement para a utilização mais eficiente dos punitive damages, viu-se que uma das medidas já adotadas por determinados Estados norte-americanos é aquela que impõe a remessa parcial ou total da indenização punitiva a um fundo público, impedindo que o valor integral seja recebido pelo ofendido como um "windfall payment". Desse fato, conclui-se não ser verídica a afirmação de que a destinação das quantias ao ofendido é elemento indissociável da indenização punitiva: por uma questão de política legislativa, a condenação imposta ao ofensor pode ser revertida integralmente à vítima, integralmente a um fundo público ou repartida entre a vítima e o fundo público ${ }^{563}$.

Como se vê, a opção por uma das duas últimas hipóteses supra nomeadas para a destinação da indenização punitiva, por restringirem (ou impedirem) que o ofendido venha a se beneficiar com o montante decorrente de tal sanção, acarreta impacto muito menor no que concerne ao incentivo ao ajuizamento de medidas judiciais "ilegítimas", justamente por limitar (ou eliminar) a possibilidade de o ofendido vir a "sobrestimar" seus possíveis ganhos.

\footnotetext{
${ }^{563}$ Como se verá abaixo, entende-se que a opção por uma das três possíveis soluções para a destinação da indenização punitiva é nada mais que uma questão de política legislativa, e a opção por qualquer delas (seja a remessa das quantias integralmente ao ofendido, a um fundo público ou a repartição entre esses dois destinatários) não torna a previsão legislativa de tal sanção mais ou menos oportuna. Contudo, por uma série de fundamentos que exporemos a seguir, entendemos que a alternativa que melhor se inseriria no ordenamento nacional seria a que prevê a remessa das quantias decorrentes da indenização punitiva a um fundo público, constituído nos moldes previstos no art. 13, da Lei 7.347/1985, utilizando-se os recursos auferidos dessa maneira para o restabelecimento da ordem social lesada, eventual reconstituição dos bens lesados (especialmente quando se tratar de ato ilícito que cause prejuízos transindividuais) e a prevenção de ilícitos futuros.
} 


\section{I.III. Incompatibilidade com a responsabilidade objetiva}

Uma terceira crítica levantada pela doutrina contra a admissão da indenização punitiva é a de que tal sanção seria absolutamente incompatível com (e inaplicável a) as hipóteses cada vez mais comuns de responsabilidade objetiva.

Ao esposar tal crítica, os opositores à indenização punitiva partem da (correta) premissa de que, nas hipóteses de responsabilidade objetiva, a culpa qualificativo subjetivo da conduta ilícita que representa pressuposto indispensável não só para a quantificação, mas, igualmente, para a incidência da indenização punitiva - "não é elemento do suporte fático de incidência da regra de atribuição de responsabilidade ${ }^{, 564}$ (o que significa dizer que, para o ajuizamento de uma demanda fundada na responsabilidade objetiva, o demandante não ostenta nem o ônus de afirmar ${ }^{565}$ nem, conseqüentemente, o ônus de $\operatorname{provar}^{566}$, a existência de culpa), para, desta premissa, extrair a (incorreta) conclusão de que, em uma demanda desta natureza, a existência de culpa jamais comporia o objeto da cognição do magistrado ${ }^{567}$, tornando impossível, portanto, a condenação do demandado ao pagamento de indenização punitiva.

564 Judith Martins-Costa - Mariana Souza Pargendler, Usos e Abusos da Função Punitiva ('Punitive Damages' e o Direito Brasileiro), in Revista da Ajuris, ano XXXII, n. 100, dez/2005, pág. 247.

565 Para Pedro da Silva DinAMARCO, "[e]m direito processual, pode-se dizer que o ônus é uma condicionante imposta pelo interesse público ao onerado para que, por meio de estímulo ao exercício de um poder, seja praticado um ato de seu próprio interesse que poderá lhe proporcionar uma situação de vantagem no processo." (Ônus Processuais: Limites à Aplicação das Conseqüências Previstas para o seu NãoCumprimento, Tese (Doutorado) - Faculdade de Direito da USP, São Paulo, 2007, pág. 44). Ao tratar, especificamente do ônus de afirmar, Cândido Rangel DINAMARCO sustenta que ,"ainda sem ser parte e antes mesmo que o processo exista, o sujeito que prentenda uma tutela jurisdicional já tem um relevantíssimo ônus, que é o de demandar - ou seja, de tomar a iniciativa do processo, dirigindo-se a um órgão jurisdicional e apresentando-lhe uma pretensão a ser satisfeita [...]. Esse ônus só é suficientemente cumprido quando o demandante, antes de concluir o pedido, afirma a ocorrência de fatos que, segundo as normas de direito substancial, conduzem ao resultado jurídico permitido (causa de pedir: art. 282, inc. III,CPC). [...] Por isso, todo aquele que dirige uma demanda de qualquer natureza ao juiz, alegando determinado direito ou situação jurídica, deve explicar como chegou a essa situação, ou seja, tem o ônus de afirmar os fatos que lhe deram origem." (Instituições de Direito Processual Civil, vol. II, $2^{a}$ ed., São Paulo, Malheiros, 2002, págs. 251/253). Vê-se, assim, que não cumprindo o demandante com o ônus de afirmar aquele que é tido como fato essencial componente de sua causa de pedir (e não sendo caso em que caberia ao juiz conhecer, ex officio, da existência de tal fato), deixará o demandane de ostentar um situação de vantagem no processo, o que, mui provavelmente, levará à improcedência do pedido deduzido em Juízo. Ainda sobre o ônus de afirmar, com profundidade, cfr. Pedro da Silva Dinamarco, Ônus Processuais: Limites à Aplicação das Conseqüências Previstas para o seu Não-Cumprimento, Tese (Doutorado) - Faculdade de Direito da USP, São Paulo, 2007, págs. 98 e ss.

566 Cândido Rangel Dinamarco, Instituições de Direito Processual Civil, vol. II, $2^{\text {a }}$ ed., São Paulo, Malheiros, 2002, pág. 252: "O ônus de afirmar antecede o de provar, uma vez que o objeto do conhecimento do juiz é composto pelas afirmações daspartes e, sem que haja estas, não haveria sequer o que provar [...]."

${ }^{567}$ Nas palavras de Kazuo WATANABE, no que toca ao mérito da causa, o objeto da cognição do juiz será composto por todas as questões suscitadas pelas partes (as quais, em se tratando de questões de fato, são por meio da alegação de um fato pelo autor, e da rejeição deste fato pelo réu), bem como por aquelas das quais o 
As considerações acerca da eventual incompatibilidade entre a indenização punitiva e a responsabilidade objetiva mostram-se particularmente pertinentes e atuais pelo fato de, em julgado recente, o E. Supremo Tribunal Federal, ao apreciar ação indenizatória movida em face da União Federal em razão de danos à pessoa causados em procedimento cirúrgico levado a efeito em estabelecimento hospitalar administrado pela Administração Federal (típico caso de responsabilidade objetiva em razão da incidência do disposto no art. $\left.37, \S 6^{\circ}, \mathrm{CF} / 88\right)^{568}$, ter referendado a condenação da União ao pagamento de indenização calculada expressamente com o intuito punir o ofensor.

Sustentou-se, para rejeitar a pretensão recursal da União e, conseqüente, manter a decisão recorrida que havia concedido uma indenização a título de danos morais no patamar de aproximadamente $\mathrm{R} \$ 150 \mathrm{mil}$ ao demandante, que o Tribunal a quo havia respeitado "a orientação que a jurisprudência dos Tribunais tem consagrado no exame do tema [o da quantificação da indenização por danos morais], notadamente no ponto em que o magistério jurisprudencial, pondo em destaque a dupla função inerente à indenização civil por danos morais, enfatiza, quanto a tal aspecto, a necessária correlação entre o caráter punitivo da obrigação de indenizar ('punitive damages'), de um lado, e a natureza compensatória referente ao dever de proceder à reparação patrimonial, de outro" 569 .

julgador deveria conhecer ex officio (por se tratarem de matérias de ordem pública, por ex.). (Da Cognição no Processo Civil, $3^{\text {a }}$ ed., São Paulo, DPJ, 2005, págs. 111/126). Como o aspecto atinente à culpa do ofensor não se trata de matéria de ordem pública, se ele não fosse alegado pelo autor (e, em regra, tal aspecto jamais seria alegado pelo autor em uma demanda que versasse sobre responsabilidade objetiva, visto que é irrelevante para a aferição da responsabilidade), ele jamais formaria uma questão de mérito e, portanto, não comporia o objeto da cognição do magistrado.

${ }^{568}$ Sérgio CAVAlieri FILHo, Programa de Responsabilidade Civil, 6 ${ }^{\text {a }}$ ed., São Paulo, Malheiros, 2005, págs. 252/253 e Carlos Roberto GonçALves, Comentários ao Código Civil, vol. 11, São Paulo, Saraiva, 2003, págs. 100/104.

${ }^{569}$ Tratava-se, na espécie, de ação de indenização por danos morais aforada por menor de idade, representado por seu pai, na qual o demandante exigia o pagamento de indenização em virtude dos danos físicos que lhe teriam sido impostos por imperícia médica cometida no momento de seu nascimento. O julgado, decisão monocrática da lavra do Ministro Celso de Melo, que menciona textualmente a inspiração nos punitive damages para a quantificação da indenização por danos morais, segue assim ementado: "RESPONSABILIDADE CIVIL OBJETIVA DO PODER PÚBLICO. Elementos estruturais. Pressupostos legitimadores da incidência do art. 37, $\S 6^{\circ}$, da Constituição da República. Teoria do risco administrativo. Fato danoso para o ofendido, resultante de atuação de servidor público no desempenho de atividade médica. Procedimento executado em hospital público. Dano moral. Ressarcibilidade. Dupla função da indenização civil por dano moral (reparação-sanção): (a) caráter punitivo ou inibitório ('exemplary or punitive damages') e (b) natureza compensatória ou reparatória. Doutrina. Jurisprudência. Agravo improvido." Em sua fundamentação, sustentou-se, para justificar a manutenção da condenação imposta pelo Tribunal $a$ quo, que "[i]mpende assinalar, de outro lado, que a fixação do quantum pertinente à condenação civil imposta ao Poder Público - presentes os pressupostos de fato soberanamente reconhecidos pelo Tribunal a quo observou, no caso ora em análise, a orientação que a jurisprudência dos Tribunais tem consagrado no 
Ainda que pese a autoridade dos críticos, a suposta incompatibilidade entre a indenização punitiva e as hipóteses de responsabilidade objetiva não se sustenta a uma análise aprofundada.

Isso porque, como já se teve a oportunidade de apreciar, quando tratamos do regime jurídico dos punitive damages nos países da common law, viu-se que o (intenso) debate sobre tema em tudo assemelhado ao presente concluiu pela admissibilidade de que se venha a obter a condenação do lesante ao pagamento de punitive damages mesmo em demanda que verse sobre responsabilidade objetiva ("strict liability").

Com efeito, o desenvolvimento da doutrina e jurisprudência sobre o tema, especialmente nos Estados Unidos da América, passou a admitir (a despeito das vozes contrárias que ainda se levantam contra a efetividade desta sorte de condenação) que, mesmo nas hipóteses de "strict liability" (especialmente aquelas em que se discute a responsabilidade pelo fato do produto, denominada "products liability"), o demandado seja condenado ao pagamento de punitive damages em adição a quaisquer quantias compensatórias. Tal condenação adicional somente ocorrerá se, no curso do processo, restarem comprovados, para além dos pressupostos necessários para a responsabilização do ofensor, aqueles pressupostos específicos, atinentes ao cabimento da indenização punitiva.

exame do tema, notadamente no ponto em que o magistério jurisprudencial, pondo em destaque a dupla função inerente à indenização civil por danos morais, enfatiza, quanto a tal aspecto, a necessária correlação entre o caráter punitivo da obrigação de indenizar ('punitive damages'), de um lado, e a natureza compensatória referente ao dever de proceder à reparação patrimonial, de outro." (STF; Agravo de Instrumento n. ${ }^{\circ}$ 455.846/RJ; Relator: Min. Celso de Mello; J. 11.10.2004). É relevante frisar, ao comentar o caso em questão, que não consta da fundamentação do julgado ter sido alegada e comprovada, durante o curso do processo de conhecimento, a existência dos elementos subjetivos indispensáveis para a imposição e quantificação da indenização punitiva (especialmente o grau de culpa do lesante direto ou dos gestores do hospital público), quer por parte da União Federal (ente responsabilizado em razão da teoria do risco administrativo), quer, ainda, por parte do médico que levou a cabo o procedimento cirúrgico. Tampouco se pôde verificar tais elementos da análise do acórdão recorrido, proferido pela C. $2^{\mathrm{a}}$ Turma do E. Tribunal Regional Federal da $2^{\mathrm{a}}$ Região (TRF 2a Reg.; $2^{\mathrm{a}}$ T.; AC 200002010629204; Relator: Des. Paulo Espírito Santo; J. 15.08.2001). Na hipótese, para a imposição da condenação ao pagamento de indenização por danos morais, houve apenas uma breve menção sobre a conduta do médico ao proceder à cirurgia, dizendo-se que "a previsibilidade do resultado consiste exatamente no conhecimento médico de que, se o nascituro estava na posição pélvica, maior cautela deveria ter sido destinada, para que o resultado [danoso] não ocorresse." Extrai-se, por meio da interpretação, que se considerou culposa a conduta do médico, contudo, não se pode aferir em que grau teria ocorrido tal culpa. Em razão a ausência de alusão aos critérios pertinentes à quantificação da indenização, Gustavo TEPEDINO, ao aludir ao caso em escrito recente, considera-o violador do "princípio da reparação proporcional ao dano" (O Futuro da Responsabilidade Civil, in Temas de Direito Civil, vol. III, Rio de Janeiro, Renovar, 2009, pág. 406). 
Por mais que se trate de soluções adotadas por países estrangeiros, dotados de regime jurídico próprio - e feitas, como devem ser feitas, todas as ressalvas nesse sentido - não há como se rejeitar, mutatis mutandis, a discussão lá travada e as conclusões a que se chegou, até mesmo por conta da semelhança dos institutos em questão ${ }^{570}$, para que se possa concluir pela inexistência de incompatibilidade entre a indenização punitiva e as hipóteses de responsabilidade objetiva.

Ainda que seja correta a premissa de que o autor de uma demanda indenizatória fundada na responsabilidade objetiva não ostenta nem o ônus de afirmar nem, tampouco, aquele de comprovar a existência de culpa ou dolo ${ }^{571}$, é certo que nada lhe impede de, caso assim deseje, acrescer à causa de pedir exposta em sua exordial a existência de tais elementos; providência esta que tomará caso pretenda deduzir pedido indenizatório que extrapole os limites do prejuízo suportado, acrescentando-lhe elemento punitivo.

Com efeito, a admissão da responsabilidade objetiva, em que a regra de imputação se dá independentemente da existência de culpa, em hipóteses cada vez mais comuns $^{572}$ não exclui a possibilidade de que se possa afirmar e considerar a existência da culpa para outros fins que não a imputação de responsabilidade. É nesse sentido que Antonio JUNQUEIRA DE AZEVEDO afirma, com propriedade, que "até mesmo nos casos de responsabilidade objetiva o juiz pode perfeitamente fazer o exame do dolo ou da culpa

\footnotetext{
${ }^{570}$ Como se viu, embora não se preveja, nos países da common law, uma cláusula geral de responsabilidade objetiva, como aquela inserida no art. 927, par. ún., CC, o regramento jurídico das hipóteses de strict liability é assemelhado ao dos nossos casos de responsabilidade objetiva. Assim em um como no outro, a imputação se dá independentemente da alegação e comprovação de culpa por parte do ofensor.

571 Fernando NoRONHA afirma que "[a] responsabilidade civil objetiva, ou pelo risco, é a obrigação de reparar danos, independentemente de qualquer idéia de dolo ou culpa. Ela nasce da prática de fatos meramente antijurídicos, geralmente relacionados a determinadas atividades [...]"; para concluir que " $a$ característica essencial da responsabilidade civil objetiva é prescindir-se da culpa". (Direito das Obrigações, vol. I, $2^{a}$ ed., São Paulo, Saraiva, 2007, pág. 484). Nesse sentido, José Rogério Cruz e TUCCI sustenta que, em uma demanda que verse sobre responsabilidade objetiva, a eventual alegação quanto à culpa do ofensor corresponde a um mero "fato secundário, sem qualquer relevância para o cerne da questão (que poderia ou não restar comprovado)", concluindo que, "[a]inda que deduzida, pelo autor, a culpa" do ofensor, "não lhe é carreado, na ação em tela, o ônus da prova quanto a tal fato (de resto, secundário). Basta que comprove o fato essencial" (= ocorrência de dano em razão de atividade de risco). (A Causa Petendi no Processo Civil, $2^{\mathrm{a}}$ ed., São Paulo, RT, 2001, págs. 171/173). Sobre a distinção entre fatos essenciais e fatos secundários, cfr. José Rogério Cruz e TUCCI, op. cit., págs. 153/154.

572 Nesse sentido, Antonio JUNQUEIRA DE AZEVEDo afirma que, em razão da constitucionalização do princípio da segurança (o qual, se não houvesse sido insculpido expressamente no art. $5^{\circ}$, caput, $\mathrm{CF} / 88$, decorreria do princípio da dignidade da pessoa humana, positivado, por sua vez, no art. $1^{\circ}$, III, CF/88), " $\mathrm{em}$ matéria de danos à pessoa, a regra é hoje a responsabilidade objetiva. A responsabilidade subjetiva, nesse campo, é atualmente exceção". (Caracterização Jurídica da Dignidade da Pessoa Humana, in Estudos e Pareceres de Direito Privado, São Paulo, Saraiva, 2004, pág. 18).
} 
grave (a culpa simples, para as nossas considerações, aqui não importa)"; para concluir que "[é] sabido que a adoção da responsabilidade objetiva pela legislação não 'eliminou do mapa' a responsabilidade subjetiva; esta continua a atuar em todas as brechas em que não cabe responsabilidade objetiva e, além disso, pode ser cumulada como causa de indenização nos casos de responsabilidade objetiva" ${ }^{\text {573. }}$.

A possibilidade de cumulação dos pedidos de indenização compensatória decorrente de uma relação de responsabilidade objetiva (cuja análise de mérito prescindirá da perquirição acerca da culpa do demandado) e de indenização punitiva (cuja análise de mérito dependerá, de maneira inafastável, da alegação e demonstração de culpa grave ou dolo por parte do demandado) decorre, justamente, do fator olvidado pelos críticos, mas referido pelo citado Antonio JUNQUEIRA DE AZEVEDO: cada um dos pedidos supra referidos se funda em uma causa de pedir que, em seu aspecto fático (causa de pedir remota) é, ao menos, parcialmente distinta da outra.

Como noticia D. G. OwEn, este fator foi levado em consideração pela jurisprudência norte-americana há mais de 150 anos, servindo de fundamento indispensável para que se concluísse pela admissibilidade de dedução de pedido de condenação ao pagamento de punitive damages em casos de "strict liability". Quanto a este ponto, o referido autor parte da (a nosso ver correta) premissa de que é inverídica a crença de que os fatos necessários para a procedência da pretensão compensatória decorrente de uma hipótese de "strict liability" (i.e. os elementos fáticos da causa de pedir) devam ser exatamente os mesmos exigidos para a procedência da pretensão punitiva (o que, ante à necessidade de que se apreciem os elementos subjetivos da conduta cometida pelo ofensor para a procedência deste último pedido, torná-lo-ia incompatível com o primeiro). Em reforço ao seu argumento, o autor cita o caso Fleet v. Hollenkemp (52 Ky. 219 1852), tido por ele como o pioneiro a envolver a condenação ao pagamento de punitive damages em hipótese de responsabilidade pelo fato do produto; no qual, ao referendar a condenação do demandado ao pagamento de punitive damages, a Corte de Apelação do Estado do Kentucky sustentou que a imposição de indenização punitiva não dependia dos estritos aspectos fáticos destinados à procedência da pretensão indenizatória, mas, sim, da alegação

\footnotetext{
573 Por Uma Nova Categoria de Dano na Responsabilidade Civil: O Dano Social, in Novos Estudos e Pareceres de Direito Privado, São Paulo, Saraiva, 2009, pág. 380. Semelhantemente, P. GALlo, Pene Private e Responsabilità Civile, Milano, Giuffrè, 1996, pág. 185.
} 
e prova de elementos particulares, tais como a gravidade dos prejuízos causados pelo ofensor, bem como da maneira como se deu a conduta lesiva, se intencional, de maneira injustificada ou maliciosa. Decidiu-se, enfim, que os aspectos fáticos subjacentes a um e a outro pedido são independentes e, portanto, cumuláveis para a obtenção de resultados conjuntos, se assim o quiser o demandante ${ }^{574}$.

Desta feita, mesmo se determinada pessoa vier a suportar prejuízos em decorrência do desempenho de uma atividade de risco (hipótese esta de responsabilidade objetiva, ex vi do art. 927, par. ún., CC), ela poderá deduzir em juízo a pretensão de condenação do demandado ao pagamento de indenização compensatória e de indenização punitiva, hipótese na qual deverá (rectius: terá o ônus de) alegar e provar a existência dos pressupostos subjetivos e objetivos exigidos para tanto ${ }^{575}$.

Como abaixo se verá com maior atenção, haverá, nessa hipótese, a formação de uma "causa de pedir complexa" ${ }^{576}$, com cumulação de pedidos em ordem sucessiva ${ }^{577}$ : (i) o pedido prejudicial, de condenação do demandado ao pagamento de indenização compensatória (chamada demanda principal); e (ii) o pedido prejudicado, de condenação do demandado ao pagamento de indenização punitiva (demanda acessória).

São, portanto, absolutamente compatíveis os institutos da indenização punitiva e da responsabilidade objetiva. Deve-se assegurar, contudo, para que a adoção da indenização punitiva seja bem sucedida, que a imposição desta sanção punitiva não ocorra em hipóteses nas quais seus requisitos não estão devidamente preenchidos e cabalmente comprovados. O que se deve evitar a todo custo é, justamente, que a condenação ao

\footnotetext{
574 Punitive Damages in Products Liability, in Michigan Law Review, vol. 74, 1976, págs. 1269/1270.

575 Nesse sentido, Eduardo UILAN, para quem "é possível a simultaneidade das duas situações: para a compensação, a dispensa da prova da culpa; para a punição, a prova da culpa especialmente qualificada ou o dolo por parte do agente." (Responsabilidade Civil Punitiva, Tese (Doutorado) - Faculdade de Direito da USP, São Paulo, 2003, pág. 85). Esta é, igualmente, a opinião esposada, a nosso ver com correção, por André Gustavo Corrêa de ANDRADE, para quem "mesmo em caso de responsabilidade objetiva será aplicável a indenização punitiva, se o ofensor, comprovadamente, tiver atuado com culpa grave ou dolo. Com efeito, nada impede que, em processo no qual se esteja a cuidar de responsabilidade civil objetiva, a parte autora produza prova acerca do dolo ou culpa do réu na produção do evento." (Dano Moral e Indenização Punitiva: Os punitive damages na experiência do common law e na perspectiva do Direito brasileiro, Rio de Janeiro, Forense, 2006, pág. 288).

${ }^{576}$ Nas palavras de José Rogério Cruz e TUCCI, "[d]iz-se complexa a causa de pedir quando, da variedade de fatos justapostos, forem individuadas várias pretensões". (A Causa Petendi no Processo Civil, $2^{\mathrm{a}}$ ed., São Paulo, RT, 2001, pág. 156).
} 
pagamento da indenização punitiva venha desacompanhada quer da alegação da ocorrência dos elementos subjetivos imprescindíveis para tanto (dolo ou culpa grave), quer de sua cabal comprovação.

Assim, mesmo diante de um caso em que a imputação de responsabilidade ao ofensor independe da análise da culpa, só se deve admitir a condenação ao pagamento de indenização punitiva se, ao final, restar cabalmente demonstrada que a conduta do ofensor foi direcionada intencionalmente com o fim de macular a saúde ou integridade do ofendido, ou que sua conduta foi marcada pela negligência grosseira para com tais valores $^{578}$; pois, como já teve a oportunidade de afirmar o Tribunal de Justiça do Rio de Janeiro, a adoção da indenização punitiva "deve ser apreciada cum grano salis, com temperamento", vedando-se sua incidência na hipótese de "ausência da culpa e dolo"579.

\section{I.IV. Vedação à dupla condenação ("ne bis in idem")}

Ainda uma última crítica que se levanta à admissibilidade da indenização punitiva é a de que, em casos extremos, tal instituto poderia representar flagrante violação ao princípio que veda o duplo sancionamento pela mesma conduta ("ne bis in idem”). Segundo sustenta a doutrina, tal violação poderia ocorrer basicamente em duas circunstâncias $^{580}$ : (i) quando uma mesma conduta consubstanciasse atos ilícitos em mais de um ramo do ordenamento, dando ensejo à aplicação de sanções punitivas de ordens diferentes (por ex., a uma multa administrativa e ao pagamento de indenização punitiva);

\footnotetext{
577 Sobre o cúmulo sucessivo de pedidos, cfr. Cândido Rangel DinAMARCO, Instituições de Direito Processual Civil, vol. II, $2^{a}$ ed., São Paulo, Malheiros, 2002, págs. 167/169.

578 Nesse sentido, Caroline VAZ, também uma adepta da possibilidade de cumulação entre a indenização punitiva e a indenização compensatória decorrente de responsabilidade objetiva, afirma que "[o] que ora se sustenta é o fato de as prestações pecuniárias poderem ser aplicadas para punir ou prevenir, mesmo quando a responsabilidade civil do agente for objetiva, caso em que os demais parâmetros serão utilizados para a fixação do quantum, a exemplo do que ocorre com as indenizações e compensações hoje existentes. [...] Saliente-se: não se está a referir-se à punição ou prevenção para agregar um valor a mais a ser pago pelo autor do dano, em toda e qualquer hipótese de condenação pelo reconhecimento da responsabilidade civil objetiva. Deverá ela advir de uma conduta na qual, em tese, todos os cuidados esperados e possíveis para o caso em concreto a fim de evitar danos a terceiros, não tenham sido adotados pelo causador, tendo ele agido com real indiferença para com os danos sociais, primando pelos eventuais lucros individuais da sua ação." (Funções da Responsabilidade Civil - Da Reparação à Punição e Dissuasão - Os punitive damages no Direito Comparado e Brasileiro, Porto Alegre, Livraria do Advogado, 2009, págs. 135/136). 579 (TJRJ; Apelação n. ${ }^{\circ}$ 2006.001.59035; Relator: Des. Antônio Carlos Amado; J. 24.01.2007) 580 Para considerações a respeito da possibilidade de cumulação de diversas sanções punitivas, cfr. S. Carval, La Responsabilitè Civile Dans Sa Fonction de Peine Privée, Paris, L.G.D.J., 1995, págs. 371/378.
} 
ou (ii) quando de uma mesma conduta ilícita (ou de uma mesma atividade) levada a efeito pelo mesmo ofensor atingisse a esfera jurídica de diversas pessoas, causando-lhes prejuízos distintos e dando ensejo a inúmeros pleitos pelo recebimento de indenização punitiva.

Quanto à primeira hipótese acima enumerada, Maria Celina Bodin de MORAES ressalta que "grande parte dos danos extrapatrimoniais, aos quais se pode impor o caráter punitivo, configura-se também como crime", concluindo, desta premissa, que admitir a incidência de uma sanção punitiva no âmbito civil, ao lado daquelas já previstas no Direito Penal, representa "não apenas uma brecha, mas uma verdadeira fenda num sistema que sempre buscou oferecer todas as garantias contra o injustificável bis in eadem. O ofensor, neste caso, estaria sendo punido duplamente, tanto em sede civil como em sede penal ${ }^{, 581}$. $\mathrm{O}$ questionamento que se põe, portanto, é o seguinte: o cometimento de um ato reputado, ao mesmo tempo, como ilícito civil, criminal e/ou adminstrativo pode ser, ao mesmo tempo, sancionado em todas essas órbitas (por ex. por meio da imposição indenização punitiva, penas criminais e multas administrativas)?

Em resposta a este questionamento, a doutrina apresenta, essencialmente, três posições distintas.

De um lado, encontram-se aqueles que advogam a impossibilidade de imposição de sanções punitivas de ramos distintos do ordenamento em atenção a uma mesma conduta ilícita, ainda que tais sanções sejam dotadas de estruturas diversas (e.g. ainda que se tenha, no âmbito civil, a imposição de indenização punitiva, sanção com a estrutura de prestação pecuniária e, no âmbito criminal, a pena de prisão, sanção com estrutura de privação de liberdade). Tal posição é esposada por P. M. LOURENÇO, para quem, "[q]uando a punição civil pecuniária excede a indemnização, a função punitiva da responsabilidade civil assume autonomia em relação à reparação e, eventualmente, pode interceptar a função punitiva da responsabilidade penal. Caso a conduta seja prevista e

\footnotetext{
581 Punitive Damages em Sistemas Civilistas: Problemas e Perspectivas, in Revista Trimestral de Direito Civil, vol.. 18, abr./jun. 2004, pág. 74. No mesmo sentido, Sérgio Luiz JunKES, A Culpa e a Punição Não Podem Servir de Critério Para a Fixação da Indenização por Dano Moral, in Jurisprudência Catarinense, ano XXXI, n. 107, 2005, pág. 230, Wesley de Oliveira Louzada BERNARDO, Dano Moral: Critérios de Fixação de Valor, Rio de Janeiro, Renovar, 2005, pág. 176 e, ainda, Marcela Alcazas BASSAN, As Funções da Indenização por Danos Morais e a Prevenção de Danos Futuros, Dissertação (Mestrado) - Faculdade de Direito da USP, São Paulo, 2009, pág. 74.
} 
punida pela lei penal, a punição civil não poderá ser aplicada ao mesmo tempo que a punição penal, sob pena de violação do princípio do non bis in idem" ${ }^{582}$.

Em sentido diametralmente oposto, posicionam-se os autores que defendem a incidência, no caso, do princípio da independência das instâncias (consubstanciado, no que toca ao Direito Privado, no art. 935, do CC/2002), advogando a admissibilidade de imposição concomitante de distintas sanções punitivas a uma mesma conduta ilícita, ainda que tais sanções sejam caracterizadas pela mesma estrutura (e.g., a imposição, no âmbito civil, de indenização punitiva e, no âmbito criminal, de pena de multa, ambas sanções com estrutura de prestação pecuniária) $^{583}$. Aos defensores desta posição, servem de ilustração as hipóteses em que uma mesma conduta poderia dar ensejo à aplicação de uma pena de multa (sanção de estrutura pecuniária) tanto no âmbito criminal quanto no âmbito administrativo (servem de exemplo, para o caso, as sanções previstas nos arts. 162 e 309, da Lei 9.503/1997, que penalizam o condutor não habilitado de veículo automotor) ${ }^{584}$.

Posição intermediária é aquela adotada por André Gustavo Corrêa de ANDRADE, da qual compartilhamos, no sentido de ser, sempre, admissível a cumulação de duas sanções punitivas de estruturas distintas. Faz-se, apenas, a ressalva de que, caso o ordenamento preveja, em outras órbitas (como, por ex., a administrativa), a imposição de uma sanção punitiva de estrutura pecuniária (tal como, por ex., a sanção administrativa de “multa simples" ao poluidor, prevista no art. $3^{\circ}$, II, do Decreto 6.514/2008), a quantificação de eventual indenização punitiva decorrente do cometimento de conduta apta a configurar a fattispecie do mesmo ato ilícito (no exemplo citado, de ato ilícito administrativo) deverá

\footnotetext{
${ }^{582}$ A Função Punitiva da Responsabilidade Civil, Coimbra, Coimbra, 2006, pág. 421.

${ }^{583}$ Nesse sentido, Caroline VAZ, Funções da Responsabilidade Civil - Da Reparação à Punição e Dissuasão - Os punitive damages no Direito Comparado e Brasileiro, Porto Alegre, Livraria do Advogado, 2009, págs. 86/87. Na jurisprudência, o princípio da independência das instâncias é usualmente referido para justificar a incidência de sanções penais e administrativas para punir o cometimento da mesma conduta. Apenas à guisa de exemplo, vejase: "SERVIDOR PÚBLICO. Militar. Sub-oficial. Prática de ato qualificado como crime e infração disciplinar. Recebimento de denúncia na esfera criminal. Instauração simultânea de procedimento administrativo disciplinar. Admissibilidade. Independência relativa das instâncias jurisdicional e administrativa. Segurança denegada. Improvimento ao recurso. Precedentes. Servidor público pode, ao mesmo tempo, responder a processo judicial penal e a procedimento administrativo disciplimar pela prática do mesmo ato". (STF; Tribunal Pleno; RMS 26510/RJ; Relator: Min. Cezar Peluso; J. 17.02.2010). Ainda, "[d]e acordo com o sistema jurídico brasileiro, é possível que de um mesmo fato (aí incluída a conduta humana) possa decorrer efeitos jurídicos diversos, inclusive em setores distintos do universo jurídico. Logo, um comportamento pode ser, simultaneamente, considerado ilícito civil, penal e administrativo". (STF; $2^{\mathrm{a}}$ T.; RHC 91110/SP; Relatora: Min. Ellen Gracie; J. 25.08.2008).

${ }^{584} \mathrm{O}$ exemplo citado é referido originalmente por André Gustavo Corrêa de ANDRADE, Dano Moral $e$ Indenização Punitiva: Os punitive damages na experiência do common law e na perspectiva do Direito brasileiro, Rio de Janeiro, Forense, 2006, pág. 314.
} 
levar em consideração também a possibilidade de o ofensor vir a ser condenado ao pagamento daquela outra sanção punitiva ${ }^{585}$.

Já quanto à segunda hipótese acima enumerada, a crítica que se põe é a de que a submissão de um mesmo ofensor ao pagamento de inúmeras possíveis indenizações punitivas em razão de uma mesma atividade ou ato que tenha gerado prejuízos a diversas pessoas impõe-lhe ônus financeiro muito severo, verdadeiro risco de que seja levado à bancarrota. Tal hipótese se mostra muito factível nos tempos atuais, ainda mais se considerarmos a possibilidade de imposição de indenização punitiva em decorrência de danos causados por fato do produto, de acidentes de trânsito ou do trabalho, casos nos quais de uma mesma conduta podem resultar prejuízos a inúmeras pessoas ${ }^{586}$.

A resposta a esta crítica não é simples e impõe não apenas a análise criteriosa das soluções apresentadas pelos países da common law, como, também, um saudável juízo de ponderação.

Como se teve a oportunidade de verificar, a orientação jurisprudencial de que se tem notícia nos Estados Unidos da América é a de admitir a cumulação de indenizações punitivas decorrentes de um mesmo ato ilícito ou de uma mesma atividade (caso, por ex., de responsabilidade pelo fato do produto). Entende-se, de maneira geral, que a garantia consubstanciada na $5^{\mathrm{a}}$ Emenda à Constituição Americana que veda a dupla condenação pelo mesmo ilícito (denominada double jeopardy clause) não tem incidência no âmbito cível e, portanto, não impede a cumulação de condenações ${ }^{587}$.

585 Dano Moral e Indenização Punitiva: Os punitive damages na experiência do common law e na perspectiva do Direito brasileiro, Rio de Janeiro, Forense, 2006, pág. 315.

586 S. Carval, La Responsabilitè Civile Dans Sa Fonction de Peine Privée, Paris, L.G.D.J., 1995, págs. $373 / 374$.

587 Nesse sentido, Eduardo UILAN cita interessante precedente criado no caso Hansen vs. Johns-Manville Products Corp.(1984), no qual se decidiu que a double jeopardy clause "só é aplicável a processos essencialmente criminais, negando provimento a uma apelação, em que a ré alegava estar potencialmente sujeita a inúmeras condenações cíveis de mesma espécia dado o extenso número de vítimas da mesma moléstia do autor, como resultado da falta de segurança no trabalho de fabricação de produtos de amianto." (Responsabilidade Civil Punitiva, Tese (Doutorado) - Faculdade de Direito da USP, São Paulo, 2003, pág. 59). $\mathrm{Na}$ mesma linha seguem as palavras de G. GEORGIADES, que sustenta que "because the gravamen of such [punitive] damages is considered civil, the procedural safeguards of the criminal law (such as the beyond-areasonable-doubt borden os proof and prohibitions against double jeopardy, excessive fines and compulsory self incrimination) have generally been held not to apply." (Punitive Damages in Europe and the USA: 
Quiçá inspirado pela solução norte-americana, André Gustavo Corrêa de ANDRADE se posiciona a favor da cumulação de diversas indenizações punitivas, impondose ao demandado tantas sanções quantas forem as vítimas de seu ato ilícito ou atividade. Para evitar a excessividade ou desproporcionalidade do montante final das condenações (a ser apurado após a imposição da última sanção punitiva), o citado autor cogita da utilização, pelo magistrado, de dois critérios para a quantificação da indenização punitiva: (i) levar em consideração a existência de eventuais outros lesados, igualmente legitimados para a propositura de ações indenizatórias, e que porventura, ainda não o tenham feito, "para deduzir do montante indenizatório a parcela que caberia àquele que ficou de fora da demanda" ${ }^{\prime 58}$; e (ii) ter em conta os valores de indenização punitiva precedentemente impostos ao ofensor em razão de prejuízos causados pelo mesmo ato ou atividade, também no intuito de quantificar de maneira razoável a sanção punitiva ${ }^{589}$.

Ainda que pese sua originalidade, quer-nos parecer que as sugestões acima apresentadas são de difícil aplicação prática e, em vez de proporcional uma adequada incidência da indenização punitiva, dão margem à quantificação da sanção em montante excessivo, superior àquele originalmente necessário para punir o ofensor pelo mal causado e dissuadi-lo (assim como a outros potenciais ofensores) do cometimento de novos atos ilícitos. Isso se dá porque, em razão da multiplicidade de lesados (os quais não necessariamente foram atingidos em um mesmo evento; basta pensar na hipótese de responsabilidade pelo fato do produto, na qual um mesmo produto perigoso pode causar danos a vítimas residentes em cidades, estados ou até mesmo países diferentes), os órgãos julgadores podem não ser os mesmos (e, muito provavelmente não o serão), o que, no mínimo, dificulta e muito a utilização dos critérios aventados por André Gustavo Corrêa de ANDRADE. É possível que o juiz de determinada comarca, ao receber uma demanda que vise à condenação do demandado ao pagamento de indenização punitiva, sequer tenha notícia da existência de outras vítimas (potenciais legitimados para o ajuizamento de novas demandas), ou, ainda, que ele sequer tenha conhecimento da quantidade e extensão de indenizações que, porventura, tenham sido impostas ao demandado.

Doctrinal Differences and Practical Convergence, in Revue Hellénique de Droit International, vol. 58, Éditions Ant. N. Sakkoulas, 2005, pág. 147).

588 Dano Moral e Indenização Punitiva: Os punitive damages na experiência do common law e na perspectiva do Direito brasileiro, Rio de Janeiro, Forense, 2006, pág. 299.

589 Dano Moral e Indenização Punitiva: Os punitive damages na experiência do common law e na perspectiva do Direito brasileiro, Rio de Janeiro, Forense, 2006, pág. 300. 
Demais disso, não se pode fechar os olhos à real possibilidade de que a múltipla condenação ao pagamento de indenização punitiva venha a levar o ofensor a uma situação de verdadeira insolvência, retirando-o do mercado em razão de uma única conduta ilícita, situação esta que se mostra extremamente prejudicial, quer para o ofensor, que ficaria obrigado a suportar punição excessiva por uma única conduta; quer para os ofendidos, os quais, em razão das primeiras condenações ao pagamento de indenização punitiva efetivamente recolhidas (e que levaram o ofensor à insolvência), poderiam deixar de ter sequer seus prejuízos efetivamente compensados; quer, ainda, para a própria sociedade, que veria desaparecer um agente econômico.

Em razão desses fatores, faz-se coro com S. CARVAL, para quem, em havendo um único ato ilícito danoso, ou uma única atividade de risco, admite-se apenas uma única condenação ao pagamento de indenização punitiva, ainda que, para a quantificação da indenização, o magistrado possa ter em conta (e, aqui, não se ignora as dificuldades que tal consideração implica) a real quantidade de vítimas atingidas pelo ilícito. Após a condenação ao pagamento da primeira indenização punitiva, as pretensões eventualmente deduzidas no futuro (frise-se: apenas no que concerne à condenação ao pagamento de indenização punitiva, nunca ao pagamento de indenização compensatória) deveriam ser julgadas improcedentes ${ }^{590}$. Ao que nos parece, tal solução é a que assegura, de maneira mais satisfatória, a aplicação adequada da indenização punitiva, coibindo a imposição de condenações desproporcionais.

\section{UMA CRÍTICA PERTINENTE: A AUSÊNCIA DE DISPOSIÇÃO LEGAL AUTORIZATIVA}

Tendo analisado e rejeitado as críticas usualmente levantadas pela doutrina contra a indenização punitiva, cumpre-nos deitar os olhos sobre a questão que, como antecipamos ao abrimos o presente capítulo, parece-nos indispensável para a escorreita admissão desta sanção punitiva em nosso ordenamento, qual seja, a necessidade de prévia cominação legal. Repetem-se, aqui, as palavras de Vitor Fernandes GonçALVES, para

\footnotetext{
${ }^{590}$ La Responsabilitè Civile Dans Sa Fonction de Peine Privée, Paris, L.G.D.J., 1995, págs. 373/374.
} 
quem "a adoção específica da indenização punitiva não prescinde de um modelo de conformação constitucional. Nesse contexto, é necessário articular o pedido da indenização punitiva com base em algum dispositivo legal que permita essa articulação, isto é, com respeito ao princípio da legalidade”. Conclui o citado autor, em reforço, que, "no que tange à imputação da indenização punitiva, por se tratar de direito excepcional, não se pode prescindir de uma base legal nesse sentido"591.

Para a análise das questões que se seguem, parte-se da premissa (não unânime na doutrina) de que, no atual estágio em que se encontra, nosso ordenamento não possui nenhuma previsão normativa que, de maneira ampla, poderia ser utilizada como fundamento legal para a utilização da indenização punitiva ${ }^{592}$.

Nesse sentido, e ao contrário do que sustenta Regina Beatriz Tavares da SILVA $^{593}$, acredita-se que, a despeito de a previsão contida no art. 944, par. ún., CC, representar uma exceção ao princípio da reparação integral do prejuízo, ela jamais poderia ser utilizada para justificar uma exceção à indenização compensatória, uma vez que só admite a perquirição a respeito da culpa do ofensor para o expresso fim de reduzir eqüitativamente o quantum indenizatório. Em nenhum momento tal dispositivo legal autoriza (expressa ou implicitamente) seja utilizada a culpa do ofensor para fins de majorar

${ }^{591}$ A Punição na Responsabilidade Civili: A Indenização do Dano Moral e da Lesão a Interesses Difusos, Brasília, Brasília Jurídica, 2005, págs. 199/200.

${ }_{592}$ Maria Celina Bodin de MoRAES, Punitive Damages em Sistemas Civilistas: Problemas e Perspectivas, in Revista Trimestral de Direito Civil, vol.. 18, abr./jun. 2004, pág. 47; Paulo de Tarso Vieira SANSEVERINO, Princípio da Reparação Integral (Indenização no Código Civil), São Paulo, Saraiva, 2010, pág. 74 e Marcela Alcazas BASSAN, As Funções da Indenização por Danos Morais e a Prevenção de Danos Futuros, Dissertação (Mestrado) - Faculdade de Direito da USP, São Paulo, 2009, pág. 75.

593 A qual sustenta que, em razão da previsão contida no art. 944, par. ún., CC (o qual autoriza a redução eqüitativa da indenização pelo julgador, "se houver excessiva desproporção entre a gravidade da culpa e o dano" causado), "[o] caráter punitivo da reparação de danos", "tanto no que se refere aos danos morais, quanto no que tange aos danos materiais", "passou a ter apoio legal". (Critérios de Fixação da Indenização do Dano Moral, in Mario Luiz Delgado e Jones Figueirêdo Alves (coords.), Questões Controvertidas no Novo Código Civil, São Paulo, Método, 2003, pág. 265). Também parece ser essa, ao menos no que toca à indenização por danos morais, a posição adotada por Teresa Ancona LoPEZ (Princípio da Precaução e Evolução da Responsabilidade Civil, São Paulo, Quartier Latin, 2010, págs. 82). Diante da redação do art. $494^{\circ}$ do CC Português (o qual, denominado de "limitação da indemnização no caso de mera culpa", prescreve que "[q]uando a responsabilidade se fundar na mera culpa, poderá a indemnização ser fixada, equitativamente, em montante inferior ao que corresponderia aos danos causados, desde que o grau de culpabilidade do agente, a situação económica deste e do lesado e as demais circunstâncias do caso o justifiquem."), semelhante à do nosso art. 944, par. ún., P. M. LOURENÇO afirma que "a jurisprudência portuguesa tem a base legal para assegurar uma efectiva tutela jurídica da personalidade humana, através da aplicação dos critérios legais elencados no artigo $494^{\circ}$ [...]. Assim, 'o grau de culpabilidade do agente' enunciado no art. $494^{\circ}$ deve permitir a atribuição ao lesado de um montante mais elevado, se o agente tiver 
a indenização, não se podendo, a nosso ver, socorrer-se dele para justificar a utilização da indenização punitiva ${ }^{594}$.

Parece-nos igualmente inaplicável, para o fim de justificar a utilização da indenização punitiva, a previsão contida no art. $945, \mathrm{CC}^{595}$. A uma, porque, assim como o faz Marcelo Junqueira CALiXTo, “nada obstante os termos do art. 945, defende-se que a hipótese aí versada é de concorrência de causas, sendo resolvida à luz das reflexões acerca do nexo de causalidade, e não de culpa"596. Não se trata, portanto, de ponderação comparativa entre os distintos graus de culpa do ofensor e do ofendido, mas, sim, de análise da "eficácia causal" de cada uma das distintas condutas para a obtenção do resultado danoso ${ }^{597}$. A duas, porque, ainda que assim não fosse, o referido dispositivo legal

actuado com dolo, e uma quantia mais diminuta, se tiver agido com negligência." (A Função Punitiva da Responsabilidade Civil, Coimbra, Coimbra, 2006, págs. 392 e 394).

${ }^{594}$ Nesse sentido, Gustavo TePEDINO - Heloísa Helena BARBOZA - Maria Celina Bodin de Moraes, Código Civil Interpretado Conforme a Constituição da República, vol. II, Rio de Janeiro, Renovar, 2006, pág. 865; Marcela Alcazas BASSAn, As Funções da Indenização por Danos Morais e a Prevenção de Danos Futuros, Dissertação (Mestrado) - Faculdade de Direito da USP, São Paulo, 2009, pág. 70; André Gustavo Corrêa de ANDRADE, Dano Moral e Indenização Punitiva: Os punitive damages na experiência do common law e na perspectiva do Direito brasileiro, Rio de Janeiro, Forense, 2006, pág. 250 e Luiz Cláudio Carvalho de AlmeIDA, A Repetição do Indébito em Dobro no Caso de Cobrança Indevida de Dívida Oriunda de Relação de Consumo como Hipótese de Aplicação dos Punitive Damages no Direito Brasileiro, in Revista de Direito do Consumidor, vol. 54, jun.-2005, págs. 161 e ss.. No direito português, versando sobre o já citado art. $494^{\circ}$, M. A. C. da FRADA afirma que tal dispositivo não pode ser invocado como fundamento para a adoção de uma função punitiva à responsabilidade civil por se tratar de "mera atenuação da indemnização". (Direito Civil Responsabilidade Civil: O Método do Caso, Coimbra, Almedina, 2006, pág. 66).

595 Vitor Fernandes GONÇALVES, a despeito de se posicionar no sentido de que a indenização punitiva demanda prévia cominação legal para sua utilização, afirma que "[n]o Brasil, releva notar que se pode defender a imposição de indenizações punitivas com muito mais base legal, tendo em vista as normas do Código Civil de 2002, do que à época da vigência do Código Civil de 1916. De fato, por meio do art. 945, o legislador de 2002 inovou e adotou, no âmbito da responsabilidade civil extracontratual, a tendência da lei ambiental italiana, assim estabelecendo: 'Se a vítima tiver concorrido culposamente para o evento danoso, a sua indenização será fixada, tendo-se em conta a gravidade de sua culpa em confronto com a do autor do dano.' Nesse sentido, na medida em que a lei autoriza o juiz a utilizar um elemento estranho à mera quantificação do prejuízo para o cálculo da indenização nos casos de culpa, critério esse concernente à gravidade da culpa, desloca o critério da reparação do efeito da lesão, isto é, do dano, para a causa da lesão, a conduta culposa, introduzindo um elemento punitivo, típico do direito penal, e, assim, abrindo a possibilidade de o juiz levar em conta esse elemento nas hipóteses de responsabilidade civil extracontratual nas quais isso é oportuno". (A Punição na Responsabilidade Civil: A Indenização do Dano Moral e da Lesão a Interesses Difusos, Brasília, Brasília Jurídica, 2005, págs. 201/202). Ressalta, ainda, o citado autor que merece "destaque o fato de que neste art. 945 - ao contrário do que ocorre na regra do art. 944, §único do mesmo diploma legal e que cuida da excessiva desproporção entre o dano e a conduta culposa - o legislador não faculta expressamente ao juiz apenas a redução do valor da indenização, como meio de implantar a equidade." (op. cit., pág. 202).

${ }^{596}$ A Culpa na Responsabilidade Civil: Estrutura e Função, Rio de Janeiro, Renovar, 2008, pág. 331.

597 Também parece ser essa a posição de Sérgio CAVALIERI FILHO, o qual ressalta que, na hipótese em questão, em vez da expressão "concorrência de culpas", "a doutrina atual tem preferido falar [...] em concorrência de causas ou de responsabilidade, porque a questão [...] é mais de concorrência de causa do que de culpa. A vítima também concorre para o evento, e não apenas aquele que é apontado como único causador do dano." (Programa de Responsabilidade Civil, 6a ed., São Paulo, Malheiros, 2005, págs. 66/67. 
somente permitiria a perquirição da culpa do ofensor para, desta análise, elaborar um juízo de ponderação com a culpa da vítima para o fim de reduzir o quantum indenizatório, nunca majorá-lo. Isso porque, se há concorrência de causas (ou, permite-se, apenas por argumentar, "concorrência de culpas"), o ofensor, ainda que tenha-se conduzido dolosamente ou com culpa grave, não foi o único causador do prejuízo e, portanto, não deve suportar integralmente a indenização dele decorrente. Reduz-se, portanto, o quantum indenizatório; não se o aumenta.

Feitas tais ressalvas, passaremos, deste ponto em diante, a analisar aquelas considerações feitas pela doutrina que, em razão da inexistência de previsão legislativa que autorize expressamente a utilização da indenização punitiva, tornam-na, a nosso ver, inadmissível (ao menos enquanto não se estabelecem os limites jurídicos de sua utilização). São elas: (i) o princípio da legalidade das penas ("nulla poena sine lege"); (ii) o princípio da reparação integral ("restitutio in integrum"); e, ao final, (iii) a vedação ao enriquecimento sem causa.

\section{II.I. O princípio da legalidade das penas ("nulla poena sine lege")}

Diante da premissa acima fixada, parece-nos que a restrição mais severa levantada pela doutrina é a de que, por se tratar de sanção com função punitiva, análoga, portanto, à sanções típicas do Direito Penal, a indenização punitiva estaria submetida ao princípio da legalidade das penas (ou da reserva legal), exigindo, para a sua adoção em nosso ordenamento, a prévia cominação legal, sob pena de flagrante inconstitucionalidade (art. 5, XXXIX, CF/88).

Em apertada síntese, sustenta a doutrina que tanto a imposição de uma quantia pecuniária destinada à punição do ofensor, independente daquela com fins compensatórios, quanto a utilização de critérios alheios ao efeito prejuízo suportado (tais como, por ex., o grau de culpa do ofensor, ou sua capacidade econômica) para a quantificação (e conseqüente majoração) da indenização, "eqüivale a impor ao ofensor 
uma pena sem previsão legal específica",598, o que contrariaria "toda a tradição dos ordenamentos de civil law" e configuraria "verdadeiro arbítrio do juiz"599.

Com vistas à pronta adoção, nos países de raiz romano-germânica, de instituto assemelhado aos punitive damages norte-americanos (a partir do que se poderia permitir que a responsabilidade civil passasse a exercer, diretamente, as funções de punição e prevenção), mesmo sem a prévia cominação legal nesse sentido, parte da doutrina defende a existência de uma diferenciação ontológica entre as sanções penais e as civis (mesmo aquelas que exercem uma função punitiva), razão pela qual estas últimas não se submeteriam ao princípio da reserva legal.

Nesse sentido, B. STARCK afirma que, "ainda que se reconheça o caráter penal de certas condenações civis, não cremos que o princípio nulla poena sine lege lhes seja aplicável"600. Isso porque, segundo o citado autor, "existe evidentemente uma diferença de graus entre a gravidade das sanções penais e civis que explica e justifica as regras de competência e procedimentais que opõem os dois ramos" ${ }^{\prime 601}$.

Inspirado por tal posicionamento, Eduardo UILAN sustenta que as sanções penais e as civis (mesmo as que exercem função punitiva) "distinguem-se pela intensidade $e$ pela gravidade com que atingem os direitos do condenado" ${ }^{\natural 02}$, no que é secundado por

\footnotetext{
${ }^{598}$ Gustavo TEPEDINO - Heloísa Helena BARBOZA - Maria Celina Bodin de MORAEs (coords.), Código Civil Interpretado Conforme a Constituição da República, vol. II, Rio de Janeiro, Renovar, 2006, pág. 863; Wesley de Oliveira Louzada Bernardo, Dano Moral: Critérios de Fixação de Valor, Rio de Janeiro, Renovar, 2005, pág. 179 e Sérgio Luiz Junkes, A Culpa e a Punição Não Podem Servir de Critério Para a Fixação da Indenização por Dano Moral, in Jurisprudência Catarinense, ano XXXI, n. 107, Florianópolis, 2005, pág. 229.

599 Anderson SCHREIBER, Novos Paradigmas da Responsabilidade Civil: Da Erosão dos Filtros da Reparação à Diluição dos Danos, São Paulo, Atlas, 2009, pág. 208. Vale observar que, sobre o princípio em questão, Guilherme de Souza NuCCI afirma que "[a] legalidade em sentido estrito ou penal guarda identidade com a reserva legal, vale dizer, somente se pode considerar crime determinada conduta, caso exista previsão legal. O mesmo se pode dizer para a existência da pena. O termo lei, nessa hipótese, é reservado ao sentido estrito, ou seja, norma emanada do Poder Legislativo, dentro de sua competência". (Princípios Constitucionais Penais e Processuais Penais, São Paulo, RT, 2010, págs. 81/82). Vale dizer: em razão do princípio da reserva legal, mostra-se inconstitucional a criação jurisprudencial de penas.

${ }^{600}$ No original: "même si on reconnâ̂t avec nous le caractère pénal de certaines condammation civiles, nous ne croyons pas que le principe nulla poena sine lege y soit applicable." (Essai d'une Théorie Générale de la Responsabilité Civile Considèrèe em as Double Fonction de Garantie et de Peine Privèe, Paris, L. Rodstein, 1947, pág. 383).

${ }^{601}$ No original: "c'est évidemment une différence de degré dans la gravité de la sanction pénale et civile qui explique et justifie les règles de compétence et de procédure qui opposent les deux ordres de jurisdictions". (Essai d'une Théorie Générale de la Responsabilité Civile Considèrèe em as Double Fonction de Garantie et de Peine Privèe, Paris, L. Rodstein, 1947, pág. 384).

${ }^{602}$ Responsabilidade Civil Punitiva, Tese (Doutorado) - Faculdade de Direito da USP, São Paulo, 2003, pág. 55.
} 
Caroline VAZ, ao sustentar que "o Direito Penal tem como conseqüência, quando da sua aplicação, a restrição da liberdade ou, no mínimo, de direitos" do ofensor, características estas supostamente não perseguidas ou atingidas pelas sanções punitivas do Direito Civil ${ }^{603}$.

Diz-se, em arremate, que somente a pena criminal "traz em si um caráter infamante que marcará a reputação do condenado em seu meio social" ${ }^{604}$, enquanto que, de outro lado, "as sanções civis não estigmatizam, com infâmia, aquele que se vê condenado em uma sentença cível. A sanção civil, ademais, em nenhuma forma atinge ou busca atingir a supressão do direito de liberdade da pessoa humana"605.

Das premissas acima aventadas, procura-se atingir a conclusão de que as sanções punitivas de Direito Civil não devem receber, para a sua aplicação, o mesmo regime das sanções punitivas típicas do Direito Penal ${ }^{606}$. Vale dizer: a indenização punitiva não se submeteria ao "modelo regulativo" no qual se insere o princípio da legalidade das penas ${ }^{607}$.

Ainda que pesem os argumentos acima apresentados, não nos parece que se possa distinguir as sanções punitivas, sejam elas oriundas de Direito Privado ou Público, com fundamento em seu suposto "fator estigmatizante", ou em uma suposta diferenciação estrutural característica, consistente da possibilidade de se restringir determinados direitos

${ }^{603}$ Funções da Responsabilidade Civil - Da Reparação à Punição e Dissuasão - Os punitive damages no Direito Comparado e Brasileiro, Porto Alegre, Livraria do Advogado, 2009, pág. 84.

${ }^{604}$ Eduardo UILAN, Responsabilidade Civil Punitiva, Tese (Doutorado) - Faculdade de Direito da USP, São Paulo, 2003, pág. 55. Nesse sentido, B. STARCK afirma que as sanções penais "sont plus dures, en général, que les sanctions civiles, et em tout cas plus déshonorantes" (Essai d'une Théorie Générale de la Responsabilité Civile Considèrèe em as Double Fonction de Garantie et de Peine Privèe, Paris, L. Rodstein, 1947, pág. 383). Sobre a inexistência desse caráter estigmatizante na indenização punitiva, cfr. S. CARVAL, La Responsabilitè Civile Dans Sa Fonction de Peine Privée, Paris, L.G.D.J., 1995, págs. 259/263.

${ }^{605}$ Eduardo UIlan, Responsabilidade Civil Punitiva, Tese (Doutorado) - Faculdade de Direito da USP, São Paulo, 2003, pág. 56. No mesmo sentido, B. R. KERN, A Função de Satisfação na Indenização do Dano Pessoal, in Revista de Direito do Consumidor, n. ${ }^{\circ} 33$, janeiro/março 2000, págs. 23/24.

${ }^{606}$ Eduardo UILAN, Responsabilidade Civil Punitiva, Tese (Doutorado) - Faculdade de Direito da USP, São Paulo, 2003, pág. 55.

${ }^{607}$ Eduardo UILAN, Responsabilidade Civil Punitiva, Tese (Doutorado) - Faculdade de Direito da USP, São Paulo, 2003, pág. 56 e 74 e André Gustavo Corrêa de ANDRAdE, Dano Moral e Indenização Punitiva: Os punitive damages na experiência do common law e na perspectiva do Direito brasileiro, Rio de Janeiro, Forense, 2006, págs. 310/311.Tal argumento foi, em recente julgado, esposado pelo Tribunal de Justiça do Estado de São Paulo, ao se afirmar que "[c]omo já tivemos a oportunidade de escrever, 'a 'pena civil' (punitive damage ou exemplary damages, como é chamada no common law) não pode ser confundida com a pena pública, aquela que tem por fim proteger a sociedade. É verdade que ambas têm um cunho intimidativo, mas a pena civil, além de o beneficiário ser a própria vítima do fato danoso, tem um caráter preventivo (art. $6^{\circ}, \mathrm{VI}$, do CDC); além do mais, como bem lembra Bonilini, a pena pública, por previsão legal, tem um valor mínimo e um máximo, enquanto a pena privada, teoricamente, é infinita. Portanto, como 
(em especial a liberdade, vez que nosso ordenamento veda a imposição da pena capital, "salvo em caso de guerra declarada", ex vi do art. 5', XLVII, 'a', CF/88), para, dessa tentativa de distinção (que nos parece artificial), procurar extrair a conseqüência de que o princípio da reserva legal seria inaplicável às sanções punitivas típicas do Direito Privado.

Por primeiro, quer-nos parecer que a possibilidade de impor ao sancionado uma pecha, por assim dizer, infamante ou estigmatizante, não é característica exclusiva das sanções do Direito Penal. Concede-se, quanto muito, que, pela maior gravidade das sanções penais, o aspecto estigmatizante seja mais severo (e, por assim dizer, mais perene) do que aquele que, a nosso ver, também pode ser característico das sanções civis punitivas.

Com efeito, ainda que se possa dizer que a imposição de sanções criminais (especialmente as restritivas de liberdade) traz consigo um reflexo social especialmente gravoso, não há como se olvidar que aplicação de determinadas sanções civis punitivas particularmente severas (tais como, por ex., a deserdação e a indignidade, principalmente em casos nos quais a sanção incide em resposta a um ato moralmente reprovável, tais como, respectivamente, a ofensa física ao testador ou o homicídio doloso do de cujus), também não carrega um fator socialmente indesejável e - por que não dizer? estigmatizante.

Por segundo, igualmente insustentável nos parece a crítica quanto às eventuais distinções estruturais entre as sanções punitivas previstas nos Direitos Penal e Civil.

A uma, porque, na esteira do quanto já exposto, o que distingue as diferentes espécies de sanção não é sua estrutura, mas, sim, sua função, de modo que não seria este o argumento a ser utilizado para justificar eventual distinto tratamento entre duas sanções jurídicas.

A duas, porque, ao contrário do quanto exposto, as sanções punitivas, mesmo aquelas atinentes a outros ramos do Direito que não o Direito Penal, também podem envolver a restrição ou supressão de direitos. Vê-se, nesse sentido, no âmbito do Direito Processual Civil, a restrição ao direito de recorrer nas hipóteses em que o 
recorrente, tendo previamente se conduzido como improbus litigator, não efetue o pagamento dos valores referentes às multas processuais a ele impostas (arts. 538, par. ún. e 557, §2º do CPC); e, no âmbito do Direito Civil, a perda dos direitos hereditários daquele que sonega bens no curso do inventário (art. 1.992, do CC/2002). Até mesmo a restrição à liberdade do indivíduo pode ser objeto de uma sanção pertinente ao Direito Civil, como se vê nos casos da (hoje inadmitida pela jurisprudência reiterada de nossos Tribunais Superiores) prisão do depositário infiel (art. 652, do CC/2002) (008 $^{6}$ e do devedor de obrigação de pagar alimentos (art. $733, \S 1^{\circ}$, CPC), sanções estas que nem ao menos ostentam o caráter de sanções punitivas ${ }^{609}$.

Não nos parece adequado, portanto, procurar erigir um conceito unitário de sanção punitiva (gênero do qual a pena privada é espécie), admitindo-se que o Direito Privado, assim como o Direito Penal (ramo do Direito Público), pode ser dotado de uma função punitiva para, diante de um obstáculo constitucional claro, sustentar que a natureza jurídica das penas civis e criminais é diferente, buscando, dessa forma, ultrapassar o referido obstáculo sem, de fato, enfrentá-lo.

A par da primeira linha de argumentos acima exposta, para que se pudesse admitir a pronta utilização da indenização punitiva (mesmo à míngua de previsão legal expressa nesse sentido), a doutrina procura levantar ainda um segundo argumento contra a incidência do princípio da legalidade das penas no âmbito do Direito Civil (e, especificamente, no que tange à admissibilidade da indenização punitiva). Sustenta-se que,

sine lege'." (TJSP; Apelação n. ${ }^{0}$ 7132299-3; Relator: Juiz Paulo Jorge Scartezzini Guimarães; J. 07.05.2007). 608 "Desde a adoção pelo Brasil, sem qualquer reserva, do Pacto Internacional dos Direitos Civis e Políticos (art. 11) e à Convenção Americana sobre Direitos Humanos - Pacto de San José da Costa Rica (art. 7º 7), ambos no ano de 1992, não há mais base legal para prisão civil do depositário infiel, pois o caráter especial desses diplomas internacionais sobre direitos humanos lhes reserva lugar específico no ordenamento jurídico, estando abaixo da Constituição, porém acima da legislação interna. O status normativo supralegal dos tratados internacionais de direitos humanos subscritos pelo Brasil torna inaplicável a legislação infraconstitucional com ele conflitante, seja ela anterior ou posterior ao ato de adesão. Assim ocorreu com o artigo 1287 do Código Civil de 1916 e com o Decreto-lei n. ${ }^{o}$ 911/69, assim como em relação ao artigo 652 do Novo Código Civil." (STF; Tribunal Pleno; RE n. ${ }^{\circ}$ 349703/RS; Relator p/acórdão: Min. Gilmar Mendes; J. 03.12.2008).

${ }^{609}$ Quanto à sanção de prisão do depositário infiel, Orlando GOMES afirma que "[t]al medida não é considerada, porém, genuína pena, mas, antes, enérgico e pronto meio para compelir o depositário a restituir o que tomo para guardar, a impedir que cometa apropriação indébita." (Contratos, $26^{\mathrm{a}}$ ed., Rio de Janeiro, Forense, 2007, pág. 421). No mesmo sentido, Gustavo TEPEDINO, Heloísa Helena Barboza e Maria Celina Bodin de MORAES sustentam que, "[p]ara a decretação da prisão, que não é pena, mas medida compulsória de natureza civil ou administrativa, não se exige culpa ou dolo." (Código Civil Interpretado Conforme a Constituição da República, vol. II, Rio de Janeiro, Renovar, 2006, pág. 416), o que, à evidência, colocam a aludida sanção no rol daquelas tidas por coercitivas. Já no que tange à prisão do devedor de 
quando se está diante de meios destinados à proteção dos direitos da personalidade (em razão das diversas hipóteses pertinentes aos detrimentos morais), reflexos que são da dignidade da pessoa humana (princípio e valor insculpidos no art. $1^{\circ}, \mathrm{III}, \mathrm{CF} / 88$ ), não se pode admitir um sistema jurídico que não se preste a proteger de maneira suficiente e adequada tais valores. E, para que se assegure tal sorte de proteção, há que se admitir que a responsabilidade civil passe a, também ela, exercer as funções punitivas e dissuasórias.

Nesse sentido, advogando a incidência das sanções punitivas como meio de assegurar a proteção aos direitos fundamentais, Caroline VAZ, sustenta que "a Constituição da República brasileira aperfeiçoou a qualidade dos instrumentos garantidores" desses direitos "ao estabelecer, no art. 5", inciso XXXV, que a lei não poderá excluir da apreciação do Poder Judiciário lesão ou ameaça a direitos" ${ }^{" 610}$. Prossegue a citada autora aduzindo que, pelo fato de a simples "ameaça a direitos" ter sido inserida no âmbito de proteção garantido pelo Poder Judiciário, não se pode mais pensar, apenas, em sanções como resposta ao ilícito já perpetrado e ao prejuízo já imposto (sanções, portanto, com finalidades compensatórias ou, até mesmo, punitivas). Há que se assegurar a proteção integral dos direitos fundamentais, o que também há de ser atingido por meio da adoção direta e imediata de sanções que, eficazmente, exerçam, para além das funções eventualmente punitiva e compensatória, também uma finalidade preventiva ${ }^{611}$.

Assim é que a citada autora defende a utilização do critério hermenêutico para que, ainda que em face da inexistência de prévias cominações legais nesse sentido, possa o Poder Judiciário lançar mão de todos os mecanismos que se entenda necessários para a eficaz e adequada proteção aos direitos fundamentais, aí incluída a indenização punitiva ${ }^{612}$.

Em sentido análogo, também se valendo de raciocínio fundado na proteção aos direitos fundamentais, André Gustavo Corrêa de ANDRADE sustenta "os direitos da personalidade não têm como ser efetivamente protegidos se não através da imposição de

alimentos, também considerada sanção coercitiva, cfr. J. O. ASCENSÃO, Introdução à Ciência do Direito, $3^{\mathrm{a}}$ ed., Rio de Janeiro, Renovar, 2005, pág. 60.

${ }^{610}$ Funções da Responsabilidade Civil - Da Reparação à Punição e Dissuasão - Os punitive damages no Direito Comparado e Brasileiro, Porto Alegre, Livraria do Advogado, 2009, pág. 113.

${ }^{611}$ Funções da Responsabilidade Civil - Da Reparação à Punição e Dissuasão - Os punitive damages no Direito Comparado e Brasileiro, Porto Alegre, Livraria do Advogado, 2009, pág. 113.

${ }^{612}$ Funções da Responsabilidade Civil - Da Reparação à Punição e Dissuasão - Os punitive damages no Direito Comparado e Brasileiro, Porto Alegre, Livraria do Advogado, 2009, págs. 92/93 e 95. 
uma soma em dinheiro que constitua fator de coerção sobre o causador do dano e de terceiros", motivo pelo qual, "na ponderação entre o princípio substancial do art. $1^{o}$, inciso III, da Constituição Federal, que consagra a dignidade da pessoa humana como fundamento da República, e o princípio consagrado no art. $5^{\circ}$, inciso XXXIX, que estabelece a garantia instrumental de que não deve haver pena sem prévia cominação legal, a balança pesaria francamente a favor do primeiro" $" 613$.

Como já se teve a oportunidade de expor, reconhece-se, na linha da premissa adotada pelos citados autores, que os valores e princípios insculpidos na Carta Constitucional de 1988 impõem a adoção de medidas jurídicas aptas a assegurar a incolumidade e segurança do ser humano. Advoga-se, ademais, pela utilização da indenização punitiva como instrumento adequado a desempenhar tais funções, em complementação com o Direito Penal e ao Direito Administrativo Sancionador. Contudo, não nos parece admissível a conclusão a que procuram chegar os mesmos autores acima referidos, no sentido de que, do princípio constitucional da dignidade da pessoa humana, pode-se extrair o fundamento legal suficiente para a imposição da indenização punitiva. Segundo se sustenta, em um juízo de ponderação, o princípio da dignidade da pessoa humana prevaleceria sobre o princípio da reserva legal, possibilitando a imposição, ao ofensor, de uma pena inédita e original, sem prévia cominação legal.

A uma, tal argumento nos parece falacioso porque, remotamente, o princípio da reserva legal também finca raízes na proteção à dignidade da pessoa humana. Trata-se de princípio basilar do Estado Democrático de Direito que, também a seu modo, procura garantir a segurança da vida privada. Nas palavras de Guilherme de Souza NuCCI, com a previsão do princípio da reserva legal, "[n] asce o direito humano fundamental de somente haver punição quando o Estado joga às claras, criando figuras delituosas antes de qualquer ato lesivo ocorrer, conferindo segurança a todos os membros da sociedade"614. Não nos parece admissível, portanto, que se desrespeite o princípio da reserva legal em favor da suposta proteção à dignidade da pessoa humana, uma vez que, em assim o fazendo, estar-se-ia cometendo outra infração, lesando-se, desta vez, não apenas os direitos do próprio ofensor (que seria punido de maneira injustificada), mas, também, reduzindo-se

\footnotetext{
613 Dano Moral e Indenização Punitiva: Os punitive damages na experiência do common law e na perspectiva do Direito brasileiro, Rio de Janeiro, Forense, 2006, pág. 312.

${ }^{614}$ Princípios Constitucionais Penais e Processuais Penais, São Paulo, RT, 2010, pág. 82.
} 
as condições de convivência social (vez que, em última análise, estar-se-ia permitindo a atuação arbitrária do julgador, livre para impor sanções punitivas contra quaisquer condutas que julgasse violadoras da dignidade da pessoa humana).

A duas, e ainda que assim não fosse, a utilização da indenização punitiva sem prévia lei que estabelecesse, ao menos em linhas gerais, suas hipóteses de incidência e os critérios para sua quantificação, dar-se-ia em desconformidade com o melhor desempenho da função educativa (a qual reflete diretamente nas funções punitiva e preventiva). Para que a sanção punitiva desempenhe adequadamente suas funções, é imprescindível que o potencial ofensor tenha conhecimento prévio e adequado das condutas passíveis de sanção, bem como dos critérios passíveis de utilização para a mensuração da pena. Tais previsões, em ordenamentos de raiz romano-germânica, somente podem ser feitas por meio de lei.

Em suma, a despeito de se sustentar, na presente dissertação, que a adoção da indenização punitiva é medida verdadeiramente imprescindível para que o instituto da responsabilidade civil (e o Direito Civil como um todo) exerça em sua plenitude as funções decorrentes dos valores constitucionalmente estabelecidos, entende-se que a imediata introdução de tal sanção punitiva em nosso ordenamento, sem prévia cominação legal quer quanto a seus pressupostos essenciais (de ordem objetiva e subjetiva), quer quanto aos critérios para a sua quantificação, serve tão-somente para dar ensejo a arbitrariedades, proporcionando aos magistrados fixar condenações em montantes vultosos, para o quê utilizarão, implícita ou explicitamente, critérios punitivos ${ }^{615}$.

Por, a nosso ver, não existirem distinções ontológicas entre as sanções punitivas originadas do Direito Penal e aquelas derivadas de outros ramos do Direito (em especial do Direito Civil), sobressai natural que o tratamento jurídico a ser dado a estas sanções seja, ao menos quanto à necessidade de observância aos seus princípios basilares, assemelhado, o que inclui, por certo, o respeito ao princípio da legalidade das penas. Segue-

\footnotetext{
615 Em sentido semelhante, segue Marcelo Junqueira CALIXTO, que, tratando sobre a utilização da responsabilidade civil com finalidades punitiva e preventiva, afirma que "admissível será o aumento do valor da reparação, como forma de desestímulo ao ofensor, desde que haja previsão legal específica - o que não se verifica no vigente Código Civil [...]”. (A Culpa na Responsabilidade Civil (Estrutura e Função), Rio de Janeiro, Renovar, 2008, pág. 310).
} 
se, então, autorizada doutrina no sentido de que, como garantia constitucional que é, o princípio da legalidade das penas não é uma exclusividade do Direito Penal ${ }^{616}$.

Vê-se a pertinência de tal raciocínio ao se analisar, apenas a título exemplificativo, outras tantas sanções punitivas presentes em nosso ordenamento. Com efeito, nem se discute que, sem prévia cominação legal, seria inadmissível a fixação de obrigação ao pagamento de multa por infração de trânsito, a condenação do credor a restituir em dobro valores que tenham sido intencionalmente exigidos ou demandados em excesso (arts. 939 e 940, do CC/2002 e art. 42, do CDC), a perda dos direitos sobre os bens sonegados no inventário (art. 1992, do CC/2002), a imposição de multas processuais (apenas como exemplo, as contidas nos arts. 14, par. un.; 18, caput; 475-J, caput; 538, par. un.; 557, $\S 2^{\circ}$; e 601, todos do CPC), a antecipação de tutela em caso de abuso de direito de defesa (art. 273, II, do CPC) ou a restrição à interposição de outros recursos sem recolhimento da multa (arts. 538, par. ún. e 557, §2 , ambos do CPC). Há que se reconhecer, portanto, que mesmo "em matéria civil, não cabe ao juiz, por sentença, criar multas que antes não existiam"617, de modo que mesmo no que tange à fixação de indenização punitiva "não se pode prescindir de uma base legal",618.

Admitir-se que, sem prévia cominação legal, o magistrado, no âmbito cível, utilize-se de critérios punitivos para majorar o quantum indenizatório, ou, de outro lado,

\footnotetext{
${ }^{616}$ Nesse sentido, S. CARVAL afirma que "[1]e principe de légalité, élément essentiel de tout Etat de Droit, ne régit pas seulement le droit pénal. [...] La peine privèe, sanction répressive judiciaire, lui est donc soumise." (La Responsabilitè Civile Dans Sa Fonction de Peine Privée, Paris, L.G.D.J., 1995, págs. 224/225). Ainda, cfr. José Ignácio Botelho DE MESQuitA, O dano Moral na Lei de Imprensa, in Teses, Estudos e Pareceres de Processo Civil, vol. 3, São Paulo, RT, 2007, pág. 229; Carlos Roberto GonÇALVES, Comentários ao Código Civil, vol. 11, São Paulo, Saraiva, 2003, pág. 364 e Marcela Alcazas BASSAN, As Funções da Indenização por Danos Morais e a Prevenção de Danos Futuros, Dissertação (Mestrado) - Faculdade de Direito da USP, São Paulo, 2009, págs. 72/73. No que toca ao Direito Administrativo, Fábio Medina OsóRIO afirma que "[a] sanção há de ser certa e determinada, tal como ocorre com as sanções penais, e prevista em leis, sejam federais, estaduais ou municipais. [...] No Direito Administrativo Sancionador, havendo uma exigência de legalidade das infrações, o mesmo se dá em relação às sanções, que não decorrerem de um genérico poder de polícia da Administração Pública. Daí que, inegavelmente, as sanções devem obediência ao princípio da legalidade nos mesmos moldes das infrações, devendo existir um mínimo de certeza e previsibilidade em seus conteúdos descritivos". (Direito Administrativo Sancionador, $3^{\text {a }}$ ed., São Paulo, RT, 2010, pág. 257).

${ }^{617}$ José Ignácio Botelho DE Mesquita, O dano Moral na Lei de Imprensa, in Teses, Estudos e Pareceres de Processo Civil, vol. 3, São Paulo, RT, 2007, pág. 226 e Maria Celina Bodin de MorAES, Punitive Damages em Sistemas Civilistas: Problemas e Perspectivas, in Revista Trimestral de Direito Civil, vol.. 18, abr./jun. 2004, pág. 69.

${ }^{618}$ Vitor Fernandes GonÇALVES, A Punição na Responsabilidade Civil, Brasília, Brasília Jurídica, 2005, pág. 200. No mesmo sentido segue R. D. PIZARro, para quem a consagração das penas privadas em lei é uma "necessidade indispensável". (Daño Moral - Prevención, Reparación, Punición: El Daño Moral em las Diversas Ramas del Derecho, Buenos Aires, Hammurabi, 1996, pág. 399).
} 
imponha ao demandado uma condenação autônoma a título de indenização punitiva, significa, a nosso ver, violar o princípio da reserva legal ${ }^{619}$.

\section{II.II. O princípio da reparação integral ("restitutio in integrum")}

Outra consideração tecida pela doutrina em razão da inexistência de previsão legal a respeito da indenização punitiva é a de que, com o advento do Código Civil de 2002, passou a viger expressamente em nosso ordenamento o princípio da reparação integral ("restitutio in integrum"), o qual, insculpido no art. 944, caput, CC, prescreve que "[a] indenização mede-se pela extensão do dano".

Ao tratar do aludido princípio, Paulo de Tarso Vieira SANSEVERINO afirma que, ao ser utilizado para a quantificação da indenização, ele exerceria, conjuntamente, três distintas funções: (i) compensatória, no sentido de que a indenização "deve manter uma

${ }^{619}$ Humberto TheOdoro JR., Dano Moral, $4^{\mathrm{a}}$ ed., São Paulo, Juarez de Oliveira, 2001, pág. 65 e Marcius Geraldo Porto de OliveIRA, Dano Moral - Proteção Jurídica da Consciência, $2^{\mathrm{a}}$ ed., Leme, LED, 2001, pág. 60. Tal argumento foi, ademais, esposado em diversas oportunidades por nossos Tribunais. Veja-se " $A$ 'teoria do valor do desestímulo' invocada pelo reclamante e tão em voga nos meios forenses, causa preocupação porque não tem apenas a conotação que lhe é imputada, mas contornos próximos aos padrões norte-americanos dos punitive damages, incompatível com nosso sistema jurídico. A tendência moderna cogita punição (teoria do valor do desestímulo) e compensação (teoria da compensação), outorgando assim caráter punitivo à sanção pecuniária. Integrando o rol dos critérios tais teorias comportam um olhar compreensivo, o que não deve ocorrer isoladamente, porque a compensação com caráter punitivo pode esbarrar na criação de pena sem prévia cominação legal, isto porque a Constituição Federal, no artigo $5^{\circ}$, inciso $X$, preconiza: 'são invioláveis a intimidade, a vida privada, a honra e a imagem das pessoas, assegurado o direito a indenização pelo dano material ou moral decorrente de sua violação;' A hermenêutica jurídica não comporta aplicação extensiva em matéria de pena. $O$ texto constitucional estabelece que quem causa dano moral está obrigado a compensar esse dano, expressando apenas seu caráter compensatório e reparatório. Assim, essa compensação não deve ser associada a uma 'compensação punitiva' para não inovar na criação de pena sem previsão legal, instalando uma excepcionalidade não insculpida no inciso XXXIX, artigo $5^{\circ}$ da Constituição Federal, que dispõe: 'não há crime sem lei anterior

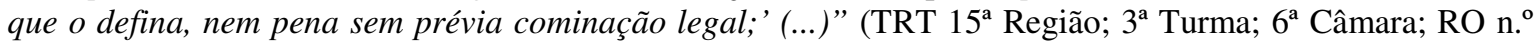
01478-2005-067-15-00-6; Relator: Juiz Samuel Hugo Lima). No mesmo sentido seguem, no âmbito do Tribunal de Justiça do Estado de São Paulo, inúmeros acórdãos da lavra do desembargador Rubens Cury. Apenas à guisa de exemplo: “O que pretende a apelante é a aplicação da 'Teoria do Valor do Desestímulo', observando-se principalmente o poder reparador do ofensor, sobretudo como forma de desestimulá-lo a promover novamente os atos ilícitos. Entretanto, nossos Tribunais têm ponderado que nosso direito difere do sistema norte americano, onde predomina a idéia de sancionamento ao lesante (punitive damages). (...) Mas em nosso país não é possível adotarmos referido sistema, até pelo princípio da legalidade das penas (art. $5^{\circ}$, XXXIX, da CF)." (TJSP; Apelação n. ${ }^{\circ}$ 1.322.018-3; Relator: Des. Rubens Cury; Julgado em 06.11.2006). Ainda: (TJSP; Apelação n. ${ }^{\circ}$ 7.002.455-0; Relator: Des. Rubens Cury; J. 16.11.2006); (TJSP; Apelação n. ${ }^{\circ}$ 1.270.465-7; Relator: Des. Rubens Cury; J. 27.07.2006); (TJSP; Apelação n. ${ }^{\circ}$ 7.005.782-4; Relator: Des. Rubens Cury; J. 30.11.2006); (TJSP; Apelação n. 3.004.747-7; Relator: Des. Rubens Cury; J. 30.11.2006); (TJSP; Apelação n. ${ }^{\circ}$ 852.960-0; Relator: Des. Rubens Cury; J. 03.12.2003) e (TJSP; Apelação n. ${ }^{\circ}$ 7.251.1745; Relator: Des. Rubens Cury; J. 22.09.2009). 
relação de equivalência, ainda que de forma aproximativa, com os danos sofridos pelo prejudicado" ${ }^{620}$, ou seja, os prejuízos suportados pela vítima são o "piso" da indenização, que não pode ser inferior a eles; (ii) indenitária, que "estabelece que a extensão dos danos constitui o limite máximo da indenização"; vale dizer: “[o]s prejuízos efetivamente sofridos pelo lesado constituem não apenas piso, mas também teto indenizatório" ${ }^{621}$; e (iii) concretizadora, que impõe ao juiz o poder-dever de realizar a "avaliação concreta dos prejuízos" sofridos pela vítima como meio necessário para o desempenho das demais funções do princípio ${ }^{622}$.

Em virtude da inexistência de prévia cominação legal, a indenização punitiva encontraria óbice na aludida função indenitária, pois que "a extensão dos danos funciona como teto indenizatório, impedindo uma indenização superior ao seu montante efetivo"623. Uma vez que a indenização punitiva representa, de qualquer maneira, a condenação do ofensor ao pagamento de uma quantia que excede os limites estritos do prejuízo suportado pelo lesado, a incidência da função indenitária do princípio da reparação integral veda expressamente sua imposição ${ }^{624}$.

Mesmo diante da previsão legal expressa insculpida no art. 944, caput, CC, Eduardo UILAN sustenta que o princípio da reparação integral não representa óbice à pronta utilização da indenização punitiva, quer porque: (i) tal princípio admitiria "inúmeras exceções legais" (tais como as cláusulas contratuais limitativas de responsabilidade, as cláusulas penais, a redução eqüitativa da indenização em razão da excessiva desproporção entre a culpa e o dano, prevista no art. 944, par. ún., CC e, ainda, a redução proporcional da indenização em virtude da "concorrência de culpas", prevista no art. 945, CC); quer,

\footnotetext{
${ }^{620}$ Princípio da Reparação Integral (Indenização no Código Civil), São Paulo, Saraiva, 2010, pág. 58.

${ }^{621}$ Princípio da Reparação Integral (Indenização no Código Civil), São Paulo, Saraiva, 2010, pág. 59.

${ }^{622}$ Princípio da Reparação Integral (Indenização no Código Civil), São Paulo, Saraiva, 2010, págs. 76/77.

${ }^{623}$ Paulo de Tarso Vieira SAnSEVERINO, Princípio da Reparação Integral (Indenização no Código Civil), São Paulo, Saraiva, 2010, pág. 74.

${ }^{624}$ Giovanni Ettore NANNI, Enriquecimento sem Causa, 2a ed., São Paulo, Saraiva, 2010, pág. 360 e Gustavo TEPEDINo - Heloísa Helena BARBozA - Maria Celina Bodin de MorAes (coords.), Código Civil Interpretado Conforme a Constituição da República, vol. II, Rio de Janeiro, Renovar, 2006, págs. 864/865. Ao tratar do tema, Antonio JUNQUEIRA DE AZEVEDo afirma que "[o] advento do novo Código Civil trouxe, pelo menos aparentemente, uma modificação no quadro anterior; introduziu regra sem correspondência no Código de 1916, o art. 944 ('A indenização mede-se pela extensão do dano') que, numa primeira leitura, impede qualquer acréscimo na indenização. Esta, segundo o artigo, somente poderá ser nos limites do dano. E o dano, dizem, é patrimonial ou moral. Logo, não seria mais possível qualquer imputação de 'punitive damages', no sentido próprio, nem como punição nem como desestímulo." (Por Uma Nova Categoria de
} 
ainda, porque (ii) a reparação integral não poderia ser admitida para quantificar a indenização decorrente de detrimentos morais $^{625}$.

Ousamos discordar de tal entendimento. Quer-nos parecer que o princípio da reparação integral deve incidir sobre todas e quaisquer indenizações (ainda que se admita o argumento de que, no âmbito da compensação por detrimentos morais, tal incidência possase dar de maneira mitigada) e seu afastamento, para o fim de majorar a indenização para além dos estritos limites da extensão dos prejuízos suportados pela vítima, somente seria admissível caso houvesse prévia e expressa cominação legal nesse sentido.

Por primeiro, a despeito de se concordar com Eduardo UILAN no sentido de que os exemplos por ele citados representam exceções ao princípio da reparação integral, discorda-se da conclusão por ele apresentada de que a existência de tais exceções poderia justificar a imediata utilização da indenização punitiva. Com efeito, das hipóteses por ele aventadas, apenas a cláusula penal comporta quantificação em patamar que supere os prejuízos efetivamente sofridos pela vítima. E assim o é em razão das expressas determinações legais de que (i) o montante não poderá exceder o "valor da obrigação principal", nada se dizendo, contudo, quanto ao valor do prejuízo sofrido (art. 412, CC); e de que (ii) o credor poderá invocar a cláusula penal ainda que não alegue prejuízo (art. 416, CC). Em todas as demais hipóteses supra cogitadas, o que se permite é o afastamento pontual do princípio da reparação integral com a finalidade precípua de reduzir o quantum indenizatório, mas nunca majorá-lo.

Por segundo, não nos parece que o princípio da reparação integral deva ser de todo afastado da quantificação da indenização por detrimentos morais. Por mais que

Dano na Responsabilidade Civil: O Dano Social, in Novos Estudos e Pareceres de Direito Privado, São Paulo, Saraiva, 2009, págs. 377/378).

${ }^{625}$ Eduardo UILAN, Responsabilidade Civil Punitiva, Tese (Doutorado) - Faculdade de Direito da USP, São Paulo, 2003, págs. 64/66. Também defendem a inaplicabilidade do princípio da reparação integral aos danos morais Judith MARTINS-Costa e Mariana Souza PARgendler (Usos e Abusos da Função Punitiva ('Punitive Damages' e o Direito Brasileiro), in Revista da Ajuris, ano XXXII, n. ${ }^{\circ} 100$, dez/2005, pág. 254) e André Gustavo Corrêa de Andrade, Dano Moral e Indenização Punitiva: Os Punitive Damages na Experiência do Common Law e na Perspectiva do Direito Brasileiro, Rio de Janeiro, Forense, 2006, págs. 279/280. Sérgio SEVERO, a despeito de não reputá-lo absolutamente inaplicável à indenização dos danos morais, afirma que o princípio da reparação integral representa, nestes casos, um "papel secundário; a partir de uma concepção no sentido de que não se trata de um princípio absoluto, pode-se adequar a satisfação à realidade fática a partir de critérios que possam assegurar a segurança jurídica e a igualdade entre os jurisdicionados." (Os Danos Extrapartimoniais, São Paulo, Saraiva, 1996, pág. 202). 
esses prejuízos não comportem equivalência pecuniária (o que torna inadmissível a utilização do critério da diferença para a caracterização do dano indenizável), o princípio da reparação integral é, sim, a eles aplicável, ainda que de maneira mitigada ${ }^{626}$.

Nesse sentido, Clayton REIS afirma que, mesmo no campo da compensação dos danos morais, "deve o ofensor entregar à vítima uma determinada importância em dinheiro equivalente ao prejuízo. É necessário que este valor exerça uma função de equivalência, sob pena de configurar lesão às partes e, ainda, contrariar a ordem constitucional, que determina seja a indenização proporcional ao agravo. Nesse particular aspecto, com a finalidade de estabelecer o princípio da equivalência, o Projeto do Código Civil brasileiro [...] inseriu um comando no seu artigo 943 [que se tornou o art. 944, caput, do CC/2002], com o seguinte teor: ‘a indenização mede-se pela extensão do dano”627.

De maneira semelhante segue Paulo de Tarso Vieira SANSEVERINO, para quem mesmo a ausência de conteúdo patrimonial dos bens lesados não impede a incidência do princípio da reparação integral na quantificação da indenização por danos morais. Das particularidades atinentes à espécie, extraem-se quatro efeitos: (i) a inadmissibilidade do tarifamento da indenização; (ii) a adoção de um tratamento razoavelmente semelhante ara prejuízos extrapatrimoniais igualmente semelhantes; (iii) a impossibilidade de que a indenização seja quantificada em desrespeito à extensão dos prejuízos (sem conteúdo econômico) suportados pela vítima, quer para representar quantia excessiva, quer, de outro lado, para representar quantia irrisória; e, por fim, (iv) a necessidade de que a indenização deva guardar "correspondência com a extensão da ofensa ao interesse lesado, conforme avaliação concreta do juiz" ${ }^{\prime 628}$.

Desta feita, o princípio da reparação integral, nos moldes previstos no art. 944, caput, do CC/2002, representa óbice à imediata utilização da indenização punitiva, óbice este que somente poderá ser ultrapassado com a prévia cominação legal das hipóteses de incidência desta sanção e dos critérios necessários para a sua mensuração.

\footnotetext{
${ }^{626}$ Nesse sentido, Sérgio Luiz JunKes, A Culpa e a Punição Não Podem Servir de Critério Para a Fixação da Indenização por Dano Moral, in Jurisprudência Catarinense, ano XXXI, n. 107, Florianópolis, 2005, pág. 230 e Carlos Roberto GonçALves, Comentários ao Código Civil, vol. 11, São Paulo, Saraiva, 2003, págs. 364/365. ${ }^{627}$ Os Novos Rumos da Indenização do Dano Moral, Rio de Janeiro, Forense, 2003, págs. 142/143.

${ }^{628}$ Princípio da Reparação Integral (Indenização no Código Civil), São Paulo, Saraiva, 2010, págs. 269/270.
} 


\section{II.III. Vedação ao enriquecimento sem causa}

Uma última crítica lançada pela doutrina contra a imediata utilização da indenização punitiva, intimamente ligada às ponderações que apresentamos acima, é a que se funda no instituto do enriquecimento sem causa (o qual, após a promulgação do Código Civil de 2002, passou a ser expressamente positivado, encontrando locus nos arts. 884 e ss., CC).

R. D. PizArro sintetiza a aludida crítica ao afirmar que "[d]iante de uma perspectiva exclusivamente ressarcitória, deve-se admitir que, como princípio, não é razoável que uma soma em dinheiro referente à indenização punitiva seja entregue à vítima (em particular, quando exceda esse rígido marco ressarcitório que apontamos anteriormente). Quem sofre um dano tem direito a ser ressarcido de maneira integral. Isto significa que o dano, qualitativa e quantitativamente, marca o limite do direito à reparação. Diante dessa idéia, todo montante superior ao dano real que componha a indenização importa em enriquecimento injusto para o ofendido e num motivo para espoliação para o responsável" ${ }^{629}$.

Os argumentos acima sintetizados são comumente abraçados pela doutrina para objetar a utilização da indenização punitiva ${ }^{630} \mathrm{e}$, recentemente, foram esposados por arestos proferidos pelo E. Superior Tribunal de Justiça, com a finalidade de rechaçar o pleito de condenação ao pagamento de indenização que, para a sua quantificação, utilizasse

\footnotetext{
${ }^{629}$ No original: “[d]esde una perspectiva netamente resarcitoria debe admitirse que, como principio, no es razonable que la suma de dinero que se manda a pagar por daño punitivo sea entregada a la víctima (em particular, cuando exceda esse restringido marco resarcitorio que apuntábamos precedentemente). Quien sofre um daño tiene derecho a ser resarcido de maneira integral. Esto importa que la entidad cualitativa y cuantitativa marcan el límite de su derecho a la reparación. Desde esse plano, todo monto superior al daño real que se mande a indemnizar importa en enriquecimiento injusto para al damnificado y um motivo de expoliación para el responsable." (Daño Moral - Prevención, Reparación, Punición: El Daño Moral em las Diversas Ramas del Derecho, Buenos Aires, Hammurabi, 1996, págs. 384/385).

${ }^{630}$ Sérgio Luiz Junkes, A Culpa e a Punição Não Podem Servir de Critério Para a Fixação da Indenização por Dano Moral, in Jurisprudência Catarinense, ano XXXI, n. 107, Florianópolis, 2005, pág. 230; Wesley de Oliveira Louzada Bernardo, Dano Moral: Critérios de Fixação de Valor, Rio de Janeiro, Renovar, 2005, pág. 177; Carlos Roberto GonçAlves, Comentários ao Código Civil, vol. 11, São Paulo, Saraiva, 2003, pág. 365; Giovanni Ettore NANNI, Enriquecimento sem Causa, $2^{a}$ ed., São Paulo, Saraiva, 2010, pág. 340 e Marcela Alcazas BASSAn, As Funções da Indenização por Danos Morais e a Prevenção de Danos Futuros, Dissertação (Mestrado) - Faculdade de Direito da USP, São Paulo, 2009, pág. 75. Clóvis Veríssimo do Couto e SILVA aponta que o óbice a que a indenização signifique um motivo de enriquecimento para o ofendido finca raízes na glosa medieval "lucratus non sit", desde a qual se impede que "através da reparação, a vítima possa ter benefícios, vale dizer, possa estar numa situação econômica melhor do que a
} 
critérios alheios à aferição da real extensão dos prejuízos sofridos. Sustentou-se, na oportunidade, que "a aplicação irrestrita das 'punitive damages' encontra óbice regulador no ordenamento jurídico pátrio que, anteriormente à entrada do Código Civil de 2002, já vedava o enriquecimento sem causa como princípio informador do direito e, após a novel codificação civilista, passou a prescrevê-la expressamente, mais especificamente, no art. 884 do Código Civil de 2002",631.

Para tanto, parte-se da premissa de que "[h]á enriquecimento ilícito [ao qual preferimos denominar "sem causa"] quando alguém, a expensas de outrem, obtêm vantagem patrimonial sem causa, isto é, sem que tal vantagem se funde em dispositivo de lei ou em negócio jurídico anterior ${ }^{\text {"632 }}$. Uma vez que a vantagem patrimonial a ser entregue à vítima tem por causa, justamente, o prejuízo causado pelo ofensor, e que a mensuração dessa vantagem patrimonial (= indenização), por força de lei, deve ser realizada dentro de estritos limites (= a "extensão do dano", ex vi do art. 944, caput, do CC/2002), diz-se que a quantificação da indenização além dos limites do prejuízo efetivamente sofrido representaria, para a vítima, a obtenção de enriquecimento sem causa, e, para o ofensor, não a atribuição de uma indenização, mas, sim, a imposição de uma pena ${ }^{633}$.

Diante desses argumentos, quer-nos parecer que dita "ausência de causa" se relaciona intimamente com o paradigma indenitário da responsabilidade civil e com a utilização (admissível, lícita, dentro dos limites constitucionalmente exigidos) da pena privada. Nesse sentido, serve-nos de premissa a afirmação de B. STARCK, para quem, “[s]e a idéia de pena privada é justa em si, torna-se evidente que o 'enriquecimento' ou o 'empobrecimento', se é que se deve empregar tais expressões, possuem uma base legal, uma causa, e, por essa razão, toda a crítica desaparece" ${ }^{\text {,634. }}$.

que se encontrava anteriormente ao ato delituoso". ( $O$ Conceito de Dano no Direito Brasileiro e Comparado, in Revista dos Tribunais, ano 80, vol. 667, mai/1991, pág. 11).

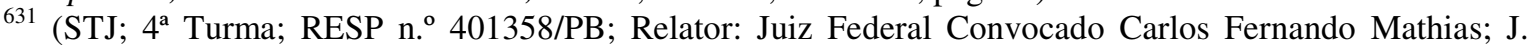
05.03.2009). Ainda: (STJ; 4 ${ }^{\mathrm{a}}$ Turma; RESP n. ${ }^{\circ}$ 210101/PR; Relator: Juiz Federal Convocado Carlos Fernando Mathias; J. 20.11.2008); (STJ; $4^{\mathrm{a}}$ Turma; RESP n. ${ }^{\circ}$ 913131/BA; Relator: Juiz Federal Convocado Carlos Fernando Mathias; J. 16.09.2008).

632 Orlando GoMEs, Obrigações, 17 ed., Rio de Janeiro, Forense, 2008, pág. 301. Prossegue o citado autor afirmando que, para a configuração do enriquecimento sem causa, "[s]ão necessários os seguintes elementos: a) o enriquecimento de alguém; b) o empobrecimento de outrem; c) o nexo de causalidade entre o enriquecimento e o empobrecimento; d) a falta de causa ou causa injusta". (op. cit., pág. 301).

${ }^{633}$ Agostinho Alvim, Da Inexecução das Obrigações e suas Conseqüências, $4^{\mathrm{a}}$ ed., São Paulo, Saraiva, 1972, pág. 181.

${ }^{634}$ No original: “[s]i l'idée de peine privée est juste en soi, il devient évident que 'l'enrichissement' ou 'l'appauvrissement', si tant est que l'on doive encore emplyer ces termes, auront une base légale, une cause, 
Aferir-se a ocorrência de enriquecimento sem causa em razão da utilização da indenização punitiva passa, a nosso ver, pela análise da "justiça" (rectius: legalidade) da imposição de tal sanção. Em sendo legal a utilização da indenização punitiva, o numerário correspondente, entregue a quem quer que seja, encontrará causa justificadora e, portanto, não dará ensejo a enriquecimento injustificado, ou sem causa.

Nessa toada, uma primeira solução nos é apresentada por André Gustavo Corrêa de ANDRADE, para quem, a sanção punitiva encontraria sua necessária legalidade na própria decisão judicial condenatória, desde que devidamente fundamentada ${ }^{635}$. O eventual enriquecimento do ofendido, portanto, encontraria sua causa na aludida decisão judicial e, remotamente, na lesão causada pelo ofensor, cujo remédio previsto é, justamente, a incidência da sanção punitiva.

Por todo o quanto expusemos, não podemos concordar com tal solução, notadamente porque, em razão da incidência do princípio da reserva legal, a indenização punitiva não poderia extrair sua legalidade da mera imposição judicial. Ao juiz, como se disse, não compete criar multas previamente inexistentes e, se assim o fizer, estará agindo arbitrariamente, violando garantias constitucionais.

Uma segunda solução, a qual julgamos adequada, é aquela aventada por Eduardo UILAN, para quem a vedação ao enriquecimento sem causa não se aplicará à quantia decorrente da utilização da indenização punitiva "desde que [sua incidência] esteja prevista e autorizada por lei. Havendo lei que lhe dê causa (justificativa) não há enriquecimento injusto" ${ }^{636}$. A prévia cominação legal, portanto, é o elemento indispensável para afastar a incidência do óbice representado pelo enriquecimento sem causa.

et toute critique disparaîtrait de ce fait". (Essai d'une Théorie Générale de la Responsabilité Civile Considèrèe em as Double Fonction de Garantie et de Peine Privèe, Paris, L. Rodstein, 1947, pág. 385).

635 Dano Moral e Indenização Punitiva: Os punitive damages na experiência do common law e na perspectiva do Direito brasileiro, Rio de Janeiro, Forense, 2006, pág. 293.

${ }^{636}$ Responsabilidade Civil Punitiva, Tese (Doutorado) - Faculdade de Direito da USP, São Paulo, 2003, pág. 68. No mesmo sentido segue Vítor Fernandes GONÇALVES, para quem "o enriquecimento do autor [da demanda indenizatória] não se amolda técnico-juridicamente à figura do enriquecimento sem causa, uma vez respeitado o princípio da legalidade [por meio da prévia cominação legal da indenização punitiva]". ( $A$ Punição na Responsabilidade Civil: A indenização do dano moral e da lesão a interesses difusos, Brasília, Brasília Jurídica, 2005, pág. 249). 
Sobre este ponto, parte da doutrina sustenta que sempre haverá enriquecimento sem causa por parte do ofendido se ele for o destinatário das quantias decorrentes da incidência da indenização punitiva. $\mathrm{O}$ enriquecimento sem causa, nesse sentido, somente seria evitado se o numerário que excedesse o suficiente para compensar os prejuízos sofridos pela vítima fosse remetido a um fundo público, a uma entidade beneficente ou a “uma pessoa jurídica, oficial ou não, desde que passível que fiscalização pelo órgão cedente do valor" 637 .

Analisando-se friamente os institutos da sanção punitiva e do enriquecimento sem causa, não nos parece ser correto referendar a ponderação acima exposta. Isso porque, como frisa, de maneira acertada, R. D. PIZARRO, "não existe obstáculo algum para que uma lei possa autorizar punições pecuniárias nos casos de cometimento de ilícitos graves, nem para que os montantes delas decorrentes sejam destinadas aos próprios ofendidos. Poder-se-á, contudo, discutir a conveniência ou inconveniência de privilegiar tal critério, mas isso é uma questão distinta" ${ }^{\text {,38. }}$.

Destinar a indenização punitiva ao ofendido ou a outra pessoa ou entidade (ou, ainda, adotar-se uma solução intermediária, com repartição das quantias entre um e outro) é apenas uma questão de política legislativa, não existindo obstáculo constitucional

\footnotetext{
${ }^{637}$ Caroline VAZ, Funções da Responsabilidade Civil - Da Reparação à Punição e Dissuasão - Os punitive damages no Direito Comparado e Brasileiro, Porto Alegre, Livraria do Advogado, 2009, pág. 84.

${ }^{638}$ No original: "[n]o existe obstáculo algun para que uma ley pueda autorizar puniciones pecuniarias en casos de graves inconductas; ni para que dichos montoss se destinen a los propios damnificados. Podrá - a lo sumodiscutirse a la conveniencia o inconveniencia de propiciar tal criterior, pero ello representa uma cuestión distinta." (Daño Moral - Prevención, Reparación, Punición: El Daño Moral em las Diversas Ramas del Derecho, Buenos Aires, Hammurabi, 1996, pág. 385). Nesse sentido, segue o art. 35, CPC, ao prescrever que "as sanções impostas às partes em consequiência da má-fé [ai incluídas não apenas a indenização pelos prejuízos decorrentes do retardo injustificado do processo, mas, também, a multa pela litigância de má-fé, prevista, e.g., no art. 18, caput, CPC, a qual é, inegavelmente, uma sanção punitiva de estrutura pecuniária, semelhante, portanto, à indenização punitiva] serão contadas como custas e reverterão em benefício da parte contrária." Ao tratar do tema, José Roberto dos Santos BEDAQUE afirma que "[i]mpostas essas sanções [decorrentes da má-fé processual], a respectiva importância pertencerá à outra parte, independentemente do resultado do processo. Não se trata de custas impostas ao sucumbente, mas a quem, voluntariamente ou não, retardou a entrega da tutela jurisdicional." (in Antônio Carlos MARCATO (coord.), Código de Processo Civil Interpretado, São Paulo, Atlas, 2003, pág. 131). Ainda sobre o tema, Helena Najjar ABDO esclarece que " $a$ regra geral é a de que o valor da multa deva reverter para a parte contrária ou para o litisconsorte", salvo exceções expressamente previstas em Lei, tais como, e.g., a multa por conttempt of court prevista no art. 14, V, do CPC, a qual, se não paga pelo litigante de má-fé, reverte em benefício da União ou do Estado (art. 14, par. ún., do CPC). (Abuso do Processo, São Paulo, RT, 2007, págs. 237/238). Nosso ordenamento, portanto, possui previsão expressa no sentido de destinar, ao ofendido, a quantia decorrente da incidência de uma sanção punitiva, não se cogitando de seu enriquecimento sem causa. Demais disso, vale lembrar que esta também é a destinação das quantias decorrentes da incidência dos arts. 939 e 940, do CC/2002.
} 
ou legal para que seja adotada uma ou outra solução ${ }^{639}$. Acredita-se, contudo e como já se teve a oportunidade de frisar, que a opção pela remessa das quantias a um fundo público é a que propicia, de maneira mais eficiente e adequada, a utilização da indenização punitiva.

Há que se frisar, contudo, que, qualquer que seja a opção adotada, ela não prescinde da prévia e expressa cominação legal da indenização punitiva. Se não houver prévia cominação legal da sanção punitiva, a condenação do ofensor e a conseqüente destinação da quantia a alguém (quem quer que seja) sempre acarretará enriquecimento sem causa, quer do ofendido (se for ele o beneficiado) quer do gestor do fundo público ou privado, ou do estabelecimento beneficente ao qual for destinada a quantia. Haverá, mesmo nestas últimas hipóteses, enriquecimento de um e empobrecimento de outro, sem causa justificadora.

${ }^{639}$ R. D. PiZArro, Daño Moral - Prevención, Reparación, Punición: El Daño Moral em las Diversas Ramas del Derecho, Buenos Aires, Hammurabi, 1996, pág. 395. 


\section{CAPÍTULO IV - INTRODUÇÃO DA INDENIZAÇÃO PUNITIVA NO ORDENAMENTO JURÍDICO BRASILEIRO}

Da análise traçada nos capítulos antecedentes, procurou-se extrair, essencialmente, duas conclusões: (i) a de que a adoção da indenização punitiva é medida verdadeiramente imprescindível para que o instituto da responsabilidade civil possa exercer, adequadamente, suas funções de punição e prevenção; e a de que (ii) para que se possa adotar tal sanção punitiva nos ordenamentos de países de raiz romano-germânica (rol no qual se insere o Brasil), é indispensável a prévia e expressa cominação legal nesse sentido. Diante de tal previsão legislativa, todos os demais obstáculos levantados pela doutrina e jurisprudência à utilização da indenização punitiva caem por terra.

Ultrapassadas as questões a respeito da viabilidade da adoção da indenização punitiva, procuraremos tratar, no presente capítulo e naquele que lhe segue, de todos os aspectos pertinentes ao regramento de tal instituto, para que ele possa ser moldado de modo a melhor perseguir os fins de punição de condutas reprováveis e prevenção de prejuízos.

Iniciaremos tal tarefa no presente capítulo, no qual analisaremos, em primeiro lugar, com qual grau de severidade a introdução legislativa da indenização punitiva deverá obedecer ao princípio da taxatividade das penas (admitir-se-á a previsão de uma cláusula geral como aquela insculpida nos arts. 186 e 927, do CC/2002?). Na sequiência, passaremos a tratar sobre as linhas gerais de incidência da indenização punitiva (quais são, essencialmente, os direitos e interesses que se procura tutelar por meio da admissão de tal sanção punitiva?) para, logo após, tratarmos, de maneira mais pormenorizada, dos pressupostos objetivos e subjetivos para a aplicação de tal sanção punitiva (em que hipóteses, exatamente, o ofensor deverá se submeter a tão grave sancionamento?). Ao final, procuraremos abranger todas aquelas questões, quer de ordem material, quer, ainda, de ordem processual que nos pareceram relevantes para a definição das linhas mestras da indenização punitiva. 


\section{A NECESSIDADE DE PRÉVIA COMINAÇÃo LEGAL}

De tudo o quanto já se expôs, vê-se que, quer em razão do princípio constitucional da reserva legal (princípio da legalidade), quer em razão da função indenitária do princípio da reparação integral, quer, ainda, em razão da vedação ao enriquecimento sem causa, é inadmissível a utilização da indenização punitiva sem a prévia cominação legal. Este é, portanto, o pressuposto essencial para a introdução de tal sanção punitiva em nosso ordenamento, sem o qual o recurso à pena privada (quer por meio da imposição de uma quantia adicional à indenização compensatória, com fins punitivos e dissuasórios, quer, ainda, pela quantificação da indenização compensatória com fundamento em critérios alheios à quantificação do prejuízo) será ilegal e, em última instância, inconstitucional.

Fixada tal premissa, põe-se, no presente momento, outro questionamento, que lhe é logicamente posterior: em que grau de intensidade as sanções punitivas de Direito Privado devem observar o princípio da legalidade?

Em resposta a tal questionamento, a posição mais rígida apresentada pela doutrina é aquela que exige, para que se possa reputar constitucional a incidência da indenização punitiva, não apenas a prévia cominação legal da existência de tal sanção, mas, também, e em atenção ao rígido princípio da taxatividade, de todas as hipóteses objetivas em que tal sanção poderia ser aplicada ${ }^{640}$. Nesse sentido, Maria Celina Bodin de MORAES sustenta que, tal qual uma verdadeira pena criminal, para que se possa prever a aplicação da indenização punitiva em nosso ordenamento, de modo a privilegiar a dita lógica do razoável, "parece imprescindível que se atribua caráter punitivo apenas a hipóteses taxativamente previstas em lei" ${ }^{\prime 641}$.

\footnotetext{
${ }^{640}$ Sobre o princípio da taxatividade, um desdobramento do princípio da reserva legal, Guilherme de Souza NuCCI afirma que "[t]axativo significa limitativo, restritivo, apertado ou estreito. [...] Se inexiste crime sem prévia definição legal, nem pena sem anterior cominação em lei, torna-se essencial garantir a eficiência do preceito delimitador da responsabilidade penal, demandando-se do Poder Legislativo a correta redação dos tipos incriminadores. [...] A taxatividade dos tipos penais tem a finalidade de aclarar o objetivo de cada figur criminosa, permitindo a exata captação do sentido dos modelos. Com isso, estabelece-se a relação de confiança entre o Estado e o indivíduo, tornando-se seguro o contorno entre o ilícito penal e o extrapenal." (Princípios Constitucionais Penais e Processuais Penais, São Paulo, RT, 2010, pág. 188).

${ }^{641}$ Punitive Damages em Sistemas Civilistas: Problemas e Perspectivas, in Revista Trimestral de Direito Civil, vol.. 18, abr./jun. 2004, pág. 76.
} 
Tal concepção extremamente severa quanto à aplicação prática da indenização punitiva é devidamente mitigada pela doutrina, que sugere que, fora do âmbito estritamente penal, a observância do princípio da legalidade (a despeito de necessária) pode-se dar de maneira mais branda, sendo desnecessária a previsão, em rol taxativo, de tipos fechados sancionáveis por meio da imposição de uma sanção punitiva ${ }^{642}$. No que toca especificamente à indenização punitiva, sustenta-se a desnecessidade de obediência ao princípio da taxatividade por, ao menos, duas ordens de fatores: (i) a uma, porque a idéia de "engessamento" da responsabilidade civil a hipóteses típicas, previstas expressa e taxativamente pelo ordenamento, é contrária aos princípios iluminadores do instituto; (ii) a duas, porque uma tal restrição contraria os fins aos quais se destina a indenização punitiva.

Por primeiro, sustenta a doutrina que o sistema de responsabilidade civil previsto em nosso ordenamento é caracterizado por uma cláusula geral de responsabilidade, composta pelos artigos 186, 187 e 927, todos do Código Civil. Tal cláusula geral expressaria verdadeiro "princípio da atipicidade do ilícito" civil ${ }^{643}$, do que se extrai, como característica, sua flexibilidade, necessária principalmente porque se destina ao regramento de situações complexas, à proteção de bens jurídicos sujeitos a constante evolução e mutação. Se assim não fosse, acarretar-se-ia o verdadeiro "engessamento" do instituto da responsabilidade civil, prejudicando o desempenho de suas funções ${ }^{644}$.

Diante desta maior flexibilidade, admite-se, para as sanções punitivas típicas do Direito Civil, uma certa atenuação do princípio da taxatividade, não se exigindo os extremos rigores típicos do Direito Penal ${ }^{645}$. Desta feita, em vez de se impor a obediência a

\footnotetext{
${ }^{642}$ Nesse sentido, S. CARVAL afirma que “[e]st-ce à dire qu'elle doive, à l'instar de la sanction pénale, n'être infligée qu'à l'ocassion d'une faute civile dons le contenu serait précisément défini par un texte? Nous ne le pensons pas. Il y a, en effet, plusieurs degrés possibles dans l'application du principe de légalité [...]". (La Responsabilitè Civile Dans Sa Fonction de Peine Privée, Paris, L.G.D.J., 1995, pág. 225).

643 Judith MARTIns-COSTA - Mariana Souza PARGENDLER, Usos e Abusos da Função Punitiva ('Punitive Damages' e o Direito Brasileiro), in Revista da Ajuris, ano XXXII, n. ${ }^{\circ}$ 100, dez/2005, pág. 251.

644 Nas incisivas palavras de Caroline VAZ, em assim o fazendo, "a responsabilidade civil ficaria condicionada à vigência de uma espécie de Código de Ilícitos Civis, no qual se descreveriam, em abstrato e por sistematização articulada, o tipos causadores de danos individuais ou coletivos, o que contrariaria a própria estrutura do Direito Civil brasileiro, além das decorrências desses danos, ou seja, as sanções por tais danos" (Funções da Responsabilidade Civil - Da Reparação à Punição e Dissuasão - Os punitive damages no Direito Comparado e Brasileiro, Porto Alegre, Livraria do Advogado, 2009, págs. 129/130).

${ }^{645}$ Vitor Fernandes GonÇALVES, A Punição na Responsabilidade Civil: A indenização do dano moral e da lesão a interesses difusos, Brasília, Brasília Jurídica, 2005, pág. 203 e Antonio JUNQUEIRA DE AZEVEDO, Por Uma Nova Categoria de Dano na Responsabilidade Civil: O Dano Social, in Novos Estudos e Pareceres de Direito Privado, São Paulo, Saraiva, 2009, pág. 379. A maior flexibilidade, a demandar uma mitigação do princípio da taxatividade, não é exclusiva do Direito Civil. Fábio Medina OsóRIO, tratando sobre o Direito
} 
tipos fechados, permite-se o recurso a "válvulas de escape" como os tipos abertos e cláusulas gerais, recursos estes, ademais, que, em certo grau, são inclusive utilizados pelo Direito Penal em determinadas hipóteses ${ }^{646}$.

Por segundo, tendo-se a indenização punitiva como um instituto também destinado à proteção dos direitos da personalidade e, mais amplamente, à proteção da dignidade da pessoa humana, vê-se que tal fim não poderia ser integral e devidamente perseguido dentro de um contexto de tipificação de condutas, de restrição das hipóteses em que tal instituto poderia incidir" ${ }^{647}$. "Deve ser lembrado que a multiplicidade $e$ complexidade das relações estabelecidas no convívio social são tamanhas que não seria possível enumerar previamente, com taxatividade descritiva, todas as condutas omissivas ou comissivas revestidas de potencial suficiente ao cometimento de ilícito hábil à geração de dano moral, da obrigação de indenizar e ainda punir elou dissuadir" ${ }^{\circ 48}$; de modo que admitir-se a indenização punitiva sob a restrição do atendimento ao princípio da taxatividade é, verdadeiramente, "podar as asas" do instituto, prevendo, de antemão, sua completa ineficácia.

\footnotetext{
Administrativo, afirma que "os tipos do Direito Administrativo Sancionador são, em regra, mais elásticos que os tipos penais, dada a utilização da dinâmica própria do terreno administrativo e a permanente inspiração dos interesses públicos e gerais a orientar a feitura e aplicação das normas. As leis administrativas mudam com grande rapidez, tendem a proteger bens jurídicos mais expostos à velocidade dos acontecimentos e transformações sociais, econômicas, culturais, de modo que o Direito Administrativo Sancionador acompanha essa realidade e é, por natureza, mais dinâmico que o Direito Penal, cuja estabilidade normativa já resulta da própria estrita competência da União Federal. [...] Nesse passo, a legalidade das infrações e das sanções é composta, no mais das vezes, por conceitos ou termos jurídicos altamente indeterminados, cláusulas gerais, princípios e descrição de valores superiores que outorgam amplos espaços à autoridade julgadora, seja ela administrativa ou judicial." (Direito Administrativo Sancionador, $3^{\text {a }}$ ed., São Paulo, RT, 2010, pág. 208).

${ }^{646}$ Guilherme de Souza NUCCI afirma que, em determinadas circunstâncias, quando se exige uma maior flexibilidade na redação dos tipos penais, permite-se o recurso a "tipos penais abertos" ou, ainda, a "normas penais em branco" (as quais demandam, para a sua complementação, o recurso a um apêndice descritivo). (Princípios Constitucionais Penais e Processuais Penais, São Paulo, RT, 2010, pág. 189).

${ }^{647}$ Nesse sentido, Gustavo TEPEDINO afirma que "no campo das relações privadas, a técnica regulamentar, pela qual se pretende tipificar os direitos da personalidade, mostra-se avessa à proteção dos direitos humanos, pois que incapaz de abranger as inúmeras e mutantes hipóteses em que se exige a intervenção judicial em favor da pessoa. A proteção constitucional da pessoa humana supera a setorização da tutela jurídica (a partir da distinção entre os direitos humanos, no âmbito do direito público, e os chamados direitos da personalidade, na órbita do direito privado) bem como a tipificação de situações previamente estipuladas, nas quais pudesse incidir o ordenamento." (A Incorporação dos Direitos Fundamentais pelo Ordenamento Brasileiro: Sua Eficácia nas Relações Jurídicas Privadas, in Temas de Direito Civil, vol. III, Rio de Janeiro, Renovar, 2009, pág. 63).

${ }^{648}$ Caroline VAZ, Funções da Responsabilidade Civil - Da Reparação à Punição e Dissuasão - Os punitive damages no Direito Comparado e Brasileiro, Porto Alegre, Livraria do Advogado, 2009, págs. 129/130.
} 
Ancorados nesses fundamentos, propugnam os defensores da adoção da indenização punitiva que, para que se torne lícita a atribuição de uma função punitiva à indenização, basta que sejam previstos, em termos gerais, seus pressupostos de incidência, distintos daqueles usualmente exigidos para a incidência da responsabilidade civil com fins compensatórios (sem que, para tanto, seja necessária a prévia definição de tipos fechados) ${ }^{649}$. Ao apreciar os fatos atinentes ao caso concreto, é admissível que o magistrado, decida, de maneira fundamentada, pela aplicação da sanção legalmente prevista.

Nessa toada, conclui-se que os atos sancionáveis por meio da indenização punitiva, segundo Eduardo UILAN e S. CARVAL, devem consistir da violação de obrigações previamente definidas em lei ${ }^{650}$. A previsão legal de tal obrigação, assim sustenta a professora francesa, deve ser suficientemente definida para permitir que o responsável possa a ela se conformar, admitindo-se, contudo, para o desempenho desse mister, o recurso a expressões mais genéricas do que aquelas usualmente utilizadas pelo legislador penal ${ }^{651}$.

\section{A INCIDÊNCIA DA INDENIZAÇ̃̃o PUNITIVA}

Por tudo o quanto se expôs até o momento, pôde-se verificar que a incidência da indenização punitiva deve-se dar de maneira excepcional, em atenção a critérios específicos, e sempre voltada à persecução dos fins e escopos aos quais tantas vezes se aludiu no presente trabalho. Vale dizer: somente se justifica a adoção de uma sanção jurídica como a indenização punitiva se sua utilização se destinar apenas à tutela dos bens e interesses da mais alta relevância (já anteriormente anunciados como os interesses existenciais e os metaindividuais) e à manutenção do equilíbrio social [garantindo, dessa maneira, a segurança social (art. $5^{\circ}$, caput, da CF/88) e o desenvolvimento de uma "sociedade livre, justa e solidária" (art. $\left.\left.3^{\circ}, \mathrm{I}, \mathrm{da} \mathrm{CF} / 88\right)\right]^{652}$.

\footnotetext{
${ }^{649}$ Eduardo UILAN, Responsabilidade Civil Punitiva, Tese (Doutorado) - Faculdade de Direito da USP, São Paulo, 2003, pág. 75.

${ }^{650}$ Responsabilidade Civil Punitiva, Tese (Doutorado) - Faculdade de Direito da USP, São Paulo, 2003, pág. 75 e La Responsabilitè Civile Dans Sa Fonction de Peine Privée, Paris, L.G.D.J., 1995, pág. 226.

${ }^{651}$ La Responsabilitè Civile Dans Sa Fonction de Peine Privée, Paris, L.G.D.J., 1995, pág. 226.

${ }^{652}$ Nesse sentido, bem sintetiza P. GALlo que "i danni punitivi assumano l'aspetto di un istituto posto a tutela di valori considerati superiori; valori che cioè si vuole escludere possano essere mercificati e ridotti a meri dati contabili [...]." (Pene Private e Responsabilità Civile, Milano, Giuffrè, 1996, pág. 168).
} 
Mais do que isso, a tutela desses interesses deverá ser feita por meio da indenização punitiva (a qual atuará sempre em conjunto com a indenização compensatória e, se o caso, com quaisquer outras técnicas processuais de tutela inibitória ou ressarcitória) apenas quando sua lesão for resultado direto de condutas do mais alto grau de reprovabilidade, marcadas pela intencionalidade do agente (que direcionou conscientemente sua atividade com o fim de desrespeitar a Lei, assumindo o risco de, dessa maneira, provocar prejuízos; ou, o que é ainda pior, direcionou conscientemente sua atividade com o fim específico de causar prejuízos, quer pelo sádico desejo de causar o mal ao ofendido, quer, ainda, pela ânsia de auferir vantagens econômicas em decorrência do ilícito perpetrado) ou por sua irresponsável desconsideração pelos direitos alheios (conduta esta que, ainda que não se repute intencional, é, no mínimo, marcada pela culpa grave $)^{653}$.

A justificativa para a incidência, nas hipóteses acima enumeradas, de uma sanção mais gravosa do que a indenização meramente compensatória, decorre da concepção de que, em determinadas circunstâncias, o ato ilícito perpetrado contra um dado ofendido é tão grosseiramente reprovável, e atinge a bens e interesses de tão alta relevância, que, de um modo ou de outro, acaba extrapolando os limites da órbita jurídica do lesado (ou, ainda, da própria coletividade, quando se está diante de lesão a interesses metaindividuais) para atingir, de maneira depreciativa, toda a sociedade.

Está-se, aqui, diante da figura que o professor Antonio JUNQUEIRA DE AZEVEDO denominou de "dano social", caracterizada, pelo citado autor, quanto afirma que "um ato, se doloso ou gravemente culposo, ou se negativamente exemplar, não é lesivo somente ao patrimônio material ou moral da vítima, mas sim, atinge a toda a sociedade, num rebaixamento imediato do nível de vida da população. Causa dano social"654. As

\footnotetext{
${ }^{653}$ É importante que se frise que, no presente trabalho, a utilização que se pretende ver emprestada à indenização punitiva é excepcional. Ou seja, acredita-se que a indenização punitiva somente deve atuar como instrumento jurídico para a tutela dos direitos e interesses existenciais e metaindividuais, ou, ainda, para a tutela do equilíbrio social, nas hipóteses em que a indenização compensatória (instrumento ordinariamente destinado a fazê-lo) não incide de maneira suficiente. Tais hipóteses, como se quer acreditar, são somente aquelas em que as condutas do ofensor são imbuídas de intencionalidade (que pode ser tanto a de apenas agir em desconformidade com a Lei quanto a mais severa, de agir ilicitamente e causar prejuízo), ou de grave desconsideração pelos direitos alheios. Dessas condutas, sobressaem em importância, pelo altíssimo grau de reprovabilidade que lhes é ínsito, as condutas insufladas pelo desejo de obter vantagens econômicas ilicitamente (i.e., de auferir lucro como resultado de uma atividade ilegal).

${ }^{654}$ Por Uma Nova Categoria de Dano na Responsabilidade Civil: O Dano Social, in Novos Estudos e Pareceres de Direito Privado, São Paulo, Saraiva, 2009, págs. 380/381.
} 
idéias, aqui esposadas, são a de que a sociedade sustenta seu ponto de equilíbrio sobre uma série de valores inafastáveis, tais como a preservação da integridade psico-física do homem e o respeito à palavra dada, e a de que o cometimento de atos ilícitos intencionais (ou gravemente culposos) que atinjam esses valores afeta não apenas a vítima individualmente considerada, mas, também, toda a sociedade, com o conseqüente "rebaixamento do nível de vida da população" (passa-se a ter uma sociedade conivente com o cometimento de danos à pessoa, ou com o descumprimento reiterado das obrigações assumidas) ${ }^{655}$.

Nessas hipóteses, os atos ilícitos dolosos ou gravemente culposos, bem como os prejuízos deles decorrentes, ainda que direcionados a uma vítima em particular, passam a ser "socialmente relevantes", ostentando, ao mesmo tempo, uma "dimensão individual" e outra "comunitária". Ao se prever a incidência da indenização punitiva apenas para essas hipóteses (nas quais se verifica a ocorrência de "dano socialmente relevante"), permite-se que tal sanção busque não apenas defender "a dignidade do indivíduo" diretamente lesado, mas, também, proteger "as normas de conduta da sociedade, influenciando o comportamento dos agentes" psico-física do homem, ou desrespeitar, com fins lucrativos, a palavra dada) ${ }^{657}$. Assim se exigirá da indenização punitiva porque, na medida em que extrapola os limites da órbita jurídica individual do lesado, e atinge a toda a sociedade, a conduta ilícita deixa de poder ser adequadamente sancionada apenas por meio da incidência de um remédio ressarcitório (o qual, se corretamente quantificado, poderá restabelecer o equilíbrio individual afetado pelo ilícito, recompondo, se possível, o patrimônio da vítima), devendo passar a comportar um plus que o permita acalentar, igualmente, o equilíbrio social afetado pelo ato ilícito.

\footnotetext{
${ }^{655}$ Antonio JunqueIRA De Azevedo, Por Uma Nova Categoria de Dano na Responsabilidade Civil: O Dano Social, in Novos Estudos e Pareceres de Direito Privado, São Paulo, Saraiva, 2009, págs. 381/382.

${ }^{656}$ P. M. Lourenço, A Função Punitiva da Responsabilidade Civil, Coimbra, Coimbra, 2006, págs. 190/191. 657 Também é esta a posição adotada por Caroline VAZ, para a qual "a análise para a aplicação das prestações punitivas e dissuasórias [nomenclatura atribuída pela autora ao que aqui se prefere denominar de indenização punitiva] deve ser de um dano que atinja a toda a coletividade, dada a gravidade da conduta do lesante, bem como a extensão do prejuízo." (Funções da Responsabilidade Civil - Da Reparação à Punição e Dissuasão - Os punitive damages no Direito Comparado e Brasileiro, Porto Alegre, Livraria do Advogado, 2009, págs. 122/123). Em sentido muito semelhante, João Carlos de LIMA, ao tratar especificamente do dano pessoal no âmbito do direito do trabalho, afirma que "ademais, restaria inócuo que em determinadas circunstâncias - dada a gravidade do ato lesivo - admita-se que apenas o trabalhador experimenta um sofrimento, um abalo reparável. Com efeito, também a sociedade é lesada (na ótica do desprestígio dos valores intrínsecos das relações profissionais consideradas em abstrato) o que sugere ir além da indenização/compensação do trabalhador para impor-se, também, uma reparação/compensação a ser revertida à sociedade”. (O Caráter Punitivo da Indenização por Danos Pessoais e a Reversibilidade da Cominação para o FAT, in Revista de Direito do Trabalho, ano 30, vol. 115, São Paulo, RT, jul./set. 2004, págs. 82/83).
} 
Vê-se, enfim, que a incidência da indenização punitiva, como aqui se propugna, deve-se dar de maneira excepcional, apenas para sancionar as condutas capazes de causar danos "socialmente relevantes", os quais impõem não apenas uma diminuição patrimonial à vítima, mas, também, "uma diminuição do índice de qualidade de vida da população" ${ }^{, 658}$.

Desta feita, entende-se que a indenização punitiva deverá ser utilizada para sancionar os ilícitos civis dotados do mais alto grau de reprovabilidade (cujos agentes devem ter obrado de maneira intencional ou gravemente culposa, com irresponsável desconsideração quanto aos direitos alheios) e que tenham lesado direitos ou interesses da mais alta relevância (a saber: os interesses existenciais e os metaindividuais) ou, ainda, servido de instrumento para a obtenção ilícita de vantagens econômicas ${ }^{659}$ (ainda que, nesse caso, os prejuízos decorrentes do ilícito sejam de natureza patrimonial).

\section{PRessupostos DE ORDEM OBJETIVA}

Uma vez traçadas as linhas gerais para a incidência da indenização punitiva, cumpre-nos perquirir sobre quais pressupostos devem obrigatoriamente estar presentes para que uma determinada conduta ilícita, causadora de prejuízos, venha a merecer tal

\footnotetext{
${ }^{658}$ Antonio JunQueIRA DE AZEVEDo, Por Uma Nova Categoria de Dano na Responsabilidade Civil: O Dano Social, in Novos Estudos e Pareceres de Direito Privado, São Paulo, Saraiva, 2009, pág. 382. A incidência excepcional da indenização punitiva é admitida até mesmo por Maria Celina Bodin de MoRAES, a qual, a despeito de se mostrar refratária à idéia de majoração da indenização para fins punitivos, confessa admitir "como exceção, uma figura semelhante a do punitive damages, em sua função de exemplaridade, quando for imperioso dar uma resposta à sociedade, isto é, à consciência social, tratando-se, por exemplo, de conduta particularmente ultrajante, ou insultosa, em relação à consciência coletiva, ou, ainda, quando se der o caso, não incomum, de prática reiterada. É de aceitar-se, ainda, um valor a mais na reparação do dano extrapatrimonial para situações potencialmente causadoras de lesões a um grande número de pessoas, como ocorre nos direitos difusos e coletivos, tanto na relação de consumo, quanto no direito ambiental'. (Punitive Damages em Sistemas Civilistas: Problemas e Perspectivas, in Revista Trimestral de Direito Civil, vol. 18, Rio de Janeiro, Padma, abr./jun. 2004, pág. 77).

${ }^{659}$ Nesse sentido, M. G. BARATELLA também admite a incidência da sanção punitiva nos casos em que existe "ilícito sem dano" (hipótese na qual a autora se refere a atos ilícitos sem dano patrimonial, como, por ex., nos casos de cometimento de prejuízos extrapatrimoniais), ou nos quais os danos impostos são irrisórios em relação aos benefícios econômicos ("introiti") decorrentes do cometimento do ilícito. (Le Pene Private, Milano, Giuffrè, 2006, págs. 214). Sobre a incidência da indenização punitiva nas hipóteses de "ilícito lucrativo" (nas quais o ofensor extrai benefícios econômicos do ilícito por ele cometido), cfr. P. GALLO, Pene Private e Responsabilità Civile, Milano, Giuffrè, 1996, págs. 177/178.
} 
sorte de sancionamento, hipótese na qual se mostraria insuficiente a condenação do ofensor ao pagamento de indenização meramente compensatória.

Nesse mister, passar-se-á a tratar inicialmente dos pressupostos de ordem objetiva, ou seja, daqueles que não dizem respeito, propriamente, ao "estado de espírito" do ofensor, que tornam o ato ilícito por ele cometido especialmente reprovável. Assim, partindo do quadro comparativo que já se desenhou quando analisamos o regime jurídico de sanção punitiva semelhante à que ora se propõe introduzir em nosso ordenamento, propõe-se responder a dois questionamentos: (i) se a indenização punitiva deve-se restringir apenas ao âmbito da responsabilidade civil extracontratual, excluindo-se-lhe, portanto, da responsabilidade contratual; e (1i) se a indenização punitiva pode incidir inclusive nas hipóteses em que do ato ilícito cometido não resultam efetivos prejuízos.

\section{III.I. Ilícito extracontratual ou inadimplemento contratual}

Como acima se expôs (em capítulo destinado à análise do regramento jurídico dos punitive damages), em razão das características particulares do sistema de responsabilidade civil dos países pertencentes à raiz da common law, não se admite, em regra, que o cometimento de um ilícito contratual (breach of contract) venha a ser sancionado por meio do pagamento de indenização punitiva (punitive ou exemplary damages), a não ser que o aludido inadimplemento venha acompanhado de uma conduta fraudulenta ou de algum outro ato intencional, abusivo ou grosseiramente negligente que se caracterize, por si só, como um ilícito aquiliano (tradução que, aqui, reiteradas as ressalvas anteriormente expostas, empresta-se à expressão tort), de modo a se aceitar, apenas em hipóteses excepcionais, a incidência dos punitive damages ${ }^{660}$.

\footnotetext{
${ }^{660}$ L. P. SIMPSON, Punitive Damages for Breach of Contract, in Ohio State Law Journal, vol. 20, 1959, pág. 284. Em razão da necessidade de concomitância entre o ilícito contratual e o, por assim dizer, ilícito extracontratual para justificar a incidência dos punitive damages, a doutrina especializada aponta três hipóteses mais comuns em que o descumprimento de um dever assumido contratualmente pode também dar ensejo à condenação do ofensor ao pagamento de indenização punitiva: (i) o rompimento de noivado; (ii) a cessação injustificada da prestação de determinado serviço público, ordinariamente prestado por uma empresa concessionária; e, ainda, (iii) o inadimplemento que, além de representar o descumprimento de uma obrigação contratual, implica a infração a um "dever fiduciário", ou "de confiança", tal como a negativa ao pagamento da indenização devida ao segurado. Sobre o tema, cfr., como já antecipado, M. M. Belli Sr., Punitive Damages: Their History, Their Use and Their Worth in Present-Day Society, in UMKC Law Review, vol. 49, n. 1, 1980, págs. 16/17 e C. CALLEROS, Punitive Damages, Liquidated Damages and Clauses Pènales in Contract Actions: A Comparative Analysis
} 
Diante de tal modelo normativo, questiona-se se, assim como os punitive damages, também a indenização punitiva deverá incidir apenas nas hipóteses em que se puder verificar o cometimento de um ilícito extracontratual, ou se, do contrário, admitir-seá sua aplicação mesmo em resposta ao descumprimento de obrigações contratuais.

Quer-nos parecer, e aqui já adiantamos nossa conclusão, que, no que toca à possibilidade de incidência da indenização punitiva, não se deve admitir uma distinção estanque entre as duas modalidades de responsabilidade civil [a saber: a responsabilidade extracontratual ou aquiliana (ou, ainda, como prefere Fernando NorONHA, "responsabilidade civil em sentido estrito" ou geral) e a responsabilidade contratual (ou, novamente adotando a nomenclatura sugerida pelo supra referido autor, "responsabilidade negocial") ${ }^{661}$ ], sendo de rigor a aplicação das linhas gerais expostas no tópico anterior para que se admita a condenação do ofensor ao pagamento de indenização agravada quer os prejuízos tenham resultado do descumprimento de cláusulas previstas em um negócio jurídico previamente entabulado entre as partes, quer não.

Por primeiro, há que se ver que, mesmo no que concerne a seu regramento geral (sem que se cogite, ainda, da incidência ou não da indenização punitiva), não se admite uma aplicação isolada de uma ou outra modalidade de responsabilidade civil, uma ve que se verifique estar diante de uma relação negocial prévia, ou não. Entende-se que, especialmente em razão de seu escopo comum, as modalidades de responsabilidade civil se aproximam uma da outra, interpenetrando-se em diversas oportunidades ${ }^{662}$.

of the American Common Law and the French Civil Code, in Brooklyn Journal of International Law, vol. 32, 2006, págs. 71/73.

${ }^{661}$ Direito das Obrigações, vol. I, $2^{\mathrm{a}}$ ed., São Paulo, Saraiva, 2007, págs. 427/432.

${ }^{662}$ Nesse sentido, Silvio de Salvo VENOSA afirma que "[a] doutrina moderna, sob certos aspectos, aproxima as duas modalidades [de responsabilidade civil, a contratual e a extracontratual]", para concluir que tais modalidades "com freqüência se interpenetram e ontologicamente não são distintas: quem transgride um dever de conduta, com ou sem contrato, pode ser obrigado a ressarcir o dano". (Direito Civil, vol. IV, $3^{\mathrm{a}}$ ed., São Paulo, Atlas, 2003, pág. 21). Semelhantemente, Fernando NORONHA afirma que, no que toca às suas finalidades precípuas, as duas modalidades de responsabilidade "têm muito em comum, ambas têm por finalidade reparar um dano, tanto quanto possível restaurando a situação objetiva que existia anteriormente ao fato lesivo (responsabilidade civil), ou que deveria existir se o negócio jurídico tivesse sido devidamente cumprido (responsabilidade negocial)". (Direito das Obrigações, vol. I, $2^{a}$ ed., São Paulo, Saraiva, 2007, pág. 500). Ainda, partindo, contudo, de outro enfoque, André Gustavo Corrêa de ANDRADE afirma que "[a] doutrina, na verdade, acusa uma tendência, se não ao desaparecimento, de relativização da tradicional divisão da responsabilidade civil em contratual e extracontratual., a partir da constatação de que os contratos cada vez. mais retiram sua força da vontade das partes, em razão da crescente interferência do direito positivo nas relações jurídicas. $O$ emprego disseminado dos contratos de adesão na sociedade de consumo coloca em xeque 
A uma, pode-se verificar a assim chamada "interpenetração" nas hipóteses em que, a despeito da existência (in fieri ou efetiva) de um negócio jurídico (a ser ou já) entabulado entre as partes, surgem prejuízos em decorrência de circunstâncias não submetidas ao regramento negocial, quer porque antes da conclusão do negócio, quer porque após sua conclusão e cumprimento. Nesse sentido, Fernando NoRONHA afirma que "[m]esmo quando tivermos um contrato, será a responsabilidade civil geral [extracontratual ou aquiliana] a regular": (1) "os danos acontecidos na fase das negociações preliminares (responsabilidade pré-contratual)”; e, ainda, (ii) “os que possam acontecer após o integral cumprimento das obrigações assumidas (responsabilidade pós-contratual)"663.

A duas, também se verifica tal "interpenetração" nas hipóteses em que o descumprimento de uma obrigação contratual vem acompanhado da violação à "obrigação de segurança" (= respeito à incolumidade psico-física do homem), a qual, nas palavras de Antonio JUNQUEIRA DE AZEVEDO, encontra-se atualmente "descontratualizada" e deve ser observada ainda que não se esteja diante de uma relação negocial previamente estabelecida $^{664}$. Assim, quando do descumprimento contratual decorrerem lesões a "bens indisponíveis, como na hipótese de danos corpóreos [em violação, portanto, à "obrigação de segurança"], haverá incidência exclusiva das regras da responsabilidade civil em sentido estrito [extracontratual ou aquiliana]"665.

Por segundo, também é certo que o fenômeno da "expansão dos prejuízos passíveis de reparação" resultou na compreensão (admitida tanto em sede doutrinária quanto jurisprudencial) de que mesmo os interesses e direitos existenciais e metaindividuais podem vir a ser atingidos como resultado do descumprimento de uma obrigação contratual ${ }^{666}$; a qual se entende não acarretar apenas prejuízos meramente patrimoniais, a serem suportados exclusivamente pelo credor diretamente lesado.

o princípio da autonomia da vontade e retira a razão de ser da summa divisio da responsabilidade civil". (Dano Moral e Indenização Punitiva: Os punitive damages na experiência do common law e na perspectiva do Direito brasileiro, Rio de Janeiro, Forense, 2006, pág. 96).

${ }^{663}$ Direito das Obrigações, vol. I, $2^{\text {a }}$ ed., São Paulo, Saraiva, 2007, pág. 441.

664 Por Uma Nova Categoria de Dano na Responsabilidade Civil: O Dano Social, in Novos Estudos e Pareceres de Direito Privado, São Paulo, Saraiva, 2009, pág. 381.

${ }^{665}$ Fernando Noronha, Direito das Obrigações, vol. I, $2^{\text {a }}$ ed., São Paulo, Saraiva, 2007, pág. 502.

${ }^{666}$ Sobre o tema, cfr. André Gustavo Corrêa de ANDRADE, Dano Moral e Indenização Punitiva: Os punitive damages na experiência do common law e na perspectiva do Direito brasileiro, Rio de Janeiro, Forense, 
É possível, portanto, que do descumprimento do prazo para a conclusão das obras de um determinado edifício resultem prejuízos extrapatrimoniais (= decorrentes de lesão a interesse existencial) de grande extensão para os adquirentes, que viram frustrado o sonho da casa própria ${ }^{667}$. Da mesma maneira, é igualmente possível que o descumprimento da obrigação de cautela do transportador (prescrita pelo art. 749, do CC/2002) cause prejuízos que extrapolem, e muito, o âmbito do patrimônio do credor, vindo a atingir a toda uma extensa coletividade, como ocorreria, por ex., se o transportador de petróleo causasse, por negligência, um vazamento do líquido em determinada baía marítima.

Quanto ao tema, é interessante notar que as mesmas circunstâncias tidas pelos tribunais norte-americanos como aptas a ensejar, excepcionalmente, a incidência de punitive damages em decorrência de ilícitos contratuais (breaches of contract) são também consideradas pela jurisprudência nacional como suficientes para acarretar a condenação do responsável ao pagamento de indenização por danos morais ${ }^{668}$, a despeito de tal condenação também ser, de ordinário, rechaçada quando se está diante de mero inadimplemento contratual ${ }^{669}$.

2006, págs. 91/104 e R. D. PIZARro, Daño Moral - Prevención, Reparación, Punición: El Daño Moral em las Diversas Ramas del Derecho, Buenos Aires, Hammurabi, 1996, págs. 143/168.

667 “Compromisso de compra e venda. Indenização por danos materiais e morais. Atraso na entrega da unidade. Não cumprimento dos prazos estipulados em contrato. Obras não entregues pela construtora. [...] dano moral configurado. Desgaste emocional e sofrimento provocado pela frustração da legítima expectativa de construção da casa própria. [...] Recurso da autora parcialmente provido, improvido o da construtora ré." (TJSP; 8 a Câm. de Direito Privado; Apelação 994.05.042093-1; Relator: Des. Joaquim Garcia; J. 11.05.2010).

${ }^{668}$ Como se vê, de modo semelhante ao que ocorre na jurisprudência norte-americana, nossos tribunais admitem a condenação do responsável ao pagamento de danos morais em razão: (i) do rompimento do noivado (TJRS; $5^{\mathrm{a}}$ Câm. Cível; Apelação 70027032440; Relator: Des. Jorge Luiz Lopes do Canto; J. 21.01.2009); (ii) da indevida interrupção na prestação de serviços públicos, como, por ex., o de forncecimento de energia elétrica (STJ; $2^{\mathrm{a}}$ T.; RESP 960.259/RJ; Relator: Min. Castro Meira; J. 06.09.2007); e, por fim, (iii) do descumprimento de um "dever fiduciário", como, por ex., a negativa de pagamento da indenização decorrente de contrato de seguro. (STJ; $4^{\mathrm{a}}$ T.; RESP 811.617/AL; Relator: Min. Jorge Scartezzini; J. 21.11.2006) e (STJ; $3^{\mathrm{a}}$ T.; AgRg no AIDDRESP 1.100.359/MT; Relator: Des. Convocado Vasco Della Giustina; J. 23.11.2010).

${ }^{669}$ Nesse sentido, por todos: "PROCESSUAL CIVIL. [...] DESCUMPRIMENTO CONTRATUAL. DANO MORAL. INADMISSIBILIDADE. AGRAVO IMPROVIDO. I. [...] II. [...] III. 'O inadimplemento de contrato, por si só, não acarreta dano moral, que pressupõe ofensa anormal à personalidade. É certo que a indobservância de cláusulas contratuais pode gerar frustração na parte inocente, mas não se apresenta como suficiente para produzir dano na esfera íntima do indivíduo, até porque o descumprimento de obrigações contratuais não é de todo imprevisível' (Resp n. 876.527/RJ, Rel. Min. João Otávio de Noronha, DJ 28.4.2008). IV. Agravo improvido." (STJ; 4 ${ }^{\mathrm{a}} \mathrm{T}$.; AgRg no Ag Rg no AIDDRESP 1.033.070/RS; Relator: Min. Aldir Passarinho Jr.; J. 16.09.2010). 
Por terceiro, também há que se verificar que, assim como acontece em situações nas quais as partes não possuem relação negocial prévia, a quebra do contrato (ou o descumprimento de uma obrigação assumida em negócio jurídico unilateral) pode ser motivada pelo ilícito objetivo de se auferir vantagens econômicas, celebrando-se, por ex., novo contrato com valores mais expressivos do que o anterior. Nessas hipóteses, mesmo que o devedor inadimplente viesse a ser condenado ao pagamento de indenização compensatória pelos prejuízos impostos ao credor prejudicado (aí abarcados os danos emergentes e os lucros cessantes), "a inexecução da obrigação poderia se traduzir em um benefício [econômico] superior ao prejuízo"670, motivando-o, portanto, de desrespeitar a palavra dada e descumprir o contrato. Era o que se sucedia, e com bastante freqüência, na celebração de contratos para a aquisição de imóveis urbanos antes do advento do Decreto Lei 58/1937, que desenvolveu a figura do compromisso de venda e compra e outorgou ao compromissário comprador o direito de exigir o cumprimento específico do contrato ainda que este não houvesse sido instrumentalizado por escritura pública (em previsão que afastou o regramento originalmente decorrente do art. 1088, do CC/1916, que autorizava qualquer das partes a, nessas hipóteses, arrepender-se do negócio antes da assinatura da escritura definitiva, apenas pagando à outra "os danos decorrentes do arrependimento") ${ }^{671}$.

Fixadas essas premissas, acredita-se que, nos exatos moldes acima anunciados, a indenização punitiva também deve ser utilizada para sancionar os casos de descumprimento contratual que sejam caracterizados por um alto grau de reprovabilidade (tendo o inadimplente obrado de maneira intencional ou gravemente culposa, com irresponsável desconsideração quanto aos direitos alheios ${ }^{672}$ e que tenham lesado direitos

\footnotetext{
${ }^{670}$ No original: "[En matière contractuelle], l'inexécution de l'obligation peut se traduire par un bénéfice supérieur au domage." (B. STARCK, Essai d'une Théorie Générale de la Responsabilité Civile Considèrèe em as Double Fonction de Garantie et de Peine Privèe, Paris, L. Rodstein, 1947, pág. 417).

${ }^{671}$ Há de se notar que, nas hipóteses em que é possível, exigir o cumprimento específico da obrigação contratualmente assumida exerce um potente escopo preventivo. Nesse sentido, cfr. C. CALLEROS, Punitive Damages, Liquidated Damages and Clauses Pènales in Contract Actions: A Comparative Analysis of the American Common Law and the French Civil Code, in Brooklyn Journal of International Law, vol. 32, 2006, pág. 97. Acredita-se que, da mesma maneira que defendemos a aplicação conjunta da indenização punitiva com as modalidades de tutela inibitória no que toca à responsabilidade civil extracontratual, o escopo preventivo do Direito será perseguido com maior eficiência caso se admita a incidência concomitante, quando assim se fizer necessário, de todas as formas de tutela possíveis, como a incidência de indenização punitiva, de indenização compensatória e, ainda, se o caso, a exigência de tutela específica da obrigação contratualmente assumida.

${ }^{672}$ Nesse sentido, ao advogar pela incidência de punitive damages mesmo em hipóteses de descumprimento contratual, C. CALLEROS afirma que "[i]f a reckless or deliberate breach of contract does more than disappoint the expectations of the other party, and if it constitutes a moral wrong or otherwise injures the public by offending community values, then the breaching party may deserve to be punished [...]." (Punitive Damages,
} 
ou interesses da mais alta relevância (a saber: os interesses existenciais e os metaindividuais) ou, ainda, servido de veículo para a obtenção ilícita de vantagens econômicas $^{673}$ (ainda que, nesse caso, os prejuízos decorrentes do descumprimento sejam de natureza patrimonial).

Por derradeiro, vale ressaltar que a indenização punitiva deverá incidir nas hipóteses acima indicadas mesmo que as partes contratantes tenham convencionado a existência de cláusula penal, e mesmo que esta cláusula não conte com a possibilidade de que a parte prejudicada possa exigir indenização suplementar (art. 416, par. ún., do $\mathrm{CC} / 2002)^{674}$.

\section{III.II. Ocorrência de prejuízo}

Já se teve a oportunidade de expor (em capítulo destinado à análise do regramento jurídico dos punitive damages) que, em razão das características particulares do sistema de responsabilidade civil dos países pertencentes à raiz da common law, admitese, em circunstâncias excepcionais, a condenação do ofensor ao pagamento de punitive damages ainda que o ofendido não tenha alegado ou comprovado a ocorrência de efetivo

Liquidated Damages and Clauses Pènales in Contract Actions: A Comparative Analysis of the American Common Law and the French Civil Code, in Brooklyn Journal of International Law, vol. 32, 2006, pág. 80).

${ }^{673}$ Assim também segue a orientação de B. STARCK, para o qual, no âmbito da responsabilidade contratual, "[s]i l'indemnité est calquée sur le préjudice, le débiteur défaillant conservera encore un avantage. Accepter cette solution, c'est donner une prime à la déloyauté, ruiner la sanction des obligations, compromettre la valeur du principe pacta sunt servanda." (Essai d'une Théorie Générale de la Responsabilité Civile Considèrèe em as Double Fonction de Garantie et de Peine Privèe, Paris, L. Rodstein, 1947, pág. 417)

${ }^{674}$ As razões para tanto são várias. Por primeiro, como bem anota Nelson RoSENVALD, "[a] regra geral de limitação do direito ao valor da pena, com exclusão do direito a indenização suplementar pelas regras comuns, aplica-se somente às hipóteses em que o devedor seja responsável por culpa leve”. (Cláusula Penal (A Pena Privada nas Relações Negociais), Rio de Janeiro, Lumen Juris, 2007, pág. 136). Inadmissível, portanto, que o devedor se escude atrás de uma cláusula penal mal fixada para se eximir das responsabilidades decorrentes do descumprimento doloso ou gravemente culposo. Por segundo, o mesmo Nelson ROSENVALD afirma, a nosso ver com correção, ser "plenamente possível a cumulação da cláusula penal - [que seja] restrita aos danos patrimoniais - com o recurso a ação de reparação pelos danos extrapatrimoniais que não foram ajustados em convenção" e que, porventura, tenham decorrido do descumprimento do contrato. (op. cit., pág. 72). Assim, tendo o devedor deixado de dar cumprimento ao contrato de maneira intencional ou gravemente culposa e, desse descumprimento, resultado prejuízos a interesses existenciais ou metaindividuais, incidirá a indenização punitiva em adição à cláusula penal, mesmo que a pena haja sido convencionada sem a ressalva estabelecida pelo art. 416, par. ún., do CC/2002. O mesmo ocorrerá, pelo que aqui se defende, se, do descumprimento intencional ou gravemente culposo, resultar benefício econômico ao devedor que supere o valor da cláusula penal previamente estipulada. Nesse caso, também incidirá a indenização punitiva, com o escopo de retirar do devedor a integralidade das vantagens econômicas por ele auferidas em razão do descumprimento contratual. 
prejuízo. Isso poderá ocorrer caso se esteja diante do cometimento de um ato ilícito (tort) que seja "dedutível per se" ("actionable per se"), i.e., um ato ilícito do qual nasça uma pretensão indenizatória legítima independentemente da ocorrência de prejuízo (como o são, por ex., os torts de "trespass to land", “assault", "false imprisonment" e "libel") 675.

Diante de tal conformação legal, questiona-se se, assim como os punitive damages, também a indenização punitiva poderá incidir mesmo em circunstâncias nas quais não se alegue ou demonstre a ocorrência de prejuízo. Vale dizer: pode um determinado ofendido pretender a condenação do ofensor ao pagamento de indenização punitiva se este último houver cometido um ato ilícito que, ainda que intencional ou gravemente culposo, não tenha causado prejuízo efetivo, quer patrimonial, quer extrapatrimonial? $?^{676}$

Em resposta a tal questionamento, e na linha do quanto já se expôs no presente trabalho, acredita-se que a indenização punitiva deva ser um instrumento submetido ao regramento comum do instituto da responsabilidade civil, que não pode se esquivar dos requisitos mínimos previstos para a sua atuação, entre os quais se encontram, em se tratando de responsabilidade subjetiva: ato ilícito, culpabilidade, nexo de causalidade e, essencialmente, dano (ex vi dos arts. 188 e 927, do CC/2002) ${ }^{677}$.

A indenização punitiva, portanto, somente poderá ser pretendida pelo ofendido em uma demanda acessória, subordinada ao sucesso da demanda principal consubstanciada na pretensão de condenação do ofensor ao pagamento de indenização compensatória. Uma vez que, para a dedução da demanda principal é verdadeiramente indispensável a ocorrência de efetivo prejuízo, não se pode concluir diferentemente quanto

\footnotetext{
${ }^{675}$ Sobre o tema, cfr. S. DEAKIN - A. JOHNSTON - B. MARKESINIS, Markesinis and Deakin's Tort Law, $6^{\text {th }}$ ed., New York, Oxford, 2008, pág. 940.

${ }^{676}$ Ainda que sem invocar, como fundamento, o regramento jurídico dos punitive damages, esta é a posição adotada por Caroline VAZ, para quem "pode ocorrer o reconhecimento da imposição de um valor a título de caráter punitivo ou preventivo, embora não se reconheçam as indenizações por danos materiais ou morais, já que as objetividades jurídicas são diferentes". (Funções da Responsabilidade Civil - Da Reparação à Punição e Dissuasão - Os punitive damages no Direito Comparado e Brasileiro, Porto Alegre, Livraria do Advogado, 2009, pág. 142).

677 A despeito de não se poder confundir a ilicitude da conduta com os prejuízos dela potencialmente decorrentes, vale lembrar, como o faz Clayton REIS, que "a ilicitude somente exercerá uma função determinante se restar demonstrada a existência de um dano, sendo este o elemento central da responsabilidade civil [...]". (Os Novos Rumos da Indenização do Dano Moral, Rio de Janeiro, Forense, 2003, pág. 220).
} 
à indenização punitiva ${ }^{678}$. Em suma: só incidirá a indenização punitiva em hipóteses excepcionais nas quais também incide a indenização compensatória, e só incidirá a indenização compensatória se houver a adequada alegação e cabal comprovação da ocorrência de danos. Sem dano, não existe indenização punitiva.

Ultrapassado tal ponto, a ele se sucede um outro questionamento: se é verdade que a condenação do ofensor ao pagamento de indenização punitiva somente é autorizada diante da ocorrência de prejuízo, é correto afirmar que tal prejuízo deve ser, necessariamente, de natureza extrapatrimonial ${ }^{679}$; ou, pelo contrário, é admissível que um determinado ofensor seja condenado ao pagamento de indenização punitiva ainda que os prejuízos decorrentes do ato ilícito por ele perpetrado sejam de natureza exclusivamente material (= monetizável)?

Afigura-se-nos que a ocorrência de prejuízos extrapatrimoniais (quer decorram de lesão a interesses existenciais, quer de interesses metaindividuais) em razão do cometimento de um ato ilícito de alto grau de reprovabilidade (intencional ou gravemente culposo) é uma das hipóteses nas quais com maior justiça se dará a incidência da indenização punitiva. Tratase, como se expôs, de interesses e direitos da mais alta relevância, e de prejuízos de difícil (senão impossível) recomposição.

A despeito da relevância dos interesses tutelados, não nos parece ser esta a única hipótese na qual se tornaria interessante a imposição de indenização punitiva. Pelo contrário, há inúmeros casos nos quais, ainda que os prejuízos decorrentes do ilícito sejam

678 André Gustavo Corrêa de ANDRADE, Dano Moral e Indenização Punitiva: Os punitive damages na
experiência do common law e na perspectiva do Direito brasileiro, Rio de Janeiro, Forense, 2006, pág. 278 .
679 Parace ser esta a posição adotada por Enoque Ribeiro dos SANTOS, em trecho no qual o referido autor
recomenda "fortemente a aplicação dos princípios do exemplary and punitive damages, que se amolda à
teoria sancionatória, [mas apenas] nos casos concretos que tramitam em grande quantidade em nossos
Pretórios, de forma a aumentar o sentimento de prevenção e de maior cuidado quando se trata de manejo de
direitos extrapatrimoniais." (Contribuições à Fixação da Indenização do Dano Moral Trabalhista-A tese
da aplicação dos exemplary ou punitive damages, in Suplemento Trabalhista, ano 40, vol. 90, 2004, pág.
400 ). Tal posicionamento restritivo, limitando a incidência da indenização punitiva à tutela dos danos
extrapatrimoniais foi também referendado por recente aresto proferido pelo E. TJRJ, no qual se lê:“[d]efinido
o dever de indenizar, necessário se faz a análise apurada dos pedidos formulados na inicial. Conforme
consta dos autos, a autora é beneficiária de pensionamento, não exercendo, pois, qualquer atividade
remunerada, de modo que eventual condenação da ré ao pagamento de pensão por incapacidade total
temporária acabaria por desvirtuar o sistema da reparação de danos materiais, eis que, a pretexto de
indenizar eventuais lucros cessantes ou danos emergentes, estar-se-ia, ao revés, utilizando tal expediente
para infligir punição não autorizada ao causador do dano, sendo certo que a autora não deixou de receber
sua pensão e, portanto, não teve qualquer perda material. Eventuais efeitos punitivos (os chamados punitive
damages) devem ser fixados em momento adequado, ou seja, quando da fixação do dano moral e não na 
de cunho exclusivamente patrimonial, os reflexos negativos impostos à sociedade são severos a ponto de acarretar um "rebaixamento imediato do nível de vida da população" $^{\text {680 }}$, justificando a condenação do ofensor ao pagamento de indenização cujo valor venha a superar os estritos limites do prejuízo causado à vítima.

Esse é o caso, como acima já se adiantou, dos atos ilícitos de que resultam benefícios econômicos para o ofensor, os quais, por vezes, superam em importância os prejuízos efetivamente causados ao ofendido. Nessas hipóteses, nas quais a imposição de indenização meramente compensatória não exerce eficientemente o escopo de prevenir a ocorrência de atos ilícitos (vez que se torna economicamente mais vantajoso ao ofensor cometer o ilícito e pagar a indenização correspondente do que evitar que o prejuízo seja cometido), é de rigor a incidência da indenização punitiva (sanção esta que deverá ser quantificada de modo a retirar, do ofensor, todos os benefícios econômicos auferidos), mesmo que os prejuízos impostos à vítima sejam de cunho meramente patrimonial; sob pena de, não o fazendo, sinalizar-se à sociedade que o respeito à Lei é apenas uma questão de custo-benefício.

Nesse sentido, Eduardo UILAN afirma que, para justificar a condenação do ofensor ao pagamento de indenização punitiva, os casos de ilícito lucrativo "não distingue [m] se os danos-prejuízos resultantes da conduta [ilícita] são ou não monetizáveis" ${ }^{681}$; ou seja: sempre que o ofensor auferir vantagens econômicas como resultado de um ato ilícito intencional ou gravemente culposo, ele deverá ser condenado ao pagamento de indenização punitiva, mesmo se os prejuízos decorrentes de sua conduta ilícita sejam exclusivamente materiais ${ }^{682}$.

Vale frisar, por derradeiro, que, se é certo que nem toda condenação ao pagamento de indenização punitiva deve-se dar no âmbito da indenização por danos morais (porque é possível que os pressupostos objetivos e subjetivos exigidos para a sua

reparação de supostos danos materiais [...]." (TJRJ; Apelação n. ${ }^{\circ}$ 2009.001.56835; Relatora: Des. Maria Augusta Vaz M. de Figueiredo; J. 08.10.2009).

${ }^{680}$ Antonio JunQueIRA De AZEVEdo, Por Uma Nova Categoria de Dano na Responsabilidade Civil: O Dano Social, in Novos Estudos e Pareceres de Direito Privado, São Paulo, Saraiva, 2009, págs. 380/381.

${ }_{681}^{6}$ Responsabilidade Civil Punitiva, Tese (Doutorado) - Faculdade de Direito da USP, São Paulo, 2003, pág. 78.

${ }^{682}$ Posição assemelhada é aquela esposada por André Gustavo Corrêa de ANDRADE, para o qual "uma teoria da indenização punitiva [...] não tem que ser necessariamente relacionada com o dano moral. Não há, a priori, razão para excluir essa forma de sanção como resposta para o dano material." (Dano Moral e Indenização Punitiva: Os punitive damages na experiência do common law e na perspectiva do Direito brasileiro, Rio de Janeiro, Forense, 2006, pág. 278). 
incidência se encontrem presentes em outras circunstâncias), é igualmente correto afirmar que, ao contrário do quanto defendido por parte da doutrina nacional, nem toda condenação ao pagamento de indenização por danos morais deve-se revestir de caráter punitivo. Essa é a conclusão que se extrai da análise do desenvolvimento observado nos países da common law quanto à reparação dos danos extrapatrimoniais (denominados de “non pecuniary losses"): desde idos do século XIX, passou-se a admitir que os prejuízos, a despeito de imateriais (= não monetizáveis), compunham o conceito de indenização compensatória (compensatory damages). Realizou-se, nesse ponto, uma cisão entre as funções a serem exercidas por cada uma das sanções: a indenização compensatória passou a apenas reparar os prejuízos suportados pela vítima (aí incluídos os de natureza imaterial), enquanto que a indenização punitiva passou a exercer, diretamente, escopos de punição e prevenção (permitindo-se sua incidência mesmo nas hipóteses em que o dano decorrente do ato ilícito é exclusivamente material ou, ainda, quando nem ao menos há que se falar em dano efetivo) ${ }^{683}$.

Assim, "quando a lesão ao interesse protegido, dano-evento, vier causada por culpa simples, não é cabível a repressão do agente lesante com a sanção punitiva", mesmo se o dano-prejuízo dela decorrente for de natureza extrapatrimonial. "Nesse caso, ou se utiliza um método de quantificação do dano-prejuízo com base em valores prefixados em escalonamento legal ou se arbitra o valor sem tomar em consideração elementos que tenham por finalidade a punição do causador do dano" ${ }^{684}$.

\footnotetext{
${ }^{683}$ Em razão da separação entre tais finalidades [de compensação, desempenhada pelos compensatory damages (os quais abarcam também os prejuízos imateriais) e de punição, desempenhada pelos punitive damages (que podem incidir mesmo quando se fala apenas em danos materiais)], Marcela Alcazas BASSAN sustenta que "essa estreita relação entre dano moral e a punição por meio da indenização construiu-se [em nossa doutrina pátria] à custa de artificialismos. Com efeito", sustenta a autora, "no sistema da Common Law, do qual provêm os punitive damages, essa conexão entre os danos morais e os punitive damages foi desfeita há muito tempo"; para concluir, na sequiência, que "não existe, no âmbito da Common Law, a função punitiva da indenização por danos morais, tal qual defende parte da doutrina nacional." (As Funções da Indenização por Danos Morais e a Prevenção de Danos Futuros, Dissertação (Mestrado) - Faculdade de Direito da USP, São Paulo, 2009, págs. 67/68).

${ }^{684}$ Eduardo UILAN, Responsabilidade Civil Punitiva, Tese (Doutorado) - Faculdade de Direito da USP, São Paulo, 2003, pág. 77.
} 


\section{Pressupostos DE ORDEM SUbJETIVA}

Ultrapassada a análise a respeito dos pressupostos objetivos para a incidência da indenização punitiva, atinentes tanto à conduta ilícita quanto ao prejuízo dela decorrente, procuraremos tratar, deste momento em diante, dos aspectos de ordem subjetiva comumente aventados pela doutrina como imprescindíveis para a imposição da supra referida sanção. $\mathrm{O}$ argumento, rotineiramente invocado, é o de que "uma vez que o propósito dos danos punitivos não é a compensação do autor, mas a punição e intimidação do réu, estes danos deverão ser atribuídos apenas para condutas para as quais este remédio é apropriado, isto é, condutas que envolvam elementos de transgressão, similares aos encontrados no crime ${ }^{, 685}$.

Nesse sentido, para serem merecedoras desse sancionamento excepcional, as condutas do ofensor devem ser dotadas do mais alto grau de reprovabilidade civil ${ }^{686}$, ou seja, devem ser cometidas de modo que os prejuízos delas decorrentes extrapolem o âmbito individual, tornando-se "socialmente relevantes". Exige-se, portanto, e à guisa do que ocorre com os punitive damages, um determinado "estado de espírito" ("state of mind") por parte do ofensor, que deve ter obrado com intenção de descumprir a Lei (característica do dolo) ou, no mínimo, com uma grosseira desconsideração para com os direitos alheios (característica da culpa grave) $)^{687}$.

Caso assim não fosse (e, do contrário, admitisse-se a aplicação de sanção punitiva em resposta a condutas meramente negligentes, sem a exigência da especial reprovabilidade), correr-se-ia o risco de causar "os fenômenos indesejáveis de hiper-

\footnotetext{
${ }^{685}$ P. C. M. Guimarães, Os Danos Punitivos e a Função Punitiva da Responsabilidade Civil, in Revista de Direito e Justiça, vol. XV, t. 1, 2001, pág. 169.

${ }^{686}$ R. D. Pizarro, Daño Moral - Prevención, Reparación, Punición: El Daño Moral em las Diversas Ramas del Derecho, Buenos Aires, Hammurabi, 1996, pág. 383.

${ }^{687}$ P. C. M. Guimarães, Os Danos Punitivos e a Função Punitiva da Responsabilidade Civil, in Revista de Direito e Justiça, vol. XV, t. 1, 2001, pág. 169. Nas palavras de Antonio JUNQUEIRA DE AZEVEDO, as quais aqui se esposa, justifica-se a incidência de um sancionamento mais severo nessas hipóteses porque " $a$ tolerância para com o dolo e para com o descumprimento da palavra (seria alterum laedere e suum cuique non tribuere, tudo ao contrário do que deveria ser) são os piores males para uma sociedade. Em resumo, é preciso repor, quer num caso, por punição, quer noutro, por dissuasão, o que foi tirado da sociedade. $O$ dano social se apresenta aqui nas duas vertentes: merece punição e acréscimo dissuasório, ou didático." (Por Uma Nova Categoria de Dano na Responsabilidade Civil: O Dano Social, in Novos Estudos e Pareceres de Direito Privado, São Paulo, Saraiva, 2009, pág. 382). Ainda, André Gustavo Corrêa de
} 
prevenção e supercompensação" ${ }^{\text {688 }}$, desestimulando de maneira inadequada a realização de atividades lícitas e o desenvolvimento da livre iniciativa (um dos fundamentos da República Federativa do Brasil e cujo valor social é reconhecido expressamente pelo art. $1^{\mathrm{o}}$, IV, da CF/88); bem como de diluir da própria noção de pena privada, que deixaria de atuar eficientemente como meio de moralização das condutas especialmente reprováveis ${ }^{689}$.

\section{IV.I. O dolo e a culpa grave}

De todos os assim chamados "estados de espírito" ("states of mind") aptos a ensejar a incidência da indenização punitiva, aquele que nos vem imediatamente à mente é justamente o dolo, reputado por J. M. ANTUNES VARELA como "a modalidade mais grave da culpa, aquela em que a conduta do agente, pela mais estreita identificação estabelecida entre a vontade deste e o facto, se torma mais fortemente censurável" ${ }^{\prime 690}$.

O citado autor justifica o alto grau de reprovabilidade do dolo ao the atribuir, ao mesmo tempo, um elemento volitivo (ou emocional) e um elemento intelectual, ambos servindo de liame entre a vontade ou consciência do ofensor e o fato ilícito por ele perpetrado. Ao agir dolosamente, o agente quis atingir um determinado resultado (elemento volitivo), ou, a despeito de saber que tal resultado era uma decorrência provável de sua conduta, com ele não se importou o suficiente a ponto de mudar ou impedir seu curso de ação (elemento emocional); e assim se conduziu, de uma ou de outra maneira, plenamente consciente "das circunstâncias de fato que integram a violação do direito ou da norma tuteladora de interesses alheios", bem como da "ilicitude do facto" (elemento intelectual) ${ }^{691}$.

ANDRADE, Dano Moral e Indenização Punitiva: Os punitive damages na experiência do common law e na perspectiva do Direito brasileiro, Rio de Janeiro, Forense, 2006, pág. 282.

688 Judith Martins-Costa - Mariana Souza PARgendler, Usos e Abusos da Função Punitiva ('Punitive Damages' e o Direito Brasileiro), in Revista da Ajuris, ano XXXII, n. ${ }^{\circ} 100$, dez/2005, pág. 256. No mesmo sentido, P. Gallo, Pene Private e Responsabilità Civile, Milano, Giuffrè, 1996, pág. 180.

${ }^{689}$ S. Carval, La Responsabilitè Civile Dans Sa Fonction de Peine Privée, Paris, L.G.D.J., 1995, pág. 332.

${ }^{690}$ Das Obrigações em Geral, vol. I, 10ª ed., Coimbra, Almedina, 2000, pág. 569.

691 J. M. Antunes VARELA, Das Obrigações em Geral, vol. I, 10 ed., Coimbra, Almedina, 2000, págs. 569/572. O trecho transcrito está especificamente em J. M. ANTUNES VARELA, op. cit., pág. 572. 
De maneira geral, a doutrina admite uma bipartição do conceito de dolo, tomando-o sob o aspecto de dolo direto (oportunidade na qual o ofensor quer cometer o resultado ilícito) ou de dolo indireto, ou eventual (oportunidade na qual o ofensor, embora efetivamente não deseje cometer o resultado ilícito, tem consciência de sua provável ocorrência e, mesmo assim, conduz-se de modo a potencialmente causá-lo, assumindo, portanto, o risco de fazê-lo) ${ }^{692}$. A distinção entre as duas modalidades encontra previsão legal expressa no art. 18, I, do CP, que prescreve ser doloso tanto o crime cometido "quando o agente quis o resultado", quanto quando ele apenas "assumiu o risco de produzi-lo".

Vê-se, assim, que a conduta dolosa é especialmente reprovável por se direcionar conscientemente para o cometimento de um resultado ilícito, quer tenha o ofensor efetivamente desejado sua ocorrência (característica do dolo direto, que é ainda mais gravoso), quer tenha ele apenas assumido conscientemente o risco de sua ocorrência (característica do dolo indireto, menos gravoso, mas ainda assim particularmente reprovável e socialmente indesejado). Não é preciso, portanto, que o ofensor deseje cometer o mal, basta que se tenha conduzido de maneira consciente, direcionando sua conduta de modo a potencialmente causar tal prejuízo, cujos riscos de ocorrência eram previamente conhecidos e assumidos ${ }^{693}$.

À luz do regramento jurídico atribuído ao instituto dos punitive damages (e renovada a ressalva a respeito dos diversos tratamentos jurídicos possíveis, em razão do regime federalista típico dos Estados Unidos da América), a doutrina favorável à introdução da indenização punitiva nos países da civil law admite a incidência de tal sanção punitiva não apenas nas hipóteses de cometimento intencional do ilícito (dolo), mas, também, naquelas em que se verifica uma grosseira desconsideração para com os direitos alheios (culpa grave).

\footnotetext{
${ }^{692}$ Marcelo Junqueira CALIXTO, A Culpa na Responsabilidade Civil (Estrutura e Função), Rio de Janeiro, Renovar, 2008, pág. 110. A essas duas modalidades, J. M. ANTUNES VARELA adiciona ainda uma terceira, a qual denomina de dolo necessário. Nessa circunstância, o ofensor, embora não querendo diretamente cometer o ato ilícito, sabe ser ele consequiência necessária, certa, segura, de sua conduta, o que, contudo, não o impede de agir. Segundo o citado autor, a distinção entre tal figura e o dolo indireto decorreria do fato de que, nesta última, existe um risco, uma potencialidade, de o evento danoso ocorrer, enquanto que na primeira (o dolo necessário), o evento danoso necessariamente ocorrerá. Inexiste risco: existe certeza. (Das Obrigações em Geral, vol. I, 10ª ed., Coimbra, Almedina, 2000, págs. 570).

693 Agostinho AlviM, Da Inexecução das Obrigações e suas Conseqüências, $4^{\mathrm{a}}$ ed., São Paulo, Saraiva, 1972, pág. 256.
} 
Nesse ponto, reputa-se de especial importância a ressalva efetuada por Eduardo UILAN, o qual, ao tratar do tema, pondera que, a despeito de não encontrar unicidade em sede doutrinária ou jurisprudencial, o conceito de culpa grave pode não ser a melhor tradução para a expressão "recklessness", usualmente referida pela doutrina dos países da common law para justificar a incidência da indenização punitiva ${ }^{694}$. Isso se dá porque, como acima já asseveramos, o conceito de "temeridade" ("recklessness") envolve necessariamente um aspecto de consciência por parte do ofensor, que "prevê, mas não deseja, o resultado causado, que não é por ele considerado como inevitável"695; assemelhando-se à figura que denominamos de culpa consciente ${ }^{696}$, e não à de culpa grave.

A despeito das divergências doutrinárias, em geral a culpa grave não é restrita à hipótese de culpa consciente ${ }^{697}$, admitindo-se sua ocorrência mesmo nos casos em que "o agente não chega sequer, por imprudência, descuido, imperícia ou inaptidão, a conceber a possibilidade de o facto se verificar", a despeito de poder e dever "prevê-lo e evitar a sua verificação, se usasse da diligência devida" ${ }^{698}$. Nesse sentido, verifica-se a culpa grave também no "erro de conduta grosseiro", na "incapacidade de perceber o que a imensa maioria dos seres humanos perceberia. Avizinha-se da culpa consciente dos penalistas" ${ }^{\circ 99}$, mas com ela certamente não se confunde ${ }^{700}$.

${ }^{694}$ Responsabilidade Civil Punitiva, Tese (Doutorado) - Faculdade de Direito da USP, São Paulo, 2003, págs. 82/83. No que toca aos pressupostos subjetivos exigidos para a incidência dos punitive damages, interessante síntese se verifica em trecho do julgamento de Bottrill v. A (3 NZLR 662 2001), no qual a Court of Appeal neozelandeza ponderou a necessidade de uma conduta consciente por parte do agente, afirmando que "the remedy of exemplary damages should be confined to cases where the defendant was subjectly aware of the risk to which his or her conduct exposed the plaintiff and acted deliberately or recklessly in taking that risk." (S. TODD, A New Zeland Perspective on Exemplary Damages, in Common Law World Review, vol. 33, 2004, pág. 261).

${ }^{695}$ No original: "the actor foresees, but does not desire, a particular result that is not regarded as inevitable”. (S. DEAKIN - A. JOHNSTON - B. MARKESINIS, Markesinis and Deakin's Tort Law, $6^{\text {th }}$ ed., New York, Oxford, 2008, pág. 31).

${ }^{696}$ Figura esta caracterizada por J. M. ANTUNES VARELA como aquela em que "o autor prevê a produção do facto ilícito como possível, mas por leviandade, precipitação, desleixo ou incúria crê na sua não verificação, e só por isso não toma as providências necessárias para o evitar". (Das Obrigações em Geral, vol. I, 10ª ed., Coimbra, Almedina, 2000, pág. 573).

${ }^{697}$ Opinião contrária é aquela esposada por Sérgio CAVALIERI FILHO, para quem, "[e]xaminada pelo ângulo da gravidade, a culpa será grave se o agente atuar com grosseira falta de cautela, com descuido injustificável ao homem normal, impróprio ao comum dos homens. É a culpa com previsão do resultado, também chamada culpa consciente, que se avizinha ao dolo eventual do Direito Pebal. Em ambos há previsão ou representação do resultado, só que no dolo eventual o agente assume o risco de produzi-lo, enquanto na culpa consciente ele acredita sinceramente que o evento não ocorrerá." (Programa de Responsabilidade Civil, 6ª ed., São Paulo, Malheiros, 2005, pág. 62).

698 J. M. ANTUNES VARELA, Das Obrigações em Geral, vol. I, 10ª ed., Coimbra, Almedina, 2000, pág. 573.

${ }^{699}$ Marcelo Junqueira CALIXTO, A Culpa na Responsabilidade Civil (Estrutura e Função), Rio de Janeiro, Renovar, 2008, pág. 109. 
Assim caracterizada, a culpa grave "se distingue da culpa ordinária [mera negligência] por seu caráter de particular gravidade - sua enormidade, como se diz - e da culpa intencional [dolo direto ou eventual] pelo fato de o seu autor não desejar causar o dano, nem mesmo, por vezes, ter consciência de que ele poderia se realizar" ${ }^{\prime 701}$. Nesse sentido é que se afirma que a culpa grave não se confunde com a culpa consciente (o que envolveria para a sua configuração, necessariamente, a consciência de que do ato levado a cabo pelo ofensor, poderia decorrer um resultado lesivo, ainda que o o ofensor não o desejasse), sendo o "bastante, para a sua caracterização, a inobservância do dever mínimo de cuidado que a todos incumbe". Ou seja, para que se entenda presente a culpa grave, é preciso que o agente se conduza "sem atenção para as cautelas mais comezinhas" ${ }^{\prime 702}$.

Diante do exposto, quer-nos parecer que, mesmo nas hipóteses em que não se verifica ter o ofensor agido com a consciência dos riscos de produzir um resultado danoso (culpa inconsciente), a culpa grave (em sua modalidade de erro grosseiro) não deixa de ser altamente reprovável e socialmente indesejada. Espera-se que o homem se conduza com um mínimo de diligência, que procure mitigar ou evitar os riscos que podem e devem ser antevistos pelo homem ordinário. A conduta que se desvia desse standard,

\footnotetext{
${ }^{700}$ Como bem anota Antonio JUNQUEIRA DE AZEVEDO, “a culpa grave é muitas vezes associada à culpa consciente, mas o cirtério de classificação da culpa em grave, leve e levíssima não deve ser confundido com o da culpa consciente e inconsciente. A culpa é tida como grave por conta de sua particular intensidade [...]. Já a culpa consciente reflete a previsão, por parte do agente, da possibilidade do resultado danoso. A culpa consciente não é, a priori, mais grave do que a inconsciente [...]. Se o agente, na culpa grave (consciente ou inconsciente) não sabia, a verdade é que deveria saber [...]. são, pois, critérios distintos, muito embora a culpa grave acabe por ser, na maioria dos casos, 'consciente', no sentido acima apontado". (Nulidade de Cláusula Limitativa de Responsabilidade em Caso de Culpa Grave. Caso de Equiparação entre Dolo e Culpa Grave. Configuração da Culpa Grave em Caso de Responsabilidade Profissional, in, Novos Estudos e Pareceres de Direito Privado, São Paulo, Saraiva, 2009, págs. 430/431).

${ }^{701}$ No original: "se distingue donc de la faute ordinaire par son caractère de particulière gravité - son énormité dit-on parfois - et de la faute intentionelle par le fait que son auteur n'a pas voulu le dommage causè, ni même, parfois, eu conscience de ce qu'il puvait se réaliser." (S. CARVAL, La Responsabilitè Civile Dans Sa Fonction de Peine Privée, Paris, L.G.D.J., 1995, pág. 333).

702 André Gustavo Corrêa de ANDRADE, Dano Moral e Indenização Punitiva: Os punitive damages na experiência do common law e na perspectiva do Direito brasileiro, Rio de Janeiro, Forense, 2006, págs. 283/284. Imiscuindo-se na seara do erro grosseiro de conduta, J. M. ANTUNES VARELA sustenta serem casos de culpa grave (a despeito de insconsciente), o "do fumador inveterado que, inadvertidamente, lança o cigarro fora, provocando incêndio em seara ou casa alheia, ou [o] do condutor imprudente e distraído que, em animada discussão com os outros ocupantes do veículo, se não apercebe sequer da passagem no cruzamento perigoso onde devia afrouxar a velocidade". (Das Obrigações em Geral, vol. I, 10 ed., Coimbra, Almedina, 2000, pág. 573).
} 
mesmo que de maneira inconsciente, é particularmente reprovável, aproximando-se do dolo $^{703}$ e dando ensejo, portanto, à indenização punitiva ${ }^{704}$.

Assim, divergimos parcialmente do quanto sustentado por Eduardo UILAN, para o qual a indenização punitiva somente deve incidir nas hipóteses em que a culpa grave é tomada "no sentido de extrema falta de cuidado" se "acompanhada de uma consciente indiferença do réu para com os direitos da vítima",705. Acredita-se que para a aplicação da sanção punitiva, basta que o erro grosseiro do ofensor venha acompanhado de uma imprudente indiferença para com os direitos da vítima. Desnecessárias, portanto, são as considerações a respeito da consciência da vítima.

Nessa linha, também se reputa possível caracterizar o agravamento da culpa, apto a ensejar a incidência da indenização punitiva, em razão da reiteração de condutas ilícitas, as quais, observadas isoladamente, poderiam ser tidas como meramente negligentes ${ }^{706}$. "É o caso", bem lembra André Gustavo Corrêa de ANDRADE, "de empresas que não se preocupam em aperfeiçoar seus produtos e serviços, a despeito da reiteração dos danos causados aos consumidores em decorrência de defeitos apresentados por esses produtos ou na prestação desses serviços" ${ }^{\prime 707}$. Verifica-se, aqui, um erro grosseiro de conduta e, no mínimo, uma imprudente indiferença em relação aos direitos dos consumidores, os quais continuam a ser reiteradamente lesados por produtos ou serviços impróprios para o consumo.

\footnotetext{
${ }^{703}$ Sobre a semelhança da culpa grave ao dolo, mesmo em se tratando de hipóteses nas quais o ofensor não anteviu o resultado danoso potencialmente decorrente de suas condutas, cfr. (STJ; $3^{\mathrm{a}}$ T.; RESP 685.791/MG; Relator: Des. Convocado Vasco Della Giustina; J. 18.02.2010) e (STJ; ${ }^{\mathrm{a}}$ T.; RESP 23.875/SP; Relator: Min. Castro Filho; J. 14.02.2006). Em doutrina, Antonio JUNQUEIRA DE AZEVEDO lembra que "[c]onstitui afirmação freqüente que a culpa grave se equipara ao dolo, havendo até mesmo um aforisma latino nesse sentido: culpa lata dolo aequiparatur. Se, na culpa grave, não está presente o elemento subjetivo característico do dolo (a intenção ou a assunção do risco de produzir o resultado danoso), ela se equipara ao dolo por conta da intensidade da negligência, isto é, da gravidade da desatenção para com os interesses da contraparte ou do interessado". (Nulidade de Cláusula Limitativa de Responsabilidade em Caso de Culpa Grave. Caso de Equiparação entre Dolo e Culpa Grave. Configuração da Culpa Grave em Caso de Responsabilidade Profissional, in, Novos Estudos e Pareceres de Direito Privado, São Paulo, Saraiva, 2009, pág. 431).

${ }^{704}$ Assim também o sustentam André Gustavo Corrêa de ANDRADE, Dano Moral e Indenização Punitiva: Os punitive damages na experiência do common law e na perspectiva do Direito brasileiro, Rio de Janeiro, Forense, 2006, págs. 280/285 e S. CARVAL, La Responsabilitè Civile Dans Sa Fonction de Peine Privée, Paris, L.G.D.J., 1995, pág. 333/335.

${ }^{705}$ Responsabilidade Civil Punitiva, Tese (Doutorado) - Faculdade de Direito da USP, São Paulo, 2003, pág. 83.

706 André Gustavo Corrêa de ANDRADE, Dano Moral e Indenização Punitiva: Os punitive damages na experiência do common law e na perspectiva do Direito brasileiro, Rio de Janeiro, Forense, 2006, pág. 284 e S. CARVAl, La Responsabilitè Civile Dans Sa Fonction de Peine Privée, Paris, L.G.D.J., 1995, pág. 333.

707 Dano Moral e Indenização Punitiva: Os punitive damages na experiência do common law e na perspectiva do Direito brasileiro, Rio de Janeiro, Forense, 2006, pág. 284.
} 


\section{IV.II. Responsabilidade objetiva}

$\mathrm{Na}$ esteira do quanto se expôs ao rejeitarmos a alegada incompatibilidade entre o instituto da indenização punitiva e as hipóteses (cada vez mais freqüentes) em que a regras de imputação são definidas independentemente da alegação, prova ou ocorrência de culpa por parte do ofensor, nada impede que, presentes os pressupostos objetivos e subjetivos para tanto, incida a indenização punitiva mesmo em um caso regrado pela responsabilidade objetiva.

Para que isso seja possível, contudo, é indispensável que o autor da demanda se desincumba dos ônus de alegar e provar a existência não apenas dos requisitos exigidos para a imputação de responsabilidade (entre os quais não se encontra a culpa do ofensor), mas, igualmente, aqueles indispensáveis para a configuração da indenização punitiva (entre os quais se encontram todos aqueles acima apontados, entre eles, e com destaque, o alto grau de reprovabilidade da conduta do ofensor, que se deve caracterizar pela culpa grave ou dolo).

Não basta, portanto, que o consumidor alegue e comprove ter suportado prejuízos em razão de defeito de determinado produto ou serviço introduzido no mercado pelo fornecedor (hipóteses estas de responsabilidade objetiva, ex vi dos arts. 12 e 14, do CDC). Para a condenação do fornecedor ao pagamento de indenização punitiva, é indispensável que a introdução ou a manutenção do produto ou serviço no mercado tenha-se dado de maneira gravemente culposa ou dolosa, expondo o consumidor a riscos desnecessários ${ }^{708}$.

Para que se possa distinguir, das hipóteses ordinárias de responsabilidade objetiva, aquelas em que se justifica a incidência de uma sanção jurídica mais gravosa, vale relembrar os critérios sintetizados por G. V. ROBREDO, pelos quais se verifica ser interessante penalizar atividades produtoras: (i) quando o demandado conhecia a existência do defeito de que padecia seu produto e, mesmo assim, assumiu o risco de desenvolvê-lo e comercializá-lo; (ii) quando o demandado auferiu importantes benefícios econômicos pela fabricação e comercialização do produto defeituoso; (iii) quanto o demandado não realizou investigações suficientes sobre os riscos potenciais do produto, ou, após aperceber-se 
destes riscos, não realizou esforço algum para evitar o prejuízo; (iv) quando o comportamento do demandado não se adequou aos standards de conduta exigidos pelo mercado, quer no que toca à realização de testes e investigações preliminares à introdução do produto no mercado, quer, ainda, no que toca às providências posteriores à introdução de tal produto (tais como, e.g., o recall); ou, ainda, (v) quando o produto defeituoso e potencialmente perigoso não oferecia benefícios substanciais a ponto de compensar o risco, assumido pelo fabricante, de introduzi-lo no mercado ${ }^{709}$.

Retomando-se tais critérios, torna-se mais simples verificar que situações hipotéticas, mas comezinhas no âmbito da responsabilidade civil, são aptas a acarretar a condenação do ofensor não apenas ao pagamento de indenização compensatória, mas, igualmente, de indenização punitiva em razão do algo grau de reprovabilidade das condutas perpetradas.

Desta feita, acredita-se fazerem jus à condenação ao pagamento de indenização punitiva (frisando-se que a enumeração das hipóteses aqui realizada tem finalidade exclusivamente ilustrativa): (i) a indústria farmacêutica que, em descumprimento às exigências legais (Lei 6.437/1977), possibilita a introdução no mercado de medicamento desprovido de princípio ativo (placebo) e que, a despeito de ciente do fato, tarda de maneira injustificada a informar os potenciais consumidores ${ }^{710}$; (ii) a empresa responsável pela manutenção de posto de combustíveis que comercializa combustível adulterado, lesando diversos consumidores para, em contrapartida, obter vantagens ilícitas $^{711}$; (iii) o hospital que, em descumprimento ao quanto disposto pela Lei 9.431/1997, deixa de instalar e manter um eficiente Programa de Controle de Infecções Hospitalares (PCIH), dando ensejo, portanto, à ocorrência de infecções dentro das instalações nosocomiais em quantidade muito superior à que seria tolerável ${ }^{712}$; (iv) a

\footnotetext{
708 André Gustavo Corrêa de ANDRADE, Dano Moral e Indenização Punitiva: Os punitive damages na experiência do common law e na perspectiva do Direito brasileiro, Rio de Janeiro, Forense, 2006, pág. 288. ${ }^{709}$ Daños Punitivos en el Proceso Civil Norteamericano, in Revista de la Universidad de Deusto, vol. 57, fasc. 97, jul-dic./ 1996, págs. 195/198).

${ }^{710}$ Trata-se do anticoncepcional Microvlar, em caso que se tornou célebre no Brasil no final da década de 1990. A seu respeito, cfr. (STJ; $3^{\mathrm{a}}$ T.; RESP 866.636/SP; Relatora: Min. Fátima Nancy Andrighi; J. 29.11.2007).

${ }^{711}$ Considerando o alto grau de reprovabilidade de condutas dessa natureza, inclusive para a quantificação da indenização, cfr. (TJRJ; 7ª Câm. Cível; Apelação 0059087-40.2004.8.19-0001; Relator: Des. José Geraldo Antônio; J. 16.02.2011).

${ }^{712}$ Vale lembrar que a jurisprudência nacional majoritária reputa a infecção hospitalar como um defeito do serviço prestado pelas instituições nosocomiais, submetendo-se, portanto, ao regramento da responsabilidade
} 
construtora que utiliza materiais de baixa qualidade, com intenção de baratear seus custos e auferir maiores benefícios econômicos com a comercialização de unidades autônomas, comprometendo a solidez e segurança da obra e expondo a riscos desnecessários o patrimônio e a saúde dos adquirentes ${ }^{713}$; (v) o estabelecimento hoteleiro que deixa de tomar as cautelas mínimas de segurança que dele se esperam, permitindo a utilização de suas instalações de lazer sem a supervisão de profissional adequado ${ }^{714}$; (vi) a empresa de transporte que deixa de fazer manutenção periódica em seus veículos, permitindo um maior índice de quebras e expondo seus clientes a riscos anormalmente elevados; e, por fim, (vii) a instituição financeira que não toma os cuidados mínimos ao abrir contas em nome de novos correntistas, possibilitando a utilização de falsificações grosseiras de documentos de identidade ${ }^{715}$.

Dos exemplos acima apresentados, pode-se vislumbrar o imenso campo de atuação que a indenização punitiva encontra, mesmo no âmbito da responsabilidade objetiva, não procedendo os argumentos no sentido de serem institutos incompatíveis.

\section{QUESTÕES MATERIAIS CORRELATAS À INTRODUÇÃO DA INDENIZAÇÃO PUNITIVA}

Ultrapassadas as discussões a respeito dos pressupostos de ordem objetiva e subjetiva para a incidência da indenização punitiva, passa-se, desde ponto em diante, a

objetiva (STJ; $4^{\mathrm{a}}$ T.; RESP 629.212/RJ; Relator: Min. César Asfor Rocha; J. 15.05.2007). Sobre o tema, cfr. Miguel Kfouri Neto, Responsabilidade Civil dos Hospitais (Código Civil e Código de Defesa do Consumidor), São Paulo, RT, 2010, págs. 220/238.

${ }^{713}$ Lembre-se, a respeito, o também célebre caso do Ed. Palace II, cujo desabamento (resultado de graves infrações durante a construção do edifício) deu ensejo ao ajuizamento de um sem número de medidas judiciais indenizatórias, para a recomposição do patrimônio dos moradores do edifício e das edificações que se encontravam no entorno, danificadas pelo acidente. Sobre o tema, entre inúmeros outros, cfr. (TJRJ; $17^{\mathrm{a}}$ Câm. Cível; Apelação 2005.001.27409; Relatora: Des. Maria Inês da Penha Gaspar; J. 08.09.2005).

${ }^{714}$ Nesse sentido, o E. TJRJ já teve a oportunidade de reputar extremamente reprovável a conduta de estabelecimento hoteleiro que, a despeito de propagandear a contratação de profissionais guarda-vidas, permitiu a utilização de suas instalações de lazer sem supervisão por criança de sete anos, permitindo que a criança viesse a por afogamento. $\mathrm{Na}$ hipótese, considerou o Des. Relator que, para a quantificação da indenização, era imprescindível fazer "uma minuciosa dosimetria da culpa [dos demandados], pois, embora dispensável dela cogitar-se [para a imputação da responsabilidade, que se afigurava objetiva], constitui elemento juridicamente relevante para a apuração de um valor justo e revestido do necessário caráter pedagógico." (TJRJ; 15 Câm. Cível; Apelação 2009.001.35620; Relator: Des. Celso Ferreira Filho; J. 25.08.2009).

715 (TJMG; $17^{\mathrm{a}}$ Câm. Cível; Apelação 1.0295.08.017725-2/001; Relatora: Des. Márcia de Paoli Balbino; J. 09.10.2008). 
tratar de algumas questões típicas do Direito Material, e que se relacionam, de um modo ou de outro, com o regramento jurídico que se acredita ser o mais adequado e eficiente para tal sanção punitiva.

Nesse mister, passaremos a tratar, em primeiro lugar, da possibilidade de que se venha a condenar ao pagamento de indenização punitiva uma pessoa diversa daquela que, diretamente, cometeu o ato ilícito danoso (em razão da incidência das regras de responsabilidade pelo fato de terceiro); em segundo lugar, da possibilidade de contratação de seguro de responsabilidade civil que transfira a uma empresa seguradora os riscos de o segurado vir a ser condenado ao pagamento de indenização punitiva; e, por fim, da transmissibilidade causa mortis do direito de crédito e da obrigação de indenizar relacionados à indenização punitiva.

\section{V.I. Responsabilidade por fato de terceiro}

Como se sabe, em hipóteses excepcionais, o Direito admite que a responsabilidade pela reparação do dano ilicitamente causado recaia sobre pessoa diversa daquela que diretamente agiu de modo ilícito. Trata-se da assim chamada "responsabilidade indireta, responsabilidade pelo fato de outrem", conjunto de regras que permitem responsabilizar pessoa diversa da que causou o dano ilícito, exigindo-se, para tanto, que ambas estejam ligadas por algum vínculo jurídico, de sorte a daí resultar "um dever de guarda, vigilância ou custódia",716.

Em nosso Código Civil, encontram-se algumas das hipóteses de responsabilidade pelo fato de outrem no art. 932, dispositivo que prescreve serem "também responsáveis pela reparação civil": (i) "os pais, [pelos atos cometidos] pelos filhos menores que estiverem sob sua autoridade e em sua companhia"; (ii) "o tutor e o curador, [pelos atos cometidos] pelos pupilos e curatelados, que se acharem nas mesmas condições"; (iii) "o empregador ou comitente, [pelos atos causados] por seus empregados, serviçais e prepostos, no exercício do trabalho que lhes competir, ou em razão dele"; (iv) "os donos de hotéis, hospedarias, casas ou estabelecimentos onde se albergue por

\footnotetext{
${ }^{716}$ Sérgio CAVAlieri Filho, Programa de Responsabilidade Civil, $6^{\text {a }}$ ed., São Paulo, Malheiros, 2005, pág. 200.
} 
dinheiro, mesmo para fins de educação, [pelos atos cometidos] pelos seus hóspedes, moradores e educandos"; e, ainda, (v) "os que gratuitamente houverem participado nos produtos do crime, até a concorrente quantia".

Pelo fato de, nessas hipóteses, admitir-se que a condenação recaia sobre o patrimônio de pessoa não diretamente ligada ao cometimento do ato ilícito e do dano, parte da doutrina advoga pela incompatibilidade entre a responsabilidade indireta e a indenização punitiva. Diz-se que a incidência da indenização punitiva nessas hipóteses representaria violação ao princípio da pessoalidade da pena, o qual, inserido no art. 5, $\mathrm{XLV}$, da CF/88, estabelece que "nenhuma pena passará da pessoa do condenado" e que apenas a "obrigação de reparar o dano e a decretação do perdimento de bens" poderão ser, nos termos da lei, "estendidas aos sucessores e contra eles executadas, até o limite do valor do patrimônio transferido" $" 717$.

Sustenta-se, ademais, que a incompatibilidade entre os dois institutos também decorreria do fato de que, nas hipóteses de responsabilidade indireta, a indenização punitiva não assumiria “uma função punitiva, já que não é o verdadeiro culpado a sofrer as conseqüências, não existindo, conseqüentemente, qualquer efeito dissuasor". Afirma-se, então, que, em vez de desempenhar adequadamente seus escopos de punição e prevenção, a indenização punitiva apresentaria "efeitos perversos", tais como "o refreamento da iniciativa económica, e a repercussão das quantias impostas nos preços dos produtos vendidos aos consumidores" ${ }^{\text {,718. }}$.

De fato, tomando-se em conta os escopos perseguidos pela indenização punitiva (em especial o de punição do ofensor pelo cometimento de um ato particularmente reprovável), parece-nos inadmissível que tal sanção recaia sobre alguém que nada praticou, i.e., que não concorreu para o cometimento do ilícito e que somente veio a ser legalmente responsabilizado em razão de um dever de guarda, vigilância ou custódia que ostenta em relação ao real causador do dano. Não se quer, contudo, dizer que a indenização punitiva é inaplicável às hipóteses de responsabilidade indireta.

\footnotetext{
${ }^{717}$ Sérgio Luiz Junkes, A Culpa e a Punição Não Podem Servir de Critério Para a Fixação da Indenização por Dano Moral, in Jurisprudência Catarinense, ano XXXI, n. 107, 2005, pág. 230. No mesmo sentido, Wesley de Oliveira Louzada Bernardo, Dano Moral: Critérios de Fixação de Valor, Rio de Janeiro, Renovar, 2005, págs. 176/177.

${ }^{718}$ P. M. LourençO, A Função Punitiva da Responsabilidade Civil, Coimbra, Coimbra, 2006, pág. 172.
} 
Com efeito, parece-nos plenamente admissível que o responsável indireto seja condenado ao pagamento de indenização punitiva se, também ele, houver se conduzido de maneira dolosa ou gravemente culposa no desempenho de seu dever de guarda, vigilância ou custódia ${ }^{719}$.

Assim, fazem jus à condenação ao pagamento de indenização punitiva: (i) o pai que, de maneira extremamente imprudente, entrega a seu filho menor de idade as chaves de veículo automotor para que ele o dirija, ainda que não possua habilitação para tanto; (ii) o curador que, a despeito de ciente da enfermidade mental de que padece seu curatelado, e que lhe causa surtos de violência incontrolável, deixa-o em contato com crianças sem a imprescindível supervisão; ou, ainda, (1ii) o empregador que contrata pessoa pessoa flagrantemente inapta a realizar a função para a qual se candidatou (como, por ex., um bêbado inveterado para o manejo de navio transportador de petróleo) ${ }^{720}$.

Assim, para que se possibilite a condenação do responsável indireto também ao pagamento de indenização punitiva, é imprescindível que o demandante se desincumba do ônus de afirmar e provar ter também ele, responsável indireto, agido de maneira gravemente culposa ou dolosa, contribuindo, dessa maneira, para o ato ilícito particularmente reprovável cometido por pessoa que se encontrava sob sua guarda ${ }^{721}$. Em nada prejudica tal conclusão o fato de a responsabilidade indireta incidir sem que seja necessária a apreciação da culpa do responsável (art. 933, do CC/2002), pedindo-se licença ao leitor para reportá-lo às considerações acima tecidas sobre a compatibilidade entre a responsabilidade objetiva e a indenização punitiva.

\footnotetext{
${ }^{719}$ Nesse sentido, André Gustavo Corrêa de ANDRADE, Dano Moral e Indenização Punitiva: Os punitive damages na experiência do common law e na perspectiva do Direito brasileiro, Rio de Janeiro, Forense, 2006, pág. 289.

${ }^{720}$ Quanto a este aspecto, em específico, P. C. M. GuIMARÃES afirma que "a imposição de danos punitivos contra o empregador serve como para o intimidar contra a contratação de pessoas que são inaptas para cargos importantes". (Os Danos Punitivos e a Função Punitiva da Responsabilidade Civil, in Revista de Direito e Justiça, vol. XV, t. 1, 2001, pág. 171).

${ }^{721}$ É interessante observar, neste ponto, a ressalva feita por Sérgio CAVALIERI FiLHO, para quem, "[n]a realidade, a chamada responsabilidade por fato de outrem [...] é responsabilidade por fato próprio omissivo, porquanto as pessoas que respondem a esse título terão sempre concorrido para o dano por falta de cuidado ou vigilância". (Programa de Responsabilidade Civil, 6a ed., São Paulo, Malheiros, 2005, pág. 200). O que aqui se defende é que, ainda que a mera omissão seja suficiente para a condenação do responsável indireto ao pagamento de indenização compensatória (responsabilização esta que, ademais, dá-se independentemente de qualquer consideração a respeito de culpa, ex vi do art. 933, do CC/2002), sua condenação ao pagamento de indenização punitiva somente ocorrerá se a falta de cuidado ou vigilância decorrer de falta grave, desobedecendo-se os limites mais comezinhos de cautela, tal como nos exemplos citados no corpo do texto.
} 


\section{V.II. Contratação de seguro para a indenização punitiva}

Como já tivemos a oportunidade de expor, particularmente quando discorremos sobre a contratação de seguro para os punitive damages, a questão ora analisada é polêmica e sujeita a controvérsias, mas, ainda assim, há forte orientação doutrinária (à qual nos filiamos) no sentido de inadmitir transferibilidade do risco de o ofensor vir a ser condenado ao pagamento de indenização punitiva.

Ainda que, à luz das características específicas do sistema da common law, fosse possível atribuir algum valor aos parcos argumentos a favor da contratação de seguro de responsabilidade civil para evitar condenações relacionadas aos punitive damages ${ }^{722}$, o mesmo não se pode dizer sob a ótica do Direito Brasileiro, cujas normas atinentes ao contrato de seguro inadmitem a transferência do risco decorrente de condutas dolosas ou gravemente culposas por parte do segurado.

Com efeito, logo nas disposições gerais do contrato de seguro, o Código Civil de 2002 fixa balizas suficientes para se defender a inadmissibilidade de tal sorte de contratação.

A uma, no art. 762, do CC/2002, prescreve-se que "[n]ulo será o contrato para garantia de risco proveniente de ato doloso do segurado, do beneficiário, ou de representante de um ou de outro". Admitir-se a transferibilidade do "risco" (tratar-se-ia muito mais de "certeza" do que, propriamente, de "risco") de cometimento de um ato doloso significaria permitir a celebração de contrato com objeto ilícito, e que se desviasse de seus fins econômicos e sociais, impondo-se-lhe a sanção de nulidade ainda que vazia fosse a dicção do aludido art. 762 , do CC/2002 $2^{723}$.

\footnotetext{
${ }^{722}$ Os quais são assim sintetizados por I. EBERT: (i) a linha divisória entre a conduta que é passível de sancionamento por meio de punitive damages e aquela que não é, por vezes, é de difícil aferição; (ii) não se poderia restringir o princípio da liberdade contratual, excluindo o risco de condenação ao pagamento de punitive damages dos objetos passíveis de seguro; e, por fim, (iii) a contratação de seguro ajuda a evitar a falência do segurado, possivelmente sujeito a condenações elevadas. (Punitive Damages and Liability Insurance, in H. KozIOL - V. WILCOX (eds.), Punitive Damages: Common Law and Civil Law Perspectives, Wien, Springer, 2009, pág. 214).

${ }^{723}$ Gustavo TEPEDINO - Heloísa Helena BARBOZA - Maria Celina Bodin de MoRAES, Código Civil Interpretado Conforme a Constituição da República, vol. II, Rio de Janeiro, Renovar, 2006, pág. 569. Nesse sentido, Sérgio CAVALIERI FILHO afirma que não "seria admissível um seguro para dar cobertura aos danos causados por dolo,
} 
A duas, ainda que se não pudesse falar em nulidade, o art. 768, do CC/2002, prescreve que "[o] segurado perderá o direito à garantia se agravar intencionalmente o risco objeto do contrato", daí se extraindo a interpretação jurisprudencial de que o segurado perderá o direito de ressarcimento se houver se conduzido não apenas com dolo, mas, igualmente, com culpa grave, agravando indevidamente o risco objeto do contrato ${ }^{724}$.

À luz dos supra referidos dispositivos legais, e considerando o quanto acima exposto a respeito dos pressupostos subjetivos para a incidência da indenização punitiva (a saber: o dolo ou a culpa grave), vê-se que um contrato de seguro que objetivasse a transferência do risco de submissão do segurado ao pagamento de indenização punitiva ou bem seria nulo (ante à vedação de transferência do "risco" de cometimento de ato doloso, ex vi do art. 762, do CC/2002), ou a cobertura devida ao segurado seria negada pela empresa seguradora (ante à impossibilidade de agravamento intencional do risco, ex vi do art. 768, do CC/2002).

Ainda que não se lhe pudesse reputar ilegal, a contratação de seguro para a indenização punitiva seria, no mínimo, indesejável. Pedindo-se licença ao leitor para relembrar argumentos já apresentados, quando analisamos a questão sob a ótica dos países da common law, por certo a transferibilidade do risco de condenação ao pagamento de uma sanção punitiva esvaziaria consideravelmente os propósitos de punição e prevenção perseguidos pela indenização punitiva ${ }^{725}$ : nesse caso, a empresa seguradora suportaria, com seu patrimônio, a indenização agravada que só veio a ser assim quantificada em razão da gravidade da conduta realizada por seu segurado. Pune-se pessoa diversa do ofensor.

pois, além de conter causa ilícita, faltar-lhe-ia o elemento aleatório (imprevisível), que é elemento essencial do seguro". (Programa de Responsabilidade Civil, $6^{a}$ ed., São Paulo, Malheiros, 2005, pág. 447).

${ }^{724}$ Observe-se: "[p] ara a configuração da hipótese de exclusão da cobertura securitária prevista no art. 768 do CC/02, exige-se que a conduta direta do segurado importe num agravamento, por culpa grave ou dolo, do risco objeto do contrato." (STJ; $3{ }^{\mathrm{a}}$ T.; RESP 1.175.577/PR; Relatora: Min. Fátima Nancy Andrighi; J. 18.11.2010). Por conta disso, entende o E. STJ que, se o segurado dirige embriagado (obrando, portanto, com culpa grave) e, em razão de sua embriaguez, causa acidente de trânsito (observa-se nexo de causalidade entre sua conduta gravemente culposa e o resultado danoso), o risco objeto do contrato de seguro foi agravado a ponto de eximir a seguradora da obrigação de indenizar. Nesse sentido: (STJ; $3^{\mathrm{a}}$ T.; RESP 973.725/SP; Relator: Min. Ari Pangendler; DJE 15.09.2008) e (STJ; 4 T.; RESP 599.985/SC; Relator: Min. César Asfor Rocha; DJE 02.08.2004).

${ }^{725}$ R. D. PiZARro, Daño Moral-Prevención, Reparación, Punición: El Daño Moral em las Diversas Ramas del Derecho, Buenos Aires, Hammurabi, 1996, pág. 399 e André Gustavo Corrêa de ANDRADE, Dano Moral e Indenização Punitiva: Os punitive damages na experiência do common law e na perspectiva do Direito brasileiro, Rio de Janeiro, Forense, 2006, pág. 320. 
De outro lado, sabedor de que todas as conseqüências prejudiciais de suas condutas serão suportadas pela empresa seguradora (ainda que resultem de grave incúria ou, até mesmo, de atos intencionais), o segurador poderá se sentir estimulado a se comportar de maneira descuidada, incorrendo-se no fenômeno denominado pelos economistas de "moral hazard"

Em adendo, Vítor Fernandes GonçALVES afirma que a vedação da contratação de seguro para a cobertura do que denomina de "riscos extremos" (i.e., aqueles decorrentes de culpa grave ou dolo, aptos a ensejar a condenação do ofensor ao pagamento de indenização punitiva, em valor potencialmente elevado) tem ainda um outro fator benéfico: a exclusão desses riscos permitiria a diminuição do valor do prêmio dos seguros básicos, possibilitando, assim, que mais pessoas celebrassem contratos de seguro, bem como a extensão de benefícios desses seguros sem aumento sensível no valor do prêmio ${ }^{727}$.

Por todos os argumentos acima expostos, conclui-se que, se o legislador "considera que a pena privada é uma sanção útil, a qual deve sempre conservar todas as suas virtudes dissuasivas, deve-se proibir a cobertura por meio de contrato de seguro"728.

\section{V.III. A transmissibilidade causa mortis dos direitos e obrigações relacionados à indenização punitiva}

Por fim, cumpre-nos tratar daquelas que nos parecem ser as duas últimas questões de interesse relacionadas à introdução da indenização punitiva, ao menos no que concerne ao Direito Material: (i) se o direito ao recebimento do crédito decorrente da indenização punitiva pode ser transmitido a causa de morte (podem, portanto, os herdeiros da vítima demandarem em face do ofensor?); e, ainda, (ii) se o mesmo se pode dizer

\footnotetext{
${ }^{726}$ Sobre o tema, cfr. E. D. BEAL, Posner and Moral Hazard, in Connecticut Insurance Law Journal, vol. 7 , 2000, págs. 81/102.

${ }^{727}$ A Punição na Responsabilidade Civil: A indenização do dano moral e da lesão a interesses difusos, Brasília, Brasília Jurídica, 2005, pág. 69.

${ }^{728}$ No original: "Soit il [législateur] estime que la peine privée est une sanction utile, auquel cas il lui doit lui conserver toute sa vertu dissuasive, en interdisant sa prise en charge par l'assurance". (S. CARVAL, La Responsabilitè Civile Dans Sa Fonction de Peine Privée, Paris, L.G.D.J., 1995, pág. 371). Semelhantemente,
} 
quanto à obrigação de indenizar (também ela se transmite aos herdeiros do ofensor em caso de falecimento deste?).

A resposta ao primeiro questionamento é mais simples e menos sujeita a controvérsias: admitindo-se (em decorrência de tudo o que aqui se expôs) que o direito ao recebimento de indenização punitiva é subordinado ao direito ao recebimento de indenização compensatória (só se reconhece a existência daquele em se reconhecendo, previamente, a existência deste), verifica-se haver entre eles verdadeira relação de acessoriedade, de modo que a sorte de um influencia a sorte do outro.

É de se admitir, portanto, a transmissibilidade causa mortis do direito ao recebimento de indenização punitiva sempre que o mesmo se puder dizer a respeito do direito ao recebimento de indenização compensatória; o que, à luz do disposto no art. 943, do $\mathrm{CC} / 2002$ (que prescreve que "[o] direito de exigir a reparação e a obrigação de prestála transmitem-se com a herança"), é a regra geral de nosso ordenamento, tanto no que toca aos prejuízos materiais, quanto, ainda e a despeito de o referido dispositivo legal nada prescrever expressamente, no que concerne aos prejuízos extrapatrimoniais ${ }^{729}$. A transmissão ocorrerá tanto no curso de demanda já proposta [oportunidade na qual se dará a substituição da vítima por seu espólio ou por seus herdeiros (ex vi do art. 43, do CPC $)^{730}$ ], quanto, ainda, antes de a demanda vir a ser deduzida (oportunidade na qual os herdeiros poderão ajuizar a demanda em substituição ao de cujus) ${ }^{731}$.

Vitor Fernandes GonçALves, A Punição na Responsabilidade Civil: A indenização do dano moral e da lesão a interesses difusos, Brasília, Brasília Jurídica, 2005, págs. 68/69.

${ }^{729}$ Gustavo TePedino, Heloísa Helena BARBOZA e Maria Celina Bodin de MoRAES afirmam que "'[e]mbora o Código não tenha se referido expressamente à hipótese de dano moral, é de se entender que também neste caso o direito ao ressarcimento se transmite com a herança. Isto porque, ainda que a lesão seja personalíssima, o direito à sua reparação é patrimonial e deve integrar o montante destinado aos herdeiros". (Código Civil Interpretado Conforme a Constituição da República, vol. II, Rio de Janeiro, Renovar, 2006, pág. 857). Vale lembrar que também nos Estados Unidos da América se admite, de maneira geral e sem grandes questionamentos, a transmissibilidade causa mortis do direito ao recebimento dos punitive damages. Sobre o tema, cfr. Vitor Fernandes GonçALVES, A Punição na Responsabilidade Civil: A indenização do dano moral e da lesão a interesses difusos, Brasília, Brasília Jurídica, 2005, págs. 74/75.

${ }^{730}$ Nesse sentido, o E. STJ já teve a oportunidade de pontuar que “[o] espólio detém legitimidade para suceder o autor em ação de indenização por danos morais.” (STJ; RESP 648.191/RS; Relator: Min. Jorge Scartezzini; DJ 06.12.2004).

${ }^{731}$ Observe-se: "PROCESSUAL CIVIL. DIREITO CIVIL. INDENIZAÇ̃̃O. DANOS MORAIS. HERDEIROS. LEGITIMIDADE. 1. Os pais estão legitimados, por terem interesse jurídico, para acionarem o Estado na busca de indenização por danos morais, sofridos por seu filho, em razão de atos administrativos praticados por agentes públicos que deram publicidade ao fato de a vítima ser portadora do vírus HIV. 2. Os autores, no caso, são herdeiros da vítima, pelo que exigem a indenização pela dor (dano moral) sofrida, em vida, pelo filho já falecido, em virtude da publicação de edital, pelos agentes do Estado réu, referente à sua condição de portador do vírus HIV. 3. O direito que, na situação analisada, poderia ser reconhecido ao 
A resposta ao segundo questionamento, por sua vez, não se dá sem alguma polêmica: como se expôs, a indenização punitiva se distancia da indenização compensatória essencialmente em razão das distintas funções por elas exercidas [enquanto que esta se caracteriza como uma sanção compensatória (destinada a recompor o patrimônio lesado pelo ato ilícito), aquela se insere no rol das sanções punitivas (destinada a punir o ofensor em razão do ato gravemente reprovável por ele perpetrado)]. Assim, ao contrário da indenização compensatória, a indenização punitiva é uma verdadeira pena e, em razão disso, deve-se subordinar aos princípios gerais relacionados à previsão e aplicação das penas, entre os quais se insere o princípio da pessoalidade da pena (art. 5, XLV, da CF/88) ${ }^{732}$.

À luz do supra referido princípio da pessoalidade da pena, acreditamos ser inaceitável que a indenização punitiva ultrapasse a pessoa do ofensor para recair, por transmissão a causa de morte, sobre seus herdeiros. Caso assim ocorresse, admitir-se-ia que pessoas inocentes, que em nada concorreram para o cometimento do ato ilícito, viessem a sofrer com as conseqüências punitivas daquele ato ${ }^{733}$.

Há de se pontuar, contudo, que a posição ora esposada não encontra unanimidade na doutrina, levantando-se, em sentido contrário, ao menos dois argumentos.

A uma, sustenta-se que, por mais que se trate de sanção punitiva, a indenização punitiva é sanção de natureza civil, distinta das penas criminais, e, por isso, justificar-se-ia um certo abrandamento do princípio da pessoalidade da pena para que se admitisse a transmissibilidade de sanção aos herdeiros do ofensor ${ }^{734}$.

falecido, transmite-se, induvidosamente, aos seus pais. [...] 5. O direito de ação por dano moral é de natureza patrimonial e, como tal, transmite-se aos sucessores da vítima (RSTJ, vol. 71/183)." (STJ; $1^{\mathrm{a}} \mathrm{T}$. ; RESP 324.886/PR; Relator: Min. José Delgado; J. 21.06.2001).

${ }^{732} \mathrm{O}$ qual, como acima já asseverado, estabelece que "nenhuma pena passará da pessoa do condenado" $\mathrm{e}$ que apenas a "obrigação de reparar o dano e a decretação do perdimento de bens" poderão ser, nos termos da lei, "estendidas aos sucessores e contra eles executadas, até o limite do valor do patrimônio transferido". ${ }^{733}$ Nesse sentido, Vitor Fernandes GonÇAlves, A Punição na Responsabilidade Civil: A indenização do dano moral e da lesão a interesses difusos, Brasília, Brasília Jurídica, 2005, págs. 72/74. Semelhante solução se verifica nos países da common law, extraindo-se, da lição apresentada por G. T. SCHWARTZ, a conclusão de que "[t]he Common Law's well-settled rule is that a punitive damages claim, not yet reduced to a judgement, does not survive the death of the defendant" (Deterrence and Punishment in the Common Law of Punitive Damages: A Comment, in Southern California Law Review, vol.56, 1982, pág. 143).

${ }^{734}$ Tal argumento é sustentado, por ex., por R. D. PIZARro, Daño Moral - Prevención, Reparación, Punición: El Daño Moral em las Diversas Ramas del Derecho, Buenos Aires, Hammurabi, 1996, pág. 399. 
Com o perdão da repetição, não nos parece admissível afastar a submissão das penas (quer elas se insiram no âmbito do Direito Penal, quer se insiram em outros ramos do Direito) aos princípios basilares a elas atinentes (entre os quais está o princípio da pessoalidade da pena), sob o simples argumento de que tais princípios seriam restritos às sanções criminais. Acreditamos, como já se anunciou, que, por se tratarem de garantias constitucionalmente previstas para a proteção dos indivíduos, tais princípios extrapolam o âmbito do Direito Penal, incidindo sobre todas as sanções punitivas ${ }^{735}$.

Há que se pontuar, ademais, que a submissão das sanções punitivas típicas do direito civil ao princípio da pessoalidade das penas é comumente aceita pelos doutrinadores civilistas. Basta, para tanto, verificar o entendimento de que, assim como ocorre com a exclusão por indignidade, reputam-se pessoais os efeitos da deserdação, a despeito de, em relação a este último instituto, inexistir previsão legal expressa à guisa do art. 1.816, do CC/2002 $2^{736}$.

A duas, sustenta-se que, em virtude da previsão contida no art. 1.792, do CC/2002, os herdeiros do ofensor jamais viriam a suportar o peso da indenização punitiva imposta ao de cujus (vez que não poderiam responder por "encargos superiores às forças da herança"), de modo que o princípio da pessoalidade da pena não encontraria violação mesmo com a admissibilidade da transmissão causa mortis da obrigação correspectiva ${ }^{737}$.

Não nos parece, contudo, ser essa a melhor solução. Em razão da função por ela perseguida, a pretensão de condenação ao pagamento de indenização punitiva somente

\footnotetext{
${ }^{735}$ Sobre a aplicabilidade do princípio da pessoalidade da pena ao Direito Administrativo, cfr. Fábio Medina OSÓRIO, Direito Administrativo Sancionador, $3^{\text {a }}$ ed., São Paulo, RT, 2010, págs. 371/373.

${ }^{736}$ Assim, Zeno Veloso afirma que "os efeitos da deserdação - como os da exclusão por indignidade - não se estendem aos sucessores do deserdado. Deserdação é pena, e seus efeitos são personalíssimos." (Comentários ao Código Civil, vol. 21, São Paulo, Saraiva, 2003, pág. 321). No mesmo sentido, Salomão de Araújo CATEB afirma que "[c]omo toda pena é pessoal, e atinge somente aqueles que, por dolo ou culpa, praticaram o ilícito, os filhos não são expostos a ela (art. $5^{\circ}, X L V$ da CF). Os filhos do herdeiro excluído por indignidade recebem por direito de representação, como se morto estivesse seu ascendente indigno e, igual procedimento no caso de deserdação." (Deserdação e Indignidade no Direito Sucessório Brasileiro, Belo Horizonte, Del Rey, 2004, págs. 128/129).

737 Assim segue a orientação de André Gustavo Corrêa de ANDRADE, para quem, "[e]m que pesem os entendimentos doutrinários em contrário, não se justifica tal proibição em relação à pena de multa [e, conseqüentemente, à indenização punitiva, que é sanção de estrutura assemelhada à pena de multa], uma vez que os sucessores nunca responderão por encargos superiores às forças da herança deixada pelo ofensor falecido, conforme estabelecido pelo art. 1792 do Código Civil." (Dano Moral e Indenização Punitiva: Os punitive damages na experiência do common law e na perspectiva do Direito brasileiro, Rio de Janeiro, Forense, 2006, pág. 316).
} 
pode ser deduzida em face do próprio ofensor. Não se admite que tal pretensão possa ser ajuizada em face de pessoas estranhas ao causador do prejuízo, que não concorreram para o cometimento do ato gravemente reprovável.

Tal conclusão, ademais, em nada é alterada pela diferente estrutura da indenização punitiva (= condenação ao pagamento de valor pecuniário, semelhante, portanto, à pena de multa) ${ }^{738}$.

\section{ASPECTOS PROCESSUAIS RELEVANTES DA INDENIZAÇÃo PUNITIVA}

Para além daqueles aspectos relacionados, particularmente, ao direito material, a utilização da indenização punitiva em nosso ordenamento também dá ensejo a uma série de questionamentos de ordem processual. Diante da perspectiva de incidência de tal sanção punitiva, indaga-se, por ex., se e como deve ser deduzido o pedido de condenação do demandado ao pagamento de indenização punitiva; quais são, e em que graus devem ser cumpridos, os ônus de cada uma das partes de um processo no qual se pretende a condenação do demandado ao pagamento de indenização punitiva; em que momento deve ser imposta e mensurada a indenização; de que maneira deve ser fundamentada a decisão judicial condenatória.

Com o intuito de abarcar, da maneira mais didática a abrangente possível, os principais temas processuais relacionados à condenação ao pagamento de indenização punitiva, optou-se por enfrentar tais questões em tópicos distintos. Tais questões foram, então, agrupadas de acordo com a ordem em que seriam apreciadas no curso de uma ação condenatória submetida ao procedimento ordinário ${ }^{739}$, procedimento este escolhido para a

\footnotetext{
${ }^{738}$ Vale ressaltar que a doutrina penalista reputa o princípio da pessoalidade da pena plenamente aplicável, mesmo em se tratando de penas de multa. Nesse sentido, Guilherme de Souza NuCCI assevera que "o respeito à personalidade da pena seria vilipendiado, caso se decida cobrar a pena de multa, aplicada ao condenado, de seus herdeiros. [...] Se a responsabilidade penal é pessoal, por óbvio não pode, jamais, atingir inocentes, não participantes do crime. [...] Ora, morto o condenado, cessa, de imediato, o interesse punitivo estatal, pois a pena não passará da pessoa do delinquente. Pouco importa se é constituída por multa, por prisão ou qualquer outra forma de restrição à liberdade individual." (Princípios Constitucionais Penais e Processuais Penais, São Paulo, RT, 2010, págs. 154/155).

739 Segundo Cândido Rangel DINAMARCO, “[o]rdinário é o procedimento de aplicabilidade geral a todas as causas para as quais a lei não determine a aplicação de algum outro" (Instituições de Direito Processual
} 
presente análise por ser referido pela doutrina especializada como o mais completo procedimento cognitivo previsto em nosso ordenamento processual ${ }^{740}$.

A presente verificação, portanto, será realizada em tópicos nos quais serão abordadas as questões atinentes: (i) à fase postulatória, a qual abarca a propositura da demanda, a citação do demandado e o oferecimento de sua defesa; (ii) às fases ordinatória e instrutória, fases nas quais, respectivamente, o juiz põe ordem ao processo e são produzidas as provas pleiteadas pelas partes para a demonstração das questões de fato; e, por fim, (iii) à fase decisória, na qual é proferido o julgamento do feito ${ }^{741}$.

\section{VI.I. Fase postulatória}

A fase postulatória é a aquela que concentra os atos de postulação das partes, comportando a dedução da pretensão do autor (o que é feito por meio da apresentação de sua petição inicial), a citação do réu (ato pelo qual a relação processual se complementa) e a apresentação de defesa pelo réu (sua postulação defensiva, ordinariamente feita por meio de contestação na qual postulará pela improcedência dos pedidos deduzidos em petição inicial). Para os objetivos aqui fixados, interessa-nos, em especial, analisar a demanda inicial e a resposta do réu, especificamente no que concerne aos ônus processuais das partes em relação ao pedido de condenação do réu ao pagamento de indenização punitiva.

Civil, vol. III, $4^{\text {a }}$ ed., São Paulo, Malheiros, 2004, pág. 345); no que é complementado por Vicente GRECO FILHO, para quem tal procedimento "é o mais comum de todos, não só porque se aplica na ausência de disposição especial expressa, mas também porque é subsidiário a todos os demais [...]. Ademais, comumente nos procedimentos especiais, após algumas providências próprias específicas e dependendo da eventualidade de contestação do réu, passa-se ao procedimento ordinário”. (Direito Processual Civil Brasileiro, vol. II, 16 ed., São Paulo, Saraiva, 2003, pág. 88).

${ }^{740}$ Nesse sentido, Cândido Rangel DINAMARCO afirma que "[d]e todos os procedimentos, o ordinário é o que mais nitidamente se reparte em fases, seja porque contém cognição literalmente completa, seja porque seus atos não são concentrados como em outros (sumário, mandado de segurança, juizados especiais cíveis [...]). Entre essas fases, distribuem-se os atos necessários à preparação e oferta da tutela jurisdicional mediante sentença, não se excluindo nenhum daqueles que são considerados elementos estruturais dos procedimentos cognitivos (demanda, citação, resposta, instrução e sentença [...]) e incluindo-se todos os demais que as leis processuais instituem e disciplinam. É, portanto, um procedimento completo em todos os sentidos". (Instituições de Direito Processual Civil, vol. III, 4 a ed., São Paulo, Malheiros, 2004, pág. 346).

${ }^{741}$ Cândido Rangel DinamarCo, Instituições de Direito Processual Civil, vol. III, $4^{\mathrm{a}}$ ed., São Paulo, Malheiros, 2004 , págs. $348 / 353$. 
Como já se teve a oportunidade de analisar ao tratarmos da suposta incompatibilidade entre a indenização punitiva e as hipóteses de responsabilidade objetiva, o primeiro ônus que ostenta o demandante (e isso, antes mesmo do ajuizamento da demanda e da formação da relação jurídica processual) é o ônus de demandar: aquele que pretende a obtenção de uma tutela jurisdicional deve, para tanto, vir deduzir tal pretensão em juízo (= demandar). Vale dizer: o ofendido, tendo suportado os efeitos prejudiciais de um ato ilícito (ou de uma atividade perigosa) cometido com alto grau de reprovabilidade, nos termos acima tratados, passa a fazer jus à condenação do ofendido tanto no que concerne ao pagamento de indenização compensatória (com o que terá seu patrimônio integralmente recomposto, em atenção ao princípio do restitutio in integrum), quanto no que toca ao pagamento de indenização punitiva (com o que o ofensor terá seu patrimônio invadido por meio da incidência de sanção pecuniária punitiva, destinada a puni-lo pelo mal causado e a dissuadi-lo do cometimento de novos atos prejudiciais).

Nesse mister, cumpre ao ofendido, em primeiro lugar, narrar adequadamente os fatos e os fundamentos jurídicos dos pedidos que irá deduzir, tanto de condenação do demandado ao pagamento de indenização compensatória quanto de indenização punitiva (art. 282, III, do CPC). Isso quer dizer, na linha do quanto já exposto, que o ofendido tem o ônus de afirmar a existência de todos os fatos que a doutrina processual denomina de "fatos essenciais", ou seja, aqueles fatos que, à luz do direito material, conduzirão ao resultado jurídico pretendido (no caso em questão, à condenação do ofendido ao pagamento de indenização compensatória e punitiva) ${ }^{742}$.

Tais fatos serão não apenas aqueles necessários para a configuração da responsabilidade civil do demandado (ordinariamente, aqueles que demonstrem a ilicitude da conduta, a culpa do ofensor, o dano suportado pelo ofendido e o nexo de causalidade entre a conduta ilícita e o dano), indispensáveis para a procedência do pedido condenatório relacionado à indenização compensatória; mas, também, aqueles relacionados à incidência da indenização punitiva (relacionados, portanto, aos pressupostos objetivos e subjetivos acima expostos), indispensáveis, por sua vez, para a procedência deste pedido condenatório.

${ }^{742}$ José Rogério Cruz e TuCCI, A Causa Petendi no Processo Civil, $2^{\mathrm{a}}$ ed., São Paulo, RT, 2001, págs. 153/154. 
Nessa linha, a petição inicial deverá trazer, para além da alegação da existência dos fatos que lhes servirão de fundamento, ambos os pedidos condenatórios (tanto o referente à indenização compensatória quanto o referente à indenização punitiva), devidamente especificados, certos e determinados (art. 282, IV, CPC) ${ }^{743}$.

A necessidade de que a exordial exponha não apenas os pedidos, mas, também os fatos e fundamentos nos quais aqueles se amparam, decorre justamente do princípio da congruência, o qual se extrai da interpretação conjugada dos artigos 128 e 460, todos do CPC, e prescreve que "o juiz está adstrito aos elementos objetivos da demanda, tal como deduzidos na inicial ou acrescentados oportunamente (arts. 262 e 264)"744, antes da estabilização da demanda.

Dessa forma, considerando que o objeto litigioso delimitado na petição inicial é composto tanto pelo(s) pedido(s) quanto pela(s) causa(s) de pedir que o(s) ampara(m) ${ }^{745}$, o juiz se encontra, por força do princípio da congruência, impedido de proferir julgamento (= prolatar sentença) fora dos estritos limites fixados por tal objeto (formado pela causa de pedir e pelo pedido), sob pena de, em assim o fazendo, proferir sentença viciada, ultra (sentença que concede quantidade ou quantia maior do que aquela pretendida pelo autor) ou extra petita (sentença que concede coisa diversa daquela pretendida pelo autor, ou com

\footnotetext{
${ }^{743}$ Contra e, a nosso ver, sem razão, segue Caroline VAZ, para quem, se o montante referente à indenização punitiva for atribuído, ex vi legis, a outro destinatário que não o próprio ofendido (como, por ex., a um fundo público, opção esta referendada pela citada autora), tornar-se-ia desnecessária a dedução de pedido expresso de condenação do ofensor ao pagamento dessa sanção punitiva. (Funções da Responsabilidade Civil - Da Reparação à Punição e Dissuasão - Os punitive damages no Direito Comparado e Brasileiro, Porto Alegre, Livraria do Advogado, 2009, pág. 133). Quer-nos parecer, contudo, que a destinação do bem da vida pretendido (pecúnia decorrente da indenização punitiva) é irrelevante no que concerne à necessidade de respeito ao princípio da congruência (arts. 128 e 460, CPC), devendo a sentença atentar aos limites estritos do objeto litigioso (formado pelo pedido e pela causa de pedir), sob pena de nulidade. Insta frisar que, mesmo no âmbito da common law, imputa-se ao demandante o ônus de deduzir requerimento expresso de condenação do demandado ao pagamento de punitive damages. Nesse sentido, a regra 16.4(1)(c) das Civil Procedure Rules inglesas determina que, se o demandante pretende o recebimento de aggravated ou exemplary damages, ele deve deduzir em juízo pedido expresso nesse sentido, amparado pelos fatos que o sustentem (prevê a regra, expressamente, que "[p]articulars of claim must include [...] c) if the claimant is seeking aggravated damages or exemplary damages, a statement tothat effect and his grounds for claiming them [...]"). Segundo V. WILCOX, as razões dessa exigência decorrem do princípio do devido processo legal, do qual se depreende que o demandado tem o direito de saber quais são as acusações movidas contra ele, bem como os fatos que as fundamentam, não se podendo submetê-lo a surpresas durante o curso do processo (Punitive Damages in England, in H. KOZIOL - V. WILCOX (eds.), Punitive Damages: Common Law and Civil Law Perspectives, Wien, Springer, 2009, págs. 46/47).

${ }^{744}$ José Roberto dos Santos BedaQue, in Antônio Carlos MARCATo (coord.), Código de Processo Civil Interpretado, São Paulo, Atlas, 2003, pág. 354.

${ }^{745}$ Essa é a posição de W. HABSCHEID, conforme noticia José Rogério Cruz e TuCCI (A Causa Petendi no Processo Civil, $2^{\mathrm{a}}$ ed., São Paulo, RT, 2001, págs. 103/106).
} 
fundamentos diversos daqueles expostos pelo autor $)^{746}$; a qual, na exata parcela $(=$ nos exatos capítulos) em que extrapola tais limites, deve ser reputada nula ${ }^{747}$.

Assim, caso o ofendido pretenda ver o ofensor condenado ao pagamento de indenização punitiva, deverá demandar em face dele e deduzir, em cumulação sucessiva, tanto (i) o pedido prejudicial, de condenação do demandado ao pagamento de indenização compensatória (chamada demanda principal), quanto (ii) o pedido prejudicado, de condenação do demandado ao pagamento de indenização punitiva (demanda acessória), o qual somente terá seu mérito apreciado se o pedido prejudicial for julgado procedente.

Admite-se, contudo, que o pedido de condenação ao pagamento de indenização punitiva seja deduzido, como estabelece o art. 286, II, do CPC, de maneira "genérica" (rectius: ilíquida), relegando-se ao juiz a atribuição de quantificar a indenização quando da prolação da sentença. Isso se dá pela impossibilidade inicial de quantificar exatamente o bem da vida pretendido (= de se mensurar a sanção punitiva, o que, em última análise, somente seria realizado pelo julgador), que é exatamente o mesmo fundamento hoje referendado pela jurisprudência para justificar a dedução de pedido ilíquido de indenização por danos morais ${ }^{748}$.

\footnotetext{
${ }^{746}$ Reputando extra ou ultra petita a sentença proferida fora dos limites definidos tanto pelo pedido quanto pela causa de pedir, afirma Teresa Arruda Alvim WAMBIER que "[a]s causae petendi têm a função de identificar o pedido, exatamente da mesma forma que os fundamentos do decisório delimitam o seu sentido. Assim, deve entender-se que a identidade entre objeto do pedido e objeto da sentença envolve também a identidade de causa de pedir (da petição inicial) e de fundamento (da sentença). Por isso é que se tem decidido que também será extra petita a sentença que aprecie e conceda o pedido, mas por outro fundamento que não a causa de pedir invocada pela parte." (Nulidades do Processo e da Sentença, 6a ed., São Paulo, RT, 2007, págs. 299/300). No mesmo sentido, José Roberto dos Santos BEDAQuE, in Antônio Carlos MARCATO (coord.), Código de Processo Civil Interpretado, São Paulo, Atlas, 2003, pág. 354.

${ }^{747}$ Em razão da aplicação da regra consubstanciada no brocardo utile per inutile non viciatur (art. 248, CPC), o vício e, conseqüentemente, também a nulidade, atacarão apenas e tão-somente as parcelas (= capítulos) da sentença que não guardarem correspondência com o objeto litigioso, mantendo-se hígidos as demais parcelas não viciadas. Assim, se o autor da demanda narrou apenas os fatos essenciais para a configuração da responsabilidade do ofensor e, desses fatos, extraiu apenas o pedido de que ele fosse condenado ao pagamento de indenização compensatória, a sentença que concedenar o ofensor ao pagamento desta indenização e, também, na não pretendida indenização punitiva, será parcialmente nula, devendo-se dela decotar o capítulo condenatório referente à indenização punitiva. Mantém-se hígido, contudo, o capítulo referente à indenização compensatória. Sobre o tema, Cândido Rangel DinAMARCO, Capítulos da Sentença, São Paulo, Malheiros, 2002, págs. 87/89.

748 "É admissível o pedido genérico em ação de indenização por dano moral por não ser possível, quando do ajuizamento da ação, determinar-se o valor devido". No mesmo sentido: (STJ; 3 T.; Agravo Regimental no AIDDRESP n. ${ }^{\circ}$ 1300075/SP; Relator: Min. Massami Uyeda; J. 03.08.2010); (STJ; $1^{\text {a }}$ T.; RESP n. ${ }^{\circ}$ 1041745/ES; Relatora: Min. Denise Arruda; J. 04.06.2009). No caso de dedução de pedido ilíquido, o valor a ser atribuído à causa deverá corresponder apenas ao valor do pedido prejudicial (demanda principal), ex vi dos arts. 258 e 259, II, CPC. Se o pedido prejudicial também comportar formulação ilíquida, admitir-se-á a apresentação de valor meramente estimativo, o qual comportará modificação posterior, quando da prolação
} 
Deduzida a pretensão inicial, delimitado o objeto litigioso e dado conhecimento ao réu da propositura da demanda por meio da citação (art. 213 e ss., do CPC), incumbe-se-lhe o ônus de responder, imperativo que deve exercer caso queira trazer a juízo afirmações contrárias àquelas apresentadas pelo autor, estabelecendo controvérsia sobre tais fatos e, conseqüentemente, convidando "o juiz a decidir conforme a prova e sua convicção" ${ }^{, 749}$. Mais do que simplesmente responder à demanda, incumbe ao demandado o ônus de impugnar especificamente os fatos narrados na exordial (art. 302, do CPC), o que pode ser feito não apenas quando se nega a existência de tais fatos, mas, também, quando se apresenta ao julgador uma nova versão dos mesmos fatos, procurando-se deles extrair conseqüências jurídicas distintas daquelas apresentadas na exordial ${ }^{750}$.

Tratando-se de imperativos de seu próprio interesse, o descumprimento, pelo demandado, dos ônus de responder e de impugnação específica, traz a ele uma mesma consequiência negativa: a de serem reputados verdadeiros os fatos narrados na exordial, quer em razão da revelia, no primeiro caso, quer, ainda, pela assim chamada "admissão da veracidade dos fatos", no segundo caso (respectivamente, arts. 319 e 302, in fine, do CPC). Nesse sentido, sustenta Umberto Bara BRESOLIN que, "[n]o atual processo civil pátrio, insista-se, [...] tanto se o réu silenciar totalmente, vale dizer, não apresentar qualquer resposta; quanto se silenciar parcialmente, no sentido de comparecer ao processo e deixar de impugnar algum dos fatos constitutivos alegados pelo autor, a conseqüência é a mesma:

da sentença condenatória. Analogamente: "CIVIL E PROCESSUAL CIVIL. AÇÃO DE INDENIZAÇÃO. DANOS MORAIS. PEDIDO GENÉRICO. VALOR DA CAUSA. ART. 258 DO CPC. 1. O valor dado à casa deve ser fixado de acordo com o conteúdo econômico a ser obtido no feito, conforme disposto nos arts. 258 e 259 do Código de Processo Civil. Todavia, na impossibilidade de mensuração da expressão econômica, o valor da causa pode ser estimado pelo autor em quantia provisória, passível de posterior adequação ao valor apurado na sentença. 2. Recurso Especial conhecido e provido." (STJ; $4^{\mathrm{a}}$ T.; RESP n. ${ }^{\circ}$ 714242/RJ; Relator: Min. João Otávio de Noronha; J. 26.02.2008). No mesmo sentido: (STJ; $1^{\text {a }}$ T.; RESP n. ${ }^{\text {o }}$ 764820/MG; Relator: Luiz Fux; J. 24.10.2006).

${ }_{749}$ Cândido Rangel DinAmarco, Instituições de Direito Processual Civil, vol. III, $4^{\mathrm{a}}$ ed., São Paulo, Malheiros, 2004, págs. 527/528. Vale ressaltar que nem todas as respostas do réu serão tidas como "respostas defensivas" (aquelas nas quais ele se opõe às pretensões deduzidas pelo autor). Pode o réu vir a juízo para apresentar as assim chamadas "respostas não defensivas", para, por ex., reconhecer a procedência do pedido, ou apenas para juntar procuração aos autos, doravante, passar a receber intimações relacionadas aos atos processuais (sobre o tema, Cândido Rangel DinAMARCO, op. cit., págs. 445/447 e Umberto Bara BRESOLIN, Revelia e seus Efeitos, São Paulo, Atlas, 2006, pág. 74). Para o que se analisará no presente tópico, contudo, interessam-nos apenas as "respostas defensivas" e, em especial, a contestação (arts. 297 e ss., CPC).

${ }^{750}$ Umberto Bara BRESOLIN, Revelia e seus Efeitos, São Paulo, Atlas, 2006, pág. 76. 
aquilo que não foi impugnado é admitido como verdadeiro, quer sejam todos os fatos alegados pelo autor (no primeiro caso), quer sejam apenas aqueles não impugnados"751.

Sob a ótica da instrumentalidade do processo, contudo, a doutrina e a jurisprudência mais modernas tendem a relativizar os efeitos da revelia e da ausência de impugnação específica dos fatos narrados na exordial mesmo para além das hipóteses excepcionais expressamente previstas em lei (previstas, por ex., nos arts. 302 e 320, CPC, e das quais vale destacar a impossibilidade de que sejam presumidos verdadeiros os fatos narrados se a demanda versar sobre direitos indisponíveis, ex vi do art. 320, II, CPC). Assim, ainda que o demandado não tenha respondido à demanda, o juiz não deve reputar verdadeiros os fatos alegados em petição inicial que se mostrem inverossímeis ou improváveis, contrapostos aos elementos de prova trazidos juntamente com a própria exordial ou, ainda, contrários a fatos notórios ${ }^{752}$.

Conclui-se que, em regra, incidem os efeitos da revelia mesmo em relação aos fatos que compõem a causa de pedir da pretensão condenatória referente à indenização punitiva (salvo, evidentemente, as exceções expressamente previstas em lei), porque conseqüência diversa não parece defluir do sistema ${ }^{753}$. Não se impede, contudo, que o juiz

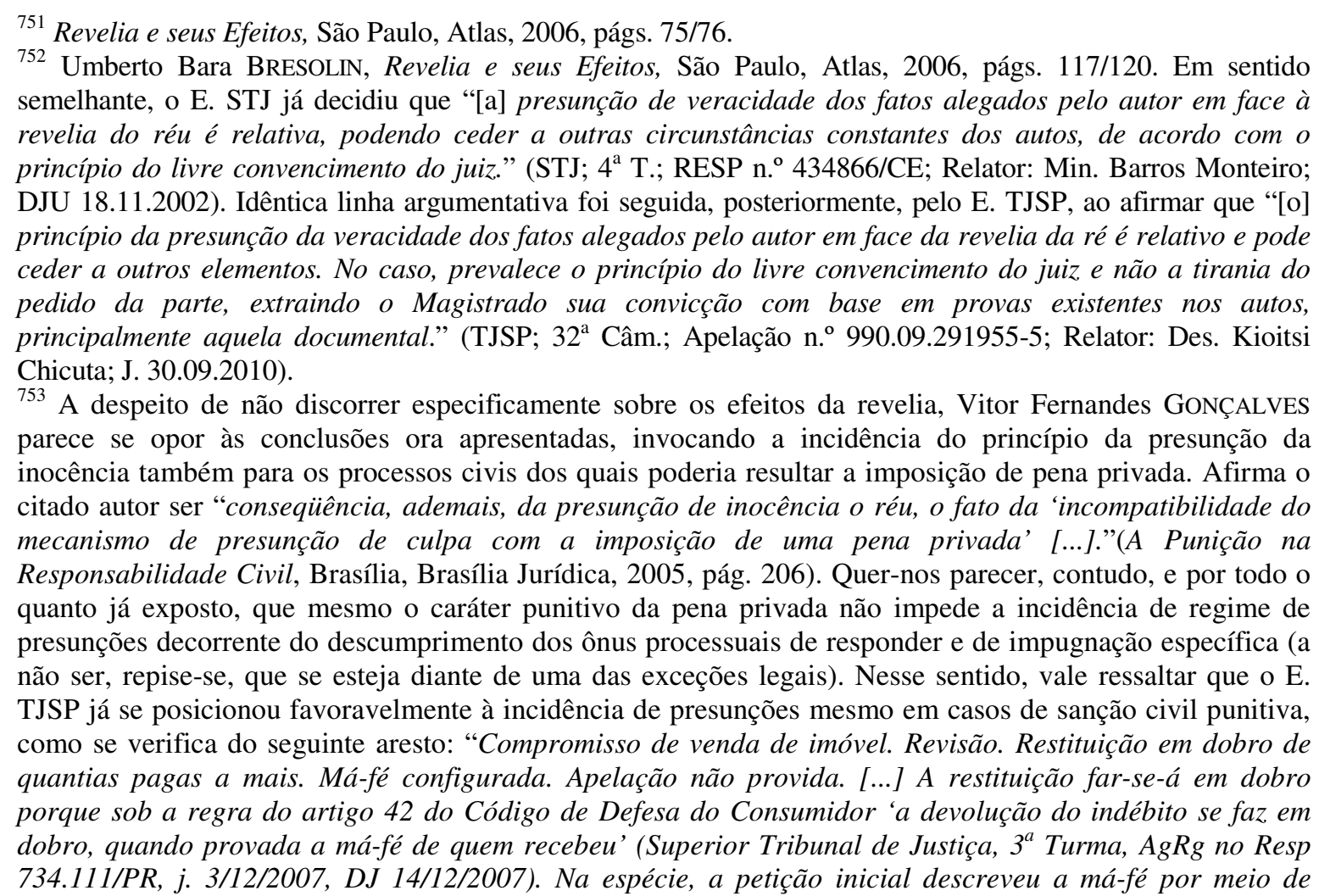


relativize tais efeitos se entender que aplicá-los contrariaria seu próprio convencimento (o qual deve ser livremente formado); o que poderá ocorrer, por ex., se, a despeito do requerimento de condenação do demandado ao pagamento de indenização punitiva fundado em ato ilícito doloso, for possível extrair dos documentos anexados à exordial que o ofensor se teria conduzido de maneira proba, procurando, tanto quanto possível, evitar o prejuízo decorrente de suas condutas.

Há que se frisar, por derradeiro, que os efeitos da revelia (ou da nãoimpugnação específica) atingem apenas e tão-somente os fatos narrados na exordial, nunca, jamais, as conclusões jurídicas que o demandante deles procura extrair. $\mathrm{O}$ juiz jamais ficará a elas adstrito e, mesmo se o demandado for revel, poderá julgar a demanda improcedente se dos fatos narrados não decorrer o direito invocado pelo autor. Nas palavras de Cândido Rangel DinAMARCO, "[n] ão obstante a revelia, os pontos de direito serão definidos segundo o entendimento do juiz, o qual tem sempre o dever de impor a norma pertinente, seja ela favorável ou contrária ao revel. Isso significa que as omissões do réu conduzem o juiz, simplesmente, a aceitar os fatos afirmados pelo autor, não necessariamente decidir a causa em favor deste" ${ }^{, 754}$.

\section{VI.II. Fases ordinatória e instrutória}

A fase ordinatória é aquela em que o juiz da causa, agindo essencialmente de ofício, "põe ordem no processo" com a finalidade de possibilitar a posterior instrução do feito para que se atinja o julgamento de mérito. Nessa fase, estão abrangidas: (i) as assim chamadas providências preliminares, pelas quais se oportuniza às partes o pleno exercício do contraditório (propriamente, arts. 323, 326 e 327, do CPC); (ii) o saneamento do feito, que envolve a tomanda (ou a ordem para que sejam tomadas) das providências necessárias para evitar a ocorrência de nulidades que pudessem viciar o feito (art. 327, in fine, do CPC), culminando com a prolação de julgamento conforme o estado do processo

certas condutas da ré (fls. 12/13) e a propósito verificaram-se os efeitos da revelia." (TJSP; 10ª̂̀m.; Apelação n. ${ }^{\circ}$ 499.217-4/0-00; Relator: Guilherme Santini Teodoro; J. 22.10.2008). Faz-se, por derradeiro, a ressalva de que a aplicação deste regime de presunções pode e deve ser mitigada, de acordo com o livre convencimento do juiz, formado em atenção à verossimilhança das alegações trazidas pelo demandante, dos demais elementos de prova produzidos no curso do processo, etc.

${ }^{754}$ Instituições de Direito Processual Civil, vol. III, $4^{\mathrm{a}}$ ed., São Paulo, Malheiros, 2004, pág. 536. 
(arts. 329 e 330, CPC), o qual pode acarretar a extinção do feito, se o caso; e, ainda, (iii) as atividades de organização da prova (arts. 324 e $331, \S \S 2^{\circ}$ e $3^{\circ}$, do CPC) ${ }^{755}$.

Não sendo o caso de pronta extinção do feito (quer em razão da impossibilidade de sanação das irregularidades, ex vi do art. 329, do CPC, quer, ainda, em razão da desnecessidade de produção de provas, ex vi do art. 330, do CPC), segue-se a fase instrutória (arts. 332 e ss., do CPC), a qual abarca, de modo geral, as atividades de instrução probatória, ou seja, de produção dos elementos de convencimento do juiz, que o levarão a apreciar o mérito da causa posta sob seu exame ${ }^{756}$.

No presente tópico, interessam-nos, em especial, as questões atinentes às atividades do juiz e aos ônus das partes no que concerne à produção da prova relacionada ao pedido de condenação do demandado ao pagamento de indenização punitiva.

O primeiro dos atos atinentes à prova é o requerimento de sua produção, deduzido pelas partes após o término da fase postulatória (art. 324, do CPC). Tal requerimento haverá de ser deduzido de maneira específica e fundamentada, com atenção aos ônus probatórios de cada uma das partes (estabelecidos no art. 333, do CPC) ${ }^{757}$.

\footnotetext{
755 Cândido Rangel Dinamarco, Instituições de Direito Processual Civil, vol. III, $4^{\mathrm{a}}$ ed., São Paulo, Malheiros, 2004, págs. 349/351.

${ }^{756}$ Cândido Rangel Dinamarco, Instituições de Direito Processual Civil, vol. III, $4^{\mathrm{a}}$ ed., São Paulo, Malheiros, 2004 , págs. 351/352.

757 Ônus dos quais as partes devem produrar se desincumbir se desejam aumentar suas chances de êxito na demanda. Ao contrário do ônus de afirmar, o qual, se descumprido, impedirá que o julgador tome conhecimento da existência dos fatos não alegados (salvo nas hipóteses em que incumbe ao juiz conhecer de fatos mesmo ex officio), o desatendimento em relação ao ônus da prova não leva, necessariamente, a um resultado desfavorável. É possível que o próprio julgador determine, de ofício, a realização de provas cuja produção incumbia, de ordinário, a uma das partes do processo (art. 130, CPC), ou que os fatos restem demonstrados por provas produzidas pela parte contrária. O que se quer dizer é que, embora o desatendimento ao ônus da prova possa não acarretar, necessariamente, um resultado desfavorável à parte (por ex., a improcedência da demanda do autor que deixa de demonstrar a existência dos fatos constitutivos de seu direito), ele, certamente, aumenta os riscos de produção desse resultado. Nesse sentido, Luiz Guilherme Marinoni - Sérgio Cruz ARenhart, Prova, São Paulo, RT, 2010, págs. 164/165 e Cândido Rangel Dinamarco, Instituições de Direito Processual Civil, vol. III, $4^{\mathrm{a}}$ ed., São Paulo, Malheiros, 2004, pág. 85. Vale lembrar, demais disso, que o ônus da prova sucede o ônus de afirmar, só havendo, em regra, a necessidade de demonstrar a ocorrência dos fatos alegados por uma das partes e negados pela outra (art. 334, II e III, CPC). Assim, caso queira ver seus pedidos acolhidos, o autor deverá ter afirmado a existência dos fatos relacionados à indenização compensatória e à indenização punitiva. Se não o fizer, não haverá o que provar, uma vez que, nas palavras de Cândido Rangel DINAMARCO, "para o processo, fato não alegado é fato irrelevante e portanto não poderá ser fundamento da decisão nem será objeto da prova [...]. Desse modo, nenhum fato irrelevante será provado no processo e portanto ninguém terá o encargo de prová-lo." (Instituições de Direito Processual Civil, vol. III, $4^{\mathrm{a}}$ ed., São Paulo, Malheiros, 2004, pág. 72).
} 
Ordinariamente, compete ao autor da ação o ônus de provar os "fatos constitutivos" de seus direitos (art. 333, I, do CPC) ${ }^{758}$, não apenas relacionados ao pedido de condenação do réu ao pagamento de indenização compensatória, mas, também, referentes ao pedido de condenação ao pagamento de indenização punitiva. Para se desincumbir de seu ônus, deverá o autor, portanto, comprovar a ocorrência dos fatos que dão ensejo à responsabilização do réu (para os casos de responsabilidade subjetiva, os fatos que demonstrem a ilicitude da conduta, a culpa do ofensor, o dano suportado pelo ofendido e o nexo de causalidade entre a conduta ilícita e o dano), e, também, à incidência da indenização punitiva (fatos que demonstrem a ocorrência dos pressupostos objetivos e subjetivos acima expostos, tais como o dolo ou culpa grave do ofensor, a obtenção de lucro em decorrência do ato ilícito, etc.) ${ }^{759}$.

Em oposição, ao réu incumbe o ônus de provar a ocorrência de "fatos impeditivos" (aqueles que impedem que os fatos alegados na exordial efetivamente constituam o direito invocado pelo autor, ou que impedem que, mesmo constituído o direito, venha ele a produzir os efeitos pretendidos, tais como, e.g., a legítima defesa, que impede a responsabilização do réu, ou a incapacidade do autor, que impede a constituição válida do contrato que pretende ver cumprido), "modificativos" (aqueles que alteram os efeitos produzidos pelos fatos alegados pelo autor, sem impedir a constituição do direito, tais como, e.g., a novação ou a transação) e "extintivos" (aqueles que, pressupondo a existência do direito invocado pelo autor, extinguem-no ou eliminam seus efeitos, tais como, e.g., o pagamento ou a prescrição da pretensão) dos direitos invocados pelo autor (art. 333, II, do CPC) ${ }^{760}$.

\footnotetext{
${ }^{758}$ Nas palavras de Fabio Guidi Tabosa PESSOA, fatos constitutivos do direito, não importando de qual das partes, são "aqueles tomados como base para a afirmação de um direito de que se imagine ela titular, e que pretenda ver reconhecido em juízo (assim, a existência da locação e a ocorrência de fato ou circunstância tidos por lei como autorizadores da retomada, em ação de despejo, a ocorrência de ato ilícito praticado pela outra parte e o prejuízo dele decorrente, em ação indenizatória)." (in Antônio Carlos MARCATO (coord.), Código de Processo Civil Interpretado, São Paulo, Atlas, 2003, pág. 1004).

759 Ao tratar do tema, Vítor Fernandes GONÇALVES sustenta que "é da vítima o ônus de demonstrar que a conduta do ofensor foi dolosa, e bem assim temperada pela malícia, pela má-fé ou por uma indiferença irresponsável aos direitos dos outros." (A Punição na Responsabilidade Civil: A indenização do dano moral e da lesão a interesses difusos, Brasília, Brasília Jurídica, 2005, pág. 143).

${ }^{760}$ Luiz Guilherme MARINONI - Sérgio Cruz AREnhart, Prova, São Paulo, RT, 2010, págs. 165/168. Não tem o réu, contudo, o ônus de provar a inexistência dos fatos constitutivos alegados pelo autor (ou seja, de provar que não ocorreram os elementos necessários para a sua responsabilização, ou que não estão presentes os pressupostos objetivos e subjetivos para a incidência da indenização punitiva). Ao réu (salvo eventual inversão do ônus da prova), basta se desincumbir do ônus de responder e de impugnar especificamente os fatos alegados pelo autor para impor a este o ônus de provar a sua existência, tornando-os, portanto, objeto da
} 
Diante dos requerimento deduzidos pelas partes, incumbe ao juiz, ao final da audiência preliminar e ainda no curso da fase ordinatória, caso não seja o caso de pronunciar a extinção do feito, organizar a produção da prova, o que significa: (i) “delimitar seu objeto", por meio da fixação dos pontos controvertidos (art. 331, § $2^{\circ}$, do CPC); (ii) "esclarecer as partes sobre o ônus da prova", advertindo cada uma delas sobre os fatos cuja ocorrência devem comprovar; e, por fim, (iii) "determinar os meios probatórios a serem realizados", optando sempre por aqueles que julgar adequados para a instrução do feito e indeferindo os inadequados ou inúteis (art. 130, do CPC) ${ }^{761}$.

Durante a fase instrutória, iniciada imediatamente após o término da audiência preliminar (nas hipóteses em que esta for efetivamente realizada), serão produzidos todos os meios de prova aptos para a descoberta dos fatos relacionados à responsabilização do réu e à incidência da indenização punitiva. No que toca, especificamente, à indenização punitiva, todos os meios previstos pelo Código de Processo Civil são, em tese, adequados, desde (i) o depoimento pessoal do réu (arts. 342 a 347, do CPC) ou sua confissão (arts. 348 a 354, do CPC), para que se possa dele extrair, por ex., seu estado de espírito durante o cometimento do ato ilícito; passando pela (ii) prova documental (arts. 364 a 399, do CPC), para que, e.g., possa-se aferir que determinada empresa construtora desenvolveu seu empreendimento imobiliário após ter obtido todas as aprovações dos órgãos públicos ambientais; e, até mesmo, pela prova pericial (arts. 420 a 439, do CPC), para que, por ex., por meio de uma análise técnica dos livros contábeis da empresa ré, possa-se aferir se, e de que forma, ela veio a obter lucros em razão do cometimento de determinada atividade perigosa, ou de determinado ato ilícito.

Ainda no curso da fase instrutória, pode o magistrado, caso se esteja diante de uma relação de consumo em que as alegações deduzidas pelo autor sejam verossímeis e reste demonstrada sua hipossuficiência em face do réu ${ }^{762}$, inverter o ônus da prova (art. $6^{\circ}$, VIII,

prova (ex vi do art. 334, II e III, CPC). Sobre o tema, Fabio Guidi Tabosa PESSOA, in Antônio Carlos Marcato (coord.), Código de Processo Civil Interpretado, São Paulo, Atlas, 2003, pág. 1004.

${ }^{761}$ Cândido Rangel Dinamarco, Instituições de Direito Processual Civil, vol. III, 4 a ed., São Paulo, Malheiros, 2004, pág. 561.

762 Nas palavras de Cândido Rangel DINAMARCO, "[e]mbora o texto [do art. 6", VIII, CDC] fale nominalmente em verossimilhança ou hipossuficiência, a leitura correta deve substituir o disjuntivo ou pelo aproximativo e, porque leitura nominal implicaria inconstitucionalidade do texto [...]." (Instituições de Direito Processual Civil, vol. III, 4 a ed., São Paulo, Malheiros, 2004, pág. 80). 
do CDC), impondo ao réu o ônus de demonstrar a inocorrência dos fatos constitutivos alegados pelo autor ${ }^{763}$. Nessas circunstâncias, admite-se a inversão do ônus mesmo em relação ao pedido de condenação do réu ao pagamento de indenização punitiva, oportunidade na qual a ele incumbirá o ônus de comprovar a inocorrência dos pressupostos objetivos e subjetivos necessários para a incidência de tal sanção ${ }^{764}$.

Ao decidir sobre a inversão, contudo, o julgador deverá se conduzir com cautela, jamais se admitindo a imposição de ônus excessivamente gravoso ao demandado, verdadeira diabolica probatio. Como bem assevera Cândido Rangel DinAmarco, a inversão do ônus da prova por “decisão do juiz não poderá ser eficaz quando for além do razoável e chegar ao ponto de tornar excessivamente difícil ao fornecedor o exercício de sua defesa. Eventuais exageros dessa ordem transgrediriam a garantia constitucional da ampla defesa e conseqüentemente comprometeriam a superior promessa de dar tutela jurisdicional a quem tiver razão (acesso à justiça)" ${ }^{, 765}$.

\footnotetext{
${ }^{763}$ A despeito de autorizada posição doutrinária no sentido de que a inversão do ônus da prova deve ocorrer no momento do julgameto da causa (por todos, cfr. Kazuo Watanabe, Código Brasileiro de Defesado Consumidor Comentado pelos Autores do Anteprojeto, $9^{\mathrm{a}}$ ed., Rio de Janeiro, Forense Universitária, 2007, págs. 814/816), entendemos que a inversão jamais pode ser utilizada como instrumento de surpresa, sob pena de infringir os princípios constitucionais do contraditório, da ampla defesa e do devido processo legal (art. $5^{\circ}$, LIV e LV, CF/88). O demandado deve ser corretamente instruído sobre os fatos cuja existência deve comprovar e, se o julgador entender ser o caso de inverter as regras ordinárias de distribuição do ônus da prova, o demandado deve ser oportunamente informado de tal decisão, tanto para que possa dela recorrer quanto, principalmente, para que possa produzir as provas que lhe incumbem. Nesse sentido, Fabio Guidi Tabosa PessoA, in Antônio Carlos Marcato (coord.), Código de Processo Civil Interpretado, São Paulo, Atlas, 2003, págs. 1006/1008.

${ }^{764}$ Em sentido contrário, André Gustavo Corrêa de ANDRADE afirma ser "no mínimo questionável a aplicação, no caso, da regra do art. 6, VIII, do Código de Defesa do Consumidor (Lei n. ${ }^{\circ}$ 8078/90), que estabelece a inversão do ônus da prova quando for verossímil a alegação do consumidor ou quando for ele hipossuficiente, segundo as regras ordinárias de experiência." (Dano Moral e Indenização Punitiva: Os punitive damages na experiência do common law e na perspectiva do Direito brasileiro, Rio de Janeiro, Forense, 2006, pág. 288). Quer-nos parecer, contudo, que tal conclusão não se sustenta. Com efeito, nada se extrai do sistema processual que impeça a inversão do ônus da prova mesmo em relação a demandas que versem sobre a imposição de sanções punitivas. Pelo contrário, quando presentes os requisitos de verossimilhança das alegações e hipossuficiência do autor, o E. TJSP já admitiu a inversão do ônus da prova mesmo para a apreciação de pedido de condenação do réu ao pagamento de indenização punitiva (como é o caso, por ex., da restituição em dobro prevista no art. 42, par. ún., CDC). Veja-se: "Prestação de serviços. Repetição de indébito. Cobrança de serviço não prestado. Pedido de devolução em dobro de quantias indevidamente cobradas. Sentença de procedência. Recurso não provido. 1. Ao contrato de prestação de serviço de telefonia aplicam-se as normas do Código de Defesa do Consumidor, em especial a possibilidade de inversão do ônus da prova nos termos do art. $6^{\circ}$, inciso VIII, em razão da hipossuficiência do consumidor frente ao prestador de serviço. 2. Compete à ré comprovar a licitude e exigibilidade dos valores em cobrança. Não o fazendo, o débito é inexigível, determinando-se a devolução dos valores pagos, com os acréscimos legais. 3. Restituição em dobro devida, já que não comprovado o engano justificável da ré e irrelevante não tenha havido dolo ou má-fé. Precedentes do STJ a respeito." (TJSP; $29^{\mathrm{a}}$ Câm.; Apelação n. ${ }^{\circ}$ 992.09.049563-1; Relator: Des. Reinaldo de Oliveira Caldas; J. 11.08.2010). No mesmo sentido: (TJSP; 30 a Câm.; Apelação n. o 992.08.068159-9; Relator: Des. Orlando Pistoresi; J. 30.06.2010).

${ }^{765}$ Instituições de Direito Processual Civil, vol. III, $4^{\mathrm{a}}$ ed., São Paulo, Malheiros, 2004, págs. 80/81.
} 
Por derradeiro, mas ainda tratando sobre a instrução probatória, vale ressaltar que, no âmbito do processo civil, no qual se desenrolará a análise da incidência da indenização punitiva, "[c]onsidera-se cumprido o onus probandi quando a instrução processual houver chegado à demonstração razoável da existência do fato, sem os extremos da exigência de uma certeza absoluta, que muito dificilmente se atingirá,"766. Assim, para que o autor se desincumba de seu ônus probatório, basta que demonstre, por quaisquer meios lícitos, que existe uma razoável probabilidade de os fatos constitutivos de seu direito (de obter a condenação do réu ao pagamento de indenização compensatória e punitiva) terem ocorrido nos exatos termos em que narrados na exordial. Para a condenação do réu, mesmo em relação ao pagamento de indenização punitiva, não se exige mais do que essa "razoável probabilidade de ocorrência" dos pressupostos objetivos e subjetivos necessários para a incidência da sanção punitiva, diferentemente do que ocorreria, portanto, no âmbito do processo penal ${ }^{767}$.

\section{VI.III. Fase decisória}

Encerrada a instrução do feito, e não se verificando a ocorrência de nulidade insanável ou outra circunstância que imponha a extinção do feito, o juiz decidirá o mérito da demanda, acolhendo ou rejeitando os pedidos condenatórios deduzidos pelo autor (tanto

\footnotetext{
${ }^{766}$ Cândido Rangel Dinamarco, Instituições de Direito Processual Civil, vol. III, $4^{\mathrm{a}}$ ed., São Paulo, Malheiros, 2004, pág. 81.

${ }^{767}$ Em oposição às conclusões acima apresentadas, André Gustavo Corrêa de ANDRADE afirma que, "[e]m se tratando de imposição de sanção de caráter punitivo, seria exigível a produção de prova convincente da culpa do réu pelo evento, à semelhança do que ocorre no processo penal." (Dano Moral e Indenização Punitiva: Os punitive damages na experiência do common law e na perspectiva do Direito brasileiro, Rio de Janeiro, Forense, 2006, pág. 288). Vitor Fernandes GONÇALVES, aludindo, de maneira ainda mais evidente, ao diversos "graus de persuasão" exigidos nos países da common law, afirma que "decorre da presunção de inocência do réu o fato de que somente é possível considerar provada a conduta e a culpa mediante provas que incutam no julgador não apenas uma mera preponderância de evidências (preponderance of evidence) senão mesmo a quase certeza absoluta da ocorrência da conduta faltosa e da culpa do réu (evidence beyond reasonable doubt)". (A Punição na Responsabilidade Civil, Brasília, Brasília Jurídica, 2005, pág. 207). Discordamos de tais posicionamentos, basicamente, por duas razões: (i) a uma, porque nosso processo civil (e, especificamente, as regras atinentes ao ônus da prova) incide sem percalços sobre diversas outras hipóteses de sanção civil punitiva (tais como a deserdação, a indignidade e a extinção do poder familiar); e, (ii) a duas, porque mesmo nos Estados Unidos da América já se decidiu, ao julgar Pacific Mutual v. Haslip, não serem inconstitucionais, em face da due process clause (em nenhum de seus aspectos), as condenações ao pagamento de punitive damages em processos regidos pelo "grau de persuasão" denominado "preponderância de provas" (499 U.S. 23 1990, pág. 23).
} 
em relação à indenização compensatória quanto em relação à indenização punitiva) na assim chamada fase decisória ${ }^{768}$.

Como já se expôs, o pedido de condenação do demandado ao pagamento de indenização punitiva somente poderá ser deduzido em cumulação com o pedido condenatório referente à indenização compensatória (o que se fará com fundamento no art. 292, CPC), cumulação esta que se dará em ordem sucessiva. O primeiro é, portanto, verdadeira demanda acessória (pedido prejudicado), subordinada ao sucesso da demanda principal (pedido prejudicial). Isso quer dizer que somente "[a] procedência do pedido principal [de condenação do demandado ao pagamento de indenização compensatória] permitirá que o juiz aprecie os demais requisitos para acolher o acessório" e que "a [eventual] improcedência daquele [pedido principal] impõe também a deste [pedido acessório, de condenação do ofensor ao pagamento de indenização punitiva]"769.

Ainda nos moldes já expostos, em razão da delimitação do objeto litigioso pelas causas de pedir e pelos pedidos deduzidos na exordial, não poderá o juiz proferir sentença de mérito que extrapole tais limites, devendo a eles atentar estritamente, sob pena de proferir decisão ultra ou extra petita, parcial ou totalmente viciada e passível de anulação (arts. 128 e 460, do CPC). Assim, se, em sua exordial, o demandante somente expuser fatos (causa de pedir remota) pertinentes à responsabilização do demandado e, destes fatos, deduzir apenas o pedido de condenação do demandado ao pagamento de indenização compensatória, não poderá o julgador proferir sentença que o condene ao pagamento de indenização punitiva, sob pena de nulidade do julgado.

Havendo, na exordial, cumulação objetiva de pedidos, a sentença que apreciar o mérito da demanda será composta de tantos capítulos quantos forem tais pedidos $^{770}$. Para o que nos interessa no momento, isso significa dizer que a sentença conterá um capítulo no qual acolherá ou rejeitará a pretensão do autor de ver o réu condenado ao pagamento de indenização compensatória e outro capítulo, cuja apreciação

\footnotetext{
${ }^{768}$ Cândido Rangel DinAmARCo assevera que, menos do que propriamente uma fase, a "fase decisória" é composta por um momento, aquele no qual o feito é efetivamente decidido por meio da prolação de uma sentença (Instituições de Direito Processual Civil, vol. III, $4^{a}$ ed., São Paulo, Malheiros, 2004, pág. 353).

${ }^{769}$ Cândido Rangel Dinamarco, Instituições de Direito Processual Civil, vol. II, $2^{\mathrm{a}}$ ed., São Paulo, Malheiros, 2002, pág. 169.

${ }^{770}$ Cândido Rangel Dinamarco, Capítulos de Sentença, São Paulo, Malheiros, 2002, págs. 64/67.
} 
será subordinada ao resultado do primeiro, no qual se decidirá se o réu deve, ou não, ser também condenado ao pagamento de indenização punitiva.

A decomposição das pretensões do autor em capítulos de sentença distintos impõe a decomposição das condenações em dois montantes diversos, por razões que, no dizer de André Gustavo Corrêa de ANDRADE, são "não apenas de conveniência, mas de necessidade" 771 . Com efeito, apenas com a separação da condenação em dois montantes distintos é que poderá o julgador expressar com maior precisão quais foram os critérios utilizados para a quantificação das verbas indenizatórias e em qual medida tais critérios incidiram para cada um dos casos (tanto aquele com fins meramente compensatórios quanto aquele com fins punitivos e preventivos) ${ }^{772}$.

É de rigor, portanto, que a decisão judicial seja devidamente fundamentada, expondo o magistrado os motivos pelos quais entendeu presentes (e em que medida) os critérios necessários para a quantificação quer da indenização compensatória, quer da indenização punitiva. É apenas o cabal cumprimento a tal exigência constitucional (art. 93, $\mathrm{IX}$, do CF/88) "que trará segurança e compreensão à pessoa eventualmente condenada e a

771 Dano Moral e Indenização Punitiva: Os punitive damages na experiência do common law e na perspectiva do Direito brasileiro, Rio de Janeiro, Forense, 2006, pág. 319.

772 As dificuldades geradas pela quantificação da indenização em montante único, destinado, ao mesmo tempo, a compensar o prejuízo suportado pela vítima e a punir o ofensor (especialmente quando se está diante de condenações ao pagamento de indenização por danos morais) é apontada por Marcela Alcazas BASSAN, a qual após análise das razões expostas em julgados que versam sobre o tema, assevera que "[h]á uma constante referência à função punitiva da indenização por danos morais, nos tribunais inferiores, que por vezes chegam até mesmo a fazer menção aos punitive damages. Entretanto, a indenização é fixada sempre em um único valor, sem se explicitar seu montante punitivo." (As Funções da Indenização por Danos Morais e a Prevenção de Danos Futuros, Dissertação (Mestrado) - Faculdade de Direito da USP, São Paulo, 2009, pág. 123). Tal preocupação é compartilhada por Wesley de Oliveira Louzada BERNARDO, o qual, a nosso ver com correção, afirma que, "[a]tualmente, mesmo sem lei autorizativa, é comum aos tribunais indicarem, no arbitramento, que a verba foi calculada tendo em conta seus 'fins pedagógicos' e o 'desestímulo' ao causador do dano, sem indicarem quanto tal parcela representa, o que inviabiliza, no mais das vezes, a possibilidade de o condenado demonstrar a inadequação do quantum debeatur." (Dano Moral: Critérios de Fixação de Valor, Rio de Janeiro, Renovar, 2005, pág. 181). A jurisprudência pátria é campo fértil para a verificação de casos nos quais a quantificação da indenização se dá sem a menor discriminação de em que medida os diferentes critérios foram utilizados para compensar o prejuízo ou punir o ofensor. Veja-se, apenas à guisa de exemplo, o seguinte aresto, no qual se referendou a condenação ao pagamento da moderada quantia de $\mathrm{R}$ \$2.000,00 pela inclusão indevida dos dados de devedor nos cadastros de restrição ao crédito, aludindo-se expressamente à função punitiva da responsabilidade civil sem, contudo, afirmar-se em que medida a culpa do demandado (de cujo grau sequer se cogitou) ou o prejuízo do ofendido influiriam para a quantificação da indenização " 1. [...] 2. Contratação de serviços de telefonia. Ausência de prova a respeito. Inserção indevida do nome da autora nos órgãos de proteção ao crédito. Reparação moral devida. Fixação moderada. Apelo improvido. [...] $O$ valor reparatório foi fixado em patamar bastante moderado - $R \$$ 2.000,00, frisando-se que a natureza do dano moral entre nós é também inibitória, à maneira sim dos 'punitive damages' ou 'exemplary damages' do direito norte-americano, fonte maior do nosso artigo $5^{\circ}$, $V e$ X, CFederal.” (TJSP; 11 a Câm.; Apelação n. o 7089397-5; Relator: Des. Soares Levada; J. 15.02.2007). 
todas aquelas que vierem a tomar conhecimento de dita decisão, pois lhes permite visualizar a menção, no corpo da sentença, dos elementos que informaram a convicção do magistrado, sob pena de o instituto estar fadado ao insucesso e à incompreensão"773.

\section{A DESTINAÇÃo DA INDENIZAÇÃ̃ PUNITIVA}

Ainda tratando sobre os aspectos que julgamos pertinentes para a introdução legislativa da indenização punitiva em nosso ordenamento, cumpre-nos tecer algumas considerações sobre a destinação final do quantum indenizatório e, nesse mister, indicar qual dos três modelos regulativos consideramos o mais adequado para emprestar à indenização punitiva o tratamento legal mais eficiente e justo possível; ou seja, se, ao cabo da demanda indenizatória movida contra o demandado, a quantia por ele paga a título de indenização punitiva deve (i) ser destinada ao próprio demandante (o qual é vítima direta ou indireta do ato ilícito), em sistema assemelhado ao que se denomina de "private attorney general"; se, de outro lado, tal quantia deve (ii) ser destinada a um fundo público ou privado, cuja finalidade seja a de financiar melhorias sociais; ou, ainda, se a solução deve-se situar no meio do caminho, (iii) partilhando-se a indenização entre a vítima do ato ilícito e um fundo, público ou privado, em iniciativa semelhante àquela denominada de "split recovery".

Antes, contudo, de passarmos a analisar pormenorizadamente os modelos regulativos acima indicados, há que se reforçar nossa posição no sentido de que a opção por qualquer um deles representa, para a adoção da indenização punitiva, nada mais do que uma questão de política legislativa. Não existe, a nosso ver, opção "equivocada", "inválida" ou que, de qualquer forma, torne "inaplicável" a indenização punitiva previamente estabelecida em lei.

\footnotetext{
${ }^{773}$ Caroline VAZ, Funções da Responsabilidade Civil - Da Reparação à Punição e Dissuasão - Os punitive damages no Direito Comparado e Brasileiro, Porto Alegre, Livraria do Advogado, 2009, pág. 139. No mesmo sentido, André Gustavo Corrêa de Andrade, Dano Moral e Indenização Punitiva: Os punitive damages na experiência do common law e na perspectiva do Direito brasileiro, Rio de Janeiro, Forense, 2006, págs. 318 e Marcela Alcazas BASSAN, As Funções da Indenização por Danos Morais e a Prevenção de Danos Futuros, Dissertação (Mestrado) - Faculdade de Direito da USP, São Paulo, 2009, pág. 108.
} 
Uma vez previstas, de maneira suficiente e adequada, as hipóteses de incidência desta sanção punitiva, ela poderá ser imposta a demandados, sendo em tudo e por tudo irrelevante para a regularidade de sua incidência a destinação das quantias a ela referentes. Na esteira do quanto já asseverado, quer-se dizer com isso que, ainda que se optasse por entregar ao demandante a integralidade das quantias referentes à indenização punitiva, tal opção não macularia a incidência de tal sanção punitiva, não se podendo argüir a (suposta) ocorrência de enriquecimento sem causa por parte do demandante ${ }^{774}$. A opção por um dos três modelos regulativos é, portanto, uma questão de conveniência, e dessa maneira deve ser enfrentada.

\section{VII.I. Destinação à própria vítima}

Tendo como inspiração o regramento jurídico dos punitive damages, sustenta parte da doutrina ser "traço característico da responsabilidade civil punitiva [a qual preferimos denominar de indenização punitiva, por todas as razões previamente expostas] o recolhimento do quantum monetário a título de pena ao patrimônio do lesado e não aos cofres do estado, providência esta própria da responsabilidade administrativa e da responsabilidade penal"775. Dessa maneira, o primeiro modelo regulativo cogitado para a destinação da indenização punitiva é aquele que prevê o integral recebimento dessas quantias pelo demandante, em sistema aparentado ao que os doutrinadores norteamericanos denominam de "private attorney general".

Para os defensores desse posicionamento, entre os quais se situa Antonio JUNQUEIRA DE AZEVEDO, a atribuição ao demandante de quantia que exceda os estritos limites dos prejuízos efetivamente suportados por ele se justificaria porque, ao ajuizar uma demanda particular, destinada não apenas a recompor seu patrimônio, mas, igualmente, a punir o lesante pelo ilícito altamente reprovável por ele praticado e a desestimulá-lo (bem como à sociedade como um todo) do cometimento de novos ilícitos, o particular não estaria protegendo apenas seus próprios direitos e interesses, mas agindo em benefício de

\footnotetext{
${ }^{774}$ Como já se teve a oportunidade de expor, o enriquecimento do demandante (resultante do recebimento de quantia que excede os limites estritos do prejuízo suportado e que, conseqüentemente, supera a mera compensação) encontra causa justificadora na prévia cominação legal da indenização punitiva.

${ }^{775}$ Eduardo UILAN, Responsabilidade Civil Punitiva, Tese (Doutorado) - Faculdade de Direito da USP, São Paulo, 2003, pág. 93.
} 
toda a coletividade. Ao assim proceder, o demandante atuaria como que em substituição ao Ministério Público, exercendo um munus que, de ordinário, não lhe competiria, motivo pelo qual seria justificável, até mesmo por uma concepção de justiça, que ele recebesse, em troca do exercício desse munus, uma recompensa que lhe estimulasse ao ajuizamento de demandas dessa natureza. Nas palavras do citado autor, "[e]mbora esse ponto não seja facilmente aceito no quadro da mentalidade jurídica brasileiro, parece-nos que é preciso recompensar, e estimular, aquele que, embora por interesse próprio, age em benefício da sociedade. Trata-se de incentivo para um aperfeiçoamento geral" ${ }^{, 776}$.

Ainda que se possa curvar à pertinência do argumento acima apresentado (de que é interessante outorgar ao demandante uma quantia em dinheiro que lhe sirva de incentivo à propositura de medidas judiciais dessa natureza, as quais, ao mesmo tempo, buscam a recomposição do patrimônio lesado e o restabelecimento do equilíbrio social atingido pelo ilícito), importa de ver que, especialmente em países do sistema romanogermânico, as premissas utilizadas para ancorá-lo são, para dizer o mínimo, mitigadas. Por tal motivo, não são poucos os doutrinadores que se opõem com veemência à atribuição da indenização punitiva ao demandante, enumerando, em defesa da inconveniência dessa opção, uma série de argumentos igualmente fortes.

Nesse sentido, Maria Celina Bodin de MoRAES afirma que "o valor a mais da indenização, a ser pago 'punitivamente', não poderá ter como destinatário a vítima, mas, coerentemente com o nosso sistema, deverá servir a beneficiar um número maior de pessoas, através do depósito das condenações em fundos pré-determinados" ${ }^{, 777}$. Tal posicionamento é seguido à risca pelo professor espanhol G. V. ROBREDO, o qual afirma categoricamente que, ainda que se pudesse considerar que a indenização punitiva cumpre, eficientemente, funções de punição e dissuasão, isso só justificaria que ao demandado se impusesse uma condenação que superasse os limites do dano efetivamente causado, "mas em nenhum caso justificaria que essa quantia, que excede o necessário para a mera

\footnotetext{
776 Por Uma Nova Categoria de Dano na Responsabilidade Civil: O Dano Social, in Novos Estudos e Pareceres de Direito Privado, São Paulo, Saraiva, 2009, pág. 383.

777 Punitive Damages em Sistemas Civilistas: Problemas e Perspectivas, in Revista Trimestral de Direito Civil, vol. 18, Rio de Janeiro, Padma, abr./jun. 2004, pág. 77.
} 
compensação, seja entregue à vítima" ${ }^{, 78}$. Mesmo na Inglaterra, país no qual não se encontram presentes as características típicas dos Estados Unidos da América que levaram ao desenvolvimento da teoria do "private attorney general", não são poucas as vozes que se levantam contra a destinação da indenização punitiva à própria vítima. Para S. DEAKIN, A. JOHNSTON e B. MARKESINIS, "ainda que se possa admitir uma condenação que retire do demandado todo o lucro que ele tenha obtido por meio de sua conduta ilícita, não existe razão para que esta quantia extra deva ser entregue ao demandante, enriquecendo-o nesta exata medida (tivesse a punição decorrido de uma multa, a quantia teria sido endereçada ao Estado), ${ }^{, 779}$.

Em contrariedade com a opção de destinar a indenização punitiva à própria vítima do ilícito, o primeiro forte argumento levantado pela doutrina segue no sentido de que, nos países de raiz romano-germânica, a teoria do "private attorney general" tem sua finalidade, no mínimo, mitigada pela inexistência da assim chamada "regra americana".

Isso porque, como se teve a oportunidade de analisar, nos Estados Unidos da América não se costuma carrear à parte sucumbente a obrigação de arcar com os custos da litigância originalmente suportados pela parte vencedora (que envolvem não apenas as custas e despesas processuais, mas, também, os honorários advocatícios). Desse modo, o ajuizamento de uma demanda judicial envolve necessariamente o desembolso (a título perdido) de expressivas quantias, as quais não serão reembolsadas mesmo que o demandante venha a se sagrar vencedor do litígio. Isso é o que se denomina de "regra americana" quanto aos custos da litigância.

Justamente em atenção a tal característica, cogita a doutrina que, em hipóteses nas quais o prejuízo suportado pelo lesado é inferior aos eventuais custos para mover uma demanda em face do lesante, aquele se sentiria economicamente desestimulado a ajuizar uma medida judicial. Por tal razão, a perspectiva de recompensa, representada

\footnotetext{
778 No original, "[...] pero en ningún caso justificaría que esa cantidad, que excede de lo meramente compensatorio, se entregue a la víctima." (Daños Punitivos en el Proceso Civil Norteamericano, in Revista de la Universidad de Deusto, vol. 57, fasc. 97, jul-dic./ 1996, pág. 186)

${ }^{779}$ No original, "[...] whereas a case can be made for mulcting the bad defendant of the profits he has made from his tortious behaviour, there ir no reason why this extra sum should then be given to the claimant, enriching him by a corresponding amount. (Had the punishment been a fine the money would have gone to the state)." (Markesinis and Deakin's Tort Law, $6^{\text {th }}$ ed., New York, Oxford, 2008, pág. 950)
} 
pelo montante expressivo dos punitive damages, seria não apenas interessante, mas, muitas vezes, indispensável para que demandas legítimas viéssem a ser ajuizadas.

Tal perspectiva de recompensa, contudo, tem sua finalidade de legítimo incentivo bastante mitigada em países nos quais não vige a chamada "regra americana", uma vez que, por força do princípio da causalidade, os custos da litigância já são impostos à parte sucumbente, não se tratando de um desembolso a título perdido ${ }^{780}$. Mais do que isso, particularmente no que concerne ao nosso país, existem uma série de mecanismos que regulamentam a assistência judiciária gratuita, os quais servem de válvulas de escape para que pessoas menos favorecidas possam ter amplo acesso ao Poder Judiciário, sem a necessidade de prévio desembolso dos custos da litigância.

Dessa maneira, fora dos Estados Unidos da América, a aplicação da teoria do "private attorney general" deixa, em determinada medida, de representar um incentivo à litigância legítima (atuando como um fator de equilíbrio entre o valor da indenização devida e os custos da litigância) para, perigosamente, passar a representar um incentivo à litigância frívola, por atuar de modo a possibilitar a "sobrestimação dos ganhos do queixoso" (o qual poderá passar a ansiar pela ocorrência de um erro judicial, na expectativa de auferir ganhos muito superiores àqueles aos quais teria direito, ou, ainda, ganhos completamente indevidos, em hipóteses nas quais não faria jus ao recebimento de quantia alguma).

Ainda um segundo argumento que se pode levantar contra a solução preconizada pela teoria do "private attorney general" é a de que, principalmente em países de raiz romano-germânica, pode-se constatar uma tendência dos julgadores de, ainda que também cogitem de uma função preventivo-punitiva da indenização, controlar o montante da indenização para que a quantia resultante não importe em um enriquecimento do lesado.

Para além de todas as discussões (às quais já nos referimos anteriormente) acerca da verificação, ou não, do instituto jurídico do enriquecimento injustificado ou

\footnotetext{
${ }^{780}$ Nesse sentido, G. GEORGIADES pontua que, a despeito de ser uma questão presente também nos Estados Unidos da América, a discussão acerca da destinação da indenização punitiva é ainda mais severa na Europa continental, uma vez que "in Europe there is no tradition of a Private Attorney General and the trial expenses are considerably less, if they are not borne by the party who has lost the case". (Punitive Damages in Europe and the USA: Doctrinal Differences and Practical Convergence, in Revue Hellénique de Droit International, ano 58, Éditions Ant. N. Sakkoulas, 2005, pág. 159).
} 
enriquecimento sem causa (conforme previsto nos arts. 884 a 886, do CC/2002), parecem temer os julgadores - quiçá mais por fatores de ordem moral do que propriamente jurídica a possibilidade de atribuir ao lesado uma quantia verdadeiramente expressiva, que lhe sirva de enriquecimento. Ao se passar em revista julgados que versem principalmente sobre indenização por detrimentos morais, pode-se verificar que o fato de o destinatário final dos valores ser o próprio lesado motiva, em diversos casos, a moderação do quantum indenizatório $^{781}$, procurando-se evitar que, de alguma maneira, o recebimento da indenização pudesse lhes representar alguma sorte de enriquecimento (ainda que apenas moralmente) injustificado (ou, por assim dizer, imerecido).

Acreditamos, portanto, que a destinação integral e irrestrita do quantum indenizatório à própria vítima pode servir de incentivo para que os julgadores quantifiquem de maneira mais moderada a sanção punitiva, limitando, conseqüentemente, a eficiência de tal medida na persecução de suas finalidades punitiva e preventiva.

Desta feita, quer por uma razão, quer por outra, acreditamos que, ainda que inexista solução juridicamente inviável ou incompatível com nosso ordenamento, a destinação do quantum indenizatório à própria vítima não é a solução mais conveniente ou adequada para que se busque a mais plena eficácia do instituto da indenização punitiva.

\section{VII.II. Destinação a um fundo público}

Divergindo da posição acima apresentada, forte corrente doutrinária pugna pela adoção de uma solução que, em vez de admitir a integral atribuição da indenização

\footnotetext{
${ }^{781}$ Nesse sentido, o Extinto $2^{\circ}$ TACSP já teve a oportunidade de assentar que "[a] tese que defende a necessidade de exemplar punição para causador do dano não pode ser utilizada sem o tempero da prudência, porque, por outro lado, estar-se-á enriquecendo injustamente a vítima, muito além do que merece." (2 $2^{\circ}$ TACSP; Apelação n. ${ }^{\circ}$ 580310/0-00; Relator: Miguel Cucinelli; DOE 01.08.2000). Semelhantemente, mas em julgamento mais recente, o TJMG asseverou que "[o] valor da indenização deve ser fixado de forma razoável, de modo a evitar enriquecimento indevido." (TJMG; Apelação n. ${ }^{\circ}$ 1.0024.06.934880-3/002; Relator: Des. Pedro Bernardes; J. 02.10.2007). A jurisprudência é, ademais, profícua em julgados de sentido semelhante, nos quais se pondera que a indenização não pode representar um enriquecimento ao lesado, motivando-se, dessa maneira, a moderação do quantum. Nesse sentido, apenas à guisa de exemplo, confira-se: (STJ; RESP n. ${ }^{\circ}$ 719354/RS; Relator: Min. Barros Monteiro; J. 24.05.2005); (STJ; RESP n. ${ }^{\text { }}$ 258245/PB; Relator: Min. Sálvio de Figueiredo Teixeira; J. 15.05.2003); (TJSP; Apelação n. ${ }^{\circ}$ 992.07.036995-9; Relator: Des. Cristiano Ferreira Leite; J. 14.09.2009); (2 ${ }^{\circ}$ TACSP; Apelação n. $^{\circ}$ 662238/000; Relator: Cambrea Filho; DOE 02.12.2004); (2 TACSP; Apelação n. ${ }^{\circ}$ 701797/9-00; Relator: Américo Angélico; DOE 25.10.2001).
} 
punitiva à própria vítima do ilícito (ou ao autor da demanda indenizatória), propugna pela atribuição desse numerário à coletividade, quer por meio da entrega desses valores a um "estabelecimento local de beneficência" (aplicando-se analogamente o quanto previsto no art. 883, par. ún., CC/2002); quer, ainda, por meio da remessa das quantias a um fundo público que passaria a administrar o numerário recebido e a utilizá-lo para a reconstituição dos bens ou interesses lesados (nos moldes, por ex., previstos no art. 13, da Lei 7.347/1985, que criou o assim chamado "fundo de defesa dos direitos difusos").

Nessa linha de argumentos, Diogo Leonardo Machado de MELO afirma que "para que o desequilíbrio social não seja acentuado, e para que a sociedade tenha uma resposta efetiva a uma ofensa à dignidade, entendemos que a pena pecuniária de valor superior ao dano provocado [...] deverá ser destinada em benefício para a própria sociedade" ${ }^{782}$; no que é secundado por Maria Celina Bodin de MORAES, para a qual, "[e]m uma indenização 'exemplar', em se tratando de resposta à coletividade, o destinatário não poderia ser mesmo outro",783.

Segundo os doutrinadores que advogam pela adoção dessa solução (em detrimento da destinação da indenização punitiva ao lesado), sua primeira grande vantagem seria a eliminação da discussão a respeito do incentivo à litigância frívola ${ }^{784}$.

Como já se teve a oportunidade de expor anteriormente, ao, de um lado, retirar da vítima e de seu patrono (o qual poderia se valer de um acordo de quota litis para procurar auferir, a título de honorários advocatícios contratados, um percentual da indenização punitiva a ser imposta ao demandado ${ }^{785}$ ) a expectativa de recebimento de uma

\footnotetext{
782 Ainda sobre a Função Punitiva da Reparação dos Danos Morais (e a Destinação de Parte da Indenização para Entidades de Fins Sociais - Artigo 883, Parágrafo Único, do Código Civil de 2002), in Revista de Direito Privado, vol. 26, jun.-2006, págs. 105 e ss..

${ }^{783}$ Punitive Damages em Sistemas Civilistas: Problemas e Perspectivas, in Revista Trimestral de Direito Civil, vol. 18, Rio de Janeiro, Padma, abr./jun. 2004, pág. 77. Também é esta a posição adotada por João Carlos de LIMA, o qual, tratando sobre os danos que podem atingir o trabalhador em razão de ilícitos perpetrados pelo empregador, afirma que "[r]eduzir o patrimônio do ofensor em favor da coletividade [...] nada mais representa do que uma tentativa de restabelecer ou prover meios para promover a paz social." ( $O$ Caráter Punitivo da Indenização por Danos Pessoais e a Reversibilidade da Cominação para o FAT, in Revista de Direito do Trabalho, ano 30, vol. 115, São Paulo, RT, jul./set. 2004, pág. 86).

${ }^{784}$ Wesley de Oliveira Louzada Bernardo, Dano Moral: Critérios de Fixação de Valor, Rio de Janeiro, Renovar, 2005, pág. 181.

785 Valendo lembrar que, ao contrário do que ocorre em outros países, a remuneração dos serviços advocatícios por meio da cláusula de quota litis é considerada válida no Brasil, expressamente autorizada pelo disposto no art. 38 do Código de Ética da OAB.
} 
vultosa quantia a título de indenização punitiva, mas, de outro, manter todas as demais características de tal sanção punitiva (que permaneceria, portanto, exercendo suas funções preventiva e punitiva), a solução ora aventada serviria para "provar a sinceridade" dos demandantes: tal solução eliminaria a possibilidade de que, ao menos no que concerne à atribuição e quantificação da indenização punitiva, os demandantes pudessem ansiar pela ocorrência de um "erro judicial" do qual pudesse resultar a "sobrestimação de seus ganhos". Nessa toada, acredita-se que o exaurimento da expectativa de recebimento de ganhos vultosos atuaria como fator de desestímulo para o ajuizamento de pretensões indenizatórias ilegítimas ${ }^{786}$.

Opositor de tais argumentos, R. D. PIZARRo sustenta que uma tal solução apresentaria duvidosa eficácia prática, uma vez que não apenas desestimularia o ajuizamento de demandas ilegítimas, mas, ao menos em um determinado grau, também o daquelas demandas legitimamente fundadas. Sustenta o citado autor que os lesados perderiam o interesse de incoar medidas judiciais ao deixarem de auferir benefícios econômicos para se tornarem, por assim dizer, financiadores do Estado, de ligas de consumidores ou de quem quer que, ao final, torne-se beneficiário das quantias resultantes da indenização punitiva ${ }^{787}$.

Ousamos afirmar que, ao menos em países nos quais não vigora a "regra americana" (como é o caso do Brasil), o receio apresentado por R. D. PIZZARRo não encontra fundamento. Queremos crer que, em sistemas processuais nos quais o sucumbente deve arcar com os custos da litigância, fica em muito mitigada a necessidade de existência de uma teoria que incentive o litigante legítimo a vir a juízo por meio da majoração de seus possíveis ganhos (à maneira da teoria do "private attorney general"). De mais a mais, há, especificamente em nosso ordenamento, uma série de "válvulas de escape" legais que asseguram o acesso gratuito ao Poder Judiciário, erodindo ainda mais a utilidade prática de uma tal teoria.

\footnotetext{
${ }^{786}$ G. V. Robredo, Daños Punitivos en el Proceso Civil Norteamericano, in Revista de la Universidad de Deusto, vol. 57, fasc. 97, jul-dic./1996, pág. 203. No mesmo sentido: J. R. MCKnown, Punitive Damages: State Trends and Developments, in The Review of Litigation, vol. 14, 1994/1995, pág. 437.

${ }^{787}$ Daño Moral - Prevención, Reparación, Punición: El Daño Moral en las Diversas Ramas del Derecho, Buenos Aires, Hammurabi, 1996, pág. 397. Ao tratar do tort reform movement, D. G. OwEN apresenta conclusões semelhantes a essas, afirmando que a substituição da teoria do private attorney general poderia reduzir indesejavelmente o incentivo dos lesados ao ajuizamento de demandas legítimas (A Punitive Damages Overview: Functions, Problems and Reform, in Villanova Law Review, vol. 39, 1994, pág. 410). Ainda sobre o tema, cfr. J. K. RoBbennolt, Determining Punitive Damages: Empirical Insights and Implications for Reform, in Buffalo Law Review, vol. 50, 2002, pág. 181.
} 
Cogitam os doutrinadores, ademais, uma segunda vantagem dessa solução em detrimento da teoria do "private attorney general", que seria a eliminação (ou, ao menos, a mitigação) da tendência, acima apontada, de moderação das quantias impostas a título de indenização punitiva em razão do temor de que sua destinação à vítima lhes represente um enriquecimento imerecido. Diz-se que, já ciente de que o quantum indenizatório terá como beneficário direto um fundo público, ou uma entidade beneficente, e, como afetação final, a reconstituição dos bens jurídicos lesados pela atuação ilícita, o juiz, ao mensurar a sanção, não mais cogitará se está, ou não, enriquecendo a vítima em demasia (ainda que tal enriquecimento pudesse encontrar, como se defende que efetivamente encontraria, sua causa justificadora na norma legal que autorizasse a quantificação da sanção em patamar superior ao prejuízo sofrido).

Nesse sentido, Fernando NORONHA afirma que, ao disciplinar a criação do chamado "fundo de defesa dos direitos difusos", ao qual será revertido o valor das condenações decorrentes de ações civis públicas de natureza indenizatória, a Lei 7.437/1985 (Lei de Ação Civil Pública) incentivou a quantificação, pelos magistrados, de indenizações que efetivamente desempenhem suas funções preventiva e punitiva, atuando sobre o lesante (e sobre a coletividade) de modo a inibi-lo(s) de, futuramente, cometer novos ilícitos ${ }^{788}$.

Por fim, sustenta a doutrina que, em razão das características específicas dos atos ilícitos que dão ensejo à incidência da indenização punitiva (atos exemplarmente reprováveis, que atingem não apenas a vítima, individualmente, mas, de modo reflexo, toda a coletividade, especialmente por representar um desvirtuamento de seus valores, desrespeito às suas instituições, reduzir a qualidade de vida das pessoas que a integram, enfim, por causar o assim chamado "dano social"), o mais adequado seria que o numerário dela resultante não servisse apenas para atribuir à vítima, individualmente, um alento pelos prejuízos sofridos (em valor que irá, necessariamente, superar os limites do prejuízo), mas, sim, para que se pudesse, além de compensar adequadamente a vítima, recompor o patrimônio social lesado pelo ilícito ${ }^{789}$.

\footnotetext{
${ }^{788}$ Direito das Obrigações, vol. I, $2^{\text {a }}$ ed., 2007, São Paulo, Saraiva, págs. 439/440.

789 Caroline VAZ, Funções da Responsabilidade Civil - Da Reparação à Punição e Dissuasão - Os punitive damages no Direito Comparado e Brasileiro, Porto Alegre, Livraria do Advogado, 2009, págs. 84/85, 134 e 140.
} 
Assim, como exemplo, caso se estivesse diante de uma hipótese em que demandado fosse punido por, de maneira flagrantemente negligente (sem a realização dos testes preliminares exigidos pelos órgãos públicos competentes), introduzir no mercado um produto perigoso e potencialmente danoso ao consumidor final (por, e.g., apresentar como efeito colateral a alta probabilidade de causar doenças pulmonares), a quantia decorrente da indenização punitiva, em vez de ser atribuída exclusivamente à vítima individual, poderia ser destinada a uma entidade beneficente cujo objeto social abarcasse o tratamento de males semelhantes aos causados pelo produto; ou, ainda, a indenização punitiva poderia ser atribuída a um fundo de gestão pública que, ao final, viesse a utilizar o numerário para financiar tratamentos médicos de doenças semelhantes, ou a construir instalações que futuramente pudessem abrigar instituições de saúde.

Ao assim se proceder, a indenização punitiva atingiria suas funções de punição e prevenção de maneira tão eficaz quanto se houvesse sido atribuída exclusivamente à vítima do ilícito (ou até mesmo de maneira mais eficaz, em especial se o julgador do caso não apresentasse, nessa hipótese, restrições à quantificação da indenização que pudesse levantar caso ela fosse ordinariamente destinada à própria vítima do ilícito), mas, também, serviria para a recomposição do patrimônio social atingido pelo ilícito extremamente reprovável, reequilibrando a qualidade de vida por ele reduzida.

Para atingir tal finalidade, a doutrina cogita de basicamente das duas alternativas anunciadas acima: () a atribuição da indenização punitiva a um "estabelecimento local de beneficência", com fundamento na aplicação analógica do art. 883, par. ún., do CC/2002; ou, ainda, (ii) a destinação do numerário um fundo gerido especialmente para a reconstituição do patrimônio social, como, e.g., aquele previsto no art. 13, da Lei 7.347/1985.

Adepto da primeira alternativa acima enumerada, Diogo Leonardo Machado de Melo afirma que, se o quantum indenizatório supera os estritos limites do prejuízo, passando, a partir daí, a exercer não apenas uma função exclusivamente compensatória, mas, também, a punir e prevenir, tal quantia excedente deve ser destinada a uma entidade beneficente. Tal solução, defende o autor, já encontraria previsão legal autorizativa no art. 883, par. ún., CC/2002, aplicável analogicamente a hipóteses em que, assim como aquela 
expressamente estabelecida no citado dispositivo legal, também se buscasse combater a ilicitude e a fraude à lei, dispensando-se, assim, a edição de nova norma especificamente relacionada à indenização punitiva ${ }^{790}$.

Em se adotando tal alternativa, atribuir-se-ia a quantia resultante da incidência da indenização punitiva a uma entidade de benemerência local, uma entidade eminentemente privada, mas sem fins lucrativos, que utiliza o numerário auferido (e.g., por meio da promoção de eventos ou em decorrência de doações de particulares) para a consecução de um fim humanitário (tais como, e.g., a defesa da inclusão social, a diminuição das desigualdades, o combate ao câncer infantil, etc.).

A única crítica que se cogita levantar contra a destinação da indenização punitiva a uma "entidade de beneficência local" decorre justamente do caráter privado de tais entidades. Por não se submeterem à ingerência de um órgão da administração pública, pode-se enfrentar, a posteriori, dificuldades para aferir se o numerário a elas atribuído a título de indenização punitiva foi, efetivamente, utilizado para a consecução do fim perseguido pela aludida entidade.

Apenas por tal razão, faz-se coro com Judith MARTINS-CosTA e Mariana Souza PARGENDLER, para as quais a solução mais adequada para a questão é atribuir as quantias decorrentes da incidência da indenização punitiva um fundo, criado por lei e de gestão pública, que assegure a utilização de todos os recursos auferidos para uma "finalidade coletiva, isto é, transindividual (e não individual, servindo a 'indenização' para beneficiar exclusivamente a vítima do dano)" ${ }^{, 791}$. Em atenção a uma solução já adotada por nosso ordenamento jurídico desde a década de 1980, cogita-se que tal fundo poderia ser justamente aquele criado pelo art. 13, da Lei 7.347/1985 e atualmente regulamentado pelo Decreto 1.306/1994 e pela Lei 9.008/1995.

\footnotetext{
790 Ainda sobre a Função Punitiva da Reparação dos Danos Morais (e a Destinação de Parte da Indenização para Entidades de Fins Sociais - Artigo 883, Parágrafo Único, do Código Civil de 2002), in Revista de Direito Privado, vol. 26, jun.-2006, págs. 105 e ss..

${ }^{791}$ Usos e Abusos da Função Punitiva ('Punitive Damages' e o Direito Brasileiro), in Revista da Ajuris, ano XXXII, n. ${ }^{\circ}$ 100, dez/2005, pág. 262. Semelhantemente, Marcelo Junqueira CALIXTO, A Culpa na Responsabilidade Civil (Estrutura e Função), Rio de Janeiro, Renovar, 2008, págs. 310/311.
} 
Trata-se, nas palavras de Hugo Nigro MAZZILLI, de um fundo "a doutrina chama de fluid recovery", cujos valores por ele geridos devem ser utilizados "com certa flexibilidade, para uma reconstituição que não precisa e às vezes nem mesmo pode ser exatamente a do mesmo bem lesado",792, especialmente nas hipóteses em que o bem não admite restauração ao status quo ante ${ }^{793}$. Diz-se, então, que "a aplicação do produto do fundo depende de discernimento e imaginação" ${ }^{\text {"794 }}$ e que os recursos inseridos no fundo não precisam, necessariamente, ser empregados especificamente na restituição dos bens lesados, admitindo-se sua utilização em "atividades conexas, como: a) projetos científicos e de pesquisa; b) eventos educativos; c) edição de material informativo; d) atividades $e$ eventos de difusão cultural correlata aos bens tutelados; e) modernização administrativa dos órgãos públicos envolvidos na defesa dos interesses supra-individuais, etc."795 (como estabelece, de maneira exemplificativa, os arts. $1^{\circ}, \S 3^{\circ}$, e $3^{\circ}$ e incisos, todos da Lei 9.008/1995).

A partir do momento em que os valores são recolhidos ao fundo, o adequado emprego desse numerário para a persecução dos fins acima enunciados passa a ser atribuição de competência exclusiva do órgão gestor do fundo (art. $3^{\circ}$, I, da Lei 9.008/1995 e art. $3^{\circ}$, do Decreto $\left.1.306 / 1994\right)$.

Por fim, é certo que, por se tratar de recursos destinados a um fundo de gestão pública, “[a] má ou equivocada destinação pode ser impugnada administrativamente ou judicialmente, em demanda autônoma"796, o que representa uma vantagem desta solução em detrimento daquela que pugna pela remessa dos mesmos recursos a uma "entidade de beneficência local".

Por todas as razões acima enumeradas, acreditamos que, em se admitindo a indenização punitiva em nosso ordenamento (o que, como dito, depende da prévia introdução de um regramento legislativo específico), a solução mais adequada para a destinação dos recursos provenientes dessa sanção é a sua remessa a um fundo de gestão

\footnotetext{
${ }^{792}$ A Defesa dos Interesses Difusos em Juízo, $5^{\text {a }}$ ed., São Paulo, RT, 1993, pág. 276.

${ }^{793}$ Prescreve o art. $7^{\circ}$, par. ún., do Decreto 1.306/1994 que os recursos destinados ao fundo devem ser empregados prioritariamente "na reparação específica do dano causado, sempre que tal fato for possível".

${ }^{794}$ Hugo Nigro MazziLli, A Defesa dos Interesses Difusos em Juízo, 5a ed., São Paulo, RT, 1993, pág. 277.

795 Ricardo de Barros LeOnel, Manual do Processo Coletivo, São Paulo, RT, 2002, pág. 388.

${ }^{796}$ Ricardo de Barros LeOnel, Manual do Processo Coletivo, São Paulo, RT, 2002, pág. 387.
} 
pública, nos mesmos moldes do "fundo de defesa dos direitos difusos" criado pela Lei 7.347/1985, e não sua atribuição à própria vítima do ilícito (a despeito de, repita-se, considerar-se que tal solução é verdadeira questão de política legislativa, e que a opção por qualquer das soluções acima aventadas não torna a incidência da sanção punitiva ilícita).

\section{VII.III. Distribuição da indenização punitiva entre a vítima e um fundo público}

Por derradeiro, vale destacar que a, principalmente à luz das propostas reformistas sugeridas pelo tort reform movement nos Estados Unidos da América, a doutrina aventa ainda uma terceira solução para dirimir as controvérsias relacionadas à destinação da indenização punitiva, solução esta que se coloca em posição intermediária entre os dois extremos acima analisados. Trata-se da adoção de medida assemelhada àquela que a doutrina norte-americana denomina de split recovery, e que consiste na repartição (que não necessita ser em parcelas igualitárias) das quantias decorrentes da indenização punitiva entre a vítima diretamente prejudicada pelo ato ilícito (ou o autor da demanda indenizatória) e uma entidade de beneficência ou, como ocorre nos Estados Unidos da América, um fundo público de gestão estatal ou o próprio erário.

A adoção desse sistema intermediário procura conjugar, ainda que parcialmente, as vantagens das duas soluções antagônicas supra mencionadas, na medida em que, de um lado, não deixa de recompensar a vítima do ilícito pelo munus público por ela exercido quando atua judicialmente também em defesa dos direitos e interesses da coletividade e, de outro, também serve de mecanismo para colocar "autores de ilícitos como financiadores de fundos públicos de recomposição de interesses lesados" ${ }^{\text {797. }}$.

\footnotetext{
${ }^{797}$ Eduardo UILAN, Responsabilidade Civil Punitiva, Tese (Doutorado) - Faculdade de Direito da USP, São Paulo, 2003, pág. 54. No mesmo sentido, cfr. P. M. LOURENÇO, A Função Punitiva da Responsabilidade Civil, Coimbra, Coimbra, 2006, pág. 406. Ao tratar especificamente sobre a responsabilidade do empregador no âmbito do Direito do Trabalho, João Carlos de LIMA sugere a adoção, pelo ordenamento nacional, de um sistema assemelhado ao de split recovery. Afirma o autor que a indenização por danos pessoais no âmbito do Direito do Trabalho deveria ser partilhada entre o trabalhador lesado e o FAT ("Fundo de Amparo ao Trabalhador", que se trata de um fundo de gestão pública e vinculado ao Ministério do Trabalho, criado pelo art. 10, da Lei 7.998/1990, e destinado ao custeio do programa de seguro-desemprego), como modo de, ao mesmo tempo, compensar o prejuízo pessoal, individualmente suportado pelo trabalhador, e fomentar a melhoria social (compensando, neste aspecto, o dano social causado pela conduta lesiva). ( $O$ Caráter Punitivo da Indenização por Danos Pessoais e a Reversibilidade da Cominação para o FAT, in Revista de Direito do Trabalho, ano 30, vol. 115, jul./set. 2004, págs. 86/90)
} 
Como toda solução intermediária, ela também não deixa, contudo, de conjugar, ainda que de maneira mitigada, as desvantagens das duas soluções anteriormente expostas.

A uma, na exata medida em que a repartição da indenização punitiva recompensa a vítima pelo exercício de um munus público, ela também proporciona à vítima uma sobrestimação de seus ganhos, o que poderia, como acima exposto, servir de incentivo à litigância frívola. A distinção, nesse quesito, em relação à solução pela destinação integral da indenização punitiva à vítima é apenas e tão-somente de ordem quantitativa: num caso, a sobrestimação dos ganhos do queixoso é ainda maior do que no outro, mas sobrestimação existe, tanto num, quanto noutro.

A duas, apesar de, com a repartição da indenização punitiva, destinar-se menos parte do numerário pago pelo demandado à persecução do reequilíbrio social abalado pelo ilícito, uma parcela significativa desse valor ainda é atribuído à vítima, que continuará a ser compensada em valor que supera os estritos limites do prejuízo efetivamente suportado. Tal fator, ainda que em proporção menor do que aconteceria na hipótese de toda a indenização ser destinada à vítima, também poderia servir para que o julgador restringisse o quantum indenizatório para procurar evitar o enriquecimento imerecido da vítima.

A três, e por fim, na mesma medida em que deixa de atribuir à sociedade a integralidade das quantias auferidas a título de indenização punitiva, optando por destinar parte dela à própria vítima do ilícito, a opção intermediária deixa de recompor integralmente o patrimônio social lesado, ou, em outras palavras, de restabelecer o equilíbrio social atingido pelo ilícito.

Por todas essas razões, reitera-se o que já se expôs para concluir que, na hipótese de se adotar em nosso ordenamento a figura da indenização punitiva, a solução reputada como a mais adequada para a destinação de tal numerário é aquela que pugna pela remessa integral dessas quantias a um fundo de gestão pública, nos mesmos moldes daquele previsto na Lei 7.347/1985. 


\section{O RECONHECIMENTO DE SENTENÇAS ESTRANGEIRAS NO BRASIL}

Por derradeiro, vale tecer algumas considerações sobre um dos aspectos pertinentes à adoção da indenização punitiva e que, a despeito de seu enorme interesse (em especial antes de que ocorra a introdução legislativa de tal sanção punitiva em nosso ordenamento jurídico), não mereceu maiores considerações da doutrina nacional: a possibilidade de que uma sentença estrangeira que contenha um capítulo condenatório ao pagamento de indenização punitiva venha a ser reconhecida e a ter sua execução autorizada, em território nacional, pelo Superior Tribunal de Justiça.

Em razão dos conceitos de soberania e de independência das jurisdições, as decisões proferidas por órgãos jurisdicionais estatais, de ordinário e de imediato, produzem efeitos apenas dentro dos limites territoriais de tal estado ${ }^{798}$. Assim, uma decisão judicial proferida, por ex., nos Estados Unidos da América que condene o demandado ao pagamento de indenização punitiva somente produzirá efeitos, de per se, dentro dos limites territoriais norte-americanos, não podendo estender seus efeitos a países estrangeiros.

Tal restrição poderia significar, contudo, verdadeira fonte de injustiças, uma vez que, dada a hipercomplexidade característica das relações interpessoais da pósmodernidade, não raras são as hipóteses em que determinado provimento jurisdicional deve estender seus efeitos além dos estritos limites territoriais do Estado em que foi proferido, "sob pena de revelar-se ilusória, do ponto de vista prático, a tutela jurídica dispensada",799. Basta que se tenha em mente, no mesmo exemplo acima referido, a hipótese de o demandado ser residente e domiciliado (bem como de somente possuir bens) em país distinto dos Estados Unidos da América, sendo, em tudo e por tudo, indispensável que o provimento jurisdicional norte-americano possa produzir seus efeitos (e, conseqüentemente, ser exeqüível) fora de seus limites territoriais, sob pena de, ante à eventual recalcitrância do devedor, o demandante jamais ver satisfeito seu direito de crédito.

\footnotetext{
798 Maria Helena DINIZ, Lei de Introdução ao Código Civil Brasileiro Interpretada, 15 ${ }^{\mathrm{a}}$ ed., São Paulo, Saraiva, 2010, pág. 406.

799 José Carlos Barbosa Moreira, Comentários ao Código de Processo Civil, vol. V, 13 ${ }^{\mathrm{a}}$ ed., Rio de Janeiro, Forense, 2006, pág. 50.
} 
Para superar tais possíveis inconvenientes admite-se que, em determinadas circunstâncias, os efeitos de um provimento jurisdicional estrangeiro sejam produzidos para além de seu território, exigindo-se, para tanto, que o Estado em que se pretende ver produzidos tais efeitos reconheça e dê execução ao provimento estrangeiro. Em nosso país, o ato jurisdicional que transforma essa potencialidade eficacial do provimento estrangeiro em verdadeira e atual eficácia é, justamente, a homologação ${ }^{800}$, a qual se dá por meio do que se denomina de juízo de delibação. Por este sistema, a homologação de sentenças estrangeiras se dá apenas por meio da verificação, a ser realizada pelo Tribunal do Foro (i.e., do país no qual a homologação irá se operar), da presença de determinados requisitos quase que exclusivamente formais da sentença estrangeira, vedando-se a reapreciação de questões atinentes ao mérito da causa já decidido pelo país estrangeiro ${ }^{801}$.

Após a edição da Emenda Constitucional n. ${ }^{\circ}$ 45/2004 (que acrescentou a alínea ' $i$ ' ao art. 105, I, da CF/88), a competência para o exercício do juízo delibatório foi transferida do Supremo Tribunal Federal para o Superior Tribunal de Justiça. Por sua vez, os procedimentos e requisitos para a homologação de sentenças estrangeiras estão previstos nos arts. 15 e 17, LICC, 483 e 484, CPC, bem como na Resolução de n. 9/2005, editada pelo Superior Tribunal de Justiça ${ }^{802}$.

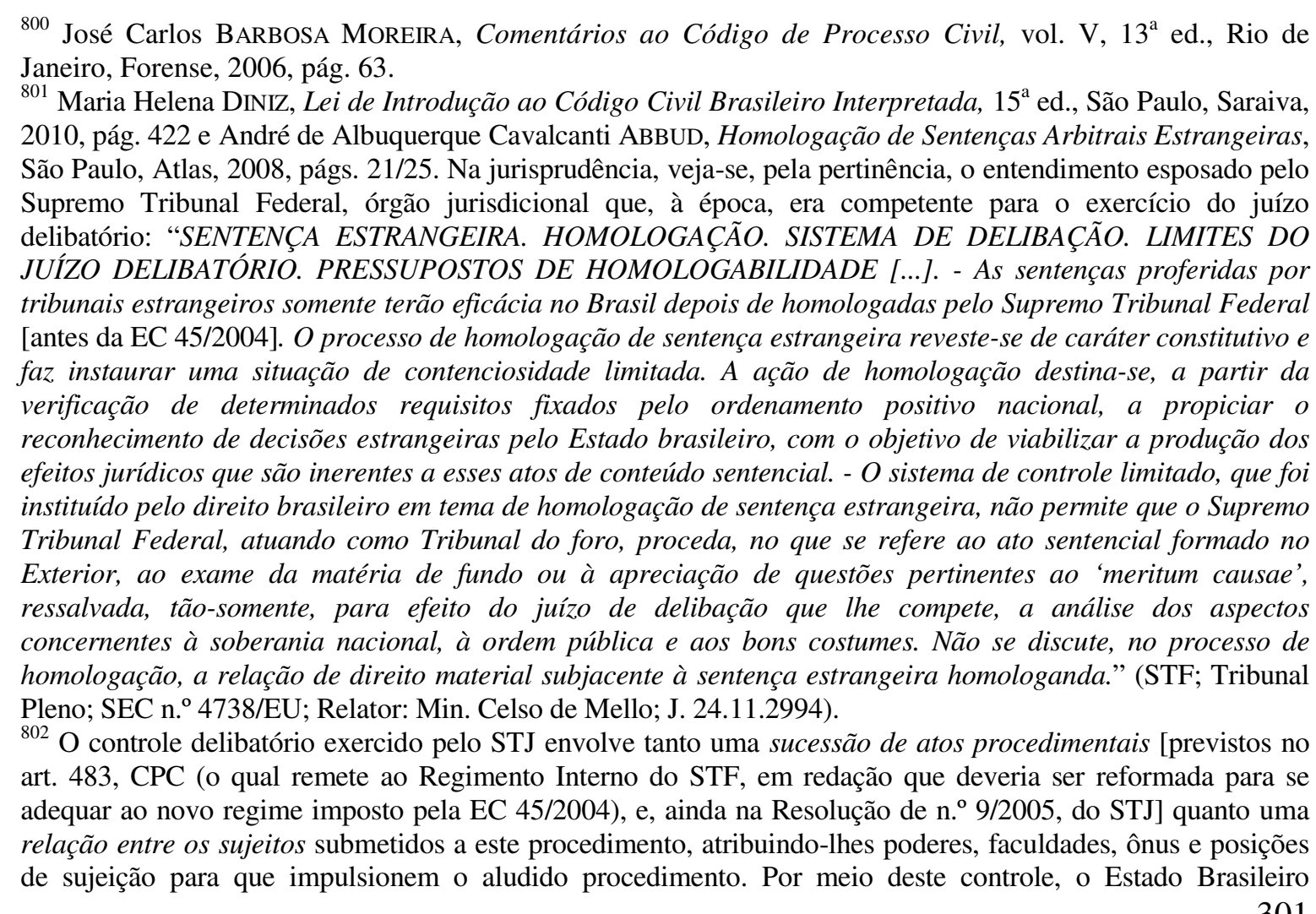


Em nosso país, exige-se, para que uma sentença estrangeira possa ser homologada: (i) haver sido proferida por autoridade competente (art. 15, $a$, LICC e art. $5^{\circ}$, I, Resolução n. ${ }^{\circ}$ 9/2005), competência internacional esta que será aferida de acordo com as normas do ordenamento brasileiro ${ }^{803}$ (vedada, portanto, a violação ao que dispõe o art. 89, CPC); (ii) terem sido as partes citadas ou haver-se legalmente verificado a revelia (art. 15, b, LICC e art. 5', II, Resolução n. ${ }^{\circ}$ 9/2005; (iii) ter transitado em julgado (art. $5^{\circ}$, III, Resolução n. ${ }^{\circ}$ 9/2005) e estar revestida das formalidades necessárias para a execução no lugar em que foi proferida (art. 15, $c, \mathrm{LICC})$; (iv) estar autenticada pelo cônsul brasileiro (art. 5 IV, Resolução n..$^{\circ}$ 9/2005 e Súmula 259, STF) e acompanhada de tradução elaborada por intérprete autorizado (art. $5^{\circ}, d$, LICC); e, por fim, (v) não ofender a soberania nacional, a ordem pública ou os bons costumes (art. 17, LICC e art. $6^{\circ}$, Resolução n. ${ }^{\circ}$ 9/2005).

Muito embora não se tenha notícia, em nosso país, acerca da homologação de nenhuma sentença estrangeira que previsse a condenação do demandado ao pagamento de indenização punitiva, quer-nos parecer que a questão jurídica de maior relevância quanto ao tema é a eventual desconformidade entre uma tal condenação e o conceito que se tem de ordem pública (art. 17, LICC e art. $6^{\circ}$, Resolução n. ${ }^{\circ}$ 9/2005); questão esta que sobressai em importância enquanto nosso ordenamento jurídico ainda não prevê, de maneira expressa, tal sorte de sanção punitiva.

Quanto ao tema, não há como se olvidar que a noção de ordem pública é “ambígua, imprecisa e variável no tempo e no espaço" ${ }^{804}$, e que, ao menos em um determinado grau, a análise quanto à conformidade entre uma lei ou sentença estrangeira e a ordem pública é atribuição que recairá, caso a caso, sobre o órgão julgador.

exercerá verdadeira atividade jurisdicional, o que atribui ao juízo delibatória características de verdadeiro processo, nos termos preconizados por Cândido Rangel DinAMARCO (Vocabulário de Direito Processual, in Fundamentos do Processo Civil Moderno, São Paulo, RT, 1986, págs. 157/160), e não mero procedimento. Trata-se, ademais, de processo de jurisdição contenciosa, marcado tanto pela cognição do julgador quanto pelo efetivo exercício do contraditório pelas partes (André de Albuquerque Cavalcanti ABBUD, Homologação de Sentenças Arbitrais Estrangeiras, São Paulo, Atlas, 2008, págs. 87/91 e Maria Helena DINIZ, Lei de Introdução

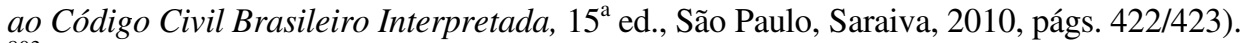

${ }^{803}$ Maria Helena DINIZ, Lei de Introdução ao Código Civil Brasileiro Interpretada, 15ª ed., São Paulo, Saraiva, 2010, págs. 418/419.

${ }^{804}$ Maria Helena DinIz, Lei de Introdução ao Código Civil Brasileiro Interpretada, $15^{\mathrm{a}}$ ed., São Paulo, Saraiva, 2010, pág. 456. Em sentido semelhante, Jacob DoLINGER, Direito Internancional Privado (Parte Geral), Rio de Janeiro, Freitas Bastos, 1986, pág. 341. 
Especificamente no que concerne ao reconhecimento de sentenças estrangeiras (notadamente norte-americanas) que tragam em seu bojo um capítulo referente aos punitive damages, é, contudo, possível traçar algumas linhas gerais, quer por meio da análise da noção mais restrita que se costuma atribuir à ordem pública quando se está diante de relação entre Estados (no caso, do reconhecimento de um provimento jurisdicional emanado por órgão judiciário estrangeiro), quer, ainda, por meio da verificação das questões suscitadas em outros países (tais como a Alemanha, a Itália e a Espanha), nos quais as matérias aqui versadas já foram apreciadas.

Assim, quanto ao primeiro ponto, parece-nos importante trazer à baila a distinção, feita por parte da doutrina, entre o que se denomina de ordem pública interna e o que se diz ordem pública internacional. Segundo os defensores de tal dicotomia, enquanto a primeira "tem aplicação nas relações desenvolvidas dentro do próprio Estado, sujeitas à

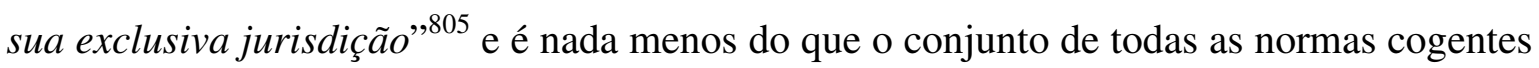
de determinado ordenamento, de cujos efeitos os cidadão não podem se subtrair $^{806}$; a segunda tem aplicação nas relações que o Estado Brasileiro mantém com Estados estrangeiros, e “constitui um limite à introdução em nosso ordenamento, por força da incidência de normas de direito internacional privado, de valores jurídicos (legislativos ou jurisprudenciais) estrangeiros" ${ }^{\circ 07}$.

Justamente por se destinar a regular as relações jurídicas inter-privadas, “o núcleo que compõe a ordem pública brasileira [= ordem pública interna] será necessariamente mais amplo do que aquele abrangido pelas relações internacionas das

\footnotetext{
${ }^{805}$ Ricardo de Carvalho Aprigliano, A Ordem Pública no Direito Processual Civil, Tese (Doutorado) Faculdade de Direito da USP, São Paulo, 2010, pág. 63. Prossegue o citado autor ao afirmar, a título exemplificativo, que a ordem pública interna se aplica “a um sem-número de situações, à generalidade das pessoas e relações jurídicas, que contratam, vendem, compram e praticam atos dentro do próprio país, com partes contrárias igualmente domiciliadas no Brasil, para que produzam efeitos e sejam executados sob a égide apenas e tão somente da legislação nacional".

${ }^{806}$ Maria Helena DINIZ, Lei de Introdução ao Código Civil Brasileiro Interpretada, $15^{\mathrm{a}}$ ed., São Paulo, Saraiva, 2010, pág. 458 e Irineu STRENGER, Direito Internacional Privado, vol.1, São Paulo, RT, 1986, pág. 355.

${ }^{807}$ No original: “[...] costituisce un limite alla introduzione nel nostro ordinamento, per effetto dell'operare di norme di diritto internazionale privato, di valori giuridici (legislativi o giurisprudenziali) stranieri." (M. L. Gonzalo, Punitive Damages e Ordine Pubblico, in Rivista di Diritto Internazionale Privato $e$ Processuale, anno XLIV, n. 1, gen.-mar./2008, pág. 79). Ao tratar do tema, Irineu STRENGER, afirma que "[p]or ordem pública [internacional] entende-se um conjunto de princípios impícita e explicitamente conhecidos, na ordenação jurídica que, considerados fundamentais, excluem a aplicação do direito estrangeiro." (Direito Internacional Privado, vol.1, São Paulo, RT, 1986, pág. 356).
} 
quais o Brasil faça parte [= ordem pública internacional]" ${ }^{\text {808 }}$. Esta última tem por função "salvaguardar apenas um núcleo fundamental de princípios irrenunciáveis" "809, qual seja, o “conjunto de valores e preceitos fundamentais que um determinado país adote em suas relações internacionais" $" 810$.

Assim, para que se possa concluir pela impossibilidade de homologação de uma sentença estrangeira sob o argumento de que ela afronta a ordem pública, não basta que tal provimento jurisdicional contenha disposição que contrarie uma norma de direito interno, mesmo que imperativa (a qual certamente comporá a noção de ordem pública interna, mas, não necessariamente, a de ordem pública internacional $)^{811}$. Uma tão drástica consequiência [= negar-se a homologação] somente se justificaria em situações nas quais houvesse "manifesto

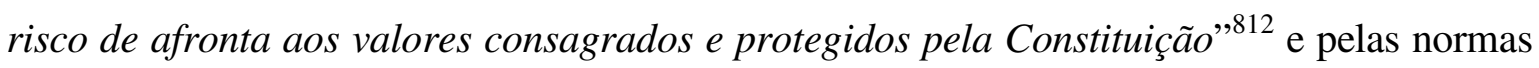
infraconstitucionais que, igualmente, estabelecem "princípios intocáveis que excluem a aplicação do direito estrangeiro" ${ }^{\prime 813}$.

${ }^{808}$ Ricardo de Carvalho Aprigliano, A Ordem Pública no Direito Processual Civil, Tese (Doutorado) Faculdade de Direito da USP, São Paulo, 2010, pág. 63. Jacob DoliNGER, a despeito de não esposar a dicotomia entre ordem pública internacional e ordem pública interna (reputando que o conceito de ordem pública é uno, ainda que suas aplicações possam-se dar em diversos âmbitos), sustenta que a proteção à ordem pública se dá em três níveis distintos e de rigor decrescente, sendo o mais rígido deles aquele que se dá no âmbito das relações internas, inter-privadas, e o menos rígido aquele que se dá para o reconhecimento de direitos adquiridos no exterior, como, e.g., por meio da prolação de uma sentença estrangeira. Também sob essa concepção, a noção que se tem de ordem pública interna é mais ampla (e, conseqüentemente, mais rígida, mais protetiva) do que aquela que se tem de ordem pública internacional. (Direito Internancional Privado (Parte Geral), Rio de Janeiro, Freitas Bastos, 1986, págs. 349/355).

${ }^{809}$ No original: "salvaguardare solo un nucleo fondamentale di principi irrenunciabili". (M. L. GONZALO, Punitive Damages e Ordine Pubblico, in Rivista di Diritto Internazionale Privato e Processuale, anno XLIV, n. 1, gen.-mar./2008, pág. 79)

${ }^{810}$ Ricardo de Carvalho Aprigliano, A Ordem Pública no Direito Processual Civil, Tese (Doutorado) Faculdade de Direito da USP, São Paulo, 2010, pág. 64. Quanto à noção de ordem pública internacional, vale lembrar que o Código de Bustamante (Código de Direito Internacional Privado, também subscrito pelo Brasil) prevê, em seu art. $4^{\circ}$, que "[o]s preceitos constitucionais são de ordem pública internacional" e, em seu art. $5^{\circ}$, que "[t]odas as regras de proteção individual e coletiva, estabelecidas pelo direito político e administrativo são também de ordem pública internacional, salvo nos casos em que expressamente se disponha o contrário".

${ }^{811}$ M. L. GonZalo, Punitive Damages e Ordine Pubblico, in Rivista di Diritto Internazionale Privato e Processuale, anno XLIV, n. 1, gen.-mar./2008, pág. 79 e A. SARAVALLE, I Punitive Damages nelle Sentenze delle Corti Europee e dei Tribunali Arbitrali, in Rivista di Diritto Internazionale Privato e Processuale, anno XXIX, n. 4, ott.-dic./1993, pág. 886.

${ }^{812}$ Ricardo de Carvalho APRIGLIANo, A Ordem Pública no Direito Processual Civil, Tese (Doutorado) Faculdade de Direito da USP, São Paulo, 2010, pág. 64. Mais à diante, o citado autor afirma que "[p]ara que uma sentença arbitral estrangeira possa ser homologada no Brasil é preciso verificar se ela não ofende preceitos de ordem pública que o Brasil estabelece em suas relações internacionais. Não se deve examinar a questão sob a ótica das normas cogentes que o País adote em suas relações internas, pois estas serão necessariamente mais amplas e abrangentes." (Ricardo de Carvalho APRIGLIANO, op. cit., pág. 64).

${ }^{813}$ Irineu STRENGER, Direito Internacional Privado, vol.1, São Paulo, RT, 1986, págs. 356/357. 
Sob tal ótica, conclui-se que não se pode negar o reconhecimento de uma sentença estrangeira que contenha um capítulo condenatório referente a punitive damages apenas sob o argumento de que tal sanção punitiva não é prevista em nosso ordenamento pátrio (ou, até mesmo, que a indenização punitiva contrariaria norma cogente interna). A homologação somente poderia ser rejeitada se, diante das previsões inseridas na Constituição Federal e em normas infraconstitucionais que, conjuntamente com a Carta da República, estabeleçam um "núcleo fundamental de princípios irrenunciáveis", os punitive damages saltassem aos olhos como verdadeiramente inadmissíveis, violadores, portanto, da ordem pública internacional ${ }^{814}$.

Como se vê, concretizar a noção de ordem pública internacional não é tarefa das mais simples. Em razão dessa dificuldade (e, demais disso, por não se ter notícia de que nossos Tribunais Superiores tenham analisado a compatibilidade entre os punitive damages e os princípios fundamentais que compõem a noção de ordem pública internacional), sobressaem em importância as discussões travadas nas altas cortes européias a respeito do tema (especialmente para que, com base nas questões jurídicas por eles analisadas, possa-se traçar os necessários paralelos para dirimir situação que, acreditamos, não tarda a ocorrer também em sede brasileira).

Ao procurarmos passar em revista os casos analisados pelas cortes européias, vale ressaltar que, da informação que se extrai da doutrina, a primeira oportunidade em que um alto tribunal europeu, de país de tradução romano-germânica, analisou a questão atinente à compatibilidade entre uma sentença estrangeira em que se impôs ao demandado condenação ao pagamento de punitive damages e a ordem pública se deu em acórdão proferido aos 4 de junho de 1992, pelo Superior Tribunal Federal (Bundesgerichtshof) alemão ${ }^{815}$.

\footnotetext{
${ }^{814}$ É nesse sentido que M. R. ISIDRO afirma que "it is one thing for an ordinary legislator to rule out a normative option because he does not believe it is appropriate for regulating domestic cases, and another for the said option not to be admitted into the system under any circumstances, because it goes against the constitutional parameters on which the system is based. With specific regard to punitive damages: it is one thing for them not to be contemplated in Spanish, Italian or French positive civil law, and another for them to be declared completely unacceptable due to intrinsic and ontological reasons." (Punitive Damages From a Private International Law Perspective, in H. KoZIOL - V. WILCOX, Punitive Damages: Common Law and Civil Law Perspectives, Wien, Springer, 2009, págs. 237/238).

815 G. V. RoBREDO, Reconoscimiento y Ejecucion em Alemania de Sentencias Extranjeras de Daños Punitivos - Comentario a la Decisión del Tribunal Federal de Justicia alemán (Bundesgerichtshof), de 4 de junio de 1992, in Revista de la Universidad de Deusto, vol. 59, fasc. 99, jul-dic./ 1997, pág. 228 e M. R.
} 
Tratou-se, na origem, de ação de indenização de danos materiais e morais ajuizada em face de demandado que já havia sido previamente condenado, pela justiça criminal, à pena de reclusão por ter perpetrado atos de abuso sexual contra o demandante, o qual, à época dos fatos, era menor de idade. A despeito de ter residido nos Estados Unidos da América, o demandado, que também possuía propriedades na República Alemã, refugiou-se nesse país tão logo proferida sentença no âmbito criminal, fato do qual decorreu a necessidade de execução, na Alemanha, da sentença civil posteriormente prolatada, que o condenou ao pagamento de indenização compensatória (compensatory damages) em valor de aproximadamente USD 350 mil e de indenização punitiva (punitive damages) no importe de USD $400 \mathrm{mil}^{816}$.

Ao receber a demanda delibatória, o Tribunal Distrital (Landgericht) reconheceu a possibilidade de execução integral da sentença condenatória, o que levou o demandado a recorrer de tal decisão. Diante das razões recursais, o Tribunal de Apelação (Oberlandesgencht) de Düsseldorf reformou parcialmente a sentença proferida pelo órgão jurisdicional a quo para reconhecer a sentença estrangeira, mas reduzir a condenação a ser executada na República Alemã a apenas USD 272.325,00. Irresignadas, ambas as partes recorreram ao Tribunal Federal de Justiça (Bundesgerichtshof), o qual decidiu por reconhecer os capítulos da sentença estrangeira que impunham ao demandado a condenação ao pagamento de indenização compensatória, decotando, contudo, o capítulo referente à indenização punitiva por reputar os punitive damages uma afronta à ordem pública alemã, o que impossibilitaria, conseqüentemente, o reconhecimento integral da sentença estrangeira ante ao previsto no $\$ 328$ (1), 4, da ZPO (Código de Processo Civil alemão $)^{817}$, dispositivo legal de redação semelhante àquela do art. 17, LICC e do art. $6^{0}$, Resolução n. ${ }^{\circ}$ 9/2005.

IsIDRo, Punitive Damages From a Private International Law Perspective, in H. KOZIOL - V. WILCOX, Punitive Damages: Common Law and Civil Law Perspectives, Wien, Springer, 2009, pág. 245.

816 G. V. RobRedo, Reconoscimiento y Ejecucion em Alemania de Sentencias Extranjeras de Daños Punitivos - Comentario a la Decisión del Tribunal Federal de Justicia alemán (Bundesgerichtshof), de 4 de junio de 1992, in Revista de la Universidad de Deusto, vol. 59, fasc. 99, jul-dic./ 1997, pág. 228 e A. Saravalle, I Punitive Damages nelle Sentenze delle Corti Europee e dei Tribunali Arbitrali, in Rivista di Diritto Internazionale Privato e Processuale, anno XXIX, n. 4, ott.-dic./1993, pág. 880.

817 G. V. RoBREDO, Reconoscimiento y Ejecucion em Alemania de Sentencias Extranjeras de Daños Punitivos - Comentario a la Decisión del Tribunal Federal de Justicia alemán (Bundesgerichtshof), de 4 de junio de 1992, in Revista de la Universidad de Deusto, vol. 59, fasc. 99, jul-dic./ 1997, págs. 228/229 e A. Saravalle, I Punitive Damages nelle Sentenze delle Corti Europee e dei Tribunali Arbitrali, in Rivista di Diritto Internazionale Privato e Processuale, anno XXIX, n. 4, ott.-dic./1993, págs. 880/881. 
Em apertada síntese, afirmou o Bundesgerichtshof que: (i) no ordenamento jurídico alemão, a única função exercida pela responsabilidade civil é a compensatória, destinando-se a ação indenizatória ajuizada pelo particular, apenas e tão-somente, a compensar os prejuízos efetivamente suportados pelo ofendido; que, em razão desse princípio, (ii) as sanções que exercem funções punitivas ou dissuasórias (ou que se destinam a proteger a ordem jurídica ou a ordem pública) fazem parte de um "monopólio punitivo" exercido pelo Estado dentro de limites estritos e por meio de um "processo especial" (o processo penal), caracterizado por garantias mais amplas dos direitos do demandado; que (iii) a quantificação dos punitive damages, realizada a forfait e sem nenhuma relação direta com os prejuízos efetivamente suportados pela vítima, viola o princípio da proporcionalidade da pena; e, por fim, (iii) que o reconhecimento e execução de sentenças estrangeiras que contivessem um capítulo condenatório a título de punitive damages colocaria os credores estrangeiros em uma inadmissível posição de vantagem em relação aos credores alemães, uma vez que possibilitaria aos primeiros receber uma quantia muito superior ao prejuízo sofrido, relegando aos últimos o recebimento de quantias limitadas à extensão dos danos suportados. Tal fato representaria, por sua vez, infringência ao princípio da paridade de tratamento (isonomia) entre alemães e estrangeiros ${ }^{818}$.

Com amparo nos argumentos acima enumerados, concluiu o Bundesgerichtshof que, "[d]e um ponto de vista local, seria inaceitável impor, em um juízo cível, o pagamento de uma considerável soma em dinheiro, a qual não se destina a compensar os danos [suportados pelo ofendido], mas é calculada essencialmente segundo o interesse público e pode ser imposta em conjunto com penas criminais pela mesma ofensa" ${ }^{\text {819 }}$. Entendeu-se, enfim, que o instituto dos punitive damages seria incompatível

\footnotetext{
${ }^{818}$ A. SARAVAlle, I Punitive Damages nelle Sentenze delle Corti Europee e dei Tribunali Arbitrali, in Rivista di Diritto Internazionale Privato e Processuale, anno XXIX, n. 4, ott.-dic./1993, págs. 881/882; E. D’ ALESSANDRO, Pronunce Americane di Condanna al Pagamento di Punitive Damages e Problemi di Riconoscimento in Italia, in Rivista di Diritto Civile, anno LIII, n. 3, mag.-giug./2007, págs. 388/389 e M. R. IsIDRO, Punitive Damages From a Private International Law Perspective, in H. KOZIOL - V. WILCOX, Punitive Damages: Common Law and Civil Law Perspectives, Wien, Springer, 2009, pág. 246.

${ }^{819}$ No original, "[d]esde un punto de vista local, sería inaceptable imponer, en un juicio civil, el pago de una considerable suma de dinero, la cual no intenta ser compensación por los daños, sino que es calculada esencialmente según el interés publico y puede ser impuesta junto con el castigo criminal por la misma ofensa [...]." (G. V. RoBREDO, Reconoscimiento y Ejecucion em Alemania de Sentencias Extranjeras de Daños Punitivos - Comentario a la Decisión del Tribunal Federal de Justicia alemán (Bundesgerichtshof), de 4 de junio de 1992, in Revista de la Universidad de Deusto, vol. 59, fasc. 99, jul-dic./ 1997, pág. 240).
} 
com a ordem pública alemã, inadmitindo-se o reconhecimento e execução de sentenças estrangeiras nesse sentido ou, ao menos, dos capítulos que previssem tal condenação.

Anos mais tarde, a Corte de Cassação italiana lançou mão de argumentos semelhantes para, também ela, deixar de reconhecer e executar uma sentença norteamericana que havia condenado o demandado ao pagamento de indenização punitiva (Cass., 19 genn. 2007, n. 1183) ${ }^{820}$.

Tratou-se, na origem, de ação indenizatória ajuizada pelo herdeiro universal de um motociclista que havia falecido em um acidente automobilístico nos Estados Unidos da América, acidente este que, pelo que se verificou no curso da demanda, teria sido causado por erros de projeto e construção da motocicleta, desenvolvida por uma empresa italiana. Uma vez reconhecida a responsabilidade de tal empresa, a sentença proferida no Estado do Alabama a condenou ao pagamento de quantia equivalente a USD 1 milhão ${ }^{821}$, valor este que, segundo os Tribunais italianos que exerceram o juízo delibatório, abarcaria não apenas uma condenação a título de indenização compensatória, mas, também, uma parcela a título de indenização punitiva ${ }^{822}$.

${ }^{820}$ Quanto ao tema, vale ressaltar que o denominador comum que se verifica nos sistemas alemão e italiano de reconhecimento e execução de sentenças estrangeiras é, justamente, a necessidade de respeito à ordem pública. Na Itália, é admissível que as sentenças estrangeiras produzam efeitos imediatos, sem a necessidade de que se passe por um processo delibatório, contanto que estejam presentes os requisitos de caráter positivo (e, conseqüentemente, ausentes os de caráter negativo) previstos no art. 64, da Lei de 31 maggio 1995, n. 218 (a referida lei, que versa sobre a "reforma do sistema italiano de direito internacional privado", modificou o sistema anteriormente regido pelos arts. 796 e ss., do CPC italiano, o qual permitia, em determinadas hipóteses, que a Corte de Apelação competente para o processo de delibação chegasse, inclusive, a reexaminar o mérito da causa julgada pela corte estrangeira). Desses requisitos positivos, para a análise que se fez sobre a possibilidade de reconhecimento de uma sentença norte-americana que previa a condenação do demandado ao pagamento de punitive damages, sobressai em importância aquele requisito inserido no art. 64, 'g', da Lei 218/1995, que veda o reconhecimento de sentenças estrangeiras se seu dispositivo produzir efeitos que violem a ordem pública. Em havendo contestação do reconhecimento de uma dada sentença estrangeira, será competente para o julgamento da matéria a Corte de Apelação (corte d'appello) do local onde deveria ser executada a sentença (ex vi do art. 67, 1, da Lei 218/1995).

${ }^{821}$ E. D'Alessandro, Pronunce Americane di Condanna al Pagamento di Punitive Damages e Problemi di Riconoscimento in Italia, in Rivista di Diritto Civile, anno LIII, n. 3, mag.-giug./2007, pág. 392 e F. QUARTA, Recognition and Enforcement of U.S. Punitive Damages Awards in Continental Europe: The Italian Supreme Court's Veto, in Hastings International \& Comparative Law Review, vol. 31, 2008, págs. 755/756.

${ }^{822}$ Apesar de fixar o montante da indenização devida ao demandante, a Corte do Alabama não indicou, nas razões de sua decisão, a que título se destinava o quantum indenizatório (se a compensar a vítima pelos prejuízos suportados, ou a punir o ofensor pelo ilícito perpetrado). Com base em um juízo presuntivo, a Corte de Apelação de Veneza (primeiro tribunal italiano a apreciar o requerimento de delibação) entendeu que a quantia se destinava a punir o ofensor, amparando tal conclusão, principalmente, nos fatos de (i) a condenação não se ancorar em decisão fundamentada, da qual se pudesse, por hipótese, extrair conclusão diversa; e de (ii) a condenação ser bastante expressiva, especialmente em confronto com os montantes usualmente concedidos na Itália para compensar parentes pelos prejuízos suportados em decorrência do falecimento de entes queridos (cfr. F. QUARTA, Recognition and Enforcement of U.S. Punitive Damages 
Por entender que a condenação imposta à empresa italiana também exercia funções preventiva e punitiva, típicas dos punitive damages, e outorgava ao demandante uma quantia que excedia aquela ordinariamente necessária para compensá-lo pelos prejuízos sofridos, a Corte de Apelação de Veneza deixou de reconhecer e executar a sentença proferida nos Estados Unidos da América (Corte App. Venezia, 15 oct. 2001, n. 1359) ${ }^{823}$.

Insatisfeito com o julgamento proferido pela Corte de Apelação de Veneza, o demandante recorreu à Corte de Cassação para sustentar, em caráter principal, que não era possível à Corte de Apelação atribuir ao quantum indenizatório um caráter punitivo (e, portanto, em suposto conflito com a ordem pública) se a própria sentença cujo reconhecimento se pretendia reconhecer não era clara a esse respeito e, em caráter subsidiário, que a condenação, ainda que ostentasse viés punitivo, não era incompatível com a ordem pública italiana, cujo ordenamento admitia sanções civis de função punitiva, tais como a cláusula penal e a indenização dos danos não-patrimoniais ${ }^{824}$. Nesse contexto, introduziu-se na mais alta corte italiana a análise de compatibilidade entre os punitive damages e a ordem pública.

No que toca à primeira das razões recursais, a Corte de Cassação sustentou não ser possível afastar o juízo firmado pela Corte de Apelação acerca da natureza punitiva da indenização imposta ao demandado por se tratar de uma questão de fato, impassível de análise na instância superior ${ }^{825}$.

Já quanto à segunda das razões recursais, a Corte de Cassação referendou o entendimento esposado pela Corte de Apelação ao sustentar que, na Itália, a função

Awards in Continental Europe: The Italian Supreme Court's Veto, in Hastings International \& Comparative Law Review, vol. 31, 2008, pág. 756).

${ }^{823}$ E. D'Alessandro, Pronunce Americane di Condanna al Pagamento di Punitive Damages e Problemi di Riconoscimento in Italia, in Rivista di Diritto Civile, anno LIII, n. 3, mag.-giug./2007, págs. 392/393.

${ }^{824}$ F. QUARTA, Recognition and Enforcement of U.S. Punitive Damages Awards in Continental Europe: The Italian Supreme Court's Veto, in Hastings International \& Comparative Law Review, vol. 31, 2008, pág. 757.

${ }^{825}$ F. QUARTA anuncia que, em matéria de delibação, cabe à Corte de Cassação apenas reinterpretar o juízo feito pela corte inferior quanto à noção de ordem pública, não lhe sendo lícito reexaminar os aspectos fáticos que levaram o tribunal a quo a firmar seu convencimento (Recognition and Enforcement of U.S. Punitive Damages Awards in Continental Europe: The Italian Supreme Court's Veto, in Hastings International \& Comparative Law Review, vol. 31, 2008, pág. 757). Trata-se de procedimento semelhante àquele adotado pelos Tribunais Superiores brasileiros, os quais também são tidos como "tribunais de teses", e não de fatos, sendo-lhes vedado o reexame de tais aspectos fáticos, ex vi da Súmula 7/STJ (a qual dispõe que "a pretensão de simples reexame de prova não enseja recurso especial'). 
punitiva era estranha à responsabilidade civil, cuja finalidade seria estritamente compensatória, assim como também lhes eram estranhas quaisquer considerações a respeito do grau de culpa do demandado. Demais disso, afirmou a Corte de Cassação que os institutos jurídicos aos quais havia aludido o recorrente não exerceriam função punitiva, quer porque, no que concerne à cláusula penal, o Código Civil italiano autoriza ao juiz reduzir a quantia nela prevista caso a julgue manifestamente excessiva (art. 1384, CC) ${ }^{826}$, o que excluiria qualquer possibilidade de tal instituto vir a ser utilizado com viés punitivo, quer, ainda, porque, no que toca à indenização por danos morais, esta somente seria devida caso o demandante houvesse efetivamente suportado prejuízos, bem como somente seria quantificada em atenção aos limites desses prejuízos ${ }^{827}$.

Uma vez que, de um lado, a função punitiva da indenização e sua quantificação de acordo com o grau de culpa do ofensor são instrínsecas aos punitive damages e, de outro, foram reputadas como incompatíveis com o ordenamento italiano, a Corte de Cassação tal instituto violaria a ordem pública italiana, obstando, portanto, o reconhecimento e execução de sentenças estrangeiras que previssem tal sorte de condenação, com fundamento no art. 64, 'g', da Lei 218/1995 $5^{828}$.

A despeito de os mais altos tribunais alemão e italiano terem firmado se entendimento no sentido de inadmitir o reconhecimento de sentenças estrangeiras que contenham um capítulo condenatório referente aos punitive damages, tal posicionamento não restou imune a críticas severas da doutrina em seus países.

Com efeito, o entendimento esposado pelo Bundesgerichtshof, no sentido de rejeitar o reconhecimento dos punitive damages na Alemanha, foi combatido por parte da doutrina tedesca, a qual passou a sustentar a inexistência de incompatibilidade ontológica entre o instituto dos punitive damages e os valores fundamentais que compõem a ordem pública alemã. Nesse sentido, E. D’AlESSANDRo cotejou três grupos de argumentos

\footnotetext{
826 O qual prescreve, in verbis: "(riduzione della penale): La penale può essere diminuta equamente dal giudice, se l'obbligazione principale è stata eseguita in parte ovvero se l'ammontare della penale è manifestamente eccessivo, avuto sempre riguardo all'interesse che il creditore aveva all'adempimento". A redação é praticamente idência àquela do art. 413, CC/2002.

${ }^{827}$ F. QUARTA, Recognition and Enforcement of U.S. Punitive Damages Awards in Continental Europe: The Italian Supreme Court's Veto, in Hastings International \& Comparative Law Review, vol. 31, 2008, págs. $758 / 759$.
} 
usualmente referidos pela doutrina para rebater as premissas assumidas pelo Bundesgerichtshof, concluindo pela possibilidade de reconhecimento de sentenças estrangeiras que condenem o demandado ao pagamento de punitive damages, uma vez que: (i) a assim chamada "função satisfativa" (Genugtuungsfunktion) da indenização por danos não-patrimoniais (Schmerzensgeld), prevista no $\S 253$, 2, do BGB, também conteria elemento punitivo ${ }^{829}$; (ii) é jurisprudencialmente aceito que a responsabilidade civil exerça funções distintas da simples compensação dos prejuízos sofridos (Schadensausgleich), especialmente para prevenir a ocorrência de prejuízos a bens que, se lesados, jamais poderão ser propriamente recompostos, como é o caso dos direitos da personalidade e dos segredos industriais; (iii) o $§ 611 \mathrm{a}$, incs. 2 e 3, do BGB (dispositivo este, contudo, já revogado), teria previsto um instituto assemelhado aos punitive damages, ao permitir a imposição de uma sanção com suposto viés punitivo ao empregador que deixasse de admitir determinado candidato por motivações discriminatórias ${ }^{830}$.

Com argumentos assemelhados àqueles apresentados pela doutrina tedesca, M. L. GonZALO confronta as conclusões apresentadas pela Corte de Cassação italiana ao afirmar que o ordenamento jurídico italiano comportaria, sim, sanções das quais se poderia extrair uma função punitiva da responsabilidade civil ${ }^{831}$ (como exemplos, o autor cita a indenização do dano ambiental, prevista no art. 18 , Lei n. $349 / 1986^{832}$, a indenização por

${ }^{828}$ M. L. Gonzalo, Punitive Damages e Ordine Pubblico, in Rivista di Diritto Internazionale Privato e Processuale, anno XLIV, n. 1, gen.-mar./2008, págs. 77/83.

${ }^{829}$ Ao tratar da indenização dos prejuízos não-patrimoniais, B. R. KERN sustenta que a Genugtuungsfunktion a eles atribuída pelo BGB exerce, segundo a doutrina e a jurisprudência consolidada do Supremo Tribunal Federal Alemão (BGH), ao menos três finalidades: (i) a "de trazer ao lesado um sentimento de satisfação, apaziguar seu senso de justiça ferido" [função assemelhada à de vingança privada, atribuída pela doutrina norte-americana aos punitive damages]; (ii) a de "impor ao ofensor um sensível sacrifício patrimonial" [nítida função punitiva]; e, ainda, (iii) a de "atuar preventivamente no futuro" [função preventiva] (A Função de Satisfação na Indenização do Dano Pessoal, in Revista de Direito do Consumidor, n. ${ }^{\circ} 33$, janeiro/março 2000, págs. 10/11). Pode-se dizer, com tais fundamentos, que também na Alemanha se atribui à indenização dos detrimentos morais uma função que abarca não apenas a compensação pelos prejuízos suportados, mas, também, a de punir o ofensor pelo mal perpetrado e a de desestimular o ofensor e a sociedade quanto ao cometimento de atos ilícitos no futuro.

${ }^{830}$ Pronunce Americane di Condanna al Pagamento di Punitive Damages e Problemi di Riconoscimento in Italia, in Rivista di Diritto Civile, anno LIII, n. 3, mag.-giug./2007, págs. 390/391.

${ }^{831}$ Punitive Damages e Ordine Pubblico, in Rivista di Diritto Internazionale Privato e Processuale, anno XLIV, n. 1, gen.-mar./2008, págs. 82/83.

${ }^{832}$ Para a quantificação da indenização, o art. 18, 6, Lei 349/1986 prevê a utilização de critérios punitivos, alheios aos estritos limites do prejuízo suportado, dispondo, in verbis: "[i]l giudice, ove non sia possibile una precisa quantificazione del danno, ne determina l'ammontare in via eqüitativa, tenendo comunque conto della gravità della colpa individuale, del costo necessario per il ripristino e del profitto conseguito dal trasgressore in conseguenza del suo comportamento lesivo dei beni ambientali". Considerando tratar-se de critérios punitivos, os quais atribuem à indenização do dano ambiental uma função "essencialmente sancionatória", cfr. M. G. BARATELla, Le Pene Private, Milano, Giuffrè, 2006, págs. 170/186. 
prejuízos causados por meio da imprensa, prevista no art. 12, Lei n. 47/1948 ${ }^{833}$ e, ainda, a indenização decorrente de litigância de má-fé, prevista no art. 96, do CPC italiano ${ }^{834}$ ), bem como que a indenização do dano moral ou não-patrimonial, prevista no art. 2059, do CC italiano, também possuiria uma função sanzionatória ou preventiva ${ }^{835}$.

Dessas premissas, extrai o autor a conclusão de que "especialmente caso se adote uma interpretação mais restritiva (e, portanto, uma aplicação verdadeiramente excepcional) da noção de ordem pública, a função preventiva-sancionatória dos punitive damages pode-se colocar em um plano de 'diversidade', em vez de num de radical incompatibilidade com os princípios fundamentais do ordenamento italiano no que concerne à responsabilidade civil" ${ }^{, 836}$; o que, como via de conseqüência, permitiria o

${ }^{833} \mathrm{O}$ dispositivo em questão permite àquele que tenha sido lesado em sua honra exigir o recebimento de uma quantia indenizatória em adendo àquela a que ordinariamente faria jus, em decorrência do cometimento de ato ilícito penal pelo ofensor, ex vi do art. 185, do CP italiano, prescrevendo que: "[n]el caso di diffamazione commessa col mezzo della stampa, la persona offensa può chiedere, oltre il resarcimento dei danni ai sensi dell'art. 185 del Codice Penale, una somma a titulo di riparazione. La somma è determinata in relazione alla gravità dell'offesa ed alla diffusione dello stampo". Para fins comparativos, vale lembrar que o art. 53 da Lei 5.250/1967 (Lei de Imprensa Brasileira) também previa a utilização de critérios punitivos para a quantificação da indenização decorrente de danos à honra causados por meio da imprensa. Ao tratar do tema, M. G. BARATELLA apresenta interessante quadro sinótico da evolução do entendimento esposado pelos tribunais italianos, o que demonstra a utilização, pela jurisprudência, de critérios punitivos, alheios ao dano efetivamente suportado pelo ofendido, para a quantificação da indenização, tais como a intensidade do dolo, a gravidade da culpa, as circunstâncias pessoais do ofensor, sua capacidade econômica ou, ainda, os benefícios econômicos auferidos por ele em razão do cometimento do ilícito. Com conta da utilização desses critérios para a mensuração da indenização, a citada autora atribui a esta sanção uma dupla função, compensatória e punitiva (Le Pene Private, Milano, Giuffrè, 2006, págs. 121/146).

${ }^{834} \mathrm{O}$ dispositivo prevê a condenação do litigante que tenha se conduzido de maneira dolosa ou gravemente culposa, prescrevendo, in verbis: "[s]e risulta che la parte soccombente ha agito o resistito in giudizio con mala fede o colpa grave, il diudice, su istanza dell'altra parte, la condanna, oltre che alle spese, al risarcimento dei danni, che liquida, anche di ufficio, nella sentenza".

${ }^{835}$ M. G. BARATELLA apresenta extenso rol de doutrinadores italianos que atribuem à indenização dos danos não-patrimoniais uma função também (ou exclusivamente) punitiva (Le Pene Private, Milano, Giuffrè, 2006, págs. 110/118), o que, na linha argumentativa acima exposta, permitiria concluir que, no que toca ao Direito Italiano, não se poderia afirmar que as funções punitiva e preventiva são alienígenas ao instituto da responsabilidade civil.

${ }^{836}$ No original, "specie ove si aderisca ad una interpretazione restritiva (e quindi ad una applicazione davvero eccezionale) della nozione di ordine pubblico, la funzione deterrent-sanzionatoria dei punitive damages potrebbe collocarsi su un piano di 'divertità', piuttosto che di radicale incompatibilità rispetto ai principi fondamentali dell'ordinamento italiano in tema di responsabilità civile." (M. L. GonZALO, Punitive Damages e Ordine Pubblico, in Rivista di Diritto Internazionale Privato e Processuale, anno XLIV, n. 1, gen.-mar./2008, págs. 83/84). A concepção de que, durante um processo delibatório, o julgador deve lançar mão de "uma noção mais atenuada de ordem pública", o que permitiria afirmar a compatibilidade de ordenamentos de países de raiz romano-germânica com o instituto dos punitive damages foi também esposada pelo Tribunal da Basilea em julgamento realizado em $1^{\circ}$ de fevereiro de 1989 , quando reconheceu e determinou a execução de uma sentença americana dessa natureza (cfr. A. SARAVALlE, I Punitive Damages nelle Sentenze delle Corti Europee e dei Tribunali Arbitrali, in Rivista di Diritto Internazionale Privato e Processuale, anno XXIX, n. 4, ott.-dic./1993, págs. 876/877). Tal posicionamento, contudo, não é unânime na doutrina italiana. Para E. D’ALESSANDRO, há sempre de se rejeitar o reconhecimento e execução de uma sentença estrangeira que preveja o pagamento de punitive damages, uma vez que, ao contrário da sanção prevista pelo ordenamento italiano para a compensação dos danos não-patrimoniais (art. 2059, do CC 
reconhecimento e execução de uma sentença estrangeira que contivesse capítulo condenatório dessa natureza.

Em contraste com o entendimento esposado pelas cortes italiana e alemã, mas em consonância com o entendimento doutrinário acima exposto, o Supremo Tribunal Espanhol, quando teve a oportunidade de fazê-lo, reconheceu e executou sentença condenatória proferida nos Estados Unidos da América que continha, em seu bojo, a imposição de indenização punitiva ao demandado. Tratou-se, na origem, de demanda indenizatória ajuizada conjuntamente por empresas sediadas nos Estados Unidos da América e na Itália, contra uma empresa espanhola com fundamento na infringência de propriedade intelectual. Proferida sentença de procedência em uma corte federal do sul do Estado do Texas, em processo que tramitou à revelia da empresa espanhola, as demandantes buscaram seu reconhecimento e execução no país no qual a demandada possuía bens a serem excutidos ${ }^{837}$.

Ao apreciar, especificamente, o capítulo da sentença condenatória que previa a imposição de punitive damages à demandada, o Supremo Tribunal Espanhol afirmou que o juízo delibatório deveria consistir apenas e tão-somente na verificação da compatibilidade entre os efeitos decorrentes da condenação estrangeira e a ordem pública espanhola $^{838}$. Tal mister, em razão do conceito restritivo de ordem pública adotado naquela

italiano), estes exercem uma função essencialmente punitiva, incompatível com a ordem pública interna e, portanto, impassível de reconhecimento ex vi do art. 64, 'g', da Lei 218/1995. A violação à ordem pública, nas palavras da autora, decorreria do fato de os punitive damages supostamente poderem ser impostos sem o necessário respeito às garantias constitucionais decorrentes do princípio da legalidade, tais como a prévia cominação legal da sanção, de suas hipóteses de incidência e, ainda, dos limites máximos da condenação. (Pronunce Americane di Condanna al Pagamento di Punitive Damages e Problemi di Riconoscimento in Italia, in Rivista di Diritto Civile, anno LIII, n. 3, mag.-giug./2007, págs. 401/406). F. QUARTA, por sua vez, encontra a incomaptibilidade entre os punitive damages e a ordem pública no princípio nulla poena sine legge, insculpido no art. 25, da Constituição Italiana (o qual dispõe, in verbis: "[n]essuno può essere punito se non in forza di una legge che sia entrata in vigore prima del fatto commesso"). Sustenta o autor que, por ser vedado aos juízes europeus (e também aos brasileiros, atuantes que são em países de tradição jurídica romanogermânica) "criar leis ou desenvolver novos remédios jurídicos sem prévia cominação legal", não lhes seria admissível reconhecer e dar execução a punitive damages, instituto jurídico reputado pelo autor como de origem exclusivamente jurisprudencial. (Recognition and Enforcement of U.S. Punitive Damages Awards in Continental Europe: The Italian Supreme Court's Veto, in Hastings International \& Comparative Law Review, vol. 31, 2008, pág. 778).

${ }^{837}$ (Supremo Tribunal Espanhol; Câmara Cível; $1^{\text {a }}$ Seção; Recurso n. o 2039/1999; Relator: Ignacio Sierra Gil de La Cuesta; J. 13.11.2001). O caso também é mencionado por M. R. IsidRo, Punitive Damages From a Private International Law Perspective, in H. KozIOL - V. WILCOX, Punitive Damages: Common Law and Civil Law Perspectives, Wien, Springer, 2009, págs. 247/248.

${ }^{838}$ Importa de ver que, a despeito de a Espanha também adotar o sistema de reconhecimento de sentenças estrangeiras por reciprocidade (cfr. André de Albuquerque Cavalcanti ABBuD, Homologação de Sentenças Arbitrais Estrangeiras, São Paulo, Atlas, 2008, pág. 23 e Maria Helena DINIZ, Lei de Introdução ao Código 
oportunidade, consistiria apenas na análise de se determinado instituto jurídico estrangeiro poderia, ou não, conviver de maneira harmônica com os preceitos essenciais do ordenamento interno espanhol ${ }^{839}$. Concluiu-se, na oportunidade, que "[n]o momento de precisar os princípios e valores essenciais com os quais se identifica o conceito de ordem pública internacional, não se pode ignorar que aqueles [princípios e valores] sob os quais se desenvolve o mecanismo de indenização de perdas e danos não são inteiramente alheios à idéia de prevenção, e que tampouco lhes são estranhos os instrumentos sancionatórios coercitivos, tanto no âmbito material - contratual, especificamente -, como na esfera processual" ${ }^{840}$; tudo para que se admitisse, enfim, que a imposição de indenização punitiva não viola a ordem pública espanhola, conferindo-se o exequatur à sentença estrangeira.

Como se pode notar, o reconhecimento de sentenças estrangeiras que contenham capítulo condenatório atinente aos punitive damages é questão jurídica das mais tormentosas, verificando-se nada mais que uma grande controvérsia na doutrina e jurisprudência alienígenas. A despeito da controvérsia, parece-nos admissível concluir, na linha argumentativa seguida pelo Supremo Tribunal Espanhol, pela possibilidade de reconhecimento de tais sentenças em nosso país, especialmente se, para o desempenho desse mister, partirmos de um conceito restritivo de ordem pública internacional, nos moldes acima preconizados.

Civil Brasileiro Interpretada, $15^{a}$ ed., São Paulo, Saraiva, 2010, pág. 409), este não foi o critério utilizado na hipótese em razão de os Estados Unidos da América não admitirem a imediata importação de sentenças espanholas (i.e., não existe reciprocidade entre a Espanha e os Estados Unidos da América).

${ }^{839}$ (Supremo Tribunal Espanhol; Câmara Cível; $1^{\text {a }}$ Seção; Recurso n. ${ }^{\circ}$ 2039/1999; Relator: Ignacio Sierra Gil de La Cuesta; J. 13.11.2001; item '9', pág. 6). M. R. IsIDRO, atribui as conclusões apresentadas pelo Supremo Tribunal Espanhol à concepção de que os limites impostos pela ordem pública variam em intensidade de acordo com "grau de proximidade" que o caso sob análise possui com o Juízo em que se realiza o processo delibatório (critério este denominado pela doutrina alemã de inlandsbeziehung). Em se tratando de demanda ajuizada por empresas estrangeiras, uma delas situada nos Estados Unidos da América, em razão de atos ilícitos perpetrados no estrangeiro, e tendo como único vínculo com a Espanha a sede da empresa demandada, o conceito de ordem pública a ser adotado no caso poderia ser ainda mais restritivo (adotando-se, portanto, a noção de ordem pública internacional, em detrimento da noção de ordem pública interna, que somente seria admissível em se tratando de lide que tivesse um "alto grau de proximidade" com o Tribunal em questão, ou seja, se todos os fatos e circunstâncias pertinentes ao julgamento da causa houvessem se dado dentro dos limites territoriais do Estado em questão). (Punitive Damages From a Private International Law Perspective, in H. KOZIOL - V. WILCOX, Punitive Damages: Common Law and Civil Law Perspectives, Wien, Springer, 2009, pág. 247).

${ }^{840}$ No original: "[a] la hora de concretar los principios y valores jurídicos essenciales con los que cabe identificar el concepto de orden público internacional, no se puede desconocer que aquellos bajo los que se desenvuelve el mecanismo de la indemnización de los daños y perjuicios no son ajenos enteramente a la idea de prevención, y que tampoco les son extraños los instrumentos sancionatorios coercitivos, tanto en el ámbito material - contractual, específicamente -, como en la esfera procesal." (Supremo Tribunal Espanhol; Câmara Cível; $1^{\text {a }}$ Seção; Recurso n. ${ }^{\circ}$ 2039/1999; Relator: Ignacio Sierra Gil de La Cuesta; J. 13.11.2001; item '9', págs. 6/7). 
Por primeiro, e em ponto no qual ousamos divergir de uma das premissas acolhidas pelos Tribunais Superiores na Itália e na Alemanha, parece-nos questionável sustentar que o princípio da reparação integral (o qual, insculpido expressamente no art. 944, caput, CC/2002, certamente representa norma de ordem pública interna e é, portanto, inderrogável) componha uma noção estrita de ordem pública internacional.

Com efeito, já se afirmou que tal princípio não é absoluto, comportando exceções pontuais previstas inclusive em nosso próprio ordenamento (como o são, por ex., as cláusulas contratuais limitativas de responsabilidade, as cláusulas penais, a redução eqüitativa da indenização em razão da excessiva desproporção entre a culpa e o dano, prevista no art. 944, par. ún., CC/2002 e, ainda, a redução proporcional da indenização em virtude da "concorrência de culpas", prevista no art. 945, CC). Por se admitir, em normas de direito interno, exceções ao princípio da reparação integral, não se poderia tachar de incompatíveis eventuais em normas de direito alienígena que, igualmente, contivessem institutos que excepcionassem de maneira pontual a incidência de tal princípio (como o são os punitive damages).

Por segundo, também nos parece questionável a alusão ao princípio da legalidade das penas (nulla poena sine lege) para obstar o reconhecimento de sentenças estrangeiras que contenham capítulo condenatório referente aos punitive damages.

Esclarece-se: tal princípio, insculpido no art. $5^{\circ}, \mathrm{XXXIX,} \mathrm{CF/88,} \mathrm{certamente}$ integra o "núcleo fundamental de princípios irrenunciáveis" que nosso país ostenta em suas relações internacionais e, conseqüentemente, compõe a noção de ordem pública internacional. Entende-se, portanto, ser absolutamente inadmissível o reconhecimento e execução de uma sentença estrangeira que condenasse o demandado a suportar uma pena que não encontrasse prévia estipulação em seu ordenamento de origem (como o seria, por ex., uma sentença espanhola que contivesse capítulo condenatório ao pagamento de punitive damages, instituto não contemplado pelo direito interno espanhol).

O que não nos parece inadmissível, contudo, é reconhecer uma sentença estrangeira que contenha capítulo condenatório referente a pena regular e previamente prevista no ordenamento interno do país em que tal sentença foi proferida, ainda que a 
previsão não se tenha dado por meio de norma legal genérica e escrita (= lei). Quer-nos parecer que o princípio da legalidade das penas deve ser interpretado de acordo com as vicissitudes do ordenamento em que a aludida pena houver sido prevista. Tratando-se de país de raízes jurídicas típicas da common law, é admissível que sanções civis (mesmo aquelas que exercem função essencialmente punitiva, como o são os punitive damages) sejam regularmente estabelecidas por meio de precedentes jurisprudenciais, sem a necessidade de elaboração de normas legais escritas (statutes) que os referendem. Ainda que assim ocorra, entende-se estar respeitado o princípio da legalidade das penas se a sanção punitiva houver sido previamente estabelecida, tendo-se definido adequadamente sua hipótese de incidência antes do cometimento do ato que deu ensejo à sua aplicação no caso concreto, o que possibilita ao infrator conformar sua conduta à norma jurídica.

Nessa toada, entende-se admissível que o Superior Tribunal de Justiça, no exercício das atribuições a ele imputadas pela Constituição Federal, reconheça e dê execução a sentenças estrangeiras que contenham capítulo condenatório atinente aos punitive damages, não se podendo afirmar que tal instituto jurídico afronta a noção de ordem pública internacional. 


\section{CAPÍTULO V - A QUANTIFICAÇÃO DA INDENIZAÇÃO PUNITIVA}

Vencidas as questões anteriormente levantadas, compete-nos, neste capítulo, tecer considerações sobre os últimos fatores que se considerou, no presente estudo, como o regramento mínimo para a introdução legislativa do instituto da indenização punitiva no ordenamento jurídico brasileiro, quais sejam, aqueles atinentes à quantificação da indenização.

Para tanto, procuraremos, em primeiro lugar, passar em revista aqueles elementos usualmente levantados como aptos a servir de critério para a quantificação da indenização punitiva, para o quê voltaremos os olhos para as considerações apresentadas pela doutrina norte-americana, no que toca à quantificação dos punitive damages e, também, para aquelas trazidas pela doutrina nacional e estrangeira, principalmente no que concerne à quantificação da indenização punitiva e da indenização por danos morais, à qual se costuma atribuir funções punitiva e preventiva.

Na seqüência, analisaremos os métodos mais comumente aventados para que se possa exercer um controle do montante final da indenização punitiva, versando tanto sobre um método a priori, de estipulação de limites legais pré-fixados, quanto, sobre um método a posteriori, para controle jurisdicional do montante da indenização, por meio da incidência dos critérios da proporcionalidade e razoabilidade.

\section{CRITÉRIOS PARA A QUANTIFICAÇÃo DA INDENIZAÇÃo PUNITIVA}

A primeira tarefa da qual pretendemos nos desincumbir ao tratar sobre o tema é analisar quais critérios devem ser considerados pelo julgador para a quantificação da indenização punitiva. Para o adequado exercício desse mister, é imprescindível ter em conta que a indenização punitiva também exerce funções de punição e prevenção, as quais são distintas da função exclusivamente reparadora exercida pela responsabilidade civil em seu viés compensatório. 
Em atenção às diferentes funções por ela exercidas, a quantificação da indenização punitiva deverá levar em consideração critérios que não se relacionem com a recomposição do patrimônio lesado (o ponto de relevância, aqui, não recai - ao menos não de maneira direta ou principal - sobre a vítima ou sobre o bem jurídico lesado), mas, sim, com a retribuição do lesante pelo mal perpetrado e a sua dissuasão ao cometimento de novas condutas ilícitas ${ }^{841}$ (o ponto de relevância passa a recair, portanto, sobre a pessoa do ofensor e a conduta por ele praticada). Assim, até mesmo para que possa exercer adequadamente as funções a que se destina, a indenização punitiva deve necessariamente poder extrapolar os limites impostos pela indenização compensatória (os quais, em nosso ordenamento, estão bem delineados no art. 944, caput, CC/2002), fugindo de seus paradigmas (o que faz que a tarefa de quantificação da indenização não se restrinja aos conceitos de dano emergente e lucro cessante).

Partindo-se da premissa acima fixada, e com vistas a proceder à análise mais completa possível de quais os critérios adequados para a quantificação da indenização punitiva, optamos pela apreciação conjugada de três fontes distintas: (i) a doutrina e a jurisprudência norte-americanas, para delas extrair os critérios usualmente considerados para a quantificação dos punitive damages; (ii) doutrina dos países da civil law, para dela extrair os critérios aventados para a quantificação de indenização punitiva; e, ainda, (iii) a doutrina e jurisprudência nacionais, para, delas, retirarmos os critérios aventados para a quantificação de indenização por danos morais, em especial nos casos em que se atribui a tal indenização não apenas uma função compensatória, mas, também, uma função punitiva.

Como já se expôs ao tratarmos do regime jurídico dos punitive damages nos países da common law, a doutrina e a jurisprudência norte-americanas, em entendimento consolidado no $\S 908$ do Restatement (Second) of Torts, enumeram três critérios para a quantificação da indenização punitiva, a saber: (i) as características da conduta do lesante (o assim chamado "grau de reprovabilidade da conduta" ou "degree of reprehensibility of the conduct", critério subjetivo relacionado ao grau de culpa ou à intencionalidade da conduta ilícita perpetrada); (ii) a natureza e extensão dos prejuízos causados ao lesado (os actual ou compensatory damages, ou, em determinados casos, os danos que, ainda que não tenham

\footnotetext{
${ }^{841}$ Eduardo UlLan, Responsabilidade Civil Punitiva, Tese (Doutorado) - Faculdade de Direito da USP, São Paulo, 2003, pág. 88.
} 
sido efetivamente suportados pelo lesado ou por terceiros, poderiam potencialmente decorrer do ato ilícito cometido pelo lesante ${ }^{842}$ ); e, ainda, (iii) a capacidade econômina do lesante ${ }^{843}$.

Os critérios acima enumerados pela doutrina norte-americana são fielmente reproduzidos pela doutrina européia e nacional ao tratar do tema da quantificação da indenização punitiva. Assim como fazem seus colegas da América do Norte ao dissertar sobre os punitive damages, os doutrinadores de países da civil law afirmam que a indenização punitiva deve ser quantificada de acordo com “a) o grau de culpa do autor do dano; b) a gravidade e repercussão (extensão) do dano, e, por fim, c) a situação socioeconômica do(s) responsável(eis) pelo dano" ${ }^{\text {844 }}$.

Por fim, ao tratar da indenização dos danos não-patrimoniais, em especial nos casos em que se atribui a tal indenização as funções de prevenção (especial e geral) e punição, a doutrina e jurisprudência pátrias não apenas reproduzem os três critérios acima enumerados, mas, a eles, costuma-se adicionar um quarto critério: a capacidade econômica do ofendido, fator este usualmente aventado com a finalidade de servir de balanceador para o quantum indenizatório ${ }^{845}$.

${ }^{842}$ Como se viu anteriormente, o segundo guidepost fixado em BMW of North America v. Gore (517 U.S. 559 1995) não previa uma relação de proporcionalidade entre os punitive damages e os prejuízos efetivamente suportados pelo demandante, abrindo a possibilidade de que se considerasse, além dos efetivos prejuízos, aqueles que potencialmente poderiam ter sido impostos ao demandante em razão da conduta vil perpetrada pelo demandado. Nesse sentido, M. A. GEISTFELD afirma que "[a]ccording to the U.S. Supreme Court, whether a punitive award is constitutionally excessive depends on the 'disparity between the actual or potential harm suffered by the plaintiff and the punitive award'. A jury award of compensatory damages only encompasses the harm actually suffered by the plaintiff. If the plaintiff could have suffered even greater harm as a result of the defendant's wrongdoing, then the single-digit ratio [criterio de proporcionalidade contido no $2^{\circ}$ guidepost fixado em Gore] applies to that amount rather than to the smaller jury award of compensatory damages." (Punitive Damages, Retribution, and Due Process, in South California Law Review, vol. 81, 2007/2008, pág. 296).

${ }^{843}$ Apontando os três critérios acima enumerados para a quantificação dos punitive damages, apenas à guisa de exemplo, cfr. M. M. Belli SR., Punitive Damages: Their History, Their Use and Their Worth in PresentDay Society, in UMKC Law Review, vol. 49, n. 1, 1980, págs. 11/12 e de G. B. BELL - P. E. PEARCE, Punitive Damages and the Tort System, in University of Richmond Law Review, vol. 22, 1987, págs. 6/7.

${ }^{844}$ Caroline VAZ, Funções da Responsabilidade Civil - Da Reparação à Punição e Dissuasão - Os punitive damages no Direito Comparado e Brasileiro, Porto Alegre, Livraria do Advogado, 2009, pág. 134. No mesmo sentido, André Gustavo Corrêa de AndRAde, Dano Moral e Indenização Punitiva: Os punitive damages na experiência do common law e na perspectiva do Direito brasileiro, Rio de Janeiro, Forense, 2006, págs. 328/329; P. GALlo, Pene Private e Responsabilità Civile, Milano, Giuffrè, 1996, pág. 196.

${ }^{845}$ Em doutrina, a utilização do supra aludido critério é defendida, entre outros, por Carlos Roberto GonçAlves, Comentários ao Código Civil, vol. 11, São Paulo, Saraiva, 2003, pág. 368. Na jurisprudência, já assentou o E. TJMG que, "[n] a verdade, a fixação [da indenização por danos morais] deve, ao mesmo tempo, compensar o sofrimento do lesado e servir de punição ao ofensor, não podendo configurar fonte de enriquecimento ou apresentar-se de forma inexpressiva, valendo ressaltar que é importante atentar para o grau de culpa do agente e a situação econômica das demandantes". (TJMG; 4 a Câm. Cível; Apelação n. ${ }^{\circ}$ 1.0569.06.007653-0/001; Relator: Des. José Francisco Bueno; J. 26.11.2009). Na mesma linha de raciocínio, 
Passaremos, então, a analisar pormenorizadamente cada um dos quatro critérios acima enumerados para verificar, isoladamente, sua pertinência (ou eventual impertinência) para a quantificação da indenização punitiva.

\section{I.I. O grau de culpa do ofensor}

Não se pode negar que, quando se passa a discorrer sobre a quantificação da indenização punitiva, o primeiro critério que vem à mente (até mesmo daqueles não versados nos estudos jurídicos) é o grau de reprovabilidade da conduta ilícita levada a efeito, ou, em outras palavras, o grau de culpa ou dolo do lesante ${ }^{846}$.

Tal critério, intimamente ligado ao desempenho da função punitiva da responsabilidade civil $^{847}$, representa uma verdadeira ruptura do dogma da unitariedade da culpa (o qual, consubstanciado no brocardo romano "in Lex Aquilia et levissima culpa venit", prescreve que, para a quantificação da indenização, os diversos graus de culpa são ordinariamente irrelevantes $)^{848}$ e diferencia sensivelmente o tratamento legislativo

o E. TJSP já firmou entendimento no sentido de que "[d]eve o valor da reparação [do dano moral] ser razoável à situação de fato, levando-se em conta a gravidade do dano, a culpa do agente e a situação econômica das partes, a fim de alcançar o almejado efeito punitivo medida para a repetição da conduta social da ré." (TJSP; Apelação n. ${ }^{\circ} 992060553501$; Relator: Des. Norival Oliva; J. 24.11.2009). Inúmeros são os julgados em sentido semelhante, os quais aludem à situação econômica das vítimas do ilícito como fator importante para a quantificação da indenização por danos morais, sempre para a mitigação do quantum indenizatório: (TJSP; $21^{\text {a }}$ Câm. de Dir. Privado; Apelação n. ${ }^{\circ}$ 991.09.065477-4; Relator: Des. Itamar Gaino; J. 11.11.2009); (TJSP; Apelação n. ${ }^{\circ}$ 1050622200; Relator: Des. Vieira de Moraes; J. 15.05.2008); (TJSP; Apelação n. ${ }^{\circ}$ 943034000; Relator: Des. Antônio Ribeiro; J. 27.03.2007); (STJ; 4 ${ }^{\mathrm{a}}$ Turma; RESP n. ${ }^{\circ}$ 207926/PR; Relator: Min. Ruy Rosado de Aguiar; J. 01.06.1999); (STJ; $4^{\text {a }}$ Turma; RESP n. ${ }^{\circ}$ 745710/RJ; Relator p/acórdão: Min. Jorge Scartezzini; J. 05.12.2006); (TJMG; $4^{\mathrm{a}}$ Câm. Cível; Apelação n. ${ }^{\circ}$ 1.0702.08.521376-8/001; Relator: Des. Dárcio Lopardi Mendes; J. 22.04.2010)

${ }^{846}$ No que toca ao instituto jurídico dos punitive damages, mas em lição que pode ser emprestada para o que se pretende no momento, D. G. OWEN afirma que "[t]he flagrancy of the misconduct is thought to be the primary consideration in determining the amount of punitive damages [...]."(A Punitive Damages Overview: Functions, Problems and Reform, in Villanova Law Review, vol. 39, 1994, pág. 387). Pelas mesmas razões, R. D. PIZARRO afirma que "[1]a falta debe ser grave pues solamente en estos casos procede la punicíon; la gravedad del reproche determina no sólo la procedencia de la pena, sino también la gradación de su cuantía". (Daño Moral - Prevención, Reparación, Punición: El Daño Moral em las Diversas Ramas del Derecho, Buenos Aires, Hammurabi, 1996, págs. 379/380).

${ }^{847}$ P. Gallo, Pene Private e Responsabilità Civile, Milano, Giuffrè, 1996, pág. 197 e Marcela Alcazas BAssan, As Funções da Indenização por Danos Morais e a Prevenção de Danos Futuros, Dissertação (Mestrado) - Faculdade de Direito da USP, São Paulo, 2009, pág. 111.

848 Assim, afirma Agostinho ALVIM que, "[q]uando, p. ex., alguém deve ressarcir, nada influirá na indenização o fato de ter havido dolo ou mesmo crime, em vez de culpa. O ressarcimento mede-se pelo dano." (Da Doação, $3^{\text {a }}$ ed., São Paulo, Saraiva, 1980, pág. 278). No mesmo sentido, cfr. o próprio Agostinho 
emprestado à sanção compensatória (da qual é exemplo maior a indenização compensatória, destinada à recomposição do patrimônio lesado e limitada pela extensão dos prejuízos suportados pela vítima) daquele atribuído à sanção punitiva (da qual é exemplo, justamente, a indenização punitiva, que se destina a punir o ofensor pelo ato altamente reprovável por ele cometido e que, no desempenho dessa função, não encontra limites na extensão dos prejuízos impostos à vítima) ${ }^{849}$.

Assim é que, procedendo-se ao "descolamento" das duas sanções (a compensatória e a punitiva), tem-se que, apenas para a adequada dosimetria da segunda é que "o agente deve pagar mais se agiu com dolo ou com maior negligência, imprudência ou imperícia, independentemente da extensão do dano" ${ }^{\text {}}{ }^{550}$.

A justificativa para a utilização de tal critério para a quantificação da sanção reside no argumento de que o malfeitor deve ser apenado com maior severidade quanto maior for sua desconsideração pelo bem jurídico atingido, ou pelo dever legal desrespeitado ${ }^{851}$. Nessa toada, e nos termos acima já expostos, aquele que se conduz de maneira gravemente negligente, com flagrante desconsideração ("reckless disregard") em relação aos direitos alheios deve suportar a incidência de uma sanção jurídica mais severa do que aquele que, a seu turno, veio a produzir o resultado danoso por simplesmente não ter assumido as cautelas que ordinariamente seriam seguidas pelo homo medius, ou pelo homem ativo e probo (e que, conseqüentemente, agiu com mera negligência). Incide, na primeira hipótese acima cogitada, a sanção punitiva, enquanto que, no segundo exemplo, bastaria a incidência da responsabilidade civil em sua função compensatória para dar remédio jurídico adequado à situação.

AlviM, Da Inexecução das Obrigações e suas Conseqüências, $4^{\mathrm{a}}$ ed., São Paulo, Saraiva, 1972, págs. 199/201 e Gustavo TePEDINO - Heloísa Helena BARBOZA - Maria Celina Bodin de MorAES (coords.), Código Civil Interpretado Conforme a Constituição da República, vol. II, Rio de Janeiro, Renovar, 2006, pág. 859, para os quais “[o] dano provocado pelo agente terá a mesma extensão, tenha ele agido com dolo, com culpa grave ou com culpa levíssima." Há que se frisar que o aludido brocardo já encontra exceção legal expressa, ao menos no art. 944, par. ún., do CC/2002, que prevê a redução do quantum indenizatório quando se verificar flagrante desproporção entre o grau de culpa e a extensão do dano.

${ }^{849}$ P. Gallo, Pene Private e Responsabilità Civile, Milano, Giuffrè, 1996, pág. 197.

${ }^{850}$ Maria Celina Bodin de MorAEs, Danos à Pessoa Humana (Uma Leitura Civil-Constitucional dos Danos Morais), Rio de Janeiro, Renovar, 2003, pág. 296 e André Gustavo Corrêa de ANDRADE, Dano Moral e Indenização Punitiva: Os punitive damages na experiência do common law e na perspectiva do Direito brasileiro, Rio de Janeiro, Forense, 2006, pág. 322.

${ }^{851}$ Foi nesse sentido que, ao analisar a pertinência da análise do "degree of reprehensibility of the defendant's conduct" para a quantificação dos punitive damages, a majority opinion da Supreme Court sustentou, em 
Ocorre que, mesmo em se tratando de casos nos quais já se decidiu pela aplicação da indenização punitiva (casos estes que, apenas por este fato, já denotam o cometimento de uma conduta mais reprovável do que aquela meramente negligente), os diferentes graus de culpa (já se partindo da premissa de que o agente se conduziu, ao menos, com culpa grave) são relevantes para a quantificação da indenização.

Nesse sentido, vale lembrar que, ao fixar o "grau de reprovabilidade" ("degree of reprehensibility") da conduta do ofensor como um dos principais fatores para se aferir a constitucionalidade de uma condenação ao pagamento de punitive damages, a Supreme Court norte-americana pontuou quatro elementos que, a nosso ver, são relevantes para que o julgador nacional, no exercício de sua atividade de quantificação da indenização punitiva, possa verificar o grau de culpa do ofensor. São eles: (i) se a conduta ilícita demonstrava uma indiferença, ou flagrante desconsideração, para com a saúde ou segurança dos outros; (ii) se a conduta ilícita demonstrava a reincidência do ofensor ou se, de outro lado, era um ato isolado; e, ainda, (iii) se a conduta ilícita se caracterizava como um ato intencional, malicioso, traiçoeiro ${ }^{852}$.

Assim, o agente que obrou imbuído da intenção de causar o ato ilícito (dolosamente, portanto) deve ser apenado de maneira mais severa do que aquele que se conduziu com grave negligência (sem intencionalidade). De outro lado, aquele que agiu não apenas de maneira intencional, mas premeditadamente, calculando antecipadamente a forma e o momento em que realizaria o ilícito, e querendo não apenas o cometimento desse ilícito, mas, também, a imposição do mal ao ofendido, deve ser punido em medida ainda mais gravosa ${ }^{853}$.

Importa de ver, contudo, que a utilização de um critério subjetivo com vistas à persecução da função punitiva da responsabilidade civil não tem apenas um viés negativo para o ofensor. Na mesma medida em que a utilização desse critério atua de modo a

BMW of North America v. Gore, que esse criterio "reflects the accepted view that some wrongs are more blameworthy than others" (517 U.S. 559 1995, pág. 575).

${ }^{852} 517$ U.S. 559 1995, págs. 575 e ss.. Vale ressaltar que, além desses elementos, também se fixou em Gore a necessidade de que o julgador levasse em consideração, para a aferição do "grau de reprovabilidade" da conduta do demandado e, conseqüentemente, para a quantificação dos punitive damages, a natureza dos prejuízos causados à vítima ("whether the harm was physical rather than economic"). No tópico abaixo analisaremos a pertinência da utilização desse critério não apenas para a correta aferição da indenização compensatória, mas, também (e ainda que em menor grau), para a quantificação da indenização punitiva. 
majorar a sanção daqueles que operaram de maneira extremamente reprovável, ela também assegura que a quantificação da indenização punitiva será arbitrada de maneira efetivamente proporcional à gravidade e reprovabilidade da conduta cometida ${ }^{854}$, evitandose, conseqüentemente, “que não seja punido da mesma forma quem agiu com dolo, e quem agiu negligentemente" ${ }^{\sharp 55}$, ainda que com grave negligência.

Por derradeiro, há que se ver que a utilização desse critério pode-se fazer presente inclusive nos casos em que incide a responsabilidade objetiva ${ }^{856}$. Na linha de tudo o quanto já expusemos no presente trabalho, o demandante é livre para acrescer à sua causa de pedir os aspectos fáticos destinados a caracterizar a fattispecie da indenização punitiva, ainda que, para a condenação do demandado ao pagamento de indenização compensatória, a ocorrência desses fatos específicos seja nada mais do que irrelevante. Caso assim opte, ele poderá alegar e, posteriormente, comprovar a ocorrência de fatos que, certamente, auxiliarão o julgador a aferir que o demandado não só obrou com culpa grave, mas a dosar a sanção punitiva em razão da gravidade das condutas perpetradas. Certamente será esse o caso se o demandante lograr êxito em demonstrar, durante a instrução do feito, por ex., que: (i) o demandado, fabricante de produto defeituoso, conhecia a existência do defeito de que padecia seu produto e, mesmo assim, conscientemente o introduziu no mercado, expondo os consumidores ao risco; (ii) o demandado, o mesmo fabricante, não realizou investigações suficientes sobre os riscos potenciais do produto, ou, após aperceber-se destes riscos, não realizou esforço algum para evitar o prejuízo; ou, ainda, que (iii) o comportamento do demandado não se adequou aos standards de conduta exigidos pelo mercado, que envolvem a divulgação de informações adequadas sobre os riscos do produto ou a realização de recalls após a constatação da existência de defeitos.

\footnotetext{
${ }^{853}$ Semelhantemente, cfr. André Gustavo Corrêa de ANDRADE, Dano Moral e Indenização Punitiva: Os punitive damages na experiência do common law e na perspectiva do Direito brasileiro, Rio de Janeiro, Forense, 2006, pág. 322.

854 P. S. KARLAN, 'Pricking the Lines': The Due Process Clause, Punitive Damages and Criminal Punishment, in Minnessota Law Review, vol. LXXXVIII, 2003/2004, pág. 882

${ }^{855}$ P. M. LourençO, A Função Punitiva da Responsabilidade Civil, Coimbra, Coimbra Editora, 2006, pág. 416. No mesmo sentido, André Gustavo Corrêa de Andrade, Dano Moral e Indenização Punitiva: Os punitive damages na experiência do common law e na perspectiva do Direito brasileiro, Rio de Janeiro, Forense, 2006, pág. 322.

${ }^{856}$ Caroline VAZ parece objetar a essa conclusão, frisando que, nas hipóteses de responsabilidade objetiva, dever-se-ia lançar mão dos demais critérios para a quantificação da indenização punitiva, tais como a natureza e a extensão dos danos causados e a capacidade econômica do ofensor (Funções da Responsabilidade Civil - Da Reparação à Punição e Dissuasão - Os punitive damages no Direito Comparado e Brasileiro, Porto Alegre, Livraria do Advogado, 2009, págs. 135/136).
} 


\section{I.II. A gravidade do dano causado}

Certamente não é sem alguma surpresa que se verifica a presença da "gravidade e repercussão (extensão) do dano" sofrido pela vítima como o segundo critério aventado pela doutrina para a quantificação não da indenização compensatória, mas, sim, da indenização punitiva. Isso porque, como se vem expondo ao longo deste trabalho, a indenização punitiva (por se tratar de verdadeira pena, ainda que de natureza civil), destina-se a castigar o ofensor pelo mal causado e não a reparar os prejuízos por ele impostos à vítima. Esta última função é exercida, no âmbito do direito civil, e com exclusividade, pela responsabilidade civil em sua função compensatória (ou seja, pela indenização compensatória). Nesse sentido, por qual razão, e em que medida, a natureza e a extensão dos prejuízos causados (real ou potencialmente) pela conduta ilícita extrapolar o âmbito da compensação e refletir também na quantificação da indenização punitiva?

Ao analisar tal questionamento, André Gustavo Corrêa de ANDRADE, certamente inspirado pelas conclusões apresentadas pela Supreme Court norte-americana em BMW of North America v. Gore (517 U.S. 559 1995), afirma que os fatores subjetivos para a quantificação da indenização punitiva (= o grau de culpa do ofensor e sua capacidade econômica) "devem estar conectados com elementos objetivos do evento lesivo, dentre os quais a espécie de interesse jurídico violado e a extensão e intensidade do dano", para concluir, utilizando as mesmas expressões invocadas pela corte estadunidense, que "não é possível desvincular a reprovabilidade da conduta da gravidade da lesão"857.

Quer-se dizer, com tal afirmação, que tão mais reprovável será a conduta do ofensor quanto mais relevantes forem os bens jurídicos por ela atingidos, ou, ainda, quanto mais graves forem tais prejuízos, quer eles tenham sido efetivamente impostos ao lesado, quer ainda, decorra do ato ilícito perpetrado uma potencialidade danosa muito superior aos danos realmente causados.

\footnotetext{
857 Dano Moral e Indenização Punitiva: Os punitive damages na experiência do common law e na perspectiva do Direito brasileiro, Rio de Janeiro, Forense, 2006, págs. 328/329. Outra não parece ser a orientação expressa por Caroline VAZ, para quem "[o] dano, sua natureza e repercussão, é deveras importante [inclusive para a quantificação da indenização punitiva], seja ele real e atual, seja ele eventual e futuro." (Funções da Responsabilidade Civil - Da Reparação à Punição e Dissuasão - Os punitive damages no Direito Comparado e Brasileiro, Porto Alegre, Livraria do Advogado, 2009, pág. 136).
} 
Quanto ao primeiro elemento, há que se lembrar que, em Gore (517 U.S. 559 1995, págs. 575 e ss.), a Supreme Court anotou que a indenização punitiva deveria ser majorada em atenção à relevância do bem jurídico tutelado, frisando-se que a sanção seria mais severa se os prejuízos causados à vítima fossem físicos, em vez de meramente econômicos ("whether the harm was physical rather than economic"). Da mesma maneira, mais severa deverá ser a indenização punitiva se os prejuízos causados forem tais que não comportem reposição ao status quo ante (como, por ex., ocorreria em atentados contra a vida, em lesões ao meio ambiente ou ao patrimônio histórico, especialmente, em relação aos dois últimos exemplos citados, nas hipóteses em que o mal causado não pode ser desfeito).

Já quanto ao segundo critério, vale destacar que a Supreme Court norteamericana, em obter dictum proferido ao julgar Haslip (499 U.S. 1 1990, pág. 21), frisou ser relevante para o cômputo da indenização punitiva não apenas os prejuízos efetivamente impostos ao demandante, mas, também, aqueles que "provavelmente poderiam decorrer da conduta do demandado"858. Posteriormente, os danos que poderiam ter sido potencialmente impostos ao demandante foram novamente tidos como relevantes para o cômputo dos punitive damages tanto em TXO (509 U.S. 443 1992, págs. 460 e ss.) quanto em Gore (517 U.S. 559 1995, págs. 580 e ss.). Desses julgados, depreende-se a orientação de que, ainda que a conduta ilícita (ou a atividade de risco) tenha, efetivamente, proporcionado prejuízos de pequena expressão, a indenização punitiva deverá ser majorada se a mesma conduta (ou atividade) for potencialmente muito mais prejudicial, colocando em risco o patrimônio de muito mais titulares de direito, ou, ainda, colocando em risco muito maior o patrimônio do próprio titular de direito lesado. Como exemplo, pode-se afirmar que a indenização punitiva devida por uma empresa que, em grave negligência, introduz no mercado consumidor um produto com defeito de concepção que o torna potencialmente lesivo, deve ser superior àquela imposta à mesma empresa, se esta, com a mesma grave negligência, apenas introduz no mercado um produto com defeito de

\footnotetext{
${ }^{858}$ Frisou-se, na oportunidade, que a análise da constitucionalidade da condenação ao pagamento dos punitive damages passava pela verificação de que o quantum indenizatório referente à indenização punitiva guardava "a reasonable relationship" com "the harm likely to result from the defendant's conduct as well as the harm that actually occurred" (499 U.S. 1 1990, p. 21).
} 
fabricação, o qual, potencialmente, lesará muito menos pessoas do que o primeiro ${ }^{859}$. Isso porque os defeitos de concepção resultam de erros de projeto, de utilização de matérias primas inadequadas, etc., e que "provocam uma reação em cadeia, alcançando todos os produtos da mesma série ${ }^{\text {} 860}$, de modo a causar, potencialmente, muito mais prejuízos do que aqueles decorrentes de um pontual defeito de fabricação.

É importante que se frise, contudo, que o critério ora aventado é secundário para a quantificação da indenização punitiva, e, portanto, não deve ser considerado na mesma medida em que o seria para a dosimetria da indenização compensatória ${ }^{861}$.Não se trata de transformar a indenização punitiva em um mero múltiplo da indenização compensatória (como que se cogitando que, "se os prejuizos efetivos eqüivalem a ' $x$ ', $a$ indenização compensatória, em razão do princípio da reparação integral, corresponderá exatamente a ' $x$ ' e, em adição a ela, a indenização punitiva também corresponderá a, no mínimo, mais ' $x$ ', podendo-se elevar em razão dos demais critérios para a sua quantificação"), mas, sim, de considerar a natureza e a extensão dos prejuízos real ou potencialmente decorrentes da conduta ilícita também como um elemento para a quantificação da sanção punitiva. Quanto mais relevante o bem jurídico protegido (por ex., a vida, em vez da boa reputação) e mais extenso o prejuízo (real ou potencialmente) resultante da conduta ilícita, mais intensa será a indenização punitiva, a qual, contudo, não guardará necessária correlação com os limites desse prejuízo (até mesmo porque o prejuízo pode ser apenas potencial). Assim é que se conclui, nas palavras do citado André Gustavo Corrêa de ANDRADE, que, "na fixação da indenização punitiva, a gravidade do dano é considerada somente como um dos elementos que compõem a medida da reprovabilidade do agente, ao contrário do que ocorre na indenização compensatória, em que a gravidade do dano constitui a medida em si da indenização" ${ }^{\prime 62}$.

\footnotetext{
${ }^{859}$ O exemplo é de André Gustavo Corrêa de ANDRADE, Dano Moral e Indenização Punitiva: Os punitive damages na experiência do common law e na perspectiva do Direito brasileiro, Rio de Janeiro, Forense, 2006, pág. 329.

${ }^{860}$ Zelmo DenARI, Código Brasileiro de Defesa do Consumidor Comentado pelos Autores do Anteprojeto, $9^{\mathrm{a}}$ ed., Rio de Janeiro, Forense Universitária, 2007, pág. 192.

${ }^{861}$ Em sentido semelhante, P. GALlo afirma que a extenção e natureza dos danos causados à vítima é um critério menos significativo para a quantificação da indenização punitiva (Pene Private e Responsabilità Civile, Milano, Giuffrè, 1996, pág. 196).

${ }^{862}$ Dano Moral e Indenização Punitiva: Os punitive damages na experiência do common law e na perspectiva do Direito brasileiro, Rio de Janeiro, Forense, 2006, pág. 329.
} 


\section{I.III. A condição econômica do ofensor}

Ainda um outro critério aventado pela doutrina como relevante para a quantificação da indenização punitiva (critério este, é de se frisar, intimamente ligado à função preventiva da indenização, em particular ao seu aspecto de prevenção especial, isto é, aquele direcionado ao próprio causador do dano) é aquele relacionado com a condição econômico-financeira do causador do ilícito.

Trata-se, é bom que se frise desde logo, de um critério ligado exclusivamente à dosimetria da indenização punitiva $^{863}$ e que em nada se relaciona à quantificação da indenização compensatória ${ }^{864}$. Aliás, a mera apreciação de elementos probatórios acerca da capacidade econômico-financeira do suposto causador do dano poderia macular a tarefa do julgador ao decidir pela imposição e quantificação da indenização compensatória, motivo pelo qual tal análise não deve ser feita, em momento algum no curso da demanda, que não o de liquidação da indenização punitiva.

Em defesa da utilização desse elemento, afirma a doutrina especializada, em argumento com o qual concordamos, que, para que a indenização punitiva possa eficazmente desestimular um indivíduo em particular a não mais cometer atos ilícitos no futuro, ela precisa ser quantificada com especial atenção às suas características econômicofinanceiras, assegurando-se, dessa maneira, que o quantum indenizatório será exatamente aquele necessário para que este indivíduo em especial não venha a considerar economicamente mais vantajoso perpetrar o ilícito do que atender ao dever legal ${ }^{865}$.

\footnotetext{
${ }^{863}$ Maria Celina Bodin de MoRAEs, Danos à Pessoa Humana (Uma Leitura Civil-Constitucional dos Danos Morais), Rio de Janeiro, Renovar, 2003, pág. 298.

${ }^{864}$ Marcela Alcazas BASSAN, As Funções da Indenização por Danos Morais e a Prevenção de Danos Futuros, Dissertação (Mestrado) - Faculdade de Direito da USP, São Paulo, 2009, pág. 113. K. S. ABRAHAM e J. C. JEFFRIES JR. são ainda mais categóricos, afirmando que a "[e]vidence of defendant's wealth is irrelevant to the purposes of compensatory damages and, hence, irrelevant to the issues that arise in an ordinary tort suit." (Punitive Damages and The Rule of Law: The Role of Defendant's Wealth, in Journal of Legal Studies, vol. XVIII, jun./1989, pág. 416).

${ }^{865}$ A. J. SeboK, Punitive Damages in The United States, in H. KozIOL - V. WILcox (eds.), Punitive Damages: Common Law and Civil Law Perspectives, Wien, Springer, 2009, pág. 180). No mesmo sentido, P. Gallo, Pene Private e Responsabilità Civile, Milano, Giuffrè, 1996, pág. 198; G. V. RoBredo, Daños Punitivos en el Proceso Civil Norteamericano, in Revista de la Universidad de Deusto, vol. 57, fasc. 97, juldic./ 1996, pág. 187 e André Gustavo Corrêa de ANDRADE, Dano Moral e Indenização Punitiva: Os punitive damages na experiência do common law e na perspectiva do Direito brasileiro, Rio de Janeiro, Forense, 2006, pág. 323. Ao tratar da função de desestímulo a ser exercida pela indenização por danos morais, Carlos Alberto BITTAR afirma que, nessa hipótese, a indenização "[c]onsubstancia-se, portanto, em uma importância compatível com o vulto dos interesses em conflito, refletindo-se, de modo expressivo, no
} 
Para o escorreito desempenho desse mister, deve o magistrado "perquirir a realidade do agente, seja pessoa física ou jurídica, de modo a repercutir o valor a ser pago a título de prestação pecuniária no patrimônio financeiro/econômico do devedor",866, considerando-se que, em atenção à função de prevenção especial, não se pode atingir, com igual montante indenizatório, uma pessoa física de parco patrimônio e uma sociedade comercial de vasto capital social $^{867}$. A quantia indenizatória suficiente para desestimular a primeira do cometimento de novos ilícitos será muitíssimo inferior àquela necessária para atingir a mesma finalidade em relação à última ${ }^{868}$.

A utilização desse critério, para fins de prevenção, é particularmente relevante para casos nos quais, para um determinado ofensor, os custos de obediência da Lei, para evitar a ocorrência do prejuízo ("costs of compliance") são mais altos do que aqueles custos nos quais ela irá incorrer para reparar o prejuízo ("costs of liability"). A indenização punitiva somente atuará eficazmente para dissuadi-lo de cometer novos ilícitos se, em atenção às suas características econômico-financeiras e, em especial, àquelas relacionadas com a sua atividade, puder elevar os custos para reparar o prejuízo, tornandoos mais elevados do que os custos para a obediência da Lei. As considerações a respeito da capacidade econômica do ofensor são, portanto, relevantes quando os custos de obediência da Lei decorrem justamente dessa maior capacidade econômica ${ }^{869}$.

patrimônio do lesante, a fim de que sinta, efetivamente, a resposta da ordem jurídica aos efeitos do resultado lesivo produzido. Deve, pois, ser quantia economicamente significativa, em razão das potencialidades do patrimônio do lesante." (Reparação Civil por Danos Morais, São Paulo, RT, 1993, pág. 220).

${ }^{866}$ Caroline VAZ, Funções da Responsabilidade Civil - Da Reparação à Punição e Dissuasão - Os punitive damages no Direito Comparado e Brasileiro, Porto Alegre, Livraria do Advogado, 2009, pág. 138.

867 André Gustavo Corrêa de ANDRAde, Dano Moral e Indenização Punitiva: Os punitive damages na experiência do common law e na perspectiva do Direito brasileiro, Rio de Janeiro, Forense, 2006, pág. 323. No mesmo sentido, Eduardo UILAN, Responsabilidade Civil Punitiva, Tese (Doutorado) - Faculdade de Direito da USP, São Paulo, 2003, pág. 89.

${ }^{868}$ S. CARval, La Responsabilitè Civile Dans Sa Fonction de Peine Privée, Paris, L.G.D.J., 1995, pág. 359 e G. V. Robredo, Daños Punitivos en el Proceso Civil Norteamericano, in Revista de la Universidad de Deusto, vol. 57, fasc. 97, jul-dic./ 1996, pág. 187.

${ }^{869}$ Admita-se, para fins ilustrativos, o seguinte exemplo: uma pequena empresa 'A' possui um grupo de 1000 clientes cadastrados. Para que tal empresa implemente um sistema muitíssimo seguro de controle de cobranças, isso lhe custará, em razão do vulto de sua atividade, $\mathrm{R} \$ 10,00$ por cliente ao mês, ou seja, um total de $\mathrm{R} \$$ 10.000,00 mensais. Caso a empresa 'A' não implemente esse sistema, suas cobranças serão realizadas de modo menos seguro, acarretando o envio indevido de cartas de cobrança a clientes adimplentes e, o que é pior, a inclusão indevida de, ao menos, os dados de um cliente adimplente nos cadastros de proteção ao crédito. Considerando-se, para os fins desse exemplo, que as indenizações médias concedidas por nossos Tribunais pátrios na hipótese de inclusão indevida nos cadastros de maus pagadores giram em torno de $\mathrm{R} \$ 5.000,00$, a empresa 'A' possuirá custos de obediência da Lei no montante de $\mathrm{R} \$ 10.000,00$ mensais e, de outro lado, custos de reparação dos prejuízos no importe de $\mathrm{R} \$ 5.000,00$ mensais. Nessas circunstâncias, a empresa ' $\mathrm{A}$ ' conscientemente deixará de obedecer a Lei, por lhe ser economicamente mais vantajoso fazê-lo. A 
Por derradeiro, vale ressaltar que, além de servir para a adequada persecução da função preventiva da indenização (principalmente no que toca ao seu aspecto de prevenção especial), a utilização desse critério também serve de limitador da função punitiva, evitando-se, se o caso, a imposição de uma sanção pecuniária que ultrapasse os limites que o ofensor possa suportar sem ter de ser necessariamente retirado do mercado. De nada adiantaria, para os fins a que se destina a indenização punitiva, impor uma sanção demasiadamente gravosa ao ofensor, se este não dispusesse de patrimônio suficiente para suportá-la ${ }^{870}$.

\section{I.III.I. O lucro obtido pelo ofensor}

Outro critério de ordem econômico-financeira, e que anda intimamente atrelado àquele acima exposto, e que também dá ensejo à incidência da indenização punitiva, é a eventual obtenção de lucros ou vantagens financeiras, por parte do lesante, em decorrência do ato ilícito por ele perpetrado. O ilícito aqui perpetrado (ou a atividade de risco aqui levada a efeito) não apenas causa prejuízos a determinada (ou determinadas) pessoas, mas, também, dele se pode extrair benefícios econômicos que superam, às vezes em grande monta, o valor da indenização compensatória que se deveria pagar ao lesado.

Admitamos, aqui, um exemplo muitíssimo comum nos dias atuais: determinada editora, responsável pela publicação de jornais e revistas, invade ilicitamente a privacidade de celebridades para expor ao público imagens comprometedoras e informações falsas, tudo com a finalidade de aumentar as vendas de suas publicações. Obtêm-se, aqui, lucros financeiros com a venda de jornais e revistas que podem superar em muito o valor eventualmente a ser pago à vítima a título de indenização por conta da intromissão indevida, ou da lesão à sua honra.

quantificação da indenização punitiva nessa hipótese, deve levar tais fatores econômicos em consideração para impedir a atuação ilícita, elevando-se o quantum indenizatório a, no mínimo, R\$10.000,00. Se, em vez da pequena empresa 'A', tivéssemos um enorme conglomerado 'B', com centenas de milhares de clientes no Brasil, o valor da indenização punitiva também deveria ser elevado para que se atentasse a tais características e se buscasse, dessa maneira, dissuadir tal empresa de praticar atos em desrespeito à Lei e aos direitos alheios. 
Outro exemplo a se cogitar é o do empreendedor imobiliário que, ávido pelo pronto lançamento de determinado empreendimento que lhe garantirá uma rápida e lucrativa vendagem de unidades, deixa de atender às posturas públicas quanto ao corte e replantio de árvores no terreno em que irá erigir suas edificações, lesando intencionalmente o meio ambiente em razão da consciência de que as indenizações posteriormente devidas serão inferiores aos lucros imediatamente obtidos.

Partindo-se desses e de tantos outros exemplos semelhantes, volta-se à alegoria das maças apresentada por P. C. M. GuIMARÃES, pela qual é indiferente, ou, muitas das vezes, até mesmo conveniente que o lesante opte pela violação dos direitos e interesses alheios, uma vez que os custos da reparação são muito inferiores às vantagens financeiras que ele poderá extrair do cometimento do ato ilícito ${ }^{871}$.

Justamente para procurar evitar tais consequiências nefastas, parte da doutrina sustenta ser oportuna a condenação civil ao pagamento de indenização punitiva “quando o réu, visando conseguir lucro por meio de conduta danosa, tenha previamente calculado que, mesmo com uma eventual reparação dos prejuízos causados, obteria vantagem econômica por meio da ação delituosa empreendida" ${ }^{\text {872. }}$.

Essa já era, há mais de meio século, a orientação seguida por B. STARCK, para o qual, nas hipóteses em que o causador do dano extrai vantagens econômicas do ilícito perpetrado, a indenização, para que possa exercer adequadamente sua função preventiva, não pode se ater aos estritos limites do prejuízo, devendo servir de ferramenta para retirar do lesante o lucro ilicitamente auferido ${ }^{873}$.

\footnotetext{
${ }^{870}$ André Gustavo Corrêa de ANDRADE, Dano Moral e Indenização Punitiva: Os punitive damages na experiência do common law e na perspectiva do Direito brasileiro, Rio de Janeiro, Forense, 2006, pág. 324. ${ }^{871}$ Os Danos Punitivos e a Função Punitiva da Responsabilidade Civil, in Revista de Direito e Justiça, vol. $\mathrm{XV}$, t. 1, 2001, pág. 178.

${ }^{872}$ Eduardo UILAN, Responsabilidade Civil Punitiva, Tese (Doutorado) - Faculdade de Direito da USP, São Paulo, 2003, pág. 78. No mesmo sentido, André Gustavo Corrêa de ANDRADE, Dano Moral e Indenização Punitiva: Os punitive damages na experiência do common law e na perspectiva do Direito brasileiro, Rio de Janeiro, Forense, 2006, pág. 330.

${ }^{873}$ Essai d'une Théorie Générale de la Responsabilité Civile Considèrèe em as Double Fonction de Garantie et de Peine Privèe, Paris, L. Rodstein, 1947, págs. 416 e ss.. Na mesma linha seguem as palavras de P. M. LOURENÇO, para quem "a restituição do lucro obtido pelo agente consubstancia a única forma de prevenir $e$ punir a repetição da conduta, sob pena de 'o lucro compensar' a violação do direito de outrem, escamoteando-se a tutela que a ordem jurídica concede aos bens jurídicos mais valiosos, atinentes à pessoa humana”. (A Função Punitiva da Responsabilidade Civil, Coimbra, Coimbra, 2006, pág. 390).
} 
Na Itália, tal posicionamento é seguido por P. GALLO, o qual, ao versar sobre a utilização indevida da imagem alheia, advoga pela adoção de uma medida que permita retirar do lesante todo o lucro auferido com a prática do ato ilícito, ao menos quando o ilícito é praticado intencional ou maliciosamente ${ }^{874}$.

A irresignação com a possibilidade de que o autor de um ato ilícito possa vir a manter as vantagens econômicas extraídas de sua conduta leva, inclusive, doutrinadores que sequer cogitam da adoção de uma função preventiva à responsabilidade civil a procurar por outras soluções jurídicas, já previstas no ordenamento, para atingir a mesma finalidade. Nesse sentido, D. L. DE CAMPOS afirma que, se estivermos diante de uma hipótese na qual, da intromissão indevida em bens alheios (ato ilícito), o lesante vier a extrair lucros que superam os prejuízos impostos ao lesado (enriquecimento superior ao dano), o instituto da responsabilidade civil não esgotará, isoladamente, a relevância jurídica do caso ${ }^{875}$. Haverá, nessa hipótese, uma “consunção impura de normas" entre aquelas que prescrevem a incidência da responsabilidade civil e aquelas que vedam o enriquecimento sem causa, o que não impedirá, mesmo em atenção à subsidiariedade deste último (ex vi do art. 886, CC/2002), a atuação conjunta dos dois institutos para suprimir absolutamente todo o enriquecimento que o lesante houver auferido por meio de seus atos ilícitos, independentemente dos limites impostos pelos prejuízos suportados pelo lesado ${ }^{876}$.

Em atenção ao que se expôs acima, e com vistas a evitar a esterilização do instituto da responsabilidade civil (incapaz que se tornaria de adequadamente evitar o cometimento de atos ilícitos), advoga-se pela inclusão, na dosimetria da indenização punitiva, de critério que leve em consideração os lucros efetivamente auferidos pelo lesante em decorrência do ato ilícito por ele perpetrado. A nosso ver, tal será a única maneira de desestimular adequadamente o cometimento de ilícitos dos quais usualmente se

\footnotetext{
${ }^{874}$ Pene Private e Responsabilità Civile, Milano, Giuffrè, 1996, pág. 147.

875 Enriquecimento Sem Causa, Responsabilidade Civil e Nulidade, in Revista dos Tribunais, vol. 560, jun./1982, pág. 263.

876 D. L. DE CAMPOS, Enriquecimento Sem Causa, Responsabilidade Civil e Nulidade, in Revista dos Tribunais, vol. 560, jun./1982, pág. 264. Prossegue o citado autor, concluindo que "[n]estes termos, o enriquecimento do lesante será suprimido através de dois institutos. Primeiro, indiretamente, através das normas de responsabilidade civil. Depois, se subsistir uma parcela de enriquecimento, esta será removida diretamente por meio do instituto do enriquecimento sem causa. Em conclusão: o montante da obrigação de indenizar ou de restituir a que estará adstrito o que interveio nos bens alheios poderá ultrapassar a medida do seu enriquecimento - tudo dependerá do montante do dano a reparar. Mas nunca poderá ser inferior ao montante do enriquecimento." (D. L. DE CAMPOS, op. cit., pág. 264).
} 
poderá extrair vantagens econômicas, tais como os exemplos acima citados, de utilização indevida da imagem alheia ${ }^{877}$ e de danos ao meio ambiente ${ }^{878}$.

\section{I.IV. Um critério inaplicável: a condição econômica do ofendido}

O último dos critérios, usualmente referido pela doutrina e jurisprudência pátrias para a quantificação da indenização por danos morais (e cuja pertinência analisaremos também para o que concerne à quantificação da indenização punitiva), é aquele atinente à condição socioeconômica do ofendido.

${ }^{877}$ Quanto a esse ponto, sobressai em interesse trecho da declaração de voto do I. Des. Ênio Santarelli Zuliani, o qual afirma que "[o] dano moral punitivo não está previsto no ordenamento jurídico e os doutrinadores não admitem que se cogite de sua incidência, preocupados que estão os doutores com a maversação dessa vertente do direito de danos. Contudo e para fins de aplacar o intuito mercantilista de empresas de entretenimento, que apostam no tabelamento por baixo das indenizações para perseverarem nas hostilidades contra vítimas indefesas ante o poder da mídia, cabe cogitar da incidência do dano moral punitivo para acertar no arbitramento. O sentimento de impunidade anima produtores e entrevistadores a invadirem a esfera íntima das pessoas famosas, na certeza de que a audiência cresce diante da curiosidade pública, o que aumenta o lucro [aumento do ibope e elevação do custo do minuto na tela]. Não é correto que empresas lucrem com a ilicitude e, nesse ponto, o dano moral atende o propósito de reprimir essa tendência oportunista. A pessoa pública passa a ser credora de uma verba equivalente às vantagens obtidas pela lesão." (TJSP; 4 ${ }^{\mathrm{a}}$ Câm. de Direito Privado; Apelação n. ${ }^{\circ}$ 315.678-4/0; Relator: Des. Jacobina Rabello; J. 28.08.2008; Trecho do voto do Des. Ênio Santarelli Zuliani). Na Europa Continental, a retirada do lucro do ofensor, e restituição ao ofendido, também se insere, por previsão legislativa expressa, no contexto da proteção a direitos decorrentes da personalidade, em situações assemelhadas àquela ora cogitada. Assim é que o art. $9^{\circ}, 2$, 'd', da Lei Espanhola de Proteção Civil do Direito à Honra, à Intimidade Pessoal e Familiar e à Própria Imagem, de 5 de maio de 1982, n. 1, prevê que "[1] a tutela judicial [da honra, da intimidade pessoal, etc.] comprenderá la adopción de todas las medidas necesarias para ponder fin a la intromisión ilegítima de que se trate y, en particular, las necesarias para: [...] [1] a apropriación por el perjudicado del lucro obtenido con la intromisión ilegítima en sus derechos."

${ }^{878}$ O lucro obtido pelo lesante em razão do cometimento do ilícito e, conseqüentemente, do dano ambiental dele decorrente, é um critério usualmente referido pela legislação ambiental. Assim o é, por exemplo, na Lei Italiana de 8 de julho de 1986, n. ${ }^{\circ} 349$, a qual prescreve, em seu art. 18, '6', que "[i]l giudice, ove non sia possibilie una precisa quantificazione del danno, ne determina l'ammontare in via eqüitativa, tenendo comunque conto della gravità della colpa individuale, del costo necessario per il ripristino e del profitto conseguito dal trasgressore in conseguenza del suo comportamento lesivo dei beni ambientali'. No mesmo sentido segue a Lei Espanhola sobre Espaços Naturais Protegidos, de 27 de março de 1989, n. 4, que prescreve (art. 39, inc. 1) que, "[1]as citadas infacciones serán calificadas de leves, menos graves, graves y muy graves, atendiendo a su repercusión, a su trascendencia por lo que respecta a la seguridad de las personas y bienes y a las circunstancias del responsable, su grado de malicia, participación y beneficio obtenido, así como a la irreversibilidad del daño o deterioro producido en la calidad del recurso o del bien protegido." A legislação pátria não foge completamente dessa orientação, a despeito de não utilizar o critério do enriquecimento ilícito do lesante para a quantificação da indenização civil. Em nosso país, a obtenção de vantagens econômicas em razão do dano ambiental é considerada como circunstância agravadora da pena criminal aplicável ao poluidor (art. 15, II, a, Lei 9.605/1998) e como critério para a quantificação da sanção punitiva de multa, a qual pode, inclusive, extrapolar os limites legais previamente estabelecidos caso o dano ambiental tenha sido causado com a intenção de auferir lucros (assim dispõe o art. 18, da Lei 9.605/1998, “[a] multa será calculada segundo os critérios do Código Penal; se revelar-se ineficaz, ainda que aplicada no valor máximo, poderá ser aumentada até três vezes, tendo em vista o valor da vantagem econômica auferida."). 
A mais adequada análise acerca do tema passa, necessariamente, por dois passos: (i) o primeiro deles, referente à verificação de qual o âmbito em que se insere, em doutrina e jurisprudência, a alusão à condição socioeconômica da vítima (se é critério pertinente à quantificação da indenização compensatória ou se, de outro lado, é critério pertinente à quantificação da indenização punitiva); para, apenas depois disso, (ii) poder-se tecer as devidas considerações quanto à pertinência deste critério para a quantificação da indenização punitiva.

No exercício desse mister, vê-se que a defesa da utilização de tal critério parte da (correta) premissa de que a indenização por danos extrapatrimoniais não visa a, exatamente, retornar ao status quo ante, desfazendo os efeitos do ato ilícito, mas, sim, à compensação do ofendido, por meio da entrega de numerário apto a lhe proporcionar momentos de regozijo que lhe serviriam, ao menos, de alento ${ }^{879}$.

De tal ponto de partida, assume-se, contudo, interpretação que julgamos inadequada, no sentido de que, para que se opere corretamente a compensação dos detrimentos suportados pelo ofendido, há que se levar em consideração sua capacidade socioeconômica, vez os bens da vida necessários para consolar ou compensar um ofendido de parcas condições financeiras, proveniente de classe social humilde, seriam de menor expressão e vulto do que aqueles necessários para acalentar o sofrimento de um ofendido de vastas posses, e oriundo de classe social abastada ${ }^{880}$.

Feitas tais considerações, é de se observar que o supra aludido critério se insere (e de maneira controvertida) no âmbito da quantificação de indenização compensatória, ligada, portanto, à idéia de recomposição do patrimônio do lesado, e não, propriamente, à de punir o ofensor pelo ilícito perpetrado, ou de dissuadi-lo do

\footnotetext{
${ }^{879}$ Clayton ReIs, Novos Rumos da Indenização do Dano Moral, Rio de Janeiro, Forense, 2003, pág. 186; Yussef Said CAHALI, Dano Moral, $2^{a}$ ed., São Paulo, Revista dos Tribunais, 1998, pág. 42.

${ }^{880}$ Essa é, e. g., a posição adotada por Carlos Roberto GONÇALVES, para quem "o critério de se atentar para a situação econômica do lesado, no arbitramento dos danos morais, pode ser utilizado porque, como já ressaltado, a reparação não deve buscar uma equivalência com a dor, mas ser suficiente para trazer um consolo ao beneficiário, uma compensação pelo mal que lhe causaram. [...] Enfim, os bens da vida capazes de consolar ou compensar a dor do lesado de modesta condição social e econômica são, também, de menor valor." (Comentários ao Código Civil, vol. 11, São Paulo, Saraiva, 2003, pág. 368). Ainda, a despeito da ressalva quanto à restrita utilização deste critério, Sérgio SEVERo, Os Danos Extrapatrimoniais, São Paulo, Saraiva, 1996, pág. 211.
} 
cometimento de novos ilícitos. Apenas por isso, já se bastaria para sustentar a inaplicabilidade de tal critério para a quantificação da indenização punitiva ${ }^{881}$.

Há que se ver, contudo, que nem mesmo para a correta quantificação da indenização compensatória tal critério merece ser utilizado, vez que "a posição social ou política do ofendido não deve ser vista como critério passível de, subjetivamente, conformar para mais ou para menos a estimativa da compensação" ${ }^{\text {"82 }}$. Trata-se, portanto, de critério absolutamente inapto a demonstrar em que medida o lesado veio a suportar prejuízos.

Nas acertadas palavras de Wesley de Oliveira Louzada BERNARDO, "partindo-se do pressuposto de que o dano moral deriva de lesão à dignidade da pessoa humana, diferenciar as vítimas por suas posses, eqüivaleria a reconhecer maior dignidade aos mais afortunados e menor aos menos favorecidos" $" 883$. Nesse toada, inafastável se mostra a conclusão de que a utilização do critério da posição econômica do lesado para a quantificação da indenização por danos morais, que conecta "a medida da dor ao tamanho do bolso”, dá-se “em flagrante desapreço pela isonomia constitucional”"884.

Inadmissível, portanto, mostra-se a utilização deste critério, quer para a quantificação da indenização compensatória, quer, ainda, para a quantificação da indenização punitiva.

Interessante notar, contudo, que, "se o critério do nível socioeconômico da vítima enseja mais iniqüidades do que benefícios, o mesmo não se dá quando são levadas em conta suas condições pessoais" ${ }^{\prime 85}$. Com efeito, nada obsta que, para a quantificação, quer da indenização compensatória, quer da punitiva (o que efetivamente nos interessa no momento), sejam levados em considerações elementos que componham o perfil pessoal do

\footnotetext{
${ }^{881}$ Também nesse sentido, André Gustavo Corrêa de ANDRADE, Dano Moral e Indenização Punitiva: Os punitive damages na experiência do common law e na perspectiva do Direito brasileiro, Rio de Janeiro, Forense, 2006, pág. 324.

${ }^{882}$ João Carlos de LIMA, O Caráter Punitivo da Indenização por Danos Pessoais e a Reversibilidade da Cominação para o FAT, in Revista de Direito do Trabalho, ano 30, vol. 115, jul./set. 2004, pág. 83.

${ }^{883}$ Dano Moral: Critérios de Fixação de Valor, Rio de Janeiro, Renovar, 2005, pág. 183.

${ }^{884}$ Gustavo TePedino, O Futuro da Responsabilidade Civil, in Temas de Direito Civil, vol. III, Rio de Janeiro, Renovar, 2009, pág. 406. No mesmo sentido, André Gustavo Corrêa de AndRADE, Dano Moral e Indenização Punitiva: Os punitive damages na experiência do common law e na perspectiva do Direito brasileiro, Rio de Janeiro, Forense, 2006, pág. 325.

${ }^{885}$ Maria Celina Bodin de MoRAES, Danos à Pessoa Humana (Uma Leitura Civil-Constitucional dos Danos Morais), Rio de Janeiro, Renovar, 2003, pág. 303.
} 
ofendido, mas que sejam alheios à sua condição socioeconômica. Pelo contrário: a consideração desses elementos pode-se mostrar, inclusive, imprescindível para o adequado arbitramento da indenização, vez que refletem, em muitas das vezes, na reprovabilidade da conduta perpetrada pelo ofensor.

Veja-se, no que tange à indenização compensatória, que um mesmo ato ilícito, com resultados físico-materiais idênticos, podem causar danos morais de ordens distintas em dois sujeitos que ostentem perfis pessoais distintos. É o caso, que se traz apenas à guisa de exemplo, de duas pessoas que vierem a suportar lesões em suas mãos, com perda parcial de seus movimentos, lesões estas causadas pela mesma conduta culposa de determinado indivíduo. Se um dos sujeitos lesados vem a suportar redução laborativa severa (porque, e.g., exercia a profissão de pianista), ele deve ser compensado com indenização mais vultosa que aquele sujeito que, a despeito de ter suportado os mesmos reflexos físicos do ilícito, não veio a suportar tal influência em sua vida pessoal (por, e.g., excercer profissão em que a perícia manual não é relevante ou indispensável).

Na mesma linha de raciocínio, mas observando-se o âmbito da indenização punitiva, há que se reconhecer que atos ilícitos perpetrados contra sujeitos de menor grau de compreensão intelectual, ou caracterizados por uma notável inocência e incapacidade de oferecer resistência (tais como crianças), mostram-se mais reprováveis do que aqueles praticados contra sujeitos plenamente aptos a compreender a plena extensão da situação à qual se submeteram.

\section{CONTROLE DO MONTANTE DA INDENIZAÇÃO PUNITIVA}

Ultrapassadas as considerações acima, cumpre-nos analisar de que maneira se poderia operar o controle do quantum indenizatório, justamente para que se evite um desvirtuamento do instituto em questão, com fixação de indenizações em patamares elevadíssimos, em discrepância com a realidade socioeconômica brasileira. Para o exercício de tal tarefa, a doutrina especializada aventa duas soluções possíveis: (i) a previsão de um controle legislativo, realizado por meio da edição de leis que imponham um limite máximo a ser atingido pela indenização punitiva; ou, ainda, (ii) a previsão de um controle judicial, 
realizado por meio do reexame das condenações por órgãos jurisdicionais superiores, os quais se utilizarão de critérios como os princípios da razoabilidade e da proporcionalidade para aferir a adequação da indenização punitiva aos fins a que se destina ${ }^{886}$.

\section{II.I. Controle legislativo}

O primeiro dos sistemas de que se cogita para o controle do quantum indenizatório é aquele que se mostra mais rígido: a adoção de limites legais, que podem ser mais ou menos rígidos, conforme assim o deseje o legislador, para a indenização punitiva. À luz das considerações feitas pelo tort reform movement, cogita-se que tal controle prévio pode-se dar, essencialmente, de duas maneiras distintas: ou (i) por meio da criação de "tetos máximos" a serem atingidos pela indenização punitiva (como, por ex., de R\$ $100.000,00$, ou quantia equivalente ${ }^{887}$; ou, ainda, (ii) por meio da adoção de uma relação de proporcionalidade entre o dano efetiva ou potencialmente causado e o valor da indenização punitiva (por meio do qual a quantificação desta última passaria a ser um múltiplo da indenização compensatória, como o dobro ou o triplo) ${ }^{888}$.

A adoção de sistema de controle prévio do montante da indenização punitiva (por meio da utilização de uma das soluções acima enumeradas), uma opção de política legislativa que em nada prejudicaria a constitucionalidade ou legalidade da indenização punitiva ${ }^{889}$, parece depender da análise de dois argumentos conflitantes. De

\footnotetext{
${ }^{886}$ Eduardo UILAN, Responsabilidade Civil Punitiva, Tese (Doutorado) - Faculdade de Direito da USP, São Paulo, 2003, pág. 88.

${ }^{887}$ Tal critério era, por ex., aquele previsto para a sanção "multa civil", originalmente estabelecida nos arts. 16 e 45 do Código de Defesa do Consumidor, e que tinha por teto máximo a quantia de "um milhão de Bônus do Tesouro Nacional".

${ }^{888}$ Tal critério é, por ex., aquele previsto pelo $\$ 4^{\circ}$, 'a', do Clayton Act, que prevê que "any person who shall be injured in his business or property by reason of anything forbidden in the antitrust laws may sue therefor in any district court of the United States in the district in which the defendant resides or is found or has an agent, without respect to the amount in controversy, and shall recover threefold the damages by him sustained, and the cost of suit, including a reasonable attorney's fee"; ou, ainda, aquele estabelecido no art. 940, do CC/2002, que prevê a condenação daquele que demandar por quantia já quitada a pagar o dobro do quanto exigido em juízo.

${ }^{889}$ Também parece ser esta a posição adotada por Eduardo UILAN, Responsabilidade Civil Punitiva, Tese (Doutorado) - Faculdade de Direito da USP, São Paulo, 2003, pág. 88 e P. M. LourençO, A Função Punitiva da Responsabilidade Civil, Coimbra, Coimbra, 2006, pág. 396. André Gustavo Corrêa de ANDRADE, a seu turno, é categórico ao afirmar que imputar ao julgador a competência para a quantificação da indenização punitiva, mesmo sem a prévia estipulação de limites legais, sejam mínimos, sejam máximos, é medida que se coaduna com o princípio da legalidade das penas e, portanto, não pode ser reputada inconstitucional ou ilegal. (Dano Moral e Indenização Punitiva: Os punitive damages na experiência do
} 
um lado, posicionam-se aqueles que defendem que a ausência de limites legislativos prévios para a quantificação da sanção punitiva criaria um desnecessário risco de que os julgadores viessem a impor condenações em valores exorbitantes, em desatenção ao princípio da proporcionalidade. De outro lado, situam-se aqueles que sustentam que a imprevisibilidade do valor final da condenação é um fator indispensável para que a indenização punitiva possa atingir suas finalidades últimas de desestímulo e prevenção, fator este que restaria comprometido caso fossem estabelecidos limites legais prévios à quantificação da indenização.

Passando em revista os argumentos esposados pelo primeiro grupo de doutrinadores, vê-se que, segundo a professora francesa S. CARVAL, a predeterminação do montante da indenização punitiva pelo legislador é, sempre que possível, uma alternativa desejável, uma vez que, em assim se fazendo, assegura-se, com maior retidão, que a severidade do quantum indenizatório guardará correspondência com a gravidade da conduta perpetrada ${ }^{890}$.

Em linha argumentativa semelhante, italiano P. GALLO afirma que, a favor da adoção de uma solução que preveja a inserção de limites máximos para a indenização punitiva, advoga o fato de que as sanções pecuniárias penais ou administrativas também apresentam limites mínimos e máximos dentro dos quais o julgador exerce a sua discricionariedade ao quantificar a pena, não podendo, contudo, ultrapassá-los ${ }^{891}$. Também para esse autor, portanto, a restrição à discricionariedade do julgador poderia atuar no sentido de garantir o respeito à proporcionalidade da condenação.

Tal preocupação se mostra ainda mais severa nas palavras de Wesley de Oliveira Louzada BERNARDO, para o qual, caso não se preveja limites legais para a dosimetria da indenização punitiva, "ao juiz se atribuirá um grau de subjetividade muito maior do que o atualmente vigente", possibilitando-lhe "aplicar uma pena sem

common law e na perspectiva do Direito brasileiro, Rio de Janeiro, Forense, 2006, págs. 307 e ss.). Concluise, nessa esteira, que a adoção de uma ou outra solução para o controle da quantificação da indenização punitiva (controle prévio, por meio da fixação de limites legais, ou controle a posteriori, por meio da incidência dos princípios da razoabilidade e proporcionalidade) é uma questão de conveniência legislativa, que pode, inclusive, variar em razão do bem jurídico protegido ou de qualquer outro critério que se julgue pertinente para tal finalidade.

${ }^{890}$ La Responsabilitè Civile Dans Sa Fonction de Peine Privée, Paris, L.G.D.J., 1995, pág. 355.

${ }^{891}$ Pene Private e Responsabilità Civile, Milano, Giuffrè, 1996, pág. 195. 
quantitativo previamente estipulado, o que abriria caminho para a concessão de indenizações milionárias, conforme se verifica na praxis norte-americana" ${ }^{\prime 892}$.

Em sentido contrário, os doutrinadores que advogam contra a adoção de limites legislativos fixos para a quantificação da indenização punitiva sustentam que tal medida poderia acarretar a "perda de flexibilidade e adaptação que o direito privado ostenta em relação aos demais ramos do direito sancionatório" ${ }^{, 893}$ (nomeadamente, o Direito Penal e o Direito Administrativo Sancionador), eliminando a indenização punitiva uma de suas principais características, que é justamente a imprevisibilidade de sua quantificação.

Nessa toada, André Gustavo Corrêa de ANDRADE afirma que, para desempenhar adequadamente sua função preventiva, a indenização punitiva deve ter em conta, não apenas os critérios da natureza e extensão do dano suportado pela vítima, e do grau de reprovabilidade da conduta do ofensor, mas, também, a capacidade econômicofinanceira deste último ${ }^{894}$, fator ao qual acrescentamos, com especial importância, a expectativa de obtenção de vantagens econômicas em decorrência do ato ilícito.

Quanto a este ponto, ao tratar de medida semelhante aventada pelo tort reform movement, bem aponta G. GEORGIADES que, se, de um lado, a adoção de limites legislativos para a quantificação da indenização punitiva pode trazer conseqüências positivas (especificamente no que concerne à diminuição do risco de imposição de sanções excessivamente elevadas), ela também pode, de outro, representar um risco para o adequado desempenho da função preventiva. Nas palavras do citado autor, "se o lucro que o ofensor espera extrair superar os limites legislativos máximos da indenização punitiva, é provável que ele prossiga com sua atividade ilícita" ${ }^{\text {" }}$.

Assim, pode-se afirmar com segurança que a restrição (ou a eliminação) da imprevisibilidade na quantificação da indenização punitiva serve a propósitos negativos,

\footnotetext{
${ }^{892}$ Dano Moral: Critérios de Fixação de Valor, Rio de Janeiro, Renovar, 2005, pág. 176.

${ }^{893}$ Eduardo UILAN, Responsabilidade Civil Punitiva, Tese (Doutorado) - Faculdade de Direito da USP, São Paulo, 2003, pág. 89.

894 Dano Moral e Indenização Punitiva: Os punitive damages na experiência do common law e na perspectiva do Direito brasileiro, Rio de Janeiro, Forense, 2006, págs. 308/309.

${ }^{895}$ No original: "[s]hould the torfeasor's expected profit be greater than the capped amount of punitive damages that can be possibly awarded, he is likely to proceed with his tortous activity." (Punitive Damages
} 
possibilitando que o ofensor venha a intencionalmente praticar atos ilícitos se estes lhe parecerem economicamente vantajosos ${ }^{896}$. A eficácia da indenização punitiva para a persecução de sua função preventiva é, portanto, “tanto maior, quanto menos hipóteses o lesante tiver de saber, antecipadamente, qual a quantia que terá de pagar, para que não faça uma previsão com base no já referido raciocínio de base puramente económica" ${ }^{\$ 97}$.

A defesa da imprevisibilidade do montante a ser fixado a título de indenização punitiva não impede, contudo, que o legislador fixe, nas hipóteses em que julgar conveniente, limites máximos para a indenização, os quais, em razão das considerações acima expostas, podem ser mais ou menos maleáveis ${ }^{898}$. Trata-se, como se disse acima, de opção de política legislativa, a qual, a nosso ver, pode ser convenientemente adotada sempre que a busca por segurança nas condenações não atentar irremediavelmente contra a eficácia da função preventiva da condenação.

\section{II.II. Controle judicial: proporcionalidade e razoabilidade}

Caso não sejam previamente fixados limites máximos para a quantificação da indenização punitiva, o controle da adequação de tal sanção à gravidade da conduta perpetrada, bem como aos demais critérios acima aventados para tanto, recai sobre os ombros dos julgadores, quer o de primeira instância, que fixa originalmente o quantum indenizatório, quer, ainda, os de instâncias superiores, que exercem o controle da quantificação da indenização em grau recursal. Para tanto, deve-se lançar mão de critérios como os postulados normativos da proporcionalidade e da razoabilidade, usualmente apontados pelos tribunais pátrios como aptos a servirem de baliza para a adequada

\footnotetext{
in Europe and the USA: Doctrinal Differences and Practical Convergence, in Revue Hellénique de Droit International, vol. 58, 2005, pág. 149).

${ }^{896}$ P. M. LourençOA Função Punitiva da Responsabilidade Civil, Coimbra, Coimbra, 2006, pág. 193 e Vitor Fernandes GonçALVES, A Punição na Responsabilidade Civil: A indenização do dano moral e da lesão a interesses difusos, Brasília, Brasília Jurídica, 2005, pág. 147.

${ }^{897}$ P. M. LourençO, A Função Punitiva da Responsabilidade Civil, Coimbra, Coimbra, 2006, pág. 396. No mesmo sentido, Eduardo UILAN, Responsabilidade Civil Punitiva, Tese (Doutorado) - Faculdade de Direito da USP, São Paulo, 2003, págs. $89 / 90$ e G. V. Robredo, Daños Punitivos en el Proceso Civil Norteamericano, in Revista de la Universidad de Deusto, vol. 57, fasc. 97, jul-dic./ 1996, pág. 187.

${ }^{898}$ Também é esse o posicionamento adotado por P. M. LOURENÇO, A Função Punitiva da Responsabilidade Civil, Coimbra, Coimbra, 2006, pág. 396.
} 
dosimetria de sanções pecuniárias ${ }^{899}$ (entre as quais certamente se insere a indenização punitiva), a despeito de, em muitas das vezes, tais referências serem nada mais do que alusões vazias, a servir tão-somente para justificar a manutenção do entendimento esposado pelas instâncias inferiores, independentemente dos fundamentos que os sustentavam ${ }^{900}$.

O assim chamado "princípio da proporcionalidade" (ou proporcionalidade em sentido amplo) desenvolveu-se como um verdadeiro "princípio de controle" dos atos do Poder Público, utilizado pelos tribunais para aferir a adequação entre determinadas medidas administrativas e o escopo por elas perseguido ${ }^{901}$. Atualmente, doutrina e jurisprudência lançam mão desse princípio para, por meio dele, buscar os meios mais adequados e eficientes para a concretização de direitos fundamentais ${ }^{902}$.

${ }^{899}$ Veja-se, apenas à guisa de exemplo, os seguintes julgados do E. STJ: "AGRAVO REGIMENTAL. DANO MORAL. [...] FIXAÇÃO DO VALOR INDENIZATÓRIO. RAZOABILIDADE E PROPORCIONALIDADE. [...] $O$ valor da indenização deve atender aos princípios da razoabilidade e da proporcionalidade, observado seu conteúdo didático, de modo a coibir reincidência do causador do dano sem enriquecer a vítima." (STJ; $3^{\mathrm{a}}$ T.; Ag. Reg. no RESP 945575/SP; Relator: Min. Humberto Gomes de Barros; J. 14.11.2007). Em sentido semelhante: (STJ; $1^{\mathrm{a}}$ T.; Ag. Reg. no AIDDRESP 1220528/PE; Relator: Min. Arnaldo Esteves de Lima; J. 07.12.2010); (STJ; $1^{\mathrm{a}}$ T.; Ag. Reg. no RESP 1160643/RN; Relator: Min. Benedito Gonçalves; J. 23.11.2010); (STJ; 2 ${ }^{\mathrm{a}}$ T.; Ag. Reg. no AIDDRESP 1330171/MS; Relator: Min. Humberto Martins; J. 26.10.2010) e (STJ; $2^{\mathrm{a}}$ T.; Ag. Reg. no AIDDRESP n. ${ }^{\circ}$ 1334755/SP; Relator: Min. Humberto Martins; J. 26.10.2010).

900 Nesse sentido, seguem as duras palavras de Wesley de Oliveira Louzada BERNARDO, para o qual "razoabilidade e proporcionalidade não são, em nosso contexto jurisprudencial, verificáveis na sentença, servindo como verdadeira 'excludente de responsabilidade' do magistrado ao fixar ou reformar a sentença. Ora se diz fundado no citado princípio para fixar o montante, sem qualquer fundamentação; ora [se] diz que o princípio foi ofendido, a fim de modificar o valor, sem demonstrar, entretanto, onde se situa a ofensa." (Dano Moral: Critérios de Fixação de Valor, Rio de Janeiro, Renovar, 2005, pág. 187). A despeito de mordazes, as considerações do citado autor, infelizmente, não fogem à realidade. Apenas para fins ilustrativos, uma breve pesquisa jurisprudencial nas bases do E. Superior Tribunal de Justiça nos apresenta resultados bastante discrepantes no que concerne à quantificação de indenizações em suposta atenção aos princípios da razoabilidade e da proporcionalidade. Sem que se tecesse uma linha sequer acerca da extensão do prejuízo suportado pelas vítimas, sobre as características pessoais da vítima ou do ofensor, ou, mesmo, sobre o grau de reprovabilidade das condutas ilícitas deste último, a $2^{\mathrm{a}}$ Turma do E. STJ considerou, em outubro de 2010, que a condenação do demandado ao pagamento de $\mathrm{R} \$ 1.500,00$, em decorrência da suspensão temporária do fornecimento de energia elétrica, coadunava-se com os critérios de razoabilidade e proporcionalidade. (STJ; $2^{\mathrm{a}}$ T.; Ag. Reg. no AIDDRESP 1334755/SP; Relator: Min. Humberto Martins; J. 26.10.2010). Três anos antes, a mesma $2^{\mathrm{a}}$ Turma do E. STJ havia considerado que uma condenação ao pagamento de R $\$ 3.000,00$, equivalente ao dobro da anteriormente cogitada, também atendia escorreitamente aos princípios da razoabilidade e da proporcionalidade (STJ; $2^{\mathrm{a}}$ T.; RESP 969744/RJ; Relator: Min. Castro Meira; J. 06.11.2007). Pior do que isso, no ano de 2009, o mesmo Min. Castro Meira considerou que indenização mais do que três vezes superior a esta última, equivalente a R \$ 10.000,00, também se coadunava com tais princípios. (STJ; $2^{\mathrm{a}} \mathrm{T}$.; RESP 858885/RJ; Relator: Min. Castro Meira; J. 23.04.2009). Já a $1^{\text {a }}$ Turma do mesmo E. STJ considerou, no ano de 2006, que a condenação do demandado ao pagamento de indenização no importe de $\mathrm{R} \$ 13.000,00$ era flagrantemente exorbitante e desproporcional à ofensa sofrida pelo demandante (ofensa esta que consistia exatamente na indevida suspensão do fornecimento de energia elétrica), motivo pelo qual acolheu a pretensão recursal do demandado para reduzir o quantum indenizatório a apenas R\$ 6.500,00. (STJ; $1^{\mathrm{a}}$ T.; RESP 796808/RN; Relatora: Min. Denise Arruda; J. 16.05.2006).

901 J. J. G. CANOTILHO, Direito Constitucional e Teoria da Constituição, $7^{\mathrm{a}}$ ed., Coimbra, Almedina, 2003, pág. 268.

902 Paulo de Tarso Vieira SANSEverino, Princípio da Reparação Integral (Indenização no Código Civil), São Paulo, Saraiva, 2010, pág. 109. Sobre o tema, cfr. Virgílio Afonso da SILVA, A Constitucionalização do Direito (Os Direitos Fundamentais nas Relações entre Particulares), São Paulo, Malheiros, 2005, págs. 
Em linhas gerais, pode-se afirmar que o ponto fulcral da aplicação do aludido princípio (o qual não se confunde com a simples idéia de proporção, mas, pelo contrário, a engloba) é a relação de causalidade entre dois elementos aferíveis empiricamente, a saber: um fim e um meio. Enquanto que o primeiro é "um estado ambicionado de coisas", o último é composto pelas medidas destinadas a ser utilizadas para a persecução daquele fim $^{903}$.

A aferição, no caso concreto, da correlação entre meio e fim será realizada justamente por meio da incidência do "princípio da proporcionalidade", a ser feita sob três perspectivas (também denominadas de "subprincípios constitutivos do princípio da proporcionalidade"), quais sejam: (i) adequação (= se a medida cogitada é apropriada para atingir o fim almejado); (ii) necessidade (= se a medida cogitada é, entre eventuais outras que se prestam a atingir o mesmo fim, a menos onerosa e restritiva) e, ainda, a de (iii) "proporcionalidade em sentido estrito", "justa medida" ou "proporção" (= se as vantagens advindas do fim almejado podem ser adequadamente balanceadas em relação com as desvantagens trazidas pela medida cogitada) ${ }^{904}$.

Vê-se, enfim, que, ao aludirem ao "princípio da proporcionalidade" como possível critério apto a impedir a fixação de indenizações em montantes exorbitantes, nossos Tribunais se referem não à concepção de "proporcionalidade em sentido amplo", mas, sim, à de "proporcionalidade em sentido estrito": cogita-se a incidência desse critério para se assegurar a proporcionalização entre a indenização punitiva e os critérios legislativamente previstos para a sua quantificação, tais como o grau de culpa do ofensor, a natureza e extensão dos prejuízos e, ainda, a capacidade financeira do ofensor ${ }^{905}$.

160/164. Diz-se, ademais, que, a despeito de não se encontrar expressamente positivado na Constituição da República, poder-se-ia extrair o "princípio da proporcionalidade" do quanto previsto no art. $5^{\circ}, \S 2^{\circ}$, da $\mathrm{CF} / 88$, "que abrange a parte não escrita e não expressa dos direitos e garantias da Constituição" (Caroline VAZ, Funções da Responsabilidade Civil - Da Reparação à Punição e Dissuasão - Os punitive damages no Direito Comparado e Brasileiro, Porto Alegre, Livraria do Advogado, 2009, pág. 144).

903 Paulo de Tarso Vieira SAnseverino, Princípio da Reparação Integral (Indenização no Código Civil), São Paulo, Saraiva, 2010, pág. 108.

904 J. J. G. Canotilho, Direito Constitucional e Teoria da Constituição, $7^{\mathrm{a}}$ ed., Coimbra, Almedina, 2003, págs. 269/270 e Paulo de Tarso Vieira SANSEVERINO, Princípio da Reparação Integral (Indenização no Código Civil), São Paulo, Saraiva, 2010, pág. 109.

${ }^{905}$ Exatamente nesse sentido seguiu a orientação do E. TJSP ao se afirmar que "[a] indenização por dano moral deve ser fixada em termos razoáveis, não se justificando que a reparação venha a constituir-se em enriquecimento indevido. Deve o arbitramento operar-se com moderação, proporcionalidade ao grau de culpa, ao porte ou condições das partes, bem como a outras circunstâncias de relevo, orientando-se o juiz 
Já o assim chamado "princípio da razoabilidade" (aqui não entendido como mero sinônimo do "princípio da proporcionalidade") incide quando se pretende aferir a relação de adequação entre uma medida cogitada em abstrato (em uma previsão legislativa ou decisão judicial) e sua aplicação em concreto (a um caso específico) ${ }^{906}$.

Segundo a doutrina, a aferição da razoabilidade de incidência da norma ao caso concreto deverá ser levada a efeito por meio da análise sob uma, de três possíveis acepções do princípio: (i) equidade (= deve-se verificar, de um lado, se a interpretação que se dá usualmente à norma justificaria sua incidência sobre o caso concreto e, de outro, se as peculiaridades do caso concreto poderiam afastar a razoabilidade da incidência da norma); (ii) congruência (= deve-se verificar se a incidência da norma ao caso concreto atenderia às "condições externas de aplicação"); e, por fim, de (iii) equivalência (= deve-se verificar se existe uma relação de correspondência entre a medida cogitada pela norma e o critério verificado no caso concreto, em situação assemelhada à de "proporção" ou "justa medida" acima indicada) ${ }^{907}$.

Uma vez que a tarefa do julgador, na quantificação da indenização punitiva (e, no mais, na quantificação de qualquer indenização, ainda que compensatória, ou, até mesmo, na dosimetria de qualquer sanção jurídica), consiste na verificação da proporção entre medidas (a indenização) e critérios (aqueles previstos em lei para tanto), parece-nos que ela diz respeito muito mais ao que se denomina de "princípio da razoabilidade" (notadamente em sua acepção de "equivalência") do que, propriamente, ao "princípio da proporcionalidade" (ao menos em sua concepção usual, de "proporcionalidade em sentido amplo" ${ }^{908}$. Pode-se, igualmente, nos termos acima expressos, cogitar da incidência do "subprincípio constitutivo" da "proporcionalidade em sentido estrito".

pelos critérios sugeridos pela doutrina e pela jurisprudência [...]." (TJSP; $11^{\mathrm{a}}$ Câm. de Direito Privado; Apelação n. ${ }^{\circ}$ 990.10.473150-0; Relator: Des. Gilberto dos Santos; J. 16.12.2010).

${ }^{906}$ Paulo de Tarso Vieira SANSEVERINO, Princípio da Reparação Integral (Indenização no Código Civil), São Paulo, Saraiva, 2010, págs. 109/110. Semelhantemente, Caroline VAZ, Funções da Responsabilidade Civil - Da Reparação à Punição e Dissuasão - Os punitive damages no Direito Comparado e Brasileiro, Porto Alegre, Livraria do Advogado, 2009, pág. 146.

907 Paulo de Tarso Vieira SANSEVERINO, Princípio da Reparação Integral (Indenização no Código Civil), São Paulo, Saraiva, 2010, pág. 110.

${ }^{908}$ Nesse sentido, Caroline VAZ, Funções da Responsabilidade Civil - Da Reparação à Punição e Dissuasão - Os punitive damages no Direito Comparado e Brasileiro, Porto Alegre, Livraria do Advogado, 2009, pág. 147 e Paulo de Tarso Vieira SAnseverino, Princípio da Reparação Integral (Indenização no Código Civil), São Paulo, Saraiva, 2010, pág. 111. 
Feitas tais ponderações, o que nos parece relevante frisar é que, no desempenho da tarefa de aplicar, ao caso concreto, a sanção da indenização punitiva, deverá o julgador ter especial atenção às vicissitudes do caso concreto, quantificando a sanção de modo a que esta guarde relação de estrita proporção (ou equivalência) com os critérios legalmente previstos para tanto.

É inegável, então, que o desempenho adequado de tal tarefa guarda íntima relação com outras duas questões acima já tratadas: (i) a previsão legislativa dos critérios para a quantificação da indenização punitiva (sem o que o julgador teria uma discricionariedade quase que ilimitada para o exercício desse mister, e o controle posterior das indenizações ficaria muitíssimo dificultado, por não se ter segurança prévia de com quais critérios a indenização deveria guardar relação de equivalência); e (ii) a suficiente fundamentação da sentença condenatória, em respeito ao quanto previsto no art. 93, IX, $\mathrm{CF} / 88$ e no art. 165, do CPC (sem o que o controle posterior do quantum indenizatório também ficaria dificultado em razão da impossibilidade de se ter conhecimento de quais critérios teriam sido utilizados pelo julgador para a dosimetria da sanção ${ }^{909}$ ).

\footnotetext{
909 É nesse sentido que Wesley de Oliveira Louzada BERNARDO afirma que, "[s]e a sentença, inevitavelmente, vem informada por convicções de seu prolator, tais convicções deverão ser explicitadas e fundamentadas, a fim de que se possa aquilatar sua conformação aos princípios e valores que fundamentam o ordenamento jurídico", entre os quais se inserem os de proporcionalidade (em sua acepção de "proporção") e de razoabilidade (em seu aspecto de "equivalência"). (Dano Moral: Critérios de Fixação de Valor, Rio de Janeiro, Renovar, 2005, pág. 192).
} 


\section{CAPÍTULO VI - A INTRODUÇÃO LEGISLATIVA DA INDENIZAÇÃO PUNITIVA NO DIREITO BRASILEIRO}

Tendo já enfrentado, nos capítulos que antecederam o presente, aquelas que nos pareceram ser as questões mais relevantes no que tocava à adoção da indenização punitiva, cumpre-nos, por derradeiro, analisar de que maneira tal sanção poderia encontrar guarida legislativa em nosso ordenamento.

Para tanto, procuraremos, em um primeiro momento, passar em revista algumas das iniciativas legislativas que, em um passado razoavelmente recente, prescreviam a incidência de sanções civis punitivas que, de alguma forma, assemelhan-se à indenização punitiva, ou estipulavam, para a quantificação da indenização, a utilização de critérios que fogem à finalidade exclusivamente compensatória. Nesse mesmo tópico, analisaremos aqueles que julgamentos ser os méritos e deméritos de recentes proposições legais, de iniciativa do Senado Federal e da Câmara dos Deputados, para a introdução legislativa de sanções assemelhadas à indenização punitiva.

Ao final, buscaremos apresentar nossa sugestão para a introdução legislativa de tal instituto.

\section{AS DIVERSAS INICIATIVAS LEGISLATIVAS: ANÁLISE, INSUFICIÊNCIAS E DEFICIÊNCIAS}

Como se teve a oportunidade de verificar ao longo da presente dissertação, as sanções punitivas não são estranhas a nosso Direito Civil. Pelo contrário, sua presença e utilização são absolutamente comuns, encontrando-se expressamente previstas em diversas oportunidades, quer em nosso Código Civil quer, por vezes, na legislação extravagante. Quanto a este ponto, contudo, vale ainda ressaltar que também a indenização punitiva não é uma completa estranha a nosso ordenamento, já se a tendo previsto de maneira expressa no passado e, ante à sua atual e momentânea ausência, apresentado uma série de propostas legislativas para re-inseri-la em nosso Direito. 
Com efeito, há quase meio século, a Lei 4.117/1962 (o assim chamado Código Brasileiro das Telecomunicações) estabeleceu, na redação original de seu artigo 84 (antes da revogação pelo DL 326/1967), que, para a compensação dos danos morais causados através de meios de telecomunicação, o juiz da causa deveria ter em conta, para além da "gravidade e repercussão da ofensa", critérios como "a posição social ou política do ofendido", "a situação econômica do ofensor" e a "intensidade do ânimo de ofender".

Mais do que isso, os parágrafos segundo e terceiro do mesmo dispositivo legal previam expressamente que o valor da indenização seria elevado ao dobro "quando comprovada a reincidência do ofensor em ilícito contra a honra" (art. 84, § $2^{\circ}$ ) ou "no caso de ser o ilícito contra a honra praticado no interesse de grupos econômicos ou visando a objetivos antinacionais" (art. 84, § $3^{\circ}$ ).

$\mathrm{Na}$ linha do quanto já exposto (e exceção feita à "posição social e política do ofendido", que, em última análise e dependendo da natureza da ofensa causada, poderia repercutir na intensidade e extensão dos prejuízos decorrentes da lesão à sua honra), os critérios acima aventados em nada se relacionam com o prejuízo efetivamente suportado pelo ofendido, servindo, em verdade, ora para atribuir à indenização uma função nitidamente punitiva (caso da "intensidade do ânimo de ofender", que atua de modo a adequar a sanção à gravidade da ofensa cometida), ora para atribuir a ela duas funções, punitiva e preventiva (caso da "situação econômica do ofensor", que serve tanto para que faça à supra citada adequação da sanção ao ofensor, como, também, em casos de cometimento de ilícito lucrativo, para retirar do ofensor o lucro obtido, desestimulando-o quanto ao cometimento de novos e semelhantes ilícitos). Por outro lado, a adoção de um multiplicador do valor da indenização (que, após sua incidência, passaria a flagrantemente extrapolar os limites do prejuízo suportado), em atenção à reincidência ou à torpeza dos motivos para o cometimento do ilícito, também era um fator direcionado à consecução da função puntiva da indenização, em nada se relacionando com a compensação dos prejuízos efetivamente suportados.

Poucos anos depois, editou-se a Lei 5.250/1967 (Lei de Imprensa), a qual previu, em seu artigo 53, critérios semelhantes àqueles aventados pelo Código Brasileiro de Telecomunicações para a quantificação da indenização por danos morais. Para além dos critérios voltados à aferição da extensão dos prejuízos impostos à vítima (art. 53, I e III), 
impunha-se ao juiz a observação de elementos como "a intensidade do dolo ou o grau de culpa do responsável", "sua situação econômica" e "sua condenação anterior em ação criminal ou cível fundada em abuso no exercício da liberdade de manifestação do pensamento e informação" (art. 53, II).

Novamente, para a quantificação da indenização, fez-se alusão a critérios destinados à consecução das funções punitiva (tais como a gravidade da conduta do ofensor, sua eventual reincidência e, ainda, sua "situação econômica") e preventiva (notadamente, sua "situação econômica", para as hipóteses já referidas).

Como bem anota a doutrina, inobstante não dizerem respeito à compensação dos prejuízos suportados pela vítima, "[a]lgumas recomendações da Lei de Imprensa, feitas no art. 53, no entanto, continuam a ser aplicadas na generalidade dos casos, como [...] o grau de culpa e a situação econômica do ofensor" ${ }^{\text {,910. }}$.

A despeito de as Leis acima referidas prescreverem, para a quantificação da indenização, a utilização de critérios que, ao menos em tese, seriam aptos à persecução de suas funções punitiva e preventiva, ambas padeciam de deficiências que lhes impediam de exercer, adequadamente, tais funções.

A uma, ambas as Leis continham normas que se destinavam a regrar campos de atuação muitíssimo específicos (nomeadamente, telecomunicações e imprensa), não abarcando previsões mais amplas, aptas a serem utilizadas para a generalidade dos casos de indenização por danos morais.

\footnotetext{
${ }^{910}$ Carlos Roberto GonÇalves, Comentários ao Código Civil, vol. 11, São Paulo, Saraiva, 2003, pág. 362. $\mathrm{Na}$ jurisprudência, a referência a tais critérios, bem como a alusão às funções preventiva e punitiva da indenização, tornou-se verdadeiro "lugar comum" no que toca à quantificação da indenização por danos morais. Apenas à guisa de exemplo: "O arbitramento da condenação a título de dano moral deve operar-se com moderação, proporcionalmente ao grau de culpa, ao porte empresarial das partes, suas atividades comerciais, e, ainda, ao valor do negócio, orientando-se o juiz pelos critérios sugeridos pela doutrina e pela jurisprudência, com razoabilidade, valendo-se de sua experiência e do bom senso, atento à realidade da vida, notadamente à situação econômica atual, e às peculiaridades de cada caso." (STJ; RESP n. ${ }^{\circ}$ 173366/SP; Relator: Min. Sálvio de Figueiredo Teixeira; J. 03.12.1998); (TJDF; Apelação n. ${ }^{\circ}$ 2003.01.1.116051-8; Relator: Des. José de Aquino Perpétuo; J. 26.09.2007); (TJDF; Apelação n. ${ }^{\circ}$ 2006.08.1.002333-2; Relator: Des. Cruz Macedo; J. 27.06.2007); (TAMG; 6 ${ }^{\mathrm{a}}$ Câm.; Apelação $\mathrm{n}^{\mathrm{o}}$ 2.0000.00.357429-4/000; Relatora: Valdete Leite Machado; J. 18.04.2002).
} 
A duas, as Leis também se limitavam a prescrever a utilização dos supra referidos critérios para as indenizações decorrentes do cometimento de danos morais, deixando de prever, portanto, a punição daqueles atos ilícitos que, a despeito de altamente reprováveis, acarretassem apenas a produção de prejuízos materiais.

A três, mesmo para os casos de indenização por danos morais, as aludidas Leis deixaram de estipular, de maneira adequada, quais os pressupostos objetivos e subjetivos necessários para que uma dada conduta ilícita pudesse ser sancionada por meio da imposição de indenização punitiva. Permitia-se, dessa maneira, que, ao lado dos mais maliciosos malfeitores, fossem também apenados ofensores meramente negligentes.

A quatro, e por fim, ambas as Leis previram limites mínimos e máximos para a quantificação da indenização (art. 84, § $1^{\circ}$, da Lei 4.117/1962 e arts. 51 e 52, da Lei 5.250/1967), o que, como já se expôs, limita (ou elimina) um fator importantíssimo para que a indenização punitiva exerça adequadamente suas funções punitiva e preventiva: a imprevisibilidade quanto à mensuração da sanção ${ }^{911}$.

Anos mais tarde, procurar-se-ia introduzir novamente em nosso ordenamento a figura da indenização punitiva por meio do Projeto Original do Código de Defesa do Consumidor. Em seu texto original, previa-se, nos artigos 16 e 45, "além das perdas e danos, indenização por danos morais, perda dos juros e outras sanções" decorrentes da responsabilidade pelo fato do produto ou do serviço (todas elas, frise-se, exercendo funções compensatórias), a existência da figura da "multa civil", a qual possuiria valor equivalente a até “um milhão de Bônus do Tesouro Nacional” [BTN], e incidiria "se comprovada a alta periculosidade do produto ou do serviço que provocou o dano" ou "grave imprudência, negligência ou imperícia" por parte do fornecedor.

\footnotetext{
${ }^{911}$ Importa de ver que a vigência dos limites à indenização, nos termos em que previstos por ambas as Leis, teve vida curta. As restrições contidas no art. 84, § $1^{\circ}$, da Lei 4.117/1962 foram revogadas pelo DL 326/1967, enquanto que os limites impostos pelos arts. 51 e 52, da 5.250/1967 foram rejeitados definitivamente pela jurisprudência após a edição da Súmula n. ${ }^{\circ}$ 281/STJ (a qual prevê que "a indenização por dano moral não está sujeita à tarifação prevista na Lei de Imprensa"). Mais recentemente, ao apreciar a questão, o Supremo Tribunal Federal decidiu que o texto da Lei de Imprensa não foi recepcionado pela Carta Constitucional, tornando conseqüentemente inaplicáveis todos os seus dispositivos (STF; Tribunal Pleno; ADPF 130/DF; Relator: Min. Carlos Ayres Britto; J. 30.04.2009).
} 
Inegavelmente, a figura da "multa civil", que somente incidiria nos casos da mais alta reprovabilidade e cujo valor deveria ser quantificado de maneira "proporcional à gravidade da infração" (critério este atinente ao desempenho da função punitiva) e "à condição econômica do infrator" (critério este relacionado ao desempenho da função preventiva), fugia dos limites da indenização meramente compensatória, atuando como verdadeira indenização punitiva.

Nos moldes em que prevista no Projeto Original do CDC, a "multa civil" era instituto jurídico inovador e que apresentada elementos de grande interesse, especialmente porque, ao menos pelo que se tem notícia, tratou-se da primeira oportunidade em que se procurou criar uma figura isolada da indenização punitiva, a qual incidiria de maneira autônoma em relação à indenização compensatória (art. 16, do CDC) e utilizaria, para a sua quantificação, apenas critérios destinados à prevenção e punição (art. 45, do CDC), não voltados para a compensação do prejuízo. Da maneira como prevista originalmante, a "multa civil" era estruturalmente muito semelhante aos punitive damages.

De outro lado, a "multa civil" também merece destaque por se tratar de sanção punitiva que incidia em hipótese de responsabilidade civil objetiva, mas que, para sua incidência, exigia a prova de pressupostos subjetivos que indicassem o alto grau de reprovabilidade das condutas do produtor ou fornecedor de serviços. Previu-se, claramente, a co-existência entre a responsabilidade civil objetiva e a indenização punitiva, a qual somente deveria ser utilizada para sancionar as condutas mais gravosas.

A nosso ver, se a "multa civil" apresentava alguma deficiência, ela se relacionava apenas ao fato de se prescrever um limite máximo para a sua quantificação (art. 16, do CDC), o que, como se vem expondo, não é considerado adequado para o eficiente desempenho das funções preventiva e punitiva da indenização.

A despeito de suas características inovadoras, a "multa civil" foi objeto de lacônico veto presidencial, no sentido de que “o art. 12 e outras normas já dispõem de modo cabal sobre a reparação do dano sofrido pelo consumidor. Os dispositivos ora 
vetados criam a figura da 'multa civil', sempre de valor expressivo, sem que sejam definidas a sua destinação e finalidade" ${ }^{912}$.

Anos mais tarde, com a promulgação do Código Civil de 2002, o qual trouxe positivado o princípio da reparação integral em seu artigo 944, caput, sem que, como já se teve a oportunidade de sustentar, houvessem sido previstas exceções legais que admitissem a majoração da indenização em atenção a critérios punitivos, pareceu-se dar por encerradas as tentativas de introdução legislativa da indenização punitiva. Tratou-se, contudo, de aparência nada mais que passageira.

Com efeito, enquanto o Código Civil ainda se encontrava em período de vacatio legis, foi apresentado o Projeto de Lei n. ${ }^{\circ}$ 6.960/2002, de autoria do então deputado federal Ricardo Fiúza, o qual, além de centenas de alterações ao longo de todo o Código Civil, previu duas modificações para o artigo 944: optou-se por transformar o atual parágrafo único (que prevê a redução eqüitativa da indenização em caso de excessiva desproporção entre a gravidade da culpa e o dano causado) em parágrafo primeiro, adicionando-se, ainda, um parágrafo segundo que prescrevia que "a reparação do dano moral deve constituir-se em compensação ao lesado e adequado desestímulo ao lesante."

Ao se justificar a proposta reformista, sustentou-se que a previsão contida no art. 944, caput, do CC/2002, seria inadequada para o arbitramento de indenizações por danos morais, restringindo-se a aplicação de tal critério apenas às indenizações decorrentes de dano material. Concluiu-se, nessa linha, que a indenização dos danos morais (mas, aparentemente, não a dos danos materiais) deveria atender uma dupla função, de compensação do lesado e desestímulo ao lesante, e que este desestímulo deveria ser desempenhado por meio da utilização de critérios subjetivos na quantificação da indenização, tais como o "grau da culpa do lesante", a "situação econômica das partes" e o "proveito obtido com o ilícito" "913.

\footnotetext{
912 O aludido veto presidencial recebeu ataques sensíveis dos autores do anteprojeto, que o consideraram "sem razão" de ser (cfr. Zelmo DENARI, Código Brasileiro de Defesa do Consumidor Comentado pelos Autores do Anteprojeto, $9^{a}$ ed., Rio de Janeiro, Forense Universitária, 2007, pág. 207).

${ }^{913}$ Segue o texto integral da justificativa: "Art. 944: O dispositivo é insuficiente, segundo nos alertou a professora REGINA BEATRIZ TAVARES DA SILVA, já que seu caput se adapta somente ao dano material não está adequado a dano moral. O critério para a fixação do dano material é o cálculo de tudo aquilo que o lesado deixou de lucrar e do que efetivamente perdeu. O critério da extensão do dano aplica-se perfeitamente à reparação do dano material - que tem caráter ressarcitório. No entanto, na reparação do dano moral não há ressarcimento, já que é praticamente impossível restaurar o bem lesado, que, via de regra, tem caráter imaterial. $O$ dano moral resulta, na maior parte das vezes, da violação a um direito da personalidade: vida,
} 
Não obstante a redação sugerida ter mencionado expressamente apenas a função preventiva (ou de desestímulo), é nítido que se tratou de mais uma tentativa de inserir em nosso ordenamento a figura da indenização punitiva, a qual, ao menos pelo que se pode extrair da justificativa do aludido Projeto de Lei, exerceria ambas as funções de punição e prevenção.

Quer nos parecer, contudo, que, da maneira como foi concebido, o aludido Projeto de Lei padecia de deficiências graves.

A uma, o Projeto de Lei introduzia a função de desestímulo apenas para a indenização dos danos de natureza extrapatrimonial, nada prescrevendo para os casos já acima referidos de atos ilícitos extremamente reprováveis (quiçá até mesmo perpetrados com o objetivo de, da ilicitude, extrair-se benefícios econômicos) que, não obstante sua alta reprovabilidade, acarretam apenas prejuízos materiais.

A duas, a despeito de o Projeto de Lei determinar que a indenização dos danos morais deveria exercer uma função de desestímulo (prevendo-se, em sua justificativa, que, para tanto, dever-se-ia utilizar critérios que fugissem à mera aferição da extensão dos prejuízos causados), não se prescreveu quais condutas ilícitas seriam sujeitas a tal distinto sancionamento. Desta maneira, permitia-se que fossem igualmente apenados ofensores que houvessem se conduzido de maneira intencional ou apenas negligente (ou, o

integridade física, honra, liberdade etc (v. Carlos Alberto Bittar, Os direitos da personalidade, $3^{a}$ ed., Rio de Janeiro, Forense Universitária; Carlos Alberto Bittar, Reparação Civil por danos morais, $3^{a}$ ed., São Paulo, Revista dos Tribunais, 1999, p. 57/65; Yussef Said Cahali, Dano moral, $2^{a}$ ed., São Paulo, Revista dos Tribunais, 1999, p. 42; Regina Beatriz Tavares da Silva Papa dos Santos, Reparação civil na separação e no divórcio, cit., p. 148 e 149). Por conseguinte, não basta estipular que a reparação mede-se pela extensão do dano. Os dois critérios que devem ser utilizados para a fixação do dano moral são a compensação ao lesado e o desestímulo ao lesante. Inserem-se neste contexto fatores subjetivos e objetivos, relacionados às pessoas envolvidas, como a análise do grau da culpa do lesante, de eventual participação do lesado no evento danoso, da situação econômica das partes e da proporcionalidade ao proveito obtido com o ilícito (v. Carlos Alberto Bittar, Reparação Civil por danos morais, cit., p. 221). Em suma, a reparação do dano moral deve ter em vista possibilitar ao lesado uma satisfação compensatória e, de outro lado, exercer função de desestímulo a novas práticas lesivas, de modo a 'inibir comportamentos anti-sociais do lesante, ou de qualquer outro membro da sociedade', traduzindo-se em 'montante que represente advertência ao lesante e à sociedade de que não se aceita o comportamento assumido, ou o evento lesivo' ( $c f$. Carlos Alberto Bittar, Reparação civil por danos morais, cit., p. 247 e 233; v., também, Yussef Said Cahali, Dano moral, cit., p. 33/42; e Antonio Jeová Santos, Dano moral indenizável, $3^{a}$ ed., São Paulo, 2001, p. 174 a 184; v. acórdãos in JTJ 199/59; RT 742/320). Ao juiz devem ser conferidos amplos poderes, tanto na definição da forma como da extensão da reparação cabível, mas certos parâmetros devem servir-lhe de norte firme e seguro, sendo estabelecidos em lei, inclusive para que 
que é ainda mais grave, ofensores que sequer houvessem sido negligentes, causando prejuízos em razão de uma atividade de risco).

A três, os critérios a serem seguidos pelo juiz da causa ao quantificar a indenização punitiva foram aventados apenas na justificativa de aprovação do aludido Projeto de Lei, mas jamais mencionados no texto legal que se procurou aprovar, o que, à evidência, deixaria ao exclusivo arbítrio do julgador a utilização de quaisquer critérios que entendesse pertinentes.

A referida proposta reformista, contudo, não teve vida longa. Ela, que ainda em período embrionário já havia recebido críticas da doutrina ${ }^{914}$, encontrou óbice à aprovação no Projeto Substitutivo apresentado no início do ano de 2004 pelo também Deputado Federal Vicente Arruda. Em sua justificativa para a rejeição da proposta de inserção do art. 944, § $2^{\circ}$, do CC/2002, sustentou-se que "a doutrina define o dano moral de várias formas. Todas as definições, entretanto, são coincidentes no que diz respeito a ser referente ao dano de bens não-patrimoniais ou não econômicos do lesado. Em nenhum lugar a indenização por dano moral é relacionado à pena. É justamente esse caráter de pena que ora se pretende dar quando o PL diz 'adequado desestímulo ao lesante'. Além do mais, confere-se ao juiz um arbítrio perigoso porque não delimita a fronteira entre o dano efetivo e o adequado desestímulo ao cometimento de futuros atos ilícitos. Cria também um duplo critério de avaliação da indenização. O critério para cálculo do valor da indenização do dano, tanto para o material quanto para o moral, deve ser o da sua extensão. Pela rejeição"915.

se evite, definitivamente, o estabelecimento de indenizações simbólicas, que nada compensam à vítima e somente servem de estímulo ao agressor."

914 Conferir, a esse respeito, o entendimento apresentado por Carlos Roberto GonÇALVES, Comentários ao Código Civil, São Paulo, Saraiva, 2003, pág. 518/519.

915 Ainda que tenhamos ressaltado as deficiências de que padecia o aludido Projeto de Lei, não se pode concordar com os argumentos apresentados pelo Projeto Substitutivo. Com efeito, e na esteira de todo o quanto exposto ao longo da presente dissertação, a doutrina e a jurisprudência nacionais discorrem acerca da dupla (ou tripla) função da indenização por danos morais (de compensação ao lesado e desestímulo e punição ao lesante) há décadas, de modo que não se pode afirmar, sem muitas ressalvas, que "em nenhum lugar a indenização do dano moral é relacionada à pena”. Defende-se, sim, que nem todos os atos ilícitos causadores de danos morais devem ser apenados, o que, conseqüentemente, significa dizer que os danos morais, assim como os danos patrimoniais, submetem-se ao princípio da reparação integral e comportam indenização exclusivamente compensatória. Contudo, existem ilícitos que, por sua particular reprovabilidade, não encontram resposta adequada e suficiente na incidência ex post da indenização compensatória, fazendose necessária, para fins de punição e prevenção (especial e geral), a utilização da indenização punitiva. Afirmar-se a inexistência, "em nenhum lugar", de correlação entre a indenização por danos morais e a pena é ignorar por completo mais de uma década de desenvolvimento doutrinário e jurisprudencial sobre o tema. 
Em razão das vicissitudes do processo legislativo, o aludido Projeto de Lei foi arquivado, tendo sido, na seqüência, reapresentado pelo Deputado Federal Léo Alcântara, que o reeditou sob a forma do Projeto de Lei n. ${ }^{\circ}$ 276/2007. Inexplicavelmente, ao menos no que concerne à modificação proposta para o art. 944, do CC/2002, foram desconsideradas as ressalvas feitas pelo supra referido Projeto Substitutivo, retomando-se a redação original prevista pelo Projeto de Lei n. ${ }^{\circ}$ 6960/2002. Tal Projeto, já com a reedição do texto originalmente sugerido para o art. $944, \S 2^{\circ}$, foi aprovado pela Comissão de Constituição e Justiça e de Cidadania da Câmara, em sessão realizada em novembro de 2010, recebendo Projeto Substitutivo da relatoria do Deputado Federal Regis de Oliveira, o qual, contudo, nada alterou o quanto se previu a respeito do art. 944.

Pouco depois do Projeto de Lei n. ${ }^{\circ}$ 6.960/2002, mas também versando sobre a quantificação da indenização por danos morais, o Deputado Federal Marcus Vicente apresentou o Projeto de Lei n. ${ }^{\circ}$ 1.914/2003. Tal Projeto prescrevia a inclusão de um parágrafo segundo na redação do artigo 953 do Código Civil (que versa sobre a indenização por injúria, difamação ou calúnia), o qual passaria a estipular que "[n]a fixação da indenização por danos morais, o juiz, a fim de evitar o enriquecimento indevido do demandante, levará em consideração a situação econômica do ofensor, a intensidade do ânimo de ofender, a gravidade e repercussão da ofensa, a posição social ou política do ofendido, bem como o sofrimento por ele experimentado."

Em sua justificação, o autor do Projeto afirmava que "[n]um país de dimensões continentais como o nosso, limitar-se a lei civil a referir que o juiz deverá agir 'eqüitativamente, na conformidade das circunstâncias do caso', como parâmetros para a fixação da indenização por danos morais, é temerário", para concluir que o parágrafo que se pretendia incluir no art. 953, do CC/2002, "auxiliará os magistrados brasileiros a alcançarem um arbitramento justo e eqüânime na fixação do dano moral, em benefício de toda a coletividade".

É desnecessária uma análise mais detalhada para que se possa concluir que tal proposta reformista é ainda mais deficiente do que a apresentada pelo Projeto de Lei 6.960/2002. Para além de padecer das mesmas insuficiências no que toca à ausência de previsão da indenização punitiva para atos ilícitos dos quais resultem apenas prejuízos 
materiais, bem como à ausência de previsão dos pressupostos objetivos e subjetivos para a incidência da indenização punitiva, tal Projeto apresenta ao menos duas outras graves falhas.

A uma, o Projeto apresenta um equívoco de tópica legislativa: sugere-se a inclusão de menção genérica, atinente à indenização por detrimentos morais, em artigo específico, que somente versa sobre a indenização decorrente dos ilícitos de injúria, difamação ou calúnia. A alteração legislativa, como no caso do Projeto de Lei anteriormente analisado, deveria se inserir no corpo do art. 944, do CC/2002, que versa, de maneira genérica, sobre a quantificação da indenização, jamais no do art. 953, do CC/2002.

A duas, o projeto também transparece um equívoco de ordem lógica: a despeito de prever, para a quantificação da indenização por danos morais, a utilização de critérios punitivos e preventivos (tais como "a intensidade do ânimo de ofender" e a "situação econômica do ofensor"), a redação sugerida prescreve que tais critérios somente seriam utilizados "a fim de evitar o enriquecimento indevido do demandante". A interpretação que se extrai de tal ressalva é a de que os critérios punitivos e preventivos aventados pelo dispositivo legal deveriam ser utilizados sempre para que a quantificação da indenização se desse em antenção ao demandado (para evitar o enriquecimento indevido do demandante), e não ao demandante e à Sociedade, o que nos parece, no mínimo, contraditório.

Assim como o Projeto n. ${ }^{\circ}$ 276/2007, o Projeto de Lei n. ${ }^{\circ} 1.914 / 2003$ foi igualmente aprovado em sessão realizada em novembro de 2010 pela Comissão de Constituição e Justiça e de Cidadania da Câmara, rumando para sua promulgação.

Por fim, e pelo que se tem notícia, o mais recente projeto a versar sobre a introdução legislativa da indenização punitiva foi o Projeto de Lei do Senado n. ${ }^{\circ}$ 413/07, de iniciativa do Senador Renato Casagrande. Sob o pretexto de dar fundamento legal ao já constante entendimento jurisprudencial e às menções doutrinárias acerca da dupla finalidade da indenização (especialmente no que toca à indenização por danos morais), propôs-se o acréscimo de um parágrafo segundo ao artigo 944, do CC/2002, o qual prescrevia que "[a] indenização atenderá às funções compensatória, preventiva e punitiva"916.

\footnotetext{
916 Assim discorre a justificação do aludido Projeto de Lei: "[a] jurisprudência pátria acolhe, como dito, a função punitiva da indenização, o que demonstra que não há, na iniciativa legislativa, nenhuma novidade que exacerbe a inteligência corrente do ordenamento jurídico. (REsp 183508 / RJ ; Resp 1998/0055614-1 -
} 
Tal proposta apresentava interessantes vantagens em relação às anteriormente comentadas. A uma, por trazer referência expressa às três atuais funções a serem desempenhadas pela responsabilidade civil (compensatória, preventiva e punitiva) e, a duas, por prever de maneira generalista a incidência da indenização punitiva, inclusive para casos nos quais os prejuízos decorrentes do ato ilícito são exclusivamente patrimonais $^{917}$.

Contudo, mesmo as supra aludidas vantagens não tornavam a proposta reformista isenta de críticas. Assim como suas predecessoras, ela também padecia de insuficiências ao não prescrever os pressupostos objetivos e subjetivos para a incidência da indenização punitiva, nem, tampouco, os critérios a serem utilizados pelo juiz da causa quando da quantificação da indenização.

Ao passar pela Comissão de Constituição, Justiça e Cidadania do Senado, o aludido Projeto recebeu uma emenda de autoria da Senadora Lúcia Vânia, a qual propôs uma alteração ao texto sugerido para o art. $944, \S 2^{\circ}$, que assim passaria a dispor: “a indenização por danos morais atenderá as funções compensatória, educativa e punitiva" ${ }^{918}$.

Sálvio Teixeira - DJ 10.06.2002 p. 212; Resp 575023/RS 2003 - Eliana Calmon; Resp 389879/MG 2001 Sávio Teixeira; TJDF Ap. Civ. 200201 025244-6 5a T. Cível Julgado em 17/05/2004; TJDF Ap. Cív. 2002 015000925-1 3a . T. Cível Julgado em 06/05/2002.) (...) No campo doutrinário, um exemplo que merece transcrição é a lição de Maria Helena Diniz: 'Não se pode negar a sua função [da reparação pecuniária do dano moral]: a) penal ou punitiva, constituindo uma sanção imposta ao ofensor, visando a diminuição de seu patrimônio, pela indenização paga ao ofendido, visto que o bem jurídico da pessoa - integridade física, moral e intelectual - não poderá ser violado impunemente, subtraindo-se o seu ofensor às conseqüências de seu ato por não serem reparáveis; e b) satisfatória ou compensatória, pois, como o dano moral constitui um menoscabo a interesses jurídicos extrapatrimoniais, provocando sentimentos que não têm preço, a reparação pecuniária visa proporcionar ao prejudicado uma satisfação que atenue a ofensa causada.' $(O$ problema da liquidação do dano moral e dos critérios para a fixação do 'quantum' indenizatório in Atualidades Jurídicas, 2, Maria Helena Diniz (coordenadora), São Paulo : Saraiva, 2000, p. 248, sem grifos). A clarificação legal da hipótese de função indenizatória punitiva é desejável na perspectiva da segurança jurídica, permitindo previsibilidade semântico-textual da norma."

${ }^{917}$ Quanto a este ponto, é importante frisar que, apesar de o texto original do PLS pretender a incidência, em geral, de uma indenização punitiva (o que abrangeria até mesmo os atos ilícitos dos quais decorressem prejuízos exclusivamente materiais), sua justificação restringia a incidência de tal sanção ao âmbito dos danos morais.

918 Ao fundamentar sua emenda, a I. Senadora advertiu que o Projeto de Lei, em sua redação original, permitiria a ampla incidência da indenização punitiva, tanto em relação aos prejuízos de ordem material quanto aos de ordem moral, o que mereceria reparo ante à adequação do princípio da reparação integral (art. 944, caput, CC) aos prejuízos monetizáveis. Ainda, deveria ser objeto de alteração a menção à função preventiva. Para a I. Senadora, a função educativa, prevista em sua emenda, além de abarcar a preventiva, traria uma melhor concepção da finalidade da indenização por danos morais: "Entendemos que, tratando-se de danos materiais, a indenização deverá obedecer unicamente a sua extensão, ou seja, deverão ser estritamente observados os elementos comprovados nos autos, de forma que o ressarcimento atingirá o 
A nosso ver, a aludida emenda, numa única oportunidade, nada fez para aprimorar o texto original do Projeto de Lei n. ${ }^{\circ}$ 413/07 (deixando, portanto, de suprir as deficiências de que padecia) e, ainda, nos dois pequenos aspectos em que o modificou, acabou por torná-lo ainda mais deficiente.

Por primeiro, excluir-se a possibilidade de que a indenização punitiva sancione, também, atos ilícitos dos quais decorrem prejuízos materiais é, por todo o quanto já exposto, insuficiente.

Por segundo, também não nos parece adequada a substituição da expressão "função preventiva" pela "função educativa". Em razão do que expusemos quando tratamos do regime dos punitive damages, acreditamos que a assim chamada função educativa se subordina às funções preventiva e punitiva, ligando-se a elas de maneira íntima para que as últimas possam incidir de maneira adequada e eficiente. Nessa linha de raciocínio, a função educativa atuará de modo a catalisar o desempenho das funções punitiva e preventiva, mas o conteúdo específico destas continuará a ser exercido por elas próprias, e não pela função educativa.

Após a emissão de relatório do Senador Marco Maciel pela constitucionalidade do Projeto de Lei, sugerindo-se sua aprovação com a emenda proposta pela Senadora Lúcia Vânia, a tramitação do aludido projeto foi suspensa ainda em meados de 2009, sem informações quanto ao seu prosseguimento.

Pode-se observar, pela breve análise acima apresentada, que a produção legislativa a respeito do tema é profícua, o que nos leva a crer estarmos na iminência de que seja introduzido em nosso ordenamento texto legal expresso readmitindo a figura da indenização punitiva.

montante correspondente ao total do prejuízo causado, salvo no caso da excessiva desproporcionalidade de que trata o atual parágrafo único do art. 944 do NCC. Por isso, cremos que as funções que se pretende atribuir através do PLS somente poderiam ser consideradas no dano de natureza moral, onde a sua definição pressupõe aspectos subjetivos. Nesse sentido, o próprio autor cita doutrina, além do que se observa em ampla jurisprudência. Por fim, vemos também necessidade de substituir a função preventiva, como apresentado, pela função educativa, por entendermos que esta melhor se coaduna com a intenção da proposta, pois, além de já carregar um conteúdo de prevenção, apresenta-se com o único objetivo de coibir a reincidência do causador do dano através de sua reeducação por medidas judiciais coercitivas.” 


\section{Proposta Para A INTRODUÇÃo Legislativa da INDENIZAÇão PUNiTIVA}

Como se viu, a despeito de nos parecer que a introdução legislativa da indenização punitiva é um fenômeno a ocorrer em um futuro próximo, os projetos de lei acima apresentados (e que se encontram na iminência de fazê-lo) apresentam uma série de deficiências que, a nosso ver, comprometem o eficiente desempenho das funções a serem perseguidas pela indenização punitiva. Tendo versado, ao longo do presente trabalho, sobre aquele que julgamos ser o regramento jurídico mais adequado para a indenização punitiva, acreditamos poder apresentar nossa modesta contribuição acerca do tema.

Por tudo o que acima se expôs, acreditamos que, para regrar eficientemente o instituto em tela, um projeto de lei deve abranger, num todo uniforme: (i) os pressupostos objetivos e subjetivos para a imposição de tal sanção punitiva ${ }^{919}$ (necessários para a fixação do an debeatur); (ii) os critérios a serem considerados pelo julgador para a mensuração da sanção ${ }^{920}$ (necessários para a fixação do quantum debeatur); e, ainda, (iii) aspectos materiais relacionados à introdução legislativa da indenização punitiva, especialmente no que se refere às hipóteses de responsabilidade indireta e à destinação da condenação ao pagamento de indenização punitiva.

\footnotetext{
${ }^{919}$ Valendo ressaltar, aqui, a ponderação apresentada por Eduardo ULIAN, no sentido de que, "tratando-se de um instrumento punitivo, a pena privada deverá ser aplicada dentro de limites previamente traçados e comunicados à sociedade, que sejam mais restritivos em relação ao regime geral da reparação de danos. Esses limites tanto poderão ser fixados pela pressuposição de situações genéricas que o legislador julgue apropriadas para dar azo à punição privada quanto, principalmente, pelo estabelecimento de um patamar mínimo de repreensibilidade da conduta causadora do dano." (Responsabilidade Civil Punitiva, Tese (Doutorado) - Faculdade de Direito da USP, São Paulo, 2003, págs. 74/75).

${ }^{920}$ A despeito de se ter em mente a ressalva bem posta por Carlos Alberto BITTAR, no sentido de que a fixação de critérios legislativos para a quantificação da indenização punitiva é tarefa das mais difíceis, uma vez que previsões legais estanques são, em regra, "insuscetíveis de abarcar as diferentes situações danosas possíveis, em razão da multiplicidade de fatores que interferem na matéria". (Reparação Civil por Danos Morais, São Paulo, RT, 1993, pág. 222), acredita-se poder selecionar um determinado apanhado de critérios que possuam aptidão generalizante, aptos a serem utilizados, senão em todos os casos, ao menos na grande maioria deles. Nesse sentido, também interessante se mostra a consideração feita por Eduardo UILAN, para o qual "[a] previsão legal dos critérios de cálculo permite lembrar aos juízes que a pena privada preenche uma outra função que não a de reparação e dá meios para que o legislador enfatize, segundo os casos e espécies, aspectos do ato ilícito que parecessem mais repreensíveis." (Responsabilidade Civil Punitiva, Tese (Doutorado) - Faculdade de Direito da USP, São Paulo, 2003, pág. 91).
} 
Em relação ao primeiro ponto (= pressupostos objetivos e subjetivos para a imposição da indenização punitiva), já afirmamos que a indenização punitiva deverá ser utilizada para sancionar apenas os ilícitos civis dotados do mais alto grau de reprovabilidade (cujos agentes devem ter obrado de maneira intencional ou gravemente culposa, com irresponsável desconsideração quanto aos direitos alheios) e que tenham lesado direitos ou interesses da mais alta relevância (a saber: os interesses existenciais e os metaindividuais) ou, ainda, servido de instrumento para a obtenção ilícita de vantagens econômicas (ainda que, nesse caso, os prejuízos decorrentes do ilícito sejam de natureza patrimonial).

Para poder regrar, de maneira ampla, tais pressupostos de incidência, acreditamos necessárias duas modificações legislativas: (i) acrescentar um parágrafo segundo ao texto do art. 944, do CC/2002, para que se possa versar sobre os prejuízos a interesses individuais; e (ii) acrescentar um artigo, numerado como 12-A, na Lei $7.347 / 1985$, para que se possa versar sobre os prejuízos a interesses metaindividuais ${ }^{921}$.

Já em relação ao segundo ponto (= critérios a serem considerados pelo julgador para a mensuração da sanção), já afirmamos que estes não se devem confundir com aquele relacionado à quantificação da indenização compensatória (a saber: "a extensão do dano"), resumindo-se nos seguintes: (i) o grau de culpa do ofensor; (ii) a gravidade do dano causado (mas apenas para que se possa aferir o grau de reprovabilidade da conduta perpetrada pelo ofensor); (iii) a condição econômica do ofensor e, ainda, (iv) os benefícios econômicos advindos do ilícito cometido.

Acreditamos que, para tanto, basta uma modificação legislativa, acrescendose um parágrafo terceiro ao texto do art. 944, do CC/2002 e enumerando-se, em seus incisos, os supra aludidos critérios.

Por fim, em relação ao terceiro ponto (= demais aspectos materiais relacionados à introdução legislativa da indenização punitiva), sustentou-se que: (i) a indenização punitiva só é compatível com as hipóteses de responsabilidade indireta se também o responsável indireto houver agido de maneira gravemente culposa ou dolosa,

\footnotetext{
${ }^{921}$ Sugestão semelhante à ora proposta, no que concerne à lesão aos interesses metaindividuais, é apresentada por Vitor Fernandes GonÇALVES, A Punição na Responsabilidade Civil: A indenização do dano moral e da lesão a interesses difusos, Brasília, Brasília Jurídica, 2005, págs. 245/246.
} 
contribuindo, dessa maneira, para o ato ilícito particularmente reprovável cometido por pessoa que se encontrava sob sua guarda; e que (ii) a solução mais adequada para a destinação dos recursos provenientes da indenização punitiva é a sua remessa a um fundo de gestão pública, nos mesmos moldes do "fundo de defesa dos direitos difusos" criado pela Lei 7.347/1985, e não sua atribuição à própria vítima do ilícito.

Para poder regrar tais aspectos, entendemos suficientes duas modificações legislativas: (i) acrescentar-se um parágrafo único ao texto do art. 933, do CC/2002, para delimitar a compatibilidade entre a indenização punitiva e a responsabilidade indireta; e (ii) acrescentar-se um parágrafo quarto ao texto do art. 944, do CC/2002, para regulamentar a destinação do numerário decorrente de eventual condenação ao pagamento de indenização punitiva no que toca às lesões a interesses individuais (já que, no que concerne à lesão a interesses metaindividuais, já e vê previsão legal suficiente no art. 13, da Lei 7.437/1985).

Em se admitindo as premissas aqui enumeradas, os dispositivos de lei mencionados seguiriam assim redigidos:

Art. 944, do CC/2002: "A indenização mede-se pela extensão do dano."

$\S 1^{\mathrm{o}}$ - "Se houver excessiva desproporção entre a gravidade da culpa e o dano, poderá o juiz reduzir, eqüitativamente, a indenização."

$\S 2^{\circ}$ - "Nos casos em que, do ato ilícito cometido com dolo ou culpa grave, resultar dano extrapatrimonial, ou do qual o ofensor extrair benefícios econômicos para si ou para outrem, o juiz poderá impor ao autor do dano, no mesmo processo e sem prejuízo das perdas e danos e demais sanções cabíveis, uma quantia a título de indenização punitiva, cujo montante poderá exceder a extensão do dano."

$\S 3^{\circ}$ - "Na quantificação da indenização punitiva prevista no parágrafo antecedente, que deverá ser feita em atenção aos princípios da razoabilidade e da proporcionalidade, o juiz terá em conta, notadamente:

I - "a intensidade do dolo ou o grau de culpa do autor do dano"

II - "a natureza e a extensão do dano"

III - "a situação econômica do autor do dano"

IV - "as vantagens pecuniárias obtidas pelo autor do dano"

$\S 4^{\circ}$ - "O produto da indenização punitiva devida reverterá para o Fundo criado pela Lei 7.347, de 24 de julho de 1985." 
Art. 933, do CC/2002: “As pessoas indicadas nos incisos I a V do artigo antecedente, ainda que não haja culpa de sua parte, responderão pelos atos praticados pelos terceiros ali referidos."

Parágrafo único: "Caso tenham-se conduzido com dolo ou culpa grave, ordenando, autorizando, referendando ou deixando de impedir que atos danosos sejam cometidos, as pessoas indicadas nos incisos $\mathrm{I}$ a $\mathrm{V}$ do artigo antecedente também responderão pela indenização punitiva a que vierem a ser condenados os terceiros ali referidos."

Art. 12-A, da Lei 7.347/1985: "Na ação de responsabilidade por danos a interesses difusos, se o ato ilícito for cometido com dolo ou culpa grave, ou se dele o ofensor extrair benefícios econômicos para si ou para outrem, o juiz poderá impor ao autor do dano, no mesmo processo e sem prejuízo das perdas e danos e demais sanções cabíveis, uma quantia a título de indenização punitiva, cujo montante poderá exceder a extensão do dano.”

Parágrafo único: "Na quantificação da indenização punitiva prevista no caput, que deverá ser feita em atenção aos princípios da razoabilidade e da proporcionalidade, o juiz terá em conta, notadamente:

I - "a intensidade do dolo ou o grau de culpa do autor do dano"

II - "a natureza e a extensão do dano"

III - "a situação econômica do autor do dano"

IV - "as vantagens pecuniárias obtidas pelo autor do dano" 


\section{CONCLUSÕES}

Com a finalidade de facilitar a compreensão do raciocício desenvolvido a respeito da indenização punitiva, seguem, abaixo expostas de maneira sintética e objetiva, as conclusões a que se chegou na presente dissertação:

1.

Pode-se verificar o grau de interesse exercido pelo tema da indenização punitiva em razão das diversas tentativas de introdução legislativa de tal sanção em nosso ordenamento, da recente produção monográfica a respeito do tema e, ainda, da aplicação praticamente pacífica que nossos Tribunais fazem da assim chamada teoria da dupla função da indenização por danos morais.

2. Com o objetivo de encontrar subsídios filosóficos e jurídicos para a implantação da indenização punitiva, doutrina e jurisprudência pátrias passaram a procurar modelos semelhantes no âmbito do Direito Comparado, lançando suas atenções sobre o instituto jurídico denominado de punitive damages.

3. Os punitive damages (também denominados de exemplary ou aggravated damages) são um instituto típico dos países da common law, consistentes na condenação pecuniária que pode ser imposta a um ofensor, por meio de um procedimento de índole civil e em adição às demais sanções de cunho compensatório, para puni-lo pelo cometimento de um ato grave ou abusivo, bem como para prevenir que o ofensor (em especial) e a sociedade (em geral) venham a cometer condutas semelhantes no futuro.

4. Ao analisar os antecedentes remotos dos punitive damages, os estudiosos afirmam que eles teriam se originado de disposições que, com a finalidade de punir o ofensor em razão do cometimento de um ato tipo por especialmente gravoso, previam sua condenação ao pagamento de múltiplos do valor correspondente à indenização. Tais previsões poderiam ser encontradas em dispositivos legais do Direito Antigo, no Direito Romano e, ainda, no Direito Inglês Medieval. 
5. À luz de tais antepassados remotos, surgiram, em meados do Século XVIII, os primeiros precedentes judiciais [em um primeiro momento na Inglaterra (Huckle $v$. Money e Wilkes v. Wood) e, depois, por influência destes, nos Estados Unidos da América (Genay v. Norris e Coryell v. Colbaugh)], a prever, expressamente, a utilização da responsabilidade civil na forma de uma sanção punitiva, destinada não apenas à compensação dos prejuízos do ofendido, mas, também e principalmente, à punição do ofensor em razão da flagrante gravidade da conduta por ele perpetrada.

6. Acredita-se que duas tenham sido as razões históricas para o surgimento e desenvolvimento dos punitive damages, a saber: (i) o fato de, nos países da common law, mesmo os processos de índole civil serem julgados por um corpo de jurados (e de os Tribunais, originalmente, encontrarem grandes restrições para acolher requerimentos de limitação das condenações impostas pelos primeiros júris); e (ii) a original impossibilidade de compensação de prejuízos que extrapolavam o âmbito patrimonial [apenas em idos do Século XIX a jurisprudência inglesa e norte-americana consolidou o entendimento de que os detrimentos imateriais ("pain and suffering" e "emotional distress") compunham os prejuízos passíveis de indenização compensatória (“compensatory damages")].

7. Em razão dos desenvolvimentos pelos quais passou o instituto ao longo dos séculos de incidência, atribuem-se aos punitive damages, essencialmente, duas grandes funções: (i) a de prevenção ou desestímulo ("deterrence") quanto ao comentimento de novos ilícitos, o qual se direciona tanto à própria pessoa do ofensor ("specific deterrence") quanto à sociedade em geral ("general deterrence"); e, (iii) a de punição, relacionada com a natureza quase criminal dos punitive damages.

8.

A essas duas funções principais, agregam-se ainda quatro outras funções marginais, a saber: (1) a de "justiça pública" ("public justice"), ao incentivar os cidadãos a perseguir o escorreito cumprimento da Lei; (ii) a "educativa" (relacionada ao ofensor, tanto o efetivo causador do prejuízo, diretamente apenado, quanto o potencial, o qual se pretende ver desestimulado de cometer ilícitos); (iii) a "vingativa", que atua de modo a prevenir que o ofendido venha a desrespeitar a Lei, respondendo ao ilícito contra ele cometido por meio do exercício arbitrário de suas razões; e, ainda, (iv) a função compensatória, referente aos prejuízos usualmente não indenizáveis em razão do ilícito perpetrado (tais como honorários advocatícios e despesas processuais). 
9. $\quad$ Por se destinarem a sancionar apenas as condutas marcadas pelo mais alto grau de reprovabilidade, a incidência dos punitive damages é excepcional, e exige a presença concomitante de pressupostos de ordem objetiva e subjetiva.

10. No que concerne aos pressupostos objetivos, vê-se que os punitive damages só incidem diante da verificação da ocorrência: (i) de um ilícito extracontratual ("tort") ou de um ilícito contratual ("breach of contract") que seja acompanhado de uma conduta fraudulenta ou de outro ato intencional, abusivo ou grosseiramente negligente que se caracterize, por si só, como tort; e, em regra, (ii) de efetivo prejuízo (remediado por meio da concessão de compensatory damages), a não ser que se esteja diante de um ato ilícito (tort) “dedutível per se" ("actionable per se"), caso no qual se admitirá o pleito indenizatório ainda que os prejuízos sejam meramente simbólicos (dando ensejo a uma condenação ao pagamento de nominal damages).

11. Já quanto aos pressupostos subjetivos, admitir-se-á a condenação do ofensor ao pagamento de punitive damages se sua conduta for caracterizada por um particular "estado de espírito": (i) a "malícia" ("malice"), que envolve não apenas o cometimento intencional de um ato ilícito, mas, também, o desejo de prejudicar o lesado; (ii) a "intenção" ("intent"), que envolve o cometimento intencional do ato ilícito; ou, ainda, (iii) a "temeridade" ("recklessness"), circunstância na qual o ofensor, embora prejeva a potencial ocorrência do resultado danoso, não o deseja. Não se justifica, portanto, a incidência de punitive damages em casos de mera negligência ("negligence").

12. Para a quantificação dos punitive damages, aventam-se, normalmente, os seguintes critérios: (i) o "grau de reprovabilidade" ("degree of reprehensibility") da conduta (critério no qual se inserem as considerações a respeito do grau de culpa do ofensor); (ii) a natureza e a extensão dos prejuízos causados; e, ainda, (iii) a capacidade econômica do ofensor.

13. A despeito de se tratar de questão polêmica, admite-se que a condenação ao pagamento de punitive damages recaia sobre pessoa diversa daquela que diretamente cometeu o ilícito [como se dá nos casos de responsabilidade indireta, das quais é uma espécie a responsabilidade do empregador por atos de seus empregados ("vicarious 
liability")], especialmente se o responsável indireto houver concorido de alguma maneira para o cometimento do ilícito, autorizando o ato antes de seu cometimento, ratificando-o posteriormente ou, ainda, contratando pessoas sabidamente inaptas para o desempenho de determinada função.

14.

Também se admite, a despeito das inúmeras críticas, que a imposição de punitive damages se dê mesmo em hipóteses nas quais a responsabilidade independe da aferição de culpa [casos de responsabilidade objetiva ("strict liability")], como, por ex., de responsabilidade pelo fato do produto ("products liability"). Para que se justifique a condenação excepcional, é imprescindível, contudo, que o responsável tenha-se conduzido de maneira intencional ou grosseiramente negligente.

15. Em outra questão polêmica, parte da doutrina sustenta que a contratação de seguro de punitive damages diluiria os fins perseguidos pelo instituto e incentivaria os segurados a se comportar de maneira descuidada. Como decorrência da discussão doutrinária, cerca de metade dos Estados norte-americanos proíbe a contratação de seguro para essa cobertura.

16. A despeito das razões históricas para seu surgimento, e das importantes funções por eles exercidas, os punitive damages são um instituto polêmico, comportanto discussões atuais quanto à sua restrição tanto na Inglaterra (país em que surgiram) quanto nos Estados Unidos da América (país em que floresceram com maior intensidade).

17. Na Inglaterra, após o julgamento, pela House of Lords, do caso Rookes $v$. Barnard (1964 A.C. 1129), a incidência dos punitive damages passou a ser extremamente restrita, limitando-se às hipóteses de: (i) atos arbitrários cometidos por funcionários do governo; (ii) condutas calculadas com a finalidade de produzir lucro ilícito para o ofensor; e, ainda, (iii) nos casos em que a imposição desse remédio já se encontrava previamente autorizada por Lei.

18. Já nos Estados Unidos da América, as discussões a respeito da limitação à incidência e quantificação dos punitive damages se dão em dois âmbitos: (i) os obstáculos constitucionais, representados pela $5^{\mathrm{a}}$ (“double jeopardy clause"), $8^{\mathrm{a}}$ ("excessive fines 
clause") e $14^{\mathrm{a}}$ ("due process clause") Emendas à Constituição norte-americana; e, ainda, (ii) as iniciativas legislativas decorrentes do assim chamado "tort reform movement".

19. Em que pesem as polêmicas quanto à sua incidência, os punitive damages continuam a ser utilizados, tanto na Inglaterra quanto nos Estados Unidos da América, como um importante instrumento para a prevenção de danos e moralização das condutas altamente reprováveis. Tanto assim que serve de modelo para o regramento que se pretende emprestar à indenização punitiva.

20. Voltando os olhos para o instituto da responsabilidade civil, nos moldes em que o conceberam os juristas da Modernidade, verifica-se que o corpo legislativo que lhe deu forma característica (o Código Civil de Napoleão) estabeleceu seus três paradigmas tradicionais, quais sejam: (1) a responsabilidade individual; (ii) a responsabilidade fundada na culpa; e, por fim, (iii) o paradigma reparatório/ressarcitório.

21. Ao longo dos séculos, os influxos advindos do sistema social evidenciaram as insuficiências desses paradigmas tradicionais, dando ensejo aos fenômenos denominados em conjunto de "desenvolvimentos contemporâneos da responsabilidade civil'. Tais fenômenos abarcaram: (i) a objetivação da responsabilidade (que impactou o paradigma da responsabilidade fundada na culpa); (ii) a socialização dos riscos (que atingiu o paradigma da responsabilidade individual); e, ainda, (iii) a expansão dos danos suscetíveis de reparação.

22. A despeito dos ditos "desenvolvimentos contemporâneos", o paradigma ressarcitório, pelo qual a indenização se mede pela extensão do dano, permaneceu intocado.

23. Nessas circunstâncias, a manutenção do paradigma ressarcitório relegou as funções de prevenção de danos e moralização de condutas ilícitas, anteriormente também desempenhadas pela responsabilidade civil, quase que com exclusividade aos ramos do Direito Penal e do Direito Administrativo Sancionador, os quais possuem deficiências particulares que os impedem de desempenhar eficientemente tais funções em todas as hipóteses nas quais se verificam lesões a bens e interesses existenciais e metaindividuais. 
24. Criou-se, assim, um "campo vazio", no qual no qual o ordenamento jurídico não logra êxito em exercer a tutela mais eficiente possível dos bens e interesses da maior relevância.

25. O supra referido "campo vazio" permite que mesmo o cometimento de atos extremamente reprováveis (marcados pela intencionalidade ou pela flagrante e irresponsável desconsideração pelos direitos alheios) deixe de receber o adequado sancionamento. Tais atos, pelo seu alto grau de reprovabilidade, extrapolam o âmbito individual, causando malefícios não apenas à vítima diretamente atingida, mas, também, à sociedade como um todo (num rebaixamento imediato do nível de vida), em fenômeno denominado de "dano social".

26.

Para eliminar tal insuficiência, atingindo-se de maneira eficiente os escopos de prevenir danos e assegurar o equilíbrio social, o ordenamento jurídico deve dispor de mecanismos adequados, os quais poderão e deverão incidir em conjunto, sempre que necessário.

27.

A responsabilidade civil, então, deverá passar a exercer, de maneira direta, as funções de prevenção e punição que lhe foram tolhidas por seus "desenvolvimentos contemporâneos", o que fará por meio da introdução de sanção que denominamos de indenização punitiva.

28. Da maneira como aqui apresentada, a indenização punitiva não se mostra incompatível com as finalidades perseguidas pelo Direito Civil. Com efeito, não são raras as sanções punitivas típicas do Direito Civil, tais como a revogação da doação por ingratidão, a deserdação e a pena de sonegados.

29. $\mathrm{O}$ uso escorreito da indenização punitiva não acarretará o incentivo à litigância frívola, e o eventual (e indesejado) abuso do instituto deverá ser rigorosamente sancionado pelos mecanismos processuais adequados.

30 .

A indenização punitiva não é incompatível com as (cada vez mais comuns) hipóteses de responsabilidade objetiva. Sua incidência nessas circunstâncias, contudo, não 
dispensará a alegação e prova de seus pressupostos objetivos e, especialmente, subjetivos (conduta perpetrada com dolo ou culpa grave).

31. Também não se verifica violação ao princípio que veda a dupla condenação pelo mesmo ato ilícito ("ne bis in idem"). De um lado, a indenização punitiva pode incidir em cumulação com outras sanções punitivas típicas de outros ramos do Direito, mas, nesse caso, a quantificação da indenização deverá levar em conta a possibilidade de o ofensor vir a ser sancionado novamente. De outro lado, uma mesma conduta ilícita não pode ser apenada mais de uma vez com a incidência de indenização punitiva: julgada procedente a primeira demanda (que deverá ter em conta as demais potenciais vítimas do ilícito), todas as subseqüentes pretensões à condenação ao pagamento de indenização punitiva (mas nunca ao recebimento de indenização compensatória) deverão ser julgadas improcedentes.

32. Obstáculo intransponível, contudo, é o representado pelos princípios da legalidade das penas ("nulla poena sine lege") e da reparação integral, bem como a vedação ao enriquecimento sem causa. Tais óbices somente poderão ser transpostos por meio da prévia cominação legal, introduzindo-se em nosso ordenamento dispositivos de Lei que estabeleçam não apenas os pressupostos objetivos e subjetivos para a incidência da indenização punitiva (fixação do an debeatur), mas, também, os critérios a serem utilizados pelo julgador para a dosimetria da sanção (estipulação do quantum debeatur).

33. Quanto à imposição da indenização punitiva, acredita-se que ela deverá ser utilizada para sancionar os ilícitos civis dotados do mais alto grau de reprovabilidade (cujos agentes devem ter obrado de maneira intencional ou gravemente culposa, com irresponsável desconsideração quanto aos direitos alheios) e que tenham lesado direitos ou interesses da mais alta relevância (a saber: os interesses existenciais e os metaindividuais) ou, ainda, servido de instrumento para a obtenção ilícita de vantagens econômicas (ainda que, nesse caso, os prejuízos decorrentes do ilícito sejam de natureza patrimonial).

34. No que concerne a seus pressupostos objetivos, vê-se que a indenização punitiva poderá incidir para sancionar atos ilícitos extracontratuais ou contratuais (contanto que desses decorram lesões a interesses existenciais ou metaindividuais, ou dos quais o inadimplente venha a extrair benefícios para si ou para outrem, não ordinariamente 
eliminados pela incidência de cláusula penal), sempre se exigindo, contudo, a ocorrência de prejuízo (não se exigindo que tal prejuízo seja necessariamente extrapatrimonial).

35. Já no que se refere a seus pressupostos subjetivos, a indenização punitiva somente incidirá para punir condutas que se tenham caracterizado pelo dolo ou culpa grave por parte do ofensor.

36. Presentes seus pressupostos objetivos e subjetivos, é de se admitir a incidência da indenização punitiva mesmo nos casos em que há responsabilidade indireta. Nestas hipóteses, contudo, é imprescindível que o responsável também se tenha conduzido de maneira dolosa ou gravemente culposa, concorrendo, de alguma maneira, para o cometimento do ato extremamente reprovável.

37.

A contratação de seguro de indenização punitiva é inadmissível, especialmente ante às previsões legais de que: (i) é nulo o contrato celebrado para garantia do risco de ato doloso (art. 762, do CC/2002); e de que (ii) o segurado perderá a cobertura se houver agravado intencionalmente o risco objeto do contrato (art. 768, do CC/2002).

38. $\mathrm{O}$ direito à imposição da indenização punitiva se transfere a causa de morte para os herdeiros e sucessores da vítima juntamente com o direito ao recebimento de indenização punitiva, sempre que isso for possível (art. 943, do CC/2002). Já a obrigação de pagar a indenização punitiva é intransferível causa mortis, em razão do princípio da pessoalidade da pena (art. $5^{\circ}, \mathrm{XLV}$, da CF/88).

39. Em se desejando impor ao ofensor a condenação ao pagamento de indenização punitiva, o autor da demanda deverá se desincumbir do ônu de demandar (deverá deduzir pedido expresso nesse sentido) e dos ônus de alegar e provar seus pressupostos objetivos e subjetivos. O pedido de condenação ao pagamento de indenização compensatória será principal e prejudicial em relação ao pedido de condenação ao pagamento de indenização punitiva, que será acessório e prejudicado.

40. Durante a instrução, caberá ao magistrado conduzir a produção da prova de modo a solucionar todas as questões de fato, inclusive aquelas referentes à indenização 
punitiva, admitindo-se que, quanto a ela, opere-se a inversão do ônus probatório (art. $6^{\circ}$, VIII, do CDC).

41. A sentença que acolher o pedido de condenação do demandado ao pagamento de indenização punitiva deverá vir devidamente fundamentada (art. 93, IX, da $\mathrm{CF} / 88$ ), expondo as razões pelas quais se entendeu presentes os pressupostos para a incidência da sanção, bem como os critérios para sua quantificação.

42. Muito embora se repute tratar de uma questão de política legislativa, entende-se que a melhor solução quanto à destinação da indenização punitiva é aquela que propugna a remessa do numerário a um fundo de gestão pública, à semelhança daquele criado pelo art. 13, da Lei 7.347/1985.

43. Mesmo antes que se opere a introdução legislativa da indenização punitiva, é admissível que o Superior Tribunal de Justiça, no exercício das atribuições a ele imputadas pela Constituição Federal, reconheça e dê execução a sentenças estrangeiras que contenham capítulo condenatório atinente aos punitive damages, não se podendo afirmar que tal instituto jurídico afronta a noção de ordem pública internacional.

44. Para a quantificação da indenização punitiva, o magistrado deverá ter em conta os seguintes critérios: (1) o grau de culpa do ofensor; (ii) a natureza e extensão do dano causado (o que se verificará apenas para a aferição do grau de reprovabilidade da conduta perpetrada); (iii) a condição econômica do ofensor; e, por fim, (iv) os benefícios econômicos por ele obtidos em razão do ato ilícito.

45.

A condição econômica do ofendido é um critério inaplicável para a quantificação da indenização punitiva. As condições pessoais e sociais da vítima, contudo, podem influenciar na quantificação da indenização punitiva quando afetarem o grau de reprovabilidade da conduta (se perpetrada, por ex., contra pessoas dotadas de menor capacidade de resistência, como as crianças ou idosos).

46. $\mathrm{O}$ controle judicial da adequação do quantum indenizatório, a ser exercido com fundamento nos princípios da proporcionalidade e da razoabilidade, é medida eficiente, que não afeta a necessária imprevisibilidade do quantum. Nesse mister, o 
julgador deverá levar em consideração os critérios fixados em Lei para a quantificação e, ainda, expor de maneira fundamentada as razões pelas quais os entendeu presentes.

47. Nos últimos anos, foram apresentados diversos Projetos de Lei que objetivavam a introdução legislativa, em nosso ordenamento jurídico, da figura da indenização punitiva (entre os quais se destacam, por sua atualidade, os Projetos de Lei da Câmara n. ${ }^{\circ}$ s 1.914/2003 e 276/2007, bem como o Projeto de Lei do Senado n. ${ }^{\circ}$ 413/2007). A despeito de suas insuficiências, se aprovados, os Projetos de Lei ora em trâmite terão o condão de cumprir com tal tarefa, ultrapassando-se os obstáculos representados pelos princípios da legalidade das penas e da reparação integral, bem como pela vedação ao enriquecimento sem causa.

48. Acredita-se que, para superar as insuficiências de que padecem tais Projetos de Lei, tornam-se necessárias alterações legislativas nos artigos 933 e 944, ambos do CC/2002, bem como a introdução de um artigo, de número 12-A, na Lei 7.437/1985. 


\section{REFERÊNCIAS BIBLIOGRÁFICAS}

ABBUD, André de Albuquerque Cavalcanti. Homologação de Sentenças Arbitrais Estrangeiras, São Paulo, Atlas, 2008.

ABDO, Helena Najjar. O Abuso do Processo, São Paulo, RT, 2007.

ABRAHAM, Kenneth S., JEFFRIES JR., John C.. Punitive Damages and The Rule of Law: The Role of Defendant's Wealth, in Journal of Legal Studies, vol. XVIII, jun./1989, pág. 415/425.

ALMEIDA, Luiz Cláudio Carvalho de. A Repetição do Indébito em Dobro no Caso de Cobrança Indevida de Dívida Oriunda de Relação de Consumo como Hipótese de Aplicação dos Punitive Damages no Direito Brasileiro, in Revista de Direito do Consumidor, vol. 54, jun.-2005, págs. 161 e ss.

ALVIM, Agostinho. Da Doação, $3^{\text {a }}$ ed., São Paulo, Saraiva, 1980.

Da Inexecução das Obrigações e suas Conseqüências, 4ª ed., São Paulo, Saraiva, 1972.

ANDRADE, André Gustavo Corrêa de. Dano Moral e Indenização Punitiva: Os punitive damages na experiência do common law e na perspectiva do Direito brasileiro, Rio de Janeiro, Forense, 2006.

ANDREWS, Neil. O Moderno Processo Civil, trad. Teresa Arruda Alvim Wambier, São Paulo, RT, 2009.

ANTUNES VARELA, João de Matos. Das Obrigações em Geral, vol. I, 10ª ed., Coimbra, Almedina, 2000.

APRIGLIANO, Ricardo de Carvalho. O Princípio do Duplo Grau de Jurisdição nos Sistemas da Common Law e Civil Law: Uma Breve Comparação, in Milton Paulo de 
Carvalho (coord.), Direito Processual Civil, São Paulo, Quartier Latin, 2007, págs. $319 / 344$.

. A Ordem Pública no Direito Processual Civil, Tese (Doutorado) - Faculdade de Direito da USP, São Paulo, 2010.

ASCENSÃO, José de Oliveira. Introdução à Ciência do Direito, $3^{\mathrm{a}}$ ed., Rio de Janeiro, Renovar, 2005.

BARATELLA, Maria Grazia. Le Pene Private, Milano, Giuffrè, 2006.

BARBOSA MOREIRA, José Carlos. Comentários ao Código de Processo Civil, vol. V, $13^{\mathrm{a}}$ ed., Rio de Janeiro, Forense, 2006.

BASSAN, Marcela Alcazas. As Funções da Indenização por Danos Morais e a Prevenção de Danos Futuros, Dissertação (Mestrado) - Faculdade de Direito da USP, São Paulo, 2009.

BEAL, Eric D.. Posner and Moral Hazard, in Connecticut Insurance Law Journal, vol. 7, 2000, págs. 81/102.

BEDAQUE, José Roberto dos Santos. Tutela Cautelar e Tutela Antecipada: Tutelas Sumárias e de Urgência (Tentativa de Sistematização), $4^{\mathrm{a}}$ ed., São Paulo, Malheiros, 2006.

BELL, Griffin B., PEARCE, Perry E.. Punitive Damages and the Tort System, in University of Richmond Law Review, vol. 22, 1987, págs. 1/17.

BELLI SR., Melvin M.. Punitive Damages: Their History, Their Use and Their Worth in Present-Day Society, in UMKC Law Review, vol. 49, n. 1, 1980, págs. 1/23.

BERNARDO, Wesley de Oliveira Louzada. Dano Moral: Critérios de Fixação de Valor, Rio de Janeiro, Renovar, 2005. 
BEVILÁQUA, Clóvis. Código Civil dos E. U. B., vol. I, ed. histórica, $7^{\text {a }}$ tiragem, Rio de Janeiro, Estácio de Sá, 1975.

BITTAR, Carlos Alberto. Reparação Civil por Danos Morais, São Paulo, RT, 1993.

BOBBIO, Norberto. As Sanções Positivas, in Da Estrutura à Função, trad. Daniela Beccaccia Versiani, Barueri, Manole, 2007, págs. 23/32.

BOTELHO DE MESQUITA, José Ignácio. O dano Moral na Lei de Imprensa, in Teses, Estudos e Pareceres de Processo Civil, vol. 3, São Paulo, RT, 2007, págs. 226/229.

BRESOLIN, Umberto Bara. Revelia e seus Efeitos, São Paulo, Atlas, 2006.

CAHALI, Yussef Said. Dano Moral, 2ª ed., São Paulo, Revista dos Tribunais, 1998.

CALIXTO, Marcelo Junqueira. A Culpa na Responsabilidade Civil (Estrutura e Função), Rio de Janeiro, Renovar, 2008.

CALLEROS, Charles. Punitive Damages, Liquidated Damages and Clauses Pènales in Contract Actions: A Comparative Analysis of the American Common Law and the French Civil Code, in Brooklyn Journal of International Law, vol. 32, 2006, págs. 67/119.

CAMPOS, Diogo Leite de. Enriquecimento Sem Causa, Responsabilidade Civil e Nulidade, in Revista dos Tribunais, vol. 560, jun./1982, págs. 259/266.

CANOTILHO, José Joaquim Gomes. Direito Constitucional e Teoria da Constituição, $7^{\mathrm{a}}$ ed., Coimbra, Almedina, 2003.

CARNELUTTI, Francesco. Arte del Derecho (Seis Meditaciones sobre el Derecho), Buenos Aires, Ediciones Juridicas Europa America, 1948.

CARVAL, Suzanne. La Responsabilitè Civile Dans Sa Fonction de Peine Privée, Paris, L.G.D.J., 1995. 
CATEB, Salomão de Araújo. Deserdação e Indignidade no Direito Sucessório Brasileiro, Belo Horizonte, Del Rey, 2004.

CAVALIERI FILHO, Sérgio. Programa de Responsabilidade Civil, $6^{\mathrm{a}}$ ed. revista, aumentada e atualizada, São Paulo, Malheiros, 2005.

COOTER, Robert D.. Punitive Damages for Deterrence: When and How Much, in Alabama Law Review, vol. 40, 1989, págs. 1143/1194.

COSTA, Paulo José da. Direito Penal (Curso Completo), 8ª ed., São Paulo, Saraiva, 2000.

D’ALESSANDRO, Elena. Pronunce Americane di Condanna al Pagamento di Punitive Damages e Problemi di Riconoscimento in Italia, in Rivista di Diritto Civile, anno LIII, $\mathrm{n}$. 3, mag.-giug./2007, págs. 383/406.

DAVID, René. Os Grandes Sistemas do Direito Contemporâneo, trad. Hermínio A. Carvalho, $4^{\mathrm{a}}$ ed., São Paulo, Martins Fontes, 2002.

DEAKIN, Simon, JOHNSTON, Angus, MARKESINIS, Basil. Markesinis and Deakin's Tort Law, $6^{\text {th }}$ ed., New York, Oxford, 2008.

DEMOGUE, Rene. Validity of the Theory of Compensatory Damage, in Yale Law Jornal, vol. XXVII, n. 5, mar/1918, págs. 585/598.

DENARI, Zelmo e outros. Código Brasileiro de Defesa do Consumidor Comentado pelos Autores do Anteprojeto, $9^{\text {a }}$ ed., Rio de Janeiro, Forense Universitária, 2007.

DINAMARCO, Cândido Rangel. Instituições de Direito Processual Civil, vol. II, $2^{\mathrm{a}}$ ed., São Paulo, Malheiros, 2002.

Instituições de Direito Processual Civil, vol. III, $4^{\mathrm{a}}$ ed., São Paulo, Malheiros, 2004. 
. Instituições de Direito Processual Civil, vol. IV, 2a ed., São Paulo, Malheiros, 2005.

. Capítulos da Sentença, São Paulo, Malheiros, 2002.

. Vocabulário de Direito Processual, in Fundamentos do Processo Civil Moderno, São Paulo, RT, 1986, págs. 101/181.

DINAMARCO, Pedro da Silva. Ônus Processuais: Limites à Aplicação das Conseqüências Previstas para o seu Não-Cumprimento, Tese (Doutorado) - Faculdade de Direito da USP, São Paulo, 2007.

DINIZ, Maria Helena. Lei de Introdução ao Código Civil Brasileiro Interpretada, $15^{\mathrm{a}}$ ed., São Paulo, Saraiva, 2010.

DOESBURG, Mary Case. Jury Instructions - Burden of Proof - Cases Requiring Proof by Clear, Cogent, and Convincing Evidence, in Missouri Law Review, vol. 42, 1977, págs. $662 / 667$.

DOLINGER, Jacob. Direito Internancional Privado (Parte Geral), Rio de Janeiro, Freitas Bastos, 1986.

DUPREE JR., Thomas H.. Punitive Damages and the Constitution, in Louisiana Law Review, vol. 70, 2010, págs. 421/434.

EBERT, Ina. Punitive Damages and Liability Insurance, in H. KOZIOL - V. WILCOX (eds.), Punitive Damages: Common Law and Civil Law Perspectives, Wien, Springer, 2009, págs. 213/217.

ENGLARD, Izhak. The Philosophy of Tort Law, Aldershot, Dartmouth, 1993.

FISCHER, Hans A. Los Daños Civiles y Su Reparación, trad. W. Roces, Madrid, 1928. 
FRADA, Manuel A. Carneiro da. Direito Civil - Responsabilidade Civil: O Método do Caso, Coimbra, Almedina, 2006.

FRANKLIN, Marc A., RABIN, Robert L., GREEN, Michael D.. Tort Law and Alternatives (Cases and Materials), $8^{\text {th }}$ ed., New York, Foundation Press, 2006.

GALLIGAN JR., Thomas C.., U.S. Supreme Court Tort Reform: Limiting State Power to Articulate and Develop Tort Law - Defamation, Preemption and Punitive Damages, in University of Cincinnati Law Review, vol. 74, 2006, págs. 1189/1264.

GALLO, Paolo. Pene Private e Responsabilità Civile, Milano, Giuffrè, 1996.

GARNER, Bryan A.. Black's Law Dictionary, $8^{\text {th }}$ ed., St. Paul, West Group, 2004.

GAUDENZI, Andrea Sirotti. La Tutela del Contraente Debole e del Lavoratore (L’Applicazione dei Punitive Damages nel Mondo Anglosassone e nell'Europa Continentale), in Lavoro e Previdenza Oggi, anno XXX, n. 3, 2004, págs. 400/416.

GEISTFELD, Mark A.. Punitive Damages, Retribution and Due Process, in South California Law Review, vol. 81, 2007/2008, págs. 263/309.

GEORGIADES, Georgios. Punitive Damages in Europe and the USA: Doctrinal Differences and Practical Convergence, in Revue Hellénique de Droit International, vol. 58, 2005, págs. 145/163.

GHIARDI, James D.. The Case Against Punitive Damages, in The Forum, vol. 8, 1972, págs. 411/424.

GILISSEN, John. Introdução Histórica ao Direito, trad. A. M. Hespanha e L. M. Macaísta Malheiros, $5^{\text {a }}$ ed., Lisboa, Fundação Calouste Gulbenkian, 2008.

GODOY, Cláudio Luiz Bueno de. Responsabilidade Civil pelo Risco da Atividade, São Paulo, Saraiva, 2009. 
GOMES, Orlando. Sucessões, 14ª ed., Rio de Janeiro, Forense, 2008.

. Contratos, $26^{\mathrm{a}}$ ed., Rio de Janeiro, Forense, 2007.

. Obrigações, 17 ed., Rio de Janeiro, Forense, 2008.

GONÇALVES, Carlos Roberto. Comentários ao Código Civil, vol. 11, São Paulo, Saraiva, 2003.

GONÇALVES, Vitor Fernandes. A Punição na Responsabilidade Civil: A indenização do dano moral e da lesão a interesses difusos, Brasília, Brasília Jurídica, 2005.

GONZALO, Marco Lopes de. Punitive Damages e Ordine Pubblico, in Rivista di Diritto Internazionale Privato e Processuale, anno XLIV, n. 1, gen.-mar./2008, págs. 77/90.

GRECO FILHO, Vicente. Direito Processual Civil Brasileiro, vol. II, 16 ed., São Paulo, Saraiva, 2003.

GUIMARÃES, Patrícia Carla Monteiro. Os Danos Punitivos e a Função Punitiva da Responsabilidade Civil, in Revista de Direito e Justiça, vol. XV, t. 1, 2001, págs. 159/206.

HARRIS, Silas A. What is a Cause of Action?, in California Law Review, vol. XVI, n. 6, 1928, págs. $459 / 477$.

HOFMEISTER, Maria Alice Costa. O Dano Pessoal na Sociedade de Risco, Rio de Janeiro, Renovar, 2002.

ISIDRO, Marta Requeijo. Punitive Damages y su Notificación em el Contexto del Convenio de la Haya de 15 de Octubre de 1965, in Revista Española de Derecho Internacional, vol. XLVIII, n. 2, jul./dic. 1996, pág. 71/97.

. Punitive Damages From a Private International Law Perspective, in H.

Koziol - V. Wilcox, Punitive Damages: Common Law and Civil Law Perspectives, Wien, Springer, 2009, págs. 237/255. 
JUNKES, Sérgio Luiz. A Culpa e a Punição Não Podem Servir de Critério Para a Fixação da Indenização por Dano Moral, in Jurisprudência Catarinense, ano XXXI, n. 107, 2005, págs. 219/234.

JUNQUEIRA DE AZEVEDO, Antonio. Por Uma Nova Categoria de Dano na Responsabilidade Civil: O Dano Social, in Novos Estudos e Pareceres de Direito Privado, São Paulo, Saraiva, 2009, págs. 377/384.

Influência do Direito Francês sobre o Direito Brasileiro, in Novos Estudos e Pareceres de Direito Privado, São Paulo, Saraiva, 2009, págs. 585/594.

Caracterização Jurídica da Dignidade da Pessoa Humana, in Estudos e Pareceres de Direito Privado, São Paulo, Saraiva, 2004, págs. 3/24.

. O Direito como Sistema Complexo e de $2^{a}$ Ordem; sua Autonomia. Ato Nulo e Ato Ilícito. Diferença de Espírito entre Responsabilidade Civil e Penal. Necessidade de Prejuízo para Haver Direito de Indenização na Responsabilidade Civil, in Estudos e Pareceres de Direito Privado, São Paulo, Saraiva, 2004, págs. 26/37.

Cadastros de Restrição ao Crédito. Conceito de Dano Moral, in Estudos e Pareceres de Direito Privado, São Paulo, Saraiva, 2004, págs. 289/299.

Nulidade de Cláusula Limitativa de Responsabilidade em Caso de Culpa Grave. Caso de Equiparação entre Dolo e Culpa Grave. Configuração da Culpa Grave em Caso de Responsabilidade Profissional, in, Novos Estudos e Pareceres de Direito Privado, São Paulo, Saraiva, 2009, págs. 427/444.

JUSTO, A. Santos. Direito Privado Romano, vol. II, $3^{\text {a }}$ ed., Coimbra, Coimbra, 2008.

KARLAN, Pamela S.. 'Pricking the Lines': The Due Process Clause, Punitive Damages and Criminal Punishment, in Minnessota Law Review, vol. LXXXVIII, 2003/2004, pág. 880/920. 
KELSEN, Hans. Teoria Pura do Direito, trad. João Batista Machado, $6^{\text {a }}$ ed., São Paulo, Martins Fontes, 2000.

KERN, Bernd-Rüdiger. A Função de Satisfação na Indenização do Dano Pessoal, in Revista de Direito do Consumidor, n. ${ }^{\mathrm{o}} 33$, janeiro/março 2000.

KFOURI NETO, Miguel. Responsabilidade Civil dos Hospitais (Código Civil e Código de Defesa do Consumidor), São Paulo, RT, 2010.

LEMOS, Patrícia Faga Iglecias. Meio Ambiente e Responsabilidade Civil do Proprietário (Análise do Nexo Causal), São Paulo, RT, 2008.

LEONEL, Ricardo de Barros. Manual do Processo Coletivo, São Paulo, RT, 2002.

LIMA, Alvino. Culpa e Risco, $2^{\mathrm{a}}$ ed. revista e atualizada por Ovídio Rocha Barros Sandoval, São Paulo, RT, 1998.

LIMA, João Carlos de. O Caráter Punitivo da Indenização por Danos Pessoais e a Reversibilidade da Cominação para o FAT, in Revista de Direito do Trabalho, ano 30, vol. 115, São Paulo, RT, jul./set. 2004, pág. 77/91.

LOPEZ, Teresa Ancona. Principais Linhas da Responsabilidade Civil no Direito Brasileiro Contemporâneo, in Antonio JUNQUEIRA DE AZEVEDO - Heleno Taveira TôRRES - P. CARbone (coords.), Princípios do Novo Código Civil e outros temas, São Paulo, Quartier Latin, 2008, pág. 661/705.

Princípio da Precaução e Evolução da Responsabilidade Civil, São Paulo, Quartier Latin, 2010.

LOURENÇO, Paula Meira. A Função Punitiva da Responsabilidade Civil, Coimbra, Coimbra, 2006.

LOVETT, William A.. Exxon Valdez, Punitive Damages and Tort Reform, in Tort Trial \& Insurance Practice Law Journal, vol. 38, 2002, págs. 1071/1128. 
LUBAN, David. A Flawed Case Against Punitive Damages, in The Georgetown Law Journal, vol. 87, 1998, págs. 359/380.

MARCATO Antônio Carlos (coord.). Código de Processo Civil Interpretado, São Paulo, Atlas, 2003.

MARINONI, Luiz Guilherme. Tutela Inibitória (Individual e Coletiva), $4^{\mathrm{a}}$ ed., São Paulo, RT, 2006.

MARINONI, Luiz Guilherme, ARENHART, Sérgio Cruz. Prova, São Paulo, RT, 2010.

MARTINS-COSTA, Judith, PARGENDLER, Mariana Souza. Usos e Abusos da Função Punitiva ('Punitive Damages' e o Direito Brasileiro), in Revista da Ajuris, ano XXXII, n. 100, dez/2005, págs. 229/262.

MASSEY, Calvin R.. The Excessive Fines Clause and Punitive Damages: Some Lessons From History, in Vanderbilt Law Review, vol. 40, n. 6, nov.-1987, págs. 1233/1276.

MAZZILLI, Hugo Nigro. A Defesa dos Interesses Difusos em Juízo, $5^{\text {a }}$ ed., São Paulo, RT, 1993.

MCALLISTER, Beth. Punitive Damages - Jodgement Granting Equitable Relief Cannot Support Award of Punitive Damages Where Actual Damages Are Not Also Recovered, in St. Mary’s Law Journal, vol. 17, 1986, págs. 529/549.

MCBAINE, J. P.. Burden of Proof: Degrees of Belief, in California Law Review, vol. 32, 1944, págs. 242/268.

MCKNOWN, James R.. Punitive Damages: State Trends and Developments, in The Review of Litigation, vol. 14, 1994/1995, págs. 419/463.

MELlO, Marcos Bernardes de. Teoria do Fato Jurídico (Plano da Validade), $8^{\mathrm{a}}$ ed., São Paulo, Saraiva, 2008. 
MELO, Diogo Leonardo Machado de. Ainda sobre a Função Punitiva da Reparação dos Danos Morais (e a Destinação de Parte da Indenização para Entidades de Fins Sociais Artigo 883, Parágrafo Único, do Código Civil de 2002), in Revista de Direito Privado, vol. 26, jun.-2006, págs. 105 e ss..

MINER, Michael L.. Expanding Availability of Punitive Damages in Contract Actions, in Indiana Law Review, vol. 8, 1975, págs. 668/689.

MORAES, Maria Celina Bodin de. Punitive Damages em Sistemas Civilistas: problemas e perspectivas, in Revista Trimestral de Direito Civil, vol. 18, abril/junho 2004, págs. 45/78.

Danos à Pessoa Humana (Uma Leitura Civil-Constitucional dos Danos Morais), Rio de Janeiro, Renovar, 2003.

MOREIRA ALVES, José Carlos. Direito Romano, vol. II, $6^{\text {a }}$ ed. Rio de Janeiro, Forense, 2000 .

MORSELLO, Marco Fábio. Responsabilidade Civil no Transporte Aéreo, São Paulo, Atlas, 2007.

NADER, Paulo. Curso de Direito Civil, vol. 3, 4ª ed., Rio de Janeiro, Forense, 2009.

NANNI, Giovanni Ettore. Enriquecimento sem Causa, 2a ed., São Paulo, Saraiva, 2010.

NEGRÃO, Theotonio. Código de Processo Civil e Legislação Processual em Vigor, 39a ed., São Paulo, Saraiva, 2007.

NERY, Rosa Maria de Andrade. Introdução ao Pensamento Jurídico e à Teoria Geral do Direito Privado, São Paulo, RT, 2008.

NORONHA, Fernando. Direito das Obrigações, vol. I, $2^{\text {a }}$ ed., São Paulo, Saraiva, 2007. 
NOWAK, John E., ROTUNDA, Ronald D.. Principles of Constitutional Law, $3^{\text {rd }}$ ed., St. Paul, Thomson West, 2007.

NUCCI, Guilherme de Souza. Princípios Constitucionais Penais e Processuais Penais, São Paulo, RT, 2010.

O'CONNEL, Jeffrey e CARPENTER, Keith. Payment for Pain and Suffering Through History, in Insurance Counsel Journal, vol. 50, 1983, págs. 411/417.

OLIVEIRA, Marcius Geraldo Porto de. Dano Moral - Proteção Jurídica da Consciência, $2^{\mathrm{a}}$ ed., Leme, LED, 2001.

OSÓRIO, Fábio Medina. Direito Administrativo Sancionador, 3ª ed., São Paulo, RT, 2010.

OWEN, David G.. A Punitive Damages Overview: Functions, Problems and Reform, in Villanova Law Review, vol. 39, 1994, págs. 364/413.

PATRÍCIO, Miguel Carlos Teixeira. Análise Económica da Litigância, Coimbra, Almedina, 2005.

PENTEADO, Luciano de Camargo. Efeitos Contratuais Perante Terceiros, São Paulo, Quartier Latin, 2007.

PEREIRA, Caio Mário da Silva. Instituições de Direito Civil, vol. III, $11^{\text {a }}$ edição, Rio de Janeiro, Forense, 2003.

Instituições de Direito Civil, vol. II, 5ª ed., Rio de Janeiro, Forense, 1978.

Instituições de Direito Civil, vol. VI, 15ª ed., Rio de Janeiro, Forense, 2004.

PIZARRO, Ramon Daniel. Daño Moral - Prevención, Reparación, Punición: El Daño Moral em las Diversas Ramas del Derecho, Buenos Aires, Hammurabi, 1996. 
PRIEST, George L.. Punitive Damages Reform: The Case of Alabama, in Louisiana Law Review, vol. 56, 1995, págs. 825/840.

Insurability and Punitive Damages, in Alabama Law Review, vol. 40, 1989, págs. 1009/1035.

Introduction: The Problem and Efforts to Understand It, in C. S. SUNSTEIN et al., Punitive Damages: How Juries Decide, Chicago, University of Chicago Press, 2002, págs. $1 / 16$.

QUARTA, Francesco. Recognition and Enforcement of U.S. Punitive Damages Awards in Continental Europe: The Italian Supreme Court's Veto, in Hastings International \& Comparative Law Review, vol. 31, 2008, págs. 753/782.

REIS, Clayton. Novos Rumos da Indenização do Dano Moral, Rio de Janeiro, Forense, 2003.

ROBBENNOLT, Jennifer K.. Determining Punitive Damages: Empirical Insights and Implications for Reform, in Buffalo Law Review, vol. 50, 2002, pág. 103/203.

ROBREDO, Goretti Vadillo. Daños Punitivos en el Proceso Civil Norteamericano, in Revista de la Universidad de Deusto, vol. 57, fasc. 97, jul-dic./1996, págs. 176/212.

- Costes Legales y Honorarios de Abogados em el Proceso Civil (Observaciones sobre la Situación em los Estados Unidos y em Europa), in Revista de la Universidad de Deusto, vol. 45, fasc. 98, ene-jun./1997, págs. 141/172.

ROSENVALD, Nelson. Cláusula Penal (A Pena Privada nas Relações Negociais), Rio de Janeiro, Lumen Juris, 2007.

RUSTAD, Michael, KOENIG, Thomas. The Historical Continuity of Punitive Damages Awards: Reforming the Tort Reformers, in The American University Law Review, vol. 42, 1992, págs. 1269/1333. 
RYAN, Claire M.. Civil Punishment of the Uncivil: The Nature and Scope of Exemplary Damages in New Zeland, in Auckland University Law Review, vol. 5, 1984, págs. 53/72.

SALLES, Carlos Alberto de. Responsabilidade Penal da Pessoa Jurídica e a Proteção ao Meio Ambiente: Finalidade e Aplicação, in Revista Brasileira de Ciências Criminais, vol. 36, dez.-2001, págs. 51 e ss.

SANSEVERINO, Paulo de Tarso Vieira. Princípio da Reparação Integral (Indenização no Código Civil), São Paulo, Saraiva, 2010.

SANTOS, Enoque Ribeiro dos. Contribuições à Fixação da Indenização do Dano Moral Trabalhista - A tese da aplicação dos exemplary ou punitive damages, in Suplemento Trabalhista, ano 40, vol. 90, 2004, págs. 397/402.

SARAVAlLE, Alberto. I Punitive Damages nelle Sentenze delle Corti Europee e dei Tribunali Arbitrali, in Rivista di Diritto Internazionale Privato e Processuale, anno XXIX, n. 4, ott.-dic./1993, págs. 867/892.

SCARSO, Alessandro P. Punitive Damages in Italy, in H. KOZIOL - V. WILCOX (eds.), Punitive Damages: Common Law and Civil Law Perspectives, Wien, Springer, 2009, págs. $103 / 114$.

SCHEINER, Allan Howard. Judicial Assessment of Punitive Damages, The Seventh Amendment and The Politics of Jury Power, in Columbia Law Review, vol. 91, 1991, págs. $142 / 226$.

SCHREIBER, Anderson. Novos Paradigmas da Responsabilidade Civil: Da Erosão dos Filtros da Reparação à Diluição dos Danos, São Paulo, Atlas, 2009.

SEBOK, Anthony J.. Punitive Damages in The United States, in H. KozIOL - V. WILCOX (eds.), Punitive Damages: Common Law and Civil Law Perspectives, Wien, Springer, 2009, págs. 155/196. 
, WILCOX, Vanessa. Aggravated Damages, in H. KozIOL - V. WILcoX, Punitive Damages: Common Law and Civil Law Perspectives, Wien, Springer, 2009, págs. $257 / 274$.

SEVERO, Sérgio. Os Danos Extrapatrimoniais, São Paulo, Saraiva, 1996.

SILVA, Clóvis Veríssimo do Couto e. O Conceito de Dano no Direito Brasileiro e Comparado, in Revista dos Tribunais, ano 80, vol. 667, mai/1991, págs. 7/16.

SILVA, Regina Beatriz Tavares da. Critérios de Fixação da Indenização do Dano Moral, in DELGADO, Mario Luiz, ALVES, Jones Figueirêdo (coords.), Questões Controvertidas no Novo Código Civil, São Paulo, Método, 2003, págs. 257/268.

SILVA, Virgílio Afonso da. A Constitucionalização do Direito (Os Direitos Fundamentais nas Relações entre Particulares), São Paulo, Malheiros, 2005.

SIMPSON, Laurence P.. Punitive Damages for Breach of Contract, in Ohio State Law Journal, vol. 20, 1959, págs. 284/288.

SIMPSONS JR., John T., Discovery of Net Worth in Bifurcated Punitive Damages Cases: A Suggested Approach After Transportation Insurance Co. v. Moriel, in South Texas Law Review, vol. 37, 1996, págs. 193/229.

SOARES, Guido Fernando da Silva. Common Law (Introdução ao Direito dos EUA), $2^{\text {a }}$ ed., São Paulo, RT, 2000.

STARCK, Boris. Essai d'une Théorie Générale de la Responsabilité Civile Considèrèe em as Double Fonction de Garantie et de Peine Privèe, Paris, L. Rodstein, 1947.

STRENGER, Irineu. Direito Internacional Privado, vol.1, São Paulo, RT, 1986.

STURLEY, Michael F.. Vicarious Liability for Punitive Damages, in Lousiana Law Review, vol. 70, 2010, págs. 501/527. 
TALAMINI, Eduardo Tutela Relativa aos Deveres de Fazer e de Não Fazer e sua Extensão aos Deveres de Entrega de Coisa (CPC, arts. 461 e 461-A, CDC, art. 68), $2^{\mathrm{a}}$ ed., São Paulo, RT, 2003.

TELLES JR., Goffredo. Iniciação na Ciência do Direito, São Paulo, Saraiva, 2001.

TEPEDINO, Gustavo. A Tutela da Personalidade no Ordenamento Civil-Constitucional Brasileiro, in Temas de Direito Civil, $4^{\mathrm{a}}$ ed., Rio de Janeiro, Renovar, 2008, págs. 25/62. . O Futuro da Responsabilidade Civil, in Temas de Direito Civil, vol. III, Rio de Janeiro, Renovar, 2009, págs. 405/408.

O Direito Civil Constitucional e suas Perspectivas Atuais, in Temas de Direito Civil, vol. III, Rio de Janeiro, Renovar, 2009, págs. 21/40.

A Incorporação dos Direitos Fundamentais pelo Ordenamento Brasileiro: Sua Eficácia nas Relações Jurídicas Privadas, in Temas de Direito Civil, vol. III, Rio de Janeiro, Renovar, 2009, págs. 41/64.

TEPEDINO, Gustavo, BARBOZA, Heloísa Helena e MORAES, Maria Celina Bodin de (coords.). Código Civil Interpretado Conforme a Constituição da República, vol. II, Rio de Janeiro, Renovar, 2006.

Código Civil Interpretado Conforme a Constituição da República, vol. I, $2^{\mathrm{a}}$ ed., Rio de Janeiro, Renovar, 2007.

THEODORO JR., Humberto. Dano Moral, $4^{\mathrm{a}}$ ed., São Paulo, Juarez de Oliveira, 2001.

TODD, Stephen. A New Zeland Perspective on Exemplary Damages, in Common Law World Review, vol. 33, 2004, págs. 255/282.

TUCCI, José Rogério Cruz e. A Causa Petendi no Processo Civil, $2^{\mathrm{a}}$ ed., São Paulo, RT, 2001. 
UILAN, Eduardo. Responsabilidade Civil Punitiva, Tese (Doutorado) - Faculdade de Direito da USP, São Paulo, 2003.

URSO, Elena. Recenti Sviluppi nella Giurisprudenza Statunidense e Inglese in Materia di Punitive Damages: $i$ Casi TXO Production Corporation v. Alliances Resources Corporation e AB v. South West Water Services Ltd., in Rivista di Diritto Civile, vol. 41, n. 1, genn.-febr./1995, págs. 81/156.

VAZ, Caroline. Funções da Responsabilidade Civil - Da Reparação à Punição e Dissuasão - Os punitive damages no Direito Comparado e Brasileiro, Porto Alegre, Livraria do Advogado, 2009.

VELOSO, Zeno. Comentários ao Código Civil, vol. 21, São Paulo, Saraiva, 2003.

VENOSA, Sílvio de Salvo. Direito Civil, vol. I, $5^{\text {a }}$ ed., São Paulo, Atlas, 2005. . Direito Civil, vol. IV, $3^{\text {a }}$ ed., São Paulo, Atlas, 2003.

WAMBIER, Teresa Arruda Alvim. Nulidades do Processo e da Sentença, $6^{\mathrm{a}}$ ed., São Paulo, RT, 2007.

WATANABE, Kazuo. Da Cognição no Processo Civil, $3^{\mathrm{a}}$ ed., São Paulo, DPJ, 2005.

WILCOX, Vanessa. Punitive Damages in England, in H. KozIOL - V. WilcoX (eds.), Punitive Damages: Common Law and Civil Law Perspectives, Wien, Springer, 2009, págs. $7 / 53$.

ZITZER, Kurt M.. Punitive Damages: A Cat's Clavicle in Modern Civil Law, in The John Marshall Law Review, vol. 22, 1988, págs. 657/684. 